\title{
FORMAR CIUDADANOS EN LA ERA DE INTERNET
}

MEDIACIONES TECNOLÓGICAS EN LA EDUCACIÓN ARGENTINA (2011-2015)
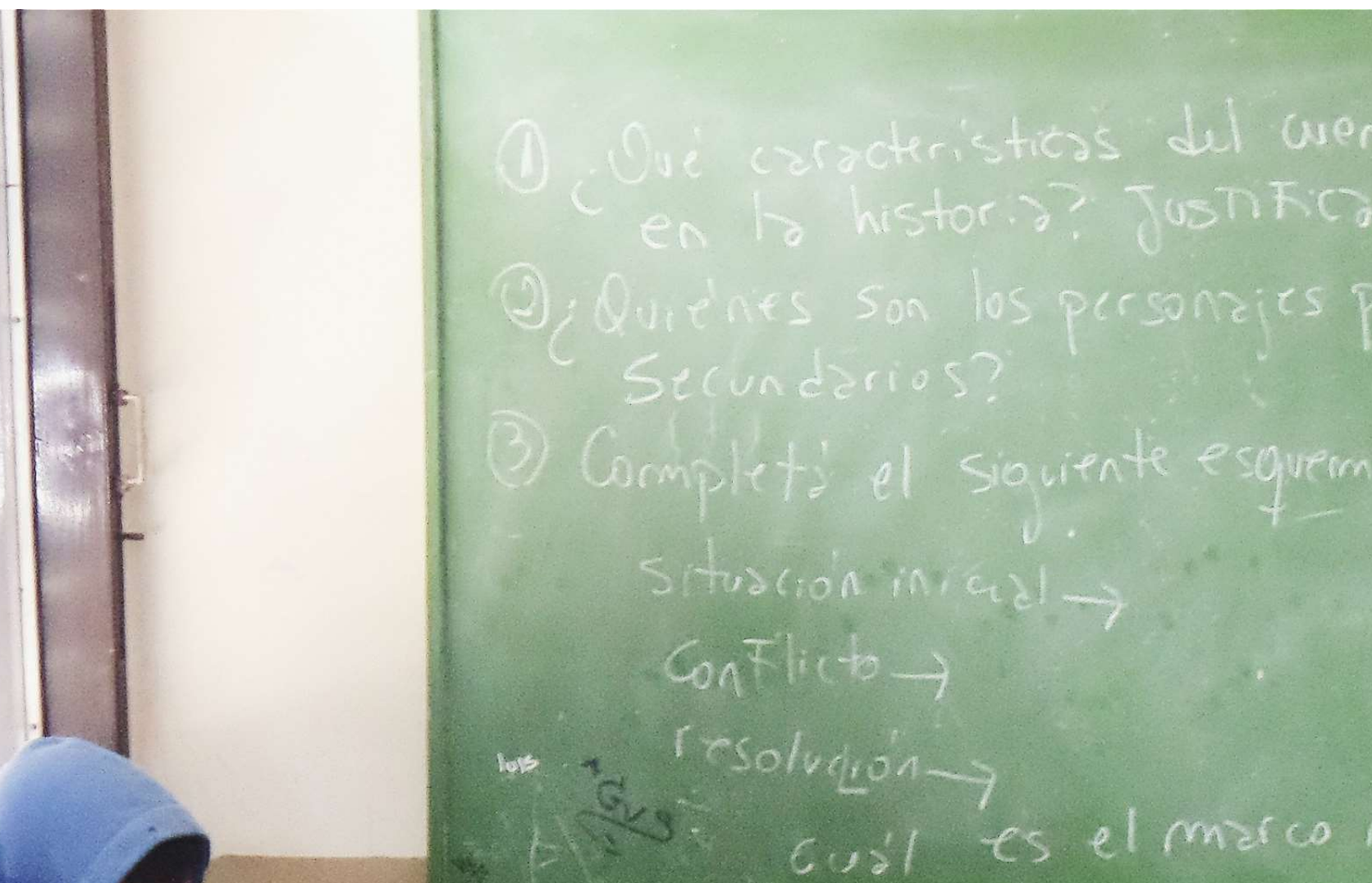

MARÍA BELÉN FERNÁNDEZ MASSARA 


\title{
UNIVERSIDAD NACIONAL DE LA PLATA \\ FACULTAD DE PERIODISMO Y COMUNICACIÓN SOCIAL
}

\author{
DOCTORADO EN COMUNICACIÓN
}

Tesis para obtener el título de Doctora en Comunicación

FORMAR CIUDADANOS EN LA ERA DE INTERNET MEDIACIONES TECNOLÓGICAS EN LA EDUCACIÓN ARGENTINA (2011-2015)

Lic. Prof. María Belén Fernández Massara

Directora: Dra. Roxana Cabello

Olavarría, diciembre de 2018. 


\section{A mis amores: Roberto, Iara y Micaela.}

Tú, lector, estarás a cierta distancia cronológica de mí... pero es muy probable que estés en tu propia atalaya, donde recibes los mensajes telepáticos. No es que sea necesario, ¿eh? Los libros son la magia más portátil que existe.

Stephen King, Mientras escribo.

Todo movimiento, cualquiera sea su causa, es creador.

Edgar Allan Poe, Narraciones extraordinarias. 


\section{AGRADECIMIENTOS}

A la familia, por el cariño enorme, la paciencia infinita y la palabra de aliento, estando tan cerca... o tan lejos.

A mis compañeros, compañeras y colegas de la FACSO-UNICEN, por los momentos oportunos, por entender y compartir las dificultades en escenarios complejos de investigación.

A mi Directora Roxana Cabello. A pesar de la distancia, sin sus conocimientos, su generosidad y su apoyo a lo largo de todo este trayecto, concluir esta tesis no hubiera sido posible.

A todos ellos, gracias. 


\section{ÍNDICE DE CONTENIDOS}

\section{PRIMERA PARTE}

CAPÍTULO 1: CONSTRUCCIÓN DEL OBJETO Y ANTECEDENTES....................9

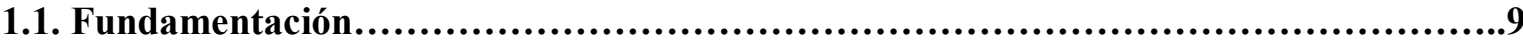

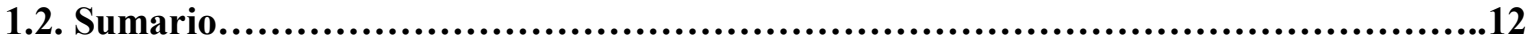

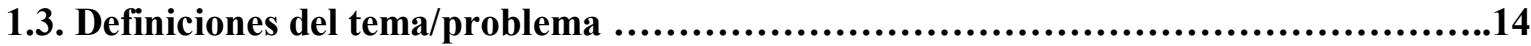

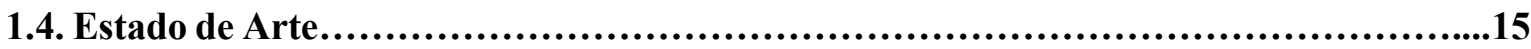

1.4.1. Escenario político e investigaciones empíricas sobre la Sociedad del Conocimiento....15

1.4.2. Breve recorrido por los marcos regulatorios de la inclusión digital....................19

SEGUNDA PARTE

CAPÍTULO 2: ENCUADRE TEÓRICO-METODOLÓGICO................................30

2.1. Conceptos ordenadores de la investigación.........................................30

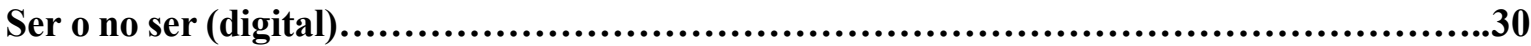

Precisiones conceptuales en el campo de la comunicación/cultura..........................31

Potencial y crítica de la Ecología de los Medios........................................34

Apuntes desde las teorías de la educación y del aprendizaje..............................36

Democracia y espacio público: principales derivas teóricas...............................39

Hacia una redefinición de la ciudadanía.............................................41

Aproximaciones teóricas a la juventud.................................................43

Interpelar a los ciudadanos en la sociedad-red.................................................44

La problemática de la ciudadanía: a modo de síntesis....................................45

2.2. Hacia la elaboración de un modelo de análisis....................................46

2.2.1. Consideraciones metodológicas...............................................46

2.2.2. Dimensiones y Áreas de Indagación.................................................50

2.2.3. El caso: la educación secundaria técnica en la ciudad de Olavarría....................57

TERCERA PARTE

CAPÍTULO 3: ACERCA DE LAS CONDICIONES PARA LA APROPIACIÓN DIGITAL 59

3.1. La cuestión del Acceso en la convergencia digital...................................59

3.1.1. Continuidades y discontinuidades en el Acceso Material..............................61

3.1.2. Saberes y Disposiciones: “una película de Fellini”"................................63

Mejoramiento institucional y acceso personal docente................................67

La falta de capacitación como obstáculo: primeros apuntes..............................70

Accesos diferenciados y significados atribuidos en los discursos juveniles.................72 
Tensiones y desplazamientos entre el modelo de laboratorio y el modelo 1 a 1 .... .75

3.1.3. Principales observaciones.......................................................77

3.2. Redefiniendo los Usos Tecnológicos...............................................78

3.2.1. Acerca de los Consumos: "no basta con el acceso"

Hacer imaginables los usos tecnológicos............................................83

3.2.2. Videojuegos y redes sociales: hacia la Producción de Contenidos....................85

¿Qué significa "hacer" en la escuela?.......................................................................................87

3.2.3. Potencialidades de la Interactividad: aprendizaje y trabajo colaborativo..............89

Sobre los teléfonos celulares y la problemática tarea de enseñar...........................91

3.2.4. Principales observaciones.......................................................

3.3. La Apropiación de TIC: la construcción de autonomía..............................96

3.3.1. El Conocimiento: de los medios a los entornos....................................99

Apropiaciones juveniles, conocimientos esperados y producidos.........................105

3.3.2. Posibilidades de Elucidación de las "divinas maquinitas"

3.3.3. La Autonomía: enseñanza crítica o el imperativo de "adaptarse" ....................110

Hacia la autonomización de los aprendizajes..........................................112

3.3.4. Trayectorias nómades, lugares de Autoafirmación.................................115

3.3.5. Principales observaciones......................................................119

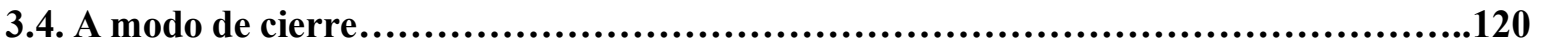

CAPÍTULO 4: CRUCES Y TENSIONES EN LAS MEDIACIONES TECNOLÓGICAS 124

4.1. Mediaciones Tecnológicas y Mediaciones Múltiples.................................125

4.1.1. Mediaciones Cognitivas en marcos de intervención....................................127

Implicaciones cognitivas de los usos juveniles......................................131

4.1.2. Mediaciones Institucionales y el orden de lo imaginario...........................133

Construir (o re-construir) la identidad: “es un monstruo esta escuela" ....................140

Enclaves juveniles: sentirse "grasas" o la escuela "linda" ..................................144

Entre la escuela "contenedora" y la "formadora"

Sobre las reformas neoliberales de la educación técnica..............................150

Recorridos intermitentes: los dilemas del "profesor taxi"

4.1.3. Las Mediaciones Situacionales: posiciones directivas y temporalidades múltiples... 156

Lo que median las tecnologías: autoridad docente y evaluación...........................159

4.1.4. Enseñar en (o desde) las Mediaciones Lingüístico-Comunicativas....................163

Las experiencias juveniles: modelos heredados, lenguajes convergentes....................166

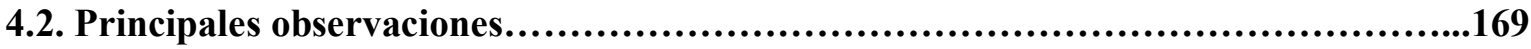


4.3. A modo de cierre.

CAPÍTULO 5: PROBLEMATIZANDO A LA ALFABETIZACIÓN DIGITAL: LA

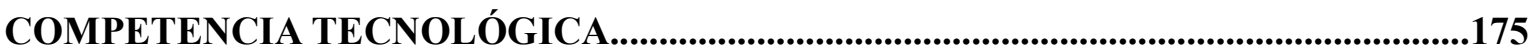

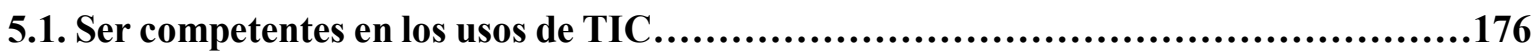

5.1.1. Competencias Instrumentales: "un montón de programas"

Lo que permanece: jerarquizar el dominio instrumental ..............................182

5.1.2. Competencias Cognitivo-Intelectuales: la capacitación docente......................186

Intervenciones docentes, lecto-escritura y multitarea.................................192

5.1.3. Acerca de las Competencias Sociocomunicacionales.................................197

"A veces distrae": multitarea y autorregulación de la práctica...........................201

5.1.4. Competencias Axiológicas: entre el discurso tecno-utópico y la innovación educativa 204

Transiciones: difusionismo tecnológico o ejercicio de la crítica.........................207

5.1.5. Competencias Emocionales y la domesticación de las TIC...........................210

Subjetividades juveniles, tramas familiares y grupos de pares............................214

5.2. Principales observaciones.....................................................217

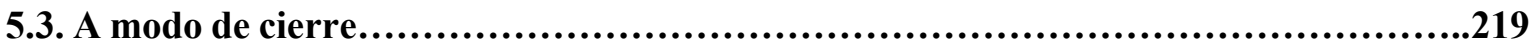

CAPÍTULO 6: CIUDADANÍAS EN CONSTRUCCIÓN: PRÁCTICAS, ESPACIOS Y

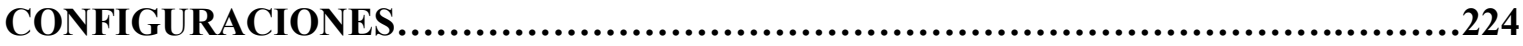

6.1. Sobre el entramado Ciudadanía/Política/Democracia...................................225

6.1.1. Capacidad de Agenciamiento..................................................228

6.1.2. Condiciones Materiales y Simbólicas para la Ciudadanía..........................231

Ciudadanos en situación: la Ley de Voto Joven........................................236

6.1.3. Globalización y Participación: "la política... afuera" .............................238

6.1.4. Principales observaciones..................................................243

6. 2. Ciudadanía/Educación: problemas y desafíos.......................................244

6.2.1. Los componentes Gnoseológicos: ¿qué significa “domesticar”?...................................246

6.2.2. La dimensión Política de la formación.........................................251

6.2.3. Representaciones acerca del problema educación/ciudadanía......................254

6.2.4. Principales observaciones....................................................261

6.3. Ciudadanía/Tecnología: tensiones emergentes y anudamientos múltiples.............262

6.3.1. Conocimientos e interpretaciones acerca de Conectar Igualdad.....................265

6.3.2. Intersticios: desafíos pedagógicos de la Inclusión Digital...........................268

Discursos estudiantiles sobre el PCI y la integración tecnológica...........................274

6.3.3. Información y Conocimiento: la problemática mediación comunicacional............278 
Libros e Internet: disputas de sentido en las percepciones juveniles....

6.3.4. Identidades Juveniles: jóvenes negativizados, sujetos en potencia.....................284

Actuaciones juveniles: contribuciones a una ciudadanía cultural........................292

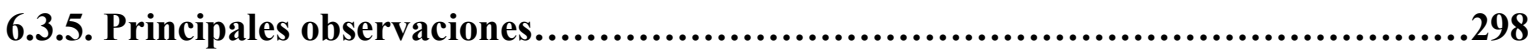

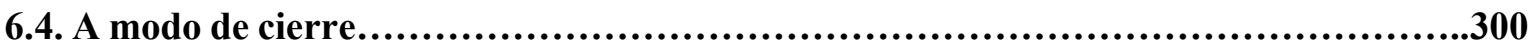

CUARTA PARTE

CAPÍTULO 7: CONCLUSIONES.................................................... 306

BIBLIOGRAFÍA....................................................................324

ANEXOS (se adjuntan en CD-ROM).

Anexo 1: Entrevistas.

Anexo 2: Matriz de datos

Anexo 3: Registro fotográfico. 


\section{CAPÍTULO 1: CONSTRUCCIÓN DEL OBJETO Y ANTECEDENTES}

\subsection{Fundamentación}

Es sabido que vivimos en un proceso de profundas transformaciones sociales, políticas, económicas y científico-tecnológicas, en el que han adquirido formidable protagonismo las denominadas Tecnologías de la Información y la Comunicación (TIC). Nuevas formas de producción económica, de desarrollo del conocimiento científico-técnico, de comunicación y de intercambio de bienes y servicios, manifiestan una aceleración vertiginosa como resultado del impacto de estas tecnologías. Así, se ha generalizado la idea de que asistimos a la denominada Sociedad de la Información o Sociedad del Conocimiento, que asume modalidades y alcances no exentos de tensiones. Los discursos en torno a la "brecha digital" condensan los imaginarios acerca del potencial democratizador de la tecnología, como también de las dificultades de gran parte de la sociedad para participar activamente de sus sentidos y sus posibilidades.

Esta discusión se da en el contexto de lo que Castells (2001) ha denominado una "globalización asimétrica", promotora de desequilibrios que exceden las variables meramente tecnológicas. En América Latina, los Estados nacionales y otros actores vienen impulsando políticas de inclusión digital, bajo la premisa de que la equidad digital es el primer y más importante paso hacia la equidad social. Si es cierto que en las últimas décadas se han consolidado las democracias como modelos de gobierno, también enfrentan el problema de extender el ejercicio de derechos a vastos sectores históricamente relegados. La educación formal es el ámbito privilegiado, si bien no el único, para comprender y orientar procesos estratégicos de mejoramiento de las condiciones de inclusión digital, social y educativa, que vuelva a los sujetos ciudadanos informados, críticos y actuantes de lo público.

En estas matrices socio-históricas se presentan entonces dos cuestiones claves: la educación y la ciudadanía. Problemáticas que asumen sus propias determinaciones, pero que articulan la dimensión más plenamente política de los esfuerzos de digitalización. Por un lado, los cruces y destemporalidades que vertebran los nuevos lenguajes, sensibilidades, modos de apropiación, que exceden las identidades relativas a la nación y otras formas tradicionales de ser ciudadano. Por otro -en relación íntima con lo anterior-, las tensiones entre esos saberes múltiples y los saberes escolares instituidos y socialmente legitimados. Un interrogante fundamental reside en cuál es la situación del sistema educativo en relación con la expansión de estas tecnologías, y cómo está 
respondiendo a las complejas condiciones pedagógicas, sociales y culturales que estas encarnan.

La problemática es emergente de una renovada discusión tanto en la opinión pública como en el campo académico: entre las reacciones apologistas y las resistencias a los "efectos" de la cultura de masas, exponentes de las dos posiciones que Umberto Eco (2004) había calificado acertadamente de integratti e apocalittici. O, en términos de Williams, "una nefasta combinación entre determinismo tecnológico y pesimismo cultural" (2017: 182), que es necesario desenredar. Ninguna de estas posturas constituye el terreno adecuado. Una comprensión crítica implicará dar cuenta de las prácticas donde las tecnologías asumen un potencial a la vez que epistémico, cultural y político: construir conocimiento crítico y socialmente productivo, permitiendo superar las desigualdades de base como así los imperativos económicos de la comunicación de masas.

Esta tesis tiende a contribuir al campo de la Comunicación desde una perspectiva crítica e interdisciplinaria, ofreciendo líneas de investigación para su profundización y desarrollo. Tiene por objeto analizar las prácticas y representaciones mediadas por las Tecnologías de la Información y la Comunicación, en sus relaciones con la educación secundaria técnica y la construcción de ciudadanía en la Argentina (2011-2015).

La propuesta se inscribe en el sub-campo de la comunicación/educación, recuperando aportes de los estudios culturales (EC), la antropología social, las ciencias de la educación, la lingüística, la teoría política, etc. En el marco del Doctorado de la FPyCS-UNLP, se encuadra en la línea denominada "Comunicación, Sociedad y Cultura", en torno a las mediaciones, los modos de recepción y consumo, la relación vida cotidiana/tecnologías, las prácticas resultantes de la globalización y de la "Sociedad de la Información", los imaginarios que vertebran esa condición, como las trasformaciones de las identidades y de las formas de concebir y ejercer la ciudadanía.

Asumimos que el campo de la comunicación/cultura no determina “objetos" delimitados sino interrogantes que conciernen a sus dimensiones simbólicas y comunicativas. Surgido de la convergencia de múltiples disciplinas, enfoques y abordajes teórico-metodológicos, define polémicas no resueltas acerca de los posibles universos de investigación e intervención, los modos de interpelarnos como intelectuales, los supuestos epistemológicos que nos orientan. Como profundizamos en otros trabajos (Fernández Massara, 2012a; Fernández Massara, Marmisolle y Pallero, 2017), la cuestión de la interdisciplinariedad no deja ser problemática, especialmente cuando los EC, hegemónicos en la teoría latinoamericana, suelen posturarla como condición constitutiva del campo. R. Follari (2003) ha advertido acerca de cierta retórica de superación de las disciplinas que puede resultar en la llana negación de su especificidad epistemológica. ${ }^{1}$ Las

\footnotetext{
${ }^{1}$ Los términos interdisciplinariedad e transdisciplinariedad son controvertidos. Follari invierte las acepciones tradicionales, para concebir a la interdisciplina como la interacción de disciplinas diferentes, de modo que las
} 
preocupaciones sobre las TIC revelan estas tensiones: entre las continuidades y las rupturas, entre el discurso teorizante y el conocimiento productivo, entre las demandas de "cientificidad" de herencia positivista y la mirada interdisciplinaria frente a fenómenos de creciente complejidad.

Ahora bien, la obsolescencia del conocimiento constituye una de las más importantes preocupaciones para quienes nos dedicamos a indagar sobre las TIC. Esta tesis dio inicio en 2011 y en todo este tiempo el tema ha atravesado diversas transformaciones. Sostiene Roxana Cabello: "Hoy, más que nunca, a medida que tratamos de dar cuenta de los acontecimientos, muchos de esos mismos acontecimientos - cuando se trata de avances tecnológicos-se nos escurren entre las manos" (2008a: 8). Es también cierto que las actuaciones de los sujetos, las instituciones o marcos experienciales donde se realizan, las formas de adopción de políticas públicas asociadas al área, propician unos cambios mucho más lentos que los que ofrece la aceleración tecnológica, configurando el espacio de sus continuidades relativas, sus dilemas y contradicciones.

La investigación se aboca al estudio del proceso de implementación de la política pública de mayor relevancia en el país: el Programa Conectar Igualdad (PCI). Tras más de veinte años de intentos de integrar tecnologías a las escuelas, la presidencia de Cristina Fernández de Kirchner impulsa en 2010 un programa integral y sistemático de inclusión digital, educativa y social que legitima el rol específico del Estado para garantizar condiciones de alfabetización digital. Bajo el modelo 1 a 1, el PCI forma parte de experiencias con diversos alcances, como el Plan Ceibal en Uruguay, Enlaces en Chile, Proyecto Huascarán en Perú, Programa Computadoras para Educar en Colombia, Programa Integral Conéctate en El Salvador y las Escuelas del Futuro en Guatemala.

En base a un estudio longitudinal, el recorte temporal 2011-2015 comprende la implementación efectiva del modelo en las instituciones escolares a comienzos de 2011, hasta la finalización del gobierno nacional que le da impulso, en diciembre de 2015. Hemos focalizado en la educación técnica de nivel medio, la primera destinataria de las orientaciones del PCI. El caso define particularidades, junto con posibilidades objetivas de generalización. Registra imaginarios vinculados a la formación socio-productiva, como a la dimensión humanística y ciudadana, de acuerdo a la Ley de Educación Técnico-Profesional (2005). La Ley de Educación Nacional (2006) es el encuadre general que orienta la formación de los/las jóvenes para el ejercicio de la ciudadanía, el trabajo y la continuación de estudios superiores. ${ }^{2}$ Un objetivo específico consiste en "desarrollar

modalidades de una de ellas sirven al objeto de otra y son incorporadas por esta última. La transdisciplina es el tipo de interrelación orgánica de distintas disciplinas respecto de un objeto que no es abordado por ninguna. En rigor, no atribuyen en sí ningún valor de legitimidad científica, en tanto la mirada "latinoamericana" no habilita a pensar una "generación espontánea" de teoría, ajena a las previas tematizaciones de tradición norteamericana y europea.

${ }^{2}$ Vale destacar que asumimos en esta tesis una perspectiva de género. Se decidió introducir cada Parte con el término "los/las" inclusivo y, en adelante, utilizar el masculino genérico a los fines de agilizar la lectura. 
las capacidades necesarias para la comprensión y utilización inteligente y crítica de los nuevos lenguajes producidos en el campo de las tecnologías de la información y la comunicación".

La investigación empírica profundiza en el caso de la escuela secundaria técnica en Olavarría (Buenos Aires, Argentina). Interpelarnos sobre los procesos de significación implica situarnos en los imaginarios sociales que atraviesan y necesariamente exceden a las instituciones educativas, para involucrar los flujos comunicacionales y culturales que se entraman en esa realidad urbana. Si bien nuestro eje de interés lo constituye el orden de lo institucional, la ciudad habrá de considerarse "en paralelo", en tanto es constantemente resignificada por los mismos actores en sus experiencias escolares, constituyendo la matriz general pero inmediata para pensar, educar y ejercer formas alternativas de ciudadanía. En base a categorizaciones de la antropología urbana, Olavarría constituye una ciudad de rango medio, con características culturales razonablemente distintivas de las propias de los centros metropolitanos. ${ }^{3}$ Indagaremos en el entramado de imágenes evocadoras de un pasado en común, organizadoras de las relaciones simbólicas entre las tradiciones de la educación técnica, el desarrollo socio-productivo, como el papel capital, todavía hegemónico, de la tecnología en esos procesos.

\subsection{Sumario}

La tesis que aquí se presenta comprende cuatro grandes Partes. La Primera Parte está centrada en esta Fundamentación: las implicaciones socio-culturales, políticas y educativas en estas coyunturas latinoamericanas, así como el carácter original y relevante de la investigación en sus contribuciones a los estudios de la comunicación y la cultura desde una postura reflexiva sobre sus condiciones teórico-epistémicas. Se presenta luego la delimitación del tema/problema y la justificación del recorte espacio-temporal, los objetivos e interrogantes que orientan el trabajo. El último apartado determina el Estado de Arte, las investigaciones que constituyen los antecedentes inmediatos y donde el problema abordado emerge como área de vacancia. Anticipamos aquí un análisis descriptivo de los marcos normativos en sus definiciones formales desde el Estado, al tiempo que registran experiencias previas de políticas de inclusión digital.

3 Deriva este interés de nuestra larga experiencia en el NACT Producciones e Investigaciones Comunicacionales y Sociales de la Ciudad Intermedia (PROINCOMSCI), radicado en FACSO-UNICEN (SPU 03/F158), junto con la actual Co-Dirección del Proyecto Comunicación y Cultura en ciudades intermedias del Centro Bonaerense (Programa Incentivos, Disp. 33/2017). La ciudad aparece caracterizada como espacio urbano significacional donde se anudan los consumos públicos (de infraestructura urbano-territorial, productiva, educativa, mediática, de salud, etc.), en el marco de las condiciones estructural-simbólicas en las que viven sus actores. 
En la Segunda Parte, se presenta el Encuadre Teórico-Metodológico. Se desarrollan las principales categorías conceptuales desde las que se aborda el problema, como las discusiones teóricas que las delimitan y sostienen. Se organiza a partir de los tres ejes analíticos: las tecnologías, la educación y la ciudadanía, tomando como perspectiva principal- pero no única- a los EC. A continuación, se fundamenta la propuesta metodológica: el paradigma interpretativo, en la consideración hermenéutica, humanista y holística del objeto. En esta clave se argumenta la necesidad de un diseño cualitativo, el Método Comparativo Constante y el Análisis Textual, referidos principalmente a los discursos de los actores y en base a los cuales se explicitan las técnicas de recolección de datos. A partir de la problematización de algunas categorías y la elaboración de otras, se propone un modelo de análisis desde una perspectiva comunicacional, definiendo Dimensiones y Subdimensiones orientadas a la generación de teoría.

La Tercera Parte presenta el desarrollo analítico, los resultados del trabajo de campo, la interpretación y el análisis. Tal como contemplan el Método Comparativo y el muestro teórico, la investigación se define por el feed-back entre la codificación y los datos empíricos, entre el marco teórico y la recolección. Recuperando los conceptos orientadores esbozados en la Segunda Parte y el modelo analítico propuesto, se desarrollan cada una de las categorías, en base a los dos grandes ejes relativos a las experiencias con TIC y la construcción de ciudadanía, dando cuenta de sus especificidades relativas como de los cruces y articulaciones que las involucran. La tesis contribuye no sólo a la revisión crítica de los conceptos nucleares del campo, sino además a la reflexión de los aportes de una metodología de Comunicación relativamente poco desarrollada.

La Cuarta Parte expone las conclusiones de todo el recorrido anterior, que no pretende cerrar el tema sino, por el contrario, abrir otros interrogantes y líneas de investigación. Si la periodización está centrada en la implementación del Programa Conectar Igualdad, los aportes de la tesis adquieren plena vigencia en tanto ratifican los procesos de retraimiento del actual Estado argentino en sus responsabilidades para garantizar el cumplimiento de derechos, impulsar políticas públicas orientadas a la mejora educativa y promover una sociedad más inclusiva, frente a los avances del neoliberalismo globalizado. Así, se esbozan algunas reflexiones acerca de cómo los cambios mediados por las tecnologías interactivas imprimen nuevas lógicas a estos escenarios de incertidumbre, reclamando posturas más activas y potencialmente transformadoras. A este apartado le sigue la Bibliografía. Por último, en presentación como Anexo (en CD-ROM), se ofrece la transcripción de entrevistas y grupos focales, la matriz de datos resultante del trabajo de codificación y análisis y, finalmente, una selección de imágenes producto del registro fotográfico en las instituciones analizadas. 


\subsection{Definiciones del tema/problema}

La tesis que aquí se presenta aborda las prácticas y representaciones mediadas por las Tecnologías de la Información y la Comunicación en contextos socio-educativos, durante el período 2011-2015. Apunta a analizar concepciones y modos de apropiación de las TIC por parte de directivos, docentes y estudiantes de las escuelas técnicas de nivel secundario de la ciudad de Olavarría (Buenos Aires, Argentina), y sus relaciones con la construcción de ciudadanía como eje vertebrador de la educación en el contexto histórico de emergencia.

Conforme a ello, se persigue el Objetivo General de conocer y analizar las prácticas y representaciones mediadas por las Tecnologías de la Información y la Comunicación en las escuelas técnicas secundarias de la ciudad de Olavarría, con respecto a las relaciones entre tecnología, formación técnica y construcción de ciudadanía durante el período 2011-2015.

Presentamos a continuación los Objetivos Específicos:

- Caracterizar condiciones y usos habituales de las TIC por parte de directivos, docentes y estudiantes de la escuela técnica secundaria: modos de acceso, disponibilidad, tipos de aplicaciones, funciones atribuidas, etc.

- Analizar discursos y representaciones detentados por los actores, relativos a sus competencias tecnológicas y sus vinculaciones con los procesos educativos: expectativas, resistencias, valoraciones, subjetividades, etc.

- Comprender las concepciones acerca de la ciudadanía, las experiencias que animan su construcción y ejercicio, los procesos culturales en que se inscriben y los modelos político-educativos que los legitiman y reproducen.

- Analizar imaginarios subyacentes a las prácticas, acerca de las relaciones entre tecnología y construcción de ciudadanía, los roles de docentes y estudiantes, la dimensión éticopolítica de la educación, alcances y limitaciones de esa formación, etc.

Tales objetivos involucran los siguientes Interrogantes:

- ¿Cuáles son las representaciones, los modos y condiciones de apropiación de las Tecnologías de la Información y la Comunicación que experimentan los actores involucrados en las escuelas técnicas de nivel secundario?

- ¿Qué discursos en torno a la construcción de ciudadanía circulan, y qué modelos políticos, institucionales y pedagógicos los sustentan y reproducen?

- ¿De qué manera las concepciones y los usos relativos a las TIC definen -o no- un modo particular de ser ciudadano? 
- ¿Cómo se manifiesta esta relación entre ciudadanía y tecnologías en las políticas educativas, por un lado, y en las prácticas comunicativas de los sujetos, por otro, particularmente en la educación secundaria técnica?

- ¿Qué características asumen las relaciones entre los imaginarios asociados a las TIC, la escuela y los procesos políticos, institucionales y educativos orientados a la construcción de ciudadanía, en el marco del resurgimiento de la educación técnica?

\subsection{Estado de Arte}

\subsubsection{Escenario político e investigaciones empíricas sobre la Sociedad del Conocimiento}

Esta problemática actualiza los debates acerca de las posibilidades de constitución de un campo específicamente comunicológico: en los términos de Jorge Rivera (1987, 1997), un aspecto notable es el destiempo entre la emergencia de los medios masivos y otras expresiones de la industria cultural, y el desarrollo teórico relativo a ellos. En los últimos años, las investigaciones se han diversificado y extendido significativamente, volviendo indispensable delinear un estado de la cuestión. Pero este trabajo no remite tanto a una historia sino a la construcción de un corte sincrónico (Crovi Druetta y Garay Cruz, 2015), que ofrece un panorama de aproximaciones inmediatamente anteriores a esta tesis. Sería imposible hacer una reconstrucción de todo un devenir histórico. Sin embargo, dado que las intervenciones del Estado revisten particular interés, es pertinente examinar las tempranas referencias políticas en la agenda internacional, junto con los estudios que derivan de esos debates emergentes, así como los marcos regulatorios que constituyen la justificación de la inclusión digital y de iniciativas afines en nuestro país.

Los primeros registros verifican que las tecnologías digitales aparecen vinculadas a la educación y, secundariamente, a la ciudadanía, pero no hemos encontrado antecedentes que vinculen las tres áreas. Mientras el PCI y políticas públicas similares en la región han despertado notable interés en la problemática TIC/educación, no hallamos investigaciones que exploren los modos de construcción de ciudadanía estructuralmente mediados por dicha relación. Tradicionalmente relegada a disciplinas como la sociología y la teoría política, solo recientemente la ciudadanía comienza a ser objeto de los estudios comunicológicos, y las categorías que intentan comprender sus vínculos con la tecnología - del tipo "ciudadanía digital”- no aluden centralmente a experiencias educativas o culturales de mayor alcance. De todos modos, se destacan un conjunto de investigaciones de relevancia, a las que presentamos en un mapa somero de sus contribuciones y problemas pendientes en el campo, con especial énfasis en América Latina y Argentina. 
El término "Tecnologías de la Información y la Comunicación” tuvo sus orígenes en la década del '80, en el marco de un nuevo modelo político-económico del neoliberalismo. Esos serían los cimientos de la Sociedad de la Información (SI). En su acepción actual, este término fue utilizado por primera vez por el sociólogo japonés Yonesi Masuda en 1981. Reaparece con fuerza en los '90, cuando se lo incluye en la agenda de las reuniones del G7 (luego G8), en foros de la Comunidad Europea y de otros organismos internacionales. En 1999, el Informe sobre Desarrollo Humano elaborado por el Programa de Desarrollo Humano de las Naciones Unidas (PNUD), enuncia que las comunicaciones tienen un papel fundamental, pero que se requieren acciones que impulsen la formación de capacidades y aptitudes necesarias para la inclusión social y el desarrollo democrático de las sociedades.

En 2001, la Organización de las Naciones Unidas (ONU) encargó a la Unión Internacional de Telecomunicaciones (UIT) la realización de la Cumbre Mundial de la Sociedad de la Información, en dos etapas: 2003 (Ginebra) y 2005 (Túnez). Entre numerosos aspectos discutidos, se destacan los cambios del sistema educativo, frente a la urgencia de incorporar masivamente las tecnologías para paliar los efectos de las desigualdades sociales. En 2003, la UNESCO ya advertía que instalar computadores y conexión a Internet en las aulas no es suficiente, "también se deben saber utilizar en la forma apropiada. Esto significa que las escuelas deberán cambiar su metodología y encontrar nuevas modalidades de transmisión de conocimientos."4

El término Sociedad del Conocimiento (SC) - acuñado Peter Drucker en 1969- fue adoptado por la UNESCO, a los fines de superar los aspectos instrumentales para incluir los cambios ligados a la producción, circulación y apropiación de los conocimientos. Tenderá a destronar a la SI, se utilizarán indistintamente o juntas como Sociedad de la Información y el Conocimiento (SIC). Se ha enunciado también como "era global", "era de la información”, "autopista de la información”, "sociedad de la comunicación", "sociedad-red”, "sociedad digital", "cibercultura" y "convergencia digital", sea para dimensionar sus beneficios como para ponerlos en discusión (Castells, 2001; Hoffmann, 2003; Crovi Druetta, 2004, 2007; Jenkins, 2008).

Informes más recientes como el de CEPAL (2009) anuncian que la difusión de las tecnologías será sostenida y acelerada, y que la próxima etapa de la era digital comprenderá no tanto la producción de infraestructura, sino nuevos enfoques cognitivos que promuevan el desarrollo de inteligencia. La perspectiva del Desarrollo Humano destaca el interés en promover el acceso a los beneficios de una cultura globalizada. Pero la complejidad y el impacto de las

${ }^{4}$ La UNESCO analizaba que, entre 1998 y 2000, el número de usuarios de Internet aumentó de 1,7 millones a 9,8 millones en Brasil y de 2.500 a 25.000 en Uganda. Sin embargo, los países "ricos" aún representaban el 79 por ciento de los 400 millones de usuarios estimados a nivel mundial. "Nuevas Tecnologías: ¿espejismo o milagro?, en La Educación Hoy- Boletín. Disponible en: http://unesdoc.unesco.org/images/0013/001319/131987s.pdf 
innovaciones tecnológicas afrontan las contradicciones que atraviesa a las democracias: el Estado en franca retirada, las prácticas culturales y simbólicas condicionadas por los mecanismos del mercado internacional, el auge de las TIC que no ha resultado en acceso equitativo.

En la Argentina, el campo de la Comunicación ha realizado fundamentales aportes al estudio de distintas prácticas tecnológicas, tales como el periodismo digital, los videojuegos o las redes sociales. Levis (1997) había definido a los videojuegos como el primer medio de masas de la era informática y precursor de los lenguajes interactivos. Posteriormente, se pone atención a las implicaciones de los juegos en red: las transformaciones de los consumos juveniles, sus modos de sociabilidad en un "entorno tecno-cultural" (Levis, 2007; Cabello, 2008a, 2009). En sus recorridos pioneros a la Ecología de los Medios, investigadores como A. Piscitelli (2009) enfatizan las relaciones posibles entre Facebook y la educación, a partir de distintas dimensiones de análisis: la "arquitectura" de la red, la participación, la identidad, la convergencia cultural, etc.

Otra serie de investigaciones exploran las concepciones y los usos que detentan los docentes sobre la integración de tecnologías, previa al modelo 1 a 1. R. Moyano (2006) apunta a conocer el contexto tecnológico donde se construyen esas representaciones, esto es, la cantidad y disponibilidad de los artefactos, a los que clasifica en analógicos (televisores, videocassetteras y equipos de sonido) y digitales (computadoras, utilitarios e Internet). El relevamiento se realiza en el área de influencia de la Universidad de Gral. Sarmiento en escuelas de nivel primario, un antecedente valioso dada la falta de datos sistemáticos. Los trabajos de Cabello $(2006,2007)$ verifican que hay una predisposición favorable de los maestros para el uso de las TIC, pero no se hallan aún incorporadas a las prácticas docentes ni a la definición conceptual de su rol. La autora recupera el concepto de "competencias tecnológicas" del mexicano Jorge González, y elabora una propuesta de análisis cualitativo a partir de indicadores como intensidad y habilidad de uso.

Otro eje problemático es la llamada brecha digital y cómo esta es resignificada por los docentes en términos de brecha social. A partir de un trabajo de campo realizado en el Conurbano Bonaerense, Géliga Vargas (2006) concluye que las asimetrías son objeto de reposicionamientos conflictivos en el marco de la crisis argentina, donde se conjugan la figura del docente mediador, el potencial democratizador de la tecnología como asimismo una concepción evocadora de los modelos difusionistas de desarrollo. En la misma línea, Aprea (2006) analiza que los usos de las TIC se conciben como complementarios, pero no como modos susceptibles de mejorar la enseñanza o atenuar los efectos de la brecha. Encontramos en Morales (2007) sus tempranas preocupaciones por las apropiaciones digitales, las representaciones predominantemente tecnocráticas y los accesos diferenciales de los estudiantes como sus principales obstáculos. 
Otras investigaciones han abordado las posibilidades de implementación de las TIC en la Universidad, en el uso de recursos de la red y la educación a distancia -particularmente en las carreras de Comunicación-, tanto en la Argentina (Cabello y Levis, 2007) como en el resto de América Latina (Crovi Druetta, 2007; Islas, 2007). Desde el campo de la tecnología educativa, Lion (2006), investiga las formas de introducción de Internet en las aulas universitarias para la producción de conocimiento: lo que predomina es una concepción instrumental de la red como "herramienta". Queda pendiente generar espacios de apropiación genuina que deben diferenciarse de la acumulación de conocimiento, lo que caracteriza como "infoconocimiento".

Un conjunto de estudios se ha centrado a la formación inicial, los estudiantes de los Institutos de Formación Docente. Como en otros trabajos (Arabito y Fernández Massara, 2007, 2008), el tema lleva a Cabello $(2009,2011)$ a poner en cuestión una categoría largamente asumida por las políticas de inclusión digital: la brecha entre nativos e inmigrantes digitales. Se demuestra que también los jóvenes/nativos pueden asumir una relación distante e instrumental con las TIC, a la vez condicionada por la falta o debilidades del acceso y el bajo nivel de competencias alcanzado. Estudios de este tipo conducen a identificar dimensiones desde las cuales puedan diseñarse propuestas de capacitación en el marco de proyectos de "migración digital", cuestión que, como veremos, sigue configurando uno de los núcleos más problemáticos de los proyectos educativos.

Más recientemente, se está produciendo un desplazamiento del interés hacia los jóvenes usuarios. Por ejemplo, Quiroz (2009) apunta a interpretar las prácticas de consumo en los adolescentes, quienes definen una trama de relaciones personales, afectivas y expresivas que con frecuencia escapan a las lógicas de la cultura escolar. Acerca de los estudiantes universitarios, Aon y Zapata (2011) presentan un trabajo de encuestas en la UNLP que indaga los consumos tecnológicos y mediáticos (cine, televisión e Internet) de los estudiantes de Comunicación Social, a quienes asumen como "nativos digitales". Partiendo de las conceptualizaciones de García Canclini, la propuesta se orienta a desarrollar espacios significativos para que puedan problematizar sus propios consumos y producciones en estas tramas culturales complejas.

Desde la perspectiva de los Consumos Culturales, se aborda la importancia de estas prácticas en contextos de crisis de la Argentina. En sus estudios sobre el cine, Wortman $(2006,2007)$ examina el consumo de las tecnologías digitales, que promueven relaciones diferentes del sujeto con la cultura, el retraimiento a la privacidad doméstica, la constitución de un "espectador multimedia”. Por su parte, Finquelievich y Prince (2007) comprenden los consumos culturales en los cibercafés. Observan que sus usuarios son niños y adolescentes de bajos recursos o en situación de calle, por lo que tales consumos contribuirían a reducir la brecha digital y social. 
Finalmente, debemos destacar los estudios de relevamiento y análisis de los proyectos de inclusión digital en América Latina. Nos centraremos en el Plan Ceibal (Uruguay) y Conectar Igualdad (Argentina). Desde mediados del año 2008, el Área de Evaluación y Monitoreo de Impacto de Ceibal viene llevando a cabo la evaluación socio-educativa del Plan. El segundo informe de evaluación presentado en 2011, se enmarca en el proceso de investigación y monitoreo proyectado para el trienio 2009- 2011. En sus conclusiones generales, el informe señala que Ceibal ha logrado un importante impacto en la democratización del acceso, en relación con las computadoras y la conexión a Internet, hay un aumento en la apropiación de recursos y en desarrollo de habilidades instrumentales en los niños, y la ampliación de los niveles de acceso a la información escolar por parte de sectores más desfavorecidos. Bajo estos objetivos, se crea en abril de 2012 el Observatorio TIC-DCTE-CIP (Observatorio de Tecnologías de la Información y la Comunicación del Concejo de Educación Inicial y Primaria de Uruguay), que comienza a realizar evaluaciones periódicas sobre la implementación del Plan.

En la Argentina, once universidades nacionales convocadas por el Ministerio de Educación, llevan adelante un estudio cualitativo sobre el impacto pedagógico, institucional y social del PCI. Los resultados de dicha investigación forman parte del informe Nuevas voces, nuevos escenarios: estudios evaluativos sobre el Programa Conectar Igualdad, presentado oficialmente en noviembre de 2011. Entre las primeras conclusiones, se valoran la predisposición de directivos y docentes hacia el uso de las netbooks, la mejora en la retención, la promoción y la convivencia escolar, y su influencia positiva en las familias. Quedan por evaluar los aspectos más problemáticos de una política de inclusión digital: las transiciones de la propiedad personal y el dominio operativo a sus modos complejos de apropiación con fines educativos; del acceso equitativo como derecho social a sus contribuciones específicas a la formación de competencias culturales y ciudadanas.

\subsubsection{Breve recorrido por los marcos regulatorios de la inclusión digital}

Los documentos oficiales en los que se inscribe el PCI se abordan en otra clave: la que articula las primeras aproximaciones al análisis empírico con el Estado de Arte, puesto que permite clarificar los antecedentes inmediatos del modelo. Como se fundamentará, el Análisis de Contenido, en su modalidad cualitativa y predominantemente descriptiva, se aplica a un corpus de documentos oficiales en atención a los propósitos que guían las actuaciones en torno a las tecnologías y la formación ciudadana, dando cuenta de sus desfasajes o entrecruzamientos. En base a un trabajo de inferencia, identificamos un conjunto de núcleos semánticos formalizados en los discursos, para determinar luego sus posibilidades concretas de realización en los contextos educativos. 
Comenzando por el DECRETO 459/2010, se establece en su Artículo $1^{\mathrm{o}}$ :

Créase el "PROGRAMA CONECTAR IGUALDAD.COM.AR" con el fin de proporcionar una computadora a alumnas, alumnos y docentes de educación secundaria de escuelas públicas, de educación especial y de Institutos de Formación Docente, capacitar a los docentes en el uso de dicha herramienta y elaborar propuestas educativas con el objeto de favorecer la incorporación de las mismas en los procesos de enseñanza y de aprendizaje.

Conectar Igualdad responde a la Constitución Nacional, consagratoria de la educación como bien público y derecho personal y social garantizado por el Estado. Es este el fundamental argumento a favor de los procesos de incorporación de tecnología que persiguen el mejoramiento educativo. Así, se reconoce la predisposición por parte de distintos sectores sociales y políticos, en base a un proyecto colectivo. La construcción de ciudadanía, si bien no es enunciada directamente, es definida en términos de derechos y obligaciones como de capacidades de agencia, lo que se desprende del contenido manifiesto de sus objetivos, basados en las premisas de igualdad y calidad: "formar sujetos responsables, capaces de utilizar el conocimiento como herramienta para comprender y transformar constructivamente su entorno social, económico, ambiental y cultural y de situarse como participantes activos en un mundo en permanente cambio.”

Bajo la misma lógica se destaca a la Asignación Universal por Hijo, con incidencia positiva en los niveles de pobreza e indigencia. Una política de inclusión digital establece vínculos directos, de afirmación recíproca, con la AUH como iniciativa verdaderamente equitativa en el cumplimiento de derechos; de ahí la correlación entre inclusión digital e inclusión social, "un gran desafío y una oportunidad histórica”. El Comité Ejecutivo creado a tal fin es responsable de la progresiva incorporación del equipamiento a las aulas, el nivel de conectividad, la obsolescencia tecnológica y la sustentabilidad del Programa.

Acompaña al Decreto el Anexo titulado "Las políticas de inclusión digital educativa. El

Programa Conectar Igualdad. Partiendo de las premisas de la Ley de Educación Nacional (LEN), incluyendo el Título VII “Educación, nuevas tecnologías y medios de comunicación”. El Anexo desarrolla una serie de argumentos, como el trabajo en las escuelas argentinas, el fortalecimiento de esas acciones desde el Ministerio de Educación (ME) mediante equipamiento, líneas focalizadas de capacitación docente, etc. Contempla la relación TIC/ciudadanía:

La integración de las TIC en el ámbito de las instituciones educativas implica repensar tanto la configuración institucional como las prácticas que de ella derivan, el desarrollo curricularescolar, así como el trabajo de docentes y alumnos en las aulas, orientados a integrar estas herramientas en la formación de ciudadanos críticos, creativos y responsables, así como de nuevos perfiles formativos para el mundo del trabajo.

Indica el Documento que estas políticas deben ser definidas en el Plan Nacional de Educación Obligatoria y en el Plan Nacional de Formación Docente, de acuerdo a las metas de 
igualdad e inclusión, calidad educativa y fortalecimiento institucional. En la relación ciudadanía/conocimiento en las sociedades actuales, es donde se manifiestan posibilidades de acceder a la información, como a la adquisición de herramientas cognitivas y competencias "que permitan accionar de modo crítico, creativo, reflexivo y responsable sobre la abundancia de datos para aplicarlo a diversos contextos y entornos de aprendizaje, así como para construir conocimiento relevante en base a ellos". De ahí el imperativo de recuperar los lenguajes de las generaciones de niños/as y jóvenes, desde propuestas que fomenten su interés y participación.

Sintetizando estos fundamentos, se establecen cuatro principios orientadores:

a- Equidad e inclusión: apunta a atenuar las desigualdades entre niños/as y jóvenes de sectores desfavorecidos. Para que la inclusión digital sea una oportunidad de inclusión social, la experiencia de incorporación de TIC debe ser significativa para ellos.

b- Calidad: una perspectiva multidimensional ha de contemplar la actualización curricular, la construcción de conocimiento y la apropiación de los diversos lenguajes, la lectura crítica de la realidad y la participación ciudadana. La promoción de "espacios de diálogo entre las generaciones" intenta reducir la distancia entre prácticas escolares y extraescolares.

c- Formación de la ciudadanía: que permita a los estudiantes desempeñarse "como sujetos conscientes de sus derechos y obligaciones, que practiquen el pluralismo y la solidaridad, respeten los derechos humanos, rechacen todo tipo de discriminación y se preparen para el ejercicio de la ciudadanía democrática”. Se los define como participantes activos, capaces de utilizar el conocimiento para comprender y transformar su entorno social, económico y cultural.

d- Innovación: supone una perspectiva pedagógica donde los docentes se reposicionen desde su conocimiento didáctico: "el dominio instrumental de herramientas tecnológicas resulta solo un paso inicial ya que el sentido esencial consiste en incorporar los aportes de las TIC a la exploración de nuevas estrategias; a la búsqueda de mejores resultados de aprendizaje..." El Plan trasciende los aspectos instrumentales arraigándose en los aspectos simbólicos y subjetivos.

Entre los Antecedentes, se hace referencia a un conjunto de políticas públicas destinadas a la incorporación de TIC en las últimas décadas. Resumiendo:

\section{a- Experiencias de iniciativa nacional}

- Portales y material multimedia, plataformas y recursos digitales y audiovisuales, entre los que se destacan el Portal Educ.ar (2000, relanzado en 2003), enfocado fundamentalmente a brindar apoyo a docentes, directivos y supervisores en la incorporación de las TIC a la práctica docente, y como parte de su proyecto, el Canal Encuentro (desde 2005), un canal educativo y cultural dirigido a todo el público e importante herramienta para la comunidad educativa. 
- Experiencias basadas en el modelo de laboratorio, a partir de la década del '90. Se concentran en la provisión de computadoras, el acondicionamiento o construcción de laboratorios de informática, así como políticas focalizadas de capacitación docente y de incorporación de las TIC: el Programa RedEs (1998 y 1999), el Programa de Mejoramiento de la Enseñanza Media (PRODYMES II) y el Plan Social Educativo (PSE) durante los '90; y entre 2003 y 2009, el Programa de Mejoramiento de la Enseñanza Media II (PROMSE), el Programa de Apoyo a la Política de Mejoramiento de la Equidad Educativa (PROMEDU), el Proyecto de Mejoramiento de la Educación Rural (PROMER), el Programa Integral para la Igualdad Educativa (PIIE) y el FOPIIE, Programa para el Fortalecimiento Pedagógico de las Escuelas beneficiarias del PIIE, etc.

- Experiencias basadas en el modelo 1 a 1 y aulas digitales: a partir del año 2008, el ME a través de Educ.ar comienza a incorporar experiencias piloto en escuelas primarias; a través del Instituto Nacional de Educación Tecnológica (INET), implementa en 2009 el Programa Nacional "Una computadora para cada alumno" (Res. CFE No 82/09) en escuelas técnicas.

\section{b- Experiencias del modelo 1 a 1 de iniciativa provincial:}

En la Provincia de San Luis junto a la Universidad de la Punta, se implementa desde 2008 una política destinada a escuelas primarias estatales, mediante distribución de laptops, conectividad, capacitación docente y entrega de softwares, con los que se abordan los llamados Núcleos de Aprendizaje Prioritarios. En la Provincia de Río Negro, desde 2005 la política consiste en la incorporación de aulas digitales móviles para todas las escuelas de nivel primario, netbooks y pizarras digitales, mientras que la Provincia de La Rioja desarrolla una experiencia similar desde 2010. En el mismo año, la Ciudad de Buenos Aires comienza a llevar adelante el modelo 1 a 1 en sus escuelas primarias, a fin de garantizar el acceso a la alfabetización digital y la inclusión social.

Considerando estos antecedentes, el PCI se crea como una política pública de inclusión digital educativa, destinada a garantizar el acceso y uso de las TIC mediante la distribución de 3 millones de computadoras portátiles a alumnos y docentes de escuelas públicas. Está gestionada por el Ministerio de Educación, en articulación con la Administración Nacional de Seguridad Social (ANSES), el Ministerio de Planificación Federal, Inversión Pública y Servicios, y la Jefatura de Gabinete de Ministros.

\section{Son Objetivos Generales del Programa:}

1) Asegurar el acceso y promover el uso de las TIC a todos los alumnos y alumnas en dichas instituciones públicas de todo el país.

2) Fortalecer las condiciones que incentiven los procesos de transformación institucional, pedagógica y cultural necesarios para el mayor aprovechamiento de las TIC. 
3) Mejorar la calidad de los procesos de enseñanza y de aprendizaje, a partir de integrar el uso de las TIC en las prácticas pedagógicas y el trabajo con las áreas de conocimiento.

4) Promover nuevos aprendizajes en alumnos con diferentes discapacidades y fortalecer procesos de integración a partir de la utilización de las TIC en su formación escolar y laboral.

5) Promover el fortalecimiento de la formación docente en el uso de las TIC y desplegar diferentes acciones de capacitación y desarrollo profesional para su mejor aprovechamiento.

6) Desarrollar una variada y pertinente producción de contenidos y herramientas digitales para dotar de nuevos recursos y materiales de enseñanza adecuados a los modelos 1 a 1.

7) Posibilitar el desarrollo de redes sociales y de redes territoriales comunitarias que promuevan vínculos solidarios entre estudiantes, las instituciones, la comunidad y las familias.

8) Garantizar un piso tecnológico para el aprovechamiento de la conectividad de manera extensiva, la instalación de redes y el uso en las aulas de una computadora por alumno.

El enfoque pedagógico responde a las siguientes características:

a) La tecnología ingresa en las instituciones educativas con el objetivo de actualizar los soportes y recursos pedagógicos y democratizar el acceso a la información y al conocimiento.

b) Hace foco en las prácticas docentes y en las dinámicas institucionales, no se limita a los aspectos técnicos, sino a todo aquello vinculado a los modos de apropiación.

c) Potencia las oportunidades de mejorar la distribución de información, las capacidades de trabajo autónomo y cooperativo, nuevas modalidades y canales de comunicación, en diálogo con la ciencia, la cultura y el trabajo. Orienta propuestas basadas en la complejidad y el aprendizaje activo, la interacción de pares, la autonomía y la auto-organización.

e) La tecnología puede sumarse a los recursos existentes, en relación con laboratorios o talleres, la lectura de libros o la palabra docente. Jerarquiza la tarea de profesores y maestros, en tanto "mediadores fundamentales en la construcción de conocimientos".

En cuanto a las características del modelo 1 a 1, la dotación de una computadora por alumno se asienta en principios basados en el acceso universal. La portabilidad del equipo permite que pueda transportarse a los hogares. Otros aspectos remiten a acciones de seguimiento y la evaluación del Programa, responsabilidad compartida entre Educ.ar y la Organización de los Estados Iberoamericanos (OEI), según lo acordado en el CFE. Pretende generar insumos de utilidad para futuras experiencias de implementación, así como para mejorar las experiencias que se realizan en el país, según dos líneas principales: a. Evaluación y Seguimiento, y b. Investigación y Desarrollo Pedagógico.

El antecedente inmediato del PCI es el PROGRAMA NACIONAL "UNA COMPUTADORA PARA CADA ALUMNO", aprobado por Res. CFE No 82/09. Establece su 
área de implementación y objetivos, en escuelas técnicas públicas de gestión estatal dependientes de las provincias y de la Ciudad Autónoma de Buenos Aires. Responde a la Ley N ${ }^{0}$ 26.206, junto con la Ley $\mathrm{N}^{\mathrm{0}} 26.058$, ante la necesidad de alcanzar mayores niveles de equidad, calidad, eficiencia y efectividad de la Educación Técnico Profesional, como ya hemos destacado.

¿Cómo encuadran estos postulados en las Leyes Nacionales de Educación? Aprobada en 2006, la LEY DE EDUCACIÓN NACIONAL No 26.206, establece, además de lo mencionado: La educación es una prioridad nacional y se constituye en política de Estado para construir una sociedad justa, reafirmar la soberanía e identidad nacional, profundizar el ejercicio de la ciudadanía democrática, respetar los derechos humanos y libertades fundamentales y fortalecer el desarrollo económico-social de la Nación.

Siendo la educación un derecho constitucional, apunta a brindar las oportunidades para desarrollar la formación integral de las personas y definir su proyecto de vida, estableciendo por primera vez la obligatoriedad del nivel secundario. La Ley enumera en su Artículo 11 los objetivos de la política educativa nacional. Seleccionamos a los fines de nuestro estudio:

-Asegurar una educación de calidad con igualdad de oportunidades y posibilidades, sin desequilibrios regionales ni inequidades sociales.

-Garantizar una educación integral que desarrolle todas las dimensiones de la persona y habilite tanto para el desempeño social y laboral, como para el acceso a estudios superiores.

-Brindar una formación ciudadana comprometida con los valores éticos y democráticos de participación, libertad, solidaridad, resolución pacífica de conflictos, respeto a los derechos humanos, responsabilidad, honestidad, valoración y preservación del patrimonio cultural.

-Fortalecer la identidad nacional, basada en el respeto a la diversidad cultural y a las particularidades locales, los valores universales y la integración regional y latinoamericana.

-Garantizar la inclusión educativa a través de políticas universales y de estrategias pedagógicas y de asignación de recursos, con prioridad a los sectores más desfavorecidos.

-Asegurar la participación democrática de docentes, familias y estudiantes.

-Fortalecer la lectura y la escritura, condiciones básicas para la educación a lo largo de toda la vida, la construcción de ciudadanía responsable y la libre circulación del conocimiento.

-Desarrollar las competencias necesarias para el manejo de los nuevos lenguajes producidos por las tecnologías de la información y la comunicación, etc.

Una temática enunciada en la Ley en su Artículo 67 expresa derechos y obligaciones docentes, el derecho a la capacitación y actualización integral, gratuita y en servicio, a lo largo de toda su carrera; significativamente, se sostiene la obligación de "capacitarse y actualizarse en forma permanente". Otro tópico lo constituye la igualdad educativa. El Ministerio de Educación: 
fijará y desarrollará políticas de promoción de la igualdad educativa, destinadas a enfrentar situaciones de injusticia, marginación, estigmatización y otras formas de discriminación, derivadas de factores socioeconómicos, culturales, geográficos, étnicos, de género o de cualquier otra índole, que afecten el ejercicio pleno del derecho a la educación.

Vinculada con la igualdad, se destaca la cuestión de la calidad: "las condiciones materiales y culturales para que todos/as los/as alumnos/as logren aprendizajes comunes de buena calidad, independientemente de su origen social, radicación geográfica, género o identidad cultural.” Las disposiciones específicas comprenden el dominio de las TIC para la inclusión en la Sociedad del Conocimiento; el ejercicio y construcción de la memoria colectiva, para generar reflexiones y sentimientos democráticos y de defensa del Estado de Derecho; el conocimiento de los derechos y la diversidad cultural de los pueblos indígenas, entre otras.

El Título VII “Educación, nuevas tecnologías y medios de comunicación”, puntualiza el reconocimiento de Educ.ar Sociedad del Estado como responsable del desarrollo de contenidos del Portal Educativo, como la realización de actividades de producción y emisión de programas de televisión educativa y multimedial destinados a fortalecer y complementar las estrategias nacionales de equidad y mejoramiento de la calidad de la educación.

Otro aspecto notable es el énfasis en la institución educativa. Se la define como "la unidad pedagógica del sistema responsable de los procesos de enseñanza-aprendizaje destinados al logro de los objetivos establecidos por esta Ley." Apunta a promover espacios de articulación entre las instituciones de la zona, a la vez que mantener vínculos regulares y sistemáticos con el medio local, la participación de la comunidad y experiencias educativas fuera del ámbito escolar.

Los ejes de la igualdad y la calidad estructuran también los derechos y deberes de los alumnos en torno a "una educación integral e igualitaria en términos de calidad y cantidad, que contribuya al desarrollo de su personalidad, posibilite la adquisición de conocimientos, habilidades y sentido de responsabilidad y solidaridad sociales y que garantice igualdad de oportunidades". Añade la Ley que los estudiantes deben ser respetados en su libertad de consciencia y en el marco de una convivencia democrática, para integrar centros, asociaciones y clubes de estudiantes u otras organizaciones comunitarias. Las obligaciones comprenden participar en actividades complementarias, respetar la dignidad e integridad de otros, etc.

La LEY TÉCNICO-PROFESIONAL N 26.058/05, cuya aprobación es inmediatamente anterior a la LEN, constituye el segundo encuadre legal al que responde el PCI. Están contenidas las instituciones de gestión pública y privada, de nivel medio, de nivel superior no universitario y de formación profesional. Entre los objetivos, destacamos el carácter integral de la formación, la articulación de las instituciones en los ámbitos de la ciencia, la tecnología, la producción y el 
trabajo; y la promoción de la cultura del trabajo, la producción para el desarrollo sustentable y la consciencia en los derechos laborales. Asimismo, la Ley apunta a favorecer "niveles crecientes de equidad, calidad, eficiencia y efectividad de la Educación Técnico-Profesional, como elemento clave de las estrategias de inclusión social, de desarrollo y crecimiento socioeconómico del país...” Y entre sus objetivos específicos:

Formar técnicos medios y técnicos superiores en áreas ocupacionales específicas, cuya complejidad requiera la disposición de competencias profesionales que se desarrollan a través de procesos sistemáticos y prolongados de formación para generar en las personas capacidades profesionales que son la base de esas competencias.

La disponibilidad de TIC se presenta como componente estructurante de esta formación. En el Capítulo II, Artículo 31, se detalla el rol del Instituto Nacional de Educación Tecnológica (INET) en el equipamiento para talleres, laboratorios y entornos virtuales, de manera que "permitan acceder a saberes científico técnicos-tecnológicos actualizados y relevantes y desarrollar las prácticas profesionalizantes o productivas en las instituciones..."

Cabe destacar la orientación inclusiva de la Ley. En el Capítulo VII, se establece que el ME implementará las acciones para garantizar "el acceso, permanencia y completamiento de los trayectos formativos en la educación técnico profesional, para los jóvenes en situación de riesgo social o con dificultades de aprendizaje" (materiales o becas, sistemas de tutorías y apoyos docentes). También prevé la incorporación de mujeres como alumnas, "para la expansión de las oportunidades educativas de las mujeres en relación con la educación técnico profesional”.

En 2015, el PCI junto con Primaria Digital se subsumen al PLAN NACIONAL DE INCLUSIÓN DIGITAL EDUCATIVA (PNIDE), por Res. CFE No 244. Parte de la LEN en cuanto a las opciones educativas basadas en el uso de las TIC que colaboren en el cumplimiento de los fines de la misma. Básicamente, el PNIDE inaugura una segunda etapa cuando el PCI ya ha cumplido con la entrega de netbooks al $100 \%$ de las instituciones previstas, el $88 \%$ cuenta con servidores escolares y el $61 \%$ tiene conexión a Internet, Educ.ar ha desarrollado para diferentes destinatarios y modalidades un conjunto de propuestas de uso educativo de las TIC. A esto se suman los avances en el Postítulo TIC y Educación en el marco del Programa Nacional de Formación Permanente "Nuestra Escuela", del cual se esperan 4.500 egresados en 2014.

Para ello se propone el Documento "Intensificación del uso de TIC en las escuelas para la mejora de los procesos de enseñanza y aprendizaje. Temas prioritarios año 2015", de acuerdo al Plan Nacional de Educación Obligatoria y Formación Docente 2012-2016 (Res. CFE 188/12). Presentado en Anexo, detalla los Ejes Prioritarios. Centrados en la capacitación docente, se orientan a fortalecer el uso pedagógico, afianzar los cambios organizacionales necesarios, 
alentar y visibilizar la producción de contenidos y aplicaciones para la enseñanza, estimular el protagonismo de los jóvenes y los proyectos innovadores por parte de sus docentes.

$\mathrm{Y}$ atendiendo a los derechos estudiantiles y a la necesidad de reconocer, formalizar y alentar las diversas formas de participación escolar, se reglamenta en 2013 la LEY NACIONAL DE CREACIÓN DE LOS CENTROS DE ESTUDIANTES N²6.877. Destaca que, en sus distintos niveles y ramas, las autoridades educativas deben reconocer los centros de estudiantes como órganos democráticos de representación, lo que supone una importante forma de igualación. Son algunos de sus principios organizadores: fomentar la formación de prácticas democráticas y de defensa de los derechos; afianzar el derecho a la libre expresión de las ideas; defender el pleno ejercicio de los derechos estudiantiles; contribuir al reconocimiento de la educación como bien público y derecho social; colaborar con la inserción en el ámbito social y en beneficio de la comunidad; promover la participación activa y responsable; etc.

A fines del mismo año, se promulga la LEY DE LOS CENTROS DE ESTUDIANTES DE LA PROVINCIA DE BUENOS AIRES No 14.581. Bajo los fines de la Ley Nacional, dictamina las formas del sistema electoral de los representantes, las obligaciones y derechos de cada órgano de gobierno, así como las funciones de las autoridades escolares en facilitar las elecciones del Centro y colaborar en sus objetivos, promoviendo "la participación activa del estudiantado en la dinámica, constitución y sostenimiento de la vida democrática en la sociedad actual, desde su puesta en práctica en el ámbito escolar y no sólo como enunciación teórica."

Concluyendo, a partir del análisis de los discursos legales que sustentan la creación del PCI, se verifica la recurrencia de núcleos significantes que se retroalimentan entre sí y que son objeto de resignificaciones, contradicciones y desplazamientos en las realidades educativas:

-La concepción humanística de la educación, considerada un bien público, un derecho social y personal, junto con el rol insoslayable del Estado nacional como garante de su cumplimiento.

-La articulación entre calidad e igualdad, en base a acciones de innovación tecnológica, pedagógica e institucional. Como declaró la UNESCO en 2005, la educación es de calidad cuando se logra democratización en el acceso y apropiación del conocimiento por parte de todas las personas, sobre todo en condiciones de desigualdad social.

-El eje inclusión digital/inclusión social que instituye plenamente el PCI, que refuerza sus vinculaciones con otras políticas de igualación de oportunidades, entre las que destaca la AUH.

-La construcción de ciudadanía en torno a derechos y obligaciones, valores y competencias: responsabilidad, respeto a la diversidad, consciencia para comprender y transformar el entorno social y cultural. 
-La relación estrecha ciudadanía/TIC, ligada a sus potencialidades en el acceso democrático a la información y la construcción de conocimiento en sociedades mediatizadas.

-Las TIC no solo como equipamiento sino en tanto lenguajes, en atención a los saberes de los jóvenes y su integración a las aulas junto con otros materiales disponibles, incluyendo los propios de la cultura escrita, en la comprensión de las aristas simbólicas y afectivas de esos usos.

-La necesidad de una política de capacitación y actualización en el uso pedagógico de TIC, a la vez derecho y obligación de los docentes en tanto mediadores centrales del conocimiento.

-El rol de la institución en la realización de acciones estratégicas de coordinación, reconfiguración y fortalecimiento orientadas a la implementación del modelo 1 a 1 .

-La participación escolar como parte de la formación ciudadana, vía los centros de estudiantes, en representación de sus derechos y en sus vinculaciones con la comunidad.

Ahora bien, la dimensión ciudadana de educar en entornos tecnológicos no está claramente establecida. En lo normativo, hay cierto desfasaje entre las propuestas de inclusión digital y la orientadas a la participación estudiantil. De todos modos, la Ley de Educación Nacional a la que adscribe toda política educativa, sostiene el imperativo de reconocer, legitimar y orientar las actuaciones de los jóvenes en tanto portadores de derechos, pero también dotados de capacidad de agencia. Esto es, una educación tendiente no solo a la convivencia y la integración social, sino como medio que permite otorgar a cada sujeto capacidades de autonomía, que lo constituye como tal. Las Leyes de creación de los Centros de Estudiantes atribuyen reconocimiento formal a experiencias ya existentes entre los jóvenes, aquellas que las instituciones escolares, en mayor o menor medida, validan como ámbitos de promoción de ciudadanía y de adscripción identitaria.

En lo relativo a Conectar Igualdad, constituye una política de alcance masivo y de mayor relevancia en la Argentina, pero no completamente novedosa. Además de experiencias similares en Latinoamérica (cuyo principal exponente es Ceibal), reconoce como antecedentes valiosas iniciativas provinciales de cierto recorrido en los niveles primario y secundario, si bien algunas investigaciones tempranas han considerado que sus características difieren notablemente entre sí. Pueden distinguirse entre políticas más integrales (como en el caso de la Provincia de Buenos Aires) y aquellas que se han focalizado en algún lineamiento particular, como la capacitación docente, la provisión de equipamiento, la extensión de la conectividad o los recursos educativos, más allá del grado de desarrollo alcanzado en cada caso (Bilbao y Rivas, 2011).

Si los documentos oficiales abundan en referencias a la igualdad social, la democratización de la educación y su valor potencialmente transformador, la dimensión ideológica de las tecnologías está ausente. Muestran continuidades con una retórica mercantilista: no solo no la cuestionan sino que parecen movilizarse en esa dirección. En palabras de Dussel, "pareciera que 
la inclusión digital implica volverse un cliente y consumidor de medios sociales, que son quienes ahora parecen definir la participación social” (2016: 156). El paradigma del conocimiento colaborativo se afirma como la arena neutral de la comunicación entre pares, la intervención ciudadana o la creación de contenidos. En los discursos analizados, no se prevén los espacios o estrategias para examinar los entramados políticos y comerciales que definen a las TIC, ni se interpelan los dispositivos de sujeción a una cultura digital estandarizada. Estas contradicciones imponen nuevos y más importantes desafíos a un proyecto de construcción de ciudadanía. 


\section{CAPÍTULO 2: ENCUADRE TEÓRICO-METODOLÓGICO}

\subsection{Conceptos ordenadores de la investigación}

\section{Ser o no ser (digital)}

La primacía de las tecnologías tuvo hondas repercusiones en los estudios en comunicación desde la década del '50, por entonces consistente con las teorías de matriz funcionalista y críticoreproductivista y las teorías del desarrollo que derivaban de ellas. En el ámbito de la educación, el supuesto básico era la relación directa y necesaria entre la incorporación de las tecnologías y la calidad educativa, organizadas ambas en torno a la idea filosófica del "progreso" y las expectativas en los alcances de la razón científico-técnica, esta vez ligada a decisiones políticas y económicas concretas. Las propuestas de innovación tecnológica sirvieron en la práctica para justificar las relaciones de dominio, imponer a Estados Unidos como modelo de desarrollo y naturalizar la condición de sub-desarrollo como un estado originario y establecido.

A partir del escenario inaugurado por la CMSI, se refuerza la hegemonía de las expectativas tecno-utópicas, cristalizando un entramado de intereses económicos, horizontes ideológicos y decisiones políticas con vastas implicaciones en Latinoamérica. Ya Nicholas Negroponte, en su famoso libro Being Digital, había delineado los contornos de la era digital:

La tecnología digital puede ser una fuerza natural que propicie un mundo más armónico (...) El acceso, la movilidad y la habilidad para propiciar el cambio son los factores que harán que el futuro sea diferente del presente. La superautopista de la información puede estar de moda ahora, pero subestima el futuro. Se extenderá más allá de lo que nadie haya sido capaz de predecir (1995: 139-140, el subrayado es nuestro). ${ }^{5}$

Pero en América Latina, los postulados del difusionismo tecnológico comienzan a someterse a discusión, definiendo los procesos de desarrollo bajo otras premisas. Irrumpen las preocupaciones acerca del acceso diferencial a las TIC, que se dio en llamar brecha digital. Desde la Comunicación para el Desarrollo, Rocangliolo (2003) relaciona el uso tecnológico con la

${ }^{5}$ Nicholas Negroponte - fundador del Media Lab del Massachussets Institute of Technology (MIT) y de la revista Wired-publicó la primera edición de Ser digital en 1995, que fue traducido a más de 40 idiomas. Muchos lo consideran profético y sigue teniendo enorme influencia en la investigación y en las políticas de inclusión digital. Como otros en la región, el Plan Conectar Igualdad está basado en su modelo OLPC (one laptop per child: una computadora por chico), desarrollado para países del Tercer Mundo. 
disolución de los espacios públicos, que la Sociedad de la Información estaba llamada a garantizar. Paradójicamente, la informatización parece alimentar la debilidad institucional y adecuarse a los parámetros del neoliberalismo económico. El término Sociedad del Conocimiento es también problemático: relega el análisis crítico de las variables que promueve una marginación creciente entre los países y al interior de cada uno (Mattelart, 2003).

Desde esta perspectiva, las posibilidades de una ciudadanía genuina convocan la participación en la toma de decisiones por parte de los/las ciudadanos/as y las comunidades, y también en lo relativo al diseño y aplicación de las tecnologías favorables a esos procesos. No obstante, como ha analizado exhaustivamente Sandoval (2012), la CMSCI atribuye a la infraestructura el rol protagónico en la SI, a la que hace depender de los requerimientos del mercado. Se comienzan entonces a problematizar las vinculaciones entre comunicación y democracia, en torno a la necesidad de debates plurales que animen el ejercicio ciudadano, la demanda de calidad de la información y el rol de los Estados. Especialmente cuando las prácticas que estas condiciones habilitan, eventualmente contradicen no solo los espacios tradicionales de interpelación política, sino además la concentración hegemónica de los medios masivos.

\section{Precisiones conceptuales en el campo de la comunicación/cultura}

Las tecnologías cobran centralidad como campo de confluencia de múltiples reflexiones. Los EC debaten cierto reduccionismo persistente sobre los medios de comunicación, centrados en las estructuras institucionales y los modos de producción, y apuntan a reconsiderar las relaciones entre esas tecnologías y las formas culturales en que se materializan en coyunturas históricas específicas. Subyace una perspectiva materialista de la cultura, que ya en los textos seminales de Birmingham, se confunde con la concepción gramsciana de hegemonía:

Es todo un cuerpo de prácticas y expectativas en relación con la totalidad de la vida: nuestros sentidos y dosis de energía, las percepciones definidas que tenemos de nosotros mismos y de nuestro mundo. Es un sistema vivido de significados y valores - constituyentes y constituidos- que en la medida que son experimentados como prácticas parecen confirmarse recíprocamente (Williams, 2009: 145).

Las transformaciones tecnoculturales generarán la necesidad de revisar la capacidad explicativa de las distintas perspectivas teóricas, cuando la comunicación deja de ser una cuestión de técnicas o medios, para transformarse en una dimensión constitutiva de la cultura. De modo que no hay ninguna mirada neutra sobre las tecnologías: de acuerdo a Williams (1992), constituyen instituciones sociales, que se inscriben en las contradicciones entre sus potencialidades democráticas y las condiciones económicas y sociales específicas que determinan su aplicación. 
Como sabemos, la propuesta teórica de Jesús Martín Barbero recupera los estudios británicos en sus aproximaciones a las mediaciones culturales. Esto es, los espacios de articulación entre las lógicas de producción, y de recepción y uso de los medios y otras tecnologías, que se materializan en los procesos de re-significación que las audiencias o receptores hacen de la cultura masiva, subvirtiendo el sentido original y hegemónico. En términos del autor, "el campo de lo que denominamos mediaciones se halla constituido por los dispositivos a través de los cuales la hegemonía transforma desde dentro el sentido del trabajo y la vida de la comunidad" (1987: 207). ${ }^{6}$ Las TIC reforzarán la importancia de las mediaciones tecnológicas en la constitución de los vínculos sociales y en la producción de conocimiento colectivo, en tanto articulan las situaciones inmediatas de uso con sus condiciones socio-económicas, políticas y culturales más amplias.

Los estudios de Comunicación han hecho destacados intentos por definir a las TIC. Cabrera (2006) cuestionaba a las "nuevas tecnologías" como un nombre vacío que designaba indistintamente video, televisión por cable, computadoras, Internet, teléfonos celulares y muchos otros. Por su parte, Moyano (2006) las ha clasificado en analógicas (televisores, DVD, equipos de sonido, etc.) y digitales, medios o tecnologías informáticas (computadoras, utilitarios e Internet). Más recientemente, han sido denominadas "tecnologías interactivas": aquellas utilizadas para el almacenamiento, tratamiento, gestión, creación y recepción de mensajes en todo tipo de formatos, que permite a los usuarios interactuar con otros en un entorno tecnológico, desarrollando procesos, creando a través de la tecnología y en ella (Cabello, 2008a, 2009). De este modo, utilizaremos indistintamente los términos TIC, tecnologías digitales o interactivas.

En tanto estas prácticas están plenamente inscriptas en matrices de producción de sentido, exploramos el orden de lo representacional. De acuerdo a Stuart Hall (2010), toda práctica social es mediada por el lenguaje, concebido como un sistema de signos y representaciones, dispuesto por códigos y articulado mediante diversos discursos. Aunque hay contribuciones que distinguen representaciones e imaginarios, consideramos aquí las íntimas vinculaciones que los involucran: siguiendo a Castoriadis, Cabrera define al imaginario como "la capacidad creativa de hacer aparecer representaciones y del conjunto de representaciones, afectos y deseos que de ella resultan” (2006: 17). Las perspectivas antropológicas recurren a lo que el psicoanálisis lacaniano entiende como lo simbólico, el repertorio de símbolos con que una sociedad tematiza y legaliza

${ }^{6}$ R. Sandoval (2013) reconoce al menos ocho acepciones que parecen subordinarse a la definición citada. Principalmente, a- la referencia al papel de géneros "bisagra" en otros géneros (de lo tradicional/popular a lo moderno/masivo); b- el rol de ciertos actores como "mediadores"; c- los medios como lugares de mediación entre esas audiencias populares y el Estado-Nación; d- aquellos dispositivos de enunciación que permiten que esos productos cumplan la función de mediación cultural. 
las imágenes de sí misma y se proyecta hacia lo diferente. Lo instituyente, aquello que se apoya en lo instituido, está siendo reelaborado, una y otra vez (Silva, 1992; García Canclini, 1999). ${ }^{7}$

En este punto, el problema de las representaciones orienta una doble pregunta: cómo comprender las transformaciones implicadas en los procesos de globalización, y cuáles son en este contexto las posibilidades de construcción de identidades colectivas. En el marco de lo que Z. Bauman ha llamado "modernidad líquida" (2013), la pluralidad de espacios, regulados por criterios contingentes y flexibles, mina los principios universales y las creencias colectivas que servían de anclaje a las identidades. En estas tensiones se realiza cierto vaciamiento de los referentes tradicionales como la nación, como argumentaba Ortiz (1997). No obstante, más recientemente el autor brasileño ha cuestionado la "sociedad global" como unidad homóloga a la sociedad nacional, definida por la integración coherente e integrada de las partes. Entiende a la globalización como una nueva situación, que penetra y articula las diversas partes de esta totalidad, "lo que permite evitar un falso problema, la oposición entre homogéneo y heterogéneo, y nos lleva a pensar simultáneamente lo común y lo diverso" (2014: 27).

Ahora bien, si la globalización expresa los poderes avasallantes del mercado, su tendencia a uniformar saberes, gustos e intereses a nivel planetario, abre asimismo cambios radicales en los modos en que los sujetos se apropian de las TIC, atribuyéndoles sentidos alternativos y eventualmente transformadores. De manera que son las comunidades locales las que están mediando las relaciones entre la cultura y la tecnología. "La comunicación y la cultura deja entonces de tener la figura de intercambio entre creadores y consumidores, para asumir la tarea de disolver esa barrera social y simbólica descentrando y desterritorializando las posibilidades mismas de la producción cultural y sus dispositivos" (Martín Barbero, 2010: 147).

Ciertamente, las identidades no son fijas ni unívocas, sino construcciones socio-históricas que articulan en los sujetos muy diversas experiencias, modos de vivir y de representarse el mundo. Entonces, cabe analizar si los procesos de globalización no conllevarán, más que una dilución de las identidades, transformaciones estructurantes en gran medida materializadas en los usos tecnológicos, que requieren otras miradas y nuevas claves explicativas. Nos interesa especialmente cómo se construyen las identidades juveniles, si devienen capaces de evocar referentes novedosos asociados a las experiencias con las TIC, al tiempo que otros tradicionales como la escuela y la nación. Identidades que expresan, como veremos, no solo procesos de desterritorialización sino

\footnotetext{
${ }^{7}$ En trabajos anteriores (2015b), hemos indagado las mediaciones tecnológicas en sus vinculaciones con las mediaciones urbanas, en su doble componente funcional-simbólico. La antropología urbana entiende al componente funcional como el conjunto de servicios y consumos colectivos ligados al valor de uso, y el componente simbólico, aquel capaz de desarrollar determinadas representaciones, significados y emblemas identitarios locales. Ambos aspectos interactúan entre sí, reelaborando construcciones imaginarias sobre la ciudad vivida.
} 
también de re-territorialización, formas en que se resignifica lo global desde las prácticas cotidianas y locales. Porque, como ha destacado Follari, "a la globalización cada uno entra (y R. Ortiz lo ha subrayado muy bien) desde un determinado lugar” (2003: 66).

\section{Potencial y crítica de la Ecología de los Medios}

En distintas publicaciones, Martín Barbero (2002a, 2002b, 2009) asume que la globalización ha dejado de ser una cuestión de medios para pasar a configurar un ecosistema comunicativo, definido no solo por nuevos dispositivos, sino por lenguajes, sensibilidades, modos de socialización, ese sensorium benjaminiano que produce la desorganización de los saberes, como de los lugares tradicionales que antes los instituían y legitimaban. El término proviene de la Media Ecology (también llamada Escuela de Nueva York, de Toronto o de San Luis). Fue oficialmente introducido por Neil Postman en 1968, pero ya había sido utilizado por Marshall McLuhan a principios de esa década. Scolari $(2010,2015)$ resume la idea básica: las tecnologías -en este caso, las tecnologías de la comunicación- generan ambientes que afectan a los sujetos que las utilizan. Incluye todos los aspectos de la comunicación, desde las relaciones entre los medios y la economía hasta los cambios perceptivos y cognitivos de los sujetos a partir de sus exposiciones a las TIC.

Por cierto, los nuevos saberes están profundamente deslocalizados y desjerarquizados, asumen más rasgos del hipertexto, la experiencia audiovisual y una oralidad secundaria (Ong, 2000), que de la cultura predominantemente letrada de la escuela. La teoría contemporánea del hipertexto lo concibe como una red heterogénea de espacios textuales a partir de zonas separadas del discurso, que permite el acceso más fácil y evita un favorecimiento a ciertos grupos. De acuerdo a Moulthrop (1989, 1991), configura un medio plural cuya función no es solamente difundir información, sino mejorar las condiciones en que la gente puede intercambiar, desarrollar y evaluar ideas. ${ }^{8}$ Ahora bien, si el hipertexto desafía nuestras concepciones de la lecto-escritura, no las abandona por completo: reconsidera la figura del lector/usuario a partir de sus experiencias múltiples con libros y pantallas, lo que relativiza los alcances de la mentada "revolución digital".

Pero el aspecto más problemático del "ecosistema comunicativo" reside en aquello que el mismo Martín Barbero había cuestionado en su clásico libro de 1987: el desmedido mediacentrismo y la despolitización de sus efectos. Para Piscitelli (2009), otro de los principales

${ }^{8}$ El término "hipertexto" es deudor de teóricos de la semiología y la literatura como R. Barthes y U. Eco. Asociado a las tecnologías informáticas, fue acuñado por T. H. Nelson a fines de los ' 60 a partir de la idea de V. Bush de 1945. George Landow (1995) es el más importante exponente de esta tradición. Define al hipertexto como un texto compuesto por un bloque de palabras o imágenes vinculadas electrónicamente por múltiples caminos que descentraliza la figura del autor, en una textualidad abierta y perpetuamente inacabada. 
referentes de la Media Ecology, estos cambios crean efectos sociales, culturales, técnicos y cognitivos cuyo nivel de efectividad depende de la naturaleza, alcance y nivel de implementación de la tecnología. En Historia de la Sociedad de la Información (2002), Mattelart le atribuía al enfoque cierto tecno-optimismo acrítico, supeditado a los imperativos ideológicos del imperialismo a los que hay que "adaptarse". El progreso deviene entonces en mito renovado, en tanto convoca una fuerte connotación de lo deseable y define un destino en el que la tecnología emerge como motor de desarrollo social, como señaló con justeza Schmucler (1997).

Más recientemente, R. Cabello (2011) ha definido el concepto de "vector tecnológico", bajo la premisa de que las sociedades latinoamericanas establecen con la tecnología una relación de sujeción y consumo, ya que carecen de recursos tanto para la producción como para la apropiación crítica. Conforme a su perspectiva, decidimos caracterizar este contexto antes que como "ecosistema", como un entorno tecnocultural complejo y discontinuo, que supone la oferta y disposición de dispositivos cada vez más variados, a la vez que verifica la participación diferencial de los sujetos. El concepto revela las lógicas de conflicto y poder que animan esas interacciones: no solo agudizan las diferencias sino que favorecen procesos de naturalización según los cuales “el artificio de ese ambiente se desdibuja por la fuerza de su presencia y por la eficacia de sus propias estrategias de seducción" (Cabello, 2008b: 136).

La mirada ecológica ha tenido además hondas derivaciones en las políticas de alfabetización digital, basadas en la brecha entre nativos e inmigrantes digitales (Piscitelli, 2005; García Canclini, 2007; Cassany y Ayala, 2008). Según los términos introducidos por Marc Prensky en 2001, los "inmigrantes" son los mayores de 30 años que han tenido una infancia ligada a la escritura, y los "nativos", niños y jóvenes que han nacido rodeados de celulares, pantallas y teclados. Entre ambos hay una "distancia conductual y comunicativa abismal", respectivamente: procesamiento secuencial y lento vs. paralelo y rápido; itinerarios de lectura lineales vs. abiertos; modalidad discursiva escrita vs. multimodal; modalidad de trabajo individual vs. interactivo; textos extensos vs. textos breves; etc. Los más jóvenes se encuentran estimulados por las pantallas, tienen usos e intereses vinculados a ellas y responden a una cultura multitasking o multitarea (la capacidad de gestionar varias tareas al mismo tiempo). En cambio, se atribuye a los inmigrantes o extranjeros un rol más pasivo, consumista y periférico, propio del libro y de la Web 1.0

A nuestro juicio, los planteos relativos a la brecha generacional entre adultos/docentes y los jóvenes/estudiantes devienen en superficiales y tecnicistas. Primeramente, el concepto de nativos deja a los más jóvenes la habilidad, la iniciativa y la responsabilidad ligadas a los medios informáticos, a la vez que culpa o excusa, según el caso, a los inmigrantes por no promover experiencias más creativas o desafiantes, especialmente en el ámbito educativo. Esta posición 
naturaliza la brecha digital en términos de edad, a la vez que relega el impacto de las desigualdades socio-económicas. Tampoco está claro por qué los adultos tendrían una actitud más pasiva frente a la web, ni mucho menos por qué esta se debe a su educación analógica. ${ }^{9}$

Nuestro posicionamiento teórico tiende a superar la Ecología de los Medios, para recuperar las reformulaciones de Cabello. En su propuesta de los procesos de migración digital:

se ponen a disposición un conjunto de condiciones, orientaciones, acciones y recursos que, de manera planificada y explícita, sistemática y recurrente, contribuyen a que las personas puedan relacionarse del modo más fluido posible con las tecnologías digitales, apropiándose de ellas en sus múltiples posibilidades y para sus diversos usos, integrándolas en sus planes de acción e interacción, evaluando sus alcances y limitaciones, y tomando nota de sus cambios (2013: 22).

La retórica nativos/inmigrantes digitales es insostenible: una persona que no puede reconocerse como nativo digital no necesariamente se define como inmigrante. Pero además es necesario recuperar la dimensión propiamente socio-histórica de las TIC, sus fundamentos ideológicos, las particularidades culturales, políticas y pedagógicas de las instituciones donde se inscriben, donde los sujetos pueden proponer, consensuar y movilizar proyectos genuinos de migración digital. Porque esas competencias no son naturales sino socialmente construidas, involucran al conjunto de los actores, de modo que estos logren mejorarlas y ayudar a otros en esa dirección. La educación deberá superar las falsas antinomias para promover espacios dinámicos de aprendizaje, que involucren los medios tecnológicos con que los chicos se enfrentan en su vida social y sobre los cuales han desarrollado habilidades específicas de apropiación.

\section{Apuntes desde las teorías de la educación y del aprendizaje}

Cuando se habla de inclusión social, la escuela puede devenir en instrumento de reproducción ideológica, como también en espacio de disputas en el campo de lo simbólico. Diversas teorías de la educación han hecho esfuerzos sistemáticos para delinear las tensiones entre las posibilidades de igualdad socio-educativa y el acceso cada vez más diferencial al capital cultural que le es específico. La pregunta sobre los principales modelos teóricos se orienta a identificar cuáles subyacen a los discursos hegemónicos de las políticas estatales. Pero, asimismo, en qué términos

9 Incluso las operaciones más superficiales como cortar y pegar requieren de habilidades que los nativos digitales no poseen naturalmente ni en todos los casos. Además, el desarrollo de competencias comunicativas prevé conocimientos ligados a la escritura analógica. Los escritores expertos pueden ser incluso más escépticos a la hora de seleccionar información y hacer un uso más productivo de los recursos de la Web. 
la función social de la escuela es constantemente renovada, discutida, resignificada, por los distintos actores involucrados, definiendo desde allí sus potencialidades político-pedagógicas.

Haremos un somero recorrido por las teorías de la educación, retomando las formulaciones que hace ya varios años hiciera Dermeval Saviani (1983). Diferencia dos grupos: las teorías "no críticas" y las teorías “críticas o crítico-reproductivistas". Las primeras entienden a la educación como un instrumento de igualdad social, una fuerza integradora y autónoma que tiene por función cohesionar los lazos sociales en una sociedad esencialmente armoniosa. Comprende:

-La pedagogía tradicional, que define a la educación como un derecho de todos y un deber del Estado, a la vez que pieza clave del proyecto de modernización y racionalización de las sociedades. En la Argentina, estos valores fueron fundantes de los sistemas de enseñanza a partir del siglo XIX, una organización escolar rígida y burocrática, un modelo pedagógico verticalista de transmisión cultural en el que el docente se erige como autoridad del saber. El alumno es convocado como "ciudadano", si bien en la práctica quedaron muchos excluidos del proyecto.

-La pedagogía tecnicista aplica los principios de racionalidad, productividad y eficiencia. El centro pasa a ser la planificación, coordinación y control de los medios para la consecución de fines: “aprender a hacer”. Con esto, el problema de la exclusión terminó por agravarse, al aumentar el nivel de la burocratización, la fragmentación del trabajo pedagógico, la deserción y repitencia de los alumnos que no podían adaptarse. Esta corriente tuvo notable impacto en Argentina, donde dio sustento teórico a las sucesivas reformas educativas del siglo XX (como las relativas a la rama técnica) y a las políticas tempranas de implementación de las tecnologías.

A propósito de las teorías "críticas", entienden que la escuela ha contribuido históricamente a favorecer la desigualdad social y a reproducir la ideología dominante. Nos interesa mencionar:

-Teoría del sistema de enseñanza como violencia simbólica: sus máximos referentes, $P$. Bourdieu y J. C. Passeron, parten de la premisa de que toda sociedad se estructura como un sistema de relaciones de fuerza material. A la violencia material o económica ejercida por los grupos o clases dominantes sobre los grupos o clases dominados, corresponde la violencia simbólica o cultural. Es en el sistema institucionalizado de enseñanza donde la acción pedagógica tiende a reforzar y naturalizar los modos de imposición de la cultura dominante.

-Teoría de la escuela como aparato ideológico del Estado: Althusser plantea que la ideología tiene existencia material, arraigada en prácticas materiales reguladas por instituciones también materiales, que operan en la reproducción de las relaciones de dominación capitalistas. La escuela es el AIE más acabado: durante años y desde la más temprana edad, enseña contenidos disciplinares, saberes prácticos y esquemas morales de acuerdo al rol que cada grupo está destinado a cumplir en la sociedad, lo que vuelve imposible la lucha de clases. 
Asumimos aquí la Pedagogía Dialógica de Freire (1973, 1985, 1998), que supera las corrientes reproductivistas para abordar a la educación desde sus conflictos y determinaciones socio-históricas, dinamizadoras de la reproducción de intereses como de espacios concretos de construcción de autonomía. A las posibilidades de la práctica pedagógica como práctica de la libertad, subyace una concepción de conocimiento crítico: aquel capaz de objetivar la realidad, identificar sus contradicciones, explicar las diferencias y plantear alternativas para una práctica transformadora de una sociedad que es valorada como injusta. Los conceptos freirianos están siendo repensados a la luz de las tensas vinculaciones entre democracia y educación. Así, "una cuestión central de la educación formal es cuál es el rol, si existe uno, que las instituciones y las prácticas educativas deberían tener en la constitución del pacto social que articule la democracia" (Torres, 2008: 208).

En la misma línea crítica, la educación radical (Giroux, 1997, 2013) no puede ser reducida a la transmisión de conocimientos y destrezas. Entronca con los EC, ofreciendo un terreno teórico fértil para reconsiderar la escolarización como una forma de política cultural, profundamente implicada en la construcción crítica de conocimientos. Quienes asumen esta perspectiva rechazan los criterios de productividad económica y apuntan al propósito de formar ciudadanos, un proyecto que es consciente de las relaciones de dominación que articulan las múltiples situaciones escolares, a la vez que propicia en los estudiantes modos alternativos de entender esas realidades y promover su transformación.

Estos conceptos nos conducen a problematizar quiénes son esos sujetos de aprendizaje desde una perspectiva constructivista. Para la psicología genético-cognitiva (Piaget, Bruner y Ausubel, entre otros), una doble significatividad lógica y psicológica presupone un individuo capaz de desarrollar actitudes emocionales, afectivas, actitudinales, hacia la experiencia de aprendizaje, en la que los nuevos saberes se generan en la interacción con los saberes previos de la estructura cognitiva. Recuperamos sobre todo la corriente genético-dialéctica (Vygotski, Luria, Leóntiev), en consideración de la apropiación del bagaje cultural que se produce en las situaciones educativas: un proceso de aprendizaje guiado en términos de "andamiaje" permite que el alumno vaya adquiriendo los saberes relativos a la cultura, la ciencia y la vida en sociedad. En Lev S. Vygotski encontramos las tempranas tematizaciones sobre las mediaciones educativas, donde la apropiación no es reproducción mecánica, sino producción creativa de sentido, a la vez que contribuye a la transformación del contexto socio-histórico más amplio (Crovi Druetta, 2013). ${ }^{10}$

${ }^{10}$ Fundador de la Escuela Sociohistórica, ya en la década del '20 Vygotski comenzó a investigar los procesos de interacción con los objetos de la cultura, sistemas semióticos, técnicas y conceptos que son apropiados al momento del aprendizaje. Estos objetos intervienen como "auxiliares externos", aportando a la construcción y reconstrucción psicológica al tiempo que al desarrollo de la sociedad y la cultura. 


\section{Democracia y espacio público: principales derivas teóricas}

¿Cuáles son las contribuciones de estas mediaciones a los procesos de democratización? La democracia constituye una noción evasiva, de profundas implicaciones históricas, conceptuales y normativas. Algunas consideraciones desde la teoría política pueden contribuir a una mirada interdisciplinaria como la que aquí se propone. Nos centraremos en cuatro modelos básicos:

-Democracia liberal: en su acepción moderna, se origina a fines del siglo XVIII y concierne al régimen político que permite la protección del ciudadano respecto del poder del Estado y de otros individuos, con lo que se conseguiría el máximo de libertad individual. Este principio positivo-liberal presupone una representación mediada por un conjunto de instituciones políticas, pero también mecanismos que limitan al poder, como la división de poderes, el Estado de derecho y el respeto de las libertades individuales. Sin embargo, esta concepción de democracia tendrá un carácter eminentemente elitista hasta muy avanzado el siglo XIX. Tras la extensión del sufragio, el surgimiento de los partidos políticos y de los movimientos sindicales, se fueron adoptando nuevas justificaciones para la representación y elementos más democráticos.

-Democracia participativa: a partir de la década del '60, los movimientos juveniles y otros colectivos protagonizaron las demandas de mayor participación en las decisiones políticas. Así comienza a hablarse de una "democracia participativa". En rigor, no pretende reemplazar a la democracia liberal, sino atenuar sus defectos. La representación es insuficiente sin una ciudadanía informada y comprometida con el interés común, por lo que apunta a democratizar los mecanismos de intermediación entre la sociedad y las instituciones políticas. No obstante, las debilidades del modelo es que tiende a centrarse en las formas locales de participación, perdiendo de vista dinámicas más globales del poder.

-Democracia deliberativa: las tensiones asociadas a la globalización conllevan desde los años '90 nuevas orientaciones, recuperando algunas tradiciones de la democracia liberal -el respeto a las libertades individuales en un Estado de derecho- y las preocupaciones sobre la educación ciudadana, el asociacionismo y la participación. En J. Habermas, “el principio democrático se debe al entrelazamiento del "principio de discurso" con la forma jurídica de los derechos reconocidos y de las instituciones y procedimientos de la democracia” (1998: 187). En una sociedad responsable, comprometida con el bien común y organizada democráticamente, es de esperar que la palabra de los ciudadanos logre influenciar las decisiones del gobierno. Esto es posible no solo a través de la comunicación "cara a cara", sino de una red simbólica de asociaciones, instituciones y medios que atraviesan el espacio público y donde se materializa la voluntad popular. 
-Democracia radical: algunos autores han señalado que la búsqueda de consensos excluye el carácter eminentemente conflictivo de las sociedades actuales, cuando el ejercicio pleno de los derechos ciudadanos está condicionado por el origen o condición de las personas. Las posiciones más moderadas buscan mayor implicación del Estado, mediante políticas de inclusión destinadas a superar la desigualdad de oportunidades, apelando a la solidaridad, el respeto por la pluralidad y niveles crecientes de participación. En cambio, las posiciones más radicales apuntan a una expresión agonista de las diferencias como premisa transformadora de la sociedad: se destaca especialmente Chantal Mouffe (1999), para quien un proyecto de democracia radical y plural significa la lucha por establecer una nueva hegemonía, enfatizando las múltiples relaciones sociales en las que existen relaciones de dominación contra las que hay que luchar. ${ }^{11}$

Por su parte, Cornelius Castoriadis planteará que la democracia constituye el régimen de la autonomía. Su correlato necesario es la igualdad. Una parte principal de la lucha por la democracia apunta hacia la instauración de las condiciones que permitan a todos el ejercicio de los derechos, donde la libertad sea efectiva, social y concreta: “¿Qué significa la igualdad en el contexto de una sociedad autónoma, autogobernada y autoconstituida? ¿Cuál es el pasaje lógico y filosófico de una (la autonomía) a la otra (la igualdad)?” (2005: 151). La alternativa es la autogestión, un proceso de autoinstitución consciente y colectiva del imaginario social, que no se funde en ningún principio natural y requiere, por ende, la información y la formación de los ciudadanos. Tampoco es una cuestión de "expertos": la política no involucra una episteme, sino la doxa aristotélica, la opinión, basada en un juicio reflexivo y orientado al bien común.

Muchos críticos vinculan al autor griego a la democracia radical, incluso en sus versiones más extremas. Al proponer a la democracia como un proyecto socialista autogestionario, se contrapone al proyecto democrático-liberal y al sistema capitalista al que legitima. No obstante, cuando Mouffe le plantea la necesidad de defender la democracia representativa frente a la directa para resguardar el pluralismo y la libertad individual, Castoriadis (2003) le contesta que la democracia representativa no es ninguna garantía, ya que lo que refleja son partidos que defienden intereses elitistas, una oligarquía liberal cuyo paradigma es la llamada "partitocracia". Consideramos, en cambio, que sus reflexiones lo acercan más bien a la democracia deliberativa: entre la diferencia tajante entre espacio público y espacio privado, queda por definir ese espacio público/privado que es precisamente el de la deliberación política.

\footnotetext{
${ }^{11}$ En Hegemonía y estrategia socialista (1987), Laclau y Mouffe se abocan a una democracia "radicalizada, libertaria y plural", desde la cual discuten el espacio público habermasiano. Conciben una politización radical, que tiende a disolver la distinción entre lo público y lo privado, no en términos de una invasión de lo privado por un espacio público unificado, sino de una proliferación de espacios políticos radicalmente nuevos y diferentes.
} 
Poniendo en discusión la teoría radical laclausiana, resulta cuestionable que deban descartarse los conceptos de esfera pública y de espacio público, en tanto no se sustentan en ningún principio unificador u homogéneo, al tiempo que comprenden la dimensión conflictiva de estas actuaciones. Desde allí los ciudadanos pueden desnaturalizar los supuestos recibidos, hacer valer los derechos individuales y participar críticamente en los debates concernientes a la vida social. Este proyecto habrá de sustentarse en un modelo que articule la democracia representativa con la democracia deliberativa. Acompañamos la perspectiva del Desarrollo Humano (Calderón, 2007), pues coloca en el centro de las decisiones no al mercado ni al Estado, sino a los sujetos, su capacidad de agencia en una esfera pública ampliada, en pos de fortalecer las posibilidades político-culturales de la ciudadanía. Solo en estos términos los principios abstractos de la democracia pueden materializarse en verdaderos procesos de democratización.

\section{Hacia una redefinición de la ciudadanía}

Las preocupaciones en torno al problema de la ciudadanía no son nuevas. Sin embargo, los cambios ligados a la globalización, la crisis de los referentes tradicionales que articulaban las identidades, las mutaciones de las relaciones entre el Estado y la sociedad civil, han alterado sus sentidos tradicionales. Y como hemos planteado, configura un área de relativa vacancia en las investigaciones en comunicación. Nos centraremos entonces en la revisión teórica, histórica y ontológica de la ciudadanía, hacia la construcción de nuevas propuestas conceptuales.

Una primera aproximación concierne a la definición clásica. T. H. Marshall (1965) aborda el proceso de constitución de la ciudadanía moderna en Inglaterra a partir del Estado de Bienestar. $\mathrm{Su}$ tesis se articula en torno a tres componentes, que se realizan, respectivamente, en los siglos XVIII, XIX y XX: los derechos políticos (relativos al sufragio y la participación política), civiles (libertades personales de los miembros de un territorio, expresión, religión, propiedad y justicia) y sociales (vinculados al Estado de Bienestar y sus políticas sociales del Estado-nación, el derecho a la seguridad y un mínimo de bienestar económico). En este sentido, la ciudadanía es el status universal e igualitario del que son portadores los individuos que pertenecen a una comunidad política. La expansión de los derechos sociales ha supuesto reconocer la reciprocidad que los une en un marco de solidaridad (Landau, 2004, 2008). ${ }^{12}$

\footnotetext{
12 Esta noción registra antecedentes en la Grecia antigua, donde el funcionamiento pleno de la democracia aparece vinculado a la formación moral e intelectual de la ciudadanía. Se trataba de una democracia directa, pero la polis, la comunidad, estaba por encima de los ciudadanos; además, los derechos no eran universales. El concepto de ciudadanía ligado al de nacionalidad recién comienza a delinearse en el siglo XVIII, a partir de las revoluciones francesa y norteamericana, con importantes derivaciones en América Latina (Molinari y Martínez, 2012).
} 
La primera reserva respecto de la teoría de Marshall es que constriñe a la ciudadanía al ejercicio de los derechos humanos, a la vez que pone el acento en la actitud pasiva del sujeto como miembro de una comunidad. No obstante, conserva validez la idea de que los derechos son concretos e históricamente constituidos, que no están subordinados los unos a los otros sino que son dimensiones igualmente esenciales de la ciudadanía. Además, cada época produce una "imagen de ciudadanía ideal" que cuestiona el universalismo de los derechos humanos. Este modelo sirve de orientación a los movimientos sociales que tenderán a hacer visibles y, por tanto, modificables las relaciones sociales dominantes.

En la América Latina del siglo XX, el Estado de Bienestar empieza a garantizar el acceso a la salud, a la educación, al trabajo, pero esta ciudadanía no es solo resultado de un status universal sino de las luchas populares por el reconocimiento de esos derechos. Como producto de la fuerte sindicalización, el concepto de ciudadano se asimila al de trabajador, a la vez que los procesos de inmigración implican la estrategia de inclusión y homogeneización desde la educación pública. ${ }^{13}$ Sin embargo, las vinculaciones entre ciudadanía e inclusión seguirán siendo problemáticas, y habrán de ser comprendidas en clave cultural: a partir del sueño moderno de los Estados-naciones, quedan fuera manifestaciones socioculturales que no encajan en los modelos férreos de sus ideales políticos (Muñoz González y Muñoz Gaviria, 2008).

Con el retorno de los regímenes democráticos tras las dictaduras militares, las políticas neoliberales de ajuste y el retraimiento de los Estados frente a los imperativos del mercado, se configura una situación paradojal: una expansión significativa de los derechos políticos formales, a la vez que el deterioro de algunos derechos civiles (como el acceso a la justicia o la libertad de expresión) y de la ciudadanía social. Se fragmenta lo social como espacio de integración, de reconocimiento de las interdependencias y de relaciones de reciprocidad. Y hacia la década del '90, se refuerzan los argumentos a favor de una nueva relación entre gobierno y participación, una "gobernabilidad democrática" o "buen gobierno" en torno a la accountability (rendición de cuentas) y su contraparte, el empowerment (empoderamiento), el desarrollo de las capacidades del ciudadano para controlar a las autoridades y cooperar activamente con ellas.

Empero, vamos a preferir el término agencia al de empoderamiento, que aparece tempranamente en los programas formulados por el Banco Mundial, el BID y muchos gobiernos neoliberales; y en este sentido, parece confirmar ciertos sustentos ideológicos de dominación en la región. Además, como ya adelantamos, la noción de agencia entronca más propiamente con la

${ }^{13}$ En Argentina, son particularmente relevantes las vinculaciones entre ciudadanía y mundo del trabajo en el caso de la educación técnico-profesional. Ya en este período, la inclusión social aparece formalmente asociada a la incorporación de los jóvenes al mercado laboral, en respuesta a los requerimientos derivados de la innovación tecnológica, el crecimiento económico y el desarrollo de los sistemas productivos del capitalismo tardío. 
teoría habermasiana y las conceptualizaciones de Castoriadis, en las cuales un proyecto de autonomía se revela cuestión medular y estructurante. Estas tensiones desafían las interrogaciones por el potencial de la ciudadanía social, al tiempo que los cuestionamientos a la división de los derechos como justificación de las condiciones de desigualdad estructural. Los estudios de la comunicación habilitan novedosas hipótesis acerca de cómo los lugares ligados a la cultura resignifican las posibilidades de participación en el espacio público, de una política no institucionalizada capaz de realizar una ciudadanía cultural más allá de los derechos.

\section{Aproximaciones teóricas a la juventud}

En nuestro país, los estudios de juventud surgen a partir de los procesos de democratización postdictatoriales que devinieron progresivamente en la fractura de las relaciones entre Estado y sociedad civil en 2001. Parafraseando a Bourdieu, Margulis y Urresti (2008) entienden que la juventud es más que una palabra, una categoría de enorme relevancia pero sujeta a un marco clasificatorio ambiguo. La definición clásica la asume como etapa de transición, desde la condición biológica o como "moratoria social” (Margulis, 1996). Otras concepciones recuperan la noción de “generación”, una construcción socio-histórica que revela las disputas en el campo político. Cada

generación no es un grupo claramente definido, sino una "conexión generacional" (Mannheim, 1993) sobre la cual los actores deben tener consciencia crítica, a la vez que reconocer reflexivamente posiciones sociales que configuran otras valoraciones, sentimientos y prácticas.

En un segundo momento, se profundizan las preocupaciones en torno a las relaciones entre jóvenes y política. La crisis de 2001 impactó directamente en ellos, acelerando las profundas desigualdades sociales y las dificultades de acceso al mundo educativo y laboral. También transforma significativamente las concepciones sobre los jóvenes: de descalificarlos por una aparente apatía desde una política normativizada o una mirada adultocéntrica (Cháves, 2005), se pasa a atribuirles un también aparente pasaje a la politización. Esta problemática ha sido escasamente indagada y demanda una comprensión más amplia de los procesos que discurren entre ambos términos, entendidos no como estados sino como posiciones dentro de una dinámica social heterogénea y permanente (Kriger, 2013; Kriger y Bruno, 2013).

Desde una perspectiva culturalista, Reguillo Cruz (2012) argumenta que las culturas juveniles realizan una ciudadanía juvenil, un redimensionamiento en términos de "culturalización de la política". Pero esto no significa atribuir carácter político a toda iniciativa juvenil. F. Saintout (2011) ha advertido sobre los riesgos de una mirada romántica que ve en cada gesto de impugnación una resistencia o la posibilidad de construir un orden social distinto. Estas prácticas 
se consideran novedosas porque revierten o reconstruyen los sentidos de esa participación, pero requieren un examen más riguroso acerca de sus condiciones de politicidad. La noción de generación tampoco agota la multiplicidad de experiencias desde las cuales los jóvenes definen sus identidades culturales o sus formas de acción colectiva. ${ }^{14}$

Apuntamos a indagar qué características asumen modos de agregación y adscripción juvenil que transcurren o bien al margen de las instituciones (como los movimientos sociales) o como sus "derivaciones" (como los centros de estudiantes), involucrando relaciones de reciprocidad con otras generaciones y sectores de la sociedad civil. Es en el terreno de la cultura donde se dirimen las posibilidades de una ciudadanización de la política (Lechner, 1996, 2000; Martín Barbero, 2002c, Martín Barbero y Lluch, 2011), que designa la variedad de agrupaciones que reclaman su derecho a ser parte actuante de lo público. Convoca una participación activa capaz de superar el derecho abstracto de la democracia, para implicar las diversas prácticas que permiten a los sujetos intervenir reflexivamente en la ciudad y en el mundo.

\section{Interpelar a los ciudadanos en la sociedad-red}

Las expectativas en torno a la sociedad interconectada contrastan con los procesos de fragmentación social, al tiempo que se materializan en formas de participación que desbordan a las organizaciones formales o los partidos políticos, para diseminarse en una pluralidad de campos de acción mediados por las TIC. Estas tensiones desafían a los Estados a emprender nuevos modos de gestión y de relaciones con la sociedad civil. Desde un punto de vista político-administrativo, una de sus expresiones es el "gobierno electrónico" (e-government). Puede ser definido como el uso de las tecnologías digitales para alcanzar el "buen gobierno" en los términos ya planteados: rendición de cuentas y empoderamiento. Apunta a hacerlo más eficiente, dotar a sus acciones de mayor transparencia, mejorar el acceso a los servicios y expandir las redes de comunicación.

El principal obstáculo es su concepción tecnocrática, ya que se centra en brindar información institucional sin verdadera participación de los usuarios ni vinculación directa con las iniciativas comunitarias. Como observan Kaufman y Piana, "sin nuevas formas de participación, el Gobierno Electrónico solo sería informatización de la gestión e implicaría un uso conservador de las tecnologías" (2007: 24). Un segundo obstáculo tiene que ver con los nuevos derechos que el gobierno electrónico estaría destinado a garantizar, “derechos sociotecnológicos” (Armony, 2011):

${ }^{14}$ La llamada Generación Red o Generación Digital (Fleixa, 2006) implica que, desde que nacieron, los jóvenes están rodeados de estos soportes, que han configurado su visión de la vida y del mundo. Ya hemos manifestado nuestras reservas respecto de estas afirmaciones, cercanas a la categoría de "nativos digitales", en este caso asociadas a formas de movilización convocadas mediante Internet o gestionadas desde los teléfonos móviles. 
el acceso, participación, protección y reconocimiento de esos derechos. Esta perspectiva enfatiza ante todo el papel del Estado y políticas públicas con la requerida flexibilidad para "adecuar" la cultura tecnológica a los cambios emergentes, lo que articula con una categoría igualmente problemática: la ciudadanía digital, también llamada ciberciudadanía o e-ciudadanía.

Nos preguntamos cómo se conjugan las tensiones entre los imperativos ideológicos, políticos, comerciales, de la Sociedad del Conocimiento, y las formas de agenciamiento ciudadano que eventualmente animan las experiencias interactivas. Por una parte, es de esperar que las tecnologías constituyan fuentes de información alternativas a los medios de comunicación hegemónicos, aun cuando medios masivos y digitales interactúan aprovechando la potencialidad convergente y multimedia (Becerra, 2010). Por otra -y es éste el aspecto que más nos interesa-, una lectura crítica del problema de la ciudadanía exige operar un desplazamiento conceptual del acceso instrumental a la apropiación material y simbólica, de los derechos formales (incluyendo a la información y a la comunicación pública) al conjunto de prácticas en que estos pueden realizarse, en fin, de la ciberciudadanía a la ciudadanía cultural.

\section{La problemática de la ciudadanía: a modo de síntesis}

A lo largo de este apartado hemos diferenciado básicamente dos concepciones de la ciudadanía. Por una parte, en cuanto a tipos de derechos. Por otra, a los jóvenes como sujetos portadores de esos derechos. Recapitulando, la ciudadanía civil ampara los derechos de los individuos como miembros de un territorio, que garantizan ante la ley la libertad de expresión, pensamiento, religión, justicia, propiedad, entre otras. La ciudadanía política refiere a los derechos al sufragio, la ocupación de cargos públicos y la participación en la vida democrática; hoy excede el cumplimiento de los derechos formales y la institucionalidad de la política para implicar diversos movimientos colectivos. La ciudadanía social incluye desde el derecho a un mínimo de bienestar y seguridad económica, hasta el derecho de participar del patrimonio social, vivir la vida de acuerdo con las pautas vigentes y acceder a los bienes materiales y simbólicos.

La cuarta expresión es la ciudadanía cultural. Pretendemos aportar a su definición teóricometodológica. Vale decir que el término se vuelve redundante: comporta el respeto a la diversidad cultural como una dimensión constitutiva, como respuesta contingente a condiciones materiales de creciente heterogeneidad social. Sin embargo, mantendremos el término, integrador de las nociones de la ciudadanía juvenil y a la ciudadanía digital. En el primer caso, en función de cierta especificidad de las prácticas culturales juveniles y de los jóvenes como sujetos de derechos y obligaciones (sin que esto remita a ninguna premisa esencialista), y en 
tanto constituyen los principales destinatarios de las políticas de inclusión digital. En el segundo caso, porque si bien los medios tradicionales y las TIC responden a lógicas diferenciadas de apropiación y uso, interactúan en el marco de una convergencia digital cada vez más acelerada, atribuyendo formas novedosas de participación en el espacio público.

De todos modos, los tipos de ciudadanía así definidas encierran ambigüedades no resueltas respecto de cuáles son las lógicas específicas que las estructuran, que permitan diferenciar unas de otras. Si bien corresponden a tradiciones teóricas de gran relevancia, encontramos, antes que categorías relativamente homogéneas, un entramado de dimensiones que se articulan en esa densidad compleja. Dar cuenta de estos cambios en el campo de la comunicación/cultura, debe atender al reconocimiento de los actores desde sus múltiples posiciones y adscripciones identitarias. Significa, además, comprender a la educación en su dimensión ético-política, en tanto constituye el espacio privilegiado para el desarrollo de competencias ciudadanas y comunicativas, asociadas a las experiencias de uso y apropiación de las TIC. Cabe aquí replantear una pregunta general: ¿cómo intervienen las relaciones con las tecnologías que se producen en la escuela secundaria técnica, en la formación de ciudadanía o de condiciones para el ejercicio de la ciudadanía?

\subsection{Hacia la elaboración de un modelo de análisis}

Las agudas transformaciones que atraviesan la educación y la construcción de la ciudadanía en el marco de una política pública de inclusión digital, conducen a desmontar el andamiaje teóricometodológico erigido desde los estudios de la comunicación como desde otras perspectivas. En este apartado, presentamos las definiciones generales, Dimensiones y Subdimensiones que desarrollaremos en Capítulos siguientes. Se apunta a evaluar su validez y pertinencia, identificar imprecisiones y lugares de vacancia, discutir sus limitaciones, para construir nuevas categorías y elaborar los instrumentos de análisis que permitan explorar el problema. Este proceso es resultante de todo el trabajo de investigación, conforme a las orientaciones de la Teoría Fundamentada.

\subsubsection{Consideraciones metodológicas}

Esta investigación parte de la necesaria reflexión sobre el paradigma en que se sustenta, entendido como el marco teórico-metodológico utilizado para interpretar los fenómenos de estudio. Desde la Escuela Hermenéutica, Hans Gadamer (2004) reflexiona que la verdad está íntimamente ligada al método y no puede considerarse una sin el otro. La consciencia hermenéutica no presupone 
entonces objetos ni métodos sino "modos de ver" del sujeto en sus condiciones históricas determinadas. Designa el carácter fundamentalmente móvil del estar ahí, que constituye su finitud y su especificidad y que abarca el conjunto de su experiencia del mundo. Del mismo modo, Bourdieu (2012) plantea que los sentidos de una "sociología de la ciencia" radican en asumir, como condiciones de producción teórica, la estructura y modo de funcionamiento del campo cientítico. Por ende, en la comprensión crítica del intelectual acerca de las disposiciones e instituciones que regulan su práctica y que determinan sus posibilidades objetivas de intervenir legítimamente en dicho campo.

En términos generales, la investigación social "es una forma de conocimiento que se caracteriza por la construcción de evidencia empírica elaborada a partir de la teoría, aplicando reglas de procedimiento explícitas" (Sauto et al, 2010: 29). Implica que la metodología no está escindida de sus articulaciones con los objetivos y el marco teórico-epistemológico. Consideramos aquí tres niveles de desarrollo teórico: 1- el paradigma como conjunto de conceptos teóricometodológicos que determinan las orientaciones generales; 2- la teoría general, que conlleva presupuestos acerca del carácter de la comunicación, la cultura y la educación; y 3- la teoría sustantiva, de menor nivel de abstracción, conformada por proposiciones específicas relativas a la parte de la realidad que se estudia. Proponemos un recorrido ordenado, no lineal, hacia la identificación y elaboración de las Dimensiones, Subdimensiones y Áreas de Indagación. El modelo analítico es resultado de todo el proceso, ya que su objetivo reside precisamente en generar teoría.

Para caracterizar la investigación en el subcampo de la comunicación/educación, asumimos aquello que la define principalmente: la interpretación de los significados que los actores atribuyen a las prácticas educativas, en contextos de interacción sujeto-sujeto, con el compromiso importante en la transformación y el desarrollo de la reflexividad (Pievi y Bravin, 2009). El paradigma que nos orienta es el interpretativo. Su fundamento radica en conocer el sentido de la acción social en el contexto del mundo de la vida y desde la perspectiva de los participantes. En palabras de Vasilachis de Gialdino (1993), la Teoría de la Acción Comunicativa de Habermas viene a superar las diferencias entre paradigmas aparentemente irreconciliables. Hay un mundo objetivo y aspectos del mundo social que son directamente observables, pero también el mundo social, el mundo subjetivo y el mundo de la vida, que involucran a un intérprete que no "da" significado a lo observado, sino que tiene que explicitar la significación dada a objetivaciones que constituyen procesos de comunicación.

Esta investigación se enmarca además en un diseño cualitativo y en los aspectos ontológicos, epistémicos y técnicos que le son específicos: abordamos una realidad dinámica, 
compleja y global que se construye en los procesos de interacción, privilegiando la vía inductiva por sobre la hipotético-deductiva. La decisión metodológica fue diferenciar nuestro trabajo tanto de las investigaciones etnográficas (descriptivas), como de aquellas orientadas a la verificación o contrastación de hipótesis (inducción analítica). Sin caer en binarismos estériles, se inscribe en una propuesta metodológica en Comunicación, superadora de los encuadres etnográficos tradicionales que han tendido a hegemonizar las aproximaciones al problema de las tecnologías digitales, especialmente en el campo de los Estudios Culturales y de la investigación educativa.

La investigación cualitativa atraviesa tres momentos analíticos: análisis preliminar, análisis intermedio y análisis final. Se trata de un movimiento cíclico, en el sentido de que "tras la culminación de datos sobreviene un proceso de análisis, y como resultado de éste se plantea una nueva recolección; y así sucesivamente hasta alcanzar la "saturación de categorías"'" (Vieytes, 2004: 675). Este enfoque tiene la ventaja de potenciar la relación dialéctica entre la teoría y la práctica: el proceso no es lineal, sino que progresa constantemente a partir de la interacción entre el marco conceptual, la recolección y el análisis de los datos.

El objeto principal es la generación de teoría de acuerdo a la Teoría Fundamentada de Glaser y Strauss, que se sustenta a su vez en dos estrategias diferenciadas. Por un lado, el Método Comparativo Constante consiste en realizar simultáneamente la codificación y el análisis. A medida que se avanza en el trabajo de campo, se codifican y analizan los datos, desarrollando conceptos mediante la comparación continua de acontecimientos específicos y teorías. De esta forma, se refinan las categorías y se descubren propiedades y relaciones entre ellas, con el objeto de construir hacia el final del trabajo una teoría coherente que explique el fenómeno de estudio en sus múltiples determinaciones. En tanto que el muestreo teórico implica que la recolección de datos y el análisis se realizan casi al mismo tiempo; se seleccionan nuevos casos según su potencial para ayudar a refinar y expandir los conceptos. Esta opción metodológica resultó determinante para poder avanzar en la comprensión del problema de la ciudadanía, casi ausente o de carácter evasivo en el conjunto de los discursos durante la primera etapa de la investigación.

Asimismo, la metodología del Análisis Textual reviste especial importancia, en tanto asume que el corpus empírico debe ser analizado desde lo que dicen los hablantes como de lo "no dicho", su nivel semántico profundo. Es decir, los modos en que manifiestan discursivamente sus interacciones socio-educativas con las TIC, como las representaciones que subyacen a ellas en una situación enunciativa dada. Comprende las tres dimensiones constitutivas de todo texto: sintácticas (la sintaxis formal), semánticas o referenciales (relativas al contenido) y conativas o pragmáticas (acerca de cómo debe interpretarse el mensaje y la relación comunicativa entre los participantes). 
Y como anticipamos, optamos por el Análisis del Contenido (AC) para abordar específicamente documentos escritos. Tradicionalmente vinculado al enfoque cuantitativo, ha cobrado nueva relevancia a partir de su debatida complementariedad con la metodología cualitativa, debido a su fertilidad analítica en la generación de categorías desde los datos. Ha sido objeto de muy diversas definiciones. Hoy entronca con la perspectiva hermenéutica y puede entenderse como el conjunto de procedimientos interpretativos aplicados a productos comunicativos o a interacciones comunicativas, previamente registradas, con el objeto de extraer y procesar datos relevantes sobre las condiciones mismas en que se han producido, o sobre las condiciones que puedan darse para su empleo posterior (Piñuel Raigada y Gaitán Moya, 1995, 1998; Piñuel Raigada, 2002).

$\mathrm{Al}$ igual que el Análisis Textual, el AC persigue el objetivo de hacer emerger el sentido latente que subyace a los actos comunicativos concretos, a partir de sus diversos componentes, léxicos, simbólicos, temáticos y evaluativos. Como adelantamos, nos permitió una aproximación mayormente descriptiva a un corpus de documentos oficiales que presentan nudos discursivos que son negociados, resignificados o directamente resistidos por los actores en sus realidades educativas. Tal análisis respondió a un doble propósito: identificar antecedentes inmediatos del PCI y examinar definiciones desde el Estado sobre los componentes de la educación, la tecnología y la ciudadanía, y las múltiples relaciones que las comprometen.

La periodización que comprende esta tesis distingue dos etapas (2011 a 2013 y 2014-2015), bajo el entendido que hacia 2014 es posible reconocer cierta estabilización del modelo 1 a 1 en los contextos escolares, donde se infieren regularidades así como aspectos relativamente novedosos. El recorte expresa, respectivamente, un momento analítico descriptivo y otro de carácter interpretativo. La decisión de extender el período analizado respondió a razones metodológicas (saturación teórica), junto con la necesidad de visualizar los efectos del paso del tiempo en la adecuación del PCI, en sus encuentros y desencuentros con la formación ciudadana.

Se esbozan a continuación las principales técnicas de recolección utilizadas:

- Entrevistas en profundidad: centradas en los procesos de intersubjetividad en el marco de las interacciones cara a cara, se orientan a la indagación exhaustiva, el acercamiento al objeto de estudio y la comprensión de las motivaciones, creencias y actitudes acerca de la problemática relacional que nos ocupa. Se sustenta en la relación dialéctica entre las prácticas y las representaciones acerca de los cambios dinamizados por la convergencia digital, las relaciones o tensiones con la educación, las posibilidades para la construcción de la ciudadanía, las dimensiones que articulan imaginariamente los discursos a torno a los roles de docente y estudiante, la función ético-política de la escuela, los modelos de enseñanza-aprendizaje, etc. 
El trabajo de campo comprendió entrevistas no estructuradas y semi-estructuradas. Se desarrollaron un total de 60 entrevistas (individuales y grupales) a directivos, profesores y estudiantes de las dos escuelas, de distintos géneros, edades, año escolar, asignaturas y orientaciones curriculares, además de psicopedagogas, la referente regional del PCI y la coordinadora de la Especialización TIC y Educación.

-Grupos de discusión o focus groups: ya que "la tarea del investigador consiste, entonces, en la conformación de un grupo que pueda expresar "representativamente" lo que la sociedad ve en relación con su problema de investigación" (Scribano, 2008: 116). Se realizaron en la primera etapa, con aportes significativos para los objetivos del trabajo, aunque se identificaron limitaciones objetivas de tiempo y espacio por parte de los actores. ${ }^{15}$ Básicamente, constituyó una estrategia inicial y complementaria en el marco del diseño metodológico, para explorar una variedad de discursos docentes relativos a condiciones percibidas de inclusión de las TIC a la enseñanza, como las negociaciones que tensionan las adecuaciones del modelo en el ámbito institucional. En algunos casos, las entrevistas grupales fueron profundizadas con entrevistas individuales a los mismos participantes durante la segunda etapa del trabajo.

-Análisis de documentos: se implementó el AC como estrategia complementaria en el marco metodológico, para explorar documentos escritos que normalizan las políticas de inclusión digital en la Argentina: Ley Nacional Técnico-Profesional № 26.058 (2005), Ley de Educación Nacional No 26.206 (2006), Res. CFE No 82/09 Programa "Una computadora para cada alumno", Decreto $N^{\circ} 459 / 10$ Programa “Conectar Igualdad.com.ar”, Ley Nacional N²6.877 (2013) Centros de Estudiantes, Res. CFE No 244/15 PNIDE, entre otros. Se examinan las concepciones y propósitos de la educación nacional y de la educación técnico-profesional; las orientaciones éticas, políticas y pedagógicas del PCI; la regulación formal de las actuaciones juveniles en los centros de estudiantes y otros espacios, favorables a formar capacidades para la ciudadanía y la vida democrática. Los conceptos resultantes son luego recuperados y complejizados en torno a las aproximaciones a la integración digital que realizan el conjunto de los actores.

\subsubsection{Dimensiones y Áreas de Indagación}

Resumimos a continuación las categorías seleccionadas y elaboradas, con vistas a avanzar en el diseño de estrategias de análisis de las vinculaciones educación/ciudadanía/TIC:

15 Cabe aclarar que el grupo de discusión se propuso como ejercicio metodológico para la asignatura Metodología de la Investigación en el marco del Doctorado, en el que se evaluaron las condiciones de diseño, planificación y ejecución de la técnica en relación al tema planteado. 


\section{CATEGORÍAS RELATIVAS A EXPERIENCIAS CON TECNOLOGÍAS:}

1. DIMENSIÓN DEL ACCESO TECNOLÓGICO: en sus aspectos físicos y simbólicos, considera dos grandes Subdimensiones:

1.1. Disponibilidad o Posesión Material de dispositivos: en cuanto a los accesos a computadoras, soportes móviles y conectividad. Se comprenden como Áreas de Indagación:

-Disponibilidad/posesión de computadoras y otros soportes en los hogares y en la escuela.

-Distribución espacial en la escuela, de acuerdo a nivel, año, orientación, etc.

-Tipos de dispositivos más utilizados (netbooks, celulares, etc.).

-Condiciones técnicas/operativas de los equipos.

-Oportunidades reales y percibidas de acceso a Internet en el hogar y en la escuela.

1.2. Saberes y Disposiciones para el Acceso Cognitivo: en relación al desarrollo de habilidades para el uso socialmente productivo de las TIC, como de las representaciones que favorecen esas habilidades y le atribuyen ciertos significados. Sus Áreas de Indagación son:

-Causas atribuidas al acceso/falta de acceso (socio-económicas, institucionales, familiares).

-Percepciones sobre las posibilidades de acceso a los saberes mediados por tecnologías.

-Relaciones atribuidas entre acceso cognitivo e inclusión digital; valoraciones sobre las políticas educativas relativas a los mismos.

-Expectativas sobre el valor de los saberes producidos, representaciones subyacentes.

2. DIMENSIÓN DEL USO TECNOLÓGICO: se vincula a las posibilidades de selección, jerarquización y utilización de la información para la resignificación y producción de saberes. Comprende tres Subdimensiones:

2.1. Consumo o Recepción de Contenidos: en términos de tipos, niveles y modalidades de consumo, como las representaciones, habilidades y dificultades percibidas de esos usos y sus alcances en el aprendizaje escolar. Son sus Áreas de Indagación:

-Tipos de consumo/recepción, soportes y aplicaciones más utilizados.

-Frecuencia e intensidad del consumo/recepción.

-Habilidades y dificultades percibidas.

-Situaciones de consumo, escolares y extraescolares; valoraciones respecto del aprendizaje.

-Relaciones atribuidas entre los consumos tecnológicos y de otros medios.

2.2. Producción de Contenidos: de modo similar, en atención a los niveles o modalidades de producción, y las significaciones asociadas a ellos. Sus Áreas de Indagación son:

-Tipos de producción, soportes y aplicaciones más utilizados.

-Frecuencia e intensidad de producción.

-Habilidades y dificultades percibidas. 
-Situaciones de producción, escolares y extraescolares; valoraciones y expectativas.

2.3. Condiciones de Interactividad: las particulares interfaces que habilitan formas de aprendizaje, sociabilidad y de trabajo colaborativo. Considera como Áreas de Indagación:

-Condiciones de los usos interactivos y otros vinculados.

-Niveles y tipos de interactividad, prácticas específicas que se realizan en la escuela.

-Significados atribuidos a la interactividad; expectativas en el ámbito educativo.

-Percepciones y actitudes reconocidas sobre el tema.

3. DIMENSIÓN DE LA APROPIACIÓN TECNOLÓGICA: se relaciona con las prácticas a través de las cuales los sujetos, habiendo logrado elucidar las determinaciones sociohistóricas de las TIC, expresan en el uso competente su libertad de adaptarlas a sus propias necesidades, con creciente autonomía. Sus cuatro Subdimensiones son:

3.1. Conocimiento: en cuanto las capacidades para promover un conjunto de saberes crecientemente diversificados y complejos, de acuerdo a objetivos personales y colectivos de los usuarios. Considera varias Áreas de Indagación:

-Percepciones y disposiciones sobre niveles y tipos de conocimientos producidos.

-Identificación de relaciones/tensiones entre el conocimiento escolar y el desarrollado con las TIC y otros medios masivos.

-Valoraciones de las relaciones/tensiones entre las TIC y otros soportes pedagógicos (escritura, libro, pizarra, etc.).

-Reconocimiento de los procesos cognitivos implicados en los usos tecnológicos.

3.2. Elucidación: implica la interrogación sobre las propias actuaciones y las determinaciones que operan sobre ella, en procesos de búsqueda, selección y utilización de la información en marcos más generales de criticidad. Sus Áreas de Indagación son:

-Significados de las determinaciones políticas, sociales, económicas, de la cultura digital.

-Imaginarios, situaciones, acciones, que favorecen o dificultan el análisis de las mismas.

-Actitudes reflexivas sobre las implicaciones de los programas de inclusión digital.

-Definiciones sobre los componentes, características y funcionamiento de los dispositivos.

3.3. Autonomía: entendida como la capacidad de las personas de actuar sin determinaciones externas y según criterios propios. En cuanto a sus Áreas de Indagación:

-Posibilidades o dificultades percibidas para generar autonomía desde las vinculaciones TIC/educación.

-Usos tecno-educativos que favorecen el análisis crítico y el desarrollo de la autonomía. -Autoevaluación de las competencias tecnológicas y de sus implicaciones en el aprendizaje. 
3.4. Autoafirmación: en tanto esas interacciones producen particulares estéticas, narrativas y sensibilidades que confirman -aunque no agotan- los modos de re-constitución del yo. Se considera como Áreas de Indagación:

-Posibilidades o dificultades atribuidas a las interacciones con las TIC para promover la subjetividad, afectos, autoconfianza, empatía, etc.

-Autopercepción de los usos tecnológicos implicados en esas capacidades.

-Valoraciones sobre sus implicaciones en los procesos de enseñanza-aprendizaje.

4. DIMENSIÓN DE LA MEDIACIÓN TECNOLÓGICA: define las matrices culturales en las que se materializan los modos de apropiación y usos tecnológicos, y que revelan estrategias específicas de aprendizaje, participación social y adscripción identitaria, desde las cuales se negocian y reconstruyen los sentidos hegemónicos de la Sociedad del Conocimiento. Entendidas también como mediaciones tecno-educativas, incluyen cuatro Subdimensiones:

4.1. Cognitiva: esquemas mentales que configuran procesos individuales de producción de conocimiento, inscriptos en condiciones culturales. Son sus Áreas de Indagación:

-Autopercepción de los saberes y procesos cognitivos implicados en el uso de tecnología.

-Identificación de ventajas/desventajas en la construcción de conocimiento escolar u otros.

-Comparaciones entre escuelas técnicas y medias sobre la formación o saberes producidos.

4.2. Institucional: en lo que respecta a los espacios donde se instituyen valores, normas y habitus, definiendo oportunidades para el uso tecnológico. Sus Áreas de Indagación son:

-Condiciones institucionales de la inclusión digital.

-Modelos institucionales, culturales, pedagógicos, que subyacen a esas condiciones.

-Reconocimiento de posibilidades/dificultades para el uso educativo de las TIC (reformas del sistema, cambios curriculares, disponibilidad de tiempo, etc.)

-Representaciones sobre la educación técnica.

-Construcciones identitarias relativas a cada escuela.

4.3. Situacional: contextos inmediatos y cotidianos, escolares y extra-escolares. Incluye como Áreas de Indagación:

-Espacios de utilización de las TIC y otros medios (áulicos, familiares, urbanos, etc.).

-Tipos y niveles de usos en esos espacios específicos.

-Identificación de posibilidades/dificultades en esa inclusión en las situaciones áulicas.

-Modelos subyacentes, morales, de comportamiento, convivencia o participación.

4.4. Lingüístico-Comunicativa: lenguajes hipertextuales y digitales, desde sus técnicas hasta sus gramáticas específicas. Comprende como Áreas de Indagación:

-Lenguajes, narrativas y sensibilidades que se juegan en esas experiencias de apropiación. 
-Sistemas de codificación involucrados en la producción de contenidos digitales.

-Modos de recepción, interpretación y consumo; beneficios esperados en la escuela.

5. DIMENSIÓN DE LA COMPETENCIA TECNOLÓGICA: en tanto competencia comunicativa, integra habilidades cognitivas, simbólicas y discursivas implicadas en la producción, interpretación y análisis de significados mediados por las tecnologías, como las condiciones y disposiciones necesarias para ejercitar esas habilidades en contextos socio-culturales múltiples. Identificamos cinco Subdimensiones:

5.1. Instrumental: uso o dominio operativos. Son sus Áreas de Indagación:

-Tipos de aplicaciones, dominio de programas y funciones operativas.

-Identificación de acciones (pedagógicas, institucionales) que promueven el uso operativo.

-Reconocimiento de habilidades implicadas en dichas experiencias.

-Representaciones sobre las competencias instrumentales; relaciones con otras.

5.2. Cognitivo-intelectual: esquemas de percepción, pensamiento y acción relativos a la construcción de conocimientos. Considerando sus Áreas de Indagación:

-Percepción y jerarquización de conocimientos producidos con las TIC y otros medios.

-Valoraciones sobre conocimientos previos, disciplinares, escolares o pedagógicos.

-Expectativas y sentidos acerca de la capacitación docente.

-Concepciones sobre materias y orientaciones que favorecen/dificultan la inclusión digital.

5.3. Socio-comunicacional: acerca de las prácticas interactivas y comunicacionales que la involucran. Sus Áreas de Indagación incluyen:

-Acciones relativas a los aspectos interactivos y comunicacionales de los usos tecnológicos. -Habilidades reconocidas en esas interacciones.

-Valoraciones y expectativas en relación a esas habilidades en la producción de saberes.

5.4. Axiológico: en base a la consciencia crítica sobre las determinaciones ideológicas, políticas y culturales. Son sus Áreas de Indagación:

-Posibilidades de objetivación de las transformaciones socio-históricas de la cultura digital.

-Significados, actitudes y valores sociales, éticos y políticos de esos cambios.

-Vinculaciones percibidas entre TIC y educación; representaciones acerca de esa inclusión.

-Espacios y contenidos en los que se promueve la consciencia crítica sobre estos problemas.

5.5. Emocional: componentes personales, expresivos y de autoconfirmación. Sus Áreas de Indagación identifican:

-Identificación de los afectos, sentimientos y pulsiones ligados a los accesos o usos.

-Percepciones acerca del papel de las tecnologías en la constitución de la subjetividad. 
-Vinculaciones entre las subjetividades mediadas por las TIC y el aprendizaje escolar; beneficios esperados.

\section{CATEGORÍAS RELATIVAS A LOS CRUCES IMPLICADOS EN LA CONSTRUCCIÓN DE LA CIUDADANÍA: \\ 6. DIMENSIÓN DE LAS VINCULACIONES}

CIUDADANÍA/POLÍTICA/DEMOCRACIA: la expansión de la ciudadanía -entendida como ciudadanía cultural- es condición fundamental para la consolidación de la democracia deliberativa, que interpela a los ciudadanos no solo como portadores de derechos sino en sus posibilidades de participación colectiva. Se reconocen tres Subdimensiones:

6.1. Capacidad de Agencia: asociada a los principios de racionalidad, responsabilidad y autonomía, como la participación en el espacio público. Reconoce como Áreas de Indagación:

-Reconocimiento de la autonomía como competencia ciudadana.

-Reconocimiento de la responsabilidad como competencia ciudadana.

-Reconocimiento de la racionalidad como competencia ciudadana.

6. 2. Condiciones Materiales y Simbólicas para la Ciudadanía: para desarrollar esas capacidades, que expresan las tensiones entre el reconocimiento de la diversidad y la búsqueda de horizontes comunes. Y como Áreas de Indagación:

-Conocimiento y valoraciones acerca de los principios de la democracia deliberativa.

-Condiciones pedagógicas, institucionales y políticas para la construcción de ciudadanía.

-Acciones que orientan o favorecen el desarrollo de las competencias ciudadanas.

-Autoevaluación respecto de esas competencias.

6. 3. Relaciones/tensiones entre Globalización y Participación Social: lugares de disputas sobre los sentidos y alcances de la globalización, las articulaciones entre lo local/nacional y lo global o entre lo institucional/escolar y lo urbano. Son sus Áreas de Indagación:

-Reflexiones en torno a los procesos asociados a la globalización (culturales, tecnológicos, socio-productivos).

-Modos de participación social que definen, ponderan o discuten sus sentidos y alcances.

-Mediaciones tecno-educativas en que se inscriben las articulaciones entre lo local/nacional y lo global, o entre lo institucional/escolar y lo urbano.

-Posibilidades de construcción material e imaginaria de la escuela como espacio público.

7. DIMENSIÓN DE LAS VINCULACIONES CIUDADANÍA/EDUCACIÓN: bajo la premisa de que la ciudadanía excede los derechos humanos, involucran capacidades para el desarrollo de la autonomía, la deliberación y el pensamiento crítico. Siguiendo la pedagogía freiriana, consideramos dos Subdimensiones, junto con los aspectos representacionales: 
7.1. Gnoseológica: asociada principalmente al conocimiento disciplinar. Se consideran como Áreas de Indagación:

-Tipos de conocimientos relativos a materias específicas (Construcción de Ciudadanía, Política y Ciudadanía, etc.).

-Tipos de conocimientos desarrollados en otras materias o áreas vinculadas al tema.

-Posibilidades y dificultades para el aprendizaje de esos conocimientos en la escuela.

7.2. Política: abarca desde los contenidos ético-normativos hasta los crítico-participativos, implicando estas Áreas de Indagación:

-Contenidos ético-normativos (valores y normas).

-Contenidos crítico-participativos (consciencia reflexiva, la deliberación, la participación).

-Situaciones y condiciones que habilitan o dificultan la apropiación de esos contenidos.

7.3. Representacional: aspectos simbólicos de la construcción de la ciudadanía, definiciones generales del rol docente, identificación de lugares de participación juvenil, etc. Se consideran como Áreas de Indagación:

-Concepciones sobre la ciudadanía y los sentidos de su construcción.

-Vinculaciones con la política y la educación formal.

-Definiciones del rol docente en la formación para la ciudadanía, el trabajo y la inclusión.

-Identificación de lugares de participación juvenil, escolares, políticos y comunitarios.

8. DIMENSIÓN DE LAS VINCULACIONES CIUDADANÍA/TIC: sintetizan la trama estructural-simbólica sobre el modelo 1 a 1, la inclusión socio-educativa, la formación y el ejercicio de la ciudadanía, como así las identidades juveniles condicionadas por la digitalización y los modos de participación que resultan de ellas. En atención a cuatro Subdimensiones:

8.1. Programa Conectar Igualdad: conforme a los conocimientos y expectativas, implicaciones con el Estado, la calidad educativa, las transformaciones del sistema. Considerando estas Áreas de Indagación:

-Representaciones acerca de los objetivos y fundamentos del Programa.

-Conocimientos acerca de políticas educativas similares en el país y la región.

-Situaciones donde se comunican, deliberan o evalúan los sentidos y alcances del PCI.

8.2. Inclusión Digital: condiciones materiales y simbólicas para su realización efectiva, en especial, en relación con la inclusión socio-educativa como fundamento central del PCI y la presencia extendida de las tecnologías interactivas. Sus Áreas de Indagación son:

-Condiciones para la inclusión digital en sus implicaciones con la inclusión social, la ciudadanía y el mundo del trabajo.

-Representaciones sobre dichas condiciones. 
-Roles atribuidos al docente en la inclusión de las TIC.

-Concepciones sobre la autoridad docente, obstáculos y posibilidades para su ejercicio.

8.3. Información y Conocimiento: la posibilidad de acceder, seleccionar, difundir y usar datos, al tiempo de desarrollar habilidades para crear contenidos y conocimientos favorables a intervenciones activas en el espacio público/mediático. Identificamos como Áreas de Indagación:

-Significados atribuidos a las TIC y otros medios masivos como fuentes de información.

-Relaciones/tensiones percibidas con los procesos de producción de conocimiento.

-Competencias tecnológicas implicadas en el acceso y uso crítico de la información.

-Autoevaluación de dichas competencias y sus vínculos con la formación ciudadana.

8.4. Configuración de Identidades Juveniles: acerca de cómo coexisten nuevas sensibilidades mediadas por las TIC con actuaciones más o menos organizadas, sentidos de pertenencia y participación escolar o social. Comprenden las siguientes Áreas de Indagación:

-Definiciones de "juventud”, identificación/ diferenciación respecto de otros referentes.

-Componentes afectivos y crítico-reflexivos de la subjetividad juvenil.

-Experiencias en las que se constituyen esas identidades (escolares, familiares, barriales, virtuales, etc.).

-Espacios de participación ciudadana, escolar o comunitaria, movimientos juveniles o posibilidades de politización, y el papel mediador de las tecnologías en esos procesos.

\subsubsection{El caso: la educación secundaria técnica en la ciudad de Olavarría}

Esta tesis doctoral constituye un estudio de caso, la educación secundaria técnica. Está orientada a la recopilación, registro e interpretación en profundidad del caso considerado ejemplar de la problemática abordada, para producir el conocimiento más completo posible de las instituciones desde una perspectiva holística y compleja, estableciendo relaciones significativas con su contexto socio-histórico. Comprende las dos escuelas secundarias técnicas de la ciudad. Sin ser este un estudio comparativo, atender a las particularidades culturales, institucionales, socio-económicas y pedagógicas - sumadas a las notables diferencias con la educación media- de ambas instituciones, permite constatar la heterogeneidad de la urdimbre material-simbólica donde se inscriben las experiencias con TIC y sus implicaciones en la construcción de ciudadanía, bajo el modelo 1 a 1 .

La provincia de Buenos Aires está dividida en 134 municipios. De acuerdo al censo 2010, el partido de Olavarría cuenta con una población de 111.320 habitantes, entre la ciudad y 19 pequeñas localidades serranas. Una de las principales es la Villa Alfredo Fortabat, en alusión a su fundador, hijo menor de Luciano Fortabat. También conocida como Loma Negra, la villa se pobló 
masivamente con la llegada de familias inmigrantes para trabajar en la fábrica cementera del mismo nombre. Con esta localidad conectan buena parte de las características estructurales y simbólicas de Olavarría: como ciudad intermedia, asume rasgos identitarios muy notables, mitologizados en el modelo socio-económico desarrollista hoy plenamente en crisis (la producción primaria minera y cementera): "ciudad del trabajo" o "del cemento" (Gravano, 2005). Sobre esas imágenes residuales se sostienen los esfuerzos de recuperación de la educación técnica, tras el deterioro resultante de las sucesivas reformas neoliberales de la década del ' 90 .

Las dos escuelas analizadas fueron las primeras destinatarias del PCI. Fundada en 1943, la EEST N² "Luciano Fortabat" es la más numerosa (más de 1000 estudiantes) y de extensa trayectoria. Presenta cuatro orientaciones: Electromecánica, Automotores, Informática y Maestro Mayor de Obras. Se la reconoce como "Industrial”, nombre que condensa las imágenes idealizadas de una memoria compartida: ligada al apoyo de Loma Negra y la Fundación Fortabat, en el marco de los proyectos de desarrollo consolidados hacia la década del '60. La figura de Luciano Fortabat encarna la relación paternalista que puso a la escuela en el lugar preponderante que aún conserva en la ciudad. Sus estudiantes registran buenos desempeños, pertenecen a familias de nivel socioeconómico medio o alto, cuentan con computadoras personales y condiciones de conectividad.

En 1987, la EEST N 1 recibe el nombre de “Dr. René Favaloro” en homenaje al prestigioso cardiocirujano y educador argentino. Ofrece dos orientaciones: Electrónica y Química. Reconoce problemas de funcionamiento, infraestructura y comunicación organizacional, $\mathrm{y}$ ha sufrido históricamente valoraciones estigmatizantes como "escuela periférica". Sus estudiantes pertenecen a un estrato social menos favorecido, presentan dificultades de desempeño, situaciones de violencia, fracaso escolar y otras problemáticas. Por lo general, la netbook del PCI es para ellos la primera computadora personal y, a menudo, también de las familias. Empero, en los últimos años, la escuela atraviesa un proceso lento pero sostenido de mejoramiento institucional. Todas estas situaciones intersectan con el imaginario hegemónico de la ciudad, donde las articulaciones entre lo local y lo global conlleva la temprana institución de los imaginarios tecnológicos ligados al proyecto socio-productivo, tensando valorativamente las apropiaciones de las TIC. 


\section{CAPÍTULO 3: ACERCA DE LAS CONDICIONES PARA LA APROPIACIÓN DIGITAL}

El Programa Conectar Igualdad (PCI) ha distribuido más de 5 millones de netbooks en instituciones educativas públicas de todo el país. Pero su importancia no radica en la distribución de equipamiento, sino en la modalidad 1 a 1 , orientada a superar la brecha digital a partir del acceso físico, al tiempo que a reemplazar los modelos tradicionales de enseñanza con las TIC. Bajo esta premisa, los Capítulos que componen la Tercera Parte se centran en el análisis, comenzando por la cuestión del acceso en su doble dimensión, material y simbólica. Diferenciar las dos grandes etapas (2011 a 2013 y 2014-2015) nos permite observar continuidades y discontinuidades a lo largo de la implementación del PCI, quiénes son sus destinatarios/as (directivos, docentes, estudiantes y otros), cómo negocian y resignifican sus propósitos, cuáles son los variados escenarios en los cuales dinamizan posibilidades político-pedagógicas de transformación.

Algunas investigaciones sostienen que, tras un momento de incertidumbre, se produce cierta estabilidad en la que los actores se movilizan hacia la construcción de sentidos en torno a la nueva tecnología a la manera de una "ventana de flexibilidad interpretativa" (Dussel y Quevedo, 2010). Tras cinco años de implementación del PCI, ¿es posible verificar rasgos de esta relativa estabilidad? Y en tal caso, ¿cuáles son sus alcances en términos de apropiación digital en las particulares condiciones materiales y simbólicas de la escuela secundaria técnica?

En consideración a las relaciones estrechas que las involucran, se abordan las Dimensiones del Acceso, Uso y Apropiación, con el objeto de interpelar las condiciones que favorecen u obstaculizan el proyecto de inclusión digital en términos de una "curva de intensidad" que transcurre desde las modalidades de acceso hacia experiencias crecientes y significativas de uso y apropiación tecnológica. A continuación, presentamos las principales orientaciones teórico-metodológicas que han guiado la elaboración de cada una de las categorías producidas, las tres Dimensiones mencionadas y sus respectivas Subdimensiones. Al finalizar el desarrollo del análisis de acuerdo a cada Dimensión, revisamos de modo esquemático los resultados más salientes, para integrarlos críticamente en las conclusiones preliminares del Capítulo.

\subsection{La cuestión del Acceso en la convergencia digital}


En el ya clásico Convergence culture, Henry Jenkins asume a la convergencia digital como el flujo de contenido "a través de múltiples plataformas mediáticas, la cooperación entre múltiples industrias mediáticas y el comportamiento migratorio de las audiencias mediáticas, dispuestas a ir casi a cualquier parte en busca del tipo deseado de experiencias de entretenimiento" (2008: 14). El concepto no se reduce a la interacción con unos aparatos mediáticos; representa un cambio cultural, por cuanto debilita la clásica división entre productores y receptores para involucrar a los usuarios en procesos cognitivos activos, que los habilita para buscar información, relacionar contenidos y producir conocimientos en muy diversos ámbitos.

En consecuencia, el acceso diferencial a estas posibilidades no se explica meramente desde la dicotomía poseedores/desposeídos tecnológicos. De modo que el acceso está siendo resignificado a partir de otras dimensiones como la capacitación, el uso comunitario y la adaptación creativa de las tecnologías. En consonancia con el informe del PNUD de 1999, estas reformulaciones no se limitan a considerar la distribución de aparatos o el nivel de penetración de Internet, sino que contemplan también los usos que realizan las personas, como asimismo las múltiples representaciones atribuidas a esos usos en contextos concretos.

Acceder tampoco es idéntico a adquirir destrezas básicas de uso operativo, sino que requiere el desarrollo de habilidades complejas en procesos de alfabetización digital. La participación con y a través de TIC involucra aquellas competencias orientadas a que los sujetos capitalicen, activen y potencien la producción de contenidos. Aspectos como la disponibilidad de Internet y la portabilidad de los dispositivos, expresan las oportunidades para aprovechar eficazmente el acceso a la información en cualquier lugar y momento, interactuar con pares y expertos e involucrar una variedad de fuentes en entornos de aprendizaje ubicuo (Burbules y Callister, 2001; Burbules, 2012). También implican capacidades de navegación discriminada por objetivos propios, para la participación ciudadana y la integración social, como el conjunto de predisposiciones para usar la tecnología de manera autónoma y socialmente responsable.

Estos aspectos han sido explorados también por Susana Morales (2013a, 2013b), quien asume que al acceso material debe agregarse el acceso cognitivo: las representaciones y conocimientos que subyacen a las expectativas de los usuarios, que los motivan a tomar contacto con los medios tecnológicos y le atribuyen sentido a esas experiencias en los complejos tecnomediáticos de los que forman parte. Recuperamos aquí nuestras objeciones a la metáfora ecológica de herencia mcluhiana (Fernández Massara, 2014, 2016a), porque la idea de "ecosistema” puede reducir la brecha digital a la cuestión de posesión o disponibilidad, o bien naturalizar la distancia entre "nativos" e "inmigrantes" como una cuestión constitutiva. En cambio, la noción de complejos tecno-mediáticos revelan su carácter inestable, definido por la obsolescencia de los dispositivos, 
el nivel creciente de portabilidad y transversalidad, y la convergencia de varios medios en el triple play (televisión, telefonía celular, Internet), como destaca Roxana Cabello (2008a, 2008b). ${ }^{16}$

El recorrido que se presenta a continuación aborda la cuestión del Acceso Digital en torno a dos grandes Subdimensiones, como ya precisamos: por una parte, Disponibilidad o Posesión Material, que habilita las posibilidades de tomar contacto físico con los dispositivos, la disponibilidad o existencia, la posesión o propiedad. Y, por otra, los Saberes y Disposiciones para el Acceso Cognitivo, las posibilidades concretas para tomar contacto simbólico/cognitivo, el conjunto de conocimientos, actitudes y disposiciones relativos a esos dispositivos.

\subsubsection{Continuidades y discontinuidades en el Acceso Material}

Asumiendo entonces que el problema del acceso no reposa meramente en la disponibilidad física de las tecnologías, sino que comprende también los modos de utilización, distinguiremos las condiciones de acceso y uso, respecto de aquellos efectivamente producidos. Como se ha mencionado, las dos escuelas técnicas de Olavarría fueron las primeras en recibir las netbooks. En 2010, el PCI subsume el Programa "Una computadora para cada alumno", orientado al Ciclo Superior de las escuelas técnicas. 15.000 en total han sido distribuidas en establecimientos de la ciudad (secundarias, de educación especial y de formación docente). Comenzaron a entregarse a las escuelas a fines de 2010 y desde 2011 a los estudiantes del Ciclo Superior (solo posteriormente empezaron a ser distribuidas en el Ciclo Básico). ${ }^{17}$ En la primera etapa, la EEST No 1 recibió 106 netbooks y la EEST $\mathrm{N}^{\circ} 2,560$. Las netbooks sobrantes fueron ubicadas en distintas dependencias, especialmente, Dirección, Regencia, Biblioteca y Equipo Orientador.

Interesan aquí los aspectos institucionales, primeramente, en términos descriptivos: la administración de tiempos y espacios, acceso y disponibilidad de recursos, percepciones de los sujetos frente a las innovaciones tecnológicas en la escuela (Loyola, 2011). Si bien desarrollaremos este problema como una de las subdimensiones de las mediaciones tecnológicas, importa examinar cómo las determinaciones institucionales repercuten en los niveles de acceso digital. Por una parte, se prevé la instalación del piso tecnológico, a los fines de enlazar a todas las netbooks entre sí con un servidor centralizado (AP), con el propósito tanto de asegurar la seguridad de las computadoras

${ }^{16}$ Una de las novedades más notables en este sentido es la televisión digital. Constituye no solo una innovación tecnológica del medio más masivo, sino que prevé niveles cada más complejos y extendidos de uso, que modifican substancialmente las posibilidades interactivas de los usuarios en sus entornos tecnoculturales.

${ }^{17}$ Las expresiones "Ciclo Básico" o "ESB” (1 ero., 2do. y 3er. Año) y “Ciclo Superior" (4to., 5to. y 6to.) remiten al Nivel Polimodal, modificado a partir de la unificación de la escuela secundaria. Sin embargo, mantendremos estos términos en consonancia con los discursos en las propias instituciones, cuyas dinámicas cotidianas se encuentran material e imaginariamente organizadas en torno a esta distinción. Por otra parte, recién en 2015 el $7 \mathrm{mo}$. Año se vuelve obligatorio para las escuelas técnicas, lo que marcará otro rasgo diferencial respecto de las escuelas medias. 
como de compartir contenidos y aplicaciones. Pero el sistema ha demostrado serias dificultades de funcionamiento, sumadas a la falta de competencias necesarias para conectarse al servidor y aprovechar el programa Maestro, con el objeto de regular los usos de los alumnos.

Otra cuestión no menor es que las aulas no cuentan con suficientes enchufes o estos se encuentran deteriorados: las baterías se descargan mucho tiempo antes de terminar una jornada extendida de más de ocho horas. Y contradictoriamente, a pesar de su deterioro edilicio y sus serias dificultades de funcionamiento institucional en esta etapa, la EEST $\mathrm{N}^{\circ} 1$ es la única que presenta condiciones de conectividad, aunque con alcance limitado, en tanto la EEST $\mathrm{N}^{\circ} 2$ solo cuenta con Internet en los laboratorios de informática. A consecuencia de ello, las nuevas netbooks son valoradas según su "practicidad" para el acceso personal y áulico, que permite optimizar los tiempos escolares y evitar trasladar a los grupos. Sin embargo, para una mayoría de los profesores, las deficiencias de la instalación de la red impiden un uso más eficiente: "es muy lenta la transferencia de datos", "toda una escuela conectada no podría trabajar tampoco..."

Como contraparte, ambas escuelas se encuentran ampliamente equipadas en los laboratorios: en la EEST $\mathrm{N}^{\circ}$ 2, siete en total con más de 40 computadoras de escritorio cada uno, sumadas a las netbooks distribuidas desde el Plan para escuelas técnicas. Pero las computadoras resultan insuficientes para una matrícula de más de mil estudiantes, están desactualizadas o presentan fallas que no son reparadas con suficiente rapidez. Al mismo tiempo, las limitaciones de espacio vuelven dificultoso el acceso: los laboratorios permanecen ocupados por los cursos, especialmente por los de orientación en Informática. Evaluar estas condiciones de base como sus cambios o continuidades a lo largo de período analizado, nos permitirá dar cuenta, entre otras cuestiones, si el modelo 1 a 1 tiende a reemplazar o a complementar productivamente al modelo tradicional de enseñanza con las TIC, tal como dictamina el PCI en sus lineamientos generales.

En la segunda etapa, dos variables se destacan especialmente en cuanto a las condiciones del acceso: las netbooks han comenzado a distribuirse en los años inferiores (ESB) y la mayoría de las existentes se encuentran bloqueadas o rotas, aproximadamente dos tercios del salón: presentan fallas por el desgaste, sumadas a las dificultades del traslado y los riesgos de robos:

Para el trabajo del aula alcanza, son equipos chiquitos pero alcanzan. El tema es la movilidad, porque a veces la cuidan pero por ahí en el camino a la casa se le caen de la mochila. Ahora no tanto, pero al principio los asaltaban. Entonces no querían traerlas... (Jefa del Departamento de Informática).

Otro punto problemático es el sostenimiento de una política de recursos y apoyo tecnológico para sustentar el cambio (reposición, reparación y asesoría técnica). Mientras que la tarea de desbloquear las netbooks se realiza en la misma escuela, las reparaciones sufren largas demoras. 
Hacia 2014, pueden extenderse hasta un año y medio, generando conflictos que se dirimen más allá de la escuela y adquieren visibilidad social en los medios de comunicación, en especial por el reclamo de los padres. Por ejemplo, una nota del diario local El Popular titulaba "La rotura de pantallas, el problema más habitual en Conectar Igualdad" (3/12/14).

Las contradicciones entre acceso físico y acceso simbólico persisten, pero adquieren diferentes características según el período analizado: a riego de generalizar, si al principio las netbooks se encuentran ampliamente disponibles pero los profesores se muestran escépticos o reacios a explorar sus potencialidades; en la segunda etapa manifiestan disposiciones favorables,

pero las netbooks ya no están en el aula. Así lo sintetiza enfáticamente otra entrevistada:

Yo traigo mi notebook, mi netbook ahora la tengo bloqueada. Esa es otra cuestión. Tardan mucho las máquinas si se estropean, se rompe la pantalla, se rompe el teclado. Ahora que empieza a ver propuestas, ¡las computadoras no están! ¡En los grupos grandes es un problema! (EEST N 1, Prácticas del Lenguaje, 3er. Año).

En cuanto a las condiciones de Internet, observamos continuidades en ambas escuelas. En tanto la EEST $\mathrm{N}^{\circ} 2$ sigue siendo una deficiencia objetiva, se han agudizado las dificultades para acceder a las salas de informática, permanentemente ocupadas por los cursos debido a un crecimiento sostenido de la matrícula. La EEST $\mathrm{N}^{\circ} 1$ mantiene sus oportunidades de conexión, aun cuando no logra aprovecharlas plenamente con propósitos educativos, como consecuencia del deterioro de las netbooks y una situación paradojal que, por razones distintas y de orden simbólico, impide el aprovechamiento de laboratorios ampliamente equipados. Como precisaremos luego, las disposiciones hacia la innovación tecno-educativa, percibida como favorable a los procesos largamente esperados de mejoramiento institucional, guardan contradicciones con los modos en que la propia escuela materializa sus lógicas de conservación, tanto de los recursos que considera valiosos como de los modelos tradicionales que definen sus sentidos y determinaciones sociales.

\subsubsection{Saberes y Disposiciones: "una película de Fellini”"}

Operan en estas situaciones, continuidades, deslizamientos y fracturas entre el acceso físico y el acceso simbólico/cognitivo. En torno a la segunda Subdimensión sobre el acceso simbólico/ cognitivo, surge entonces la pregunta acerca de las representaciones docentes, marco apropiado para interpelar estas construcciones discursivas, donde se dirimen las tensiones entre lo individual y lo social, entre lo tradicional y lo alternativo. Son individuales y cognitivas en tanto la persona se apropia de un conocimiento, recreándolo, pero son al mismo tiempo colectivas, porque han sido construidas en las escuelas y en el contexto social; desde allí se actualizan, construyen y recrean en la interacción comunicativa cotidiana (Ortiz Casallas, 2013). 
Ya en la primera etapa, los directivos anticipan los condicionamientos que habrán de mediar las posibilidades efectivas de inclusión digital. Tienden primeramente a la personalización, como a una sensación de "sorpresa" generalizada: las netbooks irrumpen repentinamente en el espacio escolar. Términos como "fantástico", "divino", "bárbaro", "buenísimo", califican favorablemente al Plan, pero revelan a la vez las contradicciones con un alto nivel de “improvisación”, en el sentido que el Estado no ha preparado a sus agentes ni considerado las particularidades de los centros educativos. Para los profesores, "no es tan simple como para implementar todo ya", "largan las computadoras sin que estén dadas las condiciones", "la política de implementación no es tan fácil”, “faltó programación”, “faltó planeamiento”, “...no se ha planificado, digamos. Todo se ha hecho... improvisado (...) creo que no se ha organizado bien".

En el caso de la Directora de la EEST $\mathrm{N}^{\circ}$ 2, conviven la desinformación, los problemas presupuestarios y los cuestionamientos a decisiones que se perciben como verticalistas y escasamente consensuadas, además de la sensación de inseguridad asociada a los robos. Se destacan el uso constante de la ironía y construcciones retórico-estilísticas: "muchachitos", "todo guardadito", “de regalo", “desesperación”, “dulce espera”, “divino”, etc. Uno de los ViceDirectores comparte la sensación de ajenidad ligada a las "imposiciones" del gobierno, las reservas con respecto al PCI que "no está cerrado" y, sobre todo, un término que cristaliza tempranamente las vinculaciones conflictivas con las netbooks: "tuvimos que regalarlas."

La posibilidad de que los chicos se lleven la computadora marcará una fractura imaginaria con el modelo previo para escuelas técnicas, al tiempo que una mirada tensionada entre la cosificación del aparato y la crítica ideológica al proyecto. "Regalar" significa subestimar sus posibilidades efectivas de integración pedagógica. Pero, además, viene a revertir la autonomía institucional, la capacidad de decisión. Años anteriores, las netbooks permanecían en la sede y eran distribuidas durante la jornada escolar, un sistema que en la EEST $\mathrm{N}^{\circ} 2$ parecía funcionar con cierta "normalidad". El PCI implica entonces una doble pérdida de "control": a- sobre los mismos equipos, que ahora los estudiantes llevan a sus hogares; y b- sobre los usos extra-escolares, que se replican en el ámbito escolar y que devienen en obstáculo concreto para propiciar el aprendizaje:

Pero yo soy muy crítico. Para mí es un error haber dado las computadoras, te lo digo desde acá (se señala el pecho). Yo te puedo decir que tenemos un gran ciber acá adentro, ¡me da una lástima terrible! ¡Yo soy terriblemente crítico! Yo no les hubiera dado nada. Están todo el día con los jueguitos, me tienen re podrido (Vice-Director).

A esto se suma una percepción que, aunque excepcional, reviste cierta importancia por cuanto contribuye a un escenario de recelos o sospechas. El Vice-Director citado advierte sobre el riesgo de que la instalación de la red eléctrica e Internet termine sometida a intereses privados, 
completamente ajenos a la escuela pública: "No quisiera ser mal pensado y que esto sea un negocio. Que venga una empresa y gane un montón de plata..." Posicionamientos que redundan en una mirada cuestionadora sobre condiciones concretas de funcionamiento que debieron preverse. El profesorado de la misma escuela suele compartir estas ideas: "Después... hay mucho de negocio, lo que salía mil termina saliendo dos mil... Pero bueno, esto nos perjudica a todos, pero por lo menos ellos tienen el beneficio de tener una computadora. Está todo agarrado con broches así..." (Electrotecnia, Orientación Electromecánica).

El segundo Vice-Director de la EEST N ${ }^{\circ} 2$ entiende, en cambio, que los problemas técnicos o de infraestructura no relativizan los beneficios del PCI, en el marco de las transformaciones asociadas a la Ley de Educación Nacional y al papel del Estado para desarrollar estos procesos. En este caso, las tecnologías pueden ocupar un lugar motorizador y casi excluyente de modalidades alternativas de acceso al conocimiento escolar: "¿Qué dice el gobierno? Que la brecha digital, que el chico que no tiene acceso a la computadora no tiene acceso al mundo. Entonces dice en 2006: si yo quiero una educación igualitaria, prescriptiva, de calidad, perfecto: acá tienen todo."

Nos detendremos luego en la persistencia de cierto determinismo tecnológico que decanta en el compromiso de responder a la tecnología en términos lineales, en base a la idea renovada de progreso. Este argumento sostiene que la educación es el agente causal, en tanto las TIC son un mero instrumento neutral que adscribe a todos sus principios, significados y potencialidades. Pero, además, esos conceptos focalizan en la supuesta incapacidad del docente para afrontar estos desafíos, evitando que "se nos desbanden los pibes" y "no se desaprovechen en jueguitos".

Ahora: hay que capacitar a los docentes. Pero el gobierno apela a la capacidad profesional de cada docente, porque si el chico, como dice Omar, no está prestando atención. ¿De quién es la culpa? ¿Del docente o del chico? Del docente, porque el docente tiene que usar una estrategia pedagógica para que los chicos estén usando las computadoras para el verdadero propósito que tiene el gobierno. Sí, en teoría es fantástico...

Así y todo, el entrevistado comparte con otros las contradicciones entre teoría/práctica, lo formal/lo real, lo prescriptivo/lo realizable. Es decir, las distorsiones entre los objetivos inclusivos del PCI y las condiciones concretas que hacen posible su funcionamiento: "en la práctica, complica al docente." Se asume a la práctica docente como eje vertebrador, sea en términos de la capacitación o del conjunto de predisposiciones que involucran su ejercicio, cuestiones que atraviesan los discursos en ambas instituciones y a lo largo de todo el período:

El PCI es fantástico, pero no sé si en la práctica se podrá llevar a cabo. Yo lo pongo en duda, porque lo he visto. Por ejemplo, vos entrás a la escuela y ves a todos los chicos con sus netbooks y decís: qué bárbaro, estamos en las puertas del siglo XXI, ¡el ideal de educación! Pero ¿qué pasa? El profesor les da para escribir: los chicos ya lo saben... (Vice-Directora EEST $\left.N^{\circ} 1\right)$. 
En la segunda etapa, las concepciones más escépticas comprenden continuidades antes que cambios sustantivos y más favorables al PCI, tanto en lo concerniente a las condiciones de interactividad en las clases como las diversas disposiciones implicadas en el acceso digital. El destiempo cobra fuerza simbólica cuando una frase popular metaforiza los retrasos en aspectos fundamentales de la implementación, actualizando cierto escepticismo extendido en torno a sus consecuencias en las escuelas. El eje de interés es la capacitación: "Porque se acaban de dar cuenta de que no se usan, poner el carro antes del caballo, se dieron cuenta un poco tarde... debieron empezar por ahí, pero bueno, démosle el beneficio de la duda" (Director EEST N²).

Estas expresiones pueden expresar condiciones generales que se vuelven incongruentes con los propósitos esperados de cambio social, escindidos del cambio educativo:

No digo que no esté bien el acceso, igualar, y que lo pueda tener fulano y mengano, pero hay que ver el contexto, que eso solo no alcanza y por eso no se empieza (...) cuando le encontremos la vuelta, o cuando los profesores hagamos un click, cuando podamos significarlo, va a ser un paso más. Pero después esa dimensión social, yo no acordaba y no acuerdo" (Vice-Directora, ex profesora entrevistada en 2011).

Por contraste, el nuevo Director de la EEST N 1 enuncia comparaciones significativas para describir sus sensaciones frente a la irrupción de las netbooks, aunque las valoraciones atribuidas a esa euforia generalizada aluden a un impacto social y familiar antes que a una función claramente educativa. Paradójicamente, en condiciones socio-económicas más adversas, las oportunidades para atenuar la brecha social pueden interpretarse en base a las dimensiones afectivas e imaginales de las relaciones que los jóvenes establecen con la netbook, que ya no es tanto un instrumento didáctico sino un lugar concreto y equitativo de experimentar la cultura.

...viste cuando estás mirando un partido de fútbol y de pronto te ves en la tribuna, mirándote cómo estás jugando al futbol. Y vos decís: ¡están todos locos! Y los pibes, ¡cómo no van a estar locos! Para los pibes, para las familias ¡era la única compu! Y cuando llega a la casa la mamá tiene su Facebook, y qué se yo, ¡harán lo que quieran hacer! Y yo veía esa situación y era como estar viendo una película de Fellini, algo descabellado. Por un lado, los pibes con una felicidad absoluta, jugando o haciendo lo que sea con la netbook...

Esta extrañeza en torno a lo "descabellado" de la situación, denota en el Director, a diferencia de otros casos, la convicción de que un aspecto de estos accesos cuya valía se recupera, es la posibilidad que ofrecen para entrar en contacto directo con las tecnologías, manipularlas, usarlas de maneras entusiastas e incluso desafiantes. No obstante, en lo que respecta a sus usos pedagógicos, los sentidos son evasivos. Tal como se la califica, la sorpresiva irrupción del PCI se traduce en las tensiones entre sus propósitos formales y sus posibilidades reales, o entre las experiencias escolares y aquellas que se vuelven significativas para las culturas juveniles. Al 
mismo tiempo, la práctica docente aparece interpelada cuando lo que está en juego no es la presencia de unos aparatos, sino las representaciones acerca de cuál es el lugar que estos ocupan en la planificación, cómo responden- si lo hacen- a los propósitos del currículum, y cuáles son los ámbitos que transitan los alumnos en sus relaciones con las TIC y que tornan posibles y necesarios los esfuerzos de integración pedagógica en el aula.

\section{Mejoramiento institucional y acceso personal docente}

Retomando la problemática de la conexión a Internet, en la EEST $\mathrm{N}^{\circ} 2$ las expectativas acerca de los accesos digitales están depositadas en los alcances de los Planes de Mejora Institucional (PMI) para complementar las acciones del PCI orientadas en esa dirección. ${ }^{18}$ En la primera etapa, los directivos expresan, por un lado, la convicción de que el uso más frecuente y productivo de las netbooks está supeditado a las posibilidades de la red; por otro, el auto-reconocimiento de la capacidad para gestionar estos proyectos, lo que constituye una marca identitaria distintiva de la institución. En cambio, en la EEST N 1 el PCI puede asumir connotaciones negativas, asociadas a otros problemas. La dificultad para ejecutar el PMI se revela expresión acabada de una situación desfavorable de larga data, la estigmatización social, la falta de compromiso docente y los tiempos burocráticos que no se condicen con las urgencias del establecimiento. Para la Directora:

O sea, que si uno mira las posibilidades que da el Plan de Mejora son muy grandes, son muy grandes, lo que pasa es que esa herramienta tiene muchas dificultades que la escuela, con sus realidades, muchas veces no puede responder y las grandes a veces tampoco...

Vale decir que las tecnologías pueden ser depositarias de cierta conflictividad entre los actores, a la luz de sus diversos posicionamientos tanto político-institucionales como formativos. Siendo comunicadora, la Vice-Directora contradice abiertamente el discurso de la Directora (ingeniera), a quien atribuye falta de personalidad, un pensamiento estructurado, la incapacidad para superar modelos tradicionales y verticalistas de gestión, todo lo cual agudiza las contradicciones percibidas entre el equipamiento técnico y las deficiencias de calidad educativa: "Después, la escuela técnica ha recibido mucha plata, muchos materiales, pero vos podés recibir

${ }^{18}$ El Consejo Federal de Educación (CFE) puso en marcha en 2009 una serie de resoluciones para dar direccionalidad a los cambios comprendidos por la LEN. Los PMI responden al siguiente propósito: "Financiar planes de mejora que fortalezcan los procesos de enseñanza, aporten condiciones para sostener las trayectorias escolares, permitan la construcción de diversos recorridos para la enseñanza y el aprendizaje y brinden condiciones para otros modos de organización del trabajo docente" (Res. CFE No 84/09, Anexo: 27). Véase Montesinos, María Paula y Schoo, Susana, La implementación de los planes de mejora institucional. Aportes para las políticas orientadas al fortalecimiento de la educación secundaria obligatoria. Serie Informes de Investigación, № 9, agosto de 2014. 
toda la plata, todo el material, pero si eso no lo podés transformar en prácticas pedagógicas para que el pibe pueda salir y pensar otra cosa..."

Si tenemos en cuenta que las netbooks comienzan a ser distribuidas en el Ciclo Superior de la educación técnica, el modelo tiende a realizar la expectativa de que habrá de suscitar mayor aceptabilidad y un uso progresivamente más intensivo, debido a la formación técnica de la planta docente y a la especificidad de las orientaciones. Ahora bien, si la mayoría de los profesores están familiarizados con las computadoras de escritorio, no es frecuente el acceso o posesión personal de computadoras portátiles. En sus valoraciones, el mayor problema radica en la entrega tardía de sus netbooks, que recibirán más de un año después que sus propios alumnos.

Entre los más escépticos, está claro que las dificultades no se reducen a la falta de acceso personal, sino que significa en la práctica la falta de "control" sobre una tecnología que los adolescentes ya manejaban con soltura y que se anticipaba como un elemento intrusivo en el ambiente del aula. De todos modos, la posesión de la netbook puede involucrarlos en una racionalidad simbólico-afectiva que los iguala con sus alumnos: "Y los profesores..., bueno, uno parece materialista, porque es: ¿para cuándo la netbook? Que es: ¿para cuándo mi netbook? Porque es esta cosa de... poseer, ¿viste? (EEST N² 2, docente de Geografía, O. Informática).

Por otro lado, acceder a la netbook puede ser, paradójicamente, una obligación: no solo es extraña, sino que representa los imperativos del sistema y las sucesivas y cada vez más rápidas transformaciones a las que hay que "adaptarse". Su correlato es un proceso persistente de cosificación. La computadora se concibe como "herramienta", sea para examinar sus aportes como para cuestionar sus limitaciones. En el total de las 60 entrevistas realizadas, el término es utilizado 88 veces, sin distinción de la posición de los informantes ni del período analizado. Se trata de un binarismo de base donde la tecnología se presenta aislada del conjunto de prácticas y representaciones que la definen, como de sus determinaciones socio-políticas más amplias.

Significativamente, la noción de adaptación da sustento simbólico tanto a las connotaciones negativas atribuidas a la netbook como a las consideraciones más favorables respecto de la posesión personal. Ambas posiciones remiten a un hondo cuestionamiento a la gestión escolar, que se revela impotente para llevar adelante las adecuaciones necesarias de una política pública. Las críticas desde los profesores de área -es decir, de la formación generalista, no técnica-, pueden materializarse en un "nosotros inclusivo" que implica un conjunto de dificultades compartidas en el ejercicio de la práctica, en el que PCI viene a cristalizar las problemáticas exigencias del sistema.

En contraste, los profesores técnicos esgrimen generalizaciones sobre una situación en la que no se sienten involucrados, bajo el entendido de que la llegada de las netbooks para los docentes conllevará la superación de las resistencias de esos "otros", incluso cuando reconocen 
junto con ellos las dificultades objetivas de implementación. Entrevistados de la EEST $\mathrm{N}^{\circ} 1$ expresan esas diferencias: "Yo tengo mi netbook. Pero los profesores no tenemos esas netbooks (...) Si el gobierno pretende que los docentes trabajemos con esto, debemos tener todas las herramientas" (Inglés). Para su colega, "significa que se deben dar sí o sí, hay toda una política curricular que marca ese cambio. Y por otro lado, está esa herramienta que tiene el chico y que el profesor no tiene" (Montaje de Proyectos Electrónicos).

En ambos casos, la alianza entre acceso y posesión personal refiere a las dificultades de no tener "la netbook del PCI", aun si cuentan con computadoras u otros soportes. Las diferencias socio-económicas de base entre los docentes pueden ser un condicionante, pero no determinan de modo absoluto las expectativas acerca de sus modos de incorporación a las actividades didácticas. Antes bien, esas opiniones suelen ser más favorables en materias que ya tenían una relación cotidiana y constitutiva con las tecnologías digitales (materias técnicas de las orientaciones):

A mí me parece fantástico el uso de las netbooks. No siempre, en ocasiones, pero a mí me facilita mucho, porque había momentos que queríamos usar el laboratorio, pero estaba ocupado, había que sacar turno, por hache o por be no tenía acceso (EEST $\mathrm{N}^{\circ} 2$, Diseño y Procesamiento Mecánico, O. Electromecánica).

Acá (en el laboratorio) hay 15 chicos, sería imposible que todos pudieran acceder, además que son máquinas de cuatro o cinco años. Ahora yo les traje un software que es sobre diseños de plaqueta, y está en Internet (EEST N 1, Proyecto y Diseño Electrónico, O. Electrónica).

A menudo, estas posiciones redundan en confusiones entre acceso y uso, en el sentido de que la disponibilidad física pueda per se garantizar la integración de carácter pedagógico, no solo instrumental. La característica más percibida es la conveniencia, articulada en torno a la practicidad, la facilidad de uso, la rapidez en el acceso y otras cualidades de orden operativo. Otra versión del determinismo tecnológico que ya no gira principalmente en el valor del progreso, sino en la idea de que la portabilidad de las netbooks viene a facilitar el trabajo docente, ahorrar tiempo en los traslados, acceder a determinados softwares, evitar el costo de libros y fotocopias. Esta problemática adquiere múltiples aristas y ofrece continuidades a lo largo de todo el proceso: “Además, cómo adoptó la escuela que los chicos tenían que usar las computadoras, yo no te puedo decir porque nosotros ya veníamos usando las computadoras. Pero profesoras de otras áreas se quejaban de que estaban jugando todo el tiempo..." (EEST N² 2, Laboratorio de Programación).

Durante la segunda etapa, los profesores de área también valoran la disponibilidad física, pero no identifican aplicaciones de utilidad para sus materias más allá de herramientas básicas como Word o PowerPoint. Los profesores técnicos pueden expresar también una distancia insalvable entre áreas, construida discursivamente en términos de ellos/nosotros. La consecuencia es que la legitimidad político-institucional del PCI y los dilemáticos esfuerzos de 
inclusión digital habrán de imprimir nuevas lógicas a las tensiones entre posiciones en pugna que se materializan en este campo educativo. En los términos de Huergo (2010), los discursos docentes se vuelven hegemónicos si generan conformismo respecto de un orden social establecido, al tiempo que se revelan contrahegemónicos si operan cuestionamientos o resistencias a las relaciones de dominación, en actitudes individualistas, en modos de pensar dogmáticos.

\section{La falta de capacitación como obstáculo: primeros apuntes}

Aunque profundizaremos luego en la capacitación docente, nos detendremos brevemente en los saberes y disposiciones (o la falta de ellos) que se actualizan en el acceso cognitivo, como asimismo en relación a dificultades u oportunidades percibidas. Las correlaciones entre acceso y capacitación han sido abordadas, por ejemplo, por Géliga Vargas (2006), en el sentido de que el acceso no comprende meramente la posesión o disponibilidad física a los equipos, sino el conjunto de capacidades para encontrar, evaluar, discernir y adaptar información disponible. La falta de capacitación docente constituye un agravante de la sensación extendida de desconocimiento y ansiedad durante la primera etapa, y también una de las manifestaciones de las destemporalidades en las condiciones de acceso y uso. Así lo advierte la Directora de la EEST $N^{\circ} 2$ :

Pero tenemos un problema: el plan de capacitación de uso de las netbooks para profesores se largó ahora. Se va a largar ahora, está la preinscripción. Ahora, yo dije el otro día: todo el año pasado tuvieron para hacer la capacitación, ¿por qué no la hicieron?

En la segunda etapa, los profesores de área comienzan a manifestar mayor predisposición a las propuestas de capacitación docente. En cambio, aquellos a cargo de áreas técnicas suelen confiar en su formación inicial, lo que da sustento a la idea de que es suficiente e indispensable haber adquirido las destrezas de tipo instrumental o el manejo de los programas informáticos para implementarlos productivamente en la enseñanza. En otros casos, hay una voluntad de integración pedagógica que se condice con reflexiones más generales sobre las TIC y sobre las oportunidades que representa actualizar sus conocimientos previos para superar la mentada brecha digital, no obstante no logran dimensionar plenamente sus sentidos ni llevar a la práctica modalidades más novedosas e interactivas con sus alumnos. Las disposiciones hacia la computadora expresan continuidades respecto de otros materiales didácticos, pero con frecuencia los usos que se realizan de los mismos se reducen a la información que pueden aportar a la clase: "Bueno, yo ya venía trabajando con la computadora y otros recursos audiovisuales, por ejemplo, el otro día vimos un fragmento de una película para que pudieran identificar características de la sociedad industrial clásica... se muestran muy interesados.” (EEST N¹, Análisis Matemático, O. Química). 
Captar la atención, motivar el trabajo áulico o negociar los ejercicios, pueden ser propósitos válidos en esas interacciones, pero reducidos a una doble concepción: que es "más fácil" o "rápido" obtener información a través de la navegación, y que el seguimiento del aprendizaje, condensado en torno al "control" de lo producido, significa "copiar en la carpeta". En consecuencia, prevalece cierto discurso racional-eficientista connivente con la concepción tecnocrática de Internet como herramienta, aquella que no favorece la discriminación de la información si no se inscribe en propuestas didácticas más complejas que orienten la producción de conocimientos. "Estos marcos reconstructivos son disciplinares, son gnoseológicos e implican una profunda comprensión de cómo se organiza la información en un entorno como Internet” (Lion, 2006: 72).

Los directores suelen ser particularmente críticos en sus discursos, donde conviven actitudes docentes "negativas" (falta de compromiso o profesionalidad, resistencia a los cambios, modelos obsoletos de enseñanza), los retrasos en las políticas de capacitación y los beneficios ponderados del acceso, mayormente asociados a las cualidades técnicas de los equipos:

Y este año (2015), con la predisposición del PCI para capacitar, para la asistencia técnica con las reuniones de directores, que les decimos: los profesores siguen realmente desorientados, la máquina divina, pero siguen desorientados. No lográs que haya un uso constante o un uso crítico de las netbooks (Vice-Directora EEST $\mathrm{N}^{\circ}$ 2).

Las acciones del Estado apuntan a resolver las deficiencias en la capacitación docente a partir de la aprobación del PNIDE (Plan Nacional de Inclusión Digital Educativa), bajo el objetivo de intensificar el uso de las TIC en la mejora continua de los procesos de enseñanza-aprendizaje. La coordinadora de la Dirección de Tecnología Educativa señalaba que si bien estas capacitaciones debieron hacerse "mucho tiempo antes", inauguran una segunda etapa una vez cubierta la totalidad del equipamiento. Muchos docentes (si bien no la mayoría) han respondido satisfactoriamente a estas propuestas. Es el caso del profesor de Sistemas Productivos (EEST N $\left.{ }^{\circ} 1\right)$ que describe su participación en cursos de capacitación y cómo ha logrado capitalizarla en las tareas didácticas: "Sí, estamos usando las compus de PCI, después tenemos una plataforma virtual, el modo donde les escribo las consignas y ellos van subiendo las actividades..."

De manera que el saber instrumental adquiere plena utilidad en tanto responda a la planificación, con claros objetivos pedagógicos, orientados a suscitar el aprendizaje significativo. Así lo entiende la coordinadora de la Especialización en Educación y TIC:

Por más que las computadoras no estén, igual los chicos tienen sus celulares y se puede trabajar con los celulares, pero para eso tenemos que estar capacitados. Los docentes tienen que estar capacitados para trabajar con los recursos existentes, que los chicos ya manejan.

En esta segunda etapa, se verifican al mismo tiempo una predisposición creciente y una participación todavía minoritaria en las capacitaciones. Los profesores comparten la idea de 
que estar capacitados contribuye a mejorar la planificación y a hacer un uso más creativo de las tecnologías. En algunos casos, evalúan que el modelo de nivel primario del aula digital (comprendido en el PNIDE) puede adecuarse a instituciones secundarias no alcanzadas por el PCI, como las escuelas privadas y los bachilleratos de adultos. ${ }^{19}$ En suma, el Plan renueva un conjunto de posibilidades al margen de la disponibilidad o no de los equipos, para repensar la utilidad de otros soportes más actualizados como tablets y teléfonos celulares, y el desarrollo de unos saberes flexibles y complejos que involucren mayor sistematicidad en el uso y un rol docente más activo.

\section{Accesos diferenciados y significados atribuidos en los discursos juveniles}

Los niveles de acceso a conexión a banda ancha en los hogares de estudiantes de la EEST $\mathrm{N}^{\circ} 2$ son muy superiores (casi en su totalidad), en tanto la mayoría de quienes asisten a la EEST $\mathrm{N}^{\circ} 1$ solo acceden en la escuela. Debido a la doble jornada, tampoco cuentan con tiempo material para asistir a otros lugares, como los cibers u hogares de amigos. Sin ser una determinante absoluta, la netbook puede ser la primera y única computadora propia y a menudo, de la casa.

En la primera etapa, estos nuevos accesos son objeto de muy diversas representaciones. Aunque no conocen propiamente los objetivos del PCI, hay en los estudiantes plena consciencia de que todos tienen ahora iguales oportunidades de participar en la cultura digital, si bien estas siguen articuladas en torno a las ventajas de la disponibilidad física, la propiedad o la posesión personal. Igualmente se verifica una repercusión simbólica que evidencia una sensación de igualación entre escuelas públicas y privadas, entre hogares con y sin tecnologías, entre chicos de distintos sectores sociales (Cabello, 2014). Un aspecto destacable remite a las expectativas sobre los efectos multiplicadores en las familias, especialmente en aquellas en situaciones de vulnerabilidad social.

Los jóvenes reconocen interacciones fluidas y dinámicas con las TIC, sobre todo computadoras de escritorio. Con el tiempo, habrán de configurar sus propias estrategias retóricoexpresivas de apropiación, que privilegian ser y sentirse propietarios de la netbook antes que compartirla con sus padres o hermanos. Estas experiencias satisfacen el propósito de igualar en el acceso individual, aglutinando un conjunto de valoraciones favorables y disposiciones afectivas, pero revierten en la práctica las pretensiones de difusión tecnológica a las familias. Una estudiante de 6to. Año de la EEST N 1 reconocía que: "Yo ya tenía computadora en mi casa, la

${ }^{19}$ El aula digital móvil consiste en una unidad de equipamiento que incluye básicamente 30 netbooks, un servidor pedagógico, un router inalámbrico y un carro de carga, guarda y transporte. Las primeras aulas se destinaron a los establecimientos incorporados al Programa Integral para la Igualdad Educativa (PIIE) por su condición de mayor vulnerabilidad y a aquellos que extienden su jornada escolar, bajo el objetivo de reducir la brecha digital y social. 
de escritorio, no la netbook. Pero es más de mi hermano. Ahora la computadora es mía, ja.” Esta individualización del consumo parece reñida con los propósitos de PCI, sea porque tiende a entorpecer el trabajo colaborativo para el aprendizaje escolar, como porque relativiza los efectos multiplicadores del acceso. Las netbooks definen formas de adscripción identitaria entendidas aunque no exclusivamente- en clave de disputa generacional. Volveremos sobre este punto.

La propiedad también puede atribuirse a la escuela, donde está mediando la trama de ordenamientos institucionales, aunque de manera más bien difusa. La escasa información que los chicos manejan es a través de sus profesores, cuando la gestión se califica como ausente en la tarea de planificar, organizar y comunicar eficientemente los distintos aspectos de la inclusión digital. Desde allí se construyen los sentidos de las dificultades operativas y de la "pesada burocracia" implicada en la reparación de los equipos, que se agudizan en la segunda etapa: "La computadora queda a cargo tus tutores, pero en sí es propiedad de la escuela” (4to. Año, Electrónica).

Las percepciones no son las mismas para quienes ya contaban con computadoras personales y acceso a Internet. Los estudiantes de la EEST $N^{\circ} 2$ suelen cuestionar las condiciones técnicas o el nivel de operatividad de los equipos: son “chiquitas", “más lentas", “se rompen”, "se bloquean”, “son pesadas". Estos discursos evocan un proceso de racionalización antes que una valoración propiamente afectiva, imágenes que hablan no tanto de los objetivos del PCI sino del grado de improvisación atribuida. Sostienen, en consonancia con la mayoría de los adultos:

1- La opinión de que se podría haber invertido en otras cuestiones, percibidas como más importantes o prioritarias para la escuela: "Creo que fue, bueno, entreguen las computadoras. Un día llegó un camión y nos dieron las computadoras. Pero hay otras prioridades, no sé, computadoras para los laboratorios..." (6to. Año, Maestro Mayor de Obra).

2- La desinformación, la falta de espacios o encuentros institucionales que comuniquen los objetivos del PCI, lo que produce, según el caso, un clima de incertidumbre o bien de indiferencia generalizada: "Si me dijeron (sobre Conectar Igualdad) no me acuerdo. No tengo idea de qué se trata. Creo que escuché en la tele o algo" (6to. Año, Automotores).

3- El retraso en la entrega de la netbook a los docentes, un punto sensible que impide un real aprovechamiento en las actividades de enseñanza-aprendizaje: "El profesor no tiene su netbook, es un problema porque no podemos empezar bien, tal vez el año que viene... Nosotros no usamos para nada la computadora el año pasado..." (5to. Año, Electromecánica).

A nivel institucional, las netbooks despiertan el temprano interés del Centro de Estudiantes (CE) de la EEST $\mathrm{N}^{\circ}$ 2. Su presidente esgrime sus desacuerdos con los criterios de distribución, la falta de planificación, las limitaciones en las condiciones de conectividad. Estos conceptos se expresan en el uso de modalizaciones, construcciones metafóricas y presupuestos persistentes 
sobre los destiempos en el proceso de implementación: "Recién este año, ¿ves las bandejas ahí arriba? Tienen los cables. Y ese es el router o el módem, pero todavía no está instalado. Hay que esperar nomás, pero de acá a que se pongan las pilas..." Internet encarna las posibilidades múltiples de la información, fundadas tanto en las características distintivas de acceso personal como también en las disposiciones generales hacia la tecnología, una matriz imaginaria que en la escuela técnica no constituye una mera premisa formal sino que se vivencia cotidianamente.

Hacia la segunda etapa, encontramos algunas continuidades. Las dificultades de conectividad trascienden las cuestiones operativas ligadas al acceso para recrear las tradiciones extendidas de la vieja escuela "Industrial" en sus íntimas vinculaciones con la Facultad de Ingeniería, su paradigma institucional siempre vigente y difícilmente cuestionado, como veremos más adelante: “Al principio hubo Internet pero tenés que tener un sistema que pueda alimentar 700 máquinas. No es imposible. Ingeniería lo hace. Tiene dos servidores de 30 megas y alimenta todas las máquinas...” (presidente del CE EEST $N^{\circ} 2$ ). Similares condiciones de acceso personal y familiar encontramos en esta etapa. Esta estudiante pone en distintas valoraciones las netbooks de su propiedad: "Tengo computadora, en mi casa hay varias, celular y notebook, y conexión a Internet. Uso mucho la compu, sobre todo la netbook porque es mía, es propia (...) Por eso cuando se me rompió la computadora (del PCI) no me importó tanto... (4to. Año, Informática).

Entre los alumnos de la EEST $\mathrm{N}^{\circ}$ 1, parece haberse expandido el acceso a Internet y otras tecnologías en el ámbito familiar, aunque en niveles comparativamente menores y por lo general, de los años superiores. La netbook del PCI puede relegarse a las tareas didácticas, en tanto hay una implicación más personal con los dispositivos "propios", a los que atribuyen mejores cualidades técnicas, capacidad de almacenamiento, velocidad, portabilidad. Es el caso de los teléfonos celulares, tablets, notebooks o netbooks más actualizadas: "Sí, teníamos computadora en casa, yo tengo una notebook, ésta la uso solo en la escuela porque se tilda, en cambio la mía la tengo a mi nivel, o uso el iPod" (6to. Año, Química). Estas distinciones permiten verificar en el análisis que las dificultades de acceso físico (obsolescencia de los equipos, deterioro o bloqueo, retrasos en el sistema de reparaciones) justifican otros cambios de orden simbólico con respecto a la primera etapa, cuando la netbook del PCI era objeto de una apropiación más íntima o afectiva.

Podría concluirse que desde estas nuevas disposiciones los jóvenes transitan desde la netbook como objeto de deseo, hacia consumos racionales o que habiliten usos escolares más eficientes. Empero, es necesario matizar esta afirmación. La distancia entre mi netbook/la netbook del PCI puede tener distintos correlatos: actualizar la brecha tradicional entre tiempo escolar/tiempo no escolar, ponerlos en tensión o atribuirles sentidos novedosos. Y factores como 
la edad, el ciclo educativo, las situaciones socio-económicas, las motivaciones personales, intervienen en los modos en que los adolescentes se apropian de estas tecnologías y las incorporan a sus vidas cotidianas. También están mediando sus demandas respecto de cómo y para qué incluirlas en sus aprendizajes. Estas representaciones desbordan todo intento de generalización, expresando, a veces en tensa convivencia, el pensar y el sentir, la razón y la emoción, en formas particulares de interpretar, valorar y experimentar las oportunidades del acceso digital.

\section{Tensiones y desplazamientos entre el modelo de laboratorio y el modelo 1 a 1}

Las condiciones institucionales ofrecen otros elementos para indagar las tensiones entre acceso físico y acceso simbólico. Un nudo de convergencia de diversas valoraciones lo constituyen las fallas técnicas de las netbooks, que revierten en la práctica las oportunidades del acceso equitativo. Siguiendo con esta segunda etapa, uno de los rasgos que se prolonga entre los discursos docentes es que si las netbooks son para los adolescentes un "regalo", ellos se vuelven "irresponsables" o "descuidados", "no las cuidan", "no se valoran", "las prestan", "borran los programas" para descargar música, guardar fotos, jugar o navegar, y esas actitudes son directas culpables de la falta de acceso en el aula. Subyacen en estos casos una mirada descalificadora, especialmente hacia los más jóvenes y cursantes de la ESB, reduciendo así las limitaciones de la implementación a problemas operativos o a usos imprudentes pero siempre "ajenos" a sus propias acciones docentes.

Cierto es que estas roturas están asociadas a la manipulación y al traslado, y en proporción mucho menor, a fallas de los discos rígidos y componentes internos, pero son los jóvenes quienes a menudo ponen estos problemas en marcos interpretativos más complejos: las fallas son tanto resultado de los maltratos individuales, como de las situaciones de desorganización áulica que tensionan y demandan un rol docente más comprometido. Como en esta estudiante de Electromecánica de la EEST No 2: "Yo recibí la computadora pero ahora no la tengo. Un caos en el salón, patearon varias computadoras, las mochilas, en el recreo, y se me rompió la pantalla...” (5to. Año, mujer). Otra condición cotidiana refiere al traslado, acarrear las netbooks durante largos trayectos y los consecuentes golpes y caídas. De ahí que en ocasiones son ellos quienes prefieren no llevarlas a la escuela, y que estén disponibles dependerá de las exigencias de cada docente.

Una de las respuestas inesperadas a los retrasos en las reparaciones de las netbooks, es que los alumnos intentan repararlas. Aunque por un lado esto implica cierta audacia para manipularlas como la aplicación de conocimientos técnicos complejos, en muchos casos producen fallas todavía más importantes, lo que termina por agravar la falta de disponibilidad y la saturación del sistema 
para resolverla. Esta situación es frecuente en la EEST $\mathrm{N}^{\circ}$ 1, lo que indica cierta incapacidad de

\section{la escuela para regular estas prácticas a la vez que problemas vinculares no resueltos:}

Se rompen, el teclado, la pantalla, se te rompe y le querés meter mano porque tardan como mínimo un año, acá estamos en el laboratorio y tratamos de arreglarlas. De diez arreglamos dos, también las desbloqueamos, jajaja. Por ahí está de licencia el técnico, no va a estar esperando, si lo podemos hacer nosotros, el técnico viene una sola vez a la semana, te quedás sin computadora, sin hacer el trabajo, te retan porque parece una excusa (7mo. Año, Electrotécnica, ex presidente del CE).

Los profesores ponen en juego muy diversas estrategias, en las que operan, contradictoriamente, la legitimidad del PCI, la creciente predisposición al uso pedagógico, las negociaciones de los imperativos de "tener que usarlas". Las actuales modalidades de inclusión digital registran ciertas discontinuidades respecto de los primeros años. Atendiendo a los modelos tradicionales de la escuela técnica, cuando faltan esas computadoras se vuelve a utilizar la sala de informática. Esto significa una renovación de los valores asignados a un espacio que no es solamente físico, sino sobre todo simbólico, animando formas específicas de apropiación institucional como nuevas maneras de concebir la enseñanza con las TIC. Los consumos tecnológicos devienen menos individuales y más colectivos, lo que favorece el trabajo colaborativo; como contrapartida, se quita a la tecnología del espacio del aula, lo que termina por desaprovechar los beneficios iniciales del acceso personal bajo el modelo 1 a 1 .

Ahora bien, la EEST $N^{\circ} 2$ presenta grupos muy numerosos -lo que complejiza el traslado a los laboratorios- y estos suelen estar ocupados por otros cursos debido a las limitaciones edilicias. No contar con las netbooks ni con el salón de informática se vuelve un problema irresoluble en el trabajo áulico cuando la tecnología asume un rol constitutivo o privilegiado: "En el caso de Informática, que vamos a los talleres, te dicen: andan mal, tarda mil años... Para ellos es más fácil trabajar en la sala de informática. Pero por el otro lado les decís que traigan pendrive porque se tienen que llevar los trabajos" (Laboratorio de Programación, O. Informática, 5to. Año).

En la EEST $N^{\circ} 1$ la dificultad no estriba en las limitaciones de espacio. Los docentes suelen referir a los temores y resistencias por parte de la Dirección al acceso libre, a propósito de la responsabilidad que entraña, la manipulación "adecuada" y para determinados usos. Subyacen tres sentidos básicos: a- cierta mirada adultocéntrica y moralizante que negativiza a los jóvenes como "descuidados"; b- los significados restrictivos de la netbook, anclada en un tiempo extra-escolar y mayormente cuestionado; c- la necesidad de "proteger" los equipos percibidos como propios que, a diferencia de la netbook, están "bajo el control” de la institución. En esta segunda etapa, y más allá de los sucesivos cambios de la gestión, la persistencia de estas orientaciones -y la mirada predominantemente instrumental que las sostienen- solo puede ser comprendida desde las 
contradicciones que un contexto socio-educativo de desventaja ejerce sobre decisiones organizacionales que pueden alentar las iniciativas de innovación pedagógica, al tiempo que restringir el acceso a lugares o recursos informáticos considerados valiosos.

Pero las iniciativas docentes pueden configurar enclaves emergentes para oponer resistencia, incentivando la participación de los estudiantes y negociando junto con ellos los tipos de uso digital y de apropiación del espacio escolar. Una profesora de Historia describe irónicamente sus reclamos a las autoridades directivas ante las limitaciones para acceder a la sala de informática:

Patalee un poquito, me dieron la llave, nos encontramos que no estaban conectadas, uno de los chicos trató de desbloquearlas, llamamos a uno de los profes, logró habilitarnos una. Y entonces estábamos todos con un montón de computadoras y isolo podíamos usar una! Y es una sala hermosa con muchas computadoras nuevas. Me dijeron: te hacés cargo. ¡Yo me hago cargo! No tengo miedo de ir con los chicos, ellos no van a romper nada. ¡Queremos las computadoras para trabajar!

En suma, se puede afirmar que el modelo 1 a 1 nunca reemplazó completamente el modelo de laboratorio. Ambos conviven en medio de prácticas y valoraciones que por lo general restringen a las netbooks a sus cualidades operativas. Por un lado, los problemas técnicos vuelven dificultoso el acceso personal, al tiempo que se agudizan las dificultades para utilizar los laboratorios. Por otro, si bien los docentes muestran mayor predisposición a la capacitación y a la integración pedagógica, estos aspectos no se materializan en experiencias más sistemáticas o extendidas. En este sentido, las innovaciones tecnológicas no conducen a la descentralización, al trabajo colaborativo, horizontal, participativo e interactivo, si no se sustentan en nuevos modelos de comunicación que involucren la reorganización del trabajo institucional y áulico, capaces de aprovechar las potencialidades múltiples de la convergencia tecnológica.

\subsubsection{Principales observaciones}

\section{Sinteticemos las primeras consideraciones acerca de la Dimensión del Acceso Digital:}

1- En cuanto a la disponibilidad física, se verifican condicionamientos diferenciales entre ambas instituciones, entre los problemas edilicios hasta los relativos a la conectividad. Hacia la segunda etapa, los docentes ya cuentan con sus propias netbooks, pero cuestionan los inconvenientes técnicos de los equipos, junto con las limitaciones, materiales y simbólicas, para acceder a la sala de informática. Persiste el modelo de laboratorio, junto con las dificultades para promover lógicas descentralizadas y menos instrumentales de utilización pedagógica.

2- En estos escenarios se negocian una serie de sentidos, ligados al acceso cognitivo: la netbook como "regalo" o "herramienta", las adopciones entusiastas basadas en los beneficios 
técnicos, las resistencias frente al carácter “improvisado" del modelo. Adquiere continuidad en el tiempo una concepción tecnocrática y, su correlato, el imperativo hegemónico de la adaptación.

3- Los desfasajes entre accesos y usos adquieren otras expresiones. Entre ellas, las tensiones entre profesores generalistas y técnicos, las tempranas preocupaciones en la falta de capacitación para una integración eficiente de las TIC. Las propuestas del PNIDE despiertan mayores disposiciones, si bien todavía no están plenamente extendidas ni incorporadas a la práctica.

4- Se observan entre los jóvenes experiencias previas, fluidas y diversificadas, aunque mediadas por sus posibilidades socio-económicas: para un grupo, la nueva netbook constituye la primera computadora, condensa un mundo de afectos, esencialmente privado; el segundo grupo muestra una sensación de distanciamiento. Estos tipos de relaciones suelen continuarse en el tiempo. Sin embargo, algo que comparten es una mirada comprensiva acerca de cómo el modelo 1 a 1 provoca tensiones al interior de las realidades escolares y para el conjunto de sus actores.

\subsection{Redefiniendo los Usos Tecnológicos}

Retomando la idea de "praxis operativa" de A. Renaud, Cabello (2006, 2009), entiende que el uso remite no solamente a la selección, jerarquización y utilización de la información, sino a la producción de contenidos y páginas web, las prácticas de conectividad intra y a través de la red y la evaluación de los cambios resultantes. La noción de uso concierne a los estudios sobre medios de comunicación y supone la utilización que los sujetos hacen de la recepción de los mensajes en el marco de sus actuaciones cotidianas. No obstante, advierte la autora que en lo concerniente a las TIC el término se vuelve más complejo, y refiere a dos aspectos mutuamente implicados: los contenidos, que exceden a la recepción como al consumo activo para involucrar las prácticas de la conectividad, de producción y resignificación de saberes; y las múltiples posibilidades asociadas a la interactividad, que refuerzan el lugar de la mediación de la tecnología respecto del establecimiento de vínculos, la participación social y la producción colectiva de conocimiento.

En relación a los contenidos, es necesario superar cierto reduccionismo tecnicista que confunde información y conocimiento. En La era de la información, Castells entiende al conocimiento como "una serie de afirmaciones organizadas de hechos e ideas que presentan un juicio razonado o un resultado experimental, que se transmite a los demás mediante algún medio de comunicación en alguna forma sistemática”, en tanto concibe a la información como los datos “efectivamente organizados y comunicados" (2001: 43). Pero lo que caracteriza a la sociedad-red no es el protagonismo de la información y del conocimiento, sino la retroalimentación entre las innovaciones y su utilización en distintos campos productivos. Con la interactividad, emergen 
nuevas relaciones entre procesos simbólicos y la producción y distribución de bienes y servicios, como así hondas transformaciones en los modos de creación y circulación del saber.

El concepto de interactividad merece cierta clarificación conceptual. Implica que las TIC asumen lógicas complementarias aunque diferentes de los medios tradicionales, más ligadas a la apropiación y al uso que a la recepción en sentido tradicional (Bettetini y Colombo, 1995; Wolton, 2000). La convergencia digital define las interacciones múltiples entre los distintos soportes, a la vez que nuevos modos de concebir y ejercer los procesos de socialización. Estos procesos contribuyen al arraigo social de las TIC, que configuran "lógicas sociales de comunicación" (Miège, 2010). Rasgos como la instantaneidad, la personalización de los mensajes, una comunicación flexible y el control de la información, pueden facilitar una mayor implicación de los sujetos y el aprendizaje en distintos ámbitos, desde los cuales puedan constituirse en consumidores críticos, al tiempo que en creadores o productores culturales. De este modo, este apartado contempla los Usos Tecnológicos en las tres Subdimensiones: Consumo/Recepción, Producción de Contenidos y Condiciones de Interactividad.

\subsubsection{Acerca de los Consumos: "no basta con el acceso"}

Evaluar la centralidad de los esfuerzos por incorporar a las TIC, requiere una mirada atenta a los tipos y niveles de uso tecnológico que los sujetos efectúan como los sentidos que imprimen a esos usos, fundamentalmente centrados en el consumo digital. Queda claro que tales usos deben inscribirse en el marco más amplio de predisposiciones, dado que la ponderación del profesorado respecto de la pertinencia pedagógica de estos recursos representa el umbral de posibilidad para la implementación de los mismos en la enseñanza. Son previos al PCI los materiales informáticos y audiovisuales, como el televisor y el proyector, las películas y las colecciones en DVD. Pero las netbooks confirman una cuestión particularmente dilemática: las discontinuidades entre las modalidades exigidas por la escuela y las realizadas efectivamente por sus alumnos.

Entre los usos docentes, podemos distinguir los pedagógicos y los sociales. La primera etapa comprende cuatro posiciones predominantes de utilización pedagógica de TIC:

1- No-usos de las tecnologías: la netbook conjuga las concepciones negativas sobre las tecnologías, como aquellas que las asimilan a los intereses recreativos de los adolescentes (música, videojuegos, redes sociales), a los diversos problemas que estos pueden acarrear en el clima áulico, como a cierta sensación de "sobrecarga" laboral o de "desamparo" frente a las exigencias del sistema. Estas actitudes descalificatorias impiden la incorporación efectiva en clase. 
2- Usos instrumentales de softwares específicos: expresa disposiciones favorables a la integración pedagógica, no obstante su principal correlato es la utilización de las funciones estrictamente operativas de programas en materias técnicas, y en menor medida, del procesador de textos y búsquedas en la web. El acceso personal está llamado a maximizar estas utilidades, pero no altera cualitativamente modelos tradicionales de uso tecnológico.

3- Usos orientados a la planificación didáctica: el modelo 1 a 1 tiende a mejorar las condiciones de equidad en el acceso personal, pero la mayoría de los docentes ya contaban con computadoras portátiles o de escritorio y estaban familiarizados con sus aplicaciones. La netbook mayormente continúa estos usos: preparar clases, buscar información en Internet, enviar e-mails, explorar programas, producir materiales didácticos, elaborar listados de evaluación, etc.

Además de los usos vinculados directamente a los procesos de enseñanza-aprendizaje, los profesores asumen usos sociales que, en términos generales, comparten con los jóvenes:

4- Usos lúdicos, de comunicación y entretenimiento: en el tiempo libre, reconocen experiencias muy diversas, en parte determinadas por las posibilidades del acceso: navegar en Internet, usar redes sociales (predominantemente, Facebook), descargar videos y escuchar música (en plataformas como Youtube), videojuegos y juegos en red, entre otros.

En la escuela, las computadoras son utilizadas, casi de modo excluyente, en Informática, materias o talleres de las orientaciones y, en menor medida, Matemáticas. Softwares como simuladores, Geogebra y Autocad condensan las capacidades percibidas de la renovación pedagógica mediante las netbooks en reemplazo del modelo de laboratorio. En cambio, en materias de área (sobre todo las humanísticas como Prácticas del Lenguaje o Historia) casi no se utilizan o quedan relegadas al procesador, la navegación, el almacenamiento o la lectura en pantalla. Si bien muchos asumen posiciones favorables, no imaginan modos de incorporación más allá de usos muy específicos o con alcances limitados, como ahorrar en fotocopias. En ambas posiciones, las netbooks actualizan las discusiones sobre el potencial educativo de los entornos tecnológicos, pero sus posibilidades concretas están supeditadas a las previas modalidades de acceso y uso.

En cambio, las experiencias docentes más frecuentes y activas se llevan a cabo fuera del espacio escolar, independientemente del área curricular. Convergen en el aula múltiples contradicciones. Esos usos sociales nos generan el interrogante acerca de las resistencias en la enseñanza, por un lado, de aplicación estrictamente instrumental, por otro, cuando ambas posiciones parecen reñidas con un conjunto de saberes elaborados y de amplio espectro (laborales, lúdicos, vinculares, entre otros). Una dificultad estriba en que los docentes no logran objetivar los alcances de sus propias competencias tecnológicas en el ejercicio de su práctica, esto es, en sus interacciones con los alumnos y en la promoción de sus aprendizajes. 
Nuestro caso adquiere otra particularidad: los docentes no suelen solicitar trabajos domiciliarios, salvo si requieren conectividad, medios didácticos o información que no se encuentren disponibles en la escuela. Como veremos, la doble jornada repercute directamente no solo en las percepciones sobre el rol de la tecnología sino en las oportunidades para promover la participación juvenil o la pertenencia institucional. La razón más esgrimida por docentes y estudiantes es la falta de tiempo, cristalizando su dimensión espacio-temporal de la escuela en la definición de lo cotidiano. Sobre todo, en tanto estructurante del "verdadero" aprendizaje, en contraste con otros ámbitos y con las prácticas de esparcimiento que normalmente se les atribuye.

En la segunda etapa, encontramos continuidades antes que cambios substantivos. Los usos instrumentales siguen teniendo el mayor peso relativo, no obstante, una vez superadas las resistencias iniciales, se empiezan a explorar otras alternativas. Entre los usos pedagógicos:

1- Usos marginales de las tecnologías: el rechazo a la integración pedagógica ya no responde tanto a posiciones tecnofóbicas sino más bien a una gama de dificultades ligadas a la implementación: el deterioro de los equipos, las limitaciones del servidor y de la banda ancha, las deficiencias de la capacitación docente. Estos problemas afectan negativamente a las disposiciones al uso y pueden implicar en esta posición también a profesores de formación técnica.

2- Usos instrumentales de softwares específicos: comparativamente, profesores de áreas técnicas manifiestan experiencias más extendidas, pero continúan privilegiando aplicaciones operativas. Si bien expresan un conjunto de saberes técnicos complejos, esa tendencia restrictiva tiende a relegar iniciativas más interactivas y raramente ponen en cuestión imágenes sedimentadas sobre el rol de la tecnología en la escuela (esto es, de corte tecnocrático).

3- Usos instrumentales desde operaciones básicas: entre profesores generalistas, la netbook está asociada a la lectura en pantalla, la navegación, el procesador de textos y modalidades similares, algo que a menudo los iguala -simbólicamente- a docentes técnicos o mejor calificados. La distribución en la ESB aporta un elemento novedoso, porque los habilita a motivar a grupos más jóvenes y numerosos, administrar mejor los tiempos y aprovechar el acceso en el salón.

4- Usos implicados en entornos de interactividad: continúan afirmándose en los recursos tradicionales, pero combinados con los recursos informáticos, no solo las netbooks del PCI sino otros como notebooks y celulares. Experiencias incipientes revelan modos de comprender, capitalizar y expandir estos usos con propósitos didácticos. Pero sus implicaciones son muy diversas: recuperar saberes previos de los alumnos puede resultar de la confianza desmedida en el aprendizaje espontáneo, o bien habilitar articulaciones en espacios híbridos de producción. 
5- Usos orientados a la planificación didáctica: los profesores se apropian de las tecnologías digitales fuera del espacio escolar, para planificar las clases o en otros usos asociados en el trabajo docente, en términos similares a la primera etapa. Aunque aún no se replican necesariamente el aula, esos contactos se vuelven crecientemente fluidos y complejos y predisponen favorablemente a otras formas de integración pedagógica.

Entre los usos sociales, docentes y estudiantes han complejizado, extendido y diversificado las prácticas mediadas por las TIC en sus vidas cotidianas. Entre ellas:

6- Usos lúdicos, de comunicación y entretenimiento: navegar y chatear; mirar, descargar y editar videos, música y fotografías; leer en pantalla, acceder a redes sociales. Sin embargo, como veremos en clave de apropiación digital, adultos y jóvenes expresan diferencias substantivas en cuanto a los niveles, intereses y saberes implicados, y cómo estos cobran relevancia al momento de recuperar eficazmente las posibilidades de la digitalización en los procesos de enseñanzaaprendizaje. Los adolescentes expresan unos usos que se vuelven estructurantes de su vida extraescolar, ya que los trabajos escolares se realizan casi exclusivamente en el tiempo de clases.

Las tres primeras modalidades tienen un común denominador a lo largo de todo el período de análisis: las persistentes caracterizaciones de las tecnologías como herramientas, que las vuelven ajenas, reducidas a la mera disponibilidad física, a sus aplicaciones operativas o a relaciones del tipo costo-beneficio. Estos supuestos dan sustento a sensaciones completamente opuestas, desde la desconfianza a la sobrevaloración, pero que en todo caso impiden superar las confusiones entre información y comunicación como lograr una comprensión más acabada de sus determinaciones culturales. Como advierten Burbules y Callister, "dicha clasificación tiende a cosificar aquello a lo cual supuestamente tales tecnologías dan acceso (la "información") y a tornar menos nítidos los activos procesos sociales mediante los cuales la información se vuelve humanamente útil” (2001: 20).

La cuarta modalidad es el emergente de experiencias interactivas que discuten este tecnocentrismo dominante. Formas novedosas de inclusión integran otros soportes digitales, en articulación con los soportes analógicos o tradicionales. De manera que las distintas tecnologías y las relaciones entre ellas, son evaluadas en función de sus alcances para reorganizar productivamente la comunicación áulica. Tales iniciativas pueden tener un impacto positivo porque no están supeditadas al imperativo de la utilización: definen secuencias didácticas, con propósitos concretos de aprendizaje; también conjugan un espacio de mediación donde los sujetos interpretan, negocian y reconstruyen, los sentidos de esa incorporación.

La quinta y sexta modalidad se continúan. Los profesores mantienen relaciones fluidas con las tecnologías, a la hora de diseñar, planificar y organizar las actividades didácticas y para la 
presentación de documentación profesional (programas, calificaciones, proyectos, planillas de evaluación, etc.). Comparten con sus alumnos consumos asociados a la comunicación y el esparcimiento, aunque los intereses que los motivan pueden ser significativamente diferentes. Por ejemplo, si los profesores han ampliado exponencialmente su participación en Facebook, el interés de los adolescentes se ha desplazado hacia redes como Twitter e Instagram, un universo simbólico que ellos viven como propio, que logran transitar sin "intromisión" de los adultos. Un desafío clave es cómo incorporar esas experiencias en los ambientes áulicos en tanto entornos ubicuos de aprendizaje y, al mismo tiempo, movilizar progresivamente sus articulaciones en proyectos institucionales o de trabajo colectivo de mayor alcance.

\section{Hacer imaginables los usos tecnológicos}

Siguiendo con la Subdimensión del Consumo, nos interesa abordar la dimensión imaginaria, la trama de representaciones, creencias y afectos sobre los que reposan esas actuaciones. Al momento de la llegada del PCI, se ha vuelto hegemónico un imaginario tecnocomunicacional, una concepción tecnocrática que, paradójicamente, sirve de sustento a formas opuestas: las resistencias al uso escolar y los usos instrumentales. Una mirada reticente o moralizante impide a los docentes problematizar su propia exterioridad con respecto a las nuevas prácticas comunicativas de sus alumnos. Pero esa exterioridad también puede expresarse en las posiciones celebratorias de la modernización tecnológica, ratificando espacios simbólicos donde se replican los desfasajes nunca resueltos entre tiempo libre y tiempo escolar. La netbook representa entonces experiencias informales y espontáneas, concebidas antes como obstáculo, que como posibilidades objetivas de innovar en la enseñanza.

Estas percepciones agudizan las discusiones acerca del acceso libre a Internet y los dispositivos de "control" que se deberían poner en ejecución. Según entienden los sujetos implicados, no deja ser contradictorio que la EEST $\mathrm{N}^{\circ}$ 2, en mejores condiciones institucionales, culturales y pedagógicas para aprovechar la conectividad, sea precisamente la que adolece de ella. Y si los alumnos cuentan con conexión en sus hogares, estos usos se representan ajenos, reclamando una mirada más atenta, tal como entiende uno de los Vice-Directores:

La computadora es una ayuda por un lado, y no es una ayuda por el otro. Hoy Internet está abierto a todo, y es bueno si vos lo usás como bueno, y es malo si lo usás como malo. Vos podés tener todos los programas que quieras, pero si no podés controlar las páginas...

Pensar que los alcances de las TIC dependen exclusivamente de sus usos, no solo es una evidente simplificación, sino que opera un vaciamiento simbólico de sus complejas condiciones 
socio-históricas y de las lógicas de poder que las definen. Como ha destacado Cabrera (2006), en el imaginario tecnológico la máquina es buena o mala según su uso, pero no soporta un enjuiciamiento moral, es decir, no técnico. Allí se activan unos significados que hacen imaginables esos usos, lo que permite dotar de sentido a un contexto de incertidumbre y articularlo coherentemente con aquello que se conoce. Y lo que se conoce -lo que se cree conocer- en la escuela técnica es la tecnología. Resulta de ello que lo que se cuestiona son las dificultades la implementación del PCI, antes que sus objetivos o la "herramienta" en sí misma. En cambio, devienen en condición natural y necesaria para la esperada transformación educativa.

Los entrevistados de la EEST $\mathrm{N}^{\circ} 1$ parecen asumir una posición más cuestionadora de las relaciones netbook/Internet: a pesar de que valoran sus propias condiciones de conectividad, poco frecuentes en las escuelas públicas, entienden que propician conflictos que hablan tanto de la actitud "facilista" de los estudiantes como de las limitaciones de los docentes para involucrarlos en experiencias creativas que no se reduzcan al mero consumo. La Vice-Directora ironizaba sobre el comportamiento de "cortar y pegar" que dificulta la adquisición de capacidades implicadas en la escritura, la lectura comprensiva, la selección y comparación de fuentes:

Me parece que está bárbaro que cada chico tenga su computadora, pero falta una articulación con las prácticas docentes, porque no pueden pensar más allá del Word, del Excel o de alguna investigación en el Google, que el chico lo maneja rapidísimo, y la investigación es cortar y pegar, cortar y pegar. Y te hago una monografía divina (...) A ver, fuentes diferentes. Olvidate, es más fácil Internet porque es más rápido, es instantáneo...

Cuando se pone el acento en la práctica docente, se manifiestan las discordancias entre la interactividad y el proyecto escolar, entre los intereses juveniles y las propuestas didácticas. No expresan diferencias insalvables relativas a una brecha generacional, sino la suma de tensiones donde modelos pedagógicos tradicionales devienen en obstáculo si impiden comprender los cambios agudos que están atravesando a la tarea de enseñar. Pero la noción de brecha digital sigue reproduciendo viejas antinomias atadas a los imperativos de la racionalidad tecnológica.

El docente de 20 años de antigüedad está acostumbrado a otra cosa y le cuesta el cambio. Esto de la brecha entre la escuela y las nuevas tecnologías hace años que se habla. Y cómo hacemos para atrapar a los chicos, si ellos están con todo esto de las imágenes, de lo audiovisual, como que estábamos atrasados, pero bueno, ahora se dio un primer paso y hay que ver cómo podemos ir solucionando estos problemas..." (psicopedagoga EEST N ${ }^{\circ}$ ).

En ambos períodos y en varios discursos, el "auto" metaforiza la computadora: no es suficiente disponer de un dispositivo si no se cuenta con las habilidades requeridas para utilizarlo con un mínimo de competencia. Apelar al sentido común articula estas imágenes en tanto confirma, incluso en posiciones más favorables, la impresión generalizada del carácter improvisado de la implementación. El reclamo hacia la capacitación docente se funda en el 
conjunto de representaciones acerca de qué y cómo es válido aprender en estas nuevas condiciones: "No basta con el acceso. No basta con tener un auto $0 \mathrm{~km}$ si no lo sabés manejar, si vamos a un ejemplo básico. Es lo mismo. No basta con tener la netbook si no tengo la claridad de sacarle provecho..." (EEST №2, Encargada de Medios de Apoyo Técnico-Pedagógico-EMATP).

A medida que avanza la normalización del PCI, el profesorado reafirma una sensación generalizada de que la escuela (y no solamente el equipo directivo) no logra responder rápidamente y de manera eficiente a estos procesos globales de inclusión digital. A menudo perpetúa esas dificultades a partir de usos aparentemente innovadores, pero ligados a modelos tradicionales. Sin embargo, es posible observar un mayor grado de consenso que si en ocasiones redunda en mero voluntarismo, en otras convoca una práctica más reflexiva acerca de cómo, cuándo, con qué objetivos pedagógicos, pueden incluirse las tecnologías interactivas, atendiendo a la diversidad de realidades socioculturales que atraviesan a cada institución.

\subsubsection{Videojuegos y redes sociales: hacia la Producción de Contenidos}

En conjunto, los videojuegos y las redes sociales devienen representativos de intereses adolescentes que se perciben triviales y ajenos al universo simbólico de la educación. Para muchos docentes, las netbooks vendrán a habilitar otros elementos disruptivos de las complejas situaciones de enseñanza, encarnados simbólicamente en el Counter-Strike, ese "juego de tiros que suben y bajan", "adictivo" porque "están re fanatizados". ${ }^{20}$ Nuevamente, se verifica en esta primera etapa una doble sensación: de destiempo en lo relativo a los usos escolares/extra-escolares y del riesgo que estos entrañan en el aula (para la autoridad docente, la tarea didáctica, el orden institucional). Estas controversias conviven con un uso pedagógico estrictamente operativo o limitado:

Usar las netbooks depende en qué materia, porque hay materias que tienen programas de cálculos, programas específicos. O también de forma rudimentaria, que las usen para tomar apuntes. Después está el problema de que se puede desvirtuar, que creo que es un problema endémico, que se usen para jugar (EEST N², Electrotecnia, O. Electromecánica).

Tres factores están mediando las relaciones interactivas de los jóvenes con los juegos: el género, la edad y la posición social. Por un lado, la mayor frecuencia e intensidad de uso y, por ende, los conflictos que potencialmente propician en el aula, son atribuidos sobre todo a los

${ }^{20}$ El Counter-Strike es un juego de acción de tipo “multijugador”. Desde su salida oficial en 2008, es el juego de acción en primera persona en línea más jugado en Internet, aunque también se puede jugar en GNU/Linux. Si bien consideramos indistintamente ambas nominaciones, cabe aclarar que "los juegos en red se ubican en la tradición que inauguran los videojuegos, pero a diferencia de estos últimos, el jugador no compite contra la máquina sino que compite con otros jugadores a través de una tecnología que posibilita asociarse o enfrentar a otros situados muy cerca o del otro lado del mundo" (Cabello, 2007: 149). Entre los juegos en red se ubican el Counter y el Preguntados. 
varones. Se los descalifica porque "no cuidan" a las netbooks, "les borran los programas (educativos)", "las cierran sin apagarlas", las “estropean”, las "desconfiguran”, las "estropean”, las "llenan de virus". En cambio, las chicas son percibidas como más responsables. Además de estas diferencias, se recrea la idea de que se trata de un bien material que hay que cuidar, mientras que para los estudiantes constituye un "chiche", un "regalo" escasamente valorado, objeto de una “obsesión espantosa" que eventualmente habrá de ser superada una vez que "se cansen".

Una excepción es la profesora de Geografía de la EEST $N^{\circ} 2$ entrevistada y también participante de uno de los grupos focales. Una posición proactiva prioriza no tanto el consumo tecnológico como las posibilidades de producción que configuran estas plataformas digitales, que no requieren conectividad ni conocimientos específicos. Si bien hay todavía cierta simplificación en las actividades que describe, contempla el interés por explorar los recursos disponibles, incorporando nuevas y más dinámicas estrategias de enseñanza asociadas a lo lúdico: "Hay distintos programas con juegos donde ellos van aprendiendo distintos nombres de capitales del norte de África, son cosas que no se dan tanto pero que están buenas para interactuar, ¿no?”

Durante la segunda etapa, si la presencia de la netbook es mayormente aceptada, no sucede lo mismo con los videojuegos: estos consumos son abiertamente rechazados o bien tolerados, pero raramente incluidos de manera productiva en las actividades escolares. Ya no hay un uso intensivo del Counter-Strike una vez pasada la "fascinación inicial", pero sigue siendo un punto crítico entre los más chicos, cuando las netbooks comienzan a llegar a la ESB. Entonces, para estas posiciones la edad es un agravante, tanto por el estado de inmadurez y los intereses juveniles asociados al juego, como porque aún no han interiorizado las normas de organización institucional y áulica. Los usos negativos de la netbook se homologan a otras problemáticas, como las asociadas a la convivencia escolar, el comportamiento en clase y el cuidado de las instalaciones:

Los chiquitos arruinan, rayan los bancos, y eso también se nota en el uso de las netbooks, porque las rompen, no las tienen. El tema es ahora no solo el Counter, ¡el Preguntados! Cuesta mucho apropiarse del lugar, vienen, pero no cuidan, rompen, hacen lío, les cuesta adquirir las pautas... (EEST N² 2, Seguridad e Higiene, O. Electromecánica).

En tales situaciones el docente parece incapaz de integrar esas experiencias juveniles con TIC, de evaluar sus posibilidades como elementos alternativos o complementarios a los modelos tradicionales. En cambio, con mayor frecuencia suele permitir al alumno jugar, acceder a Facebook o escuchar música con auriculares en ciertas circunstancias: "la computadora es un premio al que trabajó mejor" o "para que no moleste". Estas concesiones operan en ambas escuelas, unos consumos que siguen siendo ajenos, apenas tolerados, producto de una compleja negociación que 
se experimenta más bien como una pérdida. Veamos el campo léxico en el discurso de la ViceDirectora de la EEST No 2: "Es el premio, el dulce de los profesores, el día que el profesor tiene que corregir, y para que se queden quietitos un ratito, como un chupete, un paliativo..."

En otros discursos, la posición social de los usuarios no determina, pero sí condiciona los tipos de consumos en sectores vulnerables y de menor rendimiento escolar como los que integran la matrícula de la EEST $\mathrm{N}^{\circ}$ 1. Docentes que se desempeñan en ambas escuelas tienden a compararlas. Es el caso del nuevo Director de la EEST N² 2, además profesor de la EEST $\mathrm{N}^{\circ}$ 1, quien establece una correlación entre menor nivel socio-económico y juegos en red. "Si entrás al aula, el muchachito está en esos usos, yo se la hago cerrar, cerrala, porque el tipo con el Facebook, el Counter..." La relación de exterioridad es persistente, sin embargo, dificultando objetivar plenamente qué significan estas prácticas, cómo afectan a las diversas formas de apropiación.

Se han agudizado en esta escuela las dificultades implicadas en las redes sociales. Por un lado, porque resultan de relaciones intensas, afectivas, casi excluyentes, en el sentido de que para los adolescentes "las netbooks, cualquier aparato, es Facebook, es redes sociales..." Por otro, porque constituyen el espacio donde se dirimen los conflictos familiares y barriales, desplazando constantemente las fronteras tradicionales entre el adentro y afuera de la institución. Sin embargo, como empiezan a admitir los docentes, los mismos jóvenes están atribuyendo nuevas significaciones a esos desplazamientos, cuando los conflictos devienen ajenos al clima de cordialidad que se reconoce necesario para aprender, para "vivir" la cultura escolar. Los usos interactivos revelan una trama de contrapuntos entre la pertenencia institucional y otras formas de identidad, todas ellas material e imaginariamente mediadas por las TIC.

\section{¿Qué significa "hacer" en la escuela?}

Convergen en los consumos juveniles múltiples saberes, habilidades y disposiciones, eventualmente en discusión con la tendencia homogeneizadora de la globalización, en el marco de lo que Martín Barbero (2002a, 2003, 2007) ha entendido como procesos de descentramiento y deslocalización de la cultura. No es posible generalizar esos usos ni tampoco las representaciones que evocan. Es necesario debatir la relación de "fanatismo" que con frecuencia se atribuye a los jóvenes. En principio, porque lo importante para ellos no es tanto la falta de acceso personal que la netbook viene a resolver, sino los gustos que definen sus particulares estéticas, narrativas y sensibilidades y que pueden estar más o menos dinamizadas por las nuevas oportunidades del PCI. En esta clave operan desde la primera etapa otros diversos patrones de uso, generalmente ajenos a la comprensión o aprovechamiento de los adultos: 
Bueno, algunos tienen cargados juegos, como el Counter, yo no, a mí no me gusta, jaja. La uso bastante, para chatear, las redes sociales, o buscar información que nos piden en la escuela. No, no piden mucho, el profesor prefiere traer él el material (EEST N ${ }^{\circ}$ 2, 6to. Año, Maestro Mayor de Obra).

En las vacaciones ni la usé, la uso para ir a cantar reggaeton, porque yo canto reggaeton. Antes yo usaba la máquina mucho más que lo que uso la netbook, porque estaba en mi casa, no me molestaba nadie, no me distraía en la tarea, la usaba todo lo que podía (EEST $\mathrm{N}^{\circ} 1$, 4to. Año, Electrónica).

Ahora bien, los usos lúdicos son percibidos como contrarios al aprendizaje escolar. La netbook puede volverse un elemento distractivo si tiende a entorpecer la atención al docente y el trabajo en el aula. Tales consideraciones suponen la capacidad de racionalizar el conocimiento escolar como objeto de una apropiación, que requiere de la participación, el esfuerzo y el compromiso personal. Por el contrario, reproducen una mirada descalificadora sobre el potencial educativo de la inclusión digital: el Counter-Strike y el Facebook son depositarios de una sucesión de términos: la "dependencia", "perder el tiempo", "distraerse", "llevarse la materia", estar "al pedo" o "boludear". Así se expresa la polarización entre hacer/no hacer en la escuela:

Nosotros la dejamos un poco de lado, yo porque estoy en el CE, pero mis compañeros y yo el año pasado traíamos la netbook y jugábamos a los jueguitos nada más, no hacíamos nada. En aula, en mi caso, jugaba de vez en cuando, pero un chico repitió porque estaba todo el día, hacé de cuenta que no hacía nada... (EEST N² 2, 6to. Año, Automotores).

En el contexto del aula, la netbook convive con otros soportes, aunque esta interacción adquiere diversas modalidades: las materias técnicas tienden a privilegiar el uso tecnológico, pero como se ha señalado, estas experiencias son previas al modelo 1 a 1 , que aún no promueve usos más productivos en las materias de área. Ciertamente, los estudiantes tampoco valoran diferencias significativas entre leer en pantalla o en papel, escribir en la carpeta o en el procesador de textos; la ventaja que le atribuyen consiste en ahorrar fotocopias o buscar información, que luego guardan en la netbook o copian en la carpeta. Aquello que despierta mayores expectativas no es Internet sino los softwares, en particular en las orientaciones. Estas replican cierta concepción restringida a las aplicaciones operativas de las netbooks, no solo por los objetivos del PCI sino por la presencia histórica y constitutiva de las tecnologías en el proyecto formador de la escuela técnica.

Articulan en estas apreciaciones la convicción de que no son suficientes los programas ni los conocimientos disciplinares e instrumentales del docente, junto con los "riesgos" que entrañan las netbooks y las características negativas atribuidas a muchos profesores, que parecen ratificarse en las nuevas condiciones. Los chicos pueden objetivar estos problemas, cuando sus expectativas hacia la tarea de enseñanza entroncan con el papel que las TIC están llamadas a cumplir en estas mediaciones. Porque, finalmente, lo preponderante son las prácticas que pueden llevar adelante. 
Esto no los exime de sus propias responsabilidades. Por ejemplo, operar un programa que resuelve operaciones matemáticas puede ser más "fácil" pero queda claro que no implica "aprender". La netbook asume un lugar completamente distinto en los ejercicios de dibujo gráfico o cálculo matemático, si primero se realizan manualmente en la carpeta y luego son revisados a través del software, lo que anima capacidades de autonomía, auto-corrección y seguimiento:

No precisás tener Internet para usar esos programas. Son de Pascal y todo eso, y ahí te marca cómo es la línea. Está bueno. Porque por ahí lo hacés mal y ahí te explica todo cómo es, lo volvés a hacer y ahí está bien... (EEST N 1, 6to. Año, Química).

Esta escuela presenta una situación paradojal. En esta primera etapa, las netbooks vienen a complejizar los procesos de inclusión de las TIC en un contexto de severos problemas educativos. Empero, los jóvenes comprenden estos conflictos, racionalizan sus consecuencias, pueden resistir las normas a la vez que justificar las sanciones, algo que evalúan como un beneficio para su propio aprendizaje, incluso cuando esto significa impedir el acceso a un bien valioso y distintivo como es la conexión a wi-fi. En los esfuerzos de reordenamiento institucional los estudiantes encuentran los límites "necesarios" que deben regular los comportamientos, en un proyecto colectivo que habrá de interpelarlos en el mejoramiento de la imagen pública de la escuela: "El año pasado nos cortaban Internet, total no la necesitábamos porque usábamos los programas. Por un lado está bien que lo corten porque si no nos poníamos a joder y a joder, y no terminábamos nunca la tarea..."

Como vemos, la variable del tiempo sigue asumiendo densidad simbólica, en un trayecto formativo de doble jornada y a lo largo de siete años. Los jóvenes pueden elucidar las características de la formación técnico-profesional y sus articulaciones específicas con el mundo laboral, una matriz simbólica constantemente renovada que los convoca directamente y donde las tecnologías adquieren un rol central. Valores tradicionales asociados al carácter racional y responsable de las acciones individuales, como las normas igualmente racionales que regulan esos usos, son objeto de constantes desplazamientos. De manera que, en sus relaciones estructuralsimbólicas con las netbooks, los chicos les imprimen otras lógicas, resemantizando sus propósitos, las competencias requeridas en sus docentes para una incorporación productiva y las directas repercusiones de estos cambios en las instituciones que habitan cotidianamente.

\subsubsection{Potencialidades de la Interactividad: aprendizaje y trabajo colaborativo}

En la segunda etapa de análisis, los estudiantes perciben dificultades de distinto orden, una utilización todavía acotada de las netbooks y otras tecnologías, las fallas técnicas, los retrasos en el sistema de reparaciones. Evalúan que la falta generalizada de capacitación trae como 
consecuencia los temores de los docentes a perder autoridad, lo que desalienta las iniciativas de inclusión digital. Lo notable es que tienden a comprender la posición de sus profesores, de algún modo los exculpan, como una forma de interpretar aquello que se define como absurdo. La consecuencia es que están predispuestos a colaborar en el uso operativo de la netbook, un proceso percibido como un aprendizaje conjunto y sumamente enriquecedor. La inteligencia colaborativa (Jenkins, 2008) conllevará en este caso una nueva concepción de la relación docente/estudiante, que facilite una relación más fluida, flexible e interactiva con el conocimiento.

Estas posibilidades además contradicen los discursos moralizantes acerca de que "los chicos no leen", como la idea igualmente naturalizante de que solo leen o quieren leer en las pantallas. La mayoría demanda una inclusión más frecuente e intensiva de las netbooks para determinados usos; no obstante, prefieren leer en las fotocopias. El Ciclo Superior marca una diferencia, debido a sus grupos más reducidos y la disponibilidad de soportes, que habilitan entornos donde interactúan netbooks, tablets, celulares, carpetas y libros. Una estudiante entrevistada durante una clase del 6to. Año de la EEST $\mathrm{N}^{\circ}$ 1, opinaba que estas actividades son contrarias a "perder el tiempo" o "boludear", una etapa que considera superada o bien estrictamente ligada al horario extra-escolar. En suma, las diversas tecnologías móviles pueden ser legítimamente utilizadas, siempre y cuando estén subordinadas a la dinámica escolar, los conocimientos formales que deben desarrollarse y las estrategias que ponen en juego los docentes bajo tales propósitos.

Los juegos en red siguen siendo percibidos como un obstáculo, pero la llegada de las netbooks al Ciclo Básico les imprimirá nuevos y más complejos significados. En el discurso de los estudiantes mayores, la netbook genera problemas de comportamiento, especialmente cuando la "indisciplina" resulta un tema clave en grupos de preadolescentes, numerosos y heterogéneos. Funciona simbólicamente para reconstruir y legitimar posiciones dominantes en la escuela, actualizando las distinciones entre el juego y la tarea, entre el tiempo libre y el tiempo escolar. También es otra expresión de la diferencia entre ellos (ESB) y nosotros (Superior), un conjunto de valoraciones sobre la propia trayectoria en términos de socialización. En la producción de estos sentidos interviene particularmente el CE de la EEST $\mathrm{N}^{\circ}$ 2, como en el caso del ex presidente:

Usted se pone a mirar los pibes más chiquitos y pasa por los salones y escucha a las profesoras renegando con los pibitos. O va a Dirección y ve una pila de computadoras secuestradas. Qué los pibitos, nosotros a veces también. Más que nada, juegan en red y al Counter (7mo. Año, O. Electromecánica).

A la vez que están mediando otras variables de acceso y uso, nos preguntamos si el momento personal de esa trayectoria educativa (o la edad) tiene particular incidencia en las representaciones que ponen de manifiesto los más jóvenes (ESB), entrevistados en esta segunda etapa. Pudimos observar que cuando reciben sus computadoras, permanecen con ellas todo el 
tiempo, a veces en horario de clases, realizando esa "euforia" inicial que produce abiertas tensiones con los profesores. Pero progresivamente comienzan a experimentar otro tipo de relaciones. Por un lado, una posición de indiferencia o de subestimación es frecuente entre estudiantes de la EEST N ${ }^{\circ}$ 2. Esta alumna de 2do. Año advierte que los trabajos elaborados con la netbook asumen menor importancia que los de la carpeta, según los aspectos léxico-estilísticos de su discurso:

Se usa muy poco, muy de vez en cuando... y cuando la usamos es para hacer trabajos prácticos que no se estudian. O una actividad, no un texto que tenga que ser estudiado. (Pregunta) Y... sería lo mismo que en la carpeta, pero si no estuviera sería lo mismo.

Situaciones sociales de base más favorables (la mayoría cuenta con soportes propios) intervienen significativamente. Las tecnologías pueden motivar diversas imágenes, a veces cuestionadoras de sus posibilidades para promover un verdadero aprendizaje: lo que atribuye coherencia interna a estas convicciones es, nuevamente, el desfasaje entre las prácticas escolares y las del tiempo libre, o entre "netbook del PCI" y "mi netbook". Otro estudiante del mismo año demuestra que a temprana edad, los intereses vinculados a las tecnologías pueden ser estrictamente personales, una modalidad de apropiación que está, no obstante, mediada por una formación técnica que habilita espacios de producción de contenidos digitales:

A mí me gusta hacer juegos, estoy empezando hacer en 3D, siempre me interesó, por eso sigo Informática, porque quiero aprender los lenguajes informáticos. La netbook se puede usar, pero uso más mi compu, tengo la mía, la notebook.

Con notables excepciones, los videojuegos y las redes sociales configuran un área de intervención y experimentación didáctica poco explorada, que los estudiantes no logran relacionar con los contenidos escolares. No obstante, experiencias interactivas con las tecnologías están mediando otros aprendizajes y modos de subjetivación que progresivamente empiezan a ser incorporadas a las aulas. De ahí que, al decir de David Morley, resulta imperativo indagar no solamente las prácticas sino los significados que los usuarios de diversa condición cultural les otorgan a esas prácticas: "cómo son percibidas, interpretadas y utilizadas y cómo son diferencialmente vistas (o soslayadas) por sus consumidores potenciales como relevantes (o no) para ellos" (2008: 193). En consecuencia, reducir a las TIC al mero consumo impide comprender procesos de apropiación que podrían aprovecharse eficazmente, a los fines de formar no solo en el conocimiento escolar sino en personalidades críticas y socialmente comprometidas con su entorno.

\section{Sobre los teléfonos celulares y la problemática tarea de enseñar}

Investigaciones recientes demuestran que una mayoría de los adolescentes argentinos de entre 15 y 18 años tienen teléfonos celulares; su portabilidad les permite "estar conectados" todo el tiempo, 
lo que representa una importante marca de identidad (Morduchowicz, 2014). También resultan de interés las construcciones de significación mediante tecnología que producen jóvenes de diferentes estratos sociales (Murolo, 2014). En nuestro caso, muchos de ellos cuentan con teléfonos celulares -últimamente, smartphones- y su presencia en la vida cotidiana puede ser incluso más importante y constitutiva que las computadoras. Los docentes admiten estos consumos juveniles como algo ajeno: forman parte objetiva de los escenarios escolares, pero son escasamente evaluados como recursos educativos. A menudo, la utilización de celulares salva el inconveniente de las ausencias de las netbooks, de conectividad o de ingreso a los laboratorios, contradiciendo en la práctica el Decreto todavía vigente que prohíbe el uso en escuelas bonaerenses. ${ }^{21}$

Examinar las situaciones áulicas que habilitan, dificultan o censuran el uso de estos dispositivos, nos lleva a detenernos brevemente en el problema de los medios y los recursos educativos. Aunque hasta el momento hemos utilizado indistintamente ambos términos, en rigor, es posible caracterizar a los celulares como recursos que pueden cumplir una función didáctica; en cambio, las netbooks del PCI asumen sentidos y propósitos específicamente educativos. Recuperando las distinciones de Área Moreira (2002), los medios didácticos han sido diseñados o producidos para facilitar el aprendizaje, en tanto los recursos pueden o no ser medios didácticos: cualquier material que en una situación educativa dada sea utilizada en esa misma dirección.

En conjunto, estos materiales tienen múltiples alcances: permiten acceder a distintas fuentes de conocimiento, mantienen inalterable la información, tienden a fomentar capacidades intelectuales complejas, pueden ser objeto de análisis y constituyen espacios concretos para la comunicación y la expresión de las ideas. Como parte constitutiva de las situaciones escolares, interactúan con las actividades, las intervenciones didácticas, el currículum, la organización institucional y áulica. En estos términos, las tecnologías interactivas pueden ser discriminadas de acuerdo a su intencionalidad educativa, en atención a la capacidad para realizar esos alcances y las significaciones que orientan patrones más o menos productivos de inclusión pedagógica.

Nos interesa aquí examinar cuáles son los usos que se hibridan con los relativos a las netbooks a partir de Conectar Igualdad, si el proceso de normalización de la inclusión digital confirma la tendencia a marginar o excluir estos usos o bien a integrarlos progresivamente junto con otros. En la primera etapa, el celular está ausente, salvo en su carácter problemático. En una primera concepción, guarda estrecha relación con la netbook, ambos como elementos

${ }^{21}$ La Resolución N ${ }^{o}$ 1728/06 de la DGCyE instituye al celular como un elemento intrusivo: "el uso del celular en el aula descentra y desconcentra el proceso de enseñanza- aprendizaje, debiendo el acto educativo preservarse de ésta y de otras desvirtuaciones análogas", al tiempo que "el fomento de conductas y usos individuales en el contexto de un acto conjunto y socializado como es el de aprender, inviste el carácter de una actitud contraeducativa" (el subrayado es nuestro). La Res. será derogada en octubre de 2016, abriendo nuevas discusiones en este campo. 
distractivos que irrumpen en la clase produciendo indisciplina y un desafío constante a la autoridad docente. De modo que más allá de su justificación desde una política educativa, la netbook termina por habilitar la entrada de unos usos tecnológicos considerados perniciosos, profundizando la crisis de valores como respeto, responsabilidad y cultura del esfuerzo.

Estas comparaciones se mantienen avanzan la segunda etapa del PCI, en torno a las lógicas dicotómicas ellos/nosotros, en este caso, estudiantes/profesores. Sinteticemos algunos usos que verifican una creciente diversificación. Primero, los docentes reconocen el potencial de las netbooks como medios didácticos, están familiarizados con ellas y con los objetivos de la política educativa que justifica su incorporación en las aulas. Ya conocen sus funciones y han experimentado su utilización en la práctica. Empero, por lo general actualizan las modalidades de utilización de otros soportes audiovisuales. En esta línea, la netbook, la computadora de escritorio, los celulares, dan continuidad a aplicaciones restringidas, de carácter informativo o instrumental, de la televisión, los videos o las presentaciones, ligadas a mostrar un tema o a acompañar la explicación en reemplazo de la pizarra.

En segundo lugar, subestimar la posesión personal resulta de atribuir características negativas a las netbooks pero también a los celulares y a los usos ligados a la "dependencia digital", que generan conflictos en el ambiente áulico dificultando la ya problemática tarea docente:

Es un tema sacarles la computadora, porque es de ellos, es lo mismo que con el celular, a veces se los he sacado. En ellos no es tanto un problema. Los más chiquitos sí, y sobre todo las nenas. Están todo el día... (EEST N ${ }^{\circ}$, Montaje de Proyectos Electrónicos, O. Electrónica).

En tanto, la posición de tolerancia o de condescendencia verifica un crecimiento, donde todavía homologa la netbook con el celular. Se los tolera para evitar confrontar con los estudiantes, para mantener con ellos relaciones amenas, un clima de cordialidad o de motivación. A esos usos se les adjudica un rol similar a otras experiencias que favorecen la permanencia en la doble jornada (por ejemplo, que puedan deambular o tomar mate). El celular adquiere otro rasgo que le es específico y que precisaremos más adelante: mantener el contacto con las familias. De este modo, forma parte de las situaciones áulicas como un objeto vagamente aceptado, aunque nunca incorporado a las estrategias de planificación didáctica.

Estos chicos tienen un alto nivel de ruido, a mí no me molesta que pongan la música bajita, o el celular en vibrador. A mí no me molesta, ya que hace a la motivación. Acá los chicos tienen que estar ocho horas. Que puedan tomar mate, lo que pueda crear un clima de motivación, no pueden usar el celular en la escuela, pero a mí no me molestaría que lo usaran (Diseño y Procesamiento Mecánico, O. Electromecánica). 
La cuarta posición es menos habitual pero de crecimiento sostenido en los últimos años. Está supeditada tanto a las condiciones de accesibilidad como a las iniciativas docentes, a las exploraciones de las utilidades de los distintos recursos como a una mirada más flexible a la integración pedagógica de las TIC. Mientras que las otras posiciones están centradas en los consumos, en este caso abren oportunidades hacia la producción de contenidos y aquellas derivadas de la interactividad. Acceder a Internet mediante los nuevos smartphones se debe, por ejemplo, al carácter concreto que atribuyen a los contenidos las pantallas digitales, una condición especialmente valorada en el caso de conceptos de mayor abstracción y difícilmente reconocibles en los libros. Se combinan con los juegos en red y la producción de contenidos propios como videos, informes de investigación y presentaciones en plataformas virtuales.

En consecuencia, los usos didácticos del celular pueden resultar de una rigurosa planificación o bien de actividades más o menos espontáneas. La posibilidad de racionalizar esas particulares interfaces conjuga aspectos cognitivos y afectivos mutuamente implicados, de acuerdo a lo cual los celulares pueden contribuir al "control" de grupo, concebido en términos de acompañamiento en el proceso de aprendizaje y no de mero disciplinamiento de las conductas en el aula. En estos términos, una profesora de Inglés de la EEST $N^{\circ} 2$ aprovecha las potencialidades de los juegos en red, donde entraman la trayectoria profesional, un proceso constante de autoevaluación, como el reconocimiento de los intereses juveniles asociados a las TIC:

Recién hicimos el Preguntados pero le cambiamos el idioma. ¡Porque ellos hacen torneos de Preguntados impresionantes! Bueno, jugamos al Trivia Track y dividimos en dos grupos, cada uno con un celular, y jugaron re bien. Leían en voz alta y buscaban las respuestas (...) Y a mí me encanta, yo también disfruto un montón, vos fijate, dos celulares, todo controladísimo por la profesora, porque no es que un grupo estaba chateando y el otro estaba jugando a las cartas.

Motivar a los estudiantes constituye siempre un esfuerzo importante y la tecnología puede intervenir productivamente en esa dirección, aunque por razones distintas a las esgrimidas antes: por un lado, aprovechando las capacidades intuitivas y espontáneas atribuidas a los adolescentes, su curiosidad, sus interacciones cotidianas con la web, la exploración de sus múltiples intereses; y por otro, generando con ellos espacios de comunicación fuera de clase, para informar cambios de horarios, intercambiar información, realizar el seguimiento de los aprendizajes. Ahora bien, el aprovechamiento pleno de estas oportunidades resulta de una serie de condiciones. En un curso de 6to. Año de la EEST $N^{\circ} 1$, el profesor orientaba a su grupo en la elaboración de un PowerPoint, estimando como condiciones: 1- grupos pequeños o menos numerosos; 2- posesión/acceso a los distintos medios o recursos, incluyendo los analógicos; 3conexión a wi-fi; 4- capacitación docente; y 5- predisposición hacia la innovación pedagógica. 
Lo importante es que celulares, computadoras, tablets, comportan unos usos que no resultan de la mera convivencia sino de lenguajes y sistemas semióticos que comienzan a interactuar entre sí y hacen emerger espacios híbridos que pueden dar origen a nuevas formas de comunicación (Scolari, 2009). Esas tecnologías se cruzan con la escritura en carpeta y pizarra, el libro y las fotocopias. Asimismo, abren interrogantes en razón de la necesidad de expandir la enseñanza más allá de las fronteras del salón, cuando las limitaciones del tiempo constituyen un factor alentador -o un obstáculo- para las actividades didácticas. Pero, además, las representaciones positivas sobre los sujetos juveniles se desplazan hacia esas experiencias con las TIC que dan cabida a formas alternativas de producir conocimientos, de atribuir significado a los contenidos escolares.

La perspectiva sociocultural del aprendizaje da sustento a la idea de que estos entornos tecnológicos afectan los procesos internos de los sujetos que interactúan con o a través de ellos: intervienen en los modos de representar, guiar, organizar, no solo la información, sino sobre todo las estrategias y esquemas cognitivos implicados en su aprendizaje significativo (Suárez Guerrero, 2006). Tales experiencias se desarrollan en atención a las expectativas del estudiante, comprometiendo al docente en un ejercicio reflexivo y definiendo cambios estructurantes de la relación que los involucra directamente. Asimismo, exceden la aplicación inmediata, para encuadrar estos recursos en las contradicciones de la cultura digital donde se hace cada vez más necesaria la ponderación de los actores respecto de sus sentidos y determinaciones múltiples.

\subsubsection{Principales observaciones}

De acuerdo a los resultados preliminares de la Dimensión de los Usos, sintetizamos:

1- Con la llegada del PCI, los usos pedagógicos renuevan no-usos, usos instrumentales (predominantes) y con orientación didáctica, junto con los usos sociales ligados al entretenimiento. Superadas las resistencias iniciales, los no-usos se han convertido en unos marginales, se continúan

aquellos instrumentales y de aplicaciones básicas, junto con la presencia de actividades pioneras en entornos interactivos, tanto espontáneas como resultantes de la planificación. Los usos sociales se amplían y diversifican, pero siguen desfasados de los ambientes escolares.

2- Un imaginario tecnológico, hegemónico en estas actuaciones o las disposiciones hacia ellas, resulta consistente con el lugar que la educación técnica suele atribuir a la tecnología como eje de la modernización. Pero discursos alternativos ofrecen otras interpretaciones, donde el foco de interés no reside tanto en la herramienta en sí misma, sino en las habilidades implicadas en su utilización y su debatida integración en las aulas. 
3- Los juegos en red y las redes sociales se inscriben en experiencias juveniles fluidas y entusiastas que el acceso personal dinamiza, pero también son ponderados como componentes disruptivos de los procesos de aprendizaje. Expresan entre los jóvenes las distancias percibidas tiempo escolar/extraescolar, estudio/entretenimiento, adentro/afuera, si bien en sus prácticas realizan constantes desplazamientos y negociaciones con los límites áulicos e institucionales.

4- Aunque no están extendidas ni se inscriben en proyectos de mayor alcance, surgen hacia la segunda etapa experiencias alternativas que involucran redes comunicativas donde desplazan los consumos tecnológicos en sentido estricto, hacia espacios de producción cultural, mediante las tecnologías disponibles y aprovechando las oportunidades múltiples de la interactividad.

5- Mención aparte merecen los teléfonos celulares. Directamente excluidos al principio, avanzado el proceso de digitalización reciben muy diversas apropiaciones. En el caso de los docentes, desde la prohibición o la aceptación forzada, hasta la utilización en otras dinámicas de enseñanza, como recursos educativos, de manera complementaria o en reemplazo de las netbooks.

\subsection{La Apropiación de TIC: la construcción de autonomía}

Pensar la problemática de la apropiación en trayectos esperados de madurez digital (y como condición de posibilidad de la formación ciudadana), condujo a varias revisiones y precisiones conceptuales (por ejemplo, en Fernández Massara, 2017). En principio, configura dos aspectos fundamentales: los modos de acceso y uso material de los dispositivos, y las representaciones o producción de sentidos. Acompañamos las objeciones de Morales $(2009,2011)$ al concepto restringido de consumo, ya que en las audiencias/usuarios puede haber un uso creativo, no prescripto, de los productos mediáticos, pero no necesariamente la consciencia de sus posibilidades para generar proyectos de autonomía. Entonces, la apropiación de tecnologías se vincula a:

las prácticas a través de las cuales los sujetos, habiendo realizado una elucidación acerca de las determinaciones económicas, sociales e ideológicas que imponen los objetos tecnológicos que los rodean, expresan en el uso competente de esos objetos, su libertad de adaptarlos creativamente a sus propias necesidades, en el marco de la construcción de proyectos de autonomía individual y colectiva (Morales, 2009: 118).

Desde una perspectiva antropológica, Rosalía Winocur (2009, 2013a) entiende a la apropiación tecnológica como el conjunto de procesos socioculturales que intervienen en el uso, socialización y significación en diversos grupos, se realiza desde un habitus y comporta un capital simbólico que le es específico. Las implicaciones de Internet o el teléfono celular no provienen de la relación operativa con los aparatos, sino de las determinaciones mutuas entre las representaciones y los usos que producen las personas, que escapan frecuentemente de la 
racionalidad técnica dominante para volverlos compatibles con sus trayectorias biográficas y sus sistemas socioculturales de referencia. Y en el campo educativo, cobra relevancia la pregunta por las representaciones sociales en torno a estas tecnologías, en sus íntimas vinculaciones con las significaciones compartidas sobre las funciones de la escuela, los sentidos de la formación, el estatus de sus actores y la identidad social que construyen.

Partimos entonces de las dimensiones sistematizadas por Morales, con vistas a analizar los entrecruzamientos entre las lógicas de apropiación material y las disposiciones puestas en juego en estas experiencias tecno-educativas. Las primeras remiten al objeto:

-conocimiento: se vincula con la consciencia de los procesos involucrados, que el objeto y sus componentes tienen potencialidades y limitaciones que es necesario explorar y determinar.

-reflexividad: presupone la evaluación continua de las tecnologías y de los procesos políticos, económicos, sociales y tecnológicos que favorecieron su aparición, de las ideologías de las que son portadoras y de las representaciones que subyacen a su utilización.

-competencia: refiere a habilidades y destrezas, los conocimientos previos y los procesos de interpretación resultantes, y en el marco de competencias socio-comunicativas más amplias.

-uso: supone la intensidad, habilidad, percepciones de los usuarios, en el marco de escenarios culturales mediados por las TIC.

-gestión: las habilidades de adquirir, combinar, modificar, actualizar, reemplazar o excluir un objeto o sus componentes incorporados o convergentes en acciones tecnológicas específicas.

$Y$ en relación a las significaciones, se identifican:

-elucidación: partiendo de Castoriadis (2003), es una interrogación reflexiva sobre lo que hacemos, lo que pensamos y lo que damos por sentado como un saber válido, natural o establecido. Asociado a los usos tecnológicos, significa que los sujetos pueden atribuir sentido a los datos, desarrollar modalidades de búsqueda, ordenamiento, análisis de la información, leer críticamente los mensajes y evaluar su componente imaginario y socialmente instituido.

-interactividad: resulta de la distinción al tiempo que de la complementariedad con los medios tradicionales, previendo posibilidades de uso en la producción creativa, no restringida a la recepción ni al consumo de contenidos establecidos a priori.

-interacción: implica intercambiar experiencias, identificar las diferencias, reconocer nuevas formas de sociabilidad. También permite construir identidades individuales y colectivas, y evaluar las condiciones que hagan posibles las transformaciones de la propia realidad.

-proyecto: las tecnologías pueden propiciar proyectos de autonomía, que contemplan una dimensión individual y una dimensión social, íntimamente vinculadas. Retomando a Castoriadis, la autonomía individual no implica la eliminación del discurso del otro, sino la elaboración de otro 
discurso. Es esa relación donde los demás están presentes como alteridad, lo que no se reduce a la mera intersubjetividad sino que revela una existencia social e histórica.

Aunque nuestro interés no se focaliza en la construcción de subjetividad, vamos a explorar algunas conceptualizaciones para indagar su potencial como una de las Subdimensiones de la Apropiación, retomando algunas consideraciones previas (Fernández Massara, 2016b). Un aspecto dilemático que caracteriza a las redes sociales y los juegos on-line es la reconstrucción de los sentidos de lo privado. Paula Sibilia argumenta que en una sociedad altamente mediatizada y espectacularizada, se ha desvanecido la identidad como noción fija y estable, cuando ante la crisis de los referentes tradicionales "el yo no se siente más protegido por el perdurable rastro del pasado individual ni tampoco por el ancla de una intensa vida interior. Para fortalecerse y para constatar su existencia debe, a cualquier precio, hacerse visible" (2008: 252).

Desde un enfoque socio-semiótico, la subjetividad es antiesencialista, histórica y contextual, no es estable ni unidireccional sino sujeta a constantes transiciones, como una red de conexiones múltiples que es al mismo tiempo material y simbólica. Siguiendo a Braidotti, para Eva da Porta (2011a, 2012) la subjetividad constituye un interjuego entre la sujeción y la subjetivación, una negociación constante entre modelos culturales hegemónicos y modos creativos de apropiación y uso. Proceso que la autora concibe como una mediatización de la subjetividad, el complejo entramado de producción de sentido que se desarrolla a partir de la presencia de los medios y las tecnologías de la comunicación, en referencia al ya clásico término de Eliseo Verón (2001a, 2013).

Los aspectos ligados a la construcción de la subjetividad han sido también destacados por Cabello (2014). En su propuesta de operacionalización de la inclusión digital, identifica cuatro dimensiones: acceso, uso, participación y autoafirmación, estas dos últimas comprendidas bajo la idea de empoderamiento. Decidimos mantener la distinción analítica entre los aspectos colectivos (la participación en estructuras sociales y movimientos colectivos, a profundizar en torno al entramado ciudadanía/democracia/política) y los aspectos individuales ligados a la autoafirmación (los modos de subjetivación, autoconfianza o confirmación del yo), como una de las Subdimensiones. En nuestro caso, el término designa a las experiencias en las cuales los sujetos establecen con las TIC relaciones afectivas, expresivas y cognitivas, que configuran condiciones estructurantes de los aprendizajes como las posibilidades de objetivar y objetivar-se en el mundo.

Como adelantamos en el Capítulo anterior, a partir de estas nociones operamos una síntesis teórico-metodológica de la que resultan cuatro Subdimensiones: Conocimiento, Elucidación, Autonomía y Autoafirmación. Nuestra perspectiva distingue entre los aspectos relativos al objeto y los propios de las significaciones, entre los aspectos individuales y los colectivos. Empero, no los considera de manera aislada, puesto que las prácticas de apropiación digital se intersectan con, 
y se expresan a través de, un conjunto de representaciones en el marco de los más diversos contextos socioculturales, en este caso, en las singularidades de la educación secundaria técnica.

\subsubsection{El Conocimiento: de los medios a los entornos}

Los comienzos del PCI se inscriben en las tensiones no resueltas entre los propósitos de innovación educativa y los modelos conservadores. Dos aspectos explorados sobre el tema son las relaciones entre las netbooks y otras tecnologías informáticas $\mathbf{y}$ audiovisuales (televisión, proyector, computadoras de escritorio), por un lado, y entre las netbooks y los recursos analógicos (carpeta, libro, pizarra, etc.), por el otro. Allí operan las dicotomías entre lo nuevo y lo viejo, lo tradicional y lo moderno, en base a cierta concepción evolucionista que, contradictoriamente, dificulta integrar los distintos medios aprovechando todas sus gramáticas, aplicaciones y funcionamientos didácticos. Si en su componente técnico las netbooks registran continuidades con otras tecnologías, a la vez están imaginariamente escindidas de ellas.

En parte, esta creencia se debe a las posibilidades objetivas de los soportes multimedia que tienden a absorber o integrar a otros, pero también a imaginarios que cristalizan a la modernización digital como condición insoslayable de la calidad educativa. Estas expectativas, sin embargo, contrastan con el hecho de que el cine, la televisión, el proyector, las computadoras e Internet, no han modificado substancialmente las intervenciones didácticas, ni las formas de comunicación que son requeridas para mejorar los aprendizajes. Si la portabilidad de la netbook y la practicidad del acceso personal son aspectos ampliamente valorados, no queda claro en qué términos pueden optimizar los usos informáticos y audiovisuales que ya se realizaban en la escuela. Recursos que con frecuencia no son integrados más que para explicar en reemplazo del pizarrón, motivar el interés, ejemplificar un tema o incluso a "entretener" a los estudiantes en las horas libres.

Estos supuestos suelen fundarse en las debilidades percibidas de la capacitación docente, una demanda temprana y muy concreta hacia el Estado que la netbook dota de creciente visibilidad. Este problema termina por exculpar al profesorado, cuando capacitarse se vuelve indispensable para desarrolar estrategias didácticas de nuevo tipo. Hay en esta entrevistada un posicionamiento enunciativo como docente, que la involucra en un marco de comprensión compartida:

Porque hay que cambiar la forma de dar clase. Porque tenés que utilizar un recurso que antes no usabas. Porque ya no es más el pizarrón, la tiza, el marcador para el pizarrón. Ahora el pizarrón es la pantallita. Pero, claro, si a mí no me capacitan, yo soy profesora de Matemática, si a mí no me capacitan, qué se yo, yo voy a seguir usando el pizarrón y dando el trabajo práctico como di toda mi vida... (Directora EEST N² 2 ). 
En relación con la escritura, algunas posiciones entienden que la netbook no debe reemplazarla. Su presencia puede ser algo positivo para innovar en los materiales, pero en cambio se subestima su importancia frente a la escritura -o su expresión más acabada, el libro-, entendidos estos como lugares insoslayables de producción de conocimientos. Esos temores se refieren no tanto a las habilidades en sí mismas (es harto conocido que los chicos también escriben en los soportes digitales) sino en las competencias cognitivas, epistémicas y actitudinales que se atribuyen mayormente a la cultura escrita. Bajo esta premisa se reafirman los supuestos tradicionales de que "nadie acabará con los libros" (Eco y Carrière, 2010): "La computadora está desplazando los métodos más tradicionales de enseñanza, como el pizarrón y la lecto-escritura. Pero no creo que vaya a reemplazar al libro. La computadora no es que reemplaza nada, sino que es un recurso didáctico más..." (profesor EEST N 1, Análisis Matemático, O. Química).

En otros casos, las netbooks están destinadas a sustituir a los libros, si bien estas expectativas están basadas en el acceso a la información o los beneficios operativos (facilidad, practicidad, inmediatez) antes que en oportunidades de innovar en la enseñanza. Discursos de este tipo también focalizan en las netbooks como recursos didácticos, pero sobre la base de un imaginario tecnocomunicacional que aseguran que "el futuro ya está aquí": su tensión temporal refuerza un horizonte de expectativas que se inserta en la experiencia cotidiana de uso digital.

El cambio que produce la computadora es impresionante. Por ejemplo, yo les doy un trabajo práctico y directamente van a Internet y hacen una búsqueda sobre el tema. No necesitan ir al libro. Porque además los libros que hay en la escuela están completamente desactualizados. Lo actual en la tecnología es hoy, jo ayer! (EEST $\mathrm{N}^{\circ}$ 1, Proyecto y Diseño Electrónico, O. Electrónica).

Otras referencias remiten al necesario "equilibrio", la convivencia o complementariedad entre computadoras y soportes tradicionales. Estas apropiaciones remiten a la metáfora del ecosistema mediático que adquiere distintos matices, pero pueden encarnar una mirada difusa acerca de los aspectos que adopta la convergencia, la confluencia de materiales, lenguajes y sistemas de significación que "entran" en la escuela y a las que hay que "adaptarse". Una de sus expresiones en esta etapa es la sensación extendida de pérdida. En la EEST $N^{\circ} 2$, el grupo focal demuestra coincidencias entre docentes de distintas materias: son estos espacios y no las aplicaciones técnicas donde se disputan los sentidos acerca del lugar de las netbooks:

Creo que hay que encontrar un equilibrio, que no está mal que el chico utilice la netbook para hacer un trabajo pero tampoco olvidar lo otro. Mapas, por lo menos conmigo, los tienen que hacer a mano... (Geografía).

Hay que buscar un equilibrio. Porque hay que ver también cómo usan ellos otras herramientas que no es la computadora, la escritura, y en mi caso hacer los mapas manualmente. Hay programas que están buenos, pero también es cierto que se ha perdido mucho la escritura manual (Literatura). 
Las competencias de escritura y lectura constituyen un área particularmente vulnerable. Las dificultades son más severas entre estudiantes de la EEST $\mathrm{N}^{\circ} 1$, lo que se replica en los niveles de deserción y fracaso escolar. Argumentaba otro profesor que su materia técnica "no es de escribir, no escribimos informes, no, pero cuando escriben los exámenes, palabras cortadas, no se les entiende", pero esto "no es culpa de las tecnologías". Connota el supuesto dominante de que las materias técnicas no constituyen el ámbito para la producción de textos y, en cambio, sí lo son para las TIC. Nos detendremos luego en este binarismo de base. Basta destacar la idea equivocada de que las habilidades discursivas constituyen un asunto acotado a un área o solo de especialistas, y no parte de un proyecto transversal de alfabetización académica (Carlino, 2005).

Otro conjunto de preocupaciones reposa en los tipos de conocimientos mediados por TIC, y cuál es el nivel de significatividad que se les adjudica en relación al conocimiento escolar, entre lo que se aprende desde las interacciones con las tecnologías y lo que solo se puede aprender en la escuela. El eje de interés no radica tanto en los materiales didácticos, sino en la tarea docente que se ve tensionada ante unas transformaciones que se describen como negativas. Con frecuencia, se generaliza en los adolescentes saberes elaborados que deben ser capitalizados en clase, redefiniendo los sentidos del contenido escolar, los diversos modos de enseñar y aprender, las disposiciones al trabajo colaborativo. El temor es que puedan saber más que sus docentes:

Pero ¿qué pasa? El profesor les da para escribir: los chicos ya lo saben. El profesor les enseña Excel: los chicos ya los saben. Tenés que estar controlando que los chicos no estén conectados al Facebook. A lo mejor el profesor no tiene idea del Facebook, y el pibe le enseña (Vice-Directora EEST N ${ }^{\circ}$ 2).

En otros casos, el valor educativo de esas experiencias se vuelve más dudoso:

Los chicos aprenden muy rápidos, también se largan a correr descalzos, jaja, claro, pero aprenden de una manera que no es la mejor pero aprenden, de alguna forma aprenden. $\mathrm{Si}$ uno se pone de analítico o crítico, uno ve la diferencia en el plano entre el que aprendió bien y el que aprendió a los ponchazos... (profesora EEST N² 2, Matemáticas, O. Automotores).

Repeticiones y metáforas connotan una sensación de franca resignación. Evocan un panorama complejo, en el que las TIC pueden animar a los jóvenes a adquirir unos saberes específicos, diversificados, pero que no responden a los requerimientos de la escuela. Esa exterioridad en el docente termina por obturar posibilidades efectivas de integración pedagógica.

En la segunda etapa, las tecnologías audiovisuales (televisión, proyector, etc.) han sido relativamente desplazadas, dadas las utilidades percibidas y valoradas de las netbooks para cada materia (ver películas, editar videos, tomar fotografías, hacer presentaciones, usar softwares 
específicos, etc.). La mayoría de los profesores han utilizado alguna de estas aplicaciones, aunque el deterioro técnico de los equipos y la falta de habilidades más sofisticadas constituyen obstáculos muy tangibles. Los soportes analógicos muestran plena vigencia, en complejas combinaciones con las TIC, en particular en la lectura de fotocopias y la elaboración de actividades en las carpetas.

A contramano de posiciones restringidas que se continúan, algunas experiencias manifiestan los esfuerzos de repensar a las TIC no solo como recursos, sino en el marco de proyectos áulicos de otro tipo que permiten superar las dicotomías de base. Incluso docentes conservadores se muestran predispuestos a intercambiar experiencias, someter a discusión los resultados, evaluar las posibilidades de replicarlas en función de los objetivos de las materias. Son también facilitadoras del desarrollo de habilidades transversales a todas las áreas. Así, en esta profesora de Inglés (EEST $\mathrm{N}^{\circ} 2$ ), las modalizadores, las repeticiones, los ejemplos, las construcciones metafóricas, argumentan a favor de una práctica reflexiva, a la vez que afectiva, con voluntad de cambio. Se refiere a intervenciones que integran los juegos en red para trabajar la gramática inglesa, animar la participación del alumno y aprovechar sus saberes en la cultura de masas:

A mí me gusta innovar, me gusta cambiar. Estamos trabajando en la vida del creador del Preguntados (...) El Preguntados es cultura general, ahí me sorprendió... Las preguntas sobre libros, por ejemplo: ¿quien escribió Carrie? Y todos sabían, les agarra la desesperación: ¡Stephen King! Y es cultura general, hay que encontrarle una vuelta.

Aunque estas modalidades son más frecuentes entre profesores de área, pueden manifestarse en otros, en propuestas alternativas o complementarias a los usos operativos. El profesor de Derechos del Trabajo (O. Química) de la EEST $\mathrm{N}^{\circ} 1$ sintetiza dos aspectos mutuamente implicados: 1- la predisposición a conformar equipos que permitan producir saberes de manera colaborativa, un aspecto particularmente complejo supeditado a saberes previos: "Ahora se apunta a integrar contenidos, al trabajo interdisciplinario, que las TIC creo que solucionarían mucho. Pero es difícil de coordinar, por esto que estamos hablando, hay docentes que tienen un nivel de conocimientos más altos que otros". Y 2- la necesidad de discriminar los usos según los propósitos de cada materia, adecuados a una clara planificación didáctica y articulando distintos materiales: "En Arte, por ejemplo, trabajamos con la profe de Arte de manera interdisciplinaria, los chicos reflejan los contenidos de Derechos Laborales en las obras de arte. Trabajamos de manera tradicional también, con afiches, con láminas, con orales, con la carpeta..."

En suma, en la primera etapa la netbook encarna diferentes relaciones con otras tecnologías: sus sentidos novedosos o difusionistas, pero también la sensación de pérdida, una promesa incumplida, un proceso inevitable al que hay que adaptarse. Lo que articula estas posiciones es un extendido binarismo. Con el tiempo, coexisten con modos de apropiación con fines educativos, donde las TIC pueden integrarse en redes de comunicación, el efecto de sentido es global y surge 
de la confluencia de todos los elementos. Asimismo, reclamar avances hacia procesos de madurez digital demuestra que el docente constituye el motor para impulsar otro tipo de propuestas: hacia el trabajo interdisciplinario, con capacidad de liderazgo o de una participación más protagónica.

\section{Apropiaciones juveniles, conocimientos esperados y producidos}

R. Winocur ha advertido que las políticas de inclusión digital suelen asumir que los destinatarios son una hoja en blanco donde se inscribe el aprendizaje de las habilidades tecnológicas. En contraste, "cualquier acercamiento, real o imaginario, a las TIC, inevitablemente es resignificado por otras formas de socialización tecnológicas previas en el trabajo, la escuela y el hogar, y por el uso de otras tecnologías mediáticas propias del habitus de cada grupo social" (2013a: 56). En este sentido, las condiciones que los jóvenes entrevistados advierten y valoran positivamente se sustentan en las oportunidades múltiples que brinda el acceso personal, aunque esas valoraciones están más ligadas a sus propias experiencias, antes que a la implementación del modelo 1 a 1 .

Apropiarse de la netbook, en el sentido de "hacer propio" ese objeto, está lejos de explicar un fenómeno tan complejo. Una condición que dificulta particularmente las decisiones de una política de inclusión digital, es que no contempla los conocimientos ya adquiridos (técnicos, disciplinares, curriculares) como los afectos que los soportan, en aquellas experiencias novedosas que pueden producirse en condiciones de digitalización. En las diversas realidades de las escuelas públicas, es evidente que los estudiantes de la EEST $\mathrm{N}^{\circ} 2$ presentan condiciones familiares más favorables, que orientan ciertos intereses o disposiciones. Como en esta alumna de 5to. Año:

Me anoto en muchos cursos por Internet, me gusta. Por ejemplo, aprender idiomas. Ahora me voy de viaje de egresados y me estoy bajando un curso para hablar portugués, avanzado y corto... intensivo. Una vez viajé a EE.UU. y tengo amigos de allá que volví a encontrar, así que uso los traductores y eso. ¡A Aprendí a tocar el piano por Internet! (Electromecánica).

Un problema de la escuela radica en la dificultad para comprender, aprovechar y profundizar esos "saberes-mosaico" provenientes de muy diversas fuentes, que tensionan los saberes heredados de la cultura escrita y dinamizan ese descentramiento culturalmente desconcertante (Martín Barbero, 2003). Sin embargo, ¿presentan estas apropiaciones juveniles rasgos de una cultura disruptiva respecto de las generaciones anteriores? En verdad, no se expresan propiamente en clave de disputa generacional: nos señalan las claves de una cultura otra, pero esta se realiza desde complejas negociaciones de sentido con los códigos familiares y escolares, antes que desde rupturas absolutas. Por su carácter conservador, cotidiano y constitutivo de la sociabilidad

juvenil, la escuela técnica es el escenario por excelencia -a veces, por encima de la familiadefinitorio de los sistemas de significaciones que están mediando esas relaciones con TIC. 
Dos posiciones dominantes se manifiestan en esta primera etapa. Por un lado, la convicción, junto con sus docentes, de que la netbook materializa las tensiones entre lo escolar y extraescolar: entienden que, en las prácticas de entretenimiento, las tecnologías interactivas adquieren un evidente protagonismo, pero no necesariamente en respuesta a los propósitos del aprendizaje formal. Estas estimaciones son frecuentes entre estudiantes de la EEST $\mathrm{N}^{\circ} 2$, lo que se condice con una mirada más distante respecto de los significados y afectos asociados a la netbook. Aun cuando la conciben como una "herramienta más", revelan modos particulares de apropiación de las distintas tecnologías, según intereses personales o requerimientos de las tareas: "Yo prefiero la carpeta porque cuando vas escribiendo vas estudiando lo que escribiste, le das una lectura y te vas acordando. En cambio, con la computadora no podés" (5to. Año, Electromecánica).

En otros casos, los estudiantes lamentan que los nuevos dispositivos no se utilicen con mayor frecuencia en las clases. Antes que copiar o escribir en la carpeta, prefieren completar fotocopias, una tarea que se ha vuelto mecánica y en la que tampoco encuentran motivación ni verdadera relevancia. Hay entonces un cuestionamiento tácito a las actividades didácticas cuando tienen por único objetivo que se reproduzca un saber cerrado, en vez de producir de manera crítica y contextualizada. Es aquí donde la netbook actualiza proyecciones acerca de las posibilidades de otro tipo de trabajo áulico, aunque todavía no logran elucidar sus sentidos o formas de implementación. A riesgo de generalizar, esta posición es distintiva de alumnos de la EEST $\mathrm{N}^{\circ} 1$ : "Los profesores que yo tengo este año, te hacen copiar...este año trabajamos un montón, nada que ver con el año pasado. En sí, a mí dame una fotocopia. Yo te hago la fotocopia, pero copiar no me gusta. Escribir en la computadora me gusta, pero no lo hacemos...” (6to. Año. Química).

Hacia la segunda etapa del PCI, mientras que los jóvenes son usuarios tecnológicos cada vez más competentes en su vida cotidiana y demandan, consecuentemente, otros usos de las netbooks, advierten que la lectura en pantalla no es necesariamente "más fácil" y en muchos casos, la carpeta "sigue siendo más práctica". Los libros continúan teniendo escasa presencia, pero no como resultado de un uso extendido de las computadoras (consideremos, además, su deterioro técnico) sino porque se siguen utilizando fotocopias y, sobre todo en materias de área, la carpeta. Resulta de ello que la escritura no está escindida de los procesos de inclusión digital, y conjuga un espacio simbólico de complejas negociaciones entre docentes y alumnos. En cambio, el lugar para la exploración, la búsqueda de información, la investigación, es indefectiblemente, Internet.

Cuando la netbook está disponible, las limitaciones de la conectividad cobran fuerza renovada: quienes cuentan con estas condiciones, realizan actividades de investigación en sus hogares, aunque, como hemos observado, incluso los docentes -en especial, los técnicos- evitan 
solicitar tareas domiciliarias: la premisa lógica en una escuela de doble jornada es, precisamente, “trabajar en la escuela". Ahora bien, son los estudiantes de los años superiores los que están en mejores condiciones de objetivar la centralidad del rol docente en el aprendizaje mediado por web. Si esta es concebida como una valiosa fuente de información, no promueve, per se, experiencias de producción de conocimientos. La búsqueda, selección, organización y aprovechamiento de esos datos pueden sustituir a la biblioteca pero de ningún modo la orientación del docente:

Nos enseña cómo buscar, qué buscar, meter mano, jugar como quien dice, que leer diez libros. Hay muchos programas basura, que no andan ni para atrás, el profesor nos enseña a seleccionar. Acá tenemos la suerte de tener Internet libre. Hay que aprovecharlo a eso... (EEST No 1, 6to. Año, Electrotécnica).

La continuidad del PCI ofrece la oportunidad de normalizar la presencia de las TIC, aunque las contradicciones entre las prácticas juveniles asociadas a ellas y las permitidas (o resistidas) en el ámbito escolar, presentan múltiples derivaciones. En su dimensión Cognitiva, apropiarse de la netbook implica comprender dificultades objetivas para producir conocimiento, por ejemplo, si se desaprovecha un uso complementario de los distintos soportes: se utilizan unos u otros, pero raramente de manera conjunta. De manera que, a contramano de ciertas creencias docentes, los adolescentes advierten otras formas de uso, desde las cuales se discriminan aportes, significados y utilidades. Estas reflexiones alientan posibilidades de elucidación, cuando de lo que se trata es de evaluar la incorporación de distintos recursos, pero acompañada de procesos de apropiación en respuesta a las nuevas demandas de construcción crítica de conocimiento.

\subsubsection{Posibilidades de Elucidación de las "divinas maquinitas"}

Las hondas transformaciones asociadas a la Sociedad del Conocimiento desafían a las escuelas a llevar a cabo un esfuerzo de elucidación, un ejercicio reflexivo sobre lo que se sabe, pensar "de otro modo" las imágenes y significaciones instituidas o lo que forma parte del sentido común. De ahí que comprendemos esta categoría como Subdimensión de las experiencias de apropiación digital. La pregunta que deriva de ello es cuáles son las condiciones de posibilidad para que directivos, docentes, estudiantes, logren poner en juego actitudes problematizadoras que los orienten no solamente en el desarrollo de usos con alcances pedagógicos, sino en desnaturalizar las operaciones ideológicas que definen los imaginarios sobre las tecnologías y que las vuelven requisitos inevitables y necesarios para la transformación socio-educativa.

En la primera etapa de Conectar Igualdad, los directivos refieren a un panorama incierto donde su responsabilidad en la gestión se ve sometida a múltiples presiones: las directrices del sistema, el peso de la tradición en la formación técnica, las demandas de información del equipo 
docente, los intereses estudiantiles, el impacto no plenamente objetivado de la cultura digital. Estas matrices simbólicas se organizan tempranamente en torno a las netbooks como dispositivos. Las primeras evaluaciones suscriben al sesgo ideológico de carácter tecnicista, destacando los beneficios esperados del aparato antes que sus componentes político-culturales. Un claro ejemplo de cómo se materializan estos significados en los discursos es el campo léxico esgrimido por la Directora de la EEST N²; también condensa una fuerte cosificación, ligada al mismo tiempo a la sensación extendida de exterioridad como de la enfática defensa de los aspectos operativos:

¡40 programas hay! De todas las materias, que no me digas cómo son porque no tengo la menor idea, sé que hay 40 programas porque cuando me las mostraron la primera vez, dije: pero mirá la cantidad de cosas que tiene (...) Son divinas las maquinitas (me muestra una), son una pinturita, y son muy buenas máquinas, nosotros pensábamos que iban a mandar porquerías. Son preciosas, son hermosas maquinitas. Los profesores de Informática están enloquecidos. Muy buena calidad.

Las formas de elucidación derivan también de las determinaciones socioculturales, económicas, pedagógicas, que atraviesan a la institución. Para la Directora de la EEST $N^{\circ} 1$, el problema no radica tanto en la implementación de tecnología- que interpreta estrictamente en términos del equipamiento técnico-, sino en poder crear las condiciones que permitan aprovechar los beneficios de esa inclusión, contribuyendo a superar una situación histórica de desventaja. Este proyecto aparece articulado con la idea recurrente de "eficiencia", una mirada favorable pero contradictoria: suma otra dificultad a la problemática tarea de gestión institucional:

Entonces esta escuela, que tiene orientaciones distintas a la Técnica 2, que podría ser una referencia, que podría ser una escuela importante, y frente a esta normativa que es bárbara, que es importante, que la da igualdad de oportunidades y en el marco de esta ley, nosotros no logramos volvernos una institución eficiente, colmada de esa tecnología...

Un ejercicio reflexivo sobre el propio posicionamiento es más frecuente pero no privativo de docentes provenientes de áreas humanísticas. Aquí la propia formación es una variable implicada en procesos de auto-evaluación, en lo concerniente a los dilemas de utilizar productivamente a las netbooks más allá de sus aplicaciones instrumentales. Para estos docentes, el carácter "estructurado" atribuido a la formación técnica habilita un conjunto de habilidades esenciales, pero redunda en obstáculo si impide evaluar críticamente esas acciones en la complejidad de lo socialhistórico. No obstante, en la práctica, estos sentidos conviven con un doble concepto: la computadora como "herramienta" y el imperativo de la "adaptación". Y dificultan las interrogaciones sobre cuestiones de fondo: qué implica tener a adaptarse, a qué estado de cosas, con qué propósitos educativos, en el marco de cuáles determinaciones sociales.

Nuevamente, las tecnologías se invisten de carácter natural, definiendo sus sentidos en base a los beneficios que operan en la vida cotidiana, frente a los cuales la educación parece estar 
eminentemente rezagada. La dimensión temporal del mito tecnológico pone a la netbook en un lugar bien concreto: el de visibilizar estos desfasajes, la irrupción de aquello que era ajeno pero "ya llegó" y ante lo cual no queda otra opción más que adaptarse. Este pensamiento termina por neutralizar los aspectos más conflictivos de la inclusión digital y, paradójicamente, sirve de anclaje a concepciones tradicionales e igualmente binarias sobre las modalidades de enseñanza:

Nosotros los técnicos somos muy lineales, muy esquemáticos. Pero yo también soy muy crítico de las tecnologías. También ha habido resistencia a la tecnología, primero a la computadora, al celular. Pero bueno, ya está, yo digo que todo pasa por el celular, yo no uso despertador, no uso reloj, en estos teléfonos de última generación tienen todo (Vice-Director EEST N ${ }^{\circ}$ ).

Quieras o no, igualmente el uso de las tecnologías ya la está transformando (a la enseñanza), más para los docentes que vienen trabajando hace muchos más años que yo, con el método tradicional del material impreso, es un gran cambio para ellos. Porque de golpe y porrazo se encontraron con que los chicos tienen algo nuevo para trabajar en clase... (profesora de Inglés, O. Química, EEST N 1).

Las predisposiciones más favorables ponen al PCI en marcos interpretativos que establecen relaciones íntimas entre el acceso personal y el cumplimiento de derechos sociales. Otro de los Vice-Directores de la EEST N 2 es particularmente taxativo cuando evalúa que la distribución de los equipos pone en un plano de igualdad a jóvenes provenientes de distintos sectores, aunque su utilidad para promover el conocimiento no aparece claramente objetivada. Por una parte, alimenta la cosificación de la netbook como "bien de deseo", en pos de evitar la deserción escolar como condición indispensable para habilitar el cumplimiento de una política inclusiva. Por otra, actualiza la premisa compartida de que el espacio emblemático para promover estas experiencias lo constituyen la educación técnica y su proyecto histórico de movilidad social:

Entonces, cuando hay mucha brecha social, mucha injusticia social, cuando hay mucha gente que quedó en la lona por el neoliberalismo. Entonces qué pasa: la computadora es un bien de deseo. Si vas a la escuela, me dan la computadora, si dejo la escuela me sacan la computadora. Entonces están haciendo una retención a través de las nuevas tecnologías. Y, por otro lado, están tirando una igualdad, que el chico con mayores recursos tiene su computadora, y el chico que viene en una villa tiene su computadora.

Reconocidas las dificultades no resueltas de la implementación, en la segunda etapa los discursos oficiales del PCI confirman la hipótesis de que las tecnologías encuentran en la formación técnica ese lugar instituido pero movilizador de los esfuerzos de innovación tecnológica. Argumentaba la referente regional acerca de cómo las tradiciones pueden articularse orgánicamente con un proyecto de modernización. Esta concepción que intersecta con los supuestos hegemónicos de la racionalidad técnica, otorgando sustento a la distribución temprana de las computadoras en las escuelas técnicas y en continuidad con políticas de características similares: "Y también porque me gusta su forma de trabajar, por sus tradiciones y por cómo pueden 
implementar lo nuevo, tienen la tradición y a la vez la forma de implementar lo nuevo, no lo rechazan. Las implementan más que en otras escuelas..."

A esta opinión se suman las valoraciones de que la oferta de la EEST $\mathrm{N}^{\circ} 2$ contempla la orientación en Informática, pero también una mayor transversalidad de las tecnologías en la formación toda, instituyendo a ambas como condiciones necesarias para responder a las transformaciones aceleradas del sistema socio-productivo. Según el Director: "Nosotros tenemos una tecnicatura que es Informática, esa, listo. Pero las otras también incluyen, por ejemplo, el uso de Autocad, vienen alumnos de otras escuelas que no tienen y se las prestamos..." Esta idea entronca con interpretaciones en las que el propio posicionamiento político dota de inteligibilidad a las dificultades de adecuación del PCI y a las orientaciones ideológicas que se le atribuyen. El discurso metaforiza las críticas a las ambigüedades de una política inclusiva, calificada como "asistencialista" o de impacto dudoso en la calidad educativa. Retener al alumno es importante, pero "no alcanza", "el principio no estaba tan mal pero hubo un derrame de populismo..."

Un profesor de Matemática de la EEST $N^{\circ} 1$ es aún más categórico al homologar el PCI a políticas de derechos, como la Asignación Universal por Hijo y la Ley de Educación Sexual Integral, pero en sus connotaciones negativas. Estas políticas son caracterizadas como "asistencialistas", evocando una misma matriz simbólica ligada un efecto de "facilismo". Una idea renovada que descalifica a los adolescentes, pero no tanto en los términos de lo que Margulis (1996) llamaba "moratoria social", sino debido a las situaciones socioculturales en las que se inscriben esos consumos y que terminan por exculpar a los docentes por no llevar adelante actividades didácticas más novedosas o interactivas con las TIC. De ahí el uso enfático de repeticiones y modalizadores: "La mayoría recibe la AUH, las becas Progresar. Y todo cuotas, cuotas, cuotas, los padres no usan las cuotas para comprar una mesa sencilla, no, una tele, lamentablemente estas cosas así de planes, no cubren necesidades básicas..."

Cabe destacar que posiciones tan radicalizadas resultan más bien excepcionales. Podemos identificar, en cambio, dos posiciones docentes predominantes. En primer lugar, aquella que se prolonga desde la primera etapa: las expectativas sobre al futuro utópico de la revolución digital, cuando los beneficios de las tecnologías resultan comparables a los de una "bomba neutrónica" o a la "energía nuclear", las oportunidades de tener acceso a "todo" y atenuar de este modo los efectos de la brecha digital y social. Vale detenernos en el discurso del nuevo Director de la EEST $N^{\circ} 1$, cuando abunda en adjetivaciones, repeticiones, comparaciones, analogías, en un estilo particularmente expresivo, recursos que le permiten argumentar a favor de las promesas del desarrollo tecnológico cuya realización depende estrictamente de los usos: 
Las tecnologías o los elementos tecnológicos son herramientas, dependen si lo usás bien o mal. Estamos hablando de bombardear un átomo, que mide como nosotros no podemos ni imaginar (...) y produce un efecto que supuestamente reproduce jcómo se orinó la galaxia! ¡Es fabuloso! Mirá hasta dónde llegamos, ahora lo podés usar así o... Son herramientas, lo mismo que un martillo, lo podés usar para clavar un clavo o matar una persona. Ah, me salió el viejo, a dónde iremos a parar (risas).

La cuestión de los usos también está en el centro del razonamiento en una segunda posición, pero bajo significados distintos: los usos posibles y concretos que ejercitan los actores, antes que aquellos derivados de los aparatos considerados a priori. Los beneficios equitativos de la disponibilidad contrastan con el hecho de que no hay verdadera innovación pedagógica si las actividades propuestas se limitan a cambiar un soporte por otro o a incluirlas solo formalmente en la planificación. Una problemática que también interpela a la institución que, tras cinco años, manifiesta la dificultad para articular y llevar adelante un proyecto consensuado y productivo de adecuación del modelo. Ironizaba la nueva Vice-Directora de la EEST $\mathrm{N}^{\circ} 2$ acerca de las contradicciones entre las orientaciones formales y la puesta en práctica, en lo que respecta a los intentos por gestionar un plan institucional de integración tecno-educativa:

Cada profesor tiene que pensar un proyecto con TIC. Suena hermoso, no es tan hermoso... (risas) Suena lindo, en las planificaciones se ve un esfuerzo, no es masivo, pero las TIC siguen siendo un soporte. Se sigue usando como procesador de texto o con toda la furia, algún programa para editar videos, ¿viste?

Por otra parte, los discursos advierten que la brecha generacional -entre docentes o entre docente y alumno- no es una determinante que pueda, en sí misma, alentar u obstaculizar iniciativas con TIC. Hemos observado fuertes resistencias entre profesores muy jóvenes, aunque en este período son excepcionales y los argumentos que las sostienen no privilegian la cuestión de la edad. La tecnología pierde relevancia ante el reconocimiento de las prácticas de los sujetos, emergentes de trayectorias biográficas y formativas, de posicionamientos ideológicos, de los entramados institucionales donde se realizan posibilidades efectivas de migración digital. La ViceDirectora citada reclama el carácter ético y profesional de la docencia cuando entiende que la edad puede constituir más bien una excusa, rechazando las opiniones iniciales sobre las implicaciones mutuas entre juventud (o antigüedad profesional) y predisposición al cambio:

La hipótesis sería que los más jovencitos que tenemos serían los predispuestos. Y no. Yo creo que lo generacional no tiene que ver. Creo que las dos cosas, CI y la LESI, que van paralelos, que son los cambios que vinieron a sacudir la escuela, que obligan a pensarla desde otro lugar, repensar la docencia, y uno supone que la juventud absorbe mejor los cambios. Y no, incluso en algunos momentos es el núcleo más duro de resistencia.

Pensar la docencia desde un lugar alternativo entronca con una perspectiva crítica que llama la atención sobre las formas en las que se producen el conocimiento, el poder, el deseo y la 
experiencia bajo condiciones básicas de aprendizaje, y al hacerlo se rechaza la noción de que enseñar es meramente una cuestión de métodos (Giroux, 2013). Elucidar las lógicas que operan en los entornos tecnológicos significa interrogarse sobre los saberes instituidos en función de la construcción de conocimientos que se busca poner en práctica, a partir de los cuales se configuran unos modos de hacer y modificar estas realidades. Una de las oportunidades que abre una política de inclusión digital es habilitar canales de expresión para que los actores puedan cuestionar sus propias posiciones, desentrañar los mecanismos que las determinan, deliberar qué modelo de educación se persigue y cómo las tecnologías pueden motorizar esos cambios, un proyecto colectivo que requiere revisiones constantes y en diálogo permanente con los supuestos heredados.

\subsubsection{La Autonomía: enseñanza crítica o el imperativo de "adaptarse"}

Aunque en términos conceptuales el ejercicio de elucidación se constituye en condición esencial para enseñar y aprender competencias de autonomía, esta última está ausente en los discursos docentes, especialmente en la primera etapa del PCI. Este hecho anticipa para nosotros una cuestión clave: la construcción de la ciudadanía en tanto espacio ineludible para formar personalidades autónomas. Se trata de un proyecto transversal, instituido y formalizado en la educación y, sin embargo, prácticamente invisibilizado frente a las urgencias de la integración de las netbooks, o al desarrollo de las condiciones básicas que la hacen posible.

Una de las expresiones de este problema se resume en los códigos que los adolescentes han adquirido en el marco de sus experiencias con las tecnologías fuera de la escuela, y que a menudo se materializan en situaciones de resistencia a la autoridad docente. Interpretar estos cambios implica consecuentemente cambiar la práctica pedagógica, en sus relaciones dialécticas con el alumno y con el conocimiento didáctico. Sin embargo, esta práctica queda encorsetada en el ambiente del aula y a la vez supeditada a los requerimientos de la innovación tecnológica, aquella

que se vuelve el patrón organizador de unos consumos juveniles que no son plenamente comprendidos. La metáfora de "buscarle la vuelta" se repite en varias entrevistas, en referencia al carácter evasivo de estas transformaciones. Finalmente, la enseñanza es siempre una operación de adaptación. Tal el caso de la Jefa de Departamento de Informática (EEST N²):

Los chicos adquieren conocimientos de otra forma y nosotros tenemos que adaptarnos a esa forma. No es que los chicos no quieren aprender. A lo mejor no quieren aprender lo que nosotros les tenemos que enseñar, pero le podemos llegar a buscar la vuelta para que les interese un poco o ver que les puede servir para su vida. Para mí la computadora lo que hace es facilitar el vínculo entre el conocimiento y el alumno. 
Los siguientes discursos permiten dimensionar que fomentar el valor de la responsabilidad en cierto modo direcciona las propuestas de los docentes, ligadas a un ejercicio ético de la profesión; pero ese valor se reduce a un concepto empobrecido si solo exige al alumnado prestar atención en clase y cuidar la netbook (o cualquier otro material considerado valioso). Puede haber una visión igualmente empobrecida de la tecnología: esta agrega otras dificultades al quehacer cotidiano, y de ningún modo redunda en un ámbito para formar competencias de pensamiento crítico. Tampoco se ponen en cuestión otras diferencias de base, como de edad o género:

Me parece que el elemento funciona de diferentes formas, en los chiquitos es para calmarlos $o$ apaciguarlos, en Superior debe estar enmarcado en un proyecto, pero el pibe se da cuenta de que no hay un trabajo pero entonces se dispersa, se queda colgado (...) no te la presto $\mathrm{o}$ presentame un proyecto que esté armado, pasa por la ética del docente porque si vos le estás enseñando al pibe que se haga responsable... (Vice-Directora EEST $\mathrm{N}^{\circ} 1$ ).

... las chicas son más responsables en cuanto al material de trabajo que se les entrega, porque es un material de trabajo divino la netbook, usándola como corresponda. Te puedo asegurar que la chica encargada se la pasa formateando las máquinas. Y... son chiquitas. No tienen grandes memorias y las llenan de cosas, de juegos. Que se las lleven a la casa, ¿qué implica? Implica que necesitan hacerse responsables... (EMATP- EEST $\mathrm{N}^{\circ}$ 2).

Si nos detenemos suscitamente en estas variables, observamos que en la segunda etapa de análisis las referencias al género son más bien marginales, pero los problemas asociados a las fallas técnicas de los equipos renuevan las valoraciones negativas en torno la cuestión de la edad. A consecuencia de la distribución de las netbooks en los primeros años escolares, se renuevan las diversas representaciones docentes acerca de estos sujetos de aprendizaje. Se los caracteriza como "chiquitos", inmaduros, demasiados jóvenes, lo que explicaría la falta de consciencia en la manipulación de la computadora, la irresponsabilidad que provoca el maltrato. Este tipo de percepciones oscila entre la comprensión paternalista hasta cierta descalificación moralizante, y ambos casos tienden a poner el problema en el "otro", opacando la posibilidad de una práctica docente reflexiva en los procesos de inclusión de TIC.

Pero la opinión más extendida es la que se basa en la distinción a la que ya hemos hecho referencia: entre los más jóvenes, alumnos de la ESB, y los cursantes del Ciclo Superior. Lo que está mediando aquí no es propiamente la edad, sino la formación técnica desde las orientaciones, donde intervienen grupos acotados, participativos, más comprometidos con la formación técnica y de mejor desempeño escolar. En la ESB, en cambio, las netbooks vendrán a agudizar las dificultades en la enseñanza-aprendizaje, especialmente cuando motivan situaciones de conflicto o de dispersión en clase. Una de las consecuencias es que todo parece nuevamente a reducirse a la lógica de la adaptación; la dificultad para desarrollar proyectos de autonomía radica en que la escuela tiende a replicar necesariamente la reproducción del status quo, y en no poder reconocerla, en cambio, como un espacio dinámico de disputas de sentidos: "Yo pienso que es 
falta de adaptación al nivel, al no tener a la maestra todo el día tan presente, no están preparados para trabajar de manera más autónoma porque si bien uno trata de estarles más encima, no es lo mismo...” (Prácticas del Lenguaje, 3er. Año).

Otra posición reclama aproximaciones más cuestionadoras, cuando lo que se vislumbra es un marco de las contradicciones entre los propósitos de calidad educativa y la matriz de determinaciones ideológicas en que se inscriben. La presencia de la netbook está anclada en la mirada negativa sobre la industria cultural: "Y lo peor es que uno ve cuál ha sido el rendimiento del chico cuando no ha recibido la computadora y cuál es cuando la recibe. Es como decían los griegos: engolosinar al pueblo" (Filosofía, O. Informática). Las construcciones retóricoexpresivas reavivan la idea de que, si la computadora se presenta como "regalo", tiende a neutralizar las lógicas de poder que estructuran sus usos y vuelve impensable el proyecto de formar personalidades críticas, orientadas a la autodeterminación. Así describe la docente su propuesta, reticente a la propiedad personal como condición del modelo 1 a 1: "Nos venimos planteando tener las netbooks y darlas como un estímulo, te la ganaste, te la merecés, no, no, está mal esa concepción, no es para todos, jes para el que sabe! No se pudo hacer. Nooo... me dijo Marce (la Directora de entonces), ¿vos querés que me coman el hígado?”

La expresión "engolosinar al pueblo" evoca un discurso tautológico, la eterna repetición de lo mismo: si la tecnología encarna la promesa del aprendizaje, el no-aprendizaje sirve de justificación a la tecnología. Estos razonamientos, aunque excepcionales, recrean el postulado frankfurtiano: la racionalidad técnica es la racionalidad del dominio mismo (Adorno y Horkheimer, 1987). Implican entonces debatir el carácter tecnológico de la comunicación, aquel que emerge como superior o el único posible en tanto pretende sobredeterminar la sociedad y sujetar a su propio criterio eficientista al conjunto de sus actividades. Empero, la educación imprime otras lógicas a estos procesos de reproducción. Es el docente quien puede definir ciertos intersticios desde sus propias actuaciones, abrir espacios culturales potencialmente disruptivos para educar al estudiante en un marco de autonomía, donde ambos se vuelvan capaces de captar críticamente los sentidos del mundo complejo que habitan.

\section{Hacia la autonomización de los aprendizajes}

Desde el punto de vista de los estudiantes, ¿cuáles son las condiciones de posibilidad para la promoción de márgenes crecientes de autonomía? En términos generales, tienen menores oportunidades para elucidar el entramado de condiciones político-culturales que vertebran la inclusión digital, más allá de las experiencias inmediatas de trabajo en el aula. De hecho, hasta 
muy avanzado el proceso de implementación, desconocen los propósitos de Conectar Igualdad o bien los reducen a la distribución de los equipos, cuando la institución no logra comunicar eficazmente esa información que se revela necesaria para generar predisposiciones y fomentar los consensos para su adecuación a las realidades escolares.

Los estudiantes expresan agudas contradicciones entre los usos y las representaciones. Inicialmente, se manifiestan alegres y entusiastas en los usos de las nuevas netbooks, las utilizan a todas horas y esas interacciones se vuelven cada vez más fluidas; al mismo tiempo, esos usos se caracterizan negativamente como "un vicio" cuando se homologan con el entretenimiento, los videojuegos y las redes sociales, obstáculos para lograr el "verdadero" aprendizaje. Estas relaciones se caracterizan como dependencia tecnológica. En el terreno teórico, esta deriva en que, paradójicamente, hacer propio el objeto resulta expresión acabada de la alienación del sujeto, lo que Castoriadis (2003) define como una heteronomía instituida, pesadamente condicionada por las instituciones sociales. En este sentido, la tecnología se constituye en signo de una experiencia placentera, pero también en la antítesis de la verdadera autonomía.

Lo que vuelve consistentes estas percepciones radica en el elevado concepto que se tiene de los contenidos escolares. Como vimos, la apropiación digital está articulada simbólicamente en torno a la dimensión del conocimiento, algo que se constata a lo largo de todo el período y para todos los actores. En los discursos juveniles, la autonomía refuerza las contradicciones asociadas a las TIC, de acuerdo a un doble plano: a- la independencia de los padres y docentes, a partir de experiencias de sociabilidad, intereses y modos de expresión específicamente adolescentes (o que reconocen como tales); b- los márgenes crecientes de auto-control sobre los procesos de aprendizaje, aquellos considerados pertinentes y significativos para su vida y que demandan la centralidad de la mediación pedagógica. Estos conceptos están, sin embargo, ubicados en distintos niveles de jerarquías: los estudiantes pueden mostrarse reacios a la autoridad docente, pero privilegian las regulaciones que creen necesarias para una progresiva autonomización.

Esta concepción está muy arraigada entre las chicas, que en general se conciben a sí mismas como "más estudiosas y responsables" que los varones. Aunque no es determinante, la variable del género está mediando la relación simbólica con las TIC en la escuela técnica, donde las mujeres constituyen aún una minoría: "Y ellos... hay uno, que le decís: cerrá la computadora, y parece que le decís: abrila. Hay algunos que no hacen caso, que les dicen: cerrá la computadora, y se las ponen en los pies y siguen jugando o mirando el Facebook" (EEST N 1, 6to. Año, O. Química). El problema de la autonomía no está exento de las aristas ligadas a la afectividad. Para esta joven, supone afirmarse en una subjetividad femenina que entronca con las concepciones sobre el "deber ser" de los comportamientos en el aula, contrarios a la dependencia digital, como 
con las actitudes "maternales" hacia sus compañeros varones, orientadas a que ellos "no se lleven ninguna materia" en situaciones de bajo desempeño escolar. "Yo creo que las computadoras son un problema, porque perjudica a muchos chicos. Yo me sentaba con un varón el año pasado y a mí me hacía enojar. Él estaba todo el día en el Facebook y lo quería ayudar..."

En conjunto, los jóvenes resemantizan a la escuela como un poderoso ámbito socializador donde se construyen saberes, deseos, proyectos personales y colectivos, que atribuyen sentido a sus propias trayectorias formativas; al mismo tiempo, intervienen otras lógicas de aprendizaje que devienen instituyentes de realidades escolares cada vez más heterogéneas. Entre estudiantes avanzados de la EEST $\mathrm{N}^{\circ} 2$, modelos aspiracionales ligados a la Universidad representan los conocimientos especializados elegidos por vocación y el pasaje a las responsabilidades de la vida adulta, aquello que rechaza de plano las experiencias de entretenimiento con las TIC. No obstante, lo que subyace no es la crítica a la integración pedagógica en sí misma sino a usos didácticos de las computadoras que tienden a volver al aprendizaje reproductivo y vacío de significado. En opinión de esta estudiante:

Porque la idea es agregar a la base que tenemos nosotros, la tecnología, y no por usar la tecnología dejemos de lado cosas importantes. Implementar para estudiar. La mayoría de nosotros va a seguir Ingeniería. Mi hermano egresó el año pasado y trabajaban con la computadora. Y ahora va a la Facultad y los temas que trabajaba en la computadora ahora los tiene que hacer solo. Claro, ¡le das la computadora y los hace re bien! Ese es el temor que tenemos nosotros (5to. Año, O. Electromecánica).

Hacia la segunda etapa del PCI, los discursos pueden referir a situaciones de dependencia, pero la atención se desplaza hacia otras zonas de discusión, como los temores de los docentes de que "esto reemplazará a aquello": que la netbook tiende sustituir los libros, la escritura, los modos tradicionales de enseñar. La convivencia de las distintas tecnologías lleva a esta estudiante de Informática a dudar de esos prejuicios iniciales, reflexionando que es posible explorar articulaciones que impacten positivamente en el ambiente del aula. Asimismo, su relato contradice cierta concepción estrecha y aún vigente de que los adolescentes son incapaces de comprender, cuestionar o valorar de manera significativa los sentidos de la digitalización en la que intervienen:

Hay gente que no le gusta que entre la tecnología en la escuela, no sé, en general, eh... que los chicos dependan mucho de la tecnología, de la computadora y de los celulares y dejen de lado los libros. La computadora es más abierta, utilizable, Internet está ocupando mucho espacio en la vida, en la escuela, en todo. Bueno, habría que ver cómo se pueden usar las netbooks, pero también las fotocopias, la carpeta. Hay que usar todo, ¿no? (4to. Año).

$\mathrm{Si}$, por un lado, los usos predominantemente instrumentales en las actividades didácticas y su correlato, las definiciones casi excluyentes de la netbook como "herramienta", alimentan un proceso persistente de cosificación; por otro, los discursos de los jóvenes conjugan espacios de 
relativa autonomía, desde los cuales intentan encontrar razones a unas transformaciones que los interpelan directamente. Reclaman que la gestión ejerza un rol más activo y que los docentes desarrollen en función de ellos estrategias didácticas de otro orden. Esta posición se dirime directamente en la práctica en el caso de la EEST $N^{\circ} 2$ : es la propia historia institucional, ligada a patrones tradicionales de participación en los centros estudiantiles, la que cristaliza estas tensiones y vuelven a la inclusión digital un tema de temprano interés y de discusión colectiva.

Las interacciones juveniles con las netbooks pueden ser distintas en una y otra escuela, pero normalmente admiten representaciones compartidas que contradicen las miradas simplificadoras de los adultos y que parecen confirmarse con el tiempo: la convicción plena de que la netbook en sí misma no mejora substancialmente el aprendizaje. Emergentes del sentido común pero también de las previas experiencias escolares con las TIC, estas percepciones puede ser el punto de partida para hacer proyecciones hacia el desarrollo de la autonomía, entendida esta como uno de los pilares de la educación crítica y democratizadora. No se trata entonces de "adaptarse" a los cambios tecnológicos, sino de adaptar esos cambios a los propios procesos y necesidades de aprendizaje significativo, y en este ejercicio reflexivo se ponen en cuestión las formas específicas, eminentemente ideológicas, de integración digital en los ámbitos escolares.

\subsubsection{Trayectorias nómades, lugares de Autoafirmación}

Nos preguntamos ahora cuáles son los significados que adquieren los procesos de subjetivación juvenil, donde cobran relevancia los aspectos afectivos, emocionales, cognitivos, desde los cuales los jóvenes reflexionan sobre sus acciones, sus relaciones con otros y con el mundo. Los usos interactivos expresan las oportunidades de una sociedad hiperconectada, expanden los géneros, formatos, lenguajes, transformando las formas de consumir y producir la cultura y dinamizando la tensión histórica entre espacios de ocio y de producción. R. Igarza ha metaforizado acerca del impacto de los dispositivos móviles en su trascendencia temporal: "las nuevas generaciones se apropian de la tecnología de forma tal que no se cumple ninguna proposición que refuerce el poder institucional o los sistemas formales en detrimento de lo informal e individual" (2009: 25). Considera a esas "burbujas de ocio" sin especialización alguna, pero que permiten al sujeto adaptar esos tiempos a su vida cotidiana y hacerlos más personales.

No obstante, nuestro caso pone en evidencia que dichas apropiaciones pueden manifestarse de manera imbricada en esos otros tiempos considerados productivos (los del aprendizaje), de lo que resulta que el ocio no es solamente intersticial: se escurre en las pequeñas pausas, en el recreo, entre una clase y otra, pero también irrumpe en el horario del aula. Para estudiantes 
cuya vida diaria se organiza en función de la doble jornada, incluso el concepto de "tiempo libre" es resignificado. Si la netbook se articula con las previas experiencias digitales, por otro lado, entra en problemática convivencia con las dinámicas escolares tradicionalmente instituidas.

Revisemos brevemente cómo examinan los profesores estos procesos, para luego centrarnos en la perspectiva de los jóvenes. Coinciden ambos grupos en que el exponente emblemático de esas experiencias de tipo lúdico es el Counter Strike, que los estudiantes, particularmente los varones, juegan en red, una práctica que los docentes cuestionan como "adictiva", en tanto posiciones más tolerantes reconocen la esperanza de que en algún momento "se cansen". Lo que se objeta son las consecuencias de la falta de "auto-control" (en el tipo y nivel de uso, en el tiempo que le dedican) porque resiente la autoridad docente en el horario de clase. Consideremos aquí dos posiciones. La primera adquiere continuidades a lo largo de todo el período: la entrevista a esta joven profesora de la EEST $\mathrm{N}^{\circ}$ 1, egresada de la misma escuela, relativiza el efecto supuestamente determinante de la edad del docente en las disposiciones favorables al uso:

Si quieren conectarse un ratito o jugar si terminan antes, a mi no me molesta, pero a veces se abusan por ahí por falta de límites, porque saben que no se les pueden sacar la compu... "es mía y no me la podés sacar" Yo creo que se debería poder sacar la computadora, llevar a preceptoría, ellos entienden que no se puede... Eso porque no se les aclaró al principio... (Montaje de Proyectos Electrónicos, O. Electrónica).

Otro aspecto de estas negociaciones constituye una excepción, pero no por eso menos significativa: la computadora es de "ellos" pero, paradójicamente, "la prestan", lo que entraña la manipulación irresponsable a la que se atribuye el deterioro de los equipos. A contramano de los beneficios esperados de la posesión personal y de los efectos multiplicadores a las familias, “prestar" la netbook no es para esta profesora sinónimo de apropiación digital, sino del maltrato a un bien preciado, definido antes por su costo económico que por su utilidad didáctica. Este aspecto constituye un obstáculo muy concreto incluso en posiciones más favorables a la inclusión. En ambos casos, se manifiesta una dificultad objetiva para interpretar estas prácticas juveniles, como para capitalizarlas en propuestas educativas relevantes y novedosas.

Una posición alternativa es más evidente en la segunda etapa. Convoca el esfuerzo de comprender las tecnologías en su carácter de lenguajes, en tanto recupera los intereses adolescentes y explora creativamente combinaciones posibles entre soportes, narrativas y códigos en entornos interactivos. Estas propuestas son aún marginales pero reveladoras de cómo es posible asumir, de manera crítica pero proactiva, actividades donde las tecnologías emergen como potentes mediadoras del aprendizaje. El proyecto de Historia en la EEST $\mathrm{N}^{\circ} 1$ encarna las potencialidades de la producción de contenidos que además permiten fortalecer y validar los vínculos entre 
espacios que estructuran las identidades adolescentes, en su doble dimensión, racional y afectiva. Y que permiten contrarrestar los efectos de la sujeción a los mandatos hegemónicos del mercado, a partir de la interactividad, la realidad escolar, el barrio, la memoria familiar:

Como no hay respuestas inmediatas, esta cosa de querer buscar es lo que los engancha. Y me dicen: ¡en mi casa tengo fotos! Y revalorizar la historia familiar en relación a la institución (...) Y después queda decidir si esto va aquedar como una exposición, como un blog, armar una plataforma virtual de algún tipo o un Prezi, para poderlo presentar.

Por su parte, los jóvenes identifican experiencias tecno-culturales que remiten a formas singulares de autoafirmación. A partir de ellas configuran un fundamental componente a través del cual se "enredan", dan trámite a su consumo simbólico, construyen sus identidades, amplifican sus relaciones y establecen interacciones a distancia (Quiroz, 2009). A lo largo de todo el período analizado, los testimonios refieren a intereses asociados a las redes sociales y los videojuegos, pero también a la moda, la música, el deporte, las búsquedas de información sobre cine, programas de televisión u otros temas que los convocan. Estas actuaciones generan imágenes extremadamente “vivas", basadas en la personalización, la seducción del consumo, el compromiso afectivo, en entornos diversificados de convergencia digital.

Sin embargo, para los estudiantes estos modos de "pasar el tiempo" se vuelven irreconciliables de los modos de "perder el tiempo". Una mayoría reconoce que los videojuegos $\mathrm{y}$ las redes sociales vuelven dependientes a las personas y se revelan invasivos de sus acciones, lo que contrasta con el uso reflexivo, el auto-control y para propósitos educativos. La misma práctica puede significar de modo muy distinto según se realice en el tiempo libre o en el tiempo escolar, sobre todo cuando la dimensión temporal juega un papel estructurante del funcionamiento institucional. En la primera etapa, la EEST $N^{\circ} 1$ presenta severas dificultades de comunicación interna, un escenario que los alumnos comprenden acabadamente, de manera que cierto grado de autocrítica se torna consistente con un reclamo paralelo de regulaciones más formales. Ejemplo de ello son las demandas de que se "bloquee" el acceso a Facebook, bajo el entendido de que resienten el desempeño escolar, generan indisciplina y problemas vinculares:

Y, sí, la expectativa era: cuándo nos entregan las netbooks. Y más nosotros, que nos habíamos mandado una cagada grande. Prendimos fuego un banco de plástico, fui a buscar el matafuegos... No nos echaron de... De ese grupo, repitieron varios, quedamos siete (5to. Año, O. Electrónica).

Uff, sí, el año pasado jugábamos entre todos, salones contra salones, a veces apostábamos algo, todo el día. Y es porque es el tiempo... cuando te dan la máquina, son los primeros meses: la máquina, la máquina, la máquina, pero después se te pasa... (4to. Año, O. Electrónica).

Una vez superada la etapa inicial, los alumnos comienzan a producir otras significaciones acerca de las posibilidades de la integración digital. Para empezar, la presencia de las tecnologías 
en la escuela no les es extraña. La sensación extendida acerca de la "irrupción” escapa al hecho de que los establecimientos comprenden una larga trayectoria de equipamientos informáticos y que los estudiantes están familiarizados con ellos. Pero además intervienen los contextos sociales diferenciados: las interacciones que los grupos de la EEST $\mathrm{N}^{\circ} 1$ producen con sus netbooks suelen ser más personales, íntimas y afectivas. Estas experiencias contradicen en varios aspectos los discursos de los adultos: por lo general, no prestan sus netbooks a las familias (incluso cuando se trata de la única), el consumo se vuelve individual y a la vez dinamizador de distintas formas de socialización. El concepto de "hacer propio" el objeto pone en tensión los lugares de la afectividad, sin que este escenario "fellinesco" (como lo calificaba el nuevo Director) permita aseverar una determinación absoluta con respecto al nivel socio-económico.

Hay que reconocer que en el caso de la EEST $N^{\circ}$ 2, las características sociales están mediando experiencias donde la netbook no recibe una valoración tan positiva ni un uso tan intensivo, una situación en la que podemos reconocer dos aspectos íntimamente vinculados. Por un lado, los ligados a la posesión personal, ya que la mayoría de los chicos cuentan a temprana edad con computadora propia y teléfono celular, y esa posición involucra mayor distanciamiento respecto de la netbook. Y por otro, las diversas formas de experimentar cotidianamente la escuela, organizada en base a modelos conservadores pero sujetos a constantes procesos de negociación.

Yo siempre usé más la mía que la de la escuela porque es como que tenés algo que anda bien, dentro de todo, pero tenés algo que anda mejor. Una cosa es una netbook y otra cosa es la notebook (...) Y lo que hago es navegar en las redes sociales, en Internet, si tengo que hacer algo de la escuela, hago los trabajos en la computadora, aunque no tenemos mucho tiempo porque estamos acá todo el día. Me gustan sobre todo Twitter, Facebook y Youtube, paso bastante ahí, son mis amigos, jajaja (4to. Año, O. Informática).

Esta estudiante coincide con su compañera, para quien las experiencias con TIC entran en tensa convivencia los usos "abusivos" de la netbook en el aula, los dispositivos que consideran propios o más personales, y las prácticas interactivas donde conjugan modos de divertirse, afirmar su identidad y sociabilizar con sus pares, unos rasgos que se extienden en la segunda etapa:

Los demás chicos usan el celular, para las redes sociales, generalmente no usan la computadora del gobierno. Algunos tienen notebook propia o no usan computadora, no esa computadora. En hora libre, una vez, un grupo siempre lleva las computadoras y se descargan juegos que no ocupan mucho espacio y están todo el día jugando, y las profesoras los retan. Pero los chicos, los varones, juegan Minecraft, el Counter... (2do. Año).

Como vemos, estas reflexiones pueden manifestarse entre estudiantes de la ESB, a pesar de que un común denominador entre estudiantes del Ciclo Superior (y una mayoría del profesorado) refiere a los problemas que representan los usos digitales entre los más jóvenes, a quienes atribuyen falta de madurez o no haber interiorizado las normas que entran en colisión con esos usos. El 
acento está puesto no tanto en las acciones en sí mismas, sino en el lugar y momento "inadecuados" en que se llevan adelante, al tiempo que intersectan con modalidades heterogéneas de apropiación simbólica desde las cuales se hace y se vive el espacio escolar. En suma, las interacciones con TIC se fusionan en unas mediaciones culturales donde los adolescentes logran desarrollar una trama de prácticas reflexivas y modelizantes de sí mismos:

...y ves a los chiquitos sentados con las computadoras, piensan que están para jugar. Se les informa, sí, miren que esto es para hacer actividad. Igualmente no toman... consciencia (...) Pero bueno, nos sentamos en el hall, alguno trae la guitarra y cortamos las 8 horas, y hacemos lo que nos gusta (6to. Año, Electromecánica).

En estos marcos narrativos cobran importancia las experiencias constitutivas de las formas de sujeción y subjetivación donde se conjugan estas interacciones, a su vez mediadas por realidades socio-educativas cada vez más heterogéneas. La complejidad de estas cuestiones se manifiesta, siempre precariamente, en la identidad que articula al sujeto en el drama del mundo y de la vida, definiendo los límites y las posibilidades para el ejercicio de la autonomía. En palabras de da Porta, "no es otra cosa que comunicacional tanto la constricción y obturación de la experiencia operada por el lenguaje, como la posibilidad de autonomía y liberación" (2011b: 34). En las apropiaciones digitales se hibridan trayectorias nómades, recorridos múltiples y dislocados, antes que estables o claramente instituidos. Así, articulan los sentidos casi paradojales de esas subjetividades: del campo virtual a la materialidad de la vida cotidiana, del reconocimiento de los pares a la propia singularidad, de los consumos del mercado a las relaciones siempre cambiantes con la cultura y el poder.

\subsubsection{Principales observaciones}

Retomando algunas consideraciones acerca de la Apropiación Tecnológica:

1- Las TIC registran continuidades materiales con otras tecnologías (los usos dominantes se mantienen), pero imaginariamente separadas, sobre todo en concepciones evolucionistas o tecnocráticas. Una contradicción notable remite al hecho de que si la digitalización representa la modernización, la cultura del libro persiste como paradigma del conocimiento significativo.

2- Los cambios registrados competen a los desplazamientos desde los medios a los entornos tecnológicos. Expresión de ello son las distintas posiciones con respecto a la relación TIC/escritura: las TIC no reemplazarán a la escritura, tenderán a reemplazarla o bien, se logrará un "equilibrio" entre ambas. Con el tiempo, la vigencia de los soportes escritos junto con las 
disposiciones crecientes hacia la inclusión digital, comienzan a integrarse en proyectos áulicos orientados a la enseñanza de contenidos y de habilidades transversales en ambientes interactivos.

3- Las apropiaciones juveniles están ligadas a experiencias previas al modelo 1 a 1 . Las situaciones socio-económicas de ningún modo son determinantes, pero las percepciones sobre el PCI y las prácticas que habilita suelen ser razonablemente distintas en cada grupo. Por ejemplo, son los estudiantes de la EEST $\mathrm{N}^{\circ} 1$ quienes muestran vínculos más cercanos, personales y afectivos con la netbook, a la vez que reclaman usos pedagógicos más eficientes y extendidos.

4- Las posibilidades de elucidar estos cambios están asociadas a las cualidades técnicas sintetizadas en los "40 programas", la computadora como "herramienta" y el mentado adaptacionismo, o su contrario, las resistencias al facilismo que el PCI promovería con los usos áulicos. Con la segunda etapa, se agudizan las críticas a las ambigüedades de una política inclusiva, pero junto con decisiones en pos de la adecuación eficiente del modelo con verdadera intencionalidad educativa, orientada a la movilidad social o al cumplimiento de derechos.

5- El tema de la autonomía está ausente en los discursos, empieza a emerger hacia la segunda etapa y de manera indirecta. Connota las críticas al imperativo hegemónico de la adaptación como a la dependencia tecnológica, convocando, en cambio, valores como la responsabilidad y la adopción de normas orientadas a la autorregulación de las acciones. Superando la tarea meramente reproductiva, la docencia encuentra en estas decisiones intersticios para la verdadera innovación.

6- En los testimonios juveniles, se resignifican estas tensiones entre dependencia y autorregulación, en torno a la alta valoración de los contenidos escolares y de las experiencias con TIC, aunque estas se dirimen- imaginariamente- fuera de la escuela. Allí operan otros niveles de subjetivación, como los tipos de vínculos que establecen las chicas con sus compañeros varones. La distinción tiempo escolar/tiempo de ocio se mantiene como un poderoso organizador simbólico. Pero los modos de autoafirmación juvenil se entretejen con la cotidianeidad escolar, el mundo del consumo, las relaciones con sus pares y con los adultos, en trayectorias cada vez más heterogéneas.

\subsection{A modo de cierre}

Recuperemos aquí las preguntas iniciales de este Capítulo: una vez avanzada la implementación de Conectar Igualdad y cumplidas las condiciones equitativas de acceso físico en los establecimientos educativos, ¿se realiza esa "flexibilidad interpretativa" que se presupone condición necesaria para que los actores se involucren y colaboren activamente en la digitalización emergente de los procesos de enseñanza-aprendizaje? Y en relación a ello, ¿se pone en evidencia 
una "curva de intensidad", no solo de orden cuantitativo, sino hacia niveles cualitativos de uso y apropiación digital crecientemente complejos y diversificados?

Tras analizar cambios y continuidades entre ambas etapas de la implementación del PCI, es posible afirmar que si efectivamente se manifiestan estos procesos, lo hacen de manera incipiente y desde una diversidad de posiciones, a menudo al margen de - o en tensión con- las orientaciones del modelo 1 a 1 y, fundamentalmente, en el terreno de lo simbólico. Implica esto que los modos de apropiación que se juegan en estos procesos, son resultantes del conjunto de saberes, afectos y disposiciones que producen los usuarios, antes que de experiencias concretas, extendidas y más innovadoras de integración tecnológica en la escuela. Lo cual pone el foco en la dificultad de sobreestimar la influencia de las TIC y de subestimar las redes de representaciones que operan en las instituciones y que contextualizan estos esfuerzos de inclusión digital. Estas afirmaciones merecen breve síntesis que más adelante requerirá otras aproximaciones.

Emerge del análisis que el problema del acceso digital no es meramente de orden tecnológico. Es de orden educativo. Es en la escuela donde se negocian los sentidos de esa incorporación, sus posibilidades efectivas con vistas a atenuar los efectos de la brecha digital, innovar en la enseñanza y promover experiencias de aprendizaje significativo. Y es en la escuela donde además se disputan imaginariamente las particularidades de la formación secundaria técnica, y cómo esta debe reconstruir su proyecto histórico aprovechando las oportunidades de una política educativa de este tipo. No todas las significaciones que se generan son producto de relaciones sociales dominantes ni operan en la reproducción del status quo. Es posible reconocer la formación de un conjunto de significaciones que provienen de lugares distintos o potencialmente transformadores, desde los cuales se transitan cotidianamente los procesos de inclusión digital y se busca volver inteligible el clima generalizado de incertidumbre en el que estos intervienen.

Los imaginarios tecnológicos constituyen el espacio naturalizante donde las netbooks son valoradas por sus beneficios operativos, pero aun las posiciones más favorables perciben un contraste concreto con lógicas tradicionales de funcionamiento institucional y áulico. Ambas ideas se mantienen a lo largo de todo el período, poniendo a los actores en un mismo marco de comprensión que involucra varios núcleos significantes, algunos contradictorios entre sí y todos ellos articulados en torno a la dimensión temporal que se vuelve constitutiva de la escuela técnica: la "irrupción" de las netbooks, la "improvisación” del proceso de implementación, la "adaptación" a la que está obligada la escuela, los "retrasos" en la capacitación docente, la discriminación de los soportes según sean "nuevos" o "viejos", la diferencia siempre renovada entre tiempo escolar y tiempo extra-escolar (o entre tiempo productivo y tiempo lúdico). Este marco compartido no excluye posiciones diferenciales entre los docentes, cuando una mirada 
reduccionista sobre los usos tecnológicos (saber/no saber) cristaliza un binarismo de base que agudiza y vuelve visibles las relaciones de fuerza que se conjugan en este campo y que desarrollaremos en otras claves: entre formación técnica y formación de área.

A medida que se continúa implementando el PCI, estas concepciones se mantienen, pero comienzan a dialogar con tramas interpretativas más elaboradas. Por una parte, queda claro que educadores y estudiantes no están en iguales posiciones para elucidar estos procesos, no obstante, un rasgo distintivo en esta segunda etapa es que en ambos casos se reconoce un crecimiento exponencial de las disposiciones hacia la integración a la enseñanza. Dado el deterioro generalizado de las netbooks, empiezan a evaluar otros dispositivos, a la par que resignifican las utilidades de los laboratorios de informática. Ahora bien, esto no necesariamente se materializa en experiencias más dinámicas y extendidas. Por una parte, porque los modos de incorporación validados desde la formación técnica refuerzan unos usos predominantemente instrumentales, que presentan continuidades con modelos conservadores de enseñanza. Por otra, porque las propuestas docentes alternativas a dichos modelos constituyen iniciativas individuales, a veces resultantes de la planificación didáctica pero siempre basadas en intereses personales y formativos, más que en la capacitación docente, el trabajo interdisciplinario o las orientaciones de la gestión.

Ciertamente, los distintos actores se afirman en sus experiencias previas para movilizarse hacia formas personales de apropiación. Asimismo, se comprometen en la búsqueda de consensos colectivos y ese compromiso resulta particularmente significativo por cuanto no reconocen espacios más formales para llevarlos a cabo. Puede hablarse de una progresiva normalización; sin embargo, lo que se vuelve normal para las personas (la presencia de la netbook), los grados cada vez mayores de aceptación o los acuerdos tácitos que definen los tipos de integración pedagógica y que adquieren valor instituyente, prácticamente no encuentran sustento en normas claras a nivel institucional. De manera que estas propuestas incipientes resultan alentadoras, pero adolecen de marcos organizativos globales que logren capitalizarlas a mediano y largo plazo, involucrando cambios substantivos en la enseñanza y en función de las situaciones socioculturales que atraviesa cada escuela.

Una verdadera integración pedagógica requiere convocar a los estudiantes en la diversidad de sus experiencias con las TIC, los saberes, sensibilidades y modos de subjetivación que de ellas resultan y que abren novedosas relaciones con el conocimiento. Pero en esas construcciones cognitivas también convergen los mandatos escolares, que son constantemente resignificados y dotan de sentido a los modos de transitar cotidianamente la institución. Contradice todo esto la utopía aún dominante acerca de que el aprendizaje en la era de Internet puede prescindir de la mediación pedagógica: un punto compartido entre los estudiantes es la centralidad de la tarea 
docente que reclaman. Entienden que el profesor "guía" ocupa un rol fundamental para ayudarlos a discriminar, interpretar y utilizar la sobreabundancia de información disponible, y que este propósito requiere de modalidades de intervención más creativas que no se reducen a implementar una nueva herramienta. Hemos asumido que estos discursos en su carácter problematizador, revelan un punto de partida para propiciar trayectos de creciente autonomía, individual y colectiva.

Concluyendo, asumimos que es necesario trascender la concepción y uso de las netbooks como recursos didácticos, para además incluirlas en escenarios cada vez más complejos de apropiación digital. Esto es, en tanto vitales componentes de entornos tecno-educativos, aprovechando las posibilidades de la interactividad y en relaciones dinámicas con otras tecnologías culturales. La pregunta que deriva de este supuesto remite a las nuevas capacidades a formar en el sujeto de aprendizaje que habrá de constituir el proyecto de la educación. Conceptualizamos un actor que es capaz de utilizar crítica y responsablemente a las tecnologías interactivas, adecuándolas a sus propósitos personales de aprendizaje y en una diversidad de situaciones comunicativas. Y que a partir de tales experiencias emprende procesos de apropiación con niveles crecientes de autonomía, que lo habilitan a comprometerse en múltiples modos de producir conocimientos, expresar afectos y posicionamientos identitarios, establecer relaciones con sus pares y trabajar con ellos de manera colaborativa y, sobre todo, desarrollar capacidades de agenciamiento ciudadano que lo animan a cuestionar estos contextos convergentes y eventualmente, contribuir a su transformación. 


\section{CAPÍTULO 4: CRUCES Y TENSIONES EN LAS MEDIACIONES TECNOLÓGICAS}

Esta tesis recibe el título de "mediaciones tecnológicas". De acuerdo a la Teoría Fundamentada, pretende contribuir a las precisiones teórico-metodológicas del concepto, basado en la noción seminal de los estudios latinoamericanos. En principio, expresa las matrices en las cuales los sujetos materializan sus prácticas, producen, entrecruzan y desplazan las significaciones sobre las TIC, reconstruyendo de este modo la totalidad del campo cultural. De ahí que, en continuidad con el análisis de las formas de acceso, uso y apropiación digitales, las tramas donde tales actuaciones se inscriben merecen una mirada detenida en este Capítulo. Es nuestro objetivo analizar la Dimensión de las Mediaciones Tecnológicas, indagando regularidades y cambios durante la implementación del Programa Conectar Igualdad. Se trata de profundizar en otras claves los niveles de intensidad, moderados pero significativos, que emprenden los actores hacia experiencias interactivas crecientemente hábiles y fluidas, orientadas al conocimiento.

El estudio de caso invita a complejizar la investigación en función de nuevos interrogantes, a saber: ¿qué características adoptan los modos de integración escolar de las TIC, en el marco de estas mediaciones tecnológicas?, ¿en qué consisten las condiciones, percibidas y esperadas, de plena institucionalización del PCI? El recorrido se organiza a partir de la propuesta de categorías. Primeramente, se dan precisiones conceptuales acerca de las Mediaciones Tecnológicas y sus distintas Subdimensiones, Cognitivas, Institucionales, Situacionales y Lingüístico-Comunicativas.

El énfasis sobre las Mediaciones Institucionales pretende cubrir un área de vacancia relativa. Componen probablemente el aspecto menos explorado, a pesar de que las instituciones en sus más diversas realidades estructural-simbólicas, imprimen sus propias condiciones de posibilidad a la inclusión digital. Siendo este un proyecto colectivo, el orden institucional cobra autonomía dentro de las mediaciones y, al mismo tiempo, las articula. En el caso de la educación secundaria técnica, se juegan en las escuelas particulares dialécticas instituido/instituyente donde se dirimen los esfuerzos por normalizar una política educativa en tiempos de modernidad líquida, de transiciones culturales cada vez más fluidas e imprevisibles. Y renuevan el interés en la configuración de las identidades sociales estructuralmente mediadas por TIC: la escuela todavía constituye un fundamental enclave identitario, en complejas negociaciones con otros.

A continuación de todo el trabajo interpretativo, identificamos de manera esquemática sus resultados más salientes. En el cierre se presenta la síntesis general del Capítulo, a los fines de avanzar en adelante en la tematización de las competencias tecnológicas que estos contextos educativos requieren y que se tornan premisa necesaria para la formación de ciudadanías críticas. 


\subsection{Mediaciones Tecnológicas y Mediaciones Múltiples}

Las mediaciones configuran hoy un vasto campo problemático. Aunque registra una extensa trayectoria, es a partir de Martín Barbero que se han hecho significativos esfuerzos por sistematizarlas. En sus términos, las mediaciones tecnológicas conciernen a las matrices culturales que definen las múltiples experiencias de apropiación material-simbólica, que interpelan a los sujetos "íntima y estructuralmente mediados por sus interacciones desde y con la tecnología" (2008: 222). Allí se materializa ese desplazamiento de las tecnologías en sí mismas a sus modos de acceso, de apropiación y de uso; de su incidencia en abstracto a los procesos de imposición y dependencia, de dominación pero también de negociación, resistencia y resemantización.

El término ha sido reformulado como hipermediaciones por Carlos Scolari (2008) a partir de sus exploraciones a la Media Ecology. Las define como la trama de procesos de intercambio, producción y consumo simbólico que involucra gran cantidad de sujetos, medios y lenguajes tecnológicamente interconectados de manera reticular. En estas particulares interfaces se realizan, entre otros aspectos, la convergencia de los dispositivos en un único entorno, las mutaciones de las percepciones de tiempo y espacio, las nuevas modalidades interpretativas y las posibilidades para producir e intercambiar contenidos en la web, en una plataforma de difusión cada vez más compleja y sofisticada. ${ }^{22}$

A partir de sus estudios de recepción televisiva, Guillermo Orozco Gómez $(2006,2012)$ ha destacado que los usuarios interpelan sustancialmente a la convergencia digital desafiando las lógicas del mercado, produciendo cambios en la circulación y reproducción de la información. Redefine a las mediaciones como "instancias estructurantes de la interacción de los miembros de la audiencia, que configuran particularmente la negociación que realizan con los mensajes e influyen en los resultados del proceso" (1996: 74). En sus esfuerzos por operacionalizar las reflexiones epistemológicas del pasaje de los medios a las mediaciones (Saintout y Ferrante, 2006), el investigador mexicano formula una tipología que evoca las clásicas mediaciones televisivas, en el marco de una noción más amplia de mediaciones múltiples (1993): ${ }^{23}$

22 Como Scolari trata en extenso en su libro, lo hiper apela a la abundancia, el incremento exponencial prácticamente de todo: información, opciones de consumo, formas de intercambiar mensajes, en base a una configuración mucho más activa del usuario. Además de las objeciones ya planteadas a la metáfora del ecosistema, entendemos que las diversas lógicas y temporalidades de los entornos tecnológicos requieren de miradas más atentas, sin que se pueda asumir a priori que puedan producir transformaciones sustantivas en la producción de conocimiento.

${ }^{23}$ Conviene aclarar que Orozco Gómez es especialmente crítico de los EC, la "pesada tradición culturalista" hegemónica en el campo. No obstante, sus nociones no contradicen, sino por el contrario, complejizan y desarrollan 
-Mediaciones individuales: emergen del individuo como sujeto cognitivo y emotivo, que desarrolla estrategias televisivas individuales, para luego concretar también "contratos de videncia" conformando comunidades interpretativas con otros.

-Mediaciones situacionales: expresan el contexto, el espacio, los modos, en los que se inscribe el receptor. Constatan que los hábitos, valores, modelos familiares, pueden incidir de manera decisiva en esas interacciones.

-Mediaciones institucionales: los vínculos de los receptores con las instituciones sociales, como la familia, la escuela, el barrio, el trabajo, los medios, definen valores y normas institucionales que concurren también en la definición de pautas de apropiación.

-Mediaciones video-tecnológicas: relacionadas con los mecanismos, formas de codificación, gramáticas y lenguajes específicos. Definen al género como una de las estrategias culturales que favorecen la inscripción de la televisión en el universo de la recepción.

-Mediaciones de referencia: determinan intereses, hábitos de consumo, preferencias de horario y modalidades de lectura, tales como género, edad, clase social o lugar de residencia.

Ahora bien, se ha objetado que el modelo de Orozco tiende a segmentar a las audiencias en mediaciones que se asemejan a la idea tradicional de variable sociológica, al tiempo que al centrarse en situaciones inmediatas de consumo (generalmente, microcosmos familiares), dejan de lado los condicionamientos generales de producción de sentido, como nos advierte Sandoval (2013). Ciertamente, las mediaciones así definidas pueden perder de vista las diversas determinaciones de las identidades, espacios y temporalidades a partir de las cuales se construyen y reconstruyen los sentidos propuestos por los medios masivos. Este sesgo es consistente con sus derivaciones de la etnografía de audiencias, si bien en los últimos años los Estudios Culturales vienen insistiendo en la necesidad de inscribir la comprensión de los contextos situacionales en entramados socio-históricos más amplios (Morley, 2008).

Así y todo, las mediciones múltiples tienen notable validez para abordar las mediaciones tecnológicas en el campo educativo. Por caso, expresan intrincadas vinculaciones entre nuevos y viejos medios; también ejercen determinaciones importantes sobre cómo tales medios son percibidos, adoptados y utilizados por las personas, y cómo estas incurren desde allí en distintas configuraciones identitarias. En su propuesta de una Tecnología Educativa, Fainholc (2004) articula una perspectiva hermenéutica, las teorías constructivistas y los estudios de comunicación. El docente se constituye en agente mediador en tanto facilita la negociación entre el sujeto y el mundo, tiende a desarrollar en el otro funciones psicológicas superiores, lo hace conscientemente

la perspectiva de Martín Barbero, a la vez que su modelo metodológico apunta a subsanar un problema objetivo y de larga data: la proclividad por el ensayismo, en desmedro de las investigaciones de corte empírico. 
y con intencionalidad didáctica. De allí que en las "mediaciones pedagógicas" confluyen dimensiones culturales, comunicacionales, semiológicas y tecnológicas, todas ellas representadas por las acciones que se dan en el hecho educativo para facilitar la apropiación de saberes, donde adquieren carácter relacional, interactivo e históricamente situado.

En conclusión, consideraremos cuatro grandes mediaciones, en estos términos: Cognitivas, Institucionales, Situacionales y Lingüístico-Comunicativas. Porque las mediaciones tecnológicas no remiten a unos artefactos ni a saberes estrictamente instrumentales, sino a los nuevos modos de percepción y lenguaje, narrativas y sensibilidades que ponen en juego las tecnologías interactivas en esas particulares situaciones de uso. Este aspecto -ligado a la noción de hipermediaciones-, debe articularse en una categoría aún más general y en clave sociohistórica, que comprenda las matrices culturales en las que se materializan los modos de apropiación y uso tecnológicos, y que revelan estrategias específicas de aprendizaje, participación social y adscripción identitaria desde las cuales se negocian y reconstruyen los sentidos hegemónicos de la Sociedad del Conocimiento.

\subsubsection{Mediaciones Cognitivas en marcos de intervención}

Áreas indagadas como la autopercepción de los saberes previos y esquemas mentales implicados, las ventajas o desventajas atribuidas al uso digital y la cuestión escuela técnica/escuela media en sus aspectos formativos, nos permiten afirmar que las Mediaciones Cognitivas no son estrictamente individuales, como parece entender Orozco Gómez. Resultan de trayectorias compartidas, de lugares diferenciados y de singulares negociaciones con modelos heredados, todo lo cual incide en las formas de intervención didáctica. Nuestro caso comprende estructuras binarias que le son distintivas y que sirven de organizadores simbólicos de las adecuaciones del PCI. Se sostienen a lo largo de todo el proceso las caracterizaciones de los campos de formación inicial del profesorado, sea técnica o docente, cuyo correlato necesario es la distinción entre asignaturas: específicas (técnicas, talleres) y de área (Ciencias Sociales, Naturales y Exactas). Estos encuadres tenderán a ser complejizados en la segunda etapa, cuando cobra fuerza una tercera diferencia igualmente taxativa y que pone el acento en los saberes desarrollados o a desarrollar en los alumnos: Ciclo Básico y Ciclo Superior (formación general y formación técnica).

Tras las primeras distribuciones de los equipos, las preocupaciones inmediatas conciernen al conjunto de saberes profesionales: la formación inicial, discriminada según sea técnica o docente, 
y solo secundariamente, la capacitación docente. ${ }^{24}$ Los profesores técnicos tienden a subestimar la importancia de la capacitación de tipo pedagógico, y a sobrevalorar, por contraste, los saberes instrumentales. En la cita de este profesor de la EEST $\mathrm{N}^{\circ} 2$, los términos metaforizan un marco identitario que parece justificar una situación de privilegio, por oposición a los docentes de área:

Por ejemplo, yo el año pasado hice una capacitación en Ingeniería y estaba, bueno, como más en mi salsa, en mi ambiente, hablás el mismo idioma... En cambio, los cursos de capacitación docente son más... eh... los que vienen de las áreas sociales, pedagógicas, filosóficas, es como que no hablamos el mismo idioma. Pero ¡ojo! A nosotros los chicos de la escuela técnica nos piden más la parte técnica... (Diseño y Procesamiento Mecánico, $\mathrm{O}$. Electromecánica).

En esta primera etapa, son variadas las formas de validar la formación de base. Los saberes docentes están llamados a propiciar en el alumno no solo conocimientos en informática, sino unos modos de consciencia respecto de los beneficios en el aprendizaje que las tecnologías traen consigo. Sin embargo, terminan reforzando binarismos que se retroalimentan entre sí. Conforme a la diferencia escuela media/escuela técnica, el profesor antes citado caracteriza relaciones eficientes entre Internet, formación técnica y la carrera de Ingeniería en tanto modelo aspiracional. La metáfora de los "pichones" es muy elocuente en este sentido:

No sé si es característica de la escuela técnica, yo trabajo en escuela media pero no tengo alumnos a cargo, pero lo que veo es que mayormente la investigación es en Internet (...) estuvimos cuatro o cinco días sin Internet y se pusieron a investigar, pero no con libros sino iban a las casas de los compañeros o en sus mismas casas que tenían Internet. Yo no sé qué ven ustedes... pero nosotros somos como los pichones de Ingeniería y yo en Ingeniería veo cómo los estudiantes trabajan con Internet...

Este orden simbólico está siempre desfasado de las prácticas extra-escolares. Posiciones más cautelosas tampoco comprenden las comunidades interpretativas a los que los jóvenes pertenecen, ni los repertorios, esquemas mentales y guiones que guían sus actuaciones (Orozco, 1996). Sin embargo, asumen que esos saberes pueden ser reorientados a los fines del aprendizaje escolar.

Los chicos no son conscientes de que la netbook, el uso correcto de la netbook, les va a servir en su futuro laboral. Los más chicos tienen una idea equivocada de la computación. Se piensan que la computación es leer un mail, bajar información del Google. Y cuando vienen acá (al laboratorio) y tienen PowerPoint, Word, Excel, se encuentran con que tienen que estudiar (EEST N² 2, EMATP).

En la EEST $N^{\circ} 1$, las capacidades asociadas al uso de Internet revisten especial interés, sobre todo porque la escuela cuenta con condiciones de conectividad. En tanto algunos docentes

${ }^{24}$ Vale aclarar que la formación docente refiere al proceso permanente de adquisición, estructuración y restructuración de conocimientos, en el marco de la formación inicial como la que ofrecen los institutos de formación docente. La capacitación docente involucra, en cambio, los programas que apuntan a desarrollar las habilidades necesarias para desempeñar con eficiencia la docencia, es decir, entre docentes ya formados (Cabello, 2009). 
enuncian que los chicos “ya lo saben”, para otros, las experiencias de navegación pueden ser estimulantes, pero requieren de mayor acompañamiento que las tareas de investigación bibliográfica: "Igual no pueden discernir qué información buscan o dónde la buscan. Tenés que estar atrás a ver dónde las buscan. Qué buscan, qué encuentran y cómo lo usan. Porque no es como el libro que sabés que va a estar bien...” (Físico-Química y Química, O. Electrónica).

Las percepciones favorables de la netbook coexisten con las dudas para encontrarle sentidos más allá del acceso; se convierte en un elemento distractivo, especialmente problemático entre alumnos con dificultades de desempeño. Subyace una doble convicción: que resulta vital trabajar en cambios de hábitos, y que las clases seguirán organizadas en torno a modelos tradicionales mientras el docente pueda ir experimentando cuáles son los impactos concretos de los soportes informáticos: "Dije, bueno, el rendimiento bajó, entonces, vamos a dejar de lado el uso de la netbook. Por lo menos hasta que vea que ellos mismos se den cuenta que cuando trabajamos, presten atención" (Inglés, O. Química, EEST $N^{\circ} 1$ ). Los momentos de esparcimiento dependen del permiso a usar la netbook, que hace más amable la convivencia pero a costa de empobrecer su potencial didáctico: “Como bajó el rendimiento, decidí, a ver qué pasa, volvemos al método antiguo y vemos cómo andan (los chicos están silenciosos, conectados a sus netbooks). Ahora les di un ratito porque como terminamos la clase..."

La distinción entre formación técnica y formación docente se replica en otra, igualmente estructurante: entre educación técnica y media. Lo que jerarquiza a la primera son unos conocimientos específicos, articulados en torno a los valores del pragmatismo y en respuesta a las urgencias pretendidamente objetivas del sistema socio-productivo. La escuela técnica aparece construida discursivamente desde un sinnúmero de conceptos dominantes. En relación a las mediaciones cognitivas destacamos: a- el binomio técnica/tecnología, su carácter omnipresente y dinamizador de las lógicas escolares; b- una planta de docentes con formación predominantemente técnica, muchos de ellos egresados de la misma escuela, c- una modalidad de jornada extendida, marco de interiorización de valores y actitudes; d- el desarrollo capacidades técnicas para el mundo del trabajo o continuar estudios vinculados a las mismas; y e- el perfil del estudiante, sus intereses tradicionalmente asociados a los usos operativos de las TIC. Así lo sintetiza la Jefa del Departamento de Informática de la EEST $N^{\circ} 2$ :

En la escuela técnica muchos docentes ya habian incorporado el uso de la computadora como herramienta pedagógica en los laboratorios. Muchos de los docentes son egresados... No trabajo en muchas escuelas medias como para comparar el impacto. Creo que en general hay de todo, distintas interpretaciones de la ley sobre el uso. A mí me ha pasado en escuelas medias que los chicos no querían usar la computadora, porque no les gustaba... 
Según participantes de grupos focales, la escuela media adolece de posibilidades curriculares, pedagógicas y organizativas, para garantizar una formación que responda a las demandas de una sociedad competitiva. En agudo contraste, los conocimientos técnicoinstrumentales resultan prácticamente incuestionables. Imaginar los estudiantes como profesionales, futuros ingenieros, técnicos eficientes y exitosos, dota de legitimidad al proyecto aspiracional y formativo de la escuela técnica, instituyendo el espacio hegemónico necesario para justificar la inclusión tecnológica. Este discurso adeuda comprensiones más acabadas:

Para mí es más necesario todavía. No por menospreciar a las otras escuelas, pero primero ellos acá están ocho horas, entonces reciben otra educación diferente. Si hablamos de las tecnologías, son indispensables para cualquier tecnicatura, sea Electrónica, sea Informática, porque ellos si van a trabajar de esto o van a seguir Ingeniería o cualquier otra carrera vinculada a esto, se van a tener que seguir capacitando constantemente y la tecnología va a ir de la mano de esa capacitación. Yo no lo veo mal, lo veo bien (psicopedagoga).

Hacia la segunda etapa, la obligatoriedad del $7 \mathrm{mo}$. Año de cursada termina por certificar este sistema de creencias, cuando a la calidad de los conocimientos enseñados se le suma la cantidad de tiempo, la jornada extendida. Las ventajas percibidas articulan coherentemente con las promesas de la digitalización; en este punto, el contraste imaginario con la escuela media se vuelve aún más ostensible. Las mediaciones devienen culturales -y no meramente técnicasporque discurren en esas tramas material-simbólicas donde la implementación de las tecnologías puede renovar los modelos heredados o también, revelar sus contradicciones. Las prescripciones del currículum adquieren solapamientos con el sentido de pertenencia, el componente afectivo y la búsqueda de reconocimiento, que sostienen las vivencias cotidianas de los actores:

Muchos vienen a Técnica por la identidad, yo fui mirado porque tenía la campera verde y roja. Pero, querido, jvos vas a ser técnico! Cálculos intelectuales, abstracciones a temprana edad, el egresado es un profesional técnico con un título de secundario, ique no es poca cosa! (Filosofía, Política y Ciudadanía, O. Informática y Electromecánica).

A pesar de que los profesores técnicos siguen simbólicamente situados en esas áreas, se verifica en esta etapa mayor diversidad de posiciones. Las concepciones favorables suelen ser consistentes con el tecnicismo dominante, ya que la relevancia de las TIC está restringida a las operaciones que habilitan en las clases y a los conocimientos calificados que se presuponen necesarios. Esta comparación habla de un saber experto, indispensable y socialmente reconocido: "Yo no puedo decir que aquel cirujano opera mal porque no sé. Pero es cierto que debió hacerse una buena capacitación (en Informática)" (EEST $N^{\circ}$ 1, Proyecto y Diseño Electrónico, O. Electrónica). Las capacitaciones pueden adquirir escasa importancia para sus destinatarios si no resultan de demandas concretas, sobre todo, frente a los retrasos percibidos: "Sí, los programas están bien pensados, pero tendrían que habernos capacitados a nosotros, yo vengo 
renegando en las jornadas para que nos capaciten en el uso de los programas... (EEST $\mathrm{N}^{\circ} 2$, Seguridad e Higiene, O. Electromecánica). Estas distorsiones vuelven dudoso el impacto del incipiente Programa Nacional de Formación Permanente (PNFP). Volveremos sobre este punto.

Sintetizando, en la "utilidad" de la formación, en la transferencia de los aprendizajes, la educación técnica presenta características no exentas de tensiones. Allí se racionalizan los conocimientos docentes, directamente ligados a la disciplina de base, más o menos capaces de enfrentar los desafíos del PCI. Avanzada la implementación, la convicción de que no basta el dominio técnico convive con el carácter necesario -si bien tardío- de una capacitación continua, integral y situada, que dé cuenta de los requerimientos de cada centro educativo. Este proyecto revela, no obstante, relaciones evasivas con las intervenciones didácticas, a medio camino entre su impacto en el aula y sus determinaciones objetivas en el marco de una política de Estado. Una cuestión que adquiere centralidad cuando el trabajo docente se considera una actividad transformadora, pero tensionada en una suerte de paradoja en la cual, al tiempo que se lo carga de críticas, se espera que realice un aporte crucial para la mejora de la educación (Terigi, 2012).

\section{Implicaciones cognitivas de los usos juveniles}

A pesar de ser los directos destinatarios, los jóvenes no se sienten verdaderamente interpelados por el PCI más que en relación a la distribución de los equipos, en tanto "la netbook" aparece como síntesis discursiva de sus fundamentos, pero también de sus contradicciones. Si ya las tecnologías (celulares, otros dispositivos informáticos) tenían una presencia sostenida y estructurante de su vida social, empiezan a adquirir valoraciones negativas si "distrae" de aquello que merece verdadero esfuerzo: el conocimiento escolar. Como advertimos, los estudiantes suelen utilizar la netbook para divertirse, comunicarse son amigos y familiares, hacer más llevadera una jornada extendida, pero califican a tales experiencias como irreconciliables con las escolares, demandantes de otros niveles de concentración y un compromiso intelectual y creativo más agudo.

A contramano de los supuestos docentes, los chicos comprenden tempranamente que las netbooks comportan usos responsables. Resistir la autoridad, llevarse la materia, no hacer "nada", distraerse, perder o desaprovechar el tiempo, constituyen todos conceptos articuladores de un campo semántico negativo. En estas compañeras de la EEST N 1 (O. Química), el "buen uso" se

superpone con el "buen comportamiento", demostrando dos importantes dispositivos con función de negociación, moralizante o directamente disciplinadora: a- la comunicación entre pares, y blas normas institucionales. La falta de regulaciones conduce al auto-control y al control grupal: 
El profesor le dice: cerrá la compu, cerrá la compu, cerrá la compu. Y si no la cerrás, te jodés vos. No le dice así, pero nos damos cuenta, jaja. Un compañero el año pasado no hacía nada, era una materia que tenías que hacer las cosas en el día, y él no hacía nada. Es por la computadora, pero más por él.

Yo creo que se tendrían que poner firmes para que los chicos no usen las computadoras para conectarse al Facebook. Porque a veces se perjudican ellos, porque no prestan atención, porque no entregan los trabajos y después vienen los trimestres. Deberían bloquear el Facebook. ¿Por qué no se bloqueó? No sé.

Internet constituye un campo de problematizaciones. Los estudiantes no logran objetivar plenamente sus propias competencias, aunque interpretan el valor de la intervención docente para desarrollar estrategias de búsqueda, selección y utilización de los datos. Las posibilidades de la navegación dependen en gran medida de las características curriculares de la materia. Hay cierto consenso de que los talleres demandan un uso intensivo de las computadoras. Pero puede objetarse la inclusión digital si no va acompañada por un saber técnico-disciplinar, como por un saber didáctico. Y que contribuya a superar los riesgos del "facilismo" o de un uso poco provechoso:

Con Matemática al principio (se usaba), pero la computadora reemplaza números y te da resultados. El año pasado tuvimos una profesora que era ingeniera y no tenía la parte de didáctica para enseñarnos. Nos decía un problema, lo hacíamos en la computadora, te daba el resultado y te ahorrabas de hacer todo el procedimiento. ¡No aprendíamos nada!” (EEST $\mathrm{N}^{\circ}$ 2. O. Electromecánica).

En la segunda etapa, otros modos de concientización atribuyen sentidos relativamente distintos a la tensión hacer/no hacer. PowerPoint deja de ser solo un recurso expositivo, en reemplazo de la pizarra, para implicar actividades de producción de conocimientos. Durante la observación de un trabajo grupal, un estudiante describía una presentación audiovisual, bajo el título "Sistemas productivos", que incluía imágenes sobre productos, mapas conceptuales y una diversidad de contenidos investigados en libros e Internet. Un entorno interactivo supone la utilización de representaciones gráficas que favorecen procesos de percepción simbólica, al tiempo que descripciones verbales, en base a habilidades guiadas en la selección, clasificación y procesamiento de la información. En términos de Burbules y Callister (2001), la organización hipertextual de Internet, su aparente fragmentación y atomización, puede derivar en naufragio cognitivo o bien generar contratos de lectura cada vez más comprensivos.

Ahora bien, examinar el propósito educativo de las TIC, entender sus códigos, identificar sus componentes y modos de funcionamiento, utilizarlas a los fines de cada materia, no exime al profesor de un riguroso seguimiento. En el "control" de los usos prevalece el valor de la autoridad docente como así de la netbook como instrumento auxiliar, pero comporta también la idea de un espacio áulico razonablemente ordenado. Tales nociones desafían tanto los modelos verticalistas de enseñanza como el carácter "espontáneo" de los aprendizajes juveniles. Los estudiantes de 
la EEST $\mathrm{N}^{\circ} 2$ suelen mostrarse especialmente demandantes, confirmando posicionamientos personales atravesados por los ordenamientos institucionales con alto grado de estructuración, pero constantemente negociados. De ahí las comparaciones:

Tengo amigos míos que van a UNICEN (escuela secundaria) y con los profesores las usan mucho, tienen una materia que aprenden a editar videos y usan mucho PowerPoint. Y usan justamente mucho este programa que el profesor controla lo que hacen y les manda el material por ahí... (ex presidente del Centro de Estudiantes).

Ante los equipos averiados y los problemas de conectividad, los discursos juveniles privilegian los aspectos cognitivos implicados en el ejercicio docente por sobre la cuestión de acceso. Los tipos y niveles de conocimientos producidos dependerá de las capacidades técnicas, pero a la vez disciplinares y pedagógicas. En un solo caso de la totalidad de estas entrevistas, aparece referenciado el tema de la edad. Sin embargo, esta estudiante reflexiona que lo que incide fundamentalmente es el conjunto de iniciativas, saberes y disposiciones de su docente, antes que las diferencias generacionales; tampoco la formación técnica es un factor determinante: "La profe es joven, tal vez tiene que ver, porque entienden más cómo bajar del AP, entienden más sobre las tecnologías. Eso me lo enseñó una profesora de Ciencias Sociales...” (EEST Nº 2, 2do. Año).

Como ha reflexionado R. Williams (1992), la cultura constituye un proceso poderoso que se halla ligado a continuidades prácticas como las instituciones, que no son meras imposiciones ideológicas sino elementos efectivamente vividos. En estas realidades escolares los sujetos juveniles dan cuenta de sus formas de experimentar, re-significándolas, las relaciones estrechas entre las TIC, el conocimiento y la enseñanza. A medida que avanza la implementación del PCI, para ellos la función docente ya no deviene centralmente en control de los usos digitales, sino en potencia evocadora de saberes profesionales que puedan hacer de la tecnología un capital provechoso, un ambiente interactivo y no solamente una herramienta de aprendizaje.

\subsubsection{Mediaciones Institucionales y el orden de lo imaginario}

Repensar los modos de institucionalización requiere detenernos brevemente en las bases ontológicas de Cornelius Castoriadis. En La institución imaginaria de la sociedad (2003), reflexiona que solo mediante la institución de la sociedad se puede salir del caos de la potencia imprevisible que conlleva la imaginación radical, ese "magma" constante, contingente e imprevisible que es para él la esencia de la creación humana. Ese sustrato psíquico es la materia prima sobre la que se desarrolla el proceso de socialización, el cual viene a poner límites a ese devenir de representaciones pero sin hacerlo nunca de manera definitiva ni completa. Las 
significaciones imaginarias que crea la sociedad y el flujo inmotivado de representaciones que define a la psique, son fenómenos magmáticos por excelencia. ${ }^{25}$

Resulta de ello que el orden de lo histórico-social se presenta como creación de instituciones que son la encarnación de las significaciones imaginarias sociales, aquellas que no reconocen otro origen que la institución misma. En ellas se realiza además la tensión entre las estructuras dadas, lo instituido, y lo que estructura, lo instituyente. Implica asumir que hay una instancia más allá de la sociedad que constituye la posibilidad misma de la creatividad. Una muestra de la contingencia histórica que conjuga cierta estructuración precaria con un movimiento permanente y con un perpetuo exceso que se vuelve disruptivo de lo instituido.

En las revisiones de Cabrera (2006), las tecnologías convocan el conjunto de imágenes, representaciones, afectos y deseos en constante movimiento, una totalidad coherente (con relativo cierre) de creencias, y a la vez una matriz de significados compartidos a partir de la cual la sociedad se auto-representa y se instituye como tal. El imaginario tecno-comunicacional instituye a las tecnologías como portadoras de las utopías y esperanzas en un progreso natural e inevitable. Revela su fundamental dimensión ideológica cuando la Sociedad del Conocimiento, las creencias de la que es portadora, desencadenan fuerzas simbólicas que impulsan a actuar, en un determinado sentido y no en otro, como también nos advierte Mattelart (2002). Una consciencia crítica en torno a estas condiciones ha de poner en cuestión los discursos hegemónicos que justifican a priori las incorporaciones de las TIC, donde se realizan las significaciones sobre la esperada modernización.

Entendidas ambas como instituciones sociales, nos preguntamos cómo intervienen en las escuelas y las tecnologías particulares mediaciones donde convergen modelos institucionales, culturales y pedagógicos. Hay que tener en cuenta que, tal como surge de los documentos oficiales, el PCI comienza a implementarse en las escuelas técnicas bajo el presupuesto de que encuentra en ellas su espacio natural: parecen destinadas a acompañar los procesos de sensibilización hacia una progresiva integración (y luego a extenderlos a otras ramas). El modelo para escuelas técnicas se considera el principal antecedente. Pero las prácticas y representaciones sobre el tema revelan una trama de contradicciones. Una aceptación generalizada, a menudo preñada de determinismo técnico, refuerza el rol imaginario de la tecnología en el proyecto formador. Convive con esa aceptación una sensación casi unánime de desconcierto. La "improvisación” atribuida al PCI

${ }^{25}$ La palabra "magma" designa la capa que subyace a la corteza terrestre, en la base de las erupciones volcánicas, y no se corresponde con el estado sólido ni con el líquido. Metaforiza el flujo de significaciones que son sociales pero, además, imaginarias, no provienen ni de lo "real" ni de lo "racional" ni son reductibles a las representaciones individuales. Sin embargo, el individuo forma para sí una parte de las mismas, un "equivalente efectivo" que se vuelve real en las instituciones. 
difícilmente logre adscribir a marcos de referencia de instituciones que históricamente han reivindicado un alto grado de estructuración.

En todos sus aspectos, las realidades de las instituciones analizadas son radicalmente distintas. Focalizar en estas diferencias nos permite confirmar la relevancia de las Mediaciones Institucionales como categoría analítica y problematizadora. En principio, los directivos comparten la responsabilidad formal de planificar, diseñar y ejecutar los mecanismos para una adecuación integral del PCI. Pero en la práctica, se centran en garantizar la distribución de las netbooks y no tanto en sus implicaciones pedagógicas; el posicionamiento es más bien distante en este sentido. Comparativamente, los equipos de la EEST $N^{\circ} 2$ manifiestan, incluso desde muy diversas posturas, la capacidad de llevar adelante los consensos para afrontar estos cambios. Modelos centralizados (pero no personalistas) de gestión, parecen dar sustento a registros identitarios, constantemente recreados, que se mantendrán estables a lo largo del estudio.

Los nuevos condicionamientos del acceso digital irrumpen en los funcionamientos normativizados, como asimismo en las situaciones espontáneas e informales. La Directora de la EEST $N^{\circ} 2$ abunda en construcciones metafóricas en alusión a situaciones problemáticas que surgen en el quehacer diario, lo que se traduce en la sensación personal de sobrecarga:

Acá es así, pasás de un tema a otro... Y me dicen: cómo hacés, es que lo tenés que hacer, pasás de un tema a otro. Entonces pasás del pan rallado a las netbooks. Mientras ahí la neurona me funcione y me dé la cabeza para trabajar con tantas cosas, yo voy a poder seguir sentada en este sillón, cuando el chip me empiece a fallar y los cables me empiecen a hacer cortocircuito, me voy derechito al gestor para que me haga el trámite jubilatorio...

Las posibilidades de robos constituyen una preocupación inicial, relativa a la “improvisación” que se cuestiona del modelo. Remite a que, por razones burocráticas, las netbooks han permanecido en los establecimientos desde fines del 2010 sin ser distribuidas a los alumnos. "Y cuando yo me saque la última netbook de encima, me saco la historia de: no, me la van a robar ahora, porque cada vez que se disparaba la alarma y me llegaban a mi casa..." Estas situaciones provocan temores, pero solucionables en una cultura institucional razonablemente "ordenada" en el caso de esta escuela, que la vuelven visible y pensable para el conjunto de sus miembros.

A lo largo de nuestro estudio, La EEST $N^{\circ} 1$ sufrirá tres cambios sucesivos de equipos con dispares estilos de gestión. En esta primera etapa, se constatan problemas organizativos y de comunicación interna, los conflictos entre directivos, las dificultades para orientar y consensuar estrategias tendientes a resolver problemas de larga data, como el deterioro edilicio, la indisciplina y el crecimiento sostenido de los niveles de deserción, repitencia y sobreedad. La Directora también consigna una sensación de sobrecarga, pero debido a otras causas. Entre ellas: a- la falta de respuesta del Concejo Escolar ante situaciones de vulnerabilidad social; b- la falta de 
compromiso de la planta docente para ejecutar los Planes de Mejora Institucional (PMI); y c- los maltratos de los estudiantes sobre las instalaciones, el mobiliario y los materiales didácticos. Este razonamiento conduce a justificar la propia inacción en los ámbitos decisorios que son específicos de la autoridad directiva, delegando culpas y responsabilidades en otros:

Entonces estamos en una escuela técnica que vos decís: ¿por qué está tan rota? Tendría que estar en mejores condiciones. Bueno, por ahí no tenemos las cosas, los insumos. Nosotros hemos pedido al Concejo Escolar que manden los insumos, que eso lo pueden hacer los chicos, para instalar una alarma en el taller, ique ha sido desmantelado por los constantes robos! El Concejo Escolar no se hace cargo, yo hice mil notas. ¡Y qué pasa! La Directora se cansa de hacer mil notas y llega un momento que no hace más notas...

Las repeticiones, los usos de modalizadores y la tercera persona, expresan un desplazamiento hacia aquello que se rompe sin que se logre nunca construir (o reconstruir) plenamente: la identidad institucional. El discurso semiotiza un círculo vicioso: si la identidad no propicia condiciones para mejorar la realidad escolar, esta no contribuye, más bien, entorpece el funcionamiento identitario. En este contexto, la inclusión digital no forma parte de las prioridades, de hecho, está prácticamente ausente en las reflexiones de la entrevistada (le parece "bien"). Subyace la idea de que la tecnología constituye algo dado, que se implementará naturalmente y no requiere de mayores intervenciones, otra expresión del imaginario difusionista dominante.

Porque uno dice por qué los chicos la rompen, la rompen porque ya está rota, ¿o si estuviera divina la romperían igual? No sé... o si la ven fea la rompen más... Son un montón cosas que yo no sé realmente cuál es el problema. Que esta escuela no tenga ediliciamente las condiciones que tiene la otra, porque a la otra la cuidan. Chicos que no se compran la remera o lo mínimo que le piden en el taller para trabajar, y van a la Técnica 2 y lo compran. Hay una cuestión de identidad que evidentemente nosotros no lo tenemos resuelto.

La EEST $N^{\circ} 1$ se sostiene en esas matrices imaginarias que la determinan en una posición de desventaja casi inexorable. Con el transcurso del tiempo, las condiciones desfavorables se van modificando; sin embargo, la escuela nominada como "la otra", "la grande", "la Industrial" continuará expresando el paradigma institucional, el modelo que permite cotejar un repertorio de significantes autopercibidos -en el sentido de Norberto Cháves (1994)-, y que constituye el horizonte de expectativas para concretar la esperada recuperación de la institución. Una serie de opuestos canalizan discursivamente un sistema de jerarquías entre ambas escuelas: menor/mayor, chica/grande, esta/aquella, poco/mucho, fea/linda, etc. Estas representaciones no son privativas de la gestión, y alientan cierta cosificación persistente de las TIC en términos de "aparatos".

La que lo pueda llevar adelante es la escuela que tiene mayores recursos para llevar a cabo los Planes de Mejora, y la escuela chica, que quizá tiene mayores necesidades que la escuela grande, la planta docente y la realidad sociocultural, hace que los docentes sean menos y que haya alternancia de los docentes que hace que se comprometan menos para aportar en los 
PMI (...) Entonces esta escuela, que es chica, que tiene pocos recursos, porque hay que estar llenando formularios, una escuela grande, por ahí la ET 2 que tiene recursos...

La EEST $N^{\circ} 2$ ciñe sus expectativas a sus propias condiciones de posibilidad, precisamente aquellas de las que adolece la otra escuela, a saber: a- compromiso e involucramiento del equipo docente; b- capacidad de gestión, voluntad de diálogo pero también liderazgo y direccionalidad central; c- tensión entre la inercia de la burocracia estatal y el cambio hacia un paradigma de gestión centrado en la innovación. En estas situaciones favorables, y en orden de administrar una estructura escolar de gran tamaño - material y simbólico-, los problemas de implementación, por ejemplo, las deficiencias de la conectividad, se vuelven un problema inaceptable. Internet se instituye como condición necesaria para un uso intensivo y eficiente de las netbooks, y las decisiones en torno al PMI deben contribuir principalmente en esa dirección.

Breve mención merecen los Planes de Mejoramiento Institucional a los que hemos referido en el Capítulo anterior. En lo formal, apuntan a realizar diagnósticos, establecer metas y objetivos, disponer de recursos para la puesta en práctica de iniciativas que fortalezcan las capacidades de las escuelas para solucionar las problemáticas que se les plantean. Aquello que los directivos ponen en valor es que el PMI pueda complementar las acciones no previstas por Conectar Igualdad, relativas al piso tecnológico y la conectividad, garantizando así mejores oportunidades de penetración tecnológica. En rigor, las relaciones entre ambas políticas no aparecen en el resto de los entrevistados; tampoco encuentran sustento en la práctica, por lo que tenderán a desdibujarse con el tiempo. También desconocen la reciente creación del Plan Nacional "Argentina Conectada", cuya meta es "proveer de conectividad al $100 \%$ de las escuelas públicas" entre 2011 y 2015. A pesar de su importancia medular, estos propósitos no llegan a cumplirse y en la totalidad de los discursos el tema está completamente ausente. ${ }^{26}$

Hay una posición que, por excepcional, debe ser destacada. La Vice-Directora de la EEST $\mathrm{N}^{\circ} 1$ duda que la ejecución del PCI junto con el PMI faciliten la incorporación pedagógica de las netbooks. Enfrentar estos desafíos implica propiciar la articulación entre áreas; en este aspecto, las mediaciones tecnológicas operan como campo de entrecruzamientos entre los aspectos

${ }^{26}$ El Plan Argentina Conectada no puede ser desarrollado aquí con detenimiento. Baste decir que constituye una ambiciosa iniciativa del Estado orientada a garantizar la equidad en los niveles de distribución de Internet en el país. En 2011, articula con el Programa "Internet en establecimientos educativos". De acuerdo a Conectar Igualdad, en el mismo año solo el $17 \%$ de las escuelas argentinas contaba con conexión a banda ancha. Disponible en: file://C:/Users/user/Documents/argentina\%20conectada.pdf). Sin embargo, el Plan solo llega a implementarse parcialmente y de manera deficiente, y no existe suficiente información oficial al respecto: el único informe de gestión data de octubre de 2012. Un minucioso análisis lo encontramos en el informe Acceso a Internet en Argentina. Lecciones aprendidas del plan Argentina Conectada, Ferrari, Verónica, Centro de Estudios en Libertad de Expresión y Acceso a la Información (CELE) de la Universidad de Palermo. Julio de 2016. Disponible en: http://www.palermo.edu/cele/pdf/investigaciones/Acceso a internet en Argentina.pdf 
institucionales y cognitivos. Según este razonamiento, las dificultades estriban en que la mayoría de los profesores de Ciclo Superior son expertos en sus disciplinas, pero carecen de estrategias o capacidades de transposición didáctica que solo puede aportar la formación docente inicial. La fragmentación entre áreas agrava los problemas de identidad, a menos que se logren los acuerdos básicos acerca de cuál es el proyecto educativo que la articula y qué acciones le son necesarias.

Es complicado. Química funciona como un bloque conceptual, armadito, desde 4to hasta 6to., que tienen un proyector integrador. Y en Electrónica tenés unos grandes agujeros negros, que son profesores que saben muchísimo, ingenieros que tienen capacitación docente, que les cuesta la bajada, la mirada pedagógica les cuesta horrores.

En la perspectiva de los profesores, los modelos de gestión constituyen determinaciones importantes que interaccionan con los modos de transitar la institución. Los discursos comprenden disposiciones favorables hacia el uso de las netbooks (el sentido restringido del PCI) y la sensación de que llegaron "de golpe". Sobre todo en la EEST $N^{\circ}$ 2, lo que puede ser representado como "normal” está estructurado tanto por un marco normativo, como por las características percibidas del paradigma institucional de la educación técnica, que esta institución sintetiza simbólicamente en la consciencia material de sus miembros. Para esta profesora de Geografía:

Depende de la estructura de la escuela. No la estructura edilicia, sino de los parámetros de conducción, para mí acá parece más normal, no sé si normal es la palabra, más natural, pero en otras escuelas, sí es más complicado, porque no están acostumbrados.

Nuevamente, una trama valorativa opera en un doble nivel, el primero deriva de los sólidos contrastes educación técnica/educación media. En el mismo relato: "No sé, por ejemplo, un bachiller común, no por desmerecer la escuela, pero por la modalidad, por la orientación, como que causa más impacto: ¡Uy, llegaron las netbooks!” El segundo nivel se apoya en el repertorio de atributos que sirve de anclaje a la identidad de esta escuela y la jerarquiza frente a otras. Estas imágenes están cargadas de la afectividad que comportan las trayectorias laborales: esta escuela es como "estar en casa", en otras solo "se trabaja". El sentimiento de pertenencia sirve incluso para sobrellevar o resistir posiciones instituidas, lo que pone al docente en un mismo plano (imaginario) de igualdad con otros. Estas reflexiones son especialmente ilustrativas:

El tema es humano, yo acá hace la misma cantidad de años que trabajo que en la Escuela Normal, pero acá hace cinco años que soy preceptora, entonces es como que es mi segunda casa (...) pero allá hay cosas que no querés decir, o no podés... ¡no sé qué hay! Hay como un halo... en la sala de profesores... El tema es así: yo cumplo con mis obligaciones, en los dos lados soy igual, pero acá soy una más, me siento como en mi casa...

Estos docentes se perciben además capaces de entablar vínculos informales y cariñosos con sus alumnos, comprender sus intereses, alentarlos a participar de diversas experiencias, y en esos diálogos ambos actores ponen en juego una subjetividad que dota de inteligibilidad al mundo 
simbólico en el que intervienen. Las numerosas referencias a la escuela "viva", dinámica, fluida, con que se califica a la EEST $\mathrm{N}^{\circ} 2$, la construyen discursivamente como institución social y potencia evocadora de significaciones sociales que hacen imaginables otros modos de creación.

La escuela técnica es muy particular. Los talleres tienen vida propia, vos vas a entrar y los chicos están tomando mate sin ningún problema, porque están trabajando, es su área de trabajo. $\mathrm{Y}$ vas a ver chicos en los pasillos casi continuamente, porque salen a buscar una herramienta, salen a buscar un material que no tienen en el taller, salen buscar el cañón... Esta escuela tiene una vida más transitada que otras escuelas (...) Pero puede haber algo de apropiación, sí, seguramente. Porque los chicos no se quieren ir de la escuela, yo los entiendo, porque yo también tengo puesto el corazón acá. Es una escuela que se ama. Porque son muchas horas que pasan acá (...) Yo prácticamente vivo con ellos, salgo a las 12 y entro a la 1. Entonces la relación ya no es "señora profesora", sino “che, Susana..." (EMATP).

La presencia de la netbook en la EEST $\mathrm{N}^{\circ} 1$ irrumpe en otro tipo de razonamientos. En posiciones moderadas, se prioriza la necesidad de impulsar cambios culturales, inculcar hábitos de estudio y normas de comportamiento, una vida escolar más organizada, condicionamientos importantes que “debieron preverse". En defensas enfáticas, el modelo 1 a 1 se muestra capaz de operar profundos dislocamientos en modelos conservadores, de romper con estilos de gestión autoritarios o verticalistas. No obstante, estos conceptos no redundan en criterios novedosos de uso digital, antes bien, confirman las concepciones tecnocráticas. También revelan la dimensión conflictiva de las relaciones al interior de la escuela: "Y me acuerdo que poco antes de que llegaran las netbooks el año pasado, ¡la Directora prohibió que los profesores trajéramos las notebooks! Como se prohibió el celular se quería prohibir la computadora. ¡La netbook fue como una cachetada!" (Proyecto y Diseño Electrónico, O. Electrónica).

En ocasiones, la mirada se vuelve más tolerante para comprender las limitaciones de la gestión en términos de cualidades personales, que contrastan con la crisis de la imagen pública de la escuela. El diagnóstico coincide con un conocimiento cotidiano que surge del sentido común, antes que de una evaluación experta. Así lo expresa el uso de refranes y expresiones coloquiales:

Yo te digo: hazte la fama y échate a dormir. Acá también hay un problema cultural. La Directora no te lo va a decir. Yo a la Directora la conozco porque estudiamos juntas, me parece buena persona, algunos problemas ha tenido con gente... Pero está la fama de que no hacen nada, de que el profesor no viene... Es un despiole (Física, O. Electrónica).

Una serie de contradicciones atraviesan la primera etapa. La EEST $\mathrm{N}^{\circ} 1$ afronta un escenario adverso donde el componente novedoso de las TIC renueva las expectativas de mejoramiento. Sin embargo, la respuesta dominante es retraerse a sus mandatos establecidos, que no son los de su realidad particular sino los inherentes al paradigma institucional. Esto explica por qué estas tempranas significaciones constituyen el común denominador con la EEST $\mathrm{N}^{\circ}$ 2. Pero estos imaginarios adquieren notables matices. El mecanismo para actualizar la legitimidad identitaria de 
Industrial, reside en la efíciencia del ordenamiento institucional, la acción centralizada de la gestión, la estructuración de sus tradiciones y rutinas, todo un conjunto de núcleos significantes que abonan la vigencia de la racionalidad instrumental. Pero asimismo muestran una escuela "viva" y, con ello, una identidad profundamente afectiva. Por otro lado, definida por la memoria de los procesos de industrialización urbana; paradójicamente, esa aparente historicidad realiza un vaciamiento de su contenido histórico, que tiende a despojarla de sus determinaciones ideológicas: cuando cristaliza la doble temporalidad entre ese pasado mitificante que "fue mejor", y el futuro de la modernización en la que reposan las creencias y esperanzas de resurgimiento.

\section{Construir (o re-construir) la identidad: "es un monstruo esta escuela"}

Tras cinco años de la llegada del PCI y en base a lo ya analizado, ¿qué relaciones se establecen entre los dilemáticos esfuerzos de construcción identitaria y las condiciones que se predican como habilitantes de la inclusión digital? En el caso de la EEST $\mathrm{N}^{\circ} 2$, la cultura institucional está sometida un constante esfuerzo de racionalización, con el que tiende a articular de manera consistente los nuevos sentidos de la transformación tecno-educativa con los elementos tradicionales de su proyecto fundacional. Esta matriz imaginaria se mantiene prácticamente inalterable a pesar del cambio de los equipos directivos, como ya hemos señalado.

La implementación del PCI introduce nuevos y más complejos elementos a las numerosas dificultades de la EEST $\mathrm{N}^{\circ}$ 1, que atravesará sucesivos relevamientos de sus autoridades: tres equipos en menos de tres años con ideas muy disímiles respecto de cómo encarar el postergado proyecto de mejoramiento institucional. Por un lado, no cuentan con aquel marco ordenado y previsible, sus acciones se traducen en la búsqueda de opciones que permitan superar los intentos de una identidad fallida. Sin embargo, se verifican en esta etapa aproximaciones hacia características que puedan ser reconocidas y aceptadas como propias, alternativas al paradigma estructurante de Industrial. Por otro, lo que prima es el conjunto de afectos que se conjugan en el espacio de lo cotidiano, centralizado en el último equipo de gestión y donde la identidad aparece como un proyecto compartido, pero que se proyecta en tiempo presente.

El rasgo emblemático lo constituyen las relaciones que educadores y estudiantes establecen con el Director. No es un dato menor que muchos lo tutean y lo llaman por el apodo, caracterizando positivamente su estilo informal de liderazgo y adjudicándole gran parte de la responsabilidad en los procesos ostensibles de mejora institucional. Sinteticemos una entrevista que se ve interrumpida por un profesor recién designado; el humor constituye el recurso sobre el que se 
asienta una autoridad legitimada, cordial y desestructurada pero compatible con los ordenamientos formales requeridos en estos procesos de reconversión. El Director pregunta, en broma:

¿Qué vas a hacer con tanta plata, loco?” "Pagar cuentas, jaja.”-responde el docente. “¿Estás grabando?"- me pregunta. "Grabá esto: acá está institucionalizada la coima y el único que está habilitado para cobrarla es el Director. Acá hay una ley inamovible que el profesor que recién empieza, con el primer sueldo, paga el asado. Elegí la fecha, nosotros ponemos la bebida, ¡agua mineral! Jajajaja. “¿Empecé con las facturas!”- dice el profesor, todos se ríen...

La referencia a los docentes se vuelve menos condescendiente cuando se trata de su tarea. El Director entiende que deben fortalecer sus decisiones en una doble dirección: mejorar los niveles de desempeño escolar y edificar nuevas valoraciones de la imagen pública de la institución. En ambos aspectos se cristaliza la distinción adentro/afuera, pero hay una consciencia acabada de que lo que sucede al interior de la escuela repercute directamente en los significados que los públicos (la comunidad, el barrio, otras organizaciones) generan acerca de ella. Las llamadas salidas educativas (concursos, ferias de ciencias y proyectos similares) han tenido un crecimiento sostenido en los últimos años, lo que constituye un orgullo compartido, permitiendo motivar a los alumnos y dar visibilidad social a sus producciones. Contradictoriamente, representan también los temores instalados a que esos alumnos transgredan los parámetros del "buen comportamiento", una mirada docente prejuiciosa que, en la práctica, los priva de participar de tales experiencias o de generar a partir de ellas conocimientos más elaborados.

Les dije a los profesores que salgan con los chicos, porque la mayoría de los profesores tienen miedo de cómo se van a portar, les hice contar a los pocos profesores, les hice contar la experiencia y el $100 \%$ quedaron asombrados de lo bien que se portaron los pibes. Me gustaría escuchar alguna vez que esa salida sirvió para abordar un contenido, para mostrar una problemática que no sabíamos cómo. No... lo raro es lo bien que se portaron...

La ejecución de los presupuestos en el marco de los Planes de Mejora no constituye ya una preocupación, dado que el nuevo equipo directivo ha implementado los mecanismos necesarios para su cumplimiento. Este problema, tan frecuente en la primera etapa, está ausente en todos los discursos y en ambas escuelas. En cambio, un foco de atención reside ahora en las distintas formaciones disciplinares de los equipos de conducción, que favorecen modelos dialoguistas, menos centralizados. Si el estilo de gestión de la EEST $N^{\circ} 1$ es abiertamente informal, en el caso de la EEST $\mathrm{N}^{\circ} 2$ se evidencia un esfuerzo por flexibilizar modelos establecidos, de matriz tecnicista. Su Director destaca la disposición a la formación continua y diversificada, por cuanto esta contribuye estratégicamente a comprender, orientar y administrar las lógicas de funcionamiento escolar. Su posicionamiento crítico como ingeniero se inscribe en consideraciones generales acerca del impacto de estas transformaciones: “el Vice-Director es sociólogo, la Vice en 
profesora de Lengua, el marido es antropólogo y no sé si no ha pasado por Sociales, sí, tiene muy buena formación y tenemos discusiones, para entender qué le pasa al pibe..."

La Vice-Directora coincide en este punto. Pone la problemática de la digitalización en clave de los debates que se generan al interior de la institución, la escucha de las distintas opiniones, los acuerdos de trabajo, la búsqueda de intereses comunes. Si persisten las resistencias, se debe a que los profesores tienen "el miedo intrínseco de que la escuela desaparezca". En cambio, deben entender los sentidos de estos cambios y animarse a actuar como verdaderos protagonistas:

Yo lo que celebro que acá se ofrezcan los espacios para pensar y para reflexionar, para intercambiar y a veces quedamos todos peleados. Pero que se ofrezcan otros espacios, que la palabra no sea verticalista, que corran las posiciones. Porque uno arma un grupo y larga una premisa, está quien absorbe el cambio, quien lo lleva adelante, quien le resiste, quien lo niega, quien lo ignora, y cuando las voces empiezan a cruzarse, y uno dice: a mí me sirve, y otro: a mí me rompe la clase.

En cuanto a los docentes, opinan que situaciones de mayor flexibilidad facilitan la experimentación en la planificación didáctica, lo que permita explorar los nuevos soportes e integrarlos en marcos de interactividad. Esta incorporación debe estar supeditada a los propósitos de un proyecto formativo construido de manera colectiva antes que de los contenidos prescriptivos del currículum. Como nos hace saber Gimeno Sacristán, “el currículum, al expresarse a través de una praxis, cobra definitivo significado para profesores y alumnos en las actividades que unos y otros realizan, y será en la realidad aquello que esa tamización permita que sea” (1991: 4). En estos términos lo concibe una entrevistada de la misma escuela: "Acá hay apertura, no te hacen problema, pero hay que fundamentarlo bien, siempre lo que está prescripto es lo que hay que saber. Otra brecha, viste, ;lo que es y lo que debería ser!" (Seguridad e Higiene, O. Electromecánica).

Así, la incorporación de TIC "se puede hacer en otra escuela, sí, pero te cuesta más. Si me preguntás sobre la Escuela 7, mmm... se puede hacer pero tiene que estar todo mucho más controlado. Yo en esta escuela puedo proyectar, puedo innovar...” Establecer comparaciones implica poner en valor una larga trayectoria que ha acompañado los desarrollos de la escuela de pertenencia, operando complejas determinaciones en los modos de subjetivación docente y de afiliación identitaria: "Soy grasa yo, ¿eh? Soy grasa hace 23 años, trabajé también la Técnica 1, trabajo también en Sierra Chica y en Agrotécnica, pero donde yo puedo proyectar, donde puedo probar, ¡es acá!” El tamaño no es meramente un atributo físico: “es un monstruo esta escuela”.

Tres núcleos significantes podemos analizar de este discurso. Primero, la presencia de las netbooks iguala en términos de acceso material, pero no resuelve las diferencias de base: desde los modelos de conducción hasta los climas de convivencia áulica y las competencias percibidas en los alumnos, determinan los niveles y tipos de actividades que pueden efectivamente llevarse 
adelante. Segundo, un sistema de jerarquías: en la EEST N 2 se puede "proyectar”, “innovar”, "probar"; tener que "controlar más" en otras escuelas parece incompatible con la voluntad de explorar otras alternativas y, como en la etapa anterior, a ellas no se pertenece sino que solo se "trabaja". Por último, las disposiciones favorables a las tecnologías conectan con una arista emotiva desde la cual se semiotiza a la escuela "viva", lugar de trayectorias móviles y fluidas que recrean la consciencia de reconocerse "grasa". El término designa el estado pringoso de los mamelucos, pero también al hecho de que la escuela originalmente se nutría de las clases bajas, una historicidad que ancla en el presente y el conjunto de los actores reconocen como propia.

Y entre las posibilidades pedagógicas, aparece el desarrollo progresivo de la autonomía, uno de los objetivos principales que deberían perseguir las apropiaciones tecno-educativas. Una competencia que debe reconciliarse con la interiorización de valores básicos como la observancia de los límites y la responsabilidad personal. El relato abunda en entusiastas definiciones de este tipo, donde subyace un sistema de equivalencia entre formación técnica y la EEST $\mathbf{N}^{\circ} \mathbf{2}$ :

A mí me encanta trabajar en escuela técnica. Es super interesante. Lo que tiene la escuela esta es que trabajamos en un marco de libertad, y lo que puede parecer un riesgo, termina siendo una fortaleza institucional porque ingresan chicos muy chicos en cuanto a competencias de responsabilidad, se tienen que mover en una institución gigante...

En vías a los procesos de mejoramiento en lo que se sienten implicados, los docentes de la EEST $\mathrm{N}^{\circ} 1$ se orientan a formar en un conjunto de habitus. El respeto a la autoridad, el comportamiento responsable, la convivencia amable, el cuidado de los materiales y las instalaciones, son especialmente destacados en un nuevo marco de paridad con Industrial. Tras varios años de límites laxos, la transición del "libertinaje" y la "libertad", la autonomía como condición de posibilidad de cierta organización razonable, vuelve la tensión instituido/instituyente aún más compleja. Porque lo que garantiza la continuidad estructurada de la institución es al mismo tiempo lo instituyente, y son los sujetos los agentes capaces de activar y movilizar esa potencia desestructurante. Una dialéctica que articula imaginariamente estos cambios globales con la reciente distribución de las netbooks en el Ciclo Básico:

Acá pasamos de no tener ningún tipo de normas o tener algunas normas, a respetar los horarios de recreo, que en clase no anden por las galerías, entraban y salían como querían, eso generaba otro tipo de conflictos, se iban los chicos a otra aula y por ahí se agarraban a trompadas, se rompía algo en el baño, y quién fue, y no se sabía porque estaban todos afuera... Como un montón de cosas que no funcionaban para nada bien, se fueron mejorando de a poco, inculcándoles cómo sería el comportamiento adecuado, de a poco (Prácticas del Lenguaje, 3er. Año).

Si retomamos al Director de esta escuela cuando critica los recelos del profesorado acerca del "buen comportamiento", en los discursos docentes surge que esta preocupación sí parece 
conciliarse con los esfuerzos por concretar propuestas educativas más ambiciosas. Un aspecto de una práctica reflexiva reside en las resignificaciones de la cultura institucional, a caballo entre la imposición de las normas formales (aquellas que responden a su paradigma) y los vínculos informales y afectivos (rasgos incipientes de construcción identitaria). En todos los casos, parecen encontrarse en relación dialéctica la identidad escolar y la inclusión digital: si esta alimenta los esfuerzos de (re)constitución de la identidad escolar, a la vez encuentra en la misma las condiciones fundamentales para su desarrollo. Una voluntad colectiva vincula implícitamente las distintas posiciones: formar un sujeto institucionalizado que se implique en un trayecto de apropiación progresiva de la institución, en el sentido de "hacerla propia", y que pueda seguir dominando con sentido crítico el conjunto de competencias necesarias para vivir en sociedad.

\section{Enclaves juveniles: sentirse "grasas" o la escuela "linda"}

Advierte Reguillo Cruz (2003) que el Estado, la familia, la escuela, siguen pensando a la juventud como preparación para el futuro, valorada por lo que será o dejará de ser. Pero para los jóvenes, el mundo está anclado en el presente. ¿Cómo evalúan entonces estos procesos de transición? Durante la primera etapa analizada, en la EEST $\mathrm{N}^{\circ} 1$ avanzan en definiciones sobre los problemas organizacionales, que discurren entre dos estilos sucesivos de gestión: del "caos" al “autoritarismo". Una mayoría de los docentes coinciden con este diagnóstico. A modo de síntesis, nos centraremos en el siguiente entrevistado, quien registra dos contradicciones en estos escenarios de cambio. La primera alude a los mecanismos de control, representada en la figura del entonces Director. Un dispositivo de panóptico, en términos foucaultianos, representa para estos jóvenes la vigilancia de sus actos, la autoridad verticalista y arbitraria, la sensación de no ser escuchados, la honda estigmatización que experimentan. ${ }^{27}$

¡Ahora quieren poner cámaras! Si las ponen las vamos a sacar... Eso viene de Dirección, del gordo... Las cosas igual deberían cambiar porque la otra Directora no era muy recta, digamos. No ponía las reglas que tenía que poner. Ahora con Giancomano llegás tarde y ya te mira raro. (5to. Año, O. Electrónica).

Esta situación contrasta con el estado de acefalía durante la gestión anterior, pero de ningún modo resuelve los problemas de funcionamiento. Entre ellos, los entrevistados incluyen,

${ }^{27}$ Esa decisión no fue finalmente implementada, produjo agudas controversias y el pronunciamiento en contra de toda la comunidad educativa. Un caso conocido se dio en la ciudad de La Plata en 2011, a partir del cual la Justicia provincial resolvió obligar al municipio "a que de manera inmediata se abstenga de permitir la existencia y/o proveer la instalación de todo dispositivo de registro-video en cualquier espacio o establecimiento educativo departamental". Disponible en: http//www.lanacion.com.ar/1428859-prohiben-instalar-camaras-de-seguridad-en-escuelas-de-la-plata 
paradójicamente, sus propios comportamientos, en actitud desafiante tanto de la ausencia de normas como del ejercicio de poder que se percibe como injusto. La "indisciplina", nudo de una construcción identitaria negativa, es objeto de constantes desplazamientos. Cuando falla la escuela como objeto de apropiación, la que emerge como tal es el aula, donde se negocian los sentidos de la autoridad pedagógica y el conjunto de "concesiones" relativas a la presencia de la netbook: "Y sí, hacía falta... (poner reglas). Porque tenemos todo... en nuestra aula tenemos tele, equipo de música, ping pong... No para la hora de clase, claro, pero si faltan veinte minutos el profesor nos da permiso..." El uso recreativo desalienta la incorporación tecnológica con intencionalidad didáctica, pero expresa entre los estudiantes una consciencia material sobre la complejidad de estos contextos donde se muestran capaces de realizar otro tipo de aprendizajes.

La segunda contradicción involucra una trama abigarrada de imágenes, que actualizan el viejo proyecto de la educación técnica y sus relaciones dilemáticas con formas culturales emergentes. Sirven para enfrentar o compensar las diferencias de inclusión que plantean la mayoría de las instituciones tradicionales, incluyendo la propia escuela. Pero el proyecto de la movilidad social, ligado a la preparación para el mundo del trabajo, se articula imaginariamente con las expectativas de los estudios superiores. A diferencia de sus docentes, estos jóvenes en situación de vulnerabilidad social no quieren resignar el proyecto aspiracional de la Universidad: “Acá igual han egresado chicos que ahora son ingenieros. La calidad educativa es buena. A lo mejor habría que mejorar la disciplina..."

En las valoraciones de los grupos avanzados de la EEST $N^{\circ} 2$, la Universidad es el proyecto natural, asociado a su pertenencia social. Pero lo que experimentan en tiempo presente es la red afectiva que los conecta orgánicamente entre sí y con la institución. Por una parte, las adecuaciones del PCI configuran un panorama difuso, donde prima la continuidad respecto de los usos previos de las computadoras, y por otra, cierta reticencia acerca de cómo vienen a impactar estas innovaciones en formatos tradicionales en los cuales los estudiantes de Industrial instituyen el sentido de sus trayectorias, su lugar en el mundo. El nivel semántico del relato revela esta implicación compartida, en contraste con los recelos que despierta las netbooks en el salón:

Porque los que estamos acá estamos porque amamos la escuela. Tenés que estar en esta escuela, y si estás en una especialidad que te gusta, seguro que no te vas a distraer con otras cosas. A mí me gusta lo que estudio y lo que hago, entonces no me voy a distraer con una página (6to. Año, mujer, O. Informática).

Asociadas a la auto-afirmación, estas representaciones se asientan en una doble temporalidad: el presente donde se conjuga el sentimiento de pertenencia, y el pasado mitificante cristalizado en la ciudad, una memoria compartida que deriva de la herencia de los padres, 
muchos de ellos egresados de la escuela. El legado de fraternidad alimenta el propósito consciente de continuidad generacional, incluso al comunicarlo a compañeros más jóvenes:

Cuando hablaba con mi papá me explicaba lo que eran todos hermanos, que era todo hermandad, y que ningún valor iba más allá de lo normal, de lo común. Era un proyecto que nos habíamos propuesto que era concientizar a los más chiquitos sobre qué es Industrial. Las Olimpíadas eran Industrial, no era una escuela más. Éramos Industrial...

Estas afiliaciones se continúan en la segunda etapa. Si las familias influyen de modo ostensible, los estudiantes reconocen que comenzar y sostener sus trayectorias resulta de decisiones personales: Industrial es una escuela que "se elige". El Ciclo Superior constituye el “filtro", real e imaginario, que discrimina según desempeños escolares y, sobre todo, la capacidad de adaptarse a la cultura institucional. El precio de la indiferencia es el fracaso educativo. Como precisaremos luego, este cierre siempre precario del orden de lo simbólico, redunda en formas implícitas pero eficaces de exclusión. Parafraseando a Hoggart (2013), se trata de indagar el trasfondo de las actitudes entre ellos/excluidos y nosotros/incluidos en la escuela.

Yo pienso que esta escuela no es para cualquiera. ¡Te tiene que gustar! Porque es una escuela técnica, porque pasamos muchas horas del día. Y ahora tenemos $7 \mathrm{mo}$ año. La mayoría elegimos la escuela, hay gente que viene solo porque les queda cerca, pero esos son los que se van de la escuela o se quedan (repiten). Esos no eligieron la escuela... (5to. Año, O. Electromecánica)

La EEST $\mathrm{N}^{\circ} 1$ se encuentra atravesada por los esfuerzos de reconversión, valorados especialmente por los estudiantes mayores que han vivido las gestiones erráticas de los sucesivos equipos directivos. Ese marco interpretativo reside en la defensa de una escuela que comienza a resistir el deterioro material-simbólico a la que parecía destinada, de su imagen pública tradicionalmente estigmatizada. Los cambios de la estructura curricular que vuelve obligatorios el 7mo. Año y las prácticas profesionalizantes, dotan de mayor especificidad a la formación y la iguala imaginariamente a la EEST $\mathrm{N}^{\circ} 2$. Pero junto con sus docentes, los jóvenes contribuyen a las transiciones hacia un nuevo paradigma, que detenta rasgos relativamente diferenciados y verificables en la práctica. Y que sostienen el objetivo hacia un proyecto de autonomía.

Si la escuela empieza a ser esbozada como lugar válido de afiliación, el peso de la mirada externa resulta determinante, alentando las transformaciones que constituye la principal orientación de la EEST N 1 en esta segunda etapa del PCI: "Sí, puede ser que la identidad tenga que ver con la escuela, yo estoy orgulloso de pertenecer a la escuela, otro aspecto, otro ambiente, que quede linda, que quede presentable, porque antes no era así...” (6to. Año, Química). Otro aspecto reside en las preocupaciones sobre el futuro personal, de acuerdo a dos posiciones: aproyectar la posibilidad muy concreta de continuar los estudios superiores; y b- poner en valor la 
formación laboral, operando un distanciamiento respecto de las carreras universitarias. Expresión novedosa de la tensión ellos/nosotros, respectivamente, ingenieros/técnicos, que apela a la centralidad de los saberes técnico-profesionales de la formación:

Acá seguimos trabajando, es interesante, por eso estamos haciendo las pasantías, estamos en empresas, se va generando una relación con las empresas y que nos vayan teniendo en cuenta. Que cuando salgamos de acá, ya nos llamen. Nos han dicho que hay muchos ingenieros pero pocos técnicos, y lo que hacemos nosotros no lo hacen los ingenieros (7mo. Año, Electrotécnica).

Martín Barbero (2002a, 2007, 2015) ha argumentado que lo que prevalece en las juventudes actuales es un replanteamiento de las formas de continuidad cultural, que radicaliza la experiencia de des-anclaje. Vincula esta etapa con aquella que Margaret Mead había calificado como prefigurativa. Por contraste a las etapas postfigurativa y cofigurativa, esta entraña un profundo quiebre generacional, porque los aprendizajes dependen menos del legado de sus padres, que de las relaciones con sus pares y de sus propias exploraciones del mundo que habitan. No obstante, como surge del análisis, la pluralidad de modos de experimentar a las TIC, en sus complejas interacciones con las instituciones educativas, rebasan todo intento de generalización. Los estudiantes registran continuidades y discontinuidades, antes que fracturas, respecto de generaciones anteriores. Solo así puede comprenderse la voluntad de sostener y confirmar la identidad institucional que los une, o bien de operar en ella las necesarias transformaciones que contribuyan a volverla más sólida, ideológicamente efectiva.

\section{Entre la escuela "contenedora" y la "formadora"}

En el dominio de las representaciones docentes subyacen formas ideológicas, morales y políticas, que ejercen influencia sobre la enseñanza cuya función primera está vinculada a la producción cultural (Jodelet, 2011). Con la llegada del modelo 1 a 1, se renuevan los sentidos de esa formación. La escuela argentina ha asumido en las últimas décadas una función de contención, de acuerdo a los contextos socioculturales donde está inmersa. Básicamente, contener significa ocupar el lugar que en ocasiones las familias dejan vacante en el cumplimiento de derechos. El discurso sobre la contención social y afectiva oscila entre el asistencialismo y la protección paternalista, entre la estigmatización y la reparación de derechos. Y entra en conflictiva convivencia con la tarea de enseñar. En paralelo, la crisis de valores tradicionales parece ser transversal a todo el sistema educativo pero, en el caso analizado y de acuerdo a la mayoría de los entrevistados, decanta en el vaciamiento simbólico de su especificidad técnica y formativa. 
Las desventajas familiares, personales y socio-económicas sirven con derecho a justificar la legitimidad del proyecto de igualación de oportunidades. Pero la tecnología puede ser interpretada en su capacidad de "retener" y dar cumplimiento a la obligatoriedad del nivel secundario, lo que alimenta la consabida cosificación, su caracterización restringida como objeto de consumo o "bien de deseo". Se aduce que la permanencia constituye garantía de la inclusión socio-educativa, pero además ubica a la escuela en un papel transcendental, de rasgos épicos e incuestionables, incluyendo a la función de contención. Esta posición se funda en generalizaciones y lugares del sentido común: “...si la familia está destruida o no tiene una subjetividad muy definida de cómo orientar a su hijo, estamos nosotros, la escuela, porque somos la última frontera, después de la escuela viene la calle" (Vice-Director EEST N²).

Si los estudiantes de la EEST $\mathrm{N}^{\circ} 2$ pertenecen a sectores medios y medio-altos, las problemáticas que los afectan son la crisis del modelo nuclear, la falta de responsabilidad paterna, los desacuerdos entre los padres. La posición del segundo Vice-Director es distinta, porque lo preponderante no es la defensa cerrada del rol de contención, sino las realidades a menudo inesperadas y poco comprendidas que operan desplazando constantemente los límites de la institución y tensionando sus funciones específicas. Interpretar los aspectos emocionales implicados en los vínculos familiares adquiere plena importancia: "cuando tenés que llamar a los padres, pobre chico, ¡es Tupac Amaru! Uno tira de un lado, el otro tira del otro”. Las condiciones de creciente diversidad están a su vez mediando las relaciones del estudiante con la escuela, donde encuentra otros marcos, tal vez más determinantes, de subjetivación:

Yo te aseguro que acá podés hacer cien películas, cien capítulos de series de televisión por año. Hay diferentes escuelas, diferentes momentos, diferentes personas. Yo tengo un chico que se le murió el padre hace quince días, el padre tenía 31 y fue alumno de esta escuela...

Por el contrario, la percepción de muchos profesores sobre sus alumnos de la EEST $\mathrm{N}^{\circ} 1$ se basa en caracterizarlos como personas carentes en diferentes aspectos: pertenecen a familias irresponsables y poseedoras de patrones que ellos repiten en sus vidas; también mostrarían escasas capacidades intelectuales. Estas valoraciones clausuran la posibilidad de superar los determinismos, que el docente pueda romper con su propia inercia. La lectura simplificada refuerza una suma de prejuicios al interior de la escuela hacia quienes no responden a modelos "normales" de familia, condenándolos al fracaso y a los efectos de la vulnerabilidad social:

Ahora, yo que tengo dos nenas de distintas edades, son tremendas en casa, pero saben que en la escuela no van a decir malas palabras. Si el profesor se equivoca, bueno, decíselo con respeto (...) Tiene que ver tanto con la familia como con la escuela. Mi nena que fue a San Antonio y después a Normal, las amigas de ellas, todas brillantes. Claro, los papás son profesionales... Tienen una familia diferente (Física, O. Electrónica- EEST $\mathrm{N}^{\circ} 1$ ). 
A esto se suman los conflictos que motiva la presencia de las netbooks, aunque la indisciplina observada es explicable por las limitaciones inherentes al ejercicio de la autoridad y las dificultades para objetivarlas como tales, antes que por el acceso personal. Durante una clase, la mayoría de los estudiantes se encuentran conectados: "Ahí tenés la tecnología, mirá. No, no es que sea la tecnología, pero me pone loca que les digo que cierren las netbooks y nada." Una política con propósitos inclusivos como Conectar Igualdad difícilmente pueda entrar en ese horizonte de referencia, en el cual se ratifica el proyecto formativo como un mandato, pero prácticamente irrealizable. De ahí la ausencia de propuestas didácticas que conviertan ese supuesto fanatismo adolescente en espacios estimulantes de aprendizaje.

Los docentes se muestran comprensivos con los padres "entusiasmados" ante la llegada de las netbooks, pero los califican de "prepotentes" cuando "vienen a apretar" por los retrasos en las entregas, pero no asisten a las reuniones o son indiferentes a las dificultades que estos cambios conllevan. Las familias y otros vínculos irrumpen, negativamente, a partir de la mediación tecnológica: en las redes sociales que posibilita el acceso personal se motorizan los conflictos con parientes, amigos y conocidos, que luego se trasladan al ámbito escolar. Una creencia que se afinca en el supuesto tradicional adentro/afuera donde incurren las tensiones entre la presencia familiar que se reclama y la autonomía que pondera la institución, en el intento de afianzar sus patrones de organización interna y volverlos visibles en el mejoramiento de su imagen pública.

En la segunda etapa, estas significaciones se mantienen, aunque matizadas por las transformaciones que se vienen encarando, en especial en la EEST $\mathrm{N}^{\circ} 1$. Igualmente es en este contexto donde se verifican posicionamientos más negativos. Por ejemplo, la familia todavía se hace visible solo como ausencia, representando las determinaciones de la crisis que se realiza discursivamente en la netbook. El tono clientelista que se atribuye al PCI subestima sus orientaciones inclusivas. Se cuestiona ese "regalo" que aísla cada vez más a los jóvenes, dificulta sus aprendizajes y, como consecuencia, refuerza las situaciones de desamparo que ya sufren en sus hogares. El siguiente relato gira en torno a las distorsiones entre los accesos tecnológicos y la falta de estructuras familiares que acompañen unos usos orientados al conocimiento. La mirada irónica encierra un sentimiento de aceptación, que sirve de justificación a la hora de prohibir esos usos o de retraerlo a sus expresiones más elementales y empobrecidas.

La ven como un regalo. Los valores de la casa no están. Los chicos que vienen acá en general vienen solos, o vienen para que los padres cobren la asignación. Citás a los padres y no vienen... Te ponés a hablar con los chicos y no hay cultura del trabajo, o el padre fuma o es borracho. Hay muchos de estos casos. Para mí que esté en la escuela ya es un logro, porque están solos (Montaje de Proyectos Electrónicos y otras, O. Electrónica). 
Como veremos, las vinculaciones entre inclusión digital e inclusión educativa componen una trama de sentidos particularmente evasivos. Hay un sustrato ideológico compartido que se asienta en la convicción de que la escuela no debe tener como principal misión la contención social, sino proyectar acciones estrictamente articuladas en torno a la calidad educativa. Si a estos cambios sociales se suman otras problemáticas juveniles (violencia de género, adicciones, embarazo adolescente, etc.), es notable que la EEST $\mathrm{N}^{\circ} 2$ se desliga de este tipo de situaciones, lo cual, además de sus determinaciones objetivas, ratifica las percepciones favorables de un perfil de estudiante distintivo con respecto a otras escuelas. Como en el caso de esta profesora de 1er. Año:

Veo que la sociedad cambió, la familia cambió, que la mamá era contenedora y estaba en casa, y ahora con el tema de las adicciones, que el papá es borracho... No te digo acá, pero sí en general, a veces eligen el lugar de la escuela porque es donde están más tranquilos. Hay casos de violencia familiar, que la escuela puede intervenir y otras no... (Construcción de Ciudadanía).

En suma, la desconfianza hacia la presencia de la netbook a menudo expresa una larga ausencia: la familia. Estos sentidos dan temprano argumento a las dificultades para ejercer una plena integración pedagógica cuando el docente no encuentra respuesta a sus demandas de apoyo a la adopción responsable. Estas matrices simbólicas adquieren continuidad a lo largo del proceso del PCI, derivando tanto de las exigencias renovadas hacia los padres, como de la consciencia omnipresente respecto de las oportunidades que entraña una escuela de doble jornada frente a la crisis de otros principios organizadores de la experiencia. Pero la atención que merecen las problemáticas socio-económicas, vinculares y emocionales de los alumnos, nunca relega, imaginariamente, la función primordial de enseñar. Esta premisa comporta la búsqueda de los dispositivos necesarios para operar los desplazamientos de la escuela contenedora hacia otra predominantemente formativa. Y fuerza otras materializaciones de las prácticas con las TIC que empiezan a interrogar sus alcances para promover el pensamiento crítico, potencialmente superador de las desigualdades socioculturales de base.

\section{Sobre las reformas neoliberales de la educación técnica}

Otro aspecto de las mediaciones institucionales radica en los esfuerzos que desde el Estado nacional se vienen realizando para recuperar la educación secundaria técnica. En el marco de esa trayectoria compartida los actores educativos dotan de inteligibilidad a los cambios de nuevo signo que introduce una política como Conectar Igualdad, valorando como un aspecto prometedor que esta haya priorizado las escuelas técnicas. Al margen de sus distintos posicionamientos políticos, 
los sujetos entrevistados comparten una lectura fuertemente cuestionadora de la reforma educativa que impulsaron las políticas de corte neoliberal de la década del '90.

En apretada síntesis, destaquemos que a partir del año 1991 se inicia un profundo proceso de transformación en la educación argentina, que involucró cambios sustanciales a nivel político y pedagógico, en lo relativo a la función del Estado en la distribución y gestión de los saberes socialmente valorados. Asimismo, dio lugar a una nueva organización para el sistema educativo, la descentralización y la transferencia de las escuelas secundarias e institutos terciarios no universitarios a la órbita de los gobiernos provinciales. ${ }^{28}$ La provincia de Buenos Aires revela particularidades interesantes que le confieren un perfil propio, entre ellas, la asistencia pública como mecanismo central de intervención estatal en contextos de pobreza. Las críticas a la función de contención que acabamos de analizar involucran imaginariamente los resabios de los efectos perjudiciales de estas transformaciones.

Pero el tema paradigmático en los relatos consiste en los cambios curriculares relativos a la unificación del nivel secundario. Destacamos la crónica extensa que hace el Vice-Director de la EEST $N^{\circ} 2$ durante la primera etapa analizada y que comprende: a- ubicar simbólicamente a la educación técnica en una temporalidad que le es propia, en base a los múltiples atravesamientos o redefiniciones de sus lógicas de organización política, social y educativa; b- una memoria colectiva de los enormes perjuicios que resultaron de la decisión del Estado de homologar escuelas técnicas y medias; c- la vigorosa defensa de la especificidad de la escuela técnica, en su carácter plenamente instituido. Así lo expresan en el discurso los usos de marcadores temporales, impersonalizaciones y el "nosotros" inclusivo:

Ahora la escuela técnica tiene un año más. Ahora tiene seis de Primaria y siete de Secundaria. Siempre fuimos 13 años de escuela técnica, pero la Ley Federal nos había sacado un año, bah, entre otras cosas (...) Y teníamos que largar el 1ero. de Polimodal en el '99. ¡No estábamos! Después apareció un Anexo, porque se habian olvidado de la escuela técnica, y cómo nos largaron. ¡Nos largaron a la que te criaste! Yo trabajaba en Nacional ¡y resulta que los mismos programas eran para Nacional y para acá! Los talleres eran todo teoría. Los talleres eran un cementerio. ¡Nada!

Vale destacar la antítesis entre el "cementerio" que metaforiza los talleres de entonces, y las definiciones recurrentes de una escuela "viva”. Rememorar la situación de los egresados del nivel Polimodal apela al "desastre" que provocó la reforma educativa, cuando la especialización "se

\footnotetext{
${ }^{28}$ Uno de los factores que despertó mayores controversias fue la implementación del 3er. Ciclo de la Educación General Básica (EGB), tres años de escolaridad obligatoria con importantes impactos organizativos e institucionales, que redundaron en la agudización de las situaciones de exclusión, segmentación y desigualdad educativa que la reforma pretendía erradicar. Un análisis minucioso lo encontramos en Garabán, Analía (2009), Lo público de la educación pública: La reforma educativa de los noventa en Argentina. FLACSO, México.
} 
destruyó" y de este modo se perdieron muchos espacios con contenidos técnico-disciplinares. Estas distorsiones tenderán a ser resueltas con las nuevas modificaciones curriculares impulsadas desde el Estado, que incluyen la obligatoriedad del 7mo. Año y las prácticas profesionalizantes, a partir de lo cual los estudiantes egresan con el título de técnicos, conforme a la Ley de Educación Técnico-Profesional. La provincia de Buenos Aires es la primera del país en instrumentar estos cambios en el ciclo lectivo 2013, apuntando a la recuperación de la formación para el desarrollo local y el desempeño en empresas y emprendimientos personales.

Yo tengo guardado un artículo que salió en El Popular, que decía: "Se necesitan técnicos electromecánicos, egresados del viejo CONET, egresados del Polimodal abstenerse.” iNo los querían! Y qué pasó, se terminaron los egresados del CONET, de la vieja escuela técnica, y tuvieron que agarrar a los pobres chicos del Polimodal y los agarraron de cero. Calculá que tenían un solo año de Matemática, después agregaron otro año, y después como no daban pie con bola, y después de cuatro o cinco años de implementarse el Polimodal, agregaron otro año en 6to. Todo parches era...

Aparece la convicción de que el impacto fue desigual entre las escuelas. Un conjunto de términos organiza esas diferencias, cristalizando un sistema de jerarquías que resigna a la EEST $\mathrm{N}^{\circ} 1$ a su situación tradicional de desventaja: "A la escuela técnica la hicieron pedazos. A la Técnica 1 la hicieron pedazos. No la pueden levantar. Tienen dos carreras espectaculares, y yo pensé que iba a ser un satélite nuestro, porque no tiene sentido mantener semejante mole." Esta narrativa pone en contexto histórico, al tiempo que afectivo, el componente nodal de la identidad de la EEST $\mathrm{N}^{\circ}$ 2: múltiples anudamientos simbólicos con un pasado de industrialización y crecimiento económico ligado a la fábrica Loma Negra. La escuela revitaliza así un modelo hegemónico consistente con una racionalidad científico-técnica, una ética de trabajo y criterios determinados de validación y transferencia de los conocimientos. Como sostiene el entrevistado, el apoyo sostenido desde la Fundación Fortabat le permitió a la escuela atenuar los efectos de las sucesivas reformas educativas, manteniendo así su continuidad cultural y formativa.

Empero, tal como anticipamos, la mirada nostálgica hacia el pasado conduce a cierto proceso de deshistorización. Las razones esgrimidas en el caso del segundo Vice-Director no se centran en los cambios curriculares, los vaivenes políticos o las debilidades de los equipos directivos, sino en una trama ideológica donde opera la reconstrucción del palimpsesto urbano (Gravano, 2005), que se inscribe en las fusiones aparentemente armónicas entre el mito fundacional (Olavarría “ciudad pujante", “del cemento", "del trabajo") y la proyección hacia el "progreso" imaginado:

No olvidemos que esta escuela tuvo la suerte de tener la Fundación Fortabat hasta el año '90. Necesitábamos dos morochos que nos abaniquen, manden dos morochos, decía Fortabat, y las demás escuelas técnicas se fueron quedando. Después del año '90... estuvimos como 15 
años así. Por eso vos vas a La Plata y ves las escuelas técnicas hechas pedazos. Esta es una es de las escuelas técnicas mejor equipadas... ${ }^{29}$

En la segunda etapa, las referencias históricas y sus efectos paradojales, los procesos de deshistorización, forman parte de los consensos tácitos, adquiriendo otras orientaciones. Hay una matriz discursiva compartida que acentúa las diferencias entre las escuelas técnicas pero, al mismo tiempo, las conecta entre sí desde una diferencia sostenida y cada vez más estructurante respecto de las escuelas medias: la movilidad social ascendente. En situaciones de agudas desigualdades sociales, sigue siendo valorada la capacidad para generar competencias para el trabajo y el desarrollo personal. Una política de inclusión digital genera expectativas hacia el proceso de reconversión material y simbólica de la rama: "Porque realmente era movilidad social. ¡Hoy día lo que garantiza la movilidad de los secundarios es la escuela técnica! Hoy tenés incumbencia profesional, podés firmar, te podés matricular, salís con un título...” (Director EEST $\left.N^{\circ} 2\right)$. Esta presunción conlleva el propósito de que los jóvenes puedan comprender, apreciar y generar verdadera consciencia acerca de las implicaciones de una formación específica y extendida.

Porque como la escuela venía siendo una escuela de contención más que una escuela técnica, entonces se necesita que ellos sepan que están en una escuela técnica. Que tienen doble turno, que cuando egresen van a tener un título, y que ese título no es igual que cualquier otro secundario (profesora de Historia, 3er. Año, EEST $N^{\circ} 1$ ).

En estos cambios las instituciones encuentran la promesa de dejar de ser contenedoras o asistencialistas para abocarse finalmente a su proyecto formador, aquel que intenta conciliar esta doble temporalidad: la utopía del "deber ser", moderna, funcional, adecuada a las complejas transformaciones del sistema social a cuyos requerimientos responde; y el relato de "volver a ser", recuperar su especificidad técnico-profesional, activando imágenes residuales sobre las premisas de la inclusión, la movilidad y la formación laboral con que históricamente ha construido la frontera con la escuela media. La que articula estos diversos aspectos, neutralizando las contradicciones que entrañan, es la tecnología. El riesgo es que termine agudizando la adhesión al componente ideológico de la tecnicidad dominante, incurriendo en la conocida metáfora de la

${ }^{29}$ Una nota publicada en el diario local por un ex docente abunda en anécdotas de este tipo. Relata que, en 1963, el gobierno alemán brinda a la Argentina una beca para capacitar técnicos en empresas líderes. A esta beca adscribe el CONET juntamente con "don Alfredo Fortabat", quien se compromete a hacer el edificio en el cual funcionaría la escuela. Un "paracaidista político" opina que la escuela debe hacerse en Córdoba: "Por lógica, Fortabat dijo que en el único lugar que ponía el dinero para hacer el edificio era en Olavarría, y como resultado de todo esto los becados sí cumplieron con la beca, pero se evaporaron por el país y por el mundo volcando su experiencia en diferentes empresas, y solamente uno se dedicó a la enseñanza. Así que hoy, gracias a la costumbre muy argentina de "escupir el asado", el país se pierde de contar con formadores con sólidos conocimientos técnicos y con tecnologías de primer nivel." Diario El Popular, 07/05/17. Disponible en: http://www.elpopular.com.ar/eimpresa/257998/lospasos-de-la-escuela-de-artes-y-oficios-a-la-escuela-nacional-de-educacion-tecnica-n-2 
ciudad como organismo vivo. En palabras de Gravano, "cierto condicionamiento homeostático, de la exigencia de un cierto grado de equilibrio e integración armónica obligadamente previos al inicio de procesos institucionales, en una idealizada gestión sin conflictos” (2016: 85).

\section{Recorridos intermitentes: los dilemas del "profesor taxi"}

El último aspecto del dominio institucional que nos interesa analizar, son las complicadas condiciones de trabajo docente de quienes se ven obligados a desempeñarse en varios establecimientos educativos. El tema de los "profesores taxis" no es nuevo, pero en marcos de inclusión digital cobra otras dimensiones. Esta situación provoca un sinnúmero de ansiedades personales, ligadas a la precariedad laboral y los tiempos cada vez más acotados; la competencia para ganar estabilidad, titularizar o concentrar horas; la dificultad para afrontar las constantes reformas educativas, las imposiciones burocráticas y la ineficacia de la organización escolar; las exigencias para desempeñar tareas que revaliden su formación de base y ejercicio profesional, como la capacitación continua, la innovación didáctica y el trabajo en equipo.

Los docentes taxis se auto-perciben -y son percibidos- en posición de desventaja frente a otros, ya que, además, volverse competentes presupone generar un sentido de pertenencia que hace a la vida institucional, las apropiaciones sostenidas de las dinámicas que la estructuran, las relaciones fluidas que deben establecer con alumnos, colegas y directivos. Además de los profesores noveles, acusan estas situaciones desventajosas los profesores de área, quienes cuentan con carga horaria reducida o fragmentada, algo que repercute negativamente en la práctica:

Porque después uno escucha: ay, mirá la de Matemática lo que le mandó a hacer si todavía no tienen bien... Pero tenés que manejar todo eso y los tiempos, que son cada vez más chicos, pero una materia que la estabas dando en cuatro horas semanales ahora la estás dando en tres, una hora menos es mucho y bueno, genera confusión, desorden... (EEST $\mathrm{N}^{\circ} 1$, Matemática, O. Automotores e Informática).

La medición del tiempo constituye una de las variables determinantes. En este sentido, las tecnologías impactan, por un lado, en la aceleración de la vida cotidiana impuesta por los ritmos laborales y cotidianos; y, por otro, en las dificultades para llevar adelante otro tipo de estrategias didácticas, que logren aprovechar los beneficios de la digitalización. Los profesores adscriben a las caracterizaciones generales sobre las TIC: estas aceleran y mejoran el rendimiento y, como consecuencia, la idea y experiencia de velocidad lo inunda todo (Virilio en Cabrera, 2006). Entonces, usar la netbook constituye un imperativo inobjetable. Pero esta idea se contradice cuando es la misma dimensión temporal la que sirve de excusa a los docentes para evitar explorar otros recursos, reconvertir sus intervenciones o concebir la capacitación como un proyecto 
personal realizable. Tal problema puede extenderse entre docente de áreas técnicas: "Y encima, el profesor taxi, que va de una escuela a otra, yo manejo $200 \mathrm{~km}$. y el tiempo no alcanza. Y eso que estudio y leo" (EEST N 1, Montaje de Proyectos Electrónicos, O. Electrónica).

Avanzado el PCI, el eje temporal sigue siendo preponderante. "Ahorrar" tiempo, una de las tempranas expectativas asociadas al acceso áulico, contrasta con las desiguales oportunidades para hacer de él un real aprovechamiento. El Director de la EEST $\mathrm{N}^{\circ} 2$ describe su propia experiencia docente en la segunda escuela: "tengo 4 horas y tengo pocos alumnos, se trabaja re bien, no tenés que andar saltando, con gran cantidad de alumnos...” Destaca la diferencia con la institución a la que conduce, que cuenta con cursos más numerosos y heterogéneos, en especial en la ESB. Así lo ejemplifica: "El pobre tipo de Geografía, imaginate, te volvés loco, y pretendemos que cuando llega a la casa se ponga a investigar el software de Geografía, y con menos receptividad de los chicos, ¿no? Porque son más chicos, más inmaduros...”

Otro campo de tensiones es la diferencia con la Universidad, donde se visibilizan las falencias nunca resueltas en los mecanismos de selección de los educadores secundarios o la escasa retribución que reciben por realizar otras tareas: "El docente universitario es de otra categoría, el exclusivo tiene que dedicarse a investigar. Acá tenés que dar clase, no te pagan un segundo para leer nada." La aguda crítica a los gremios resulta excepcional pero no menos importante a la hora de elucidar la complejidad de estos contextos socio-políticos, poniendo en jaque el optimismo dominante de la primera etapa que pretendía opacar estos conflictos: “...está la Ley Nacional de Educación Técnica, pero está la Ley Provincial, donde la corporación secundaria, los gremios, no deja que técnica se separe, cuando las escuelas técnicas jodieron mucho, nos dieron los talleres."

Entre los docentes taxis, a menudo se redunda en incorporaciones superficiales de la netbook, una suerte de "estrategia de supervivencia" ante cambios acelerados que han sido preconfigurados de manera heterónoma por otros. Si la Dirección aún no logra establecer normas claras sobre las adecuaciones del PCI, en cambio, traza direccionamientos, tácitos y formales, respecto de cómo el docente debe involucrarse en la vida escolar más allá del dictado de clases. “¿Cómo hacés con las reuniones? Te tiran la bronca: ah, preferís la otra escuela, no, no es eso, pero cómo hago... Siempre estamos, bueno, hagamos un esfuercito todos, pero uno de los problemas más graves es el profesor taxi..." (Seguridad e Higiene, O. Electromecánica). El espacio de autonomía es el aula: orientado por una cuidadosa planificación, en la clase se observa un clima participativo, donde los alumnos exploran los simuladores en netbooks y computadoras de escritorio. ${ }^{30}$

${ }^{30}$ Los simuladores, softwares de descarga libre o en línea, son recursos importantes, por ejemplo, en el aprendizaje de la electricidad y la electrónica, para realizar diseños y mostrar el funcionamiento de los circuitos de 
Otros entrevistados enuncian otras variables de análisis, como los cambios del diseño curricular, la pertenencia disciplinar y las características de los cursantes de la ESB. Una docente de Prácticas del Lenguaje argumentaba que la escasez horaria constituye una limitación objetiva a la hora de planificar con TIC, dado que la prioridad es orientar los procesos de transición hacia el nivel secundario, fundamentales para reducir los niveles de fracaso y deserción todavía significativos en la EEST $N^{\circ} 1$. La netbook la pone en una continua disyuntiva: inculcar los habitus de trabajo escolar o motivar el interés de grupos de preadolescentes, heterogéneos y numerosos:

Tengo un 1ero., un 2do. y este 3ero. En 1ero., muchos chicos que venía trabajando bien (la recibieron a mitad de año), dejaron de trabajar. Se ponen en la computadora, no quieren hacer más nada, y yo les hablo pero... vienen bien con la materia y terminan llevándosela... se les habla y demás pero es algo tan... vicio. Pienso que los de 1ero. son distintos, todavía no saben las normas de lo que es la escuela secundaria, no entienden bien si se retiran antes. Hay más libertad, y ellos se toman más libertad, hasta que se adaptan, en 2do. o 3ero...

Binarismos como antes/después, trabajo/vicio, libertad/adaptación, adquieren rasgos relativamente distintos, que permiten a la docente objetivar las contradicciones entre la implementación (que valora favorablemente y ha experimentado en la práctica) y las situaciones de los primeros años de cursada donde comienzan a incorporarse las netbooks. Así, límites menos laxos cobran relevancia en términos de "adaptación al nivel". Actitudes más desafiantes apuntan a explorar recursos en diálogo con los alumnos, las articulaciones entre los niveles educativos, los espacios de trabajo interdisciplinario, todo lo cual excede el currículum prescripto para concebirlo en relación a dispositivos flexibles y problematizadores de la práctica.

En paralelo con la tendencia creciente a la inclusión digital, su realización concreta depende de estas posibilidades "en terreno", la voluntad personal y la comunicación fluida con pares y alumnos, no tanto de las directrices del modelo 1 a 1 . Las capacidades que resultan de estos recorridos se estabilizan relativamente en el ejercicio cotidiano. Cierto es que en la falta de tiempo y la precarización laboral se juegan dificultades objetivas para la innovación, pero transitar por distintas instituciones también dota de una experiencia compleja, integral y contextualizada, donde el docente puede volverse capaz de adecuar sus estrategias, explorar otras modalidades y mejorar sus prácticas ante una multiplicidad de situaciones. Este desempeño no constituye la aceptación de lo dado, sino un acto intelectual, comprometido con la transformación.

\subsubsection{Las Mediaciones Situacionales: posiciones directivas y temporalidades múltiples}

forma virtual antes de su montaje con componentes reales, promoviendo así competencias de observación, interpretación y análisis de los resultados alcanzados. 
El orden de lo cotidiano configura un vasto campo de actuaciones. El lugar por excelencia donde se materializan las mediaciones situacionales es el aula, algo en lo que los sujetos entrevistados suelen estar de acuerdo. No obstante, en el caso de los directivos, los inicios del PCI generan preocupaciones mayormente centradas, por un lado, en las urgencias de la implementación formal, la distribución de los equipos, la instalación de los servidores, las convocatorias a los padres. Por otro, cientos de chicos permanentemente conectados transitando por la institución, constituyen un escenario novedoso. Puede argumentarse que esto no es consecuencia de la presencia de las netbooks; sin embargo, como afirman Dussel y Quevedo (2010), aparatos ubicuos que permiten "estar y no estar" en varios lugares a la vez, promueven en mucho mayor medida que antes un borramiento de las fronteras de los espacios físicos y también de sus reglas y códigos específicos.

Además, los directivos no suelen convocar al profesorado ni involucrarse en las decisiones de integración didáctica, a las que consideran de estricta responsabilidad docente. Implica este supuesto un importante problema comunicacional. Hemos señalado que aquello que los profesores podrían interpretar como la confianza atribuida a su ámbito decisorio, se experimenta en cambio como cierta sensación de desamparo. Pero la razón de fondo no es la desinformación generalizada, sino las concepciones sistémicas que sostienen la estructura escolar. La escuela técnica es particularmente proclive a ordenamientos de este tipo, donde a cada quien se le asigna una función específica y se le impone la obligación de integrarse. La consecuencia inesperada, no claramente objetivada, es la desarticulación entre mediaciones institucionales y áulicas.

De todos modos, los directivos realizan diversas apreciaciones sobre las situaciones concretas que desafían, tensionan o animan esas incorporaciones. Si focalizamos en las diversas temporalidades que expresan estos discursos, sintetizamos:

-Posiciones apologistas: consistentes con el tecnologismo donde la técnica se muestra como afirmación acrítica de sí misma negando toda posibilidad de negación. De acuerdo a Schmucler (1997), propicia no una reflexión "sobre" la técnica sino que produce discursos "desde" la técnica, que es siempre "una y necesaria". Las acusaciones recaen en los docentes por sentirse temerosos o intimidados, unas sensaciones que se suponen comprensibles en un cuadro de incertidumbre, pero que habrán de superarse con el tiempo, una vez que se acostumbren o logren "adaptarse".

Yo creo que va a ser muy positivo, que va a llevar cinco o seis años, para el chico la computadora ya no va a ser una novedad, va a llegar al aula, va a abrir su computadora, se va a poner a trabajar, porque el docente va a estar canchero. Porque ahora está tímido, está reacio: ¿cómo la implemento?... (Vice-Director EEST N ${ }^{\circ} 2$ ).

-Posiciones descalificadoras: discuten los alcances de una política educativa si minimizan los impactos negativos que sobre las situaciones áulicas tiene el acceso personal. Consideran, entre 
otros aspectos, la falta de previsión en los mecanismos necesarios para regular usos contrarios a los propósitos de la enseñanza. La distinción presente/futuro se unifica en un mismo escenario caótico, donde las culpas se desplazan a los estudiantes en directa confrontación con sus docentes: ¡Están desesperados! ¿Para qué quieren las computadoras? Para estudiar, me dicen...Ustedes no las quieren para estudiar, las quieren para jugar. ¡Y es real! Entonces nos falta, porque está tardando mucho, el arma para controlar nosotros las computadoras, porque como meten un jueguito meten una porno, iy meten lo que se les dé la gana!... (ViceDirector EEST $\mathrm{N}^{\circ}$ 2)

-Posiciones indiferentes: implican un estado de apatía en respuesta al desconcierto generalizado, como de preocupaciones que se juzgan más urgentes. Hay además una confusión notable entre políticas que pueden coincidir en la distribución de equipamiento informático, pero atienden a objetivos y lineamientos distintos, como son el PCI y los PMI. Por razones contrarias a las anteriores, estos discursos operan cierto vaciamiento de contenido de la inclusión digital:

Soy una persona que quiero que las usen, que las usen los profesores, los preceptores, porque había muchas computadoras que sobraban y no tenemos muchas acá, hay una en secretaría, otra para el equipo orientador, que es algo que también facilita (Directora EEST N 1).

En la segunda etapa, ciertos procesos de estabilización del modelo 1 a 1 se verifican en el hecho de que las preocupaciones contemplan las prácticas que los usuarios efectivamente realizan o no con las tecnologías, ya no centradas ni reducidas a las netbooks. Las posiciones anteriores coexisten con otras más complejas, de acuerdo a su componente temporal:

-Posiciones tolerantes pero críticas: interpelan a la tarea docente considerando los desfasajes entre las exigencias formales de la planificación didáctica y las dificultades para concretar experiencias no restringidas al dominio operativo. Vale recuperar este relato de la ViceDirectora de la EEST $\mathrm{N}^{\mathrm{o}}$ 2, para quien el proyecto institucional de integración tecnológica no ha redundado en cambios significativos en las prácticas de enseñanza-aprendizaje: “...en las planificaciones se ve un esfuerzo, no es masivo, pero las TIC siguen siendo un soporte. Se sigue usando como procesador de texto o con toda la furia, algún programa para editar videos, ¿viste?”

-Posiciones de acercamiento a las experiencias juveniles con las TIC: acentúan la importancia de la trama de lenguajes que conocen, producen y dominan los adolescentes en sus contextos cotidianos, un capital simbólico valioso que debe ser incorporado en las clases. Estos atravesamientos culturales exceden largamente las determinaciones del PCI, convocando redefiniciones del rol docente que tiendan a la exploración de recursos, la búsqueda de alternativas y una mirada empática o menos prejuiciosa sobre esos consumos juveniles.

A ver, cómo los pibes aprendieron a jugar si no tenían la computadora. Y por qué el adulto no puede aprender. ¿Y está mal jugar al Counter? No, no (...) Entonces cómo tiene que hacer para aprender a manejar estas cosas. Obviamente a mí me parecen importantísimos y 
fundamentales los programas de capacitación, pero de última la decisión sigue siendo personal (Director EEST N 1).

-Posiciones críticas sobre el rol de Internet: según los niveles de conectividad, constituye un deseo o una valiosa posibilidad para aprovechar las infinitas fuentes de información, pero puede tener efectos adversos. Por caso, la relación entre las redes sociales y los conflictos que resultan a menudo de esos usos, devienen en importantes obstaculizadores del clima necesario para favorecer los aprendizajes. En su dimensión temporal, Internet actualiza los dilemas entre la disposición al uso pedagógico y la irrupción del mundo extra-escolar durante el horario de clase.

En la escuela lo que más se nota ahora es que Facebook produce problemas de conducta, porque traen discusiones personales, barriales (...) Y las implicancias es que genera peleas en la escuela. Y ves que la mayoría de los problemas viene de afuera de la escuela, y que Facebook los potencia, porque lo que se dicen o se dejan de decir. Entonces qué hacemos. Internet hay en la escuela porque tienen que usar las netbooks. Pueden usar solamente el servidor pero a veces necesitan Internet, investigar, buscar (Vice-Directora EEST $N^{\circ} 1$ ).

En sus posiciones dominantes, los directivos confirman un tecnicismo consistente con el grado de estructuración con que caracterizan tácitamente a la escuela, un obstáculo para examinar las contradicciones entre las expectativas de innovación y las lógicas tradicionales asociadas al dominio instrumental. Se destaca la voluntad personal, en tanto indicadora de la capacidad del docente de integrarse funcionalmente en respuesta a estos cambios. Con el tiempo se diversifican las posiciones, cuando el foco deja de ser la incorporación de TIC para intentar comprender en su complejidad las mediaciones situacionales que efectivamente dificultan o animan avances sostenidos hacia la digitalización. Se trata de formas de institucionalización que transgreden la antinomia inicial entre el pesimismo y el entusiasmo apologista, proyectando otras posibilidades. Retomando a Schmucler: "La metáfora de la técnica se reduce a explicar el mundo en su funcionamiento maquínico. La poiesis, en cambio, la técnica como creación, instala al hombre en la posibilidad más rigurosa de la metáfora, "ir más allá” (meta-fora)" (1997: 57).

\section{Lo que median las tecnologías: autoridad docente y evaluación}

Recuperando brevemente cuestiones analizadas sobre usos y apropiaciones, confirmamos que las mediaciones situacionales están atravesadas por configuraciones discursivas que caracterizan a las netbooks como herramientas, según las cuales se sopesan sus beneficios en la enseñanza. Cabe recordar que avanzado el año 2012, los docentes no han recibido todavía sus propias netbooks. Esta demora agudiza las sensaciones de destiempo y de exterioridad personal. Pero una vez concretados esos accesos, las disposiciones no se modifican en lo substantivo: 
No sé, la computadora es una herramienta, no es para todo, para todo el día, en algún momento tenés que dejar la computadora y prestar atención a la pizarra. Eso lo negociás al principio con los chicos, si vos hablás con los chicos, los chicos entienden (EEST $\mathrm{N}^{\circ} 2$, Diseño y Procesamiento Mecánico).

Estas posiciones dan cuenta de los desplazamientos entre lugares concebidos como opuestos: pizarras y pantallas, trabajo y juego, escolar y extra-escolar. La netbook es objeto de negociaciones con los alumnos que puede derivar en la aceptación forzosa, extraña a las decisiones didácticas: "a mí no me molesta que pongan la música bajita..." Con frecuencia, las TIC resienten la ya complicada autoridad docente, si esta carece de actitudes reflexivas acerca de cómo mejorar la práctica a partir de las nuevas condiciones de acceso: "Vos ves en otros lados y decís, ah, mirá, pero cuando tienen un momento de descanso no se ponen a trabajar, se ponen a jugar. Vos podés negociar, primero se trabaja, pero después cada uno tiene su computadora...” (Electrónica).

Imaginar el sentido de las tecnologías conlleva otras dimensiones de la autoridad docente. Su sustento es el reconocimiento y la valoración de aquello que funciona como "potencia de origen" (el rol, el conocimiento, la experiencia, etc.), como sus posibilidades de producir algún tipo de desarrollo personal y social (Diker, 2008). Puntualizaremos luego en este tema. Baste decir que los profesores evalúan los dispositivos a su alcance para validar su tarea en estos escenarios. Los Acuerdos de Convivencia Institucional, juntamente con los Acuerdos Pedagógicos, se conciben como recursos válidos, pero de ningún modo suficientes. Nuevamente, la institución revela sus falencias ante una política simbólicamente reducida a la distribución de los equipos y cuyos lineamientos son mayormente desconocidos. Una consecuencia es la resistencia docente que, en el caso de la EEST $\mathrm{N}^{\circ} 2$, no responde a problemas de indisciplina, como a la defensa de la propia autoridad. El discurso expresa la difícil convivencia con las netbooks en las aulas:

No es motivo de conflicto. Eso está en el AIC... no, no sé si está escrito pero supongo que se va a escribir, porque eso se plantea como una problemática, porque te dicen: Ah, ¿por qué con el profesor tal usamos las netbooks y con usted no? Porque no, porque yo estoy explicando y no pueden estar así mirando las netbooks o mirando la ventana, es una falta de atención, una falta de respeto hacia mí. Y si no se ha implementado aún en el AIC lo van a tener que implementar porque va a generar conflicto, si las cosas están claras, firmes, no va a generar conflicto (Geografía, O. Informática y Maestro Mayor de Obras).

El docente se ve interpelado en la construcción de actitudes proactivas en el manejo de las TIC, generando con ellas relaciones crecientemente confiadas, fluidas y con intención didáctica. Pero en lo inmediato, afronta la disyuntiva entre utilizar a favor esa herramienta disponible y evitar las tensiones que la misma genera. Un problema que en la EEST $\mathrm{N}^{\circ} 1$ suele ponerse en términos relativamente simples y de matriz difusionista: el grupo como integración de las partes, el control de la acción individual, la adaptación al cambio, la neutralización del conflicto: 
Un tema es poder controlar a los alumnos. Este es un grupo especial (de 5 alumnos) pero ¿qué hacés con un grupo de 30 o 35 ? Podés estar viendo cada computadora en cada pupitre a ver si están trabajando en la consigna o conectados al Facebook porque lo minimizan y ya está... (Análisis Matemático, O. Química).

La contracara del "desorden" es el "orden": la netbook sirve para "calmar" a los adolescentes, para que "no molesten" y se mantengan "tranquilos". Remite en realidad a una ironía: dos mundos paralelos que no se encuentran, si no es desde una incorporación forzada y empobrecida. Algo especialmente valorado cuando la autoridad se traduce en disciplinamiento de los cuerpos, lo que confiere al aula la ilusión de una comunidad pacífica y de jerarquías establecidas.

Un aspecto positivo es el orden que provocan en el aula. Los chicos están capturados, absortos con esta tecnología. Antes, bueno, entrabas y era un caos. Y hasta que saludás, llenás el libro, era un desorden. Ahora están absorbidos por la netbook. Canalizan el desorden por ahí (...) Donde hay netbooks, no hay desorden. Cada cual está en su mundo. Ahora, ¿cómo hacemos para traerlos a este mundo? (Montaje de Proyectos Electrónicos).

Ahora bien, en opinión de otros docentes, las actitudes desafiantes de los alumnos son casi inevitables, pero el ejercicio de su autoridad es posible si logran someter la netbook a los propósitos de la evaluación. Constituye esta un área particularmente sensible. Puede ser definida como los procesos de seguimiento, control y valoración de los conocimientos adquiridos a lo largo de todo el proceso de enseñanza-aprendizaje. Desde una perspectiva constructivista, la evaluación convoca una práctica reflexiva, articulada con los propósitos pedagógicos, los contenidos y los marcos metodológicos, que recupera los saberes previos de los estudiantes como los intereses implicados en sus aprendizajes. Ahora bien, ¿cuáles son los modelos evaluativos que efectivamente organizan las prácticas, en los esfuerzos de incorporación de las TIC? Y sobre todo, ¿pueden las TIC contribuir a enriquecer los procesos de evaluación?

Los profesores pueden responder con intervenciones conservadoras, fuertemente arraigadas, a las que subyacen modelos de evaluación de base conductista, concepciones del aprendizaje como proceso mecánico y reproductivo. Las interacciones entre el modelo de evaluación predominante y el pensamiento tecnocrático juegan una confirmación recíproca. Al decir de Lipsman (2014), los nuevos métodos con las TIC pueden sustituir a los anteriores dando un aura de modernidad pero sin mejorar concretamente las prácticas vigentes. ${ }^{31}$ En las descripciones del siguiente entrevistado conviven dos modelos. Primero, la evaluación “administrada" valora los conocimientos

31 Acompañamos las críticas de la autora acerca de cuatro supuestos básicos: a- el conocimiento como declarativo, factual y cerrado, no problematizador ni contextualizado; b- el alumno aprende solo "cuando el docente le enseña", lo que impide entender que ese hecho se da en un marco de diálogo y socialización; c- el docente constituye un actor principal, frente al cual el alumno solo reproduce; cuando, en realidad, ambos son actores principales, el docente resignifica su rol como "director de escena": lidera, orienta, coordina, gestiona, etc.; y d- la evaluación sigue anclada en modelos estructurados, lo que se evalúa no es el proceso sino los resultados del producto final. 
alcanzados en términos de eficiencia, como en el caso de los cuestionarios. La computadora agrega agilidad al proceso, pero no redunda en un enfoque novedoso que supere el manejo instrumental. Existen diversas aplicaciones y plataformas en línea que conllevan un saber más o menos experto, pero lo que se pondera son las funciones para reemplazar la carpeta, elaborar planillas de control y medir los resultados finales, incluso en base a sistemas tradicionales del tipo premio-castigo.

También el riesgo es que se copien, porque están en red, pero yo tengo un sistema que no necesitás ser un especialista para darte cuenta: si entregan varios en el mismo momento, y el archivo tiene la misma cantidad de bytes (...) si copian de Internet no es tanto, pero se la arreglan para copiarse entre ellos. Si se copia le digo "fijate, corregilo", porque escribírselo en la carpeta es...bueno... Pero mirá, esto es bárbaro, hasta me saca los promedios, los porcentajes de asistencias... (Proyecto y Diseño Electrónico, O. Electrónica, EEST N ${ }^{\circ}$ ).

Segundo, discursos de este tipo sostienen la expectativa de la respuesta "correcta $\mathbf{y}$ automática" a la consigna, también derivada de modelos conductistas:

Ellos me mandan el trabajo por mail, yo se lo corrijo. Mirá (me enseña su notebook): yo tengo todo en la computadora, le doy los enunciados - por Hotmail, pero es más rápido por Messenger-, ellos buscan en Internet y cuando termina la clase me lo entregan. $\mathrm{Y}$ en estas carpetas -yo acá tengo 3ero., 4to. y 5to.- tengo notas de ellos día por día...

Desde esta perspectiva, la introducción de la tecnología permite un automatismo que en cierto modo habilita una retroalimentación, pero supeditada a los requerimientos de la herramienta y a la cuantificación estricta del tiempo escolar. Defiende la disponibilidad de fuentes, la velocidad en el acceso, la practicidad del dispositivo, pero esos atributos nada nos dicen acerca de qué o cómo aprenden los alumnos ni el grado de significatividad que atribuyen a esos conocimientos.

En atención a la segunda etapa, la calificación persistente de la netbook como herramienta convive con la carpeta como organizadora de los espacios situacionales, sobre todo en materias de área. Representa las resistencias, ahora mayormente solapadas, a ejercitar la creatividad didáctica y a explorar usos más innovadores de las tecnologías. En el caso de la Vice-Directora de la EEST $\mathrm{N}^{\circ} 2$, antes entrevistada como profesora, atribuye continuidades entre ambos períodos de implementación del PCI en relación a actitudes arraigadas en modelos conservadores, basadas en la distancia entre formación técnica y generalista: "Sí, sigue siendo así, hay también diferencias al utilizar la netbook como instrumento, la formación general está aferrada a la carpeta. Que no nos saquen la hoja y la carpeta porque desaparecemos, y no podemos salir de ahí."

Empero, la actitud de "aferrarse" a ciertos recursos no está reservada a la formación general. El deterioro de los equipos, las instalaciones deficientes, las dificultades de acceso al laboratorio, la falta de mecanismos institucionales y, en ocasiones, el desinterés de los estudiantes, son impedimentos muy concretos en materias informáticas: “...si te dicen: está rota, dónde, en casa, 
bueno tráela, a ver si la puede arreglar, y vos no sabés si es cierto, si te mienten, no sabés. No sabés si las tienen, si especulan. Como profesora no podés controlar eso, eso lo tienen que controlar a otro nivel" (EEST $\mathrm{N}^{\circ} 2$ ). La evaluación sigue siendo un problema importante si "se termina haciendo algo tradicional", impidiendo no solo innovar en las prácticas sino objetivar sus contradicciones, los enfoques que las sostienen y sus alcances en los aprendizajes.

Estas tensiones son también frecuentes en la EEST $N^{\circ} 1$, donde las falencias estructurales representan los problemas no resueltos del PCI: "Y con el tema de las tecnologías, son poquitos, cuatro y solo uno tiene la netbook. Entonces vamos a biblioteca. O a la sala de informática, pero el tema es que esta escuela está bastante desprotegida" (Historia, 3er. Año). En relación con el contenido, la cantidad de alumnos y la etapa de la cursada son las opciones disponibles en pos de animar formas más flexibles de ejercer la evaluación: "Porque el único chico que tiene la netbook tiene la batería agotada y como verás no hay enchufes. Pero ellos traen sus tablets o sus celulares y lo trabajamos de otra manera." Secuencias articuladas que comprenden distintas aplicaciones y plataformas educativas, permiten al docente ajustar los marcos metodológicos en función de avances y obstáculos percibidos durante todo el proceso.

Es posible entonces constatar un tercer modelo evaluativo mediado por las TIC. Podemos vincularlo con aquel que Lipsman describe como una fuente para diseñar la clase, es decir, "asociado a la evaluación formativa, en la medida en que estas propuestas de evaluación de los alumnos permiten dar cuenta, en alguna medida, del desempeño docente y sus prácticas de enseñanza" (2014: 219). La planificación didáctica sigue constituyendo una estrategia esencial si intenta resolver cierto efecto de péndulo generalizado: de la confianza en los saberes espontáneos de los adolescentes (que deja librado al azar el ambiente escolar en tanto "los chicos ya lo saben") y los formatos rígidos ligados a la evaluación lineal y la transmisión del saber pedagógico (basados en concepciones instrumentales del conocimiento). La dificultad reside en que estas experiencias no suelen ser comunicadas ni compartidas a nivel institucional. El siguiente desafío es poder encuadrarlas en propuestas colaborativas de evaluación que logren instalar el PCI como un proyecto integrador y racionalmente consensuado.

\subsubsection{Enseñar en (o desde) las Mediaciones Lingüístico-Comunicativas}

Martín Barbero ha insistido en que lo que caracteriza hoy a las culturas juveniles es el profundo dis-locamiento y des-centramiento de los saberes, asociados a la conversación oral, la combinación de códigos, las estéticas y narrativas ligadas al hipertexto. Las nuevas formas de sociabilidad remiten a otras prácticas: "las del chat que descoloca a los maestros por su impura amalgama de 
oralidad con escritura, y las del hipertexto que, en su maleabilidad hipermedial, hace estallar tanto la linealidad de la escritura como su enclaustramiento en el libro" (2015: 15). Nos preguntamos en qué consisten estas transformaciones, cuáles son las mediaciones lingüístico-comunicativas que las tensionan o dinamizan y qué componentes les atribuyen a las propuestas de digitalización de la enseñanza. Tras analizar brevemente a profesores y directivos, nos centraremos en los estudiantes, cuyas prácticas y concepciones se revelan desafiantes de los discursos simplistas, moralizantes o condescendientes que sobre ellos producen los adultos.

Entre estos últimos reconocemos dos posiciones contrapuestas en la primera etapa. Los códigos juveniles son el emergente de las mutaciones aceleradas de una sociedad hiper-conectada, frente a las cuales la escuela parece haber quedado obsoleta. Constituye este uno de los principales argumentos a favor de la inclusión digital; cercanos a la perspectiva de la Ecología de los Medios, asumen como hecho comprobado la superación de las formas tradicionales de lecto-escritura. Sin embargo, eluden al hecho de que las TIC establecen muy diversas relaciones con otras tecnologías (no solo de ruptura), dependiendo de los sujetos que las realizan: "Con el avance de las TIC, qué se empezó a ver: que los adolescentes tenían otras formas de comunicación, que tenían otros códigos, otra escritura. La escuela tenía un formato tradicional, y los adolescentes estaban demandando otro tipo de conocimientos..." (Vice-Director EEST N ${ }^{\circ} 2$ ).

Una ventaja del acceso personal es que permite individualizar la evaluación y adecuarla a los ritmos y necesidades. Pero los usos docentes tienden a la generalización, cuantificando estrictamente el tiempo áulico bajo la lógica de la evaluación administrativa o en tanto dispositivo de control grupal. Y evitan problematizar métodos estructurados ya instalados, que redundan en el aprendizaje memorístico, los contenidos cerrados y con escasa significatividad.

Yo no he tenido problemas. Entramos 13,30 y menos 25 les estoy dando los enunciados. Tienen una hora para trabajar, les pido el trabajo: "No, profesor, no lo hice, o está mal", pero ya saben que tienen el 1. Yo no sé si están en Facebook porque pasás por las mesas y a lo mejor minimizan y ves que están en el trabajo. Pero si no entregan ya saben que va el $1 .$. (profesor EEST N ${ }^{\circ}$, Proyecto y Diseño Electrónico, O. Electrónica).

Paradójicamente, posiciones antagónicas se sostienen en premisas similares, igualmente difusionistas. Bajo la polarización antes/después, una concepción tecnofóbica puede adquirir la forma de resignación: los avances de la tecnología se experimentan como regresivos, pero inevitables. Parece evidente que los jóvenes aprenden de los consumos culturales, pero lo hacen con unos fines, ritmos y modalidades distintos que luego trasladan a la escuela. La experiencia del entretenimiento banaliza los intereses, fragmenta el conocimiento, altera la percepción del tiempo, dispersa la capacidad de atención. Además, genera situaciones de dependencia digital y de maltrato 
de los equipos. Coincide el equipo orientador en este punto: "Esto de la brecha entre la escuela y las nuevas tecnologías hace años que se habla. Y cómo hacemos para atrapar a los chicos, si ellos están con todo esto de las imágenes, de lo audiovisual, como que estábamos atrasados..." Las ilustraciones sirven para referenciar "esto", es decir, aquello que no se puede nominar:

El chico no resiste. Y si no tiene que ir con un pote así de pochoclo, con gaseosa, como si fueran a un picnic. Antes no se comía en el cine, si hacías ruido con un papel de caramelo... Y ahora, si querés ir al cine, si te gusta ir al cine, es un problema, es todo un circo. Hay cosas que han cambiado. O ahora los celulares... (psicopedagoga EEST $\mathrm{N}^{\circ} 2$ ).

Entre docentes "permisivos" y alumnos "especuladores", tolerar el uso del celular parece atenuar los conflictos, pero carece de orientaciones productivas hacia el uso. Los marcadores temporales y los términos adaptacionistas son significativos en la segunda psicopedagoga:

Antes se prohibía, ahora se permite. Lo tienen y algunos profesores los dejan que los tengan arriba de las mesas, porque tienen excusas: que mi mamá se preocupa, que pasó esto, que pasó lo otro... Ahora no hemos tenido quejas de los celulares, es como que nos vamos adaptando, es todo un proceso... Claro, ahora tienen las netbooks. Hay que buscar el equilibrio...

Hacia la segunda etapa, la falta de las netbooks en los salones parece confirmar los maltratos y los usos abusivos, a la par de la obsolescencia de los equipos y los retrasos en las reparaciones. Sin embargo, es un dato conocido que los jóvenes discriminan los usos según preferencias, gustos o necesidades. Con frecuencia, ellos mismos deciden no llevarlas a la escuela, y no se muestran particularmente motivados a la inclusión a menos que responda a objetivos curriculares claros. La Jefa de Informática de la EEST $N^{\circ} 2$ evaluaba que una experiencia pionera de aula virtual no generó los resultados esperados: “...Se tenían que conectar, era un día que no tenían clase, nooo, me quedo durmiendo, pero ante una eventualidad o cualquier problema, que se puedan conectar." Estas situaciones desconciertan a los docentes, pero los animan a explorar estrategias, redes de comunicación menos centralizadas que despierten el interés o que traspasen las fronteras del aula.

Cuando las netbooks comienzan a ser distribuidas en los primeros años, se reafirma la tendencia a tipificar a los estudiantes según pertenezcan al Ciclo Superior o al Básico. Como hemos advertido, estas valoraciones se asientan en las características diferenciadas que los docentes les atribuyen, aquellas que definen las condiciones adecuadas para la ejecución del PCI como para la formación de los futuros técnicos. Es así que a los estudiantes mayores se los describe como maduros, responsables, autónomos y respetuosos de la autoridad docente, con mejor desempeño y compromiso con la escuela, a la que eligen por gusto personal y no solo por influencia paterna. A los cursantes de la ESB se los define precisamente por los rasgos opuestos. 
Quienes pertenecen a la EEST $N^{\circ} 2$ naturalizan en los más jóvenes un estado de inmadurez no solo debido a la edad sino en tanto sujetos a las transiciones hacia el nivel Superior, el cual comprende, en tensión dialéctica, el objetivo de interiorizar los códigos instituidos de comportamiento y de acrecentar aquellos otros asociados a la autonomía. Para la profesora citada, dictar clases en ESB requiere de estrategias diferenciadas: "son muchos chicos, los más chiquitos son más demandantes, no están acostumbrados a las herramientas, los mayores se manejan más solos." Como contrapartida, "tienen menos miedo, y si les decís que investiguen algo, y si lo quieren hacer, lo van hacer. Pero también por ahí rompen, le instalan juegos..."

Los avances hacia la digitalización muestran los límites de las miradas difusionistas: adeudan interrogaciones críticas acerca del potencial educativo de las experiencias interactivas, mediadoras de afiliaciones y modos de sociabilidad que desbordan los tiempos y espacios instituidos y reconvierten las relaciones con el conocimiento. Se trata de asumir otro enfoque pedagógico que no se limita a encontrar sentido al aparato, sino que involucra otras formas de pensar y ejercitar la docencia, con vistas a generar en los estudiantes condiciones para un “aprendizaje auténtico" (Sabelli, 2011). Tales procesos los invitan a explorar, evaluar y discutir lo que aprenden en el marco de actuaciones que les son relevantes, no solo con las tecnologías sino con muchos otros lenguajes representativos, textuales e hipertextuales.

\section{Las experiencias juveniles: modelos heredados, lenguajes convergentes}

Las nuevas condiciones de portabilidad de los equipos abren distintas manifestaciones de la personalización. Para los jóvenes, el acceso físico representa, primeramente, un mundo privado que no se comparte con las familias. Esta posibilidad los iguala material e imaginariamente con otros, sobre todo cuando se trata de la primera computadora y la escuela es el lugar casi excluyente de acceso a Internet, como es el caso de la EEST $N^{\circ} 1$. Sin embargo, el entusiasmo inicial decanta en un acostumbramiento que desplaza el interés hacia apropiaciones más sofisticadas, diversas y selectivas, en convivencia con otras experiencias individuales, con familias y amigos. La sensación de desapego tenderá a agudizarse con el paso del tiempo, produciendo formas más complejas de igualación: "No me atraía, no me atrae... Tengo ahora la netbook y todo pero no le presto atención. Me gusta el fútbol, los jueguitos cuando juego con ellos nada más, cuando jugamos en red. Facebook, sí a veces...” (4to. Año, O. Electrónica).

La cuestión de lo privado se altera fundamentalmente cuando se refiere al aprendizaje escolar, particularmente en la primera etapa. En las comparaciones entre la netbook y la carpeta, las ventajas de una constituyen las desventajas de la otra. El lugar de materialización de lo 
producido (aprendido) lo ocupa, casi de manera excluyente, la carpeta: práctica, segura o "íntima”. Los temores a perder ese conocimiento almacenado contrastan con la sensación de seguridad anclada en la estabilidad del papel, una idea extendida entre estudiantes de la EEST $\mathrm{N}^{\circ} 2$.

Los demás eligieron la carpeta porque, no sé, va más allá de la prolijidad, porque en computadora es más prolijo. Es más íntimo para vos, o por ahí más resguardada, la carpeta la tenés siempre, la computadora se te puede perder o romper... (5to. Año, Electromecánica).

Los contenidos y criterios de acreditación, los materiales que requieren, las modalidades de enseñanza-aprendizaje que las orientan y estructuran, constituyen a las asignaturas en gramáticas de producción de saberes, a la vez depositarias de un mundo de afectos, intereses y preocupaciones desde los cuales los estudiantes esgrimen las razones para incorporar (o no) las netbooks al trabajo escolar. En esta etapa se restringen a las áreas técnicas. Los conceptos negativos sobre jugar y chatear recrean los supuestos de que las relaciones con las TIC son valiosas, placenteras y divertidas, pero conformes a fines educativos, deben involucrar una utilización más responsable. La repetición de términos cumple la función de enfatizar la preocupación sobre la "dependencia":

Yo no uso la netbook, no la tengo, se me rompió, pero todos, todos, la usan para el Facebook. Todo el día con la computadora. Y eso hace mucho mal a todos. Algunos profesores les dicen algo y hay otros que no, los dejan. Y así después desaprueban todas las materias (EEST ${ }^{\circ}$ 1, 6to. Año, O. Química).

Si bien los entornos tecnológicos dinamizan las múltiples narrativas ligadas al hipertexto, estas coexisten con textualidades de la cultura letrada, determinadas tanto por mediaciones escolares como por preferencias de carácter personal. Por ejemplo, escribir en las carpetas o imprimir los textos digitalizados, prácticas que habitualmente son atribuidas a los "inmigrantes digitales". Los estudiantes pueden sentirse abrumados con la presencia de la computadora en el aula; este tipo de referencias son numerosas en la orientación de Informática de la EEST $\mathrm{N}^{\circ} 2$. Como en esta estudiante de 6to. Año: "Todos los días usamos la computadora... A mí no me gusta usar la computadora en las materias de aula. Porque me cansa, prefiero la carpeta..." La apropiación simbólica del libro sirve de resistencia ante actividades repetitivas y poco estimulantes: “¡Estamos todo el día con la computadora! Y cuando venís a la escuela te dan ganas de hacer otra cosa. Bueno, vamos a buscar en libros, vamos a escribir..."

Durante la segunda etapa del PCI, la familia sigue teniendo un lugar preponderante en el mundo afectivo de los adolescentes. Como profundizaremos luego, uno de los rasgos de continuidad generacional está dado por los consumos de otras tecnologías: la televisión configura una mediación temporal que define las actividades y rutinas familiares. En contraste, no hay sobre la netbook una utilización compartida: "Antes igual teníamos computadora en casa, Internet, pero 
esta es mía" (EEST $N^{\circ} 1$, 3er. Año). Pero estudiantes avanzados de la misma escuela ofrecen distintas representaciones, entre ellas, el desapego afectivo que antes encontrábamos solo entre los grupos de la EEST $\mathbf{N}^{\circ}$ 2. Por un lado, el acceso a otros dispositivos móviles ha tenido un crecimiento exponencial en los últimos años y atraviesa todos los segmentos sociales. Por otro, las interacciones con las distintas tecnologías se fundan en las diferencias renovadas entre escolar y extra-escolar; de ahí que la apropiación personal puede estar ligada a otros equipos, mientras que la netbook empieza a ser relegada a la escuela: "En cambio, la mía la tengo a mi nivel, o uso el iPod..." (6to. Año, O. Química).

Además de la distinción entre materias técnicas y de área, los estudiantes avanzados centran su atención en las transiciones hacia el Ciclo Superior. Capaces de valorar estos cambios desde sus propias trayectorias, validan los conocimientos especializados como la adquisición de códigos necesarios en un marco de socialización. Estas mediaciones son el lugar de negociación entre apropiaciones digitales con las relativas al espacio escolar. En la EEST $N^{\circ} 2$ :

Tenemos un lugar, el sucucho, jajaja. Sí, ahí nos juntamos a charlar, jugamos al ping pong. Nos gusta el compañerismo, que a veces no se ve en otras escuelas. Y algunos nos quedamos a comer, y ves a los chiquitos sentados con las computadoras, piensan que están para jugar. Se les informa, sí, miren que esto es para hacer actividad... (6to. Año, O. Electromecánica).

Avanzar hacia la madurez digital aboga por usos que se perciben criteriosos y productivos, y que pueden ser fomentados en compañeros más jóvenes. Las relaciones horizontales (aunque desde una tácita posición de poder) apuntan a la interiorización de normas que regulan cómo moverse en esos espacios, cuáles son las acciones permitidas y cuáles no, cómo comprometerse con la cultura escolar. Pero a la vez definen, recrean y disputan los sentidos de esas actuaciones.

Estas matrices significantes intersectan con las valoraciones que hacen del profesorado. El fortalecimiento que atraviesa la EEST $\mathrm{N}^{\circ} 1$ se torna visible porque atañe al clima del aula, una estructura organizada, modelos comunicacionales más flexibles y participativos, las relaciones empáticas que unen a jóvenes y adultos en un mismo marco vivencial. En contraste, algunos docentes socavan las bases de su autoridad, proyectando sentimientos de descalificación o desconfianza y negando necesidades genuinas que conviven con otras estrictamente educativas. Los contactos con los hogares durante una larga jornada escolar, además, refutan la idea prejuiciosa acerca de la ausencia de los padres o la ruptura generacional con ellos.

Hay profesores que vienen enojados y enseguida te sacan las computadoras, que copiemos en la carpeta. Pero en mi casa no tengo Internet, así que aprovecho acá. Y yo estaba hablando con mi vieja, porque vivo lejos, y me cagó a pedo. No... que estás chateando todo el día. Y le expliqué que estaba haciendo el trabajo, mire, estoy trabajando... (5to. Año, Electrónica). 
Por otra parte, en el $7 \mathrm{mo}$. Año las prácticas profesionales definen una etapa final, ahora obligatoria. En la EEST $N^{\circ} 1$ suelen tratarse de grupos acotados debido a los altos niveles de deserción, por lo cual alcanzar ese objetivo se vive como un triunfo personal y emotivo. También está asociado a las ansiedades que suscita la sobrecarga de actividades, la preparación para el trabajo y las proximidades a la vida adulta. Así describía su jornada diaria este estudiante:

A la mañana tenemos las prácticas, yo en Loma Negra, ellos (dos compañeros) en Ferrosur, al mediodía, bueno, yo antes trabajaba, ahora no, así que me quedo, y a la tarde tenemos los talleres a las 4 . De 1 a 4 dormimos, yo hago deportes así que entreno. Para el tiempo libre tenemos celulares, ahora tendrían que mandar tablets, bah, no sé, igual es incómoda, te seguís manejando con el celular.

A los teléfonos se les atribuyen rasgos positivos que con anterioridad solo calificaban a la netbook: propiedad, portabilidad, practicidad, conectividad, etc. Junto con los tiempos personales, estas características reposan en la creencia de que los dispositivos se modifican por la lógica de la obsolescencia a la que están subsumidos, y surgen permanentemente nuevas aplicaciones y posibilidades para aprender (Cabello, 2013). La tendencia al uso pedagógico deriva del deterioro de las netbooks y de la conexión deficiente, como de experiencias donde las pantallas se reconcilian con la explicación oral, la pizarra y la carpeta, el mate y la música. En estas interfaces cobran sentido las contradicciones de la digitalización: "Por eso usamos los celulares, que están prohibidos, pero incluso los profesores nos dejan usar los celulares, pero para qué tenemos las computadoras si tenemos que usar los celulares” (EEST N², 4to. Año, Informática).

En suma, la educación debe considerar las implicaciones de la convergencia digital: cuando las diferentes retóricas abandonan sus respectivas ventanas en la pantalla y se contaminan entre sí: emergen espacios híbridos que dan lugar a otras formas de comunicación (Scolari, 2009). Asumido esto, el carácter completamente inédito o transformador que suele atribuirse a estos lenguajes, merece examinarse con mayor prudencia. Porque los jóvenes realizan permanentes negociaciones con los modos heredados de leer y escribir, conocer y comunicarse, resignificando las orientaciones de la inclusión digital de acuerdo a sus objetivos de aprendizaje. En estas experiencias encuentran continuidades y discontinuidades con el pasado. ${ }^{32}$

\subsection{Principales observaciones}

${ }^{32}$ En trabajos anteriores (Fernández Massara, 2012b, 2014) discutimos la "revolución cognitiva" producida por la convergencia digital, según entienden las concepciones ecologistas. Si nos centramos en la noción de hipertexto, la lógica multisecuencial necesariamente altera el uso del lenguaje. Sin embargo, no se trata de algo enteramente nuevo ni restringido al entorno virtual; ejemplo de ello es la Rayuela de Cortázar. El lector-usuario pone en juego todo un conjunto de conocimientos previos y habilidades de lecto-escritura, pasadas y presentes, con libros y pantallas. 


\section{Sinteticemos someramente la Dimensión de las Mediaciones Tecnológicas:}

1- Desde unas mediaciones cognitivas, la escuela pretende alentar saberes expertos y crecientemente complejos, pero redunda en incorporaciones predominantemente instrumentales, basadas en sus distinciones taxativas como educación técnica/de área. En posiciones críticas, el acceso personal distrae del conocimiento en las aulas. Con el tiempo, otras formas de concebir y promover los aprendizajes empiezan a disputar esos binarismos de base.

2- El modelo 1 a 1 irrumpe en escenarios normativizados en la EEST $N^{\circ} 2$, ciertamente adversos en la EEST $\mathrm{N}^{\circ} 1$, y la capacidad de decisión y los consensos necesarios para crear condiciones de implementación, son componentes diferenciadores. Con el tiempo, la EEST $\mathrm{N}^{\circ} 1$ muestra un cambio de dirección, capaz de conciliar mayor flexibilidad con los ordenamientos requeridos para la reconversión institucional, junto con la inclusión digital que le resulta favorable.

3- En la identidad escolar se dirime el interjuego instituido/instituyente. La EEST $\mathrm{N}^{\circ} 2$ adquiere continuidad en atributos simbólicos equivalentes al paradigma, fundado en una doble superioridad: sobre la educación media y sobre la EEST $\mathrm{N}^{\circ} 1$. Son numerosas las referencias a la escuela "vida", modelizadora del sentimiento de pertenencia, de la identidad de ser "grasas". Los estudiantes transitan entre el imaginario tecnicista y la experiencia afectiva, entre la novedad y el arraigo de las tradiciones, entre el auto-reconocimiento y la continuidad generacional.

4- La EEST $N^{\circ} 1$ reconoce una identidad precaria, siendo Industrial la contracara, horizonte aspiracional y portadora de valores positivos. Ubica a las TIC en lugares de cosificación consistentes con el modelo instrumental y, con ello, igualmente deshistorizadores. Los procesos de reconversión conducirán a cambios substantivos, mejorando su imagen pública y volviéndose disruptivos del paradigma dominante.

5- Acerca de otros aspectos que hacen a la problemática temporalidad del orden institucional: a- la función de la educación según la antinomia contener/educar, dado que el PCI actualiza las críticas a un supuesto asistencialismo y los consensos sostenidos sobre la prioridad de enseñar; blas reformas neoliberales, ponderando favorablemente, por contraste, los actuales cambios curriculares como fortalecedores de la especificidad técnica; y c- los profesores taxi, pues la inestabilidad laboral y un tiempo fragmentado dificultan la innovación, pero progresivamente animan actuaciones reflexivas y estratégicas en estos contextos de creciente diversidad.

6- En los aspectos situacionales, registramos entre los directivos concepciones apologistas, descalificadoras e indiferentes. La segunda etapa incluye posiciones más flexibles, no excluyentes: tolerantes pero críticas, comprensivas de las experiencias juveniles y centradas en Internet.

7- En la construcción de la autoridad docente se negocian los usos de las netbooks, simbólicamente organizados en opuestos: pizarra/pantalla, estudio/entretenimiento, escolar/extra- 
escolar, orden/desorden, etc. En etapa inicial del PCI prima una introducción forzada, apenas tolerada, incluso disciplinadora. Las relaciones con la evaluación condensan una serie previos, modelos de base conductista, eficientistas y orientados a la respuesta correcta y automática. En la segunda etapa, formas alternativas de integrar a las TIC, en articulación con otros soportes, contribuyen a evaluaciones de nuevo tipo, más flexibles y centradas en el aprendizaje significativo.

8- El enfoque instrumental, el imperativo de la adaptación, la tendencia a disociar los dispositivos de las intervenciones, la generalización sobre los consumos juveniles, aparecen en posiciones de docentes y directivos, incluso si son completamente opuestas. En adelante, una mirada más atenta supone comprender cómo los jóvenes responden a la inclusión digital: pueden oponer resistencia, si esa actividad no está orientada por propósitos didácticos claros y menos centralizados en el dominio operativo.

9- En base a una sólida adscripción identitaria, los alumnos de la EEST $\mathrm{N}^{\circ} 2$ colaboran en procesos de socialización, cuando las prácticas con las netbooks de sus compañeros de ESB contrarían los modos esperados. Quienes asisten a la EEST $\mathrm{N}^{\circ} 1$ reconocen progresivamente un marco de auto-confianza, se afirman orgullosamente en la formación y resisten la mirada prejuiciosa que todavía reciben. En conjunto, ponen en jaque concepciones evolucionistas que han pretendido forzar la integración de las TIC. Valiosas interfaces que no redundan en mutaciones radicales, sino en continuidades y discontinuidades, articuladas con otras múltiples mediaciones.

\subsection{A modo de cierre}

En este Capítulo, nos centramos en las mediaciones tecnológicas en sus múltiples expresiones, de acuerdo a: 1- las características que adoptan las iniciativas de integración de TIC en las aulas, sus contribuciones reales o posibles al mejoramiento de los procesos pedagógicos; y 2- los esfuerzos de institucionalización del PCI, frente a los cuales las escuelas afrontan los dilemas de asumir su propia reconversión como proyecto colectivo y efectivamente realizable. Así, el orden de lo cotidiano se afinca en el plano histórico desde donde se reconstruyen las configuraciones escolares, materializando las tensiones entre lo nuevo y sus modos arraigados de funcionamiento.

Hemos precisado una serie de binarismos que organizan estos marcos interpretativos, se retroalimentan entre sí e imprimen lógicas particulares a las adecuaciones del modelo 1 a 1 . En un nivel institucional: educación técnica/educación media, asignaturas específicas/de área, formación técnica/formación docente y, hacia el segundo período analizado (cuando las netbooks comienzan a ser distribuidas en los cursos inferiores), Ciclo Superior/Ciclo Básico. 
Entre profesores de formación técnica, sus conocimientos autopercibidos los ponen en situación dominante en el campo institucional. Salvo excepciones, adoptan tempranamente a las nuevas netbooks para la enseñanza. No obstante, tienden a emular las experiencias de laboratorio, privilegiando la especialización y perpetuando modalidades de tipo operativo. Por una parte, en el acceso personal y las cualidades de los softwares descansan las expectativas sobre la netbook, simbólica y materialmente retraída a su rol de herramienta. Por otra, estas imágenes contribuyen a la institucionalización de la educación técnica como espacio hegemonizante de la inclusión digital. Para los generalistas, en cambio, los saberes requeridos entran en colisión con sus saberes previos. La netbook se representa como distractiva o bien reducida a sus aplicaciones básicas, sin que puedan elucidarse claramente cuáles son las ventajas de su utilización didáctica.

Resulta paradojal que mientras la institución escolar deviene ausente, constituye la urdimbre simbólica donde estas transformaciones pueden llevarse adelante. En este plano se realizan asociaciones y distanciamientos entre las TIC y las escuelas, entendidas ambas como significaciones imaginarias sociales. En consonancia con los discursos oficiales, docentes y directivos de la formación técnica suelen afirmarse como sus destinatarios naturales, aun cuando seguirán cuestionando los destiempos percibidos en la implementación. Lo que prima en sus valoraciones no es la obligatoriedad del nivel secundario, sino la jerarquización de la formación técnico-profesional frente a los requerimientos de una sociedad global y tecnificada. La distinción relativa a las áreas se difumina a favor de creencias compartidas donde los sujetos ratifican, como un supuesto inamovible, el proyecto cultural de la escuela técnica. Allí se vuelve inteligible la

\section{dialéctica entre los altos grados de estructuración que reivindican, y la potencia desestructurante que ellos mismos motorizan en sus actuaciones cotidianas.}

Paralelamente, los imperativos de la modernización conectan con una memoria colectiva en torno a las políticas neoliberales de los años '90. En ese proceso selectivo, las transiciones actuales hacia el resurgimiento de la educación técnica, articulan de modo consistente con la legitimación del modelo 1 a 1 como política de Estado. Además, estas transformaciones reinstalan un debate clave: la tensión entre enseñar y contener aparece como una dicotomía insalvable. En situaciones de vulnerabilidad social, económica y afectiva, lo más destacado es el retraimiento de las familias en el cumplimiento de esas funciones. Las mediaciones escolares y familiares renuevan la dimensión conflictiva que las involucra entre sí, donde la escuela reclama al mismo tiempo mayor compromiso y se defiende de la intromisión innecesaria. En todo caso, la función de enseñar recibe el consenso unánime, algo que se confirmará con el correr del tiempo, definiendo nuevos interrogantes acerca de cómo los esfuerzos de digitalización pueden operar en esa dirección. 
Confirmamos el hecho de que, antes que una des-territorialización, las mediaciones tecnológicas promueven y dinamizan procesos de re-territorialización. La EEST $\mathrm{N}^{\circ} 2$ es "Industrial", paradigma naturalizado y utopía realizable de lo que de la educación técnica debe ser (y volver a ser) y que se experimenta en presente como escuela "viva". En estas múltiples temporalidades desborda sus límites, para restaurar la potencia evocadora de los imaginarios residuales de la "ciudad del trabajo" y proyectar las conexiones orgánicas con la Universidad. En agudo contraste, la EEST $N^{\circ} 1$ semiotiza un círculo vicioso: una digitalización precaria parece agudizar los problemas identitarios; estos problemas impiden aprovechar las posibilidades del acceso digital. Son sus estudiantes quienes comienzan a reclamar ese territorio compartido, a resistir la marca negativa de su imagen pública, como la falsa antinomia entre desorden y autoritarismo, entre la debilidad institucional y los mecanismos de control desde los cuales la escuela ha intentado resolver infructuosamente los efectos de una identidad fallida.

Entre los directivos, sus distintos posicionamientos hablan de la dificultad para establecer criterios razonablemente unificados, y que al mismo tiempo identifiquen la heterogeneidad de estas condiciones como una variable determinante. Además, no suelen implicarse en los problemas pedagógicos que las tecnologías representan, a los que consideran de absoluta responsabilidad docente. Por su parte, la respuesta del profesorado suele constituir una regresión a modelos conservadores. Por ejemplo, una evaluación eficientista y la netbook como dispositivo de disciplinamiento, una suerte de inversión del problema de la distracción, bajo la ficción del "aula silenciosa" opuesta al paradigma de la movilidad que tanto se pondera. Aunque estos usos tenderán a flexibilizarse con el tiempo, continúan vacantes proyectos de migración digital que realicen la voluntad estratégica de evaluar, diseñar y articular entre sí los espacios institucionales y áulicos.

Tras cinco años de implementación del PCI, una de las escuelas cristaliza su posición de poder en los imaginarios urbanos y en la comprensión de sus realidades cotidianas. Sus activos participantes aportan conscientemente a esa dialéctica constitutiva, involucrando la constante recreación o subversión de lo instituido. La segunda escuela transita procesos objetivos de mejoramiento con vistas a superar su situación histórica de desventaja, en los cuales los actores normalizan progresivamente una reconstrucción identitaria en la que se sienten personal y colectivamente implicados. De este modo disputan simbólicamente el predominio de Industrial y el paradigma hegemónico al que representa. En estos entramados intervienen una diversidad de posicionamientos docentes y juveniles, que se apoyan en el mundo afectivo que ahora comparten.

En sus relaciones con las TIC, los adolescentes producen saberes complejos, si bien no logran objetivarlos acabadamente como un capital culturalmente valioso. Progresivamente advierten que las actividades escolares reclaman unos usos responsables y criteriosos, a la vez que orientaciones 
docentes más estimulantes que los anime a aprovechar esos saberes producidos. En los ambientes áulicos convergen textualidades múltiples, desde las hipertextuales hasta las asociadas a la carpeta y el libro, la música y la televisión, y estos desplazamientos también se producen en los hogares y en la totalidad de la vida cotidiana, cuestionando los márgenes establecidos, todavía fuertemente arraigados, de la cultura escolar.

La temporalidad de la tecnología adquiere otros sentidos. Por caso, la mediación televisiva sigue representando el encuentro familiar, regulador de las rutinas y en tensa convivencia con los dispositivos móviles. Como veremos, estos dispositivos pueden ser utilizados por los jóvenes para mantener el contacto con sus hogares, resignificando unas interfaces mayormente asociadas a la posesión personal. Así, reivindican un mundo de imágenes, vivencias y afectos desde los cuales elaboran subjetividades en disputa con el legado de los padres, pero también establecen en diálogo con ellos importantes dispositivos de identificación. Ratificamos que las culturas juveniles escapan a sus definiciones como "prefigurativas", ya que las diferencias generacionales no suponen rupturas absolutas sino complejas negociaciones, en base a la reconstrucción de los valores heredados y la rearticulación constante de los códigos de pertenencia.

Concluyendo, la centralidad de los cambios motorizados por el PCI no reside en el modelo 1 a 1 , sino en potenciar su dimensión cognitiva, otro tipo de vínculo pedagógico y relaciones más genuinas con el conocimiento. En esas experiencias los sujetos logran redefinir los múltiples espacios que transitan, bajo criterios que no son estrictamente los de las instituciones tradicionales, pero tampoco los de la modernización tecnológica. La pregunta que sigue remite al tipo de competencias que estas mediaciones promueven (o pueden promover), donde las TIC emergen en su densidad política si crean las condiciones para emprender aprendizajes críticos, aquellos que permitan escapar a la sujeción de los modelos establecidos. Es que, como sostiene Cabrera (2009), la autonomía es precisamente lo contrario a la adaptación a un estado de cosas. 


\section{CAPÍTULO 5: PROBLEMATIZANDO A LA ALFABETIZACIÓN DIGITAL: LA COMPETENCIA TECNOLÓGICA}

De lo expuesto hasta el momento, surge que Conectar Igualdad abre oportunidades novedosas, pero son los actores quienes pueden realizar otros niveles de apropiación digital, volviéndose cada vez más competentes en esos usos y más conscientes de sus determinaciones específicas. Las experiencias digitales no constituyen, sin embargo, el espacio excluyente, cuando se trata de hipermediaciones que conectan un sinnúmero de lenguajes y formatos, que circulan por muy diversos ámbitos cotidianos. Nos preguntamos entonces en qué consisten esas competencias tecnológicas, las percepciones y auto-percepciones que se generan sobre ellas, los hábitos y disposiciones hacia su uso escolar o con valor pedagógico, en razón de las permanencias y alteraciones registradas a lo largo de todo el período de implementación del PCI.

Formar en competencias adquiere gran preponderancia porque constituye el objetivo primario de un proyecto de mejoramiento educativo. Es esperable que las nuevas condiciones favorezcan estrategias para articular habilidades instrumentales (una experticia altamente valorada en la educación técnica, consistente con su imaginario dominante) con otras de orden intelectual y comunicativo, de naturaleza ética y afectiva. Este Capítulo empieza por desambiguar las Competencias Tecnológicas a partir de una propuesta conceptual, en el marco de la problemática TIC/educación. Se exponen luego las categorías elaboradas, Subdimensiones Instrumentales, Cognitivo-Intelectuales, Sociocomunicacionales, Axiológicas y Emocionales.

Estos dos últimos aspectos merecen especial detenimiento. Por una parte, la educación debe promover posicionamientos críticos acerca de las matrices hegemónicas donde las tecnologías intervienen; por otra, en las mismas tecnologías los usuarios encuentran modos de interpelación, lugares afectivos que con frecuencia discurren a los márgenes de las orientaciones institucionales. En este punto, el concepto de domesticación aporta otra perspectiva de análisis. Si bien entronca con el conjunto de competencias, atender centralmente a sus vínculos con lo emocional apunta a profundizar en las experiencias donde los usuarios hacen propio un dispositivo tecnológico y lo subordinan a sus propios fines, generando trayectos efectivos y diversificados de subjetivación.

Optamos por terminar el recorrido analítico con un somero resumen donde se enuncian esquemáticamente los resultados del trabajo, a fin de clarificar la lectura. En el cierre del Capítulo se sintetizan los lineamientos generales. Allí se retoma la importancia de la autonomía como eje vertebrador de la construcción de ciudadanía, ejercida en y desde la cultura. En un sentido barberiano, los encuentros entre todos estos ámbitos competenciales registran los desplazamientos 
de lo inteligible a lo emocional, de la razón a la imaginación, en los cuales los sujetos pueden contribuir conscientemente a un desmontamiento de la hegemonía racionalista.

\subsection{Ser competentes en los usos de TIC}

Tradicionalmente, la educación formal ha sido concebida como alfabetización: el proceso de formación de un sujeto para que pueda interpretar las formas simbólicas a través de los cuales se transmite la cultura, así como dominar las herramientas y códigos que le permitan expresarse y comunicarse socialmente. En las últimas décadas, la alfabetización ligada a la lecto-escritura se ha ampliado para implicar alfabetizaciones múltiples, nuevas alfabetizaciones, multialfabetizaciones, alfabetización digital o electrónica (Cassany, 2002). Ya hemos sometido a discusión las aproximaciones apologistas, como las que reivindican la "dieta cognitiva" de los nativos digitales que da sustento a la "revolucionaria infraestructura del conocimiento" que producirían las TIC (Piscitelli, 2009). En cambio, para Área Moreira (2009, 2011), la alfabetización digital supone aprender a manejar los aparatos, desarrollar las habilidades cognitivas necesarias para la obtención, comprensión y elaboración de información, la comunicación e interacción social, y asimismo generar actitudes y valores que otorguen significado moral, ideológico y político a esas acciones.

Vinculamos esta última posición a la Enseñanza para la Comprensión (Stone Wiske, 2006), entendida esta como la habilidad de pensar y actuar con flexibilidad a partir de lo que se sabe. Una posición que da un giro constructivista relativamente diferente cuando afirma que aquello que se construye no son principalmente representaciones (modelos mentales y esquemas de acción) sino capacidades de desempeño flexible. Hay comprensiones que no descansan en modelos mentales, en tanto los esquemas de acción nada agregan a la capacidad de desempeño. En este sentido, la inclusión de las TIC favorecerá el verdadero aprendizaje en tanto desafíe al estudiante no a "adquirir" algo, antes bien, a desarrollar niveles crecientes de comprensión, superando el uso instrumental, la memorización, el pensamiento y la acción rutinarios.

Todos estos aspectos adquieren pleno sentido en relación a una problemática clave, para nosotros la quinta dimensión del problema: la Competencia Tecnológica. Es preciso desambiguar el término "competencia", que ha cobrado fuerza cada vez mayor en los estudios de comunicación/educación. ${ }^{33} \mathrm{Si}$ asumimos a la competencia en su sentido cognitivo, habría que

33 Venido del campo de la lingüística, el concepto remite a N. Chomsky, cuando a partir de la dicotomía saussuriana lengua/habla, avanza sobre la lingüística del habla, distinguiendo la competencia (la capacidad para comprender y producir frases) y la performance (la realización concreta de esa capacidad). Aunque dejaba de lado el contexto sociocultural, este planteo sirvió de base a la noción de competencia comunicativa, ligada al enfoque pragmático de Austin, la "competencia para la comunicación" en Hymes, las clásicas reformulaciones de KerbratOrecchioni y de Eco. En Habermas (1998), expresa distintas categorías de saber: concerniente a las orientaciones de 
asociarlo principalmente con el concepto de habitus en el pensamiento de Bourdieu: el sistema de disposiciones en el que se integran las experiencias, la trayectoria cultural o los modos de adquirir esas disposiciones. A partir de allí el mexicano Jorge González define a la competencia tecnológica "como un sistema finito de disposiciones cognitivas que nos permiten efectuar infinitas acciones para desempeñarnos con éxito en un ambiente mediado por artefactos y herramientas culturales" (1999: 157). En nuestros términos, esta concepción es consistente con la Enseñanza para la Comprensión, en cuanto a la relación dialéctica entre disposiciones y acciones, que habilita el desarrollo de capacidades de desempeño flexible en el marco de estos entornos digitales. ${ }^{34}$

Es posible afirmar que en los usos competentes los sujetos apelan a formas de "domesticar" las tecnologías. Derivados de la etnografía de audiencia de tradición británica, los estudios de domesticación surgen como alternativos a los modelos dominantes, como el de los Usos y las Gratificaciones. Las primeras tematizaciones proponen las relaciones íntimas entre domesticación y apropiación, entendida esta última como el momento en el objeto tecnológico abandona el mundo de las mercancías y el sistema generalizado de equivalencia e intercambio, el sujeto toma posesión del mismo y se convierte en dueño (Silverstone, 1996). La metáfora adquiere notable vigencia para explorar las competencias tecnológicas, particularmente en sus dimensiones emocionales, puesto que los usuarios movilizan en esas experiencias un mundo de afectos donde se juegan modos complejos y diversificados de subjetivación.

Retomando nuevamente a Área Moreira en su modelo educativo integral, contextualizado y globalizador, se contemplan cinco ámbitos competenciales que se producen simultáneamente:

-Competencia Instrumental: relativa al dominio técnico de cada tecnología y de sus procedimientos lógicos, para el uso del hardware y del software o programas informáticos.

-Competencia Cognitivo-Intelectual: relativa a la adquisición de los conocimientos y habilidades cognitivas específicas que permitan buscar, seleccionar, analizar, interpretar y recrear la información disponible, como las formas de comunicación mediadas por las TIC.

-Competencia Sociocomunicacional: relativa al desarrollo de habilidades en la creación de textos de naturaleza diversa (hipertextuales, audiovisuales, icónicos, etc.), difundirlos a través de distintos soportes y establecer comunicaciones fluidas a través de ellos. Involucra también una actitud social positiva hacia los demás, como el respeto y el trabajo colaborativo.

acción racional con arreglo a fines (un saber empírico y un saber analítico) y a la acción racional con arreglo a valores (un saber práctico-moral y también un saber estético-expresivo).

34 No podemos dejar de mencionar el Modelo TPACK (Mishra y Koehler, 2006). Orientado a la toma de decisiones, contempla tres conocimientos, de cuyas intersecciones surge el conocimiento tecnológico-pedagógicodisciplinar. Su utilidad reside en comprender que la integración de TIC requiere de dichas interrelaciones. Entre sus limitaciones, sintetizamos: 1- el conocimiento es simplificado como producto resultante; 2- lo que se nomina como conocimiento tecnológico está restringido al dominio instrumental; 3- deja fuera las competencias emocionales y axiológicas del usuario; 4- se centra en la intervención áulica, omitiendo el contexto sociocultural más amplio. 
-Competencia Axiológica: la toma de consciencia de que las TIC no son asépticas ni neutrales, sino que inciden significativamente en el entorno cultural y político de nuestra sociedad, así como los valores éticos y democráticos con relación a los usos tecnológicos.

-Competencia Emocional: relativa al conjunto de afectos, sentimientos y pulsiones provocados por la experiencia con la tecnología, el control de emociones negativas, el desarrollo de la empatía y el equilibrio afectivo-personal. Implica también la capacidad de domesticar a las TIC, en trayectos de configuración de la propia subjetividad y en la relación con otros.

Ciertamente, la alfabetización digital requiere mayor problematización si tiende a centrarse en el equipamiento informático y en la capacitación docente de tipo operativo. Puede ser reformulada en tanto proyecto de migración digital, como precisamos desde Cabello (2013). Se trata de formar al sujeto en las capacidades de organizar y comprender información numerosa pero fragmentaria, otorgarle sentido en función de saberes previos, desarrollarla como instrumentos válidos para analizar la realidad, para ir más allá de los procedimientos técnicos, el consumo de contenidos o la utilidad a corto plazo. En consecuencia, no es posible escindir las competencias tecnológicas de las competencias comunicativas de vasto alcance, si por tales entendemos las habilidades cognitivas, simbólicas y discursivas implicadas en la producción, interpretación y análisis de significados mediados por las tecnologías, el conjunto de condiciones que resultan favorables a su creación y desarrollo, como asimismo las disposiciones necesarias para ejercitar esas habilidades en contextos socioculturales múltiples.

\subsubsection{Competencias Instrumentales: "un montón de programas"}

Conforme se comienza a implementar el modelo 1 a 1 , crecen las preocupaciones acerca de dos aspectos en relación íntima: el dominio operativo y las competencias requeridas para ello. Predominan las valoraciones sobre la cantidad de softwares instalados en la netbook: “ $i 40$ programas tienen!”. Así, profesores de áreas técnicas pregonan los atributos de la herramienta porque "tiene todo" o, bajo la forma de cierta personificación, "hace todo". Pero a lo largo del tiempo los programas efectivamente utilizados siguen siendo escasos, en continuidad con los usos previos: Word, PowerPoint, buscadores de Internet, simuladores, Geogebra, Autocad, etc.

Conocimientos técnicos precisos que obedecen a la formación de base, ponderan el desafío de la actualización frente a la rápida obsolescencia de softwares y aplicaciones. En ocasiones, estas apreciaciones adoptan la forma de críticas a las imposiciones de la industria informática, si bien en sus aspectos pragmáticos ligados al ejercicio profesional antes que ideológicos: 
...hice un curso para profesionales Autocad 2, del 12 se pasó al 13 que no sirvió para nada (...) Del 2000 en adelante son todos muy parecidos, cambian en detalle en las versiones, no sé si para vender las versiones o qué, hay muy poquitas variaciones (profesora EEST $\mathrm{N}^{\circ} 2$, Matemática, Orientaciones Automotores e Informática).

Pero la posición dominante es que aquella en la que las aplicaciones técnicas están fuertemente sobredimensionadas. Saberes sofisticados y sistemas de creencias arraigados en la especialización consagran una serie de significaciones que no dejan de ser paradojales: la ansiedad que provoca una herramienta disponible y no poder aprovecharla plenamente, la tecnología como presente inmediato y signo de una ausencia, los contrastes entre Internet como mundo de posibilidades infinitas y contextos escolares de precaria digitalización.

Ah, sería poderosísimo. Hay cosas interesantes, cosas de corrientes y tensión. Porque acá faltan instrumentos y no es tan fácil. Pero sé que hay modelos de simulación de circuitos. Hay, pero hay que aprender. Internet tiene un potencial infinito. El tema es cómo implementarlo (EEST N 1, Montaje de Proyectos Electrónicos, O. Electrónica).

Los conocimientos técnicos proveen de bases sólidas para asumir las demandas externas, especialmente socio-productivas, en tanto determinaciones absolutas de la educación secundaria. Están llamados a “evolucionar", según la defensa sostenida que se hace de ellos en el marco de las orientaciones curriculares de cada escuela y sus relaciones con el mundo laboral. El mentado adaptacionismo tiene efectos de sentido aparentemente opuestos: en los siguientes relatos, la convicción de que va a "desaparecer" Informática o de la creciente importancia de la Electrónica.

Sin embargo, un fondo ideológico común adscribe a las premisas de la transversalidad de la técnica, del carácter inasible pero imaginable de los procesos de desarrollo tecnológico:

Esa tecnología es a la que nosotros tenemos que adaptarnos, entonces nosotros tenemos que congeniar con los alumnos, con la industria, con el intendente, a ver qué necesidades hay. Acá nosotros vemos que hay una carrera que se viene muriendo que es Informática, no existe más Informática (...) podés hacer películas, podés compaginar, buscar algo como Gestión Administrativa porque Informática va a desaparecer (Vice-Director EEST $\mathrm{N}^{\circ} 2$ ).

...Electrónica cambia rápidamente, a diferencia de otras áreas, porque la Electrónica es un poco la que atraviesa todas las otras disciplinas, la autonomización, el control, lo aplicás en un proceso químico, en el proceso electromecánico... Ahora la práctica es la que moviliza, tiene que haber una parte de práctica muy importante, también estar referenciada a los contextos laborales que forman parte de la comunidad (Directora EEST $\mathrm{N}^{\circ} 1$ ).

El "nosotros" inclusivo o la impersonalización hacia el "otro", expresan la afinidad hacia las áreas de pertenencia y la consecuente subestimación de las contrarias (percibidas como tales). Las propuestas de capacitación docente convocan muy diversas posiciones enunciativas. La entrevistada anterior adquiere aquí cierto tono condescendiente: "Sobre todo (para) profesores de Lengua, porque los profesores de las materias técnicas estamos acostumbrados a trabajar con 
la computadora, pero un profesor de Historia... no quiere decir que no la sepan usar, tienen mucho interés..." En cambio, la Vice-Directora (comunicadora de formación) pone en duda la utilidad de los cursos si se concentran en las destrezas operativas: "Yo tengo la idea de que van a ser todo sobre herramientas, con manejo de programas, ojalá me equivoque." Nuevamente, el discurso está centrado en la polarización: “Todo el mundo está contento con las netbooks, la escuela técnica es muy seria en estas cuestiones, pero nosotros tenemos una visión muy crítica desde lo social..."

Las competencias instrumentales de los estudiantes adoptan significados difusos, escasamente explorados. A la opinión entusiasta acerca de que "ya saben usar" las computadoras, se contraponen lecturas más cautelosas, advirtiendo que los jóvenes muestran una confianza desmedida en la transferencia de esas habilidades a las tareas escolares: "no son conscientes", "tienen una idea equivocada", "se encuentran con que tienen que estudiar". Pero estas ideas pueden conllevar el propósito de recuperar esos saberes y dotarlos de mayor complejidad y valor educativo. Para una tercera posición, tales saberes no solo son extraños, sino amenazantes. Hemos analizado una situación en la que los estudiantes vulneran las normas básicas de respeto, conversan entre sí, se movilizan por el salón, se arrojan aviones de papel, continúan jugando o chateando. Para la docente, la presencia de la netbook se vuelve material e imaginariamente incontrolable. La falta de dominio instrumental, las diferencias generacionales, el desinterés del grupo, sirven de excusas para asumir sentimientos de autocompasión:

Porque ellos obviamente de computación saben más que yo, y buscamos en Google, pero nada más, no conozco los programas. (¡Chicos! ¡Cuando les retire la hoja se van a calmar!) Yo en casa uso la computadora como máquina de escribir, para hacer los trabajos prácticos. Sé cortar, pegar, imprimir y nada más... (EEST N 1, Física, O. Electrónica).

La necesidad de "motivar" constituye un argumento poderoso a favor de la incorporación de la netbook, definiendo los sentidos de lo permitido y de lo censurado. La tensión que impera en los razonamientos docentes involucra a los videojuegos. Su caracterización negativa frente a las potencialidades de las aplicaciones confirma el lugar de mediación de los contenidos que se imparten, como las dificultades asociadas a la presunta fascinación adolescente por el nuevo aparato. Las situaciones áulicas de la EEST $N^{\circ} 2$ parecen menos caóticas, pero potencialmente conflictivas: "También les dejo hacer los gráficos de torta o de barras en la computadora. Bueno, la motivación es la clave, porque a mí me motiva, pero yo entro al salón y los chicos están jugando con sus netbooks" (Geografía, O. Informática y Maestro Mayor de Obra).

¿Cómo dialogan estas prácticas con las que reconocen los alumnos? La perspectiva de la Enseñanza para la Comprensión nos permite introducir algunas categorías novedosas, bajo el supuesto de que formar en competencias tecnológicas genuinas convoca capacidades de 
desempeño flexible. Recuperados por el enfoque de mediaciones múltiples, conceptos como el de "modelo mental" pueden ser ampliados y complejizados, si se asume que no es condición suficiente para la comprensión: es necesario dominarlo, operar sobre él. Aprender un tópico comprensivamente no reside en construir alguna representación que se adecue al tópico, como desarrollar una capacidad de desempeño flexible alrededor del mismo (Perkins, 2006).

Resulta evidente que los jóvenes aprenden no solo contenidos en sentido estricto, sino en y desde la multiplicidad de sus interacciones cotidianas. Los entornos tecnológicos los proveen de unos saberes des-centrados pero que, además, no responden necesariamente a los modelos mentales o esquemas prácticos que se espera de ellos. Dos pares de significaciones predominan entre los jóvenes en esta primera etapa: a- los nuevos y numerosos softwares de la netbook, que conllevan las promesas de las aplicaciones potenciales en las clases, asociadas a los modos previos de utilización; y b- su correlato negativo, el hecho de que los programas no se utilizan sistemáticamente o de manera interactiva, sumado a que ellos mismos los "borran" para instalar juegos y otras aplicaciones. Desde allí se sopesan beneficios y dificultades del acceso personal:

La netbook, bueno, por un lado, es un problema por la distracción, por otro, es una ventaja porque tiene un montón de programas para trabajar. En Matemáticas, por ejemplo, tiene un montón de programas que te sirven. Para Física, para Química (EEST N 1, O. Electrónica, 5to. Año).

Tenemos para Análisis Matemático, para Física, para Química, para los Talleres, tenemos programas. Tenemos instalado el Autocad que es un programa de dibujo técnico que dibujás en la computadora y después imprimís, indica si el proyecto está bien... Porque a mano alzada te queda desprolijo (EEST N², O. Electromecánica, 5to. Año).

Además de la distracción, la desventaja más mencionada es que la netbook puede facilitar en exceso el trabajo áulico $\mathrm{y}$, en consecuencia, resentir el esfuerzo cognitivo, la atención concentrada, el tiempo dedicado a la lecto-escritura y a la resolución de problemas. Estas nociones contradicen los discursos docentes, tanto si estos exageran o naturalizan los saberes juveniles como si niegan los modos de consciencia que estos ponen de manifiesto. Resulta notable que los estudiantes son más proclives a discutir los efectos de esa polarización, desde las miradas celebratorias hasta las más pesimistas. Por ejemplo, someten a discusión sistemas de evaluación de tipo "administrativo", estructurados y escasamente problematizadores, en los que la mediación tecnológica se ve reducida al instrumento. Así ironizaba el entrevistado acerca del uso del AutoCad: "Cuando había una función, se dibujaba sola, vos ponías la cuenta y se resolvía sola. Una ventaja para nosotros, jajaja. Pero el profesor no nos alienta."

Los softwares de simulación son valorados positivamente en el desarrollo de competencias tecnológicas, claramente delimitadas. En el 6to. Año de Automotores de la EEST $\mathrm{N}^{\circ}$ 2, $\operatorname{los}$ estudiantes admiten que "en las materias normales" no usan la netbook, pero en las "materias 
específicas" la utilizan "todo el tiempo", guardan los manuales, leen los materiales en la pantalla y practican en los simuladores para "probar los autos de turismo de carretera" Otra estudiante agrega que "en talleres sí usamos la computadora. Estudiamos el funcionamiento, cómo se arman y demás. Porque hay profesores que quieren aplicar la orientación a las materias" Así, las distinciones taxativas entre áreas no son privativas de Informática, pero en este campo se torna más visible un dato clave: la aplicación específica contradice en la práctica el atributo percibido de transversalidad y, por ende, las predicciones acerca de su "desaparición".

En síntesis, la carga simbólica de la que es portadora la tecnología en los comienzos del PCI, viene a profundizar la brecha técnico/no técnico, arraigada en los criterios organizadores de la formación. Una brecha constantemente alimentada desde la ponderación casi excluyente de las competencias instrumentales: ser competente significa tener la capacidad de usar con confianza

las aplicaciones informáticas. Este reduccionismo se materializa en el "montón de programas", una expresión que si, por un lado, canaliza los beneficios de la inclusión, por otro, implica dar continuidad a intervenciones con las TIC donde los docentes se reconocen hábiles y seguros. Lo que está ausente en sus discursos es aquello que los estudiantes califican como los riesgos del "facilismo"; si bien ponderan favorablemente los usos instrumentales, pueden reconocer sus limitaciones o prever otras posibilidades de utilización. En estos marcos de comprensión se vuelve un proyecto posible formar en competencias de nuevo tipo, un repertorio de desempeños flexibles que ofrezcan una base para un trabajo sofisticado y significativo en el dominio de las disciplinas.

\section{Lo que permanece: jerarquizar el dominio instrumental}

Cinco años después, el centro de interés ya no es la disponibilidad ni las aplicaciones informáticas, sino que retorna al propósito general de la formación en saberes. Los docentes han creado hábitos de exploración de recursos y experiencias con tecnologías, pero delegan la responsabilidad de la capacitación en las propuestas oficiales del PCI. Además, esos saberes siguen principalmente definidos en torno a sus aspectos instrumentales. Legado de la primera etapa, se verifica un círculo vicioso: los conocimientos tecnológicos validados están asociados al manejo operativo, y en ellos se apoyan las expectativas hacia la mejora de la enseñanza; sin embargo, terminan replicando modelos conservadores, que no generan los cambios esperados, por lo que demandan nuevamente la actualización de tales conocimientos. También se agudiza la sensación de los retrasos de la capacitación: "me parece que el gran rollo que se está entendiendo, por las reuniones, por lo que venimos conversando, es que se largaron las netbooks sin formar a los formadores. Ahora es exactamente igual (que en 2011)" (Vice-Directora EEST N²). 
Si la experiencia demostró como un equívoco que la orientación de Informática estaba destinada a "desaparecer", el incremento de sus cursantes sostiene, paradójicamente, la misma tesis que antes: la omnipresencia de la tecnología y la consecuente jerarquía de los contenidos producidos en el área. La relevancia de las destrezas operativas puede estar marcada incluso entre profesores de áreas no técnicas, como es el caso de la Vice-Directora: “...ahí, sí, se manejan bárbaro en eso pero cuando llegan a 4to. Año y con los profesores específicos. Están con los AP, hacen las redes, se pasan archivos, funcionan divino, pero en una fracción mínima."

En consideración al Informe de UNICEF 2015 sobre el impacto de la política de inclusión digital, podemos corroborar uno de sus enunciados pero contradecir otros. Si efectivamente Informática es la orientación donde hay mayor integración de computadoras, las Ciencias Sociales y Prácticas del Lenguaje no registran necesariamente usos más frecuentes o extendidos; en todo caso, los datos cuantitativos no explican estas diferencias. ${ }^{35}$ En directa relación con el asignatura de desempeño, la formación inicial en esas áreas es el prisma desde el cual se examinan las condiciones percibidas de desventaja respecto de áreas técnicas (y esta situación no es privativa de la educación técnica). De ahí las consideraciones un tanto escépticas sobre los sentidos de la capacitación: "Hay un montón de programas, tienen más conocimientos sobre los programas, han dictado cursos en la Facultad, siempre son de Matemáticas, lo tienen más presentes. Pero el área de Sociales queda más relegada, no hay otro uso...” (EEST N 1, Prácticas del Lenguaje).

Pero en contraste a la primera etapa, los profesores de Informática pueden reconocer dificultades en la implementación. Se trata de apreciaciones con sentido pragmático, que encierran los temores a quedar rezagados en el marco de una modernización acelerada. Las capacitaciones son cuestionadas porque no responden a esas expectativas. Por ejemplo, el programa Maestro permitiría visibilizar las pantallas de los alumnos, bloquear sus dispositivos y tutoriar sus actividades, pero esas funciones requieren de saberes más sofisticados, tanto a nivel instrumental como pedagógico. Esa promesa incumplida convoca una trama de imágenes, deseos $\mathrm{y}$ anhelos en constante movimiento de solidificación, pero que empieza a cuestionar las

\section{imposiciones del tecnologismo dominante:}

Cuando quisieron traer la capacitación, para nosotros no era, porque suponían que los profesores de Informática sabían... supongo que era muy básico. Pero el programa Maestro, por ejemplo, nosotros no sabíamos cómo usarlo, tuve que entrar a Internet, averiguar, leer el manual, iporque nosotros no sabíamos cómo usarlo! Sabemos cosas básicas (EEST № 2, Laboratorio de Programación, O. Informática).

\footnotetext{
${ }^{35}$ Según el informe de UNICEF, Informática es el área de mayor utilización (66 \%), seguida por Prácticas del Lenguaje, Historia y Geografía (22, 20 y 17 \% , respectivamente) y por Matemática, Artes, Física, Química y Biología $(13,12,9,8$ y 4 \%). Cabe aclarar que el estudio discrimina entre Ciencias Sociales, Naturales y Exactas, a diferencia de nuestro trabajo que, siguiendo las percepciones de los entrevistados, distingue materias técnicas/de área (que incluyen los tres bloques), formación profesional técnica/docente y también formación específica/formación general.
} 
En otros casos, esos niveles ostensibles de desconocimiento pueden traer aparejados la negativa de incorporar a las TIC, explorar los recursos que estas implican o buscar alternativas para actualizar la formación: "Yo jamás entré a los programas de PCI, nunca vi los tutoriales ni nada. No me interesa. Por ahi la traigo y se las presto para que trabajen." (EEST N 1, Montaje de Proyectos Electrónicos, O. Electrónica). Este posicionamiento es consistente con la subestimación de los saberes instrumentales de los alumnos, la mirada es ajena y poco comprometida: "Y como ellos son técnicos lo primero que hacen es desarmarlas..."

Otro aspecto destacado refiere a los cambios curriculares que instituyen los propósitos de la modernización, en torno a los problemas de adaptación de los profesores de mayor antigüedad. Las diferencias generacionales pueden reducir una multiplicidad de factores, acentuando el tono pesimista de esta docente, de formación técnica, muy joven y egresada de la EEST $\mathrm{N}^{\circ} 1$.

...en Lenguajes Tecnológicos, se divide en Dibujo Técnico e Informática, y cuando tienen que dar Informática me dicen: qué doy. Entonces terminan dando solo Autocad. Que no lo dan, hay también generaciones que quedan medio descolgadas. Obviamente los profesores más viejos es distinto que los recién egresados que lo manejan de taquito.

No obstante, los avances de la adecuación del PCI se demuestran en posiciones donde las competencias instrumentales involucran nuevos dispositivos, otros ámbitos competenciales y en situaciones de interactividad. Entre ellos: 1- los accesos personales, determinados por el tiempo material y la disponibilidad de los equipos; 2- los acuerdos interdisciplinarios para promover o profundizar proyectos formativos de competencias diversificadas; 3- las relaciones de empatía con los estudiantes, articulando los aprendizajes espontáneos con muchos otros que requieren de la orientación docente. En estas claves operan las reelaboraciones del nudo significante del “montón de programas" hacia las limitaciones y posibilidades percibidas en la práctica:

Tenés un montón de programas, de aplicaciones, que se podrían adaptar. Yo también doy Lenguajes Tecnológicos en 3ero. y nos pusimos de acuerdo con los docentes a enseñarles a hacer mapas conceptuales en el Cmaps Tools. Yo no tengo tiempo de empezar a mirar, pero ellos pueden, y les interesa mucho. Ver para qué sirven tales cosas, por ejemplo, el AutoCad, ellos dicen que lo saben, cuando hacemos planillas de Excel pensamos que saben, pero se quedan mirando... Ah, ¿no era que sabian? (EEST № 2, Seguridad e Higiene).

La opinión compartida es que los jóvenes se muestran dispuestos al uso pedagógico de los equipos, pero en ocasiones, presentan actitudes negativas, incluso resistentes, que no se condicen con las competencias instrumentales y cognitivas que supuestamente ostentan los "nativos" (dominio operativo, multitarea, lectura hipertextual, trabajo colaborativo, etc.). Para el docente, fomentar el interés en estas actividades se convierte en un desafío cotidiano, especialmente frente a grupos numerosos y con dispares desempeños como los que componen la ESB: 
Hay mucha negación ante lo que no conocen. No lo conozco, lo dejo. Usamos Movie Maker, pero nadie lo entregó. El tema del uso de las TIC es romper ese obstáculo de que no lo entiendo no lo hago. Ante el mínimo obstáculo, no me sale, no lo entiendo, lo dejo... (EEST $\mathrm{N}^{\circ}$, Historia).

En lo que respecta a los discursos juveniles en esta segunda etapa, la presencia de las computadoras no es especialmente valorada cuando solo "se usan porque están". De acuerdo a estos estudiantes de la EEST N²: "Las profesoras no saben hacer bien un PowerPoint o un Prezi. Es la impresión que yo tengo porque tampoco están usando las computadoras, nosotros somos las que las usamos, nos hacen usarlas, pero ellos tampoco explican” (6to. Año, O. Informática). "En Lenguajes Tecnológicos usamos un programa para hacer planos, no sé cómo se llama, pero usamos la sala de informática, no la netbook" (3er. Año). Una mayoría entiende que el desarrollo y aprovechamiento de las competencias instrumentales de sus docentes son componentes importantes, pero no suficientes. Aunque no logran comprender plenamente sus implicaciones, asumen que una mirada docente estrictamente apegada a esas habilidades tiende a relegar otras potencialidades didácticas del uso digital. Unos supuestos que incurren en interpretaciones acerca de cómo la tecnología ha de subsumirse a los requerimientos del aprendizaje, y no a la inversa.

Parte de estos procesos de madurez digital es la consciencia en torno a las contradicciones entre las condiciones de acceso a las netbooks y la falta de previsión de los saberes docentes, actualizados y específicos, que incumben a su utilización. Estas reflexiones no conducen a menoscabar la autoridad docente, sino a ponerla en un marco dialógico, en redes de intercambio y trabajo colaborativo. Los retrasos de las capacitaciones también pueden servir para justificar las deficiencias de esa inclusión. Este estudiante de 6to. Año parece apelar al sentido común:

La capacitación docente tendría que haberse hecho antes de entregar las computadoras, eso es lógico, ¿no? Si querés que los profesores usen con los chicos las computadoras, antes tenés que capacitarlos a ellos. Falta capacitación, porque hay profesores que los tenemos que ayudar nosotros. No es culpa de los profesores si no los capacitan (O. Electromecánica).

Para finalizar, no podemos dejar de mencionar las operaciones discursivas a partir de las cuales se nominan a las orientaciones como "carreras", homologándolas a las carreras universitarias. En consonancia con los cambios y continuidades que hemos analizado, el concepto de "carrera" bajo esta acepción se mantiene a lo largo de todo el período en la EEST $\mathrm{N}^{\circ}$ 2. Las referencias son explícitas: "la carrera de Informática", "dos carreras espectaculares", "una carrera técnica pero de nivel secundario." Asumen diversas connotaciones, priorizando a la formación técnico-profesional en el desarrollo de competencias indispensables para ingresar a las carreras técnicas de nivel universitario. La asociación simbólica con Ingeniería es casi excluyente. 
La diferencia con la EEST $N^{\circ} 1$ merece ser destacada. En los inicios del PCI, en esta escuela la referencia a las carreras universitarias está ausente por completo. Desde relaciones conflictivas, sensaciones de pesimismo, problemas identitarios, se atribuyen otros sentidos a las orientaciones, socialmente menos prestigiosos pero que abrazan una proyección más concreta, como es la formación para el trabajo. Emergente de las transiciones que atraviesa la escuela, el término "carrera" así entendido aparece recién en la segunda etapa. Es portador del mejoramiento objetivo de las orientaciones como de las definiciones implícitas de la universidad como un horizonte posible e imaginado. Se verifica, además, un reforzamiento de la formación laboral, que se inscribe en los acercamientos y alejamientos simbólicos entre ambos centros educativos, en los cuales las competencias instrumentales ocupan un lugar privilegiado y dinamizante. En todo caso, en el nudo semántico trabajo/universidad encuentran articulaciones coherentes con los requerimientos diversificados de la Sociedad del Conocimiento.

\subsubsection{Competencias Cognitivo-Intelectuales: la capacitación docente}

Las propuestas oficiales de capacitación se orientan a dar impulso a los docentes para explorar, evaluar y enriquecer sus experiencias con las TIC. Con este sentido se implementa en 2011 el Plan Escuelas de Innovación, a fin de desarrollar acciones que acompañen los objetivos estratégicos del PCI. Tiene como propósitos: a- fomentar y mejorar el uso de TIC en las prácticas de enseñanza y la gestión institucional, y b- ofrecer propuestas documentadas de enseñanza y gestión con TIC en todas las escuelas. Propone un conjunto de acciones de formación presencial y acompañamiento on-line a los actores educativos, que incluyen cinco módulos: Matemáticas, Ciencias Sociales, Ciencias Naturales, Competencias Digitales y Narrativas Digitales. En 2015, es aprobado el Plan Nacional de Inclusión Digital Educativa (PNIDE), al que se subsumen el PCI y Primaria Digital, a fin de intensificar el uso digital en la mejora continua de los procesos escolares. A ello se suman los contenidos digitales disponibles en el Portal Educ.ar, la oferta de cursos dependientes del INFOD (Instituto Nacional de Formación Docente) y la Especialización TIC y Educación.

Entre los docentes, las netbooks constituyen la materialización primera e inmediata, a la vez que símbolo, de los propósitos escasamente comprendidos de una política de inclusión digital. Afirmamos que la capacitación docente constituye un segundo símbolo o nivel de representación. Las inquietudes en torno a ella se mantienen a lo largo de todo el período analizado y encuentran anclaje en las orientaciones de la Sociedad del Conocimiento. Salvo excepciones, la disposición hacia la capacitación docente (no siempre su realización concreta) es directamente proporcional a los esfuerzos de integración de las TIC. 
En consideración de los agentes involucrados, podemos acompañar a grandes rasgos la categorización propuesta por Brunner (2008): 1- un grupo reducido de innovadores tempranos (early adopters); 2- quienes apoyan a los primeros y se constituyen en una mayoría temprana; 3una mayoría tardía que se va integrando con lentitud a los grupos anteriores; 4 - un grupo totalmente renuente a la incorporación de estos cambios. Pero la problemática de la capacitación añade más complejos componentes a estas posiciones, en las cuales establecen entre sí sucesivos acuerdos, matices y desplazamientos en sus transferencias -o la falta de ellas- al ámbito escolar.

Durante la primera etapa, la percepción preponderante, incluso entre los pioneros o innovadores tempranos, es la de retraso, dificultando el aprovechamiento de una oferta amplia y diversificada de cursos que hubieran generado un capital cognitivo de relevancia para poder adoptar las netbooks con solvencia, de manera eficaz y sostenida en el tiempo. ${ }^{36}$ Este es el común denominador de una diversidad de posiciones, entre ellas:

1- Posiciones favorables en torno a los alcances de la capacitación: docentes que pertenecen a áreas informáticas o afines, son los primeros convocados como facilitadores TIC. ${ }^{37}$ Reconocen relaciones orgánicas entre su disciplina de base, experiencias previas de capacitación y el acceso a información sobre el tema que los pone en situación privilegiada con respecto a sus pares. Como la Jefa del Departamento de Informática de la EEST $N^{\circ} 2$, en cuyo discurso el tiempo presente es indicativo de un aspecto material, las acciones personales (no colectivas) para afrontar eficazmente las urgencias de la difusión tecnológica, y otro representacional, los significados acerca de la obsolescencia de los saberes asociados a tecnologías en rápida transformación.

Estoy haciendo la capacitación de PCI, es un seminario, hubo charlas técnicas y siempre estoy capacitándome en lo que tiene que ver con mi área. Ahora va a haber cursos de PCI, hoy nos llegó un mail para los primeros días de junio, que son capacitaciones específicas para trabajar con las netbooks...

2- Posiciones favorables pero dudosas, basadas en la formación técnica: los profesores técnicos no suelen mostrarse particularmente dispuestos. Algunos acompañan las propuestas alertando acerca de su impacto en la formación: la estructura docente, la organización institucional, los métodos de enseñanza, tienden a perpetuar modelos conservadores que priorizan la integración

${ }^{36}$ El informe Nuevas voces, nuevos escenarios (2011) hace una descripción exhaustiva de las capacitaciones y de recursos disponibles en el Portal Educ.ar, destinados a la sensibilización, la alfabetización o profundización en saberes digitales y otras acciones de seguimiento, evaluación y sistematización. Se destaca el armado territorial de los equipos directivos, lo que habla de la importancia temprana que el Programa asigna a la institución escolar. Pero si se demuestra una apertura a procesos más novedosos, sigue siendo un desafío el desarrollo de proyectos colectivos, la búsqueda de respuestas orgánicas e institucionales a estos cambios, como también sostiene Maggio (2012).

${ }^{37}$ Las escuelas se ven afectadas por una presencia desigual de administradores de red, referentes técnicos, coordinadores o facilitadores TIC. La capacitación constituye un compromiso personal, pero no redunda en estrategias sostenidas de contención, apoyo o acompañamiento de los colegas. En nuestro caso, la referencia al facilitador está ausente, o bien circunscripta a las tareas de asistencia técnica (desbloqueos, reparaciones, conexiones de red, etc.). 
instrumental por sobre la innovación pedagógica. En ocasiones, trascienden su área disciplinar, para poner el acento en la cultura escolar, en vías a una "reculturización" (Fullan, 2002) que transforme los hábitos, habilidades y prácticas hacia una comunidad profesional más amplia.

En Media se va a ver más el problema, creo, porque el profesor de técnica es muy particular (se le pregunta por qué). Por su formación, la mayoría son técnicos o ingenieros, yo soy ingeniero. El profesor de Media tiene una mayor trayectoria pedagógica y está más preocupado por lo pedagógico (...) además porque en escuela técnica hay toda una relación con la tecnología... (EEST N 1, Montaje de Proyectos Electrónicos, O. Electrónica).

3- Posiciones desfavorables debidas a los destiempos de la capacitación: puede ser calificada negativamente incluso entre quienes se encuentran participando en ella. Los desfasajes respecto de la temprana distribución de las netbooks tornan dudoso no tanto la significatividad de estos saberes, sino sus potencialidades de transferencia a las situaciones de enseñanza. Además, será necesario ajustar los tiempos de implementación en función de las necesidades inmediatas de sus destinatarios. La capacitación formal no es obligatoria pero se vivencia como tal:

Porque ahora estamos haciendo cursos, cuando las netbooks están desde el año pasado. Pero todo eso debió hacerse previo a la entrega de las netbooks, y si nosotros hubiéramos estado medianamente capacitados, saber qué estrategias utilizar o cómo usarlas. Después de eso, sí. (EEST N 1, Físico-Química y Química, O. Electrónica).

\section{4- Posiciones desfavorables acerca de la utilidad o los modos de implementación: el} docente difícilmente se manifieste del todo en contra de la capacitación continua, pero encuentra diversas formas para manifestar su malestar ante situaciones que escapan a su control y le generan inseguridades personales. Los sentidos evasivos del "deber ser" aparecen expresados en un tiempo potencial, por desconocer las ofertas de cursos o no sentirse implicado en ellas: "No, no, qué... ¿hay? Sí, haría falta para capacitarnos nosotros, para tomar consciencia, para tomar medidas” (EEST N ${ }^{\circ}$, Física, O. Electrónica). Algunas posiciones refieren a experiencias previas en Centros de Investigación Educativa (CIE), INFOD, etc. Problematizan los contenidos, la organización o formas de desarrollo, si no han resultado en aprendizajes significativos que justifiquen la inversión de tiempo y esfuerzo, un tema sensible en situaciones de sobrecarga laboral.

...hace como cinco años hice un curso, creo que de Ministerio de Educación: teníamos que hacer con el área de Sociales, Naturales e Informática un software. Pero no fuimos bien asesorados y quedó en la nada. Además hace cinco años tener la computadora en el aula era como impensable. No sé si puedo contarte esto, pero la tutora nos dijo que ella tenía que justificar el gasto de la capacitación. Está bien que se gaste en capacitación, pero algo que cierre el círculo, ¿me entendés? (EEST N², Geografía, O. Informática).

\section{5- Posiciones de subestimación debidas a la formación inicial, la auto-confianza o los}

recursos disponibles: como dijimos, en contraste a las previsiones del PCI, los profesores de formación técnica no siempre se muestran predispuestos. La capacitación se representa como algo 
impuesto pero además, innecesario. La actitud es más bien de resistencia, negando las complejidades de la propia práctica y perpetuando usos digitales instrumentales y poco novedosos. "Estar en la salsa", "en el mismo ambiente", "hablar el mismo idioma", "estar empapado", son términos que relegan lo diferente, lo "problemático". En una de las citas antes analizadas:

El problema es la capacitación. Y esa capacitación que ha llegado de las netbooks es para nosotros problemática, digo, para nosotros, los que venimos de la Ingeniería o las carreras más técnicas. Yo estoy haciendo un curso de PCI, es de introducción... eh, no sé cómo se llama... (EEST N², Diseño y Procesamiento Mecánico).

Un grupo significativo constituye la excepción a la relación entre disposición a la capacitación e integración digital, en los términos señalados. En esta joven profesora, sus conocimientos auto-percibidos dan sustento a cierta descalificación hacia profesores de mayor antigüedad que no están familiarizados con las TIC. Solo para estos casos, considera a la capacitación relevante y necesaria. La exploración personal se pone al servicio de la planificación, demuestra auto-confianza e iniciativa en las decisiones, pero a consecuencia de desautorizar propuestas formativas que podrían enriquecerlas:

No todos los profesores tienen idea del uso. Convengamos que hay profesores que vienen trabajando desde hace mucho tiempo y por ahí tienen desconocimiento sobre el uso. Para el que la necesite (la capacitación), me parece bárbaro (...) Yo estoy todo el tiempo buscando recursos, entonces quieras o no estás un poco al día. Vivo investigando. Si a mí me decís: ¿necesitás? Te digo: no, porque ya lo tengo incorporado (EEST N 1, Inglés, O. Química).

La segunda etapa del PCI apunta a paliar las deficiencias de la formación docente, a partir de una difusión amplia de capacitaciones encuadradas en diferentes organismos, bajo distintas modalidades, encuentros institucionales y con diversificación de las áreas disciplinares. El programa más novedoso en este sentido es el PNIDE. Es por demás conocido que las netbooks y otros dispositivos todavía no tienen una presencia sostenida y pedagógicamente fundada en el contexto de clase, al tiempo que están directamente ausentes en los proyectos institucionales. ${ }^{38} \mathrm{La}$ coordinadora regional explica que los cursos incluyen a todos los niveles, Primaria, Formación Docente, Media y Técnica, organizados en los incipientes encuentros de núcleo:

Son tres talleres: de Ciencias Sociales, de Ciencias Naturales y de Prácticas del Lenguaje. Están enfocados a la inclusión de las TIC en el aula en esas áreas. Por ejemplo, en Ciencias Naturales para hacer documentales, en Prácticas del Lenguaje para hacer cortos de ficción basados en lecturas de libros, y en Ciencias Sociales para usar un software de imágenes...

${ }^{38}$ Coincidimos con el informe de la segunda etapa del PCI Cambios y continuidades en la escuela secundaria. Las universidades públicas conectando miradas (2015), acerca de que los profesores explicitan el reconocimiento y la valoración de las propuestas de formación continua. Pero en nuestra investigación, una mayoría no ha participado de las capacitaciones formales, tampoco en ámbitos académicos como congresos nacionales o universidades. En cambio, destacan las capacitaciones en servicio en el marco del PNFP y la Especialización TIC y Educación. 
Mención aparte merece la Especialización de Nivel Superior en Educación y TIC (Res. ME $\mathrm{N}^{\circ}$ 856-12), dependiente del INFOD, cuyos propósitos son: formar a los docentes de educación secundaria, modalidad especial y formación docente en el uso pedagógico de las TIC, promover nuevos saberes para la enseñanza-aprendizaje y estimular la reflexión sobre las prácticas. ${ }^{39}$ Si bien se implementa en 2012, el Postítulo adquiere presencia en los discursos, representaciones y actuaciones en esta segunda etapa, un hecho consistente con conocimientos más extendidos. Conlleva una diversificación de las áreas disciplinares y temáticas hacia 2015 (Alfabetización Inicial, Matemáticas, Literatura, Ciencias Sociales, Ciencias Naturales, Prácticas Socioeducativas, Derechos Humanos, entre otras).

La coordinadora de la Especialización que se dicta en la sede del ISFD $\mathrm{N}^{\circ} 22$, explica que si bien la propuesta no está formalmente articulada con el PNIDE, configura una valiosa experiencia que puede predisponer, acompañar y favorecer los procesos de integración pedagógica bajo las orientaciones de Conectar Igualdad. Tratándose de una carrera de 2 años de duración y a pesar del importante interés que demuestran los cursantes, un dato objetivo son los niveles sostenidos de deserción, mayormente atribuidos a las situaciones de sobrecarga laboral:

Yo creo que muchos trabajan muchas horas, dejan todo para el fin de semana y no alcanzan a leer toda la bibliografía obligatoria, que esa lectura además sea a consciencia, para que sea beneficiosa. Como coordinadoras los orientamos. Hay gente que sigue con mucho sacrificio, pero es exitosa, ha tenido muy buenos resultados...

Actualizar los saberes previos resulta elemental para mejorar las estrategias de intervención didáctica en marcos de rápidos cambios educativos, pero las preocupaciones personales y laborales pueden privar al profesorado de participar activamente de esas propuestas. Identificamos:

1- Posiciones favorables pero que contrastan con las dificultades de realización: esgrimen distintas razones, sobre todo, la falta de tiempo disponible. También señalan la necesidad de marcos institucionales capaces de animar, gestionar o direccionar espacios formativos adecuados a las configuraciones de cada establecimiento. Esta situación es destacada entre el profesorado de la EEST $\mathrm{N}^{\circ}$ 1, en escenarios de reorganización donde las tecnologías tienen aún un lugar evasivo. Los encuentros de PNFP, en horario de servicio y de carácter obligatorio, suelen presentar escasa significatividad. ${ }^{40}$ Hay que resaltar, además, que los adoptantes tempranos no han propiciado acciones de apoyo u otras modalidades de transferencia:

${ }^{39}$ Disponible en: http://postitulo.educacion.gov.ar/

${ }^{40}$ E1 PNFP 2013-2016, aprobado por Res. 201/13 del CFE, apunta a fomentar acciones de capacitación integral, gratuita y en servicio que involucren al universo total de los docentes del país, con características únicas y estrategias combinadas. Entre los contenidos generales para el nivel secundario, se comprende la "enseñanza de la disciplina mediada por las TIC". Disponible en: http://www.me.gov.ar/consejo/resoluciones/res13/201-13 01.pdf 
Yo en mi caso no hice ninguna capacitación y por lo que he hablado con otros docentes, estamos todos más o menos igual, porque la última reunión, la última jornada del viernes, los profesores pedimos una capacitación (...) Pero si vos no venís en ese día y no tenés libre, no te justifica la falta en otra escuela... (Prácticas del Lenguaje, 3er. Año).

Junto con su orientación pragmática y la reciente diferenciación por áreas, un Postítulo de calidad constituye un proyecto personal largamente ambicionado. Un número significativo de docentes muestran interés en esa propuesta; el obstáculo es también la falta de tiempo:

... no me dan los tiempos, es la tercera vez que la empiezo. A su vez yo soy docente en Seguridad e Higiene a distancia en la Facultad (Ingeniería), me insume mucho tiempo conectarme y responderle a cada uno. Y le saco tiempo a otras cosas. Y me da un poco de vergüenza, pero ¡la verdad es que no me da el tiempo! (EEST N 2, Seguridad e Higiene).

Dos años es mucho tiempo, y para el profesor que tiene muchas horas en escuelas distintas con materias distintas, es complicado encontrar el tiempo. Y más que desde la escuela se pretende trabajar con proyectos, con distintas actividades y modos de llegada y obviamente eso lleva más tiempo (EEST N², Laboratorio de Hardware).

El siguiente entrevistado es el único caso que ha logrado concluir la Especialización TIC y Educación. Reflexiona que, además del tiempo, importan las "necesidades" personales; su propia experiencia le llevó “dos años y medio" y "mucho sacrificio". En un distinto nivel de valoración, igualmente positivo, pone a otros espacios de formación en los que ha participado, de directa transferencia a las secuencias didácticas de integración eficiente de las TIC:

La mayoría de los cursos los he hecho del CIE, lo he aprovechado bastante, me lamento no poder seguir porque la superposición horaria porque son fuera del servicio. Sí, me han servido muchísimo. Están relacionados con radio, lo he utilizado mucho, he hecho radioteatro, he hecho cursos de edición de video en Movie Maker. El otro día hicimos uno acá, un corto de ficción. (EEST N ${ }^{\circ}$, Sistemas Productivos y Derechos del Trabajo).

2- Posiciones favorables pero críticas de los contenidos o modalidades: desde el área de Informática se intenta explicar por qué la capacitación no ha alcanzado a una mayoría del profesorado, como esta docente de la EEST N 2: "Y lo que faltó fue capacitación, más que nada de los profesores de área, porque los profesores no hacen las capacitaciones virtuales. Alguien de Informática se puede capacitar por Internet, pero para alguien que no está familiarizado no es fácil." Se objetan objetan los sentidos, la factibilidad y la pertinencia de la Especialización.

Yo creo que lo que sigue faltando es capacitaciones presenciales y por área, por ejemplo, a los profesores de Matemáticas los capaciten en el uso de programas de Matemáticas, porque la mayoría cursar por Internet no es tan cómodo, se necesita intercambio, el apoyo pedagógico, para llegar a la gente grande y más para docentes de área. El Postítulo es semipresencial, la mayoría de la gente quiere aprender a usar una herramienta o dos... 
3- Posiciones favorables pero que enfatizan los destiempos acceso/capacitación: sobre la dimensión cognitiva se soportan los desplazamientos discursivos desde los aparatos hacia los saberes producidos. Pero si hay un consenso acerca de las conveniencias de la capacitación, los retrasos en las decisiones del PCI explican en buena parte las dificultades generalizadas, una sensación que se agudiza respecto de la primera etapa. El tiempo pasado refuerza una memoria colectiva: "El gran problema fue la capacitación docente, llegó mucho tiempo después entonces se generó... si bien hay mucha predisposición. Yo soy además coordinadora del Postítulo y te das cuenta de que hay predisposición, pero llego mucho después...” (EEST N 1, Historia).

4- Posiciones desfavorables acerca de la capacitación: excepcionales pero persistentes, permiten relativizar las relaciones lineales entre distintas variables, como las motivaciones hacia la capacitación, los usos frecuentes, las habilidades fluidas, la edad o antigüedad y la formación de base. La cuestión tiempo como justificación de las acciones articula una matriz simbólica compartida. En cambio, el desconocimiento conduce a una sensación de disgusto, una opinión irónica y pesimista acerca de los efectos negativos de las tecnologías en el aprendizaje escolar, como en el caso de esta joven entrevistada de la EEST $\mathrm{N}^{\circ} 1$ :

No sé nada, nunca me interioricé, cuando empecé a dar clase me dijeron: te anoto. Dale, qué tengo que presentar, traje los papeles sin pensar que me la iban a dar y me la dieron... ya había pasado el boom, vi un cartel abajo que hacían una capacitación en TIC, le pregunté a una compañera y me dijo: ¡yo la hice un año y no sirven para nada! Entonces dije: cargarme con otra cosa, este año tengo 26 horas, tampoco tengo tiempo (Proyectos de Montajes Electrónicos, O. Electrónica).

La capacitación docente anuda muy diversas representaciones. Si en la primera etapa los problemas para realizarla constituían un sólido argumento en contra, en los últimos años se sitúan en marcos comprensivos críticos pero abiertos a sus potencialidades. Siguen siendo razones de peso para las posiciones reticentes la confianza en la formación inicial o en la voluntad autodidacta, la falta de marcos institucionales y el predominio de contenidos instrumentales en las propuestas. Así y todo, las participaciones se han acrecentado paulatinamente y las motivaciones que las sostienen son también más variadas. Es interesante advertir que demandan capacitación quienes ya han realizado algún curso en este campo. Este hecho indica que deben recibir respuestas pertinentes que a la vez logren capitalizar otras experiencias con TIC, si lo que se pretende es que motoricen cambios significativos, consistentes con la práctica y adecuados a sus necesidades.

\section{Intervenciones docentes, lecto-escritura y multitarea}

Poniendo el acento en las competencias juveniles, una cuestión dilemática reside en cómo adoptan los profesores -si lo hacen - los sentidos de la brecha digital en términos generacionales, uno de 
los pilares teórico-ideológicos del PCI. Conocida es la fórmula de acuerdo a la cual, en palabras de Winocur (2009), los adultos tienen que lidiar en un mundo que no fue concebido por ellos ni para ellos, que no reconoce sus tradiciones ni saberes previos; por contraste, los jóvenes se mueven con la soltura y naturalidad de los "nativos". Los efectos distorsivos de estos binarismos son múltiples. En tanto aceptan como dato consumado las habilidades inherentes a los "nativos", terminan instituyendo, paradójicamente, un orden imaginario que clausura las posibilidades formativas del "inmigrante" (quien, por definición, nunca puede salir de su condición de tal) y con ello, profundizando las diferencias. Encuentran así justificaciones las orientaciones instrumentales y difusionistas de las capacitaciones, sus contenidos específicos y marcos de abordaje. ${ }^{41}$

Ahora bien, las nuevas prácticas comunicativas incluyen a una mayoría de adultos que aprenden, se informan e interactúan de manera diferente a la que adoptan en el espacio escolar, comprendiendo una diversidad de experiencias no reductibles a una situación de "extranjería". Y los jóvenes pueden revelarse analfabetos digitales si no comprenden el lenguaje cultural que las TIC encarnan, ni logran desarrollarlas en escenarios enriquecidos de promoción de conocimientos.

Especialmente en la primera etapa, la brecha generacional suele reforzar la antinomia entre cultura analógica y cultura digital, a propósito de las dificultades percibidas de escritura y comprensión lectora. Configura esta una de las mayores preocupaciones en todo el nivel secundario. En consideración de profesores de Informática, los estudiantes ofrecen resistencia a la escritura manuscrita y muestran bajo desempeño en este sentido, en abierto contraste con sus competencias en el uso de las TIC. Ahora bien, la portabilidad de los trabajos y la prolijidad de las presentaciones son estimulantes, pero nada nos dicen del grado de significatividad de los saberes producidos o cómo contribuyen a mejorar las competencias intelectuales.

Las producciones que hacen para mí son mejores en las netbooks que en papel porque les cuesta mucho escribir, cuando uno les pide que hagan un trabajo con papel y birome, protestan más, que tienen fea letra, que no les gusta escribir y escriben poco, cuando lo tienen que hacer con la compu, insertan imágenes... (EEST $\mathrm{N}^{\circ} 2$, Informática).

Otras posiciones dimensionan a la escritura como algo valioso, mediadora del verdadero conocimiento y constantemente amenazada. Expresan argumentos arraigados en la trayectoria profesional, en sus vínculos con adolescentes a quienes reconocen desafiantes de la autoridad

${ }^{41}$ Vale como ejemplo haber participado en 2011 de los cursos virtuales del INFOD “TIC y educación” y “TIC, lectura y escritura académicas". Comprenden foros de intercambio, trabajo colaborativo en producción de contenidos y aulas virtuales, bibliografía amplia y actualizada. El problema es el apologismo acrítico que teoriza acerca de las habilidades "intuitivas" de los nativos, como el procesamiento paralelo o multitarea (Cassany y Ayala, 2008) en la revolución digital, "una mutación epistemológica que transforma las modalidades de construcción y acreditación de los discursos del saber" (Chartier, 2008: 37). Los cursos presentan niveles altos de deserción; salvo casos, no han repercutido concretamente en la práctica, todo lo cual obliga a revisiones proactivas, pero más problematizadoras. 
docente y ahora "fanatizados" por la presencia de la netbook. En el grupo focal de la EEST $\mathrm{N}^{\circ} 2$, las repercusiones negativas de esa incorporación tensan las valoraciones acerca de la formación técnica, tal como expresan selecciones léxicas, modalizadores e ironías.

-Y me pasó que con este tema la mayoría devaluó, es decir, no llegó a aprobar. Entonces, como justo era el tema de cómo escribir un texto, cómo empezar a desarrollar una idea, cómo usar los recursos necesarios, lo planteamos como una manera de comunicarnos (...) Yo creo que para ellos (los alumnos de Técnica) escritura es sinónimo de escuela: Y a mí la escuela no me gusta, y entonces es un bodrio (Literatura).

- No, no estoy de acuerdo. Como te decía el otro día, sí hay facilismo, pero no creo que sea por la escuela técnica. Es en general. Trabajo en escuela media y veo que los mandan a biblioteca e igual hacen las investigaciones mayormente en Internet (Electrotécnica)

- Pero a veces hay como una especie de negación a la escritura. Les das los libros y no quieren escribir. ¡Ah, entonces ahí las nuevas tecnologías les va a venir fantástico! (Literatura).

Objeciones de este tipo a menudo se vinculan con el desarrollo de capacidades analíticas, contrarias al sentido reproductivo atribuido a los usos tecnológicos. Como en esta profesora de Física de la EEST No 1: "Yo no sé si hay alguna utilidad más allá del Google. En Matemática sé que la han usado (a la netbook) para hacer gráficos. Acá no sé, porque esta es una materia para pensar..." Una posición defensiva tiene como correlato la mirada descalificadora hacia otras materias donde la inclusión digital se presume necesaria, a la vez que el acceso a Internet no parece replicarse en unos usos particularmente productivos: “...para el Google y para la teoría, porque buscamos para la parte práctica pero no había nada de interesante. Es más interesante lo que tengo en la cabeza hace 24 años dando clase." Con menor frecuencia, la formación técnica puede actualizar un mundo afectivo hacia el libro como forma de jerarquizar los saberes analógicos en el pensamiento reflexivo y la lectura placentera:

Me parece que hay otras actividades, trabajos prácticos, que son indispensables. A mí me gustan mucho las producciones de los chicos. Yo soy amante de los libros. Yo tengo hijos adolescentes y buscan todo en Google, bajan todo, cortan y pegan, cortan y pegan. Yo la investigación en libros no la dejaría de lado jamás (EMATP EEST N ${ }^{\circ}$ 2).

Registramos un grupo importante de profesores técnicos que entienden que a través de las TIC se pueden instrumentar un conjunto de desempeños complejos, no escindidos de otros saberes expertos para el ejercicio profesional. En las prácticas profesionalizantes se manifiestan dificultades agudas en lecto-escritura, lo que se vuelve una importante falencia en el marco de una sociedad demandante, altamente competitiva. En el área de Electromecánica, por ejemplo, se presenta como proyecto fundamental forjar competencias de escritura especializada:

...los técnicos tienen que entregar trabajos, informes, a otros, y te puedo asegurar que presentan informes... no sé, "ambiente" con hache. Después vos ves la carrera y no tiene nada de redacción. Lengua y Literatura, qué se yo, aunque parezca que no tiene nada que 
ver, pero ellos se quejan. Vos tenés que integrar lo que aprendés acá, porque el día de mañana no es que vas a arreglar nada más que motores, tenés que escribir.

En consecuencia, el área de pertenencia no es enteramente determinante, pero sí parte de una trama donde se dirimen las luchas entre los docentes y las posiciones simbólicas donde intervienen: “¿Vos creés que la metodología de trabajo que tienen (en Prácticas del Lenguaje) ha mejorado la escritura? Yo creo que no. ¡No saben escribir!” (EEST N 1, O. Electrónica). Estas dificultades parecen transversales, en el sentido de que impactan negativamente en el rendimiento general del alumno; a la vez, es un asunto que compete solo a "especialistas", una concepción restringida que torna más difícil la apropiación de los usos del lenguaje que son propios de cada disciplina en el marco de una "alfabetización académica" más amplia, como observa Carlino (2005, 2013). Este tipo de juicios son especialmente contradictorios. En la misma escuela:

Yo que doy Física y Química, no escriben mucho, yo hago que escriban. No les hago escribir demasiado porque tampoco entiendo lo que quieren poner. Les hago hacer cosas más acotadas y de respuesta más puntual, y en cuanto les pido que hagan más... ¡Incluso en la universidad! A veces les pido que me lean en voz alta lo que escribieron. Pero cuando buscan en Internet, copian los cuatro primeros renglones iy hasta que entienden...!

Entre los profesores de Lengua, estas tensiones no son ajenas a sus determinaciones, entre ellas, los tiempos fragmentarios del profesor taxi y la reducción de carga horaria debida a los cambios curriculares. Las concepciones negativas afirman los desempeños tradicionales, donde la netbook difícilmente ocupe un lugar preponderante. Comporta un soporte, raramente una tecnología potencialmente movilizadora de usos adecuados y reflexivos del lenguaje, lo que permitiría optimizar el tiempo de cursada y dotarla de mayor significado. Ratifica, en cambio, la sensación de desventaja frente a la mirada acusatoria desde otras áreas. Retomando al grupo citado:

...tener el resto de los profesores que te dicen: mirá, los chicos de Lengua no saben nada, mirá cómo escriben, mirá cómo hablan, mirá cómo producen. Ah, obviamente es un tema de Lengua... En las otras materias también producirán, pero la culpa la tiene el profesor de Lengua: ¿Qué hacen ustedes que los chicos no escriben bien, no producen? Y ahora, imaginate, con el uso de las nuevas tecnologías.

Significativamente, el campo problemático que unifica los posicionamientos de profesores de distintas asignaturas no es la lecto-escritura, sino Internet. Este aspecto confirma varios registros de sentido, como la transversalidad atribuida a las TIC en las diversas áreas de conocimiento $\mathrm{y}$, en paralelo, la tendencia a restringir la apropiación digital $-\mathrm{y}$, por ende, las destrezas o dificultades implicadas- al acceso físico. Usos perjudiciales entre los alumnos como el aprendizaje repetitivo o "cortar y pegar", justifican la convicción de que las acciones de buscar, 
seleccionar, interpretar y gestionar la información, no reposan únicamente en las capacidades espontáneas de navegación, sino que requieren de un cuidadoso seguimiento pedagógico. ${ }^{42}$

Además, los docentes reconocen como una característica de los "nativos" la multitarea: la destreza de gestionar varias tareas de manera simultánea o casi simultánea; mientras resigna la posibilidad de comprender esos procesos o de discutirlos como un hecho establecido, el docente advierte las consecuencias en las aulas, generalmente de signo negativo: la desautorización de su rol, la dependencia digital, la distracción, el bajo rendimiento escolar. La multitarea puede servir tanto a ratificar el pesimismo tecnológico como la confianza desmedida, de acuerdo a esas habilidades complejas que detentarían los "nativos" pero desaprovechadas en la escuela.

Las preocupaciones sobre la propensión a copiar de Internet y el agravamiento de deficiencias en lector-escritura, se extienden significativamente en la segunda etapa. Esas dificultades y otras directamente vinculadas (de pensamiento lógico-matemático, de capacidad de conceptualización, de identificación y resolución de problemas, de investigación, etc.), dotan de argumentos renovados al mal desempeño escolar de los "nativos". El proyecto de alfabetización debería reforzarse desde temprana edad. "En Básica tienen que ver mucha lectura, mucha escritura, mucha oralidad, porque el chico se estrangula si tiene que expresar algo, iporque no lo puede verbalizar! Usted me entiende, me dice. ¡No, yo no te entiendo!” (EEST N² 2, Filosofía).

Además de los usos abusivos de Internet, la multitarea sigue siendo un gran interrogante compartido. Para algunos entrevistados, los jóvenes no cuentan necesariamente con esas habilidades. Para otros, estas están bastante extendidas y les son distintivas: "ellos tienen una cultura diferente. Totalmente distinta a la nuestra. Pueden hacer más de una cosa a la vez, y no se aburren tanto, en algunos casos los motiva” (EEST $\mathrm{N}^{\circ}$ 1, Prácticas del Lenguaje, 3er. Año). Inmediatamente, la entrevistada sostiene que "cuesta que hagan las dos cosas a la vez, hay chicos que sí pueden, y a mí no me molesta que estén en Facebook. Ya el juego es distinto porque tenés que estar más concentrado.” La contradicción se explica por el distinto nivel de valoración que reciben las redes sociales y los videojuegos pero, sobre todo, por el hecho de que las tareas escolares demandan un trabajo intelectual menos disperso, mucho más elaborado. Pero no hay aún una observación aguda de los procesos cognitivos implicados, las características que asumen o con qué repercusiones en los aprendizajes.

\footnotetext{
${ }^{42} \mathrm{El}$ estudio de UNICEF ya citado establece que una importante proporción de docentes (7 de cada 10) se manifestó de acuerdo con que "el acceso a Internet estimula en los alumnos la copia de textos ajenos y no la producción propia". Aproximadamente la mitad de los profesores entrevistados coincidió en que "el uso de estas tecnologías está provocando desinterés por la lectura y agravando los problemas de ortografía de los alumnos" (2015: 39).
} 
De todos modos, verificamos la tendencia a problematizar la retórica maniquea que opone nativos a inmigrantes. Asumir la complejidad de los usos juveniles y de las competencias involucradas, no determina a los profesores en una condición de absoluta "extranjería", ya que ellos mismos se reconocen transitando apropiaciones digitales cada vez más complejas. Paralelamente, la lecto-escritura adquiere creciente importancia, como objeto de enseñanza y de aprendizaje. Todas estas experiencias exigen revisar marcos disciplinares, definiendo posicionamientos más flexibles orientados a mejorar las prácticas. Ya hemos analizado el lugar preponderante que ocupa la asignatura en las valoraciones sobre el PCI. M. Maggio (2016) ha constatado que una inclusión genuina, no forzada, involucra a docentes que justifican la incorporación de las TIC a partir del valor que le atribuyen en el campo del conocimiento que es objeto de enseñanza. A este sentido epistemológico se le suma un sentido cultural: reconocer en su complejidad la trama de competencias que detentan los sujetos juveniles, a fin de maximizar el aprovechamiento de la disposición tecnológica en proyectos concretos de creación didáctica.

\subsubsection{Acerca de las Competencias Sociocomunicacionales}

Examinar las potencialidades de las tecnologías interactivas conduce a indagar en las experiencias de interpretar y producir diversos sistemas simbólicos, formatos hipertextuales y multimedia, que encarnan modalidades múltiples de codificar, representar y comunicar la cultura. En este sentido, el modelo 1 a 1 genera valiosas oportunidades para observar las prácticas de los usuarios como objeto substantivo de intervención educativa, en vistas a atenuar los efectos generalizados de una brecha digital que no se resuelve con el acceso físico. Porque, como advierte Área Moreira (2011), la Sociedad del Conocimiento puede devenir en "sociedad de la ignorancia" en el sentido de que la acelerada transformación tecnológica, los profundos cambios sociales, económicos y comunicativos que conllevan, generan también analfabetos socioculturales.

Sin embargo, en los comienzos del PCI, una mayoría de los profesores se sienten intimidados ante adolescentes constantemente conectados. Reclaman medidas de "control", revelando inseguridades personales que se correlacionan con la inacción percibida de la gestión en este aspecto: "Yo creo que si estuviera bloqueado el uso del Facebook, si se pudieran controlar esas cosas, ahí sí sería educativo..." (EEST N 1, Inglés, O. Química). Las expectativas sobre las redes sociales son discriminadas según la dicotomía extra-escolar/escolar, a contramano de un contexto donde esas fronteras se vuelven cada vez más porosas. Por un lado, en tanto valiosos espacios de sociabilidad juvenil, pero marginados del aprendizaje escolar: "Las redes sociales se inventaron para eso, para las personas que son muy tímidas a través de esa red, pueda relacionarse 
con otros. De hecho, se ve. Entonces, en ese sentido si han tenido un impacto..." Y, entre los efectos negativos, el empobrecimiento en el uso del lenguaje y, nuevamente, la responsabilidad de la escuela que "debería hacer algo para cambiarlo, de lo contrario vamos cada vez peor."

Recuperando consideraciones previas, formar lectores críticos y escritores avezados constituye un proyecto ampliamente consensuado en la educación secundaria, si bien, en la práctica, la educación técnica ofrece argumentos sólidos para jerarquizar las competencias instrumentales. Implícitamente, en esta tesis reside su "especialidad". Algunas concepciones oscilan entre el valor positivo de las netbooks como fruto espectacular de la inclusión digital y el deterioro manifiesto de las habilidades lingüísticas, aunque la relación que une ambos hechos no es de estricta causalidad (la tecnología es "agravante"). Pero no explican qué ventajas comunicativas conlleva esa incorporación, ni qué consecuencias trae integrarse funcionalmente a las nuevas situaciones en el marco de la crisis que atraviesa la misma escuela:

Es una herramienta fabulosa. Total, los chicos igual escriben en el teclado, letra por letra, ¿no? Hasta creo que en el teclado es mejor (...) Igual tienen problemas para escribir a mano, abrevian como en el chat, para escribir "casa" escriben "ksa". Y a veces no les entendés qué pusieron, ahora hay que acostumbrarse (Montaje de Proyectos Electrónicos, O. Electrónica).

La inclusión digital se erige en mecanismo adaptativo en otro sentido: hacer más amable y liviana la larga jornada escolar. Implica una inversión retórica de esa "molestia" con que suele calificarse a la netbook. Bajo ciertas condiciones acordadas de antemano, el estudiante puede utilizarla "sin molestar" o bien "para que no moleste", por ejemplo, al terminar antes la tarea. Para el docente significa resignarse a lo inevitable: la "intromisión" del tiempo libre. Las oportunidades de la conectividad no redundan en capitalizar esos saberes donde los jóvenes se sienten entusiastas, confiados y hábiles. Porque esos saberes no son reconocidos como competencias con potencial educativo: "El problema es la tensión entre los temas específicos y el uso de la netbooks... cosa que debió preverse. Esa es la incógnita que tengo, la duda que tengo.”

La relación con las netbooks puede ser distante, poco proclive a la experimentación. A menudo se traduce en la aplicación del aparato, un sentido compulsivo resultado de una disponibilidad física que no puede ser desaprovechada. Se examina el valor de la herramienta, $\mathbf{y}$ solo luego los propósitos didácticos. Así ironizaba esta docente en un grupo de discusión, en su relato acerca de una actividad con la netbook: "La mayoría se puso a trabajar, pero después pasé y había algunos jugando al contact (¿o Counter?) No sé, yo me río porque para mí el contact es para forrar el cuaderno" (EEST N², Literatura). En estos casos, la imagen de dependencia digital asociada a los videojuegos agudiza la sensación extendida de pérdida. En el mismo grupo focal 
se destacan dos campos léxicos opuestos: "he enganchado" (jugando), “exceso", "adicción”, los chicos "pierden esa comunicación", con respecto al libro, son "cosas distintas", "otra cosa", etc.

Otras posiciones no representan tanto al uso tecnológico en términos de diferencias, sino de interconexiones que se soportan en un conjunto de competencias previas y que habilitan otras formas de pensar la autoridad docente. El desafío reside en convertir el consumo individual en redes adecuadas de comunicación, donde el aula constituya un espacio dialógico, más estimulante y educacionalmente más productivo. Un propósito destacado es el aprendizaje conjunto que involucra a docente y alumnos en un mismo marco de construcción de conocimiento. Si las mediaciones tecnológicas discuten los saberes expertos y las fuentes legitimadas de información, el profesor debe vencer sus prejuicios, contribuyendo al intercambio de experiencias sociales entre generaciones que tienen distintas, pero no irreconciliables, relaciones con las TIC:

Pero para mí el chico que se va a distraer, se va a distraer con cualquier otra cosa. La resistencia de los docentes es eso, y otra cosa: cierto miedo de que los chicos sepan más que ellos. ¡Que es así! Pero pueden aprender mutuamente... (EEST $N^{\circ} 2$, Informática).

En la segunda etapa, las iniciativas de inclusión digital se desprenden de valoraciones acerca de las previas competencias sociocomunicacionales. La complejidad de los lenguajes tecnológicos y la rapidez de sus cambios, conllevan las crecientes preocupaciones sobre la toma de decisiones pedagógicas. En este caso, reinterpretando los sentidos de la brecha generacional:

Yo lo que veo no sé de qué manera se puede hacer..., algo que se interactivo, que les llame la atención a ellos, de hecho te pasan por arriba por los conocimientos que ellos tienen. Y lo digo yo que soy de la misma época, digo, generacionalmente estoy más cerca de ellos (EEST $\mathrm{N}^{\circ}$ 1, Prácticas de Lenguaje).

El siguiente relato utiliza el mismo modismo para nominar un estado de situación todavía problemático: los desfasajes entre el equipamiento informático y las deficiencias de la capacitación docente. El campo semántico donde se inscribe esa expresión abunda en términos negativos:

Acá llenaron la escuela de netbooks, pero nunca nos preparamos a los docentes, no es que es un сисо, pero no voy a enseñar lo que no sé. Pero con la rapidez que ellos aprenden te pasan por arriba de una forma tremenda (EEST $\mathrm{N}^{\circ} 2$, Política y Ciudadanía).

La progresiva normalización del modelo 1 a 1 adquiere características diferenciales de acuerdo a los ciclos escolares. En Superior, las netbooks han dejado de representar un objeto conflictivo, en la medida en que los estudiantes interiorizan las normas básicas que regulan sus usos. Como demuestra la EEST $\mathrm{N}^{\circ}$ 1, las situaciones de convivencia con las TIC y las disposiciones resultantes hacia su integración pedagógica, derivan de los procesos de mejoramiento que atraviesa la cultura institucional en constantes negociaciones instituido/instituyente. En la ESB, videojuegos y redes sociales constituyen todavía para los 
docentes un único núcleo problemático, contradiciendo las valoraciones positivas sobre la multitarea en grupos más numerosos, heterogéneos e indisciplinados. A veces, las opiniones negativas confirman razonamientos prejuiciosos: "No, no pueden hacer dos cosas a la vez, porque la desconcentración es tal que les pregunta 2 más 2 y se quedan pensando...” (Matemática).

Posicionamientos más flexibles predican la formación de competencias tecno-comunicativas de las que a menudo adolecen los "nativos" y que merecen ser desarrolladas. Un problema especialmente destacado remite a la credibilidad de la información disponible en Internet y la necesidad de establecer criterios de búsqueda, discriminación y utilización de fuentes fiables. A contramano de tendencias anteriores, este grupo docente subordina el sentido de la herramienta a los objetivos de la planificación didáctica, alentando ambientes de socialización del conocimiento sobre la base de relaciones de intercambio y de trabajo colaborativo. "El año que ingresaron las netbooks, el grupo que yo tenía trabajamos bien, los chicos no sabían prenderlas, no sabían trabajar en Word, usar el programa de red. Trabajamos bastante en hacer presentaciones en PowerPoint" (EEST N 1, Historia).

Si bien todavía aisladas, las experiencias observadas son el emergente de nuevas narrativas hipertextuales. Presentaciones audiovisuales, videodocumentales, fotonovelas, simulaciones, etc., implican múltiples contratos de lectura, la integración de datos fragmentarios, la articulación de códigos con distintos niveles de complejidad. "En el diseño de hipertextos, además de pensar en secuencias, jerarquización y sistemas de enlaces entre contenidos, se trata de recuperar, entonces, estrategias didácticas que por su fuerza generen procesos de apropiación reconstructiva del conocimiento" (Lion, 2006: 192). Bajo la guía docente, los jóvenes se movilizan hacia formas alternativas de usar a las tecnologías y establecen con ellas relaciones fluidas y de auto-confianza que los animan a valorar críticamente los resultados de esas diversas actuaciones.

En lo relativo a la lecto-escritura, el PCI viene a confirmar tradiciones arraigadas desde la formación técnica, entre las habilidades discusivas como proyecto central y la tendencia a subestimar su importancia frente al desarrollo de competencias instrumentales. Sin embargo, como ya hemos analizado, esos sentidos empiezan a ser disputados por otros marcos reflexivos. El uso crítico del lenguaje adquiere centralidad en base a la inclusión social que se pretende: el problema no es que el adolescente maneje otro código, sino que solo maneja éste. Desde esta perspectiva, escritores competentes pueden utilizar con soltura los lenguajes tecnológicos porque también dominan los propios de la cultura letrada. Retomando a la profesora de Política y Ciudadanía:

Los códigos adolescentes todos los tuvimos. La escuela debe ser otra cosa, no es lo mismo que la computadora, el celular, el club, el barrio... Si en tu casa te faltan el respeto, acá el docente no te va a faltar el respeto, y vas a entender que en la escuela no se habla de esa 
manera. ¡El lenguaje! En la casa no hablan, no se discuten ideas, estas cosas no pasan, pero que pasen en la escuela, ipor el amor de Dios!

Rebatir las previas definiciones implica entender que el uso competente no se reduce al dominio instrumental. Significa saber expresarse y comunicarse a través de los múltiples lenguajes digitales. Matizando los supuestos de que el contexto actual tiene a la convergencia como modalidad excluyente, la fusión de formas y prácticas, antes independientes, en la pantalla como un punto focal (Buckingham, 2008), constatamos que los entornos tecno-educativos configuran, también, importantes desplazamientos: entre nuevos y viejos medios, el juego y el estudio, el aprendizaje espontáneo y la orientación pedagógica, la adopción de las normas y la promoción de la autonomía. Implicadas en una fundamental relación dialéctica, las TIC irrumpen en los formatos normativizados, a la vez que los ambientes escolares median las apropiaciones que los sujetos realizan cotidianamente de las TIC.

\section{“A veces distrae": multitarea y autorregulación de la práctica}

Nos interesa detenernos en cómo perciben los mismos estudiantes sus propias competencias sociocomunicacionales. Cabe recordar que los marcos experienciales donde tales competencias se manifiestan y desarrollan, están en buena medida determinados por las condiciones socioeconómicas de base: entre los cursantes de la EEST $N^{\circ}$ 1, la netbook es objeto de un consumo individual, suele representar la primera computadora personal y, con frecuencia, la única en el hogar. Este rasgo marca características diferenciales de apropiación digital, más íntimas o afectivas, como forma de igualación simbólica, donde operan procesos de exclusión/inclusión. Investigaciones recientes han analizado, por ejemplo, que en hogares con muchos habitantes, la conectividad ofrecida por el aparato supliría la ausencia de una habitación individual en cuanto espacio tan caro para los procesos de identificación juveniles (Benítez Largui, 2016).

Al margen de las diferencias socio-económicas, lo que comparten todos los estudiantes es la preponderancia que atribuyen a sus familias. Asociadas a una diversidad de intereses, las tecnologías interactivas adquieren vínculos con otros consumos, de modo que el uso individual de la netbook coexiste con la lectura atenta o la exposición a otros medios en los hogares. En torno a la posesión de la netbook: "Yo la uso para varias cosas, leo el diario, juego, Facebook. Leo el Clarín, o el diario de acá, Infoeme o El Popular. Mi familia compra el diario y yo a veces leo, para estar un poco informado. La pantalla capaz es más cómoda" (EEST N 1, 5to. Año, Electrónica).

Asimismo, la familia se presenta como transmisora de un legado cultural y orientadora de proyectos aspiracionales ligados a la vida adulta. La posición de género puede tener relativa 
incidencia. En grupos con amplia mayoría de varones, las mujeres establecen actitudes "maternales" que operan como reguladoras de la "dependencia tecnológica" de sus compañeros varones. En otros casos, la mediación familiar entrama con sistemas morales en base a los cuales se sancionan esos usos: “Sí, el Counter sigue estando, están re fanatizados. A mí no me gusta, será por mi papá que no me gustan los juegos de armas. Redes sociales, sí" (EEST $\mathrm{N}^{\circ} 2$, Electromecánica). La dimensión afectiva adopta continuidades con trayectorias familiares, en las cuales se conjugan desintereses o afinidades: "A mí la tele me interesa bastante, los programas de ciencia, National Geographic, programas de campo. El campo me interesa porque tengo campo y tengo pensado seguir una carrera agropecuaria."

Si bien los entrevistados no precisan definiciones, avanzan hacia la comprensión de las capacidades de desempeño sobre las cuales se cimenta la multitarea. Implica para ellos focalizar en los momentos adecuados, realizando varias tareas al mismo tiempo pero con distintos niveles de concentración, para abordar los múltiples requerimientos que la información presenta. Los videojuegos -las experiencias que más menciones reciben- son distractivos: jugar en clase resulta divertido, pero equivale a "no hacer nada". Allí conviven desde las transgresiones a las normas, hasta los efectos adversos sobre los resultados del aprendizaje: “Ufff, sí, el año pasado jugábamos entre todos, salones contra salones, a veces apostábamos algo, todo el día..." (4to. Año, Electrónica). Estas concepciones resienten las caracterizaciones dominantes sobre los "nativos digitales", pero también manifiestan la falta de propuestas que indaguen en sus posibilidades didácticas: "Yo he estado con la computadora, con los auriculares, la profesora explicando y yo haciendo un trabajo práctico y he terminado el trabajo práctico. Bueno, a veces distrae..."43

La netbook constituye un elemento disruptivo, condensando un mundo de oportunidades pero también de dificultades para delimitar sus funciones: cómo y cuándo implementarla, qué propósitos persigue esa incorporación, cuáles son los resultados esperables. Los estudiantes logran comprender que la digitalización excede la introducción de la netbooks, para implicar diversos ámbitos decisorios. Por una parte, se pondera positivamente cierta disciplina docente, aún en situaciones de conflictividad. Por otra, los cambios que se reclaman comportan niveles necesarios de autorregulación, articulados con otras formas de ejercitar la responsabilidad. Una comunidad compartida en torno a las relaciones empáticas con las TIC, involucra también un "control colectivo", en consonancia -y a veces, en tensión con- las directivas más o menos

43 Como responsable del Portal Educ.ar, Piscitelli ha examinado las características favorables y poco exploradas de los videojuegos para el desarrollo cognitivo: la hiperestimulación sensorial, el dinamismo vertiginoso, la coordinación motriz, la integración de estímulos visuales y auditivos, etc. Pero de ningún modo se desprenden de tales experiencias consecuencias directas en el aprendizaje escolar ni puede aseverarse, junto con el autor, que "la educación debe convertirse en industria del deseo si quiere ser industria del conocimiento" (2005: 190). 
explícitas de la institución. En el relato de esta estudiante de 6to. Año: "El año pasado me conectaba más, estaba en clase y me conectaba al Facebook pero me desconcentraba mucho, así que ahora no la traigo tanto. Fue al principio. Ahora nos frenamos bastante."

Para quienes pueden establecer comparaciones, la segunda etapa no demuestra los cambios esperados en cuanto a modalidades, intensidad de uso o consecuencias pedagógicas. La trama de competencias emocionales y comunicativas implicadas no han sido plenamente integradas a las actividades, sumado a las tres condiciones ligadas al acceso físico: a- los problemas no resueltos de conectividad; b- la distribución de la netbooks en los años superiores; c- el deterioro técnico de los equipos: "Los chicos la usan fuera de la escuela, para juntarse, no sé qué hacen, escuchar música, jugar al Counter, cuando tenía la mía también jugaba. En la escuela, no, no mucho...” (EEST $N^{\circ} 1,3$ er. Año). Ante la pregunta respecto de cómo volver más productiva la utilización de la netbook, se renuevan los sentidos de la dependencia: "Debería dejar de viciar... jajaja."

Los entrevistados reconocen competencias básicas de uso de los buscadores, pero la mediación pedagógica es siempre ampliamente valorada en este aspecto: si mantienen relaciones fluidas con Internet, necesitan las orientaciones del docente para la utilización provechosa de la información. $Y$ en continuidad con la primera etapa, cuestionan los alcances de la multitarea: se atribuyen la capacidad de realizar varias tareas al mismo tiempo pero en la experiencia del entretenimiento, con distinto nivel de concentración y supeditadas al ejercicio de auto-control: “Ah, no, si estás en Twitter o Facebook... o escuchás música, pero si estás trabajando en la tarea, no. Si estás leyendo, ¡menos! No podés estar leyendo y escuchando música, no, no te podés concentrar...” (EEST N 1, 6to. Año, O. Química).

Como se dijo, un cambio destacado en esta etapa es el uso de los teléfonos celulares. A pesar de sus amplios niveles de penetración entre jóvenes de diversos sectores sociales, la utilización didáctica es todavía minoritaria, debido a las prohibiciones formales como al desconocimiento de sus aplicaciones específicas. En cambio, hay un crecimiento sostenido en el acceso a contenidos audiovisuales, imágenes y videos que los jóvenes exploran en la red, más por propia iniciativa que como objeto de una planificación docente rigurosa. Estas experiencias espontáneas en clases adquieren relaciones ambiguas con el tiempo libre. Definido por el horario extra-escolar como por los recreos, las pausas entre turnos y materias, el tiempo libre gira en torno al valor de "vivir conectados". En esos espacios de ocio intersticial se juegan los sentidos de la interacción social con fuerte carga emotiva, transiciones que recrean la realidad tangible del tiempo en otras claves, no solo ni principalmente las escolares, pero tampoco las del mercado de consumo. 
Y lo que hago es navegar en las redes sociales, en Internet, si tengo que hacer algo de la escuela, hago los trabajos en la computadora, aunque no tenemos mucho tiempo porque estamos acá todo el día. Me gusta sobre todo Twitter, Facebook y Youtube, paso bastante ahí, son mis amigos, jajaja. (EEST N², 4to. Año, Informática).

Un caso aparte es el rol de los celulares en los centros estudiantiles (CE). Como desarrollaremos luego, a través de las redes sociales se nuclean intereses comunes, se da difusión a las reuniones, se articulan proyectos colectivos. Explicaba el presidente del CE de la EEST $\mathrm{N}^{\circ}$ 2 que todos cuentan con celular, se convocan por WhatsApp y gestionan una página de Facebook. Estos usos actualizan el sentido de comunidad que excede a la escuela, operando sobre ella un proceso de institucionalización y, a la vez, desafiando sus límites. Como destaca Silverstone, "no es solo una cuestión de estructura: de las instituciones que permiten la participación y la organización de la pertenencia. También es una cuestión de creencia, un conjunto de demandas de ser parte de algo, compartible y singular" (2004: 157). En esa comunidad se transitan las luchas por las significaciones sobre la tecnología y sobre el control de su potencia.

Si todas las acciones en que se pone en operación la competencia tecnológica generan percepciones de lo que cada quien es capaz de hacer (González, 1999), tales acciones incluyen las expectativas acerca del "control" en su acepción favorable, no meramente represiva y constantemente negociada. Tal como aparece nominado entre los jóvenes, comprende: a- el control docente, que evite usos abusivos y direccione otros más adecuados o criteriosos; b- el control institucional, dispositivos culturales y organizativos que movilicen trayectos ordenados de adopción de las TIC; c- el control colectivo, en base a códigos compartidos que habilitan y sancionan las experiencias de cada grupo de usuarios; d- el auto-control, el dominio sobre las propias decisiones en la utilización reflexiva. Avanzados los procesos de normalización del PCI, los cuatro ejes confluyen en la idea fuerza de la autorregulación, de acuerdo a la cual es posible para los sujetos evaluar conocimientos previos, articularlos en diálogos complejos y contextualizados y, con ello, subordinar a las tecnologías a objetivos personales de aprendizaje.

\subsubsection{Competencias Axiológicas: entre el discurso tecno-utópico y la innovación educativa}

Cuando referimos al orden de lo axiológico, aludimos a los modos de consciencia en relación a las determinaciones ideológicas, políticas, sociales y éticas donde intervienen las TIC, atendiendo a su complejidad cultural y resignificando su incorporación en los espacios escolares. En los términos de Pérez Gómez (2007), una perspectiva holística e integrada destaca la reflexividad como sustrato inexcusable del comportamiento competente. Se basa en reconocer la incidencia que sobre las prácticas docentes operan las condiciones de una sociedad globalizada, como su rol 
estratégico en la formación de agentes críticos capaces de utilizar la tecnología a su alcance de manera responsable. Un proyecto que deviene central para la construcción de ciudadanía y sobre el cual profundizaremos en el siguiente Capítulo, para el caso de las competencias juveniles y sus desarrollos en estos contextos de convergencia tecnológica.

Como modo predominante, la inclusión digital activa unas significaciones imaginarias que determinan a la escuela en una posición de retraso con respecto a un contexto que se acepta globalizado, irreversiblemente tecnificado y con un destino tecnológico ya trazado. La única respuesta posible es la integración funcional. Si nos centramos en el campo semántico:

Es un trabajo que va a llevar años, décadas, torcer culturas pedagógicas que están instaladas. Yo ya era vice-director cuando vino el Ejército y bajaron una por una 356 computadoras, cinco routers... Y si vos te encontrás con directivos que no estén de acuerdo con este Plan, entonces no están teniendo una acción reflexiva sobre las nuevas generaciones (ViceDirector EEST N ${ }^{\circ}$ 2).

En la función del directivo es donde materializan las relaciones de poder, se hace explícita la sanción de la norma y el ejercicio de la violencia simbólica. También, en base a consensos que constriñen los sentidos de las TIC a sus beneficios operativos, atributos que las vuelven indispensables para una educación de calidad o más equitativa. La premisa de la inclusión se ampara en las capacidades intrínsecas de las que serían portadores los nativos digitales, y que fuerza, como una obligación natural, la actualización de los saberes docentes. El correlato paradojal es desvalorizar el rol del profesorado: el centro es la enseñanza, siempre y cuando esté organizada en función del uso digital.

Te repito que somos agentes estatales, y si tengo un profesor de Geografía aunque tenga 70 años, yo como directivo le tengo que decir: o te jubilás o te capacitás, y yo voy a supervisar de que uses esa tecnología en el aula, de que los chicos usen las nuevas tecnologías en tu materia. Y si no: o te jubilás, o te capacitás, o me pedís movimiento docente a otra escuela, o te paso el informe desfavorable (...) habrá mucha resistencia a lo nuevo, porque estoy cómodo, porque lo nuevo me puede incomodar, después me doy cuenta de que me puede incomodar, pero ese cambio psicológico cuesta. A los adolescentes no les cuesta, porque están formados en la cultura digital.

Las respuestas a estas posiciones provienen de otras claves explicativas. Los saberes autoreconocidos, la disciplina objeto de la enseñanza, constituyen organizadores simbólicos desde los cuales se interpretan las diferencias "abismales" entre formación técnica y humanística. Las acusaciones no apuntan tanto a las dificultades objetivas de implementación del PCI, sino a las estrategias instrumentales, calificadas como fallidas, de los profesores técnicos a la hora de integrar las netbooks: parece claro que estos replican formatos conservadores. Este pesimismo es compartido por buena parte de las posiciones críticas. Si bien no se corresponden a posiciones estrictamente tecnofóbicas, cristalizan otra expresión de la brecha digital, que se vuelve tan 
reduccionista como las posiciones dominantes que se cuestionan. En cualquier caso, subyace la convicción de que estos procesos producen profundos dislocamientos en situaciones didácticas instaladas o en las que los docentes se sienten "cómodos":

El docente no tiene las herramientas, pero no porque no sepa, porque viene del área de la formación técnica y jamás se le ocurriría cruzar los datos de un libro con los de Internet. No se les ocurre, y si se le ocurre es mucho laburo. Los que vienen de otras áreas, Sociales, Humanas, tienen otra mirada, pero no pueden articular, terminan encapsulados, solos como loco malo." (Vice-Directora EEST N 1).

El modelo 1 a 1 genera una pluralidad de sentidos sobre las inconsistencias entre las posibilidades del acceso personal y los retrasos en las capacitaciones, entre los lineamientos formales del PCI y las adecuaciones efectivamente realizables. De ahí el uso recurrente de marcadores temporales: "Y yo digo, el año pasado, que tuvimos todo el tiempo para hacer la capacitación. ¿Por qué las autoridades de Ministerio de Educación no largaron la capacitación, por qué la largan ahora? Entonces el año pasado los profesores se hubieran ido capacitando..." (Directora EEST $\mathrm{N}^{\circ}$ 2). Estas distorsiones perturban ostensiblemente la gestión a su cargo, relacionadas con la intencionalidad política del PCI, según surge de su relato cargado de ironías.

El año pasado tuve que viajar a La Plata, donde el gobernador, el ministro de Economía, Oporto, toda la gente, nos entregaban formalmente para la foto las netbooks, tipo setiembre por ahí, en un acto político, entonces yo me fui con cuatro pibes y otro profesor. Tuve que pasar al escenario con un chico, para la foto, así, nos entregaban la máquina, y después la teníamos que dejar a la pasada, porque no era para nosotros, era para la EEST de Mar del Plata que ese día se la habían dado. De ahí nos vinimos con la entrega simbólica y a los 15 o 20 días, cayó un camión del Ejército que las repartía...

Rememorar esa "entrega simbólica" entronca con los perjuicios de "posar para la foto", someterse a decisiones arbitrarias, a requerimientos burocráticos que no se comparten. Dan sustento a la convicción de que los problemas que entorpecen la implementación del Plan expresan el carácter autoritario del sistema educativo, erosionando la posibilidad de arribar a consensos. El mundo ajeno es la "política" cuando "invade" la vida escolar, reforzando el tiempo como dato tangible. Para el segundo Vice-Director de la EEST $\mathrm{N}^{\circ}$ 2: "Hay que ser realistas. Tenemos elecciones en octubre. ¿Por qué les dieron las computadoras el año pasado sin abrirlas? ¡Porque esos chicos votan!" La tensión percibida entre dos conceptos de "política" sugiere una disyuntiva: entre la presunción de las urgencias de la implementación atadas a propósitos electorales y la puesta en valor de una política educativa de envergadura, indisociable del conjunto de iniciativas del gobierno nacional y favorables a la reconstrucción de la formación técnica.

Yo no estoy en contra de los Kirchner, porque ellos ayudaron a la escuela técnica, y nadie nos había ayudado. Pero también digo lo otro. ¡Esto fue un apresuramiento mal! Esto era para hacerlo tranqui, viendo la capacitación, formando a la gente. Esto se entregó ¡yummm! 
Para los profesores, capacitarse significa adquirir herramientas, recursos y saberes con valor pedagógico y verificables en la práctica. Constituye siempre un mandato naturalizado y poderoso (y en razón de las restricciones de tiempo, difícilmente realizable), pero el modelo 1 a 1 genera problemas inéditos, visiblemente más urgentes. Resumiendo, la capacitación forma parte de las competencias axiológicas en la medida en que constituye el marco para volver inteligibles las dificultades de la inclusión, en tono de distanciamiento e incluso de resistencia: "Mmm.... No sé, no hubo una notificación desde la escuela, nada. Yo me enteré por los otros profesores. Después nos metimos en Internet y nos anotamos y ahí empezamos. Es muy general... Utilización de algunos programitas..." (EEST $\mathrm{N}^{\circ}$ 1, Físico-Química, O. Electrónica). En el relato estas propuestas pueden directamente ser descalificadas: "Pero ¿para qué me sirve saber subir videos a Youtube? ¿Para qué poner la carita así? ¿Qué me importa subir videos? Me enojé mucho...”

Destaquemos el focus group en el que las psicopedagogas esgrimen argumentos relativamente distintivos, donde la capacitación requiere no solo una implementación formal sino la responsabilidad indelegable para comprometerse personalmente en ella. Acusan el descontento o indiferencia de los profesores de área, implicando, por contraste, a los profesores técnicos en los usos operativos, la experticia y la predisposición hacia la capacitación.

Se van a tener que seguir capacitando constantemente y la tecnología va a ir de la mano de esa capacitación. Yo no lo veo mal, lo veo bien. Justamente los profesores que más han tratado de incorporarlas han sido los profesores de los talleres. Ellos han sido los que más se han preocupado para ver qué programas tenían, para ver cómo las podían incorporar, ellos han sido los que más se han preocupado, y en aula sigue generando cierta resistencia.

Tales representaciones decantan en naturalizar las brechas entre materias técnicas y de área; ya se ha analizado que los profesores técnicos suelen ser los más reticentes a emprender capacitaciones, a causa de la autoconfianza en sus saberes especializados. Además, en el relato cierta despolitización neutraliza las contradicciones entre el compromiso personal que se reclama y el carácter inasible, pero valorado, de las exigencias de la Sociedad de Conocimiento. Cuando los docentes adolecen de posicionamientos críticos que vayan más allá de la crítica sesgada, difícilmente logren generar en sus propios estudiantes no meramente usos competentes de tecnologías sino habilidades para explorar las relaciones de poder en las que estas se inscriben.

\section{Transiciones: difusionismo tecnológico o ejercicio de la crítica}

Cinco años de implementación del PCI han alterado estructuras cosificadas, y es la institución escolar el actor fundamental para comprender, encarar y resignificar estos cambios. En opinión de 
la nueva Vice-Directora de la EEST N², "es desenroscarse la cabeza y volver a enroscarla." La normalización del modelo es conducente a actitudes críticas que desafían el tecno-utopismo hegemónico. No se trata de adaptarse, sino de conciliar las nuevas demandas con las competencias cognitivas, actitudinales y sociales que solo es capaz de proveer la escuela. El discurso abunda en imágenes metafóricas que aportan fuerza argumentativa a la defensa del proyecto formador:

A mí me parece interesante. Que vengan y nos peguen un palo en la cabeza, así uno va a poder revitalizar lo bueno que tiene la escuela, esta enseñanza cuerpo a cuerpo, que la remo y la remo hasta que el chico aprenda algo, eso también es la escuela. El primer momento que socializa, que conoce a gente que no son sus amigos, eso también es la escuela. En el acceso a determinada información o a determinado suceso, eso también es la escuela.

Una de las preocupaciones centrales sigue siendo las falencias de la formación inicial. En el contexto de los cambios organizativos que se atraviesan, el Director de la EEST $\mathrm{N}^{\circ} 1$ reflexiona que las capacitaciones constituyen una política de Estado, pero invoca mayor compromiso del docente en función de los contenidos que constituyen sus demandas. La atención a la responsabilidad personal como aspecto clave de la capacitación adquiere rasgos de continuidad:

Aparte cuando el docente reclama capacitación, perdón, cuando reclamamos capacitación, porque no me quiero poner en el lugar de directivo, ¿en qué? Porque es fácil decir, pero en $q u e ́$. Yo soy profesor de Electrónica y en qué pido capacitación: pedagógica, específica, en manejo de situaciones conflictivas, en abordaje en técnicas de estudios.

El discurso se muestra optimista, en cambio, en lo que respecta a un mundo sobredimensionado de oportunidades: "los cambios científico-tecnológicos que hubo en los últimos años han sido más acelerados como nunca en la historia, jamás. Es la primera vez en la historia del mundo. Explicame cómo podés tener todo esto en este aparatito" (celular). La portabilidad, las aplicaciones sofisticadas, la ampliación del acceso, son atributos importantes que permiten salvar la ausencia de las netbooks, pero no especifican cómo impactan concretamente en el aprendizaje. Si estas nociones reposan en un relativo tecno-utopismo, una diferencia respecto de la primera etapa es que los tipos de uso ya no se corresponden tanto a las materias técnicas/de área, sino a los Ciclos Básico/Superior, si bien el diagnóstico puede seguir restringido a las cualidades operativas en las áreas que se perciben afines:

Yo lo volvería expresar, me parece que se le da mejor utilización en el Ciclo Superior que en Ciclo Básico, y esto lógicamente trae una interpretación paralela, que Superior tiene muchas más materias técnicas que en Básica, por ejemplo, en Superior tienen laboratorio y usan las netbooks porque es más fácil. Es más fácil para el profesor mostrar una unión química, que lo vean en la pantalla, que explicarlo en abstracto, en el aire.

Apreciaciones centradas en los objetos pueden reavivar relaciones no problemáticas entre acceso digital y desarrollo socio-educativo. "Fíjense cómo estábamos hace 5 años. Yo, todo lo que 
tradujimos se cumplió. En el 2000 teníamos con los chicos un texto y no podíamos traducir la palabra tablet, se traducía como tableta, esa de los medicamentos, te juro, ¡no lo podíamos traducir como techie!" (profesora EEST $\mathrm{N}^{\circ} 2$, Inglés). Anudan estos sentidos la asignatura, el nivel de experticia valorado y reconocido, y más profundamente, matrices difusionistas fundadas en un imaginario social, sus condiciones de posibilidad y representabilidad. La introducción de tecnología ya no está solo atada al progreso, cobra existencia plena: “ $¡ Y$ tenemos un atraso de 8 a 10 años! No existía la tablet para nosotros. Y ahora miro esas tablets que tienen ese proyector, y está buenísimo, ¿te das cuenta? ¡A mí me gusta!”

En otro grupo docente, se acentúan las diferencias socioculturales percibidas. Los modos de implementación del PCI suelen ser debatidas y ya no se reducen a la disponibilidad física. En la EEST $N^{\circ} 1$, los desarrollos tecnológicos pueden recibir desaprobaciones en varios aspectos. Al deterioro técnico resultante de la obsolescencia acelerada, se suman las apreciaciones renovadas acerca del "maltrato" de las que las netbooks son objeto, una problemática que contradice las posibilidades del acceso personal dificultando situar estas y otras tecnologías en ambientes de enseñanza más ricos y participativos. Las críticas hacia la dimensión política de la inclusión digital van dirigidas a una política de derechos si se traduce en propiciar el consumo efímero en sectores vulnerables. La mirada hacia las familias se vuelve abiertamente descalificatoria:

Todos tienen un celular que no lo tenés ni vos. La realidad es así. La mayoría recibe la AUH, las becas Progresar. Y todo cuotas, cuotas, cuotas, los padres no usan las cuotas para comprar una mesa sencilla, no, una tele, lamentablemente estas cosas así de planes, no cubren necesidades básicas. A mí me encanta, ¿eh? Pero la realidad es que están mal usados... (EEST N 1, Matemática, 2do. Año).

La conectividad aparece como un componente de ese "asistencialismo" cuestionado. El relato replica la misma calificación del "regalo" que para los estudiantes significaría la netbook, la subestimación de sus experiencias como consumidores precoces, lo cual opera, paradójicamente, un vaciamiento del sentido político del PCI en el cumplimiento de derechos: “iporque tienen 8 horas de Internet gratis!” En la práctica, exime al docente de la responsabilidad de limitar esos usos, entender su potencial en la promoción de innovaciones didácticas de importancia como repensar el compromiso ético que lo interpela personalmente en esta tarea.

Otras interpretaciones registran los intentos de sintetizar las antinomias de base: el "regalo" junto con el "estímulo", los "derechos" junto con las "obligaciones", el "consumo" junto con la "crítica". Emergentes de los nuevos entornos interactivos, valores como responsabilidad y autonomía se anudan en los esfuerzos de problematizar junto con los alumnos las matrices ideológicas donde las tecnologías intervienen. Estas experiencias favorecen procesos comprensivos de las significaciones sociales que hacen de aquellas medios y no herramientas 
vacías potencialmente útiles a cualquier propósito que el usuario les imponga (Morales, 2011). Ya hemos enunciado que, sin ser una determinante, hay áreas disciplinares proclives a llevar adelante estas reflexiones. Esta profesora de Filosofía de la EEST $N^{\circ} 2$ revierte la negación de los saberes juveniles: la confianza en el otro vuelve realizable una pedagogía dialógica y liberadora:

...está muy acostumbrado a pregunta-respuesta, tu intelecto está adormecido... que vos lo elijas, bueno, pero no dejés que manejen tu pensamiento, tu intelecto y tus ideas. Ellos se dan cuenta, cuando hablás de pensamiento como la condición humana del sujeto libre, y ahora hablamos de conocimiento como un instrumento del poder del mercado, se recontra dan cuenta.

La promoción de competencias axiológicas constituye una tarea de primer orden. En primer lugar, en atención a las previas habilidades con las TIC, cuando la escuela se muestra poco permeable a las configuraciones juveniles en escenarios de incertidumbre. En segundo lugar, repensar el ejercicio docente pone en evidencia las limitaciones del pensamiento tecnocrático como un pesimismo más o menos explicitado, posiciones ambas centradas en los objetos que desalientan verdaderos cambios educativos. Una tercera posición, ahora verificable, interviene en pos de capacidades críticas sobre la duda fundada y la práctica reflexiva, la identificación de problemas y la exploración de alternativas, la discusión acerca de las representaciones del mundo que medios y pantallas instalan en el imaginario colectivo. En consideraciones de J. Bruner, "el objetivo es generar destreza en los ciudadanos, destreza para lograr las metas que tienen una significación personal, y para asegurar una sociedad en la que la significación personal aún sea posible" (2016: 130). Continuaremos profundizando en el orden de lo axiológico en el siguiente Capítulo, en torno a los cruces implicados en la construcción de ciudadanía.

\subsubsection{Competencias Emocionales y la domesticación de las TIC}

Nos preguntamos cómo operan los deseos, sentimientos y pulsiones en estos ámbitos competenciales. De acuerdo a Da Porta (2017), se trata de dimensionar las instancias de mediación donde la cultura escolar, el tipo de propuesta educativa, la intervención docente, las tecnicidades disponibles, pueden ofrecer a los estudiantes la oportunidad de apropiarse creativamente de esos recursos y atravesar experiencias significativas en términos (inter)subjetivos. En el plano emocional, cobra importancia la metáfora de la domesticación. El término connota no solo poner bajo control, "amansar la vida salvaje", sino también la expresión de la subjetividad de los usuarios

a través de la posibilidad de formar y transformar objetos y sentidos mediante la apropiación de los mismos, hasta integrarlos en la propia identidad (Yarto Wong, 2010). 
En principio, las posiciones de los adultos son indistintas de sus posiciones formales en el sistema de jerarquías de la escuela, puesto que sus valoraciones están regidas ante todo por sus disciplinas de pertenencia. Acompañan la dimensión racional-técnica de la profesión docente con elementos de tipo afectivo asociados a la noción tradicional de vocación (Tenti Fanfani, 2010). En la sensación de ansiedad frente a lo desconocido se articulan las competencias auto-percibidas: “uno sabe usar la compu pero por ahí están estas cositas, pero, ay, cómo lo uso" (Directora EEST $N^{\circ}$ 2). Esta expresión confirma la cosificación sobre la tecnología, como un completo extrañamiento que contradice las expectativas iniciales acerca de la formación técnica para emprender adopciones eficientes. "Adaptarse” a los requerimientos de la inclusión digital entra en colisión con la sobrecarga laboral y los tiempos disponibles cada vez más acotados: "Mirá que yo soy medio bruta con las netbooks, aprendo a los sopapos, si a mí me dicen tenés que aprender, sí, ¡si tengo tiempo de estar sentada en mi casa! ¿En qué momento querés que me siente a aprender?”

Posiciones opuestas coinciden en desplazar el interés al sujeto de aprendizaje, pero a contramano de las transformaciones que se ponderan, devienen en procesos de sujeción a un orden establecido. Los imaginarios tecnológicos funcionan como mecanismos adaptativos o de conservación en tanto recrean y solidifican los sentidos de la brecha generacional, las habilidades naturales que detentan los "nativos" y las correspondientes obligaciones de los "inmigrantes":

Pero también debemos asumir que frente a 25 chicos, cada uno con su computadora, yo docente, como agente estatal indispensable para crear una subjetividad acorde a las nuevas tecnologías, al conocimiento acorde al mundo social contemporáneo, tengo que ser un poco responsable y capacitarme, porque no puedo estar frente a un adolescente que tiene otro idioma, otro lenguaje (Vice-Director EEST N²).

Un aspecto significativo en esta etapa es que posiciones distintas pueden arribar a conclusiones similares, cuando parten de razonamientos igualmente binarios y naturalizantes. La noción de brecha generacional aparece atada a imaginarios sociales más amplios, donde la subjetividad docente pretende afrontar los saberes híbridos, difusos y fragmentarios que los adolescentes producen, pero a los que no comprenden más que por su diferencia con los saberes letrados. Una mirada humanística no resulta ajena a cierto ejercicio de personalización de las TIC, otra expresión de la cosificación: para la Vice-Directora de la EEST N 1, "la tecnología le tiene que dar al docente y al alumno pensar desde otro lugar, de hacer nuevas formas de investigación, de comparar datos. Primero: los pibes están diez veces más adelantados que nosotros”. Las transiciones entre conocimientos escolares y extra-escolares representan una empresa casi insalvable: "Entonces vos tenés que pensar lo que trae el pibe y lo que vos traés, que nosotros venimos de la cultura del libro, y cómo poder desde ahí construir otra cosa y es difícil”. 
Buena parte de las caracterizaciones positivas de las subjetividades propias y adolescentes resultan de relacionar la escuela con la carrera de Ingeniería. Ambas están simbólicamente articuladas en torno a la tecnología. Constituye esto un importante componente afectivo de la identidad institucional, condensando los sentidos de una posición privilegiada en la formación técnica y altamente estructurante de los esfuerzos de implementación del PCI. Desde otra diferencia taxativa, entre áreas humanísticas y técnicas, el profesor se siente "en mi salsa", "en mi ambiente", "el mismo idioma", dotando de significado pleno a los procesos de auto-identificación como "grasas" o "los pichones de Ingeniería".

Las disposiciones negativas hacia el modelo 1 a 1 pueden materializarse, en cambio, en las críticas al sistema educativo por no resolver las problemáticas de la enseñanza secundaria. De ahí las imágenes de una burocracia estatal enquistada, del ejercicio del poder que sanciona la norma y nunca en sus funciones para facilitar el desempeño docente. El lugar de la tecnología está prácticamente invisibilizado o aparece como un agravante de situaciones dificultosas que se enfrentan en el quehacer cotidiano, en especial en los complicados escenarios de la EEST $\mathrm{N}^{\circ} 1$ :

A principios de mayo cuando vino la Inspectora, bueno, jes tan fácil hablar detrás de un escritorio! Entonces, cuando hablan de la escuela, nos mostraron que se puede. Pero es distinto tener un chico así (problemático) en un grupo de 20, que cinco. ¿Cómo hacés? Ahora, después de 24 años de docencia, no me callo nada. Yo hablaba con esta Inspectora... y ves que por pensar diferente te bajan la caña, como quien dice ¿Dónde estamos parados? Esa mujer no se debe acercar al salón hace años... (Física, O. Electrónica, EEST N 1).

Una línea de continuidad entre ambas etapas reside en la noción de "hacerse amigo", frecuente en los discursos docentes. En un primer sentido, refuerza las imágenes negativas de la "dependencia digital": alumnos conectados permanentemente, desafiantes de rutinas y ordenamientos escolares, hacen visibles las dificultades del docente para domesticar esas tecnologías y, por tanto, los saberes juveniles que resultan de ellas. En un segundo sentido, implica la auto-percepción sobre sus competencias. En muchos casos, las resistencias a la inclusión digital derivan de la sensación de tener que lidiar con un mundo desconocido. En otros, parece evidente que las propias experiencias extra-escolares (que se reconocen hábiles y fluidas) no se replican directamente en el ejercicio pedagógico. Se impone entonces la necesidad de "hacerse amigo" de la netbook, pero no tanto para controlarla sino para volverla más "amable". Lo que se traduce en cierta resignación frente a la inevitabilidad de estos cambios.

Bueno, como todo proceso, a medida que se va implementando se van viendo los problemas que surgen, porque hay cosas que no se pueden prever. Y en lo pedagógico, como todo, si no podés contra algo, mejor hacete amigo (Psicopedagoga EEST $\mathrm{N}^{\circ} 2$ ). 
Y durante la segunda etapa, "amigarse" con la tecnología en el aula puede significar integrarla productivamente, según una cuidadosa planificación y con claros propósitos didácticos. Expresa la puesta en diálogo entre las competencias personales con aquellas que vivencian los adolescentes en la diversidad de sus aproximaciones cotidianas. Y en lugar de eludir la naturaleza conflictiva de la netbook, la idea de domesticación la pone en evidencia, revelando márgenes visibles para la acción docente. La misma frase del sentido común connota estas opciones:

Es una herramienta que al profesor lo pone de los pelos, es una pelea constante. Te llegan las quejas: ¡ah, están todo el día con las netbooks! Y sí, las tienen que usar, ya la están usando, este año más o menos lo están entendiendo, lo estamos piloteando (...) si terminan antes... pero ¿por qué no incluís a la netbook? Hacete amigo de la tecnología. Incluíla, para que no te moleste, trabajá con la netbook (Vice-Directora EEST N²).

La condición básica es tratar de superar los enojos o temores iniciales, pero desde una postura proactiva en pos de conciliar los saberes escolares con otros lenguajes, sensibilidades y modalidades de aprendizaje. La referencia a la adaptación persiste, pero relativizada desde exploraciones didácticas basadas en la capacitación docente o el autodidactismo. Por ejemplo, la utilización de imágenes, simulaciones y animaciones enriquece la enseñanza, puede ilustrar contenido de gran abstracción que de otro modo serían difíciles de comprender por el alumno.

Una parte de los docentes sostiene que tales utilidades siguen siendo dudosas, a la hora de consensuar unos usos razonables o salvar el deterioro de los equipos, todo lo cual afecta la aplicabilidad de los saberes resultantes de la capacitación. Además, una relación simbiótica sirve de metáfora a los sentidos renovados de la dependencia digital, sobre todo entre los grupos de la ESB: "Y sobre el PCI, yo estoy de acuerdo... soy un defensor. Tiene cosas buenas y cosas malas, pero es una herramienta de aislamiento, más que conectarse se aíslan. Es como una prótesis, una prolongación de su brazo" (EEST N 1, Matemática, 2do. Año). Así, domesticar la tecnología ya no presupone solo una personalización total, sino que muchos usuarios la consideran parte del cuerpo (Morley, 2008), a la vez que desvirtúa comunicaciones supuestamente más valiosas y genuinas que las virtuales. Pero cierta mirada sesgada evita entender que lo que está juego en esa apropiación no es una subjetividad estática sino en construcción, dinámica e inacabada.

Los teléfonos celulares despiertan creciente interés: más actualizados y disponibles, comienzan a ser integrados a las clases incluso en contra de las normativas que los prohíben. Una secuencia emblemática en la EEST $N^{\circ} 1$ es la reconstrucción de la historia institucional donde un grupo de 3er. Año puede fotografiar, filmar y producir contenidos mediante los distintos dispositivos. Definidos como herramientas, son también examinados en su valor para construir conocimiento colectivo: para guardar la memoria de procesos significativos del barrio, la escuela y la familia, dando testimonio de luchas personales y colectivas de superación. Estas 
experiencias son doblemente relevantes en un contexto de mejoramiento institucional, de ahí las comparaciones con otras escuelas de la profesora de Historia cuando relataba que sus alumnos:

tenían que buscar información sobre los pueblos originarios y estaban todos con el celular medio escondidos... y estaban trabajando re bien, ¡re enganchados! Acá son más abiertos en ese sentido. Y eso también tiene que ver con enseñarle al chico que hay que usarlo con responsabilidad, que hay situaciones en que hay que guardarlo y hay situaciones en que es una muy buena herramienta.

De este modo, las tecnologías interactivas encuentran en la motivación de los grupos y en las cualidades del uso operativo sólidos argumentos a favor de su inclusión, pero no se reducen a ellas. En sus aspectos emocionales, entran en interacción con muchas otras agencias culturales donde se configuran subjetividades que permiten volver habitables y significativos los espacios escolares. Avanzado el PCI, buena parte del profesorado logra objetivar que las actuaciones juveniles contradicen las miradas celebratorias que las ubican en posiciones de ruptura absoluta con generaciones anteriores, como aquellas otras que las menoscaban en términos de mero consumo. Las prácticas de enseñanza pueden entonces propiciar procesos de relacionamiento, comprensión y utilización crítica de las TIC, si primero exploran los enclaves identitarios donde estas intervienen en toda su conflictividad social y potencialidad comunicativa.

\section{Subjetividades juveniles, tramas familiares y grupos de pares}

Las prácticas con TIC comportan una diversidad de competencias emocionales. Los adolescentes valoran la disponibilidad personal a la hora de reforzar o resignificar unos hábitos de uso que preceden al PCI. A partir de ellos amplían sus redes de comunicación, sedimentan unos discursos y reelaboran otros, diseminan estéticas y expresan sus demandas, difunden prescripciones que contribuyen a configurar lugares de pertenencia e identificación con los pares. Estas experiencias transcurren en un espacio cotidiano imaginariamente escindido del escolar. Ahora bien, si esta diferencia replica una racionalidad dominante, también pone en cuestión la relación pasiva con la netbook, el aislamiento o la dependencia como formas de domesticación.

Las preferencias de uso son personales, a la vez que mediadas por los contextos socioculturales: la sensación de desapego con respecto a la netbook (aunque no a las TIC) es frecuente en los grupos de la EEST $\mathrm{N}^{\circ}$ 2: "Yo no me pongo a leer en una computadora ni loca. Copio en la carpeta. Igual estamos acostumbradas a buscar en Internet, en la casa. La del gobierno, no..." (5to. Año, O. Electromecánica). La diversidad de estas decisiones, a contramano de las tendencias homogeneizadoras del mercado, dan cuenta de unas prácticas razonablemente autónomas de acuerdo a las cuales los jóvenes hacen valer sus diferencias, y de ese modo pueden 
asumirse como sujetos de discurso y como agentes sociales con capacidad de apropiarse (y de movilizar) los objetos simbólicos y sociales como materiales (Reguillo Cruz, 2012). Con el tiempo, las condiciones de disponibilidad generan también entre estudiantes de la EEST $\mathrm{N}^{\circ} 1$ relaciones de distanciamiento, propiciando otros usos tecnológicos, con mayores niveles de criticidad.

Una preocupación temprana reside en las implicaciones de Internet. Aun si hay una apropiación entusiasta de la netbook, también se activan los sentidos de una intimidad valiosa y constantemente amenazada, recurrentes durante la primera etapa y en la EEST $\mathrm{N}^{\circ}$ 1: "Vos entrás en tus documentos y encontrás una foto que decís: de dónde salió. $\mathrm{O}$ te chusmean tus cosas. Tu intimidad. No podés tener nada porque ellos te miran todo" (6to. Año, O. Química). En el ámbito escolar es la carpeta la que condensa las significaciones de lo privado, porque se percibe más "íntima" o "segura". La visibilidad de las imágenes -especialmente a partir de la masificación de las fotografías en las redes sociales-, junto con la defensa de la privacidad, constituye una antinomia no resuelta y por completo ausente como tema en la enseñanza escolar.

Ahora bien, las condiciones de acceso a Internet, algo distintivo de esta escuela, se vivencian como una suerte de compensación en situaciones socio-educativas muy desfavorables. A lo largo de la jornada escolar los adolescentes están frecuentemente conectados, lo que los docentes cuestionan como algo problemático pero que ellos experimentan como parte estructurante de su vida y que los equipara socialmente a otros. En este sentido, el modelo 1 a 1 se reafirma como una parte fundamental de una política pública. Lo que falta en esta etapa es materializar actividades que permitan salvar progresivamente los problemas de aprendizaje mediados por Internet: en la práctica, los estudiantes presentan dificultades para validar la información, discriminar su pertinencia y utilizarla con sentido educativo, como en las acciones de "copiar y pegar".

Una opinión compartida es que los profesores no suelen formar en competencias de uso crítico y selectivo de los datos. Que esas experiencias resulten productivas para el aprendizaje dependen antes de las propias demandas, intereses e iniciativas. Si en algunos casos se priorizan las carpetas, libros de texto o fotocopias, en otros, las expectativas contemplan el uso intensivo de la netbook, pero raramente pueden estimar cómo interactúan esas tecnologías, qué escenarios son posibles para animar nuevas y más eficaces modalidades de uso que permitan trascender el uso operativo. En la joven antes citada: "Yo, por ejemplo, con el libro se me da vuelta todo, porque no sé nada. En cambio, vos buscás una información en la computadora y te aparece enseguida, lo encontrás más rápido..." Sin embargo, no se trata de una condición generacional. Una consciencia crítica permite desnaturalizar los saberes atribuidos a los "nativos": "Yo creo que suponen que sabemos... Creen que sabemos todo y a veces no es asi’' (6to. Año, O. Química, EEST N 1). 
Hacia la segunda etapa, las tecnologías ofrecen formas de comunicación con los pares cada vez más vitales: los afectos de los que son portadores, a la vez que la potencialidad de las redes sociales para ampliar esos grupos interpersonales. Así como estas redes desplazan los ámbitos de lo público/privado, también recrean la "amistad" como núcleo significante (la cantidad de seguidores o de "me gusta" constituyen valiosas marcas de subjetivación). ${ }^{44}$ Los crecientes niveles de disponibilidad de computadoras y celulares aceleran particulares interfaces donde operan las redes, las plataformas digitales y los videojuegos, consignado distintos niveles de apropiación:

Y la computadora la uso para ver videos de Youtube que son largos y que en el celular no puedo... En esa red social descubrís gente interesante o en los tutoriales aprendés cosas. Videojuegos comentados, está bueno. ¡O escuchás blogs, stand up y te reís...! (2do. Año, EEST N ${ }^{\circ}$ 2).

Como lugar de mediación social, la familia activa una serie de competencias en complejas vinculaciones con las que las tecnologías proponen. Cuando la netbook irrumpe en los ámbitos hogareños (en especial, si no hay experiencias previas con dispositivos móviles), es objeto de múltiples negociaciones entre familiares, dada la tendencia casi excluyente a la personalización. Sin embargo, como ya señalaba Martín Barbero en su libro de 1987, la familia configura el espacio de las relaciones cortas y de la proximidad. Y, como anticipamos, el lugar de encuentro, aquello que sigue la regulando la cotidianeidad familiar, es la televisión. Pasado el entusiasmo inicial con las netbooks, los jóvenes advierten la diversificación de sus intereses, que difuminan las fronteras entre nuevos y viejos medios, desde temporalidades propias, como también familiares:

Yo llego y veo con mis viejos Elegidos, Masterchef, el informativo, mi hermanito se pone a ver otras cosas... ¡Cuando nos llegó la computadora estaba hasta las 11 de la noche conectado! Sábado por medio nos juntamos y nos peleamos por la netbook para jugar, aunque está la de escritorio. Llegó un momento que me aburrí... ahora la uso media hora, chateo, escucho música, bajo videos (5to. Año, Electrónica, EEST N 1 ).

El lugar de los lazos familiares en las competencias emocionales, adquiere otras características. En contextos de jornada escolar extendida, los padres necesitan monitorear a los hijos, y estos valoran y resignifican esa necesidad. El teléfono celular connota, a la vez, cierto grado de autonomía personal y de control familiar. Esto es, aquello que Winocur calificaba como dispositivo imaginario para mantener bajo control la incertidumbre, en base a "este pacto de simulación, que también constituye una condición de inclusión y visibilidad dentro de la red de pertenencia, le exige a sus miembros estar siempre conectados, disponibles y localizables" (2009:

${ }^{44}$ Diversos investigadores vienen analizando de qué maneras se reelaboran los sentidos de la amistad en la red. La identidad de los adolescentes no puede entenderse sin sus amigos. Valoran esas relaciones tanto como las generaciones anteriores, solo que Internet promueve nuevas maneras de relacionarse, nuevas formas de sociabilidad, donde para ellos la "popularidad" constituye un valor prioritario y constitutivo (Morduchowicz, 2010, 2014). 
37). No se trata de ampliar las redes de conocidos o de entablar nuevas relaciones, sino de evitar perder el contacto con los "nuestros". En el relato citado se expresa la mediación de otra temporalidad, la de la escuela: "Ahora se me borró el WhatsApp y le aviso a mi mamá por Facebook, es que pasamos acá muchas horas".

Las fronteras siempre móviles entre el adentro y el afuera adquieren sentidos contradictorios. Ya hemos analizado que si los entrevistados se muestran entusiastas usuarios en su tiempo libre, las mismas experiencias en la escuela significa "boludear" o "perder el tiempo", en continuidad con la primera etapa. El tiempo productivo convoca distintas interpretaciones, en base a deseos y afectos, la responsabilidad personal, los acuerdos con los profesores, los contenidos curriculares, las normas que rigen la cultura institucional. En la medida en que comienzan a incorporarse verdaderas innovaciones pedagógicas, se potencian formas de la sensibilización hacia el uso educativo de las TIC. Incluso posiciones polarizadas, desde la reticencia hasta la plena aceptación, expresan que lo prioritario ya no es el acceso sino las prácticas interactivas, los propósitos que las impulsan y la valoración que se hace de sus resultados. En la producción de contenidos: “A mí me gusta hacer juegos, estoy empezando hacer en 3D, siempre me interesó, por eso sigo Informática, porque quiero aprender los lenguajes informáticos...” (EEST N² 2, 2do. Año).

La fuerza de los componentes emotivos nos anima a dimensionar una Enseñanza para la Comprensión, que relega la incorporación de aparatos o la adquisición de modelos mentales, para centrarse en el desarrollo de capacidades de desempeño flexible. Hemos advertido experiencias incipientes que se movilizan bajo ese propósito. Pero es necesario avanzar en la recuperación de esas subjetividades en base a las cuales los jóvenes transitan lugares de experimentación, que median las relaciones con sus pares, su entorno familiar y sus representaciones del mundo. Las disponibilidades de los dispositivos e Internet serán mejor aprovechadas si se les enseña a formular preguntas, recortar los problemas con enfoques novedosos, pertinentes y significativos, que los prepare no solo en la apropiación del conocimiento escolar sino, fundamentalmente, en una participación más activa en la vida pública.

\subsection{Principales observaciones}

A continuación, resumimos esquemáticamente los resultados preliminares acerca del conjunto de Competencias Tecnológicas, a saber:

1- Como modo dominante, tales competencias son identificadas casi excluyentemente con las instrumentales. El modelo 1 a 1 está restringido material y simbólicamente a los beneficios operativos y la cantidad de aplicaciones, las expectativas por el "evolucionismo" y las 
preocupaciones por la obsolescencia. Mientras que los estudiantes cuestionan esos binarismos, los docentes oscilan entre la negación hasta la confianza de que aquellos "ya saben"; con el tiempo intentan comprender qué significan esos saberes y cómo integrarlos en sus estrategias didácticas.

2- Esos esfuerzos de integración tienen relación directa con la tendencia a la actualización de los saberes docentes, entre posiciones que van desde los adoptantes tempranos hasta los renuentes. La problemática de la capacitación cobra centralidad a raíz de los cambios que introduce el PCI. Bajo este propósito se crea en 2011 el Plan Escuelas de Innovación y hacia 2015, el PNIDE.

3- Acerca de la capacitación docente, en la primera etapa se observan posiciones: afavorables; b- favorables pero dudosas; c- desfavorables debidas a los destiempos; ddesfavorables acerca de la utilidad o modos de implementación; e- subestimadas a causa de la formación inicial, auto-confianza o recursos. En la segunda etapa: a- favorables, contrastantes con su realización; b- favorables pero críticas de los contenidos o modalidad; c- desfavorables sobre los destiempos acceso/capacitación; d- desfavorables, desinteresados. Aun con las dificultades para concretarlas, las participaciones en las propuestas del PCI y otras han crecido exponencialmente, junto con las exploraciones personales de recursos y estrategias.

4- Otros aspectos de las competencias intelectuales residen en el lugar de la netbook como agravante de las deficiencias de lecto-escritura, una competencia que, complementaria al dominio instrumental, recibe alta valoración. La multitarea suele ser considerada una destreza del "nativo", pero excluida en sus potencialidades para desarrollar esas capacidades. Avanzado el PCI, se discute la brecha generacional: el docente no se reconoce "extranjero" ni atribuye habilidades naturales al "nativo"; ambos parecen estar implicados en trayectos de migración digital.

5- Siguiendo con el profesorado, las experiencias juveniles con TIC adquieren valor positivo como espacios sociocomunicativos, antes que intelectuales, correlato de la polarización extraescolar/escolar en la cual la lecto-escritura es un importante diferenciador. Pero hacia la segunda etapa, las propuestas interactivas, donde intervienen distintos soportes, permiten dimensionar no solo la relevancia social de las TIC sino de la lecto-escritura como mecanismo de inclusión social. Las competencias tecnológicas se complejizan en sus sentidos más abarcativos: las que vuelven a los sujetos capaces de expresarse y comunicarse fluidamente a través de los lenguajes digitales.

6- Revelan las actuaciones juveniles la negociación con los criterios escolares y del mercado, es decir, no reducida al consumo sino en atención a capacidades sociocomunicativas complejas. La utilidad de la netbook en la escuela requiere formas básicas de regulación, una referencia compartida entre los estudiantes y con continuidad en el tiempo. Enuncian positivamente diferentes niveles de "control": a- docente, b- institucional, c- grupal, d- autocontrol. 
7- Las competencias axiológicas ratifican las valoraciones mencionadas. Para muchos docentes, la escuela está sujeta a un retraso constitutivo frente a estos escenarios de cambio. Otros acusan la intencionalidad electoral del PCI, ignorando sus propósitos como política de derechos hacia la inclusión y la calidad educativa. Ambas posturas revelan verdaderos obstáculos para la innovación. Una tercera tiende a superar esas dicotomías, ya que no se trata de resistir o adaptarse, sino de incorporar críticamente a las TIC en respuesta a los objetivos de cada comunidad, problematizando los mandatos de la industria cultural o de la modernización tecnológica.

8- El PCI provoca inicialmente sensaciones de incertidumbre, ansiedad, sobrecarga. Domesticar significa "hacerse amigo" de la netbook, cierta resignación que redunda en la utilización forzada o estrictamente operativa. En referencia a los estudiantes, esa apropiación es negativa, dependiente o "simbiótica". Las experiencias alternativas tenderán a aprovechar no solo a las TIC sino las competencias emocionales que se generan con ellas o que median esas relaciones.

9- Los jóvenes reconocen lugares múltiples de subjetivación. La relación "simbiótica” como forma de domesticidad que los adultos les atribuyen, no los exime de usos cada vez más activos y razonados. Además de las tecnologías y la vida escolar, en las familias se juegan continuidades generacionales y consumos compartidos: si la netbook configura un mundo privado, la televisión continúa siendo estimada como lugar de encuentro familiar. Los celulares ofrecen otras matrices donde articulan de modo consistente la protección de los padres y la autonomía personal.

\subsection{A modo de cierre}

Entendidas como competencias comunicativas, en las competencias tecnológicas convergen gran diversidad de habilidades, como las disposiciones y las acciones concretas que se llevan adelante en estos entornos ubicuos de aprendizaje. Sin embargo, como destacan los estudiantes, las clases se concentran en el manejo operativo, unos usos que valoran positivamente, pero revelan un contraste con la distracción de la tarea y un facilismo excesivo, cuestiones ambas que reclaman responsabilidad personal, pero también ordenamientos áulicos y docentes comprometidos con el cambio. Estas reflexiones permiten relativizar el entusiasmo acrítico con que los caracterizan los adultos, en tanto dan cuenta de las tensiones entre las competencias instrumentales en sentido restringido y las de tipo cognitivo-intelectuales que merecen ser desarrolladas.

En consideraciones del profesorado, la técnica opera, paradójicamente, un proceso de deshistorización: se sostiene tautológicamente por su propia legitimidad. Calificaciones entusiastas defienden su rol "poderosísimo", su utilización "práctica”, “fácil” o "interesante”, el "potencial infinito" de los "40 programas". Otro calificativo persistente, la transversalidad, dota a 
la Informática de su especialización como área, a la vez estructurante de toda la educación técnica; en la práctica, justifica la introducción de la netbook en materias específicas, en tanto sanciona los usos, por superficiales o poco productivos, en materias de área. Por su parte, los profesores generalistas suelen asumir una posición compartida de extrañamiento. Uno de los argumentos centrales reside en las vinculaciones entre el deterioro de las capacidades discursivas, de lectoescritura, y las experiencias juveniles tecnológicamente mediadas.

Si la capacitación docente aparece como una problemática estructural de larga data, las urgencias de la digitalización le aportan nuevas significaciones. Hemos identificado una diversidad de posicionamientos docentes en esta primera etapa. En contraste a la creencia generalizada, los técnicos no suelen mostrarse predispuestos a la capacitación, mayormente debido a la sobrevaloración de su área de formación, el desinterés en los aspectos pedagógicos y la confianza en el auto-aprendizaje. Algunos pueden interesarse en aprender ciertas aplicaciones o campos temáticos, o bien en capacidades de desempeño flexible.

Los profesores de área suelen lamentar la falta de tiempo para concretar una propuesta formativa; la sobrecarga laboral es su causa principal, junto con la distancia respecto de los contenidos instrumentales o los problemas de la implementación. Sumado a ello, no suelen estimar la capacitación como proveedora de recursos que los ayuden a tomar decisiones acerca de los usos "adictivos" en las aulas. Nuevamente, afirmar diferencias taxativas entre lo escolar y lo extraescolar, inhibe otra comprensión acerca del potencial didáctico que estas experiencias conllevan.

En un plano axiológico, hay un claro predominio de los imaginarios tecnológicos que entraman con las representaciones sobre los docentes como agentes estatales que deben integrarse funcionalmente al sistema y ayudar a otros a concretar ese tipo de integración. Pero estos mandatos responden a las características asumidas de la racionalidad científico-técnica, antes que a los propósitos de una educación de calidad y más equitativa. Una de sus consecuencias es el esfuerzo de despolitización del PCI, sea bajo la forma de caracterización como "electoralista" o bien supeditado a las determinaciones de la Sociedad del Conocimiento.

Los anudamientos entre la dimensión afectiva y la domesticación tecnológica se agudizan a medida que progresa la digitalización, incluso contrariando sus fundamentos u orientaciones. Entre los jóvenes, una "conversación ampliada" con sus pares se proyecta y redimensiona en la red, les permite participar creativamente de la virtualidad dotando de nuevos componentes a esas subjetividades en construcción. Así escapan de las miradas acusatorias acerca de la "dependencia" tecnológica como una condición constitutiva. Pueden estar todo el tiempo conectados, mostrarse entusiastas y felices con la netbook, y a la vez discriminar sus utilidades y cuestionar usos abusivos en la escuela. Pero estas reflexiones son enteramente marginadas de la enseñanza. 
Tras cinco años de implementación del PCI, experiencias aún incipientes no alteran las dicotomías constitutivas que recrean el proyecto ideológico de la educación técnica, la posición de jerarquía con respecto a la educación media y, con ello, la autoridad simbólica de sus docentes técnicos. La perspectiva sistémica dominante no es privativa de estas escuelas, pero encuentra en ellas modos emblemáticos de realización. La EEST $\mathrm{N}^{\circ} 2$ constituye el modelo paradigmático, la fuerza dominante para sus miembros pero también para la comunidad en la que encuentra legítimo reconocimiento. A la par de estos atributos fundacionales, es posible verificar algunos aspectos novedosos. Por ejemplo, el nuevo equipo directivo reconoce una formación interdisciplinaria y problematizadora, alterando las matrices tecnocráticas como único marco interpretativo. Por su parte, la EEST $\mathrm{N}^{\circ} 1$ empieza a moldear rasgos identitarios propios, orientados a reconstruir su sentido de pertenencia y con una autonomía razonable, entre la búsqueda del orden y los lazos afectivos, un liderazgo desestructurado y la progresiva reconversión de su imagen pública.

Los estudiantes pueden dar continuidad, resignificándolos, a los mandatos escolares. Y también reconocerse como sujetos actuantes de otras racionalidades, en pos de la reconstitución de la cultura institucional, alternativa -incluso resistente- a la larga hegemonía de "Industrial". Se trata de lugares instituyentes que expresan las interconexiones entre la pertenencia y la diversidad, entre las vivencias del presente y las transiciones hacia la vida adulta. En la EEST $\mathrm{N}^{\circ}$ 1, encontramos a quienes defienden la titulación de los profesionales técnicos (ahora formalizada en las prácticas profesionalizantes) y otros que pretenden continuar estudios superiores, un proyecto aspiracional que los equipara imaginariamente a otros. En todo caso, resignifica el propósito tradicional de la movilidad social. Constituyen estas representaciones espacios para la promoción del pensamiento crítico, la autonomía y la responsabilidad, a partir de los cambios culturales que las tecnologías interactivas efectivamente introducen.

Dados los problemas de conectividad y el deterioro de las netbooks, los teléfonos celulares empiezan a complementar otras tecnologías, incluyendo las analógicas. Las transiciones entre Ciclo Básico y Superior configuran un importante organizador en este sentido, en base a las características percibidas -y auto-percibidas- de los estudiantes de los últimos años: responsables, comprometidos y maduros, características que se transfieren imaginariamente a los tipos de uso tecnológico que se espera de ellos. En estos términos, discuten los modelos verticales y transmisivos, para abogar por ordenamientos claros y con finalidad didáctica, junto con el conjunto de conocimientos técnico-profesionales que forman parte de sus expectativas y que de ningún modo se reducen al dominio instrumental. Todas estas consideraciones retoman la idea de que antes que rupturas, las culturas juveniles establecen continuidades y discontinuidades con el legado de sus mayores, los códigos de pertenencia, las instituciones como instancias de socialización. 
Por otra parte, las asignaturas donde las TIC intervienen siguen siendo predominantemente técnicas, pero encontramos mayores niveles de problematización acerca de las dificultades en la integración pedagógica y la búsqueda de soluciones adecuadas. Los profesores empiezan a evaluar, demandar e implementar otros ámbitos competenciales, como la flexibilidad para adecuar las actividades a la disponibilidad de los equipos, la disposición al trabajo colaborativo y la ponderación de los saberes juveniles. Estas problemáticas requieren mayores aproximaciones a la capacitación, que continúa siendo uno de los obstáculos más importantes. Encontramos una diversidad de actitudes docentes, generalmente entre la mayor disposición y la postura crítica. De todos modos, las participaciones se han acrecentado ostensiblemente. La mayor difusión de los cursos, las aplicaciones concretas y la oferta diversificada por áreas suelen ser alicientes importantes; el PNIDE constituye el marco más significativo en este sentido.

El conjunto del profesorado establece un juego de distancias y acercamientos acerca de las destrezas atribuidas a los nativos. Además de los obstáculos que este supuesto conlleva, analizamos las vinculaciones entre la incorporación de las TIC con los problemas de lectoescritura. Estas capacidades son ampliamente valoradas, pero al mismo tiempo, subordinadas al saber técnico o relegadas al área de Prácticas del Lenguaje. Lo que condensa, desde posiciones incluso antagónicas, las oposiciones tradicionales cultura tecnológica/cultura letrada, componentes todos que adquieren continuidades con respecto a la primera etapa.

Así y todo, las tecnologías interactivas empiezan a ser examinadas en tanto lenguajes, en sus contribuciones a comprender y profundizar una diversidad de competencias sociocomunicativas. Se destaca la importancia que atribuyen los discursos juveniles a dominar la tendencia al aislamiento, la dependencia digital, los usos que reconocen abusivos y perjudiciales para el desempeño escolar. Las actitudes que ponderan favorablemente remiten, en contraste, a un “control” necesario, en sus cuatro niveles (institucional, docente, grupal y el auto-control), todo lo cual redunda en ordenamientos simbólicos consensuados, desplazamientos prácticos y enunciativos hacia formas de autorregulación como premisa de base para el aprendizaje.

El PCI es campo de disputas entre una pluralidad de puntos de vista, desde el "asistencialismo", hasta la mirada celebratoria ceñida de manera inconsciente a los fundamentos del determinismo tecnológico. La técnica misma se convierte en instrumento del orden que sostiene las promesas del cambio educativo. Empero, en esta etapa se registran posicionamientos críticos que hablan de cierta madurez interpretativa. Entre los docentes se empiezan a materializar en propuestas didácticas, evocadoras de valores y actitudes que vuelven al alumno un activo participante de sus condiciones de vida y de las decisiones que hacen a su transformación. 
Junto con los componentes axiológicos, cobra nueva relevancia la dimensión emocional, sujeta a atravesamientos aparentemente contradictorios: los dispositivos móviles adquieren la forma de personalización donde los jóvenes construyen las relaciones con sus pares, pero también conservan el contacto con los padres; la televisión sigue siendo la mediación social organizadora de la temporalidad familiar; la pertenencia escolar instituye una memoria compartida que tensa los dispositivos del consumo globalizado. Los sujetos pueden desplegar reflexiones críticas y cuestionar una racionalidad tecnocrática, aquella que parece imponerles como verdad establecida el divorcio entre lo racional y lo emotivo. En suma, en los cruces entre la afectividad y la crítica se definen fundamentales dialécticas entre subjetivación y objetivación.

El diseño de capacitaciones docentes centradas en competencias tecnológicas, las estrategias didácticas destinadas a enseñar tales competencias, implicarían considerar todos estos componentes, en el marco de creciente heterogeneidad en el que operan las prácticas, representaciones y deseos de los actores involucrados. Además de capitalizar esos saberes, resulta necesario el acompañamiento de las tareas, la reorganización de las redes de comunicación, los consensos sobre los objetivos que persigue la digitalización y los dispositivos institucionales de apoyo. Aunque las escuelas no ofrecen transformaciones substantivas en este aspecto, actividades áulicas innovadoras, incluso alternativas, pueden movilizar esas trayectorias colectivas. Como ha advertido Fullan (2002), son los cambios en las prácticas, antes que una buena idea en sí misma, los que determinan las respuestas a una política de inclusión digital y es la cultura de las instituciones el filtro por el cual estas propuestas pueden llevarse adelante. 


\section{CAPÍTULO 6: CIUDAdANÍAS EN CONSTRUCCIÓN: PRÁCTICAS, ESPACIOS Y CONFIGURACIONES}

Siendo Conectar Igualdad una política educativa de carácter inclusivo, resulta vital indagar si las condiciones que la introducción de tecnología promueve, genera espacios potenciales o efectivos de agenciamiento ciudadano. Este Capítulo concierne a los cambios y regularidades que discurren entre las dos etapas (2011 a 2013 y 2014-2015), delimitadas, vale recordar, bajo el entendido de que hacia 2014 se verifica cierta normalización del modelo 1 a 1 en las realidades escolares y desde las experiencias de apropiación de sus actores. Además de la necesidad de evaluar las consecuencias del paso del tiempo, la ampliación del recorte temporal respondió al criterio de saturación teórica, dado que la ciudadanía constituye una problemática medular, pero prácticamente ausente en los discursos durante toda la primera etapa.

El vasto campo de los cruces implicados en la construcción de ciudadanía, se organiza en torno a tres entramados, Dimensiones de naturaleza relacional y problemática: aCiudadanía/Política/Democracia; b- Ciudadanía/Educación; c- Ciudadanía/Tecnología. Problematizamos conceptos mutuamente implicados, como ciudadanía, democracia, representatividad, participación, globalización, política y espacio público, recuperando algunas de las conceptualizaciones ya planteadas, reformulando y elaborando otras. Esta propuesta resulta de un esfuerzo de sistematización teórico-metodológica, que resultan de una construcción original de las categorías, subcategorías y áreas de indagación de acuerdo a la Teoría Fundamentada.

Se apunta a interpelar las diversas formas de participación de los sujetos juveniles, cuáles son los niveles de politicidad que adquieren y cómo intervienen en y desde la educación formal. Estas actuaciones presentan vínculos complejos con los espacios formativos que las escuelas sostienen en este campo, en tanto emergen otros canales que se alejan relativamente de las vías institucionales, o bien contribuyen a su continuidad histórica. Los desafíos de la digitalización encarnan nuevos interrogantes: si estos complejos tecnoculturales tensionan o habilitan condiciones progresivas para formar ciudadanías críticas, una democracia más allá de los derechos.

Este Capítulo responde a una estructura similar a los anteriores. Para cada una de las Dimensiones, se presenta el apartado conceptual correspondiente, seguido de los resultados del análisis y síntesis de los datos $\mathrm{y}$, finalmente, una presentación esquemática que permitirá ir comprendiendo los aportes de cada tema al desarrollo general de la investigación. En las conclusiones, recuperamos los lineamientos generales para avanzar en las precisiones de la teoría generada. El eje vertebral es la ciudadanía cultural, categoría medular que dota de sentido a los 
datos y a sus relaciones con la democracia, la política, la educación y la tecnología, contribuyendo de este modo a la integración, densidad y focalización de dicha producción teórica.

\subsection{Sobre el entramado Ciudadanía/Política/Democracia}

La cuestión de las democracias actuales constituye un vasto campo teórico. Desde una perspectiva política, Guillermo $\mathrm{O}^{\prime}$ Donnell ha advertido sobre los reduccionismos que conciben a la democracia como equivalente a poliarquía o régimen democrático, determinado por libertades públicas y por elecciones "limpias e institucionalizadas". 45 Esta concepción conlleva otro obstáculo: equiparar al Estado exclusivamente a su aparato burocrático y por ende, externo a la sociedad civil. En verdad, la democracia encuentra entre uno de sus puntales básicos el Estado de derecho. Consiste en que "toda ley debe haber sido redactada y promulgada por autoridad competente y que dicha ley se aplica equitativamente por las instituciones estatales relevantes, incluyendo no solo el poder judicial" (O' Donnell, 2007: 180). Desde esta perspectiva, la dificultad para extender la igualdad formal a una igualdad real impide consolidar un Estado de derecho, que además debe ser democrático.

La ciudadanía concierne entonces al derecho de ser tratado por otros como igual respecto a la formulación de decisiones colectivas, como la obligación de quienes instrumentan dichas decisiones de responder por igual frente a todos los ciudadanos. A la inversa, remite a la obligación de los gobernados de respetar la legitimidad de las decisiones resultantes de la deliberación entre iguales; y a los gobernantes, el derecho de actuar con autoridad a fin de promover la eficacia de esas decisiones y proteger al sistema político (O' Donnell y Schmitter, 1986; Schmitter y Karl, 1993). Etimológicamente, la democracia designa al pueblo como portador de derechos universales pero también dotado de capacidad de agencia, es decir, de responsabilidad (la consciencia plena para reflexionar, orientar y valorar las consecuencias de sus actos), autonomía (la capacidad de ejercer la libertad de pensamiento y acción, sin determinaciones de otros) y racionalidad (pensar, evaluar, actuar, de acuerdo a la razón).

Estos tres principios ratifican nuestro posicionamiento teórico: la democracia deliberativa. La teoría crítica de Habermas $(1989,1997)$ aporta sus fecundas conceptualizaciones sobre el

\footnotetext{
${ }^{45}$ Los países latinoamericanos constituyen nuevas poliarquías que se sostienen sobre otras formas de institucionalidad, cuya característica principal es una ciudadanía de "baja intensidad": aún si se respetan los derechos políticos, existe escasa efectividad de los derechos civiles y sociales. Ya en 1992, el autor anunciaba la persistencia de una "democracia delegativa", cuyo disparador inicial en la Argentina fue la presidencia de Carlos Menem; en adelante ha expresado sus dudas respecto de que esa democracia se haya extinguido. Una rediscusión de su significado y alcances en O' Donnell, G., Iazzetta, O. y Quiroga, H. (2011): Democracia delegativa. Buenos Aires: Prometeo.
} 
espacio público, donde los ciudadanos se reúnen y conciertan libremente, sin presiones y con la garantía de poder manifestar y publicar su opinión acerca de las oportunidades de actuar según intereses colectivos. En este punto, cabe una aclaración: la teoría política contemporánea se sustenta en la distinción entre el carácter instituyente y simbólico de lo político (lo ontológico) y la esfera de lo instituido, de la política (lo óntico), un sector particular de actividades, relaciones e instituciones. Autores como C. Lefort (1991) aducen que el lugar instituyente de lo político puede sostenerse solo si se lo exime de una acepción racionalista y deliberativa.

Sin embargo, el espacio público desborda la racionalidad en sentido estricto (cognitivoinstrumental) para implicar una racionalidad comunicativa, que revela también la trama de afectos, sentimientos y construcciones imaginarias, las posibilidades de la creatividad humana y de niveles crecientes de autonomía. No es un espacio político (en el sentido de "la política") sino ciudadano, del "mundo de la vida". Tampoco configura una institución ni un sistema, sino una red para la comunicación. Si bien debe ser problematizado a la luz de las actuales transformaciones políticoculturales, en general deviene en espacio "político" en tanto no se restringe a la política institucionalizada, sino que aboga por las diversas formas de organización y deliberación colectivas donde se realizan las condiciones de una democracia, como una manera efectiva de asegurar y expandir el principio de la ciudadanía a vastos sectores de la sociedad. ${ }^{46}$

Pensar la ciudadanía en América Latina no puede sustraerse de las condiciones de profunda diversidad cultural donde se constituyen las identidades colectivas. De acuerdo a Reguillo Cruz (2003), este problema cobra fuerza en un debate que revela a la cultura como plataforma para la ciudadanía, o a las pertenencias y adscripciones culturales como componentes indisociables en la definición de la ciudadanía. Esta idea ha sido vinculada a los planteos de García Canclini (1995, 2006) acerca de una ciudadanía consumidora. Son conocidos sus aportes para superar las miradas restringidas sobre el consumo, para abordarlo en relación a matrices comunicacionales en las que se realizan los procesos de apropiación y uso. Si los medios de comunicación emergen como el lugar de enunciación de ciudadanía, es porque materializan la crisis de las instituciones en la articulación del espacio público y en la definición de las identidades sociales. ${ }^{47}$

Aun admitiendo la validez teórica de los “consumos culturales" en los Estudios Culturales (EC), sintetizamos tres puntos críticos de la noción de ciudadanía consumidora. En primer lugar,

${ }^{46}$ En Qué es la política (1997), Hannah Arendt partía de dos premisas: 1- la política se basa en el hecho de la pluralidad de los hombres. 2- la política trata de estar juntos y los unos con los otros de los diversos. De modo que la política, en sus implicaciones con la ciudadanía, presenta a la diversidad como una cuestión sustantiva. Porque una participación equitativa en el entramado social solo es realizable en tanto atienda a la diversidad de posiciones políticoculturales desde las cuales se articulan las posibilidades de una ciudadanía plena, efectivamente realizable.

${ }^{47}$ Estas consideraciones convergen en el enfoque de los Consumos Culturales acerca de las nuevas dinámicas en que operan las industrias culturales ligadas al cine, la televisión, la literatura, las TIC, entre muchas otras. Véase, por ejemplo, la perspectiva sociológica de Ana Wortman $(2006,2007)$ en sus estudios sobre el cine en la Argentina. 
la tesis "el consumo sirve para pensar" confirma cierta mirada instrumental: el acceso a los bienes culturales no favorece per se una mayor democratización, tampoco garantiza la conformación de una ciudadanía crítica o con capacidad de agencia frente a los poderes hegemónicos, sean estos estatales o mediáticos. El segundo lugar, la delimitación del “consumo cultural” como una práctica específica frente a la práctica más extendida del consumo, resulta discutible, en tanto esa autonomía aparece sometida a un creciente desdibujamiento, a un entrelazamiento cada día más denso entre economía y cultura (Sunkel, 2006). Finalmente, los medios ponen en escena al "otro", no obstante el consumo no siempre se traduce en una mayor apertura a la diversidad, como ha destacado Winocur (2013b). Esas representaciones mediáticas no necesariamente redundan en mayor aceptación sino en indiferencia, intolerancia o incluso discriminación.

Por su parte, María Cristina Mata ha conceptualizado la ciudadanía comunicativa para dar cuenta de las nuevas modalidades y temporalidades de interacción que favorecen la democratización en el acceso a la producción cultural y comunicacional. Recuperando a Hopenhayn, la vincula a los derechos civiles y políticos, jurídicamente consagrados, al tiempo que a los derechos sociales y culturales, asociando el ejercicio ciudadano "al compromiso de las personas con la "cosa pública", es decir, la participación en la deliberación pública y en la contingencia política, y el compromiso activo en la construcción colectiva de proyectos de sociedad" (Mata, 2006: 13). Presupone además el reconocimiento de la capacidad de ser sujeto de derecho y demanda en el terreno de la comunicación pública, y el ejercicio de ese derecho.

Así entendida, la ciudadanía comunicativa es solidaria con la ciudadanía cultural. Prevén ambas nociones no solamente las relaciones Estado-ciudadano, sino las relaciones ciudadano-ciudadano, que buscan revindicar los derechos en un sentido substancial y no meramente formal. Y si la diversidad pone en jaque la función integradora de la política, habrá que explorar cómo determinados grupos responden a su situación de subalternidad, qué estrategias ponen en juego y, en conjunto, como reconstruyen la cultura en la que viven. Los referentes que orientan sus acciones los llevan a comprometerse en lugares de muy diverso orden, donde la ciudadanía se produce, negocia y articula en procesos de comunicación.

¿Cómo se conjuga la aparente contradicción entre integración y diferencia? Siguiendo a Renato Ortiz (2014) en sus consideraciones sobre la modernidad-mundo, la idea de "diversidad" no es equivalente a la diferencia. Confundirlos no solo es un error conceptual, sino que puede contribuir a justificar ideológicamente la exclusión de esos "otros" culturales. Lo "diferente" remite a otra cosa, pero esa comparación ha sido históricamente construida. En otros términos, la defensa de las diferencias es siempre la diferencia de lo mismo, en el sentido de "lo mismo no es lo igual" (Cullen, 2012). En contraste, la diversidad supone la coexistencia de racionalidades 
múltiples, que se inscriben en la materialidad de los conflictos que definen sus sentidos y modos de organización, generando posibilidades de equidad social. ${ }^{48}$

En consecuencia, hemos optado por la categoría de ciudadanía cultural, por cuanto considera la diversidad de características y posiciones de los sujetos, en especial de aquellos históricamente marginados (mujeres, estudiantes, trabajadores, minorías de género, etc.), como asimismo sus relaciones dinámicas de subalternidad y resistencia respecto de los poderes hegemónicos. El desafío fundamental radica en comprender si las tecnologías interactivas animan nuevas definiciones de la esfera pública, donde los intereses del bien común pueden coexistir con las demandas fragmentadas de los distintos actores. En este sentido, la ciudadanía juvenil se concibe como ciudadanía cultural, a los fines de abordar qué significados asume para los actores, cómo en esas diversas experiencias intervienen las tecnologías, cómo estas pueden contribuir a realizar -o no- un proyecto político-cultural de transformación.

En suma, identificamos para la Dimensión Ciudadanía/Política/Democracia tres Subdimensiones en sus diversas áreas de indagación: la Capacidad de Agencia (desde una perspectiva habermasiana, implicada en las competencias de racionalidad, responsabilidad y autonomía, como los lugares de participación) las Condiciones Materiales y Simbólicas para la Ciudadanía (pedagógicas, institucionales, políticas) y las Relaciones/tensiones entre Globalización y Participación Social (entre lo global y lo local, entre lo escolar y urbano, etc.).

\subsubsection{Capacidad de Agenciamiento}

La primera subcategoría recupera la idea de que el desarrollo de la democracia convoca un sujeto de derechos, pero también la presunción o atribución de competencias de agenciamiento ciudadano. La escolarización apuntará a construir capacidades que trascienden lo cognitivo, involucrando dimensiones éticas y actitudinales. ¿Cuáles son entonces las condiciones de posibilidad que cobran fuerza a partir de la implementación del PCI? Los directivos de la EEST $\mathrm{N}^{\circ} 2$ encuadran al modelo en la reorganización institucional, curricular y organizativa que se viene transitando. Una serie de repeticiones, imágenes y marcadores temporales ponderan las diferencias antes/después en base a la democratización de la gestión, en el relato del Vice-Director:

La figura del director ya no es la del fiscal omnipotente que era antes que el modelo verticalista casi militar que había antes, hoy en día las escuelas tienen que estar gestionadas por un equipo de gestión. Entonces el director no tiene la potestad que tenía antes, que decía: esa puerta se pinta de negro y se pinta de negro, y no consulta con el equipo de gestión.

\footnotetext{
${ }^{48}$ Aunque usamos indistintamente ambos términos, en algunas concepciones actuales "equidad" tiende a reemplazar a "igualdad", ya que el primero concierne al respeto de las diversidades culturales, socio-económicas, étnicas, de género, etc., en tanto el segundo refiere, en rigor, al principio liberal de la democracia.
} 
Estos contextos habilitan canales para desarrollar criterios de responsabilidad. Constituye esta la característica que más referencias recibe, asociada a la formación en valores que se presenta antes como una construcción colectiva basada en consensos, que como imposición de marcos normativos. En situaciones de vulnerabilidad como las que atraviesa la EEST $\mathrm{N}^{\circ}$, la responsabilidad aparece en primer plano como una de las competencias esperadas de la formación y signo de sus falencias. Pero para la Vice-Directora, el problema no es meramente la indisciplina, sino incentivar la auto-confianza, la motivación en el propio aprendizaje y, con ello, modalidades de apropiación institucional que alteren las jerarquías establecidas de una escuela "muy estructurada": "Al chico de 17 años lo hablás, que ya entiende, para que se comprometa como un pibe grande. Que tome decisiones como un adulto, que se responsabilice." Sus argumentos anticipan la importancia de las diferencias entre ciclos, que se agudizará más adelante:

Los chiquitos de trece años están en una fase, que yo digo de boludos, una vez los reté porque estaban corriendo y me di cuenta de que estaban jugando a la mancha. Pero a los grandes, los delegados, por ejemplo, les das la posibilidad de que se hagan responsables y se hacen responsables porque les estás dando otro lugar que no es el autoritario...

Entre los profesores, la orientación pragmática de la formación no excluye el desarrollo de la autonomía, si bien el término no aparece nominado directamente: "Una formación sistémica, que es la nueva política. Que el técnico sea capaz de adaptarse al Capitalismo industrial de la Posmodernidad. Pero también que sea crítico y dueño de sí mismo" (Profesor EEST N ${ }^{\circ}$, Montaje de Proyectos Electrónicos). Con sus tradicionales vinculaciones con las tecnologías, la educación técnica se anticipa como el lugar privilegiado para trabajar esas capacidades; sin embargo, también materializa sus tensiones. La posición predominante se concentra en los usos responsables con que los alumnos deberían encarar los accesos a las netbooks. Una segunda posición advierte, en cambio, que "obviamente, el compromiso, la responsabilidad, son valores elementales para la formación ciudadana, pero esto no tiene que ver solo con las tecnologías" (EMATP EEST $\mathrm{N}^{\circ} 2$ ). Fomentar estos modos de consciencia implica lograr trascender, material y simbólicamente, las desventajas socioeconómicas de base. Esta entrevistada es redundante en este sentido:

Al chico hay que concientizarlo de que su vida puede cambiar, y el cambio se produce mediante la capacitación y el estudio, que él no está arraigado a esa situación- porque acá hay chicos con muchísimos problemas-, pero él no está aferrado a esa situación, él puede cambiar su destino. Y el destino se cambia con esfuerzo, con estudio y con capacitación...

La segunda etapa muestra las continuidades acerca de las referencias destacadas hacia la responsabilidad. Ahora también encuentran en las Prácticas Profesionalizantes el espacio para reafirmar hábitos básicos como el respeto a la autoridad, los horarios y las tareas asignadas, que, 
junto con los saberes específicos, conjugan condiciones mejores para la empleabilidad y la terminalidad escolar. Este discurso expresa cómo la escuela debe lidiar con la carencia de esos hábitos, incluso en posiciones flexibles como la del Director de la EEST $\mathrm{N}^{\circ} 1$ :

Y este año tenemos un 7 mo. de Química que son un desastre, y sé que no se van a recibir, iban a las Prácticas Profesionalizantes y se tenían que presentar a las 8 a Bromatología y: ¿por qué no fuiste? No, porque tenía que ir al centro a llevar a arreglar el celular. Y yo por un lado me caliento y por otro, entiendo que yo me formé de otra manera, con otro sentido de responsabilidad laboral.

En un marco de flexibilidad, la institución no renuncia a esos hábitos, sino que los afirma como proyecto educativo y a la vez condición de funcionamiento. La responsabilidad es equivalente a la interiorización de normas, derivadas de acuerdos establecidos. Una acción regulada por normas supone que todos los miembros tienen derecho a esperar unos de otros que en ciertas situaciones se ejecuten u omitan, respectivamente, las acciones obligatorias o prohibidas (Habermas, 1997). Los "límites" se instituyen en tensión constante con aquellos ordenamientos difusos resultantes de "esa conjunción, de esa mezcolanza" que conciernen a sociedades cada vez más complejas y globalizadas: "La cuestión de los límites es una cuestión cultural. Que se van formando a través de las coincidencias colectivas de pensamiento, en un momento donde las comunicaciones han tenido tanto avance a nivel mundial que obviamente influencia..."

Pero es en la vida escolar donde el estudiante está implicado en las negociaciones de las interpretaciones susceptibles de consenso. La obediencia de la norma se convierte en la progresiva autorregulación de las acciones, en procesos que definen los principios organizadores de la propia experiencia, y no de mero disciplinamiento: "Parecía que tenía clavada la visera, como la campera, no era para él una falta de respeto. Ahora en los actos escolares se sacan la visera y nadie le tiene que decir" (Vice-Directora EEST $\mathrm{N}^{\circ}$ 1). Tales hábitos articulan, en un todo consistente, responsabilidad, racionalidad y autonomía hacia una nueva ciudadanía, excediendo lo formal para apelar a sujetos socialmente constituidos en el marco de sus prácticas comunicativas. La educación se auto-percibe como el último reducto para formar en valores básicos. La construcción metafórica pone a la EEST $\mathrm{N}^{\circ} 2$, en posición ventajosa: "La familia... bueno, vemos cada cuadro de desatención, y eso que acá dentro de todo vivimos en una isla..., pero no te vayas a creer, también tenemos. Y eso que en la escuela técnica aprenden criterios, responsabilidades...” (Director).

Nominado como tal, el problema de la autonomía surge avanzada esta segunda etapa. Esta competencia es eje de contradicciones, dado que la escuela tiende a neutralizar los conflictos $\mathrm{y}$, en consecuencia, toda tentativa de demandar igualdad y sumirse a las diversas formas de integración a lo establecido. Progresivamente, emerge en la consciencia de los actores unos modos de subjetivación que suponen "salirse de la explicación que ordena para pasar a la implicación de 
los sujetos, del pedido de obediencia al reconocimiento del otro, del control a la confianza instituyente" (Vidoz y Coicaud, 2015: 21-22).

Ironizaba la profesora de Construcción de Ciudadanía (CDC) de 1er. Año de la EEST $\mathrm{N}^{\circ} 2$ : Generar formas de autonomía, voy al baño a controlar si fue a hacer pis porque tenemos miedo a que le pase algo. O que haga algo. Si se pudiera promover en el chico la autonomía desde el jardín de infantes, creo que esa sería la forma de promover un verdadero cambio.

Las asociaciones entre la responsabilidad y la racionalización de los beneficios del acceso digital, se continúan, pero en torno a otros aspectos. Consideraciones de este tipo no están desfasadas de los usos instrumentales y sus implicaciones efectivas para el aprendizaje en marcos intersubjetivos. En términos habermasianos, es posible reconocer una racionalidad cognitivoinstrumental en diálogo con una racionalidad comunicativa. El uso de celulares como recursos didácticos permite complementar las netbooks o resolver las necesidades de conectividad, abriendo espacios que validan las intervenciones del estudiante, en diálogo con otros sujetos y con el conocimiento. El centro de estas actividades es el lenguaje reflexivo, antes que las TIC:

Y eso también tiene que ver con enseñarle al chico que hay que usarlo con responsabilidad, que hay situaciones en que hay que guardarlo y hay situaciones en que es una muy buena herramienta. Me ha pasado de estar explicando sobre Napoleón Bonaparte y que uno de los chicos lo busque en el celular y me diga: jéste es! (profesora EEST $\mathrm{N}^{\circ} 1$, Historia).

Frente al retraimiento de los modelos tradicionales, la escuela se constituye en espacio de trabajo consciente y sistemático en la adopción de normas como modo efectivo de aprender a vivir con otros. Desde allí intenta afrontar el dilema de reconstruir los ordenamientos formales, los códigos compartidos, la cultura institucional, por una parte, y los esfuerzos de democratización que permitan resolver el fracaso de una organización autoritaria o su contrario, la fragilidad de sus límites. El desafío es la reestructuración progresiva de las tres competencias que definen a un sujeto agente con especial énfasis, en la última etapa, en la autonomía y la racionalización. Bajo esta premisa, una política de inclusión digital contribuye a discutir la idea de que no se trata solo de unos usos responsables sino de capacidades de pensamiento crítico. Empero, estas posibilidades no aparecen claramente delimitadas en torno a la construcción de ciudadanía o cómo las TIC pueden obrar en esa dirección, un marco comprensivo multidimensional y todavía difuso.

\subsubsection{Condiciones Materiales y Simbólicas para la Ciudadanía}

Las apreciaciones positivas que recibe inicialmente el PCI adquieren complejas asociaciones con el entramado ciudadanía/política/democracia. Hay un interjuego entre la integración formal al sistema educativo y la autonomía en las decisiones que en la institución se arroga como derecho. 
La reacción inmediata es más bien defensiva. Entre autoridades de opiniones muy diversas, identificamos dos campos semánticos, el primero en torno a la "imposición" (y su correlato, la “improvisación"): "te llenan de computadoras", "había que entregarlas", "nos sacamos un problema de encima", "nos tiraron todo esto", "te mandan las computadoras”, “¿por qué de repente?". El segundo campo construye la idea negativa de "la política": "entrega simbólica", “acto político", "medio en pañales", “campaña electoral”, "cuestión política", "año electoral”.

Algunas posiciones prefieren poner el acento en los sujetos, superando actitudes pasivas para emprender cambios hacia una adecuación efectiva. Pero es solo la EEST $\mathrm{N}^{\circ} 2$ la que presenta estas condiciones, donde las diferencias entre directivos tienden a resolverse de manera razonablemente democrática. Un Vice-Director sintetiza tres planos. Primero, el compromiso docente hacia la innovación: "Ahora los educadores tenemos que tener la responsabilidad de buscar estrategias pedagógicas para que no se nos desbanden los pibes..." Segundo, los sentidos de una política pública tendiente a la igualación de oportunidades: "Somos ciudadanos de un país. Educación común, educación igualitaria, tenemos que eliminar las brechas de que un chico tiene más herramientas que otro." Finalmente, un proyecto en el que las instituciones deben involucrarse directamente: "Hay escuelas técnicas que van a ir y van a decir: este gobierno de mierda, y es inaplicable el plan, pero tenemos gente que se rompió el culo horas y horas trabajando en el plan..." El segundo Vice-Director desplaza el interés de la tecnología hacia el rol de las escuelas técnicas en la promoción de derechos humanos, que articula de modo consistente con el carácter inclusivo del PCI: “¿En Brasil qué hicieron? ¡Pusieron escuelas técnicas en medio de las favelas!”

Entre profesores, una sucesión de términos define dos campos léxicos: una "intencionalidad electoral" y la "irrupción" de las netbooks que no invalidan sus beneficios operativos, pero ponen en cuestión sus alcances socio-educativos: “....eso es más política. Creo, a mi modo de entender, es una herramienta más, que a lo mejor el chico no tiene en la casa, para que un chico pueda acceder a una computadora equitativamente con otro chico" (EEST N², Diseño y Procesamiento Mecánico). En posiciones reticentes, configuran otro argumento las diferencias estructurales: "Las netbooks... cualquier cosa... Largaron por largar, por una cosa politica, por un voto más. En este contexto... Los chicos de Técnica 2 deben tener Internet en la casa, ¿no?” (EEST N 1, Física).

Las críticas a la "imposición” del PCI adquieren aristas inusitadas. Creencias prejuiciosas acusan la imposibilidad de una educación inclusiva, contrariando posiciones anteriores. "La igualdad es un discurso", afirma la docente de Física antes citada. Determinar a sus propios estudiantes a las certezas de un destino adverso, le impide elucidar que la integración deficiente de lo que los acusa es resultado de las desigualdades que el sistema necesita para reproducirse: "Yo siempre digo: somos iguales ante Dios. Después, un chico, desde que está en la panza de la 
mamá ya está condenado, ya se sabe si va a ir a la universidad o va a ir a una cárcel." En base a estos prejuicios cuestiona esas contradicciones, pero a costa de clausurar todo compromiso ético: "Por un lado, tenés el discurso de la Inspectora que es prescriptivo, después que... si vos tomás eso no te aprueba nadie. Entonces, ¿qué hago? En los exámenes les tomo dos o tres pavadas...”

Estas percepciones coexisten con la tendencia a criticar sin demasiado fundamento la diversidad cultural, especialmente en las situaciones problemáticas de la EEST $\mathrm{N}^{\circ} 1$. Se percibe como obstáculo para la planificación didáctica, el clima de convivencia o el trabajo colaborativo, pero de ningún modo como condición estructurante de identidades juveniles, diversas entre sí y con los adultos, que deriven producciones más enriquecedoras. En la EEST $N^{\circ} 2$ los razonamientos no se basan en discrepar con la heterogeneidad de los grupos (a los que definen como socialmente homogéneos), sino abogar por la interiorización de habitus adecuados al nivel secundario. Estructuran el orden simbólico los límites dentro/fuera, pero el foco está puesto en el 1er. Año donde existe "mucha mezcla de las escuelas de donde vienen". La diversidad se simplifica como un problema que tenderá a resolverse -o atenuarse sus efectos- en marcos de socialización.

Subyace la idea de que el acceso a las TIC no forma parte de los derechos básicos y no puede en sí garantizarla. Esta objeción marca el hecho de que la sociedad debería zanjar primeramente otras deficiencias: "no se puede resolver la inclusión digital del sistema educativo en el siglo XXI si no están saldadas las deudas del siglo XX” (Aguiar, 2007: 99). Otros casos remiten a marcos teóricos sólidamente arraigados en la formación técnica; el más referido es la jerarquía de necesidades según Maslow. ${ }^{49}$ La consecuencia es negar a jóvenes de sectores socioeducativos vulnerables la oportunidad de alcanzar otros niveles de desarrollo. Las contradicciones en el discurso connotan el valor de una concepción humanista, los límites taxativos entre áreas y los sentidos de la tecnología como artefacto, y no como parte de un proyecto integral y educativo:

No creo, debe ser... no sé, muy de Filosofía: como está todo muy tecnificado, si te cortan el camino a la tecnología, es como que te están cercenando tus derechos. Creo que tiene un impacto mediato. Mmm... no sé si habrán hecho un estudio de la Pirámide de las Necesidades -no sé si conocés la teoría de Maslow-, digo, lo tecnológico no forma parte de las necesidades básicas, y no sé si en la Argentina están cubiertas todas las necesidades básicas... (profesor EEST N², Electrotecnia).

El problema de las necesidades sociales conlleva la pregunta sobre los alcances equitativos del PCI, dadas las desiguales situaciones donde se inscriben esos esfuerzos. Este desfasaje da

49 Abraham Maslow se inscribe en la psicología humanista y propone una teoría según la cual existe una jerarquía de las necesidades: fisiológicas, de seguridad, de afiliación, de reconocimiento y de autorrealización. Solo conforme se satisfacen las necesidades más básicas, los seres humanos pueden aspirar a desarrollar necesidades y deseos más elevados. 
fundamento a opiniones reticentes, como en este profesor, participante del grupo focal de la misma escuela, quien utiliza idénticas expresiones que el anterior entrevistado:

Yo no sé si la computadora tendrá un impacto social, habrá que ver. Es una herramienta más. Que todos tengan acceso es bárbaro, pero no sé si en la Argentina están cubiertas todas las necesidades básicas. Y la computadora no forma parte de las necesidades básicas. ¿No habrá otras necesidades primero? No sé... esto tiene mucho de campaña política (Diseño y Procesamiento Mecánico).

Sus colegas del mismo grupo pueden ser aún más enfáticos. La recurrencia a las mismas expresiones, como a las teorías, las posiciones ideológicas y las creencias de sentido común que las sostienen, está extendida entre estos profesores, provenientes de muy diversas asignaturas:

- ¿Que la tecnología tenga que ver con la igualdad? ¿Con la igualdad de oportunidades? Nosotros lo vemos como apoyo. Porque todos tienen los mismos derechos, yo doy los mismos contenidos a todos, tengan o no tengan la tecnología, a ver si vos me entendés (Matemáticas).

-Bueno, es que la cuestión la equidad... con el acceso no basta. Todos tienen sus netbooks ahora, pero habrá que ver cuáles son las condiciones de uso en las escuelas, en los hogares (...) El uso depende de ese entorno social (Geografía).

Hacia la segunda etapa, los procesos de normalización del modelo 1 a 1 conducen a mayor nivel de aceptación. Los cuestionamientos persistentes sobre las "imposiciones" y la "intencionalidad política", se ubican en otros marcos comprensivos. La tesis de que "la computadora no forma parte de las necesidades básicas" adquiere ahora múltiples expresiones con sentido ideológico, que no se reducen a los accesos materiales (incluso debatiendo el carácter determinista del modelo de Maslow). La nueva Vice-Directora de la EEST $\mathrm{N}^{\circ}$ 2, antes entrevistada en un grupo, ratifica sus opiniones de entonces: "La última vez que me hiciste esa pregunta se armó la podrida, jajaja (...) Nos recontra peleamos con el otro profesor.” Incluir a los sujetos supone garantizar en ellos un mínimo de calidad de vida que las TIC en sí mismas no proveen. Abunda en expresiones coloquiales, imágenes y construcciones metafóricas:

Pero en ese momento el tema de la inclusión social o la calidad de vida, creo que eso se logra garantizando la salud, la vivienda... primero. Y la netbook suma si está garantizado lo otro. Sola, no suma. Me acuerdo esa discusión, porque ese día yo le decía al profesor: si el chico vende la netbook porque necesita la guita, no está mejorando su calidad de vida, hay otras cosas que están faltando y la netbook entra en este tembleque.

Frente a la antinomia no resuelta entre una función asistencialista y otra estrictamente formativa, la problemática de los derechos sociales lleva al siguiente razonamiento lógico: si la tarea educativa no consiste en el cumplimiento de necesidades básicas y la computadora no forma parte de las mismas, parece sensato concluir que debe haber un aprovechamiento pedagógico y no solamente operativo de las TIC. Significativamente, los beneficios percibidos del acceso digital 
conducen a moderar las opiniones iniciales, predominantemente negativas, para abrir otras posibilidades de incorporación:

Yo sigo viendo al chico con la misma zapatilla rota y la netbook, y ahí bajo la persiana... Cumplimiento de los derechos desde el rol del Estado, después la escuela que no tiene ese papel de garantizar las necesidades básicas de sus alumnos, solo uno de sus derechos que es la educación, desde ese plano, sí la netbook vino a ayudarnos, a garantizar el acceso, a igualar...

Siguiendo con las funciones educativas, la formación laboral resulta decisiva: "y en el mundo del trabajo vas a tener una relación con la ciudadanía", en tanto "lo importante es que entiendan que deben ser respetuosos" (profesora de Inglés, EEST $N^{\circ} 2$ ). Pero no se explicita qué implica esa relación ni cuáles son las condiciones para su desarrollo. Otros logran avizorar la construcción de ciudadanía como proyecto transversal: "En cada área, porque uno forma no solo desde lo disciplinar sino como buenos ciudadanos, yo creo que se debe trabajar mucho en valores. Por ejemplo, en mi espacio trabajo mucho en la cultura del trabajo" (Sistemas Productivos, EEST $\mathrm{N}^{\circ} 1$ ). La díada educación-trabajo requiere lecturas atentas en materia de normalización, formación y certificación de competencias laborales, no solo en la instrumentación sino en la creación organizacional y colectiva del saber (Granosvsky, 2016). Comprende otras capacidades de desempeño flexible, actitudinales, éticas y comunicativas, con vistas a formar disposiciones críticas en entornos crecientemente competitivos y diversificados.

Otro factor de complejización reside en la distinción entre el Ciclo Superior y la ESB, en la cual irrumpe el PCI en esta segunda etapa. Si antes dominaban las distinciones taxativas entre escuelas, ahora ambas avanzan hacia reordenamientos institucionales que hacen propicias las condiciones estructural-simbólicas para la ciudadanía. La EEST $\mathrm{N}^{\circ} 1$ atraviesa un proceso de transición, discutiendo valoraciones negativas que solo parecían rescatar a estudiantes "mejorcitos" o "no tan contaminados". La EEST N 2 abraza continuidades o fortalecimientos de sus modos de organización. Las construcciones verbales son distintivas en cada caso:

Estamos tratando de generar otros hábitos, no es fácil porque el chico viene doble jornada, almuerza acá, se está trabajando en valores, de construir un sentido de pertenencia. (...) Pero es tanto más complejo trabajar con lero., 2do. o 3ero., tiene que ver con esto: con valores, con cuidar la escuela, mantener la atención, es difícil mantenerlos sentados, son hiperactivos, están acostumbrados a deambular mucho... (EEST N 1, Sistemas Productivos,).

Hay que seguir trabajado con el valor (...) Que cada derecho implica también obligaciones, compromiso con el otro, con la sociedad, con uno mismo. Un respeto, esto medianamente se logra. Acá hay mucho sentido de trabajo, de pertenencia, de identidad, más que nada desde Superior, porque es una escuela que hace cosas y ellos lo ven (EEST $\mathrm{N}^{\circ} 2$, Informática).

Otras lecturas ponen en jaque la igualdad formal como un derecho real y establecido: "El chico se queda en el modelo, en la igualdad, pero vos no podés enseñar igual en una escuela técnica 
que en una escuela periférica. Eso no es igualdad. Y te dicen: inclusión. No, inclusión con calidad" (EEST $\mathrm{N}^{\circ}$ 2, Filosofía). Encarar, discutir y resolver estas contradicciones son carencias persistentes de la educación, parte de un sistema global donde, al decir de Ortiz, "un pluralismo jerarquizado organiza las diferencias según las relaciones de fuerza” (2014: 38). La diversidad continúa siendo un obstáculo para la enseñanza. Pero puede derivar en posiciones que logren, por ejemplo, objetivar dificultades lingüísticas, una "diversidad atroz" que "no es mala”, pero que implica al docente en el compromiso ético de modificar estas situaciones: "el chico que es diverso enriquece al grupo. Pero maneja 20 palabras y está tres años en 1er. año. ¡Es una estafa!”

Una política de inclusión digital materializa un problema central de la democracia: ¿cómo avanzar desde la igualdad formal hacia la igualdad real? La educación formal apunta a ampliar competencias que residen en el sujeto y en la riqueza cultural distribuida en cada contexto, y que se consideran básicas para el ejercicio de la ciudadanía. Esta no puede ser sino cultural. Pero situada en lo cotidiano, puede solapar los poderes globales y sus contradicciones. Además, si por un lado, se rechaza lo heterogéneo en pos de igualar en el aprendizaje, por otro, respetar acríticamente las diferencias conduce a perpetuarlas. Algunos docentes afrontan estos dilemas y los discuten a nivel de las prácticas: el rol de la enseñanza será deconstruir la premisa de la diversidad, si tiende a enmascarar ideológicamente la reproducción de las desigualdades.

\section{Ciudadanos en situación: la Ley de Voto Joven}

Especial atención merece la Ley Nacional de Voto a los 16 años (26.776/12), que dictamina, en su Artículo 1 que: "los argentinos que hubiesen cumplido la edad de dieciséis (16) años, gozan de todos los derechos políticos conforme a la Constitución y a las leyes de la República". El tema provoca no pocas controversias en la opinión pública y tiene directa repercusión en los procesos de escolarización hacia la segunda etapa analizada. Se trata de un problema social que enfrenta a los docentes a entender cómo los jóvenes pasan de la esfera del "ideal del ciudadano" al de sus posicionamientos subjetivos como “ciudadanos en situación” (Kriger y Daiban, 2015).

Si bien se encuadra en una ciudadanía política, el derecho de participar en el ejercicio del poder político, los apoyos entre el conjunto de los actores son excepcionales: "Estoy de acuerdo con el voto, lo que más me gusta es que sea voluntario, me parece que va a votar más gente porque es voluntario. Generar consciencia sin apretujar cuellos, genera más consciencia" (Vice-Directora EEST $N^{\circ}$ 2). Tal como describe, una mayoría de docentes son reticentes a tratar el tema en sus clases. Los encuentros convocados desde el Estado y otras organizaciones, se vivencian como una irrupción a las restricciones escolares, generando situaciones de conflicto: 
Acá se dio una discusión cuando estábamos haciendo el taller, de un profesor a las 4 de la tarde que fue a decir: Yo quiero mis alumnos en el salón. Y fueron dos chicas que no eran de la escuela a decirle que el taller era voluntario, que faltaban 20 minutos y que los chicos tenían derecho a terminar el taller. El profesor, de 60 años, dijo: Cuando yo fui a votar, agarré la boleta, fui, voté, ¡no le pregunté a nadie! Y una de las chicas le dijo: Mire, como usted votó, así nos fue a todos, jajaja. Le dijo a una eminencia de acá la escuela, y el profesor dijo: A mí me importa un pito, esta es mi clase (...) esta es una escuela técnica, iy los técnicos no piensan! Y las chicas decían: “'los técnicos también votan, porque son ciudadanos!

Una segunda posición pone el acento en una formación ciudadana, no política, que requiere de un profundo trabajo de comprensión histórica. Significa la reconstrucción de una cultura compartida, prácticas vitales y simbólicamente efectivas que se materializan en la vida cotidiana. Lo cuestionado en estos casos no es la ley en sí misma sino la ausencia de competencias ciudadanas indispensables para la toma de decisiones. Si nos centramos en los conectores adversativos, estructuran lógicamente los discursos con la finalidad de oponer o contradecir ideas:

Estoy de acuerdo con el voto a los 16. Pero haría falta por parte de los docentes prepararlos un poco más, informarles nosotros qué posibilita esto, qué pasaba en otras épocas, qué posibilidades hay de conocer a los candidatos, poder acercarles a ellos... (EEST $\mathrm{N}^{\circ} 1$, Prácticas de Lenguaje).

Estoy de acuerdo con el voto a los 16 , pero hay que darles herramientas desde la escuela (...) volver a las Olimpíadas, a cuidar la escuela. Ahora estamos con la idea de rasquetear todo, a pintar, a inculcar esa responsabilidad, esa identidad o ese sentido de pertenencia (EEST N 1, Matemáticas).

Un tercer grupo asume una posición de rechazo explícito. La edad, la falta de madurez intelectual y el desinterés son las razones de mayor peso. Pero a la subestimación de la Ley subyacen fundamentos más determinantes: la negación de la política, con frecuencia bajo la convicción weberiana de que el docente "no debe inculcar" sus opiniones. Y además, una concepción idealizada, des-politizada, del ciudadano joven, custodio de valores morales y políticos pero sin capacidad de ponerlos en ejecución. El voto joven representa una intromisión innecesaria:

La mayoría de los chicos me han dicho que no van a ir a votar. Yo no estoy de acuerdo. Sí me gustaría que se trabajara pero que no influyera en el resultado final, pero no tienen demasiado conocimiento ni interés. No es un tema que se discuta especialmente en la escuela. Hubo una charla y la mayoría iban a venir para zafar de la clase, pero los que no tenían clase no vinieron y algunos ni siquiera para zafar... (EEST $\mathrm{N}^{\circ} 2$, Informática).

\section{¿Cuáles son las definiciones que reconocen los jóvenes como directos implicados en el} voto a los 16 años? Registramos una sola opinión a favor, asociada a intereses personales que se motorizan en espacios participativos ajenos a la escuela. Ahora bien, no excluye el examen de las contradicciones entre la opción de votar y las responsabilidades, entre la reducción de la minoridad y la ampliación de derechos en base a la autonomía como condición necesaria del ser ciudadano. 
Pero ahora sí, nos preguntaban si estábamos de acuerdo, sí estoy de acuerdo pero, bueno, si tenés edad para votar, yo les digo ¿también tenés edad para falsificar el DNI, para entrar al boliche? Porque es una contradicción, también porque sos ciudadano para poder votar pero no para ir preso si cometés un delito, ¿no? (EEST N ${ }^{\circ}$ 2, varón, 17 años, Secretario del CE).

Estas observaciones se agudizan en opiniones desfavorables, sin perjuicio de la edad, el género o la pertenencia institucional. Lejos de cierta concepción idealizada, aducen la falta de preparación escolar, el desinterés, la desinformación, la sensación de sentirse obligados. La decisión del voto está sujeta a la interpelación ética y en ámbitos de discusión que no niegan su conflictividad, lo que permite salvar lo que Cullen ha definido como la tentación de la democracia deliberativa: cierto "paternalismo responsable", cuando el otro no quiere o no sabe dialogar:

...si no tenés edad para manejar, ¡no tenés edad para elegir quien va a gobernar tu país! Ahora los de 16 son más chicos, son re inmaduros, así que menos. No tienen ganas, casi que los obligan. Y la escuela no los prepara para eso, no hablamos de eso, pero tampoco tiene que prepararnos. Tenemos que ver programas de política, estar informados (EEST $\mathrm{N}^{\circ} 2$, mujer, 13 años).

Yo sinceramente no sabría a quién votar, por más que me lo expliques, no entiendo, no nos interesa a nosotros, a los 18, bueno, ahí tenés otra mirada (...) Yo tengo amigos que van a votar por los padres, cuando tenga que votar, no estoy preparado, la escuela no nos prepara, o así nomás (EEST N 1, varón, 16 años).

Los desacuerdos con la Ley del Voto Joven, predominantes entre docentes y estudiantes, apelan a una madurez política que la escuela debería formar, pero esa formación es también aquello que se excluye. Es notable que los jóvenes no perciben el voto a los 16 años como un derecho adquirido sino como una responsabilidad para la que no se sienten preparados, un modo de consciencia que reclama un grado de autonomía que parece resultar de todo el proceso de escolarización. Esto es, la capacidad de decidir por sí mismos y de percibir la naturaleza social de las normas, sean aceptables o cuestionadas. Asimismo, operan en estas percepciones imaginarios sólidamente arraigados acerca de la neutralidad política de la educación, desfasada por completo de las valoraciones positivas que recibe la ciudadanía como proyecto formativo. Así y todo, como se desarrolla en adelante, los espacios escolares pueden constituirse en esferas públicas de deliberación colectiva, posibilitando la integración de las subjetividades juveniles en formas de participación que no se restringen al cumplimiento de derechos.

\subsubsection{Globalización y Participación: "la política... afuera"}

Como política de Estado, el PCI representa un campo de tensiones entre las formas de participación social desde una pluralidad de espacios culturales, y la tendencia dominante a uniformar características, donde las TIC encuentran sus posibilidades de expansión y desarrollo a nivel 
global. En el marco de la trama ciudadanía/política/democracia, verificamos en la primera etapa que globalización y participación aparecen disociadas, de acuerdo a: 1- las transformaciones socioculturales aceleradas; 2- los modos novedosos de comunicación y su incidencia en las relaciones cotidianas; 3- los desarrollos del sistema productivo y el trabajo; y 4- la experiencia localizada, donde la digitalización se presenta como un factor de creciente complejización.

Una perspectiva subraya a la comunicación como difusión de información desde un enfoque de tipo funcional, siendo frecuentes las alusiones a la conectividad y sus beneficios en términos de integración o eficacia en la socialización de valores, aunque en el marco de los principales centros del capitalismo desarrollado (Bruno, 2011): "Vos te conectás a Canadá, a cualquier lado. Yo tengo una hermana en EE.UU., abro la computadora y a través de Skype, veo la fotografía..." (ViceDirector EEST $\mathrm{N}^{\circ}$ 2). Atender a las nuevas expresiones de los reclamos colectivos, reposa en una defensa encendida que permite asimilar estos cambios, pero a costa de clausurar lecturas más agudas acerca de sus implicaciones ideológicas. El mismo discurso está centrado en los niveles de productividad económica, antes que de participación política: “¡De hecho, el mundo está en crisis por las nuevas tecnologías! La revolución árabe se produjo por Facebook, porque un ingeniero árabe dice: cómo, estoy cobrando un dólar por día, y en América, en otros países...”

Estas transformaciones configuran en la EEST $\mathrm{N}^{\circ} 1$ un mundo ajeno, frente a las preocupaciones centradas en un deterioro institucional que ha ido en progresión en los últimos años. Prácticamente invisibilizadas en el discurso, las tecnologías solo indican las contradicciones entre la provisión de recursos desde el Estado y las dificultades estructurales o de aprendizaje. Al mismo tiempo, acusan la desantención por parte del Municipio. La Directora se muestra apesadumbrada por estas situaciones, intentando justificar las deficiencias de su gestión. Marcas enunciativas como apelativos, repeticiones y calificativos construyen esta vivencia personal:

Y yo soy una persona tímida, para pedir para mí, pero para pedir para la escuela me atrevo. Estaba el Intendente, entonces me le aproximé y le dije: Mirá, necesitaríamos una entrevista. ¿Por qué motivo?, me dijo. Nosotros el año pasado presentamos una carpeta. Me dijo una serie de groserías que no puedo repetir. Volví... Veníamos en el auto con la chica y no le quería transmitir... Pero me sentía mal. Yo se ve que decía: qué cosa, qué barbaridad, y la chica me miraba y me decía: qué le pasa. Y me vine amargada, porque no le dije nada, yo soy un poco sumisa en ese sentido. Y ha hecho un montón de obra que no tiene que ver con la escuela pública, y todos me decían: ¿Por qué no le dijiste? Me vine con la cabeza gacha...

Estas características auto-percibidas representan la posición de sumisión de la escuela frente a la indiferencia del Estado, correlato de la mirada acusatoria de la comunidad toda. El testimonio continúa describiendo una serie de dificultades cotidianas, en el marco de una experiencia fuertemente localizada, alejada de las interpretaciones sobre la globalización: 
...y entre las cosas que me dijo, que me lo dijo bien, es: No sé qué va a pasar con esa escuela, porque esa escuela tiene problemas. Nosotros vivimos en una comunidad chica, la gente se maneja con chusmerio barato, no sé a este muchacho qué le llegó porque él nunca vino acá a ver, nunca se interiorizó. Que es una escuela con problemas, sí, que hay chicos bravísimos, que hay chicos violentos, me va decir a mí que es una escuela con problemas.

Pero incluso en estas situaciones desfavorables, hay consensos sobre la formación para el trabajo, que unifica a los docentes en un mismo marco comprensivo: "Pero además porque en escuela técnica hay toda una relación con la tecnología. Esto está en el marco de la Ley de Educación Técnico-Profesional, que es todo un movimiento, que responde a las demandas del país” (EEST N ${ }^{\circ}$ 1, Montaje de Proyectos Electrónicos). Estas nociones conllevan los interrogantes acerca de la significatividad de los aprendizajes, la obsolescencia del conocimiento, las estrategias que debe emprender el docente para promover capacidades de desempeño con mayor flexibilidad: "Yo me pregunto: lo que les enseño, ¿lo van a aplicar de esta manera? Creo que no. Se desempeñan en el trabajo y la empresa los forma, porque además las tecnologías avanzan tan rápido..."

La Enseñanza para la Comprensión puede ser vinculada con la centralidad de la premisa de “aprender a aprender", que reposa en las perspectivas constructivistas. Especialmente en escenarios de cambio acelerado, se apunta a que los alumnos se vuelvan capaces de gestionar sus propios procesos de aprendizajes, con creciente autonomía. Así lo destaca el mismo entrevistado:

Sí, socialización es lo más fuerte que está aportando la escuela. No está tan mal. Porque además hay una gran atomización del conocimiento. Un profesor me acuerdo que me dijo: el técnico tiene que tener capacidad de aprender a aprender. Más que la cantidad de conocimiento.

Excepcional en esta primera etapa, el trabajo interdisciplinario tiende a promover un conjunto de saberes actualizados, profesionales y competitivos para afrontar las determinaciones del capitalismo. Describe esta profesora de Geografía un proyecto de Electromecánica (EEST N 2), lecciones-paseos en las cuales los alumnos se sienten motivados y dotan de significatividad a los contenidos: "lo que entra por los ojos, no se lo olvidan más", en especial acerca del impacto de la técnica en el sistema productivo, "porque lo que antes lo hacían diez obreros ahora lo hace uno que aprieta un botón." Los alcances de actividades de este tipo dependen de cómo los docentes enseñan a aplicar conceptos, métodos y estrategias, a articular un creciente cuerpo de conocimientos y a poner en práctica una comprensión compleja y sofisticada. En la medida en que se integran orgánicamente a los propósitos de enseñanza, las salidas educativas propician la contextualización del conocimiento y la apertura a otros niveles de participación escolar y social.

En la segunda etapa, los ejes mencionados se continúan, otros son relativamente novedosos. Un aspecto clave es la problemática constitución de las identidades colectivas. Hay algunas que se 
retraen, se desplazan, pero de ningún modo desaparecen. Siguiendo a Hall (2010), lo que se está debatiendo es la tensión entre lo global y lo local, donde las identidades nacionales representan una forma particular de apego o pertenencia. A partir del PCI, la nación activa unos procesos de re-localización y al mismo tiempo, se hace presente como expresión del Estado, otorgándole a los sujetos cierta sensación de seguridad y certeza constantemente amenazada. Cierto es que el tema no aparece inmediatamente: "yo no tengo registro que se esté trabajando la idea de nación. Por ahí algún profe de CDC... pero yo no tengo referencia" (Vice-Director EEST $N^{\circ} 2$ ). Pero avanzados este y otros relatos, comienzan a enunciarse valores nacionales, resignificados o instituidos. La escuela tiende a afirmar esa cultura compartida en sus esfuerzos por normalizar los cambios y lograr recomponer sus propias configuraciones identitarias.

Los actos patrios son insuficientes para movilizar esa construcción. Pero la escuela los conserva más allá del protocolo, bajo la doble lógica de visibilizar una memoria común, una temporalidad menos evasiva que resiste el dominio de lo efímero, y un espacio colectivo, en el que los estudiantes pueden colaborar activamente y otorgarles significado. El proyecto promotor de ciudadanía persigue el respeto a los símbolos patrios, aunque desde nuevas representaciones que sintetizan una afectividad que no se explica desde diferencias generacionales: "Para ellos el significado del himno, de la bandera, la ven reflejada más en el deporte. Pasa también en los adultos, el ciudadano común, ahora no ves en las casas las banderas" (Vice-Directora EEST No 1).

Si bien basados en el calendario escolar, los actos patrios motivan espacios para abordar esos temas en las aulas, alternativos al currículum. Como en el caso de Prácticas del Lenguaje:

Se habla en ocasiones especiales, trato de llevar algún texto según el acto que sea, que lo trabajemos, y ellos participaron muchísimo (...) en los actos antes nadie escuchaba... Después de todo ese trabajo que se hizo, cambió muchísimo, re bien ellos, participan, todo... A mí me llamó la atención, todos los docentes lo charlamos (EEST No 1).

La disociación entre globalización y participación se extiende en esta segunda etapa. Y lo que la profundiza es el esfuerzo extendido de despolitización. En el orden institucional, los modos reconocibles de participación ratifican el lugar preponderante que en los discursos educativos ocupa la acción cotidiana, escindida de toda manifestación política. En el caso de la EEST $\mathrm{N}^{\circ}$ 2, comprenden prácticas estudiantiles no solo aceptables, sino inherentes a sus tradiciones. Estas apreciaciones adquieren, sin embargo, ciertos matices, entre la negación de la política y su afirmación consciente, pero que no es percibida por otros como tal.

La participación estudiantil está anclada en la escuela y ni siquiera ahí manifiestan mucho interés en la política. En esta escuela menos. Hay una concepción más bien negativa (...) son muy activos, pero es una política estudiantil en sentido estricto (profesora Informática). 
Acá no se ve esa politización, no sé, tal vez tenga que ver con las ciudades, en Buenos Aires toman las escuelas, acá tiene que ver con... pintar. Esa participación es cotidiana, pero es también política. El tema es que ellos no lo ven así (profesora Seguridad e Higiene).

Estos consensos básicos adquieren múltiples correlatos en torno a nuestro segundo eje, la globalización. Pueden fundarse en una perspectiva sistémica si rechazan por distorsivos los efectos de una sociedad interconectada que vuelven permeables las fronteras escolares. Paradójicamente, también refuerza el imaginario tecnocrático que esa misma sociedad reclama. La coordinadora regional del PCI opera una separación taxativa entre el modelo y los ordenamientos políticos de la ciudad. Esos límites sobre los cuales se construye el ideal de la escuela aséptica, resultan de sólidas representaciones, en vistas a normalizar una política educativa sin "interrupciones":

Es un distrito muy movido, y con lo del Intendente me han cacheteado de todos lados, que tienen que llegar las computadoras, que el servicio técnico. Antes el Municipio no se metía (...) Yo siempre digo lo mismo: la política puede pasar... de las puertas de la escuela para afuera. No pueden hacer lo que quieran. Trabajo mucho con la Inspectora regional y soy muy cuidadosa con eso, que no vayan a hacer campaña política... Se cuida mucho.

Un orden moral construye ese "deber ser" que adquiere vinculaciones problemáticas con las derivas de la globalización. Ante la pregunta por la ciudadanía, advierte la entrevistada que “todo pasa por el mundo digital", pero la escuela afronta el desafío de mantenerse ajena de sus determinaciones ideológicas: "Y mucho tienen que ver con los medios de comunicación, y están influenciando mucho. Yo digo que la escuela debe ser apolitica, no debe estar condicionada por nada más que por la educación." En contraste, las transformaciones tecnológicas adquieren valoraciones positivamente cuando se trata de la profesionalización técnica, basada en decisiones institucionales y pedagógicas orientadas a producir mayores acercamientos con el sector empresarial de la región, otra expresión de la pretendida despolitización: "Pero ¡cuándo nos vamos a juntar! Y el nexo podría ser la tecnología” (profesora EEST N² 2, Seguridad e Higiene).

Sin embargo, a propósito del capitalismo tardío que "va al trote”, “está en su auge”, es imperativo crear consciencia crítica en los estudiantes, no solo condiciones de empleabilidad, en tanto las empresas "son más poderosas que las naciones" y "la tecnología empieza a suplantar cosas que antes hacía el hombre con la tecnología" (Director EEST $\mathrm{N}^{\circ} 2$ ). El discurso utiliza subjetivemas, ironías y metáforas, poniendo en cuestión tanto el valor formativo de la tecnicidad dominante, como asimismo los sentidos de una ciudadanía motorizada por el consumo:

El gran éxito que tienen estos muchachos, este capitalismo, que se la va comiendo a la población. Yo creo que la sociedad, la cultura, pierden, le tiran deporte, futbol, esto, lo otro, y si uno analiza el sostén profundamente de hoy en día (...) es un modelo de consumo y no de producción. Digamos que tampoco... es Cristina, pero el modelo ese es mundial... 
Enseñar para la ciudadanía supone así concretar espacios de deliberación de ideas, formas efectivas de problematizar con los alumnos las implicaciones de la hegemonía cultural por parte de los países centrales. Estos intercambios definen ámbitos privilegiados para desnaturalizar los supuestos recibidos y adquirir habilidades orientadas a su transformación. Reconociendo cierto fastidio personal, esta profesora de Historia (EEST $\mathrm{N}^{\circ} 1$ ) se esfuerza por integrar los intereses de los adolescentes, percibidos en sus tensiones y puestos en debate con ellos:

A mí me sorprende porque doy las Invasiones Inglesas, me duele en el alma. La primera invasión, nos invadieron... Y me dicen: Qué bueno que hubieran ganado, seríamos ingleses. ¿iPerdón!? Hablaríamos en inglés... Al final, ipara qué explique este tema! (...) No, la simbología y la conquista ideológica que hace Inglaterra es fantástica, mal que nos pese. El consumismo y la mirada que ellos tienen, y cuando uno trabaja la identidad nacional, sí el país Argentina, sí el fútbol, pero cuando tienen estas propuestas salen estas cosas.

Aunque estas reflexiones no siempre remiten a la formación ciudadana, permiten discutir dos supuestos: la despolitización de la educación y la disolución absoluta de las identidades bajo las premisas de la globalización. Relativizan lo que los EC suelen asumir como el vaciado de densidad simbólica de la nación, su capacidad de convocar y aglutinar un sentido de comunidad. Mattelart y Neveu (2004) han cuestionado cierto abandono del ciudadano por el consumidor, a expensas de la interrogación sobre la recomposición de la nación como sobre el estatuto del consumo, cada vez más integrado a las industrias culturales. Así, la identidad nacional puede encarnar el signo de una carencia, pero que se hace presente en el encuentro con otras identidades, sobre todo las escolares. Los discursos también registran una progresión desde una disociación notoria entre globalización y participación, hacia sus entrecruzamientos, que les permiten a los actores interpretar las repercusiones del PCI en el marco de sus experiencias localizadas.

\subsubsection{Principales observaciones}

Sintetizando de manera esquemática la Dimensión que configura el entramado Ciudadanía/Política/Democracia como experiencia situada, se verifica que:

1- La ciudadanía está ausente como problema. Sin embargo, se priorizan capacidades ciudadanas, si bien no definidas en esos términos: principalmente, la responsabilidad, en el tipo de utilización de la netbook, el trabajo áulico, la adopción de normas en marcos de socialización. Ante el predominio de una racionalidad instrumental, empieza a verificarse una racionalidad comunicativa. La cuestión de la autonomía adquiere múltiples aristas, y es definida y puesta en práctica en clave de autorregulación de las acciones avanzada la adecuación del PCI. 
2- Las condiciones materiales y simbólicas de la ciudadanía permiten clarificar el interjuego entre integración y autonomía que se da al interior de las escuelas en los comienzos del modelo. Se experimenta como algo externo e impuesto, lo que redunda en calificaciones negativas de la política como propagandística, poniendo en duda sus sentidos inclusivos y democratizadores.

3- La diversidad no es observada como condición estructurante de una ciudadanía cultural. La naturaleza heterogénea de los grupos se traduce en obstáculo para la enseñanza y la introducción razonablemente uniforme de las netbooks. Además, la tecnología no parece formar parte de las necesidades primarias o los derechos básicos. Con el tiempo, la diversidad adquiere otros sentidos, en atención a las experiencias extra-escolares, la distinción entre ciclos y la formación de saberes con mayor flexibilidad. Se advierte que el respeto a la diversidad puede alentar la reproducción de la desigualdad; el rol docente es el de actuar para su transformación.

4- Emergen en esta segunda etapa los debates acerca del voto joven. Si bien se considera el pleno ejercicio de la ciudadanía política, tiende a ser descalificado por el conjunto de los actores. Los jóvenes aducen desinterés, no sentirse preparados ni acompañados por la escuela, la falta de competencias indispensables. Responsabilidad, racionalidad y autonomía emergen con fuerza como capacidades ciudadanas para la toma de decisiones, a contramano de la acción política.

5- Separadas entre sí, globalización y participación se hacen presentes en estas tramas interaccionales, materializando las tensiones global/local. Cierto es que las dificultades que atraviesa una escuela la lleva a relegar estos temas, mientras en la otra predomina una razón tecnocrática, que mide estrictamente los efectos de la tecnología en los saberes profesionales. Pero experiencias didácticas, de tipo interdisciplinario o bajo el propósito de "aprender a aprender", tienden a afrontar en la experiencia localizada los efectos de una sociedad interconectada.

6- Avanzado el PCI, la participación estudiantil está situada en la escuela, lo cual, por un lado, refuerza la imagen de la política como ajena y descalificada; por otro, resiste a las orientaciones de la cultura globalizada. Otro desplazamiento opera a nivel de las identidades colectivas: la nación reactiva elementos residuales, en relaciones y tensiones constantes con los consumos culturales. Y bajo la guía docente, las TIC no solo habilitan la conectividad, también ofrecen alternativas para comunicaciones más fluidas, alternativas a la tecnicidad dominante.

\section{2. Ciudadanía/Educación: problemas y desafíos}

El sub-campo de la comunicación/educación contribuye al reconocimiento de que la ciudadanía solo es comprensible en y desde las prácticas de los sujetos históricamente situados. Por tanto, entendemos que la formación de ciudadanía no puede limitarse a la enseñanza de los derechos 
humanos ni de los contenidos de una materia específica. Tal formación exige nuevas formas de articulación entre la teoría y la práctica, la reorganización de las prácticas de enseñanzaaprendizaje, la reestructuración curricular y del funcionamiento mismo de las instituciones, en términos de consensos establecidos entre los distintos actores. Interpelar lo educativo desde las prácticas culturales permitirá entonces superar lo que Huergo (2010) ha definido como representaciones reduccionistas: la que considera a la educación como una acción aislada de sus determinaciones socio-históricas, y otra que la vincula de modo excluyente a la institución escolar.

Las aproximaciones a la noción clásica de "formación" (bildung) nos conducen a la hermenéutica de Gadamer (2004) quien, a partir del pensamiento kantiano, designa la formación como el modo genuinamente humano de dar forma a las disposiciones y capacidades naturales del hombre. Una consciencia formada implica también el reconocimiento de los puntos de vista distintos, por lo que comprende un sentido de mesura con el otro, abierto al mundo como universo simbólico, una auto-comprensión histórica fundamentada. Recuperando la Teoría de la Acción Comunicativa de Habermas, la autonomía emerge como estrategia para educar la ciudadanía, asociada con la idea de lo público como espacio donde los iguales ejercitan la razón a partir del uso reflexivo del lenguaje (Sgro, 2008). Comprende también un sentido ético en el desarrollo de conocimiento crítico, que requiere de sujetos responsables, solidarios y comprometidos con la consolidación de la democracia.

Estas nociones pueden inscribirse en una concepción dialéctica del conocimiento, donde la educación emerge como praxis transformadora y, por ende, política. Al decir de Paulo Freire, "es praxis, que implica la acción y la reflexión de los hombres sobre el mundo para transformarlo" (1985: 84). Esta tarea convoca a los educadores que no devienen meros técnicos o servidores públicos que deban "adaptarse" al sistema; antes bien, han de encarar las condiciones materiales e ideológicas que les permitan mediar, legitimar y actuar en su calidad de intelectuales, hacia el cambio social democrático (Giroux, 2013). Es así que deberán incorporar nuevas experiencias juveniles y los saberes que de ellas resultan, los movimientos sociales -aun en sus formas más difusas- y otras posibles articulaciones de la lucha por la ciudadanía.

En consecuencia, las escuelas no se reducen a ser aparatos ideológicos según la tesis althusseriana, pero tampoco responden a ninguna mirada esencialista. Por una parte, las instituciones pueden dinamizar la construcción de hegemonía, en la que las culturas subordinadas presionan las prácticas, las representaciones, los lenguajes supuestamente no problemáticos y homogéneos de la cultura dominante. Por otra, la formación de ciudadanía implicará poner en cuestión los imperativos heredados del proyecto modernizador, largamente renovados e instituidos: la noción falsamente igualadora de la ciudadanía, que niega las profundas 
desigualdades de clases, creando la ilusión de que la educación per se desarrollará las condiciones para la participación crítica, pluralista y equitativa de todos los sujetos.

Una mirada histórica resulta indispensable para explorar la llamada "despolitización" de los jóvenes, a fin de revisar su vigencia, sus presupuestos, sus alcances, sus vinculaciones con la posterior "politización" y la producción de significados específicos, propios y alternativos, atribuidos a la política. El concepto de "comprensión histórica" pone de manifiesto que sin formación histórica no hay comprensión política -condición necesaria pero no suficiente- "y que el reconocimiento por parte de los jóvenes de su propia dimensión histórica es condición sine que non para que se puedan autocalificar como sujetos políticos" (Kriger, 2010: 214). Paradójicamente, la escuela ha legitimado los valores instituidos de la historia oficial, pero al mismo tiempo, es hoy el lugar privilegiado que puede dotar a los "nuevos ciudadanos" de herramientas culturales, cognitivas y disciplinares, necesarias para la plena comprensión histórica y, en consecuencia, de una ciudadanía crítica y problematizadora.

\subsubsection{Los componentes Gnoseológicos: ¿qué significa “domesticar”?}

Comenzando por la dimensión gnoseológica de la relación ciudadanía/educación, nos centramos en las materias específicas (Construcción de Ciudadanía, Política y Ciudadanía, correspondientes, respectivamente, a 1er. y 5to. Año), los tipos de conocimientos producidos, percibidos y esperados. La construcción de ciudadanía aparece atada a las definiciones sobre la ciudadanía. En relación a ambas, la primera observación es un alto grado de indefinición. Al igual que con otros temas, el marco de referencia tiende a ser la asignatura. Los discursos parecen entonces disociar dos acepciones generales: a- restringida a los contenidos específicos, y b- como problemática transversal o proyecto educativo. La primera es la dominante.

Entre los profesores, subyacen concepciones arraigadas sobre las materias a cargo, las características que las delimitan con respecto a otras y definidas por su grado de especialización. Estas valoraciones son recurrentes en las materias técnicas y exactas de área en ambas escuelas, lo que relega las preocupaciones sobre la formación ciudadana como un proyecto compartido:

¿Cómo formar un ciudadano, que pueda pensar críticamente, desde otro lugar? ¿Cómo actúa la escuela con eso? Todavía no lo tengo claro, porque tienen CDC, pero más allá de los derechos... Cada materia tiene sus cuestiones, sus problemas, ¿no? (EEST $\mathrm{N}^{\circ} 2$, Matemáticas).

Claro que hay una materia específica, $\mathrm{CDC}$, en la Básica, que trata estos temas, muy bien no sé, mi materia forma parte de la formación científico tecnológica, no tiene mucho que ver que digamos (EEST Nº 1, Análisis Matemático). 
La segunda posición se materializa casi exclusivamente en la EEST $\mathrm{N}^{\circ}$ 2. Reposa en dos ejes, el primero es la participación en la vida institucional: "Hay una democratización de la escuela, se les da participación a los centros de estudiantes, se forman órganos de participación para que ellos nos ayuden a gestionar la escuela, y para que vayan viviendo la vida democrática... (Vice-Director). El segundo eje es el trabajo por proyecto, no solo en cuanto modalidad didáctica sino en su potencial para la formación ciudadana. Apela a la articulación entre áreas, el intercambio de saberes, redes de comunicación para el desarrollo de la autonomía. Un caso es un proyecto en el que profesores de Informática y Política y Ciudadanía animan a alumnos de Informática a compartir habilidades de dominio operativo con compañeros y docentes de otras orientaciones.

En esta clave podemos retomar la cuestión de la domesticación. Además de domesticar a las TIC en base a experiencias personales y colectivas de apropiación, se reconoce un segundo sentido del término, igualmente sugestivo, que desborda largamente los componentes gnoseológicos de la ciudadanía. A la manera de El Principito de Antoine de Saint-Exupèry, "domesticar" en este caso significa “crear lazos", no la sujeción a lo dado, sino ser y sentirse parte (del latín domus: casa). Los mandatos de la educación técnica son conservadores, pero son sus agentes quienes operan constantes reconversiones, donde desarrollar capacidad de autonomía emerge como uno de los principios de la escolarización. El estudiante forma parte si logra adecuar la cultura escolar a sus propias motivaciones, saberes y afectos, en una suerte de "domesticación cruzada":

Que se adapte al trabajo, pero desde una formación ciudadana. Mmmm... Creo que la escuela forma un sujeto institucionalizado. Los ves cómo entran a 1ero. y cómo salen de 5 to. Nada que ver. Al chico se lo "domestica", por así decir... Sí, creo que hoy la escuela apunta a la socialización, que no es poco ¿eh? (EEST N 1, Montaje de Proyectos Electrónicos).

¿Cómo se juegan entre los estudiantes estas representaciones? Sinteticemos cuatro puntos. Primero, la relación entre tecnología y ciudadanía está por completo ausente, a pesar de que las consideraciones acerca del modelo 1 a 1 tienden a ser favorables en razón de su carácter inclusivo; este aspecto es compartido con docentes y directivos. Segundo, los discursos juveniles comprenden la importancia de la educación orientada al propósito de construir ciudadanía. Si bien se trata de un proyecto no siempre realizable, educación y ciudadanía aparecen como prácticamente equivalentes, significados que registran continuidad en el tiempo. Tercero, las dos materias específicas son directamente subestimadas, sobre todo a causa de la naturaleza irrelevante que atribuyen a sus contenidos. Finalmente, la ciudadanía como tal está predominantemente asociada al conjunto de derechos y obligaciones. Comporta un marco difuso entre valoraciones positivas y sentidos abstractos que se tornan difíciles de aprehender: "No... tuvimos la materia, pero no me acuerdo de qué se trataba, de derechos ¿no?” (EEST N 1, 6to. Año, Química). 
Sin embargo, el sentido de transversalidad recrea el dualismo entre los contenidos restringidos de la ciudadanía como asignatura, y lo que se considera verdaderamente importante: una trayectoria extendida, plenamente vivida, en esa "segunda casa" que es la escuela. En los marcos institucionales se promueven los niveles de domesticidad, "el respeto, con la responsabilidad, que tienen que ver con la ciudadanía." Allí se inscriben las negociaciones constantes entre subjetividades juveniles e identificaciones escolares. Al tema de la ciudadanía:

no se lo trata muy puntualmente, es como general, todo el tiempo te están construyendo como persona, en todos los años de la escuela. Porque la escuela en sí te ayuda a formarte como persona, estás en un ambiente en el que estás con otras personas, donde aprendés a relacionarte con esas personas, ¡durante seis, siete años! Pero de CDC no me acuerdo nada (EEST Nº 2, 5to. Año, Electromecánica).

Hacia la segunda etapa, observamos continuidades de ambas concepciones de la ciudadanía, como área curricular y proyecto transversal. Pero ahora son complementarias. Como asignatura, sigue estando "pendiente": "Los de CDC, pobres, los pusieron de materia de relleno, generalmente la última hora y separada. No tienen especificidad, y está el nomenclador y quienes están habilitados, y terminan dando los profesores de Educación Física" (Director EEST N 1). Estas contradicciones aparecen marcadas en ambas escuelas, dada la subestimación de los docentes a cargo, la ambigüedad en el currículum, los problemas de implementación: “CDC no está construyendo ciudadanía, no sé si en todos lados es así, pero en sus fundamentos, primero por esta cuestión que la da cualquiera que no es que esté mal, pero hace que pierda substancia la materia" (Vice-Directora EEST N ${ }^{\circ}$ 2).

Es la profesora de CDC quien retorna a las características del área, los lineamientos generales y el trabajo concreto por proyecto. Abunda en calificativos: "La materia es genial, está re bien pensada. Ciencias Naturales, Educación Física -yo soy de esas áreas-, te almidonás un poco. CDC estuvo bastante ninguneada, ahora no." La metáfora cuestiona la mirada de otros, ponderando la falta de especificidad curricular como un valor añadido, con suficiente flexibilidad para abordar gran cantidad de temas: “...que no haya un perfil definido supone que todo docente esté capacitado para trabajar en esta construcción ciudadana. Hay un montón de ámbitos para trabajar y son re variados: diversidad cultural, derecho y política, derechos humanos, trabajo, medioambiente."

Esta opinión no deja de ser excepcional, contraria a las experiencias que reconocen los propios estudiantes. CDC se dicta en 1er. Año, a grupos de pre-adolescentes, numerosos y heterogéneos que aún no han interiorizado valores considerados básicos para la formación. Las definiciones siguen siendo evasivas: no logran explicitar qué tipos de contenidos, conceptuales y actitudinales, o las formas de aprendizaje a ellos asociados, pueden contribuir a formar ciudadanos. Las críticas desde materias vinculadas redundan en la falta de conocimientos previos: 
...en el 5to. hace dos años que les hago leer el Preámbulo de la Constitución que para mí es hermoso, no lo conocían. Después de tres años de Ciudadanía, porque el espacio es hermoso pero lo que están haciendo, jun desastre! Y entonces hablamos de la memoria cognitiva, noooo... y yo hablo como me sale. ¿Quién te dijo eso? (EEST N², Política y Ciudadanía).

La propia asignatura adquiere características diferenciales, no tanto en base a las prescripciones curriculares sino en las motivaciones que llevan a la docente a intervenir en la práctica. Pensada estratégicamente, la comunicación constituye la clave para alentar oportunidades de creación cultural, en marcos de interacción entre sujetos capaces de defender sus argumentos y debatir en forma libre en condiciones de igualdad. Estas premisas apelan a una redefinición de la formación política, aun si no es enunciada como tal. Se sostiene en el retorno a la idea republicana de espacio público, como lugar de encuentro de los ciudadanos donde se debate y genera opinión pública, en el marco de una sociedad deliberativa (Calderón, 2007). En el mismo relato:

Me dijeron: podemos hacer el Preámbulo de la escuela. Y lo escribieron ellos, en el marco del Preámbulo de la Constitución y lo leyeron en el acto del 9 de julio: "Nos, los representantes de la escuela Industrial reunidos en el Aula Magna..." (...) Brillante, claro que el chico te va decir que le es difícil, pero nosotros ¿cuántas veces leemos el Prólogo? Si al chico le das los instrumentos, pero ¡ojo con los instrumentos que le damos!

Una mayoría de profesores coinciden en la transversalidad del área, si bien el nivel de involucramiento en la práctica es diferente en cada caso. En áreas técnicas, el problema refuerza los límites entre asignaturas técnicas/de área, porque "es muy difícil en una materia muy técnica que salgan otras cosas" (Laboratorio de Programación, EEST N² 2). La búsqueda de alternativas para la deliberación de temas, más o menos afines a los contenidos curriculares, constituyen los esfuerzos de innovación entre docentes de materias humanísticas: “Tratar, yo, por ejemplo, desde Prácticas de Lenguaje traerles textos que para ellos sea un conflicto. Por ejemplo, estamos tratando texto expositivo sobre igualdad de género, para que salga algún debate...” (EEST N 1).

No es un dato menor que los estudiantes colaboran en tareas de limpieza, pintura y refacción del edificio, en pos de modificar favorablemente las condiciones que transitan, generar un sentimiento de pertenencia a la institución, "entender que la educación pública es algo que entre todos se hace”. De modo que si la asignatura sigue siendo el principal marco de referencia, comienzan a enunciarse espacios que la trascienden, acompañando los procesos de reconstrucción identitaria de la escuela. Un registro de sentido que confirma la importancia de los canales de comunicación, como el quehacer cotidiano en el cual todos se sienten individual y colectivamente implicados.

Más extendidos en esta segunda etapa, los proyectos institucionales se articulan en espacios de participación, convocando, por una parte, una inserción activa en la comunidad y el 
mejoramiento de la imagen escolar. Por otra, un conjunto de acciones razonadas, según "objetivos que sean realizables" para luego proyectar “objetivos más ambiciosos" (EEST $\mathrm{N}^{\circ}$ 1, Sistemas Productivos). Junto con la profesora de Arte, este docente ha planificado actividades que sus estudiantes llevan adelante con los vecinos, en el marco de los festejos del $40^{\circ}$ Aniversario del barrio. Por ejemplo, pintar murales donde "quede plasmada la cultura del trabajo", valores que puedan ser extendidos a toda la sociedad. La ciudadanía es el hilo conductor, punto de encuentro entre asignaturas y en la construcción de una experiencia localizada en el contexto comunitario.

Entre los estudiantes, la cuestión gnoseológica continúa remitiendo a derechos y obligaciones. Esta idea está anclada en la concepción de la educación como derecho social y humano. Pero en tanto área curricular, la debilidad de los contenidos y la falta de formación docente específica, vuelven las definiciones todavía más borrosas. La cualidad de la "importancia" es muy repetida: "Los profesores no se especializan en esa materia entonces no les importa tanto como si fuera su materia principal, por ejemplo, el que tenemos ahora es de Biología y la anterior era de Inglés" (EEST N 2, 2do. Año). "El año pasado teníamos CDC, desde 1ero a 3ero., no me pareció importante la materia porque no tenía los contenidos que... no eran nada interesantes" (EEST N², 4to. Año, Informática). Los conceptos son escasamente trabajados: "En CDC. No fue muy importante que digamos, los derechos y las obligaciones" (EEST $\mathrm{N}^{\circ} 2$, 5to. Año).

Coexisten estos planteos con la demanda de espacios que habiliten debates más profundos sobre temas de agenda pública, como la Ley de Voto Joven y los cambios ligados a la comunicación. El tratamiento es, en cualquier caso, superficial, como ejemplifica el uso repetido de pronombres que designan esa realidad indeterminada, cuya identidad se desconoce o no se puede especificar:

Hasta 4to. vimos CDC, vimos algo de las drogas, prevención y eso, pero mucho no me quedó. En 4to. recién llegaban las computadoras, pero no, no me acuerdo que hayamos visto algo, ah, del tema de la comunicación, del acceso a la información (EEST No 1, 6to. Año, Química).

La subestimación que reciben las áreas curriculares contrasta con la revalorización del centro de estudiantes (en adelante, CE). Para la EEST $\mathrm{N}^{\circ}$ 1, se trata de un mundo imaginable y posible que la ubica en un plano de igualdad con Industrial, modelo paradigmático de participación estudiantil. Si las definiciones de la construcción de ciudadanía son ambiguas, en cambio, adquieren materialidad en el presente cotidiano de la institución: "En Política y Ciudadanía, nosotros no relacionamos eso. Pero desde el CE, sí: formar el técnico desde un pensamiento... ciudadano... Hacer valer los derechos dentro de la propia escuela, y después afuera” (7mo. Año, Electrotécnica). Es que, como analizaremos, estas actuaciones juveniles no se agotan en la reivindicación de valores básicos, sino que convocan formas novedosas de sociabilidad. 
El valor de las TIC se inscribe en los dilemas de la formación ciudadana. La relación sigue siendo evasiva. Algunas consideraciones remiten a las expectativas hacia los aprendizajes formales, portadores de un conocimiento más calificado o genuino que los que puede proveer el acceso digital. Otros jóvenes apelan a superar esta dicotomía: corresponde a la educación integrar a la tecnología, pero solo en tanto sea desafiante de la concepción tecnocrática que suele gobernar las orientaciones de esa integración. Asociada al pensamiento crítico, la ciudadanía puede ubicarse en un marco de comprensión acerca de las contradicciones que vertebran los procesos de digitalización y, por tanto, tácitamente vinculada a unos usos más conscientes y responsables.

La construcción de ciudadanía oscila entre los contenidos y la participación, la debilidad curricular y el proyecto transversal, la importancia del área y sus significados restringidos a derechos y obligaciones. Progresivamente, el ciudadano es concebido como sujeto agente, en el sentido de $\mathrm{O}^{\prime}$ Donnell, dotado de razón práctica y discernimiento moral, en uso de “de su capacidad intelectual y motivacional para tomar decisiones que son en principio razonables en su función de su situación y metas de las cuales, salvo prueba concluyente en contrario, se considera que es el/la mejor juez/a" (citado en Vidoz y Coicaud, 2015: 27). En el campo de la comunicación los jóvenes logran comprender procesos de reconversión de identidades en las que se reconocen de manera consciente. Solo así se entiende la compleja relación que entrama la búsqueda de autonomía con la visión alternativa de “domesticar”, en el sentido más amplio -y político- de educar.

\subsubsection{La dimensión Política de la formación}

En lo que respecta a la Política, indagamos en tres áreas principales: los contenidos éticonormativos (valores y normas), los contenidos crítico-participativos (orientados a la consciencia reflexiva, la deliberación, la participación), como asimismo las situaciones que habilitan o dificultan la apropiación de esos contenidos. La relevancia del tema radica en las posibilidades de una ciudadanización de la política, sobre la base de un conjunto de competencias necesarias para su ejercicio responsable y criterioso en el espacio público. Los contenidos ético-normativos se vinculan con los sentidos políticos de la educación, en conflicto con las tradiciones presuntamente neutras orientadas al mundo del trabajo predominante en la educación técnica y a las determinaciones específicas de la Sociedad del Conocimiento.

Vos hablás en un concurso de la construcción del sujeto pedagógico y te miran así (gesto de extrañeza). Porque para ellos la escuela técnica es el mundo del trabajo, y eso está atravesado por cuestiones ideológicas. Porque forma para el mundo del trabajo, pero ¿qué estoy formando? Mano de obra salariada. Yo no quiero eso (Vice-Directora EEST $\mathrm{N}^{\circ} 1$ ). 
El relato abunda en refranes. "Yo creo que aunque la mona se vista de seda... (mona se queda)", es decir, la organización escolar puede mudar de apariencia pero en esencia seguirá siendo la misma. "Yo tengo una visión muy ácida de 6 años de remarla en dulce de leche", connota una actividad extremadamente difícil, agotadora, casi imposible. La estructura rígida que se le atribuye a la escuela parece condenarla a problemas prácticamente insalvables. Subyace la convicción de que las potencialidades del PCI difícilmente puedan realizarse en instituciones conservadoras, con docentes reticentes a movilizar esas innovaciones. Paradójicamente, creencias de este tipo obturan decisiones para encarar los cambios que se reclaman a nivel de la gestión.

Las observaciones negativas o indiferentes hacia el modelo 1 a 1 pueden responder a una noción restringida de política en tanto partidaria o electoralista, de decisiones que se imponen al aula como espacio ideológicamente aséptico. Se traduce en una percepción de la tecnología que deja de ser una herramienta educativa para convertirse en dispositivo de disciplinamiento. Este razonamiento se basa en el par de opuestos manipulación/crítica, bajo el supuesto de que la educación debe retraerse de los avances perjudiciales del consumo tecnológico:

Es por eso que yo veo algo político, yo no sé si acá los profesores lo ven: es mejor que estén jugando todo el día. Cada uno con su computadora todo el día, en el sentido de que así son más fáciles de manejar... (profesor EEST N² 2, Electrotecnia).

Creo que seguimos reduciendo la agilidad mental de nuestros alumnos, que seguimos reduciendo su capacidad de pensamiento. El docente debe evaluar que, desde hace 6 o 7 años para atrás, hemos perdido ese alumno crítico, pensante (...) ¡Todo lo que estamos implementando en educación de diez años a esta parte, nos está destrozando la educación! (EMATP EEST N²).

En la segunda etapa, el énfasis en la cuestión ética de la tarea docente responde a un escenario de progresiva normalización del PCI. La falta de disponibilidad a los equipos constituye un inconveniente importante, pero lo preponderante es la reorganización de las redes de comunicación que devienen favorables a su inclusión pedagógica. Queda claro que mejorar la enseñanza no depende de la modernización tecnológica sino de la actualización de los saberes, el compromiso profesional, la responsabilidad con el trabajo diario y el establecimiento de vínculos:

...salta cada cosa que te querés morir. Porque los alumnos vienen y te dicen: no, con tal profesor no entendemos nada. Y ¿por qué? Dicho acá el año pasado: porque el profesor tal viene con cara de culo y así uno no tiene ganas de aprender (Director EEST No 1 ).

La formación básica es esencial para desarrollar posiciones flexibles y abiertas al cambio, una condición que traspasa las diferencias generacionales entre docentes. Las expresiones enfáticas y coloquiales son la marca estilística del Director en sus críticas a la formación: “tenés que tener cierto grado de pensamiento político frente a la vida, donde supuestamente a vos te 
interesa la formación de un niño o adolescente. Y los profesores nuevos son más fascistas que los profesores viejos..." En los procesos de digitalización impulsados por el PCI parece ineludible la pregunta por el docente y su forma de intervenir en estas estructuras escolares y sociales.

\section{Los contenidos crítico-participativos de la política adquieren mayor centralidad en esta} segunda etapa. Proyectan la necesidad de pensar, construir y sostener mecanismos de participación social al interior de la escuela. Este es un componente nuevo de la EEST $\mathrm{N}^{\circ} 1$, donde la conformación de los $\mathrm{CE}$ es algo pendiente, si bien no de los objetivos inmediatos de la gestión.

Mmmm... no sé. No, el anteaño pasado se hizo un proyecto muy piola, una chica que estaba haciendo su tesis, fue para armar un CE, no como si fuera una comisión para chinchón, truco y canasta, sino una comisión CE donde previamente se hubiera trabajado en cuestiones políticas, no políticas partidarias, siempre lo aclaro, la idea era esa. Se laburó bien, los pibes estaban muy contentos, pero después tenía que seguir caminando solo, se fue cayendo, se fue cayendo...

En el caso de la EEST $\mathrm{N}^{\circ}$ 2, la larga tradición de los CE se sostiene en esa lógica instituido/instituyente, configurando canales de demandas donde se deliberan intereses comunes y se acuerdan decisiones con impacto en las aulas. La búsqueda de soluciones a problemas vinculares docente-alumnos no se sustentan tanto en un liderazgo centralizado que logre mediar esa relación, sino en la intervención directa desde una política estudiantil. Precisaremos luego que, con la conformación de la Federación de Centros de Estudiantes, el CE apunta a trabajar con otras organizaciones escolares, una iniciativa que tiende a expandir los lugares de participación.

En las aulas, ceder la palabra al alumno, discutir los temas, desarrollar habilidades de lectura crítica, son posibilidades supeditadas a la disposición docente a la reflexión sobre la práctica. También dependen de las condiciones profesionales donde esa práctica puede ser ejercida, como en lo relativo a las restricciones del tiempo material y la formación de base. El trasfondo es ideológico, como deja entrever este entrevistado: “Creo que no es inocente, nadie va tan profundo, más que nada... vive. Entonces no hay tantos que indagan, que cuestionan el mundo, tal vez los de Sociales, los demás no..." (Director EEST N²).

El esfuerzo de democratización desde la gestión puede dar lugar a otras discusiones. La perspectiva de género ocupa un lugar completamente excepcional en los discursos. Puede ser enunciada a razón de la reciente aprobación de la LESI y, sobre todo, del crecimiento exponencial de la cantidad de profesoras y alumnas en la educación técnica como cambio preponderante de las últimas décadas. "Una escuela de varones" se ve desafiada en sus patrones naturalizados de "normalidad", de una moralidad ciudadana y su correspondiente "deber ser", como de legitimidad genérica articulada con la identidad juvenil. Desmontar estos supuestos supondría revisar las categorías que nombran y simultáneamente invisibilizan a ciertas prácticas y perfiles, 
que no pueden reducirse a la lógica dual del "adentro" o el "afuera" de las instituciones, sino que se ubican en sus intersticios, en los lugares de fuga o en los espacios "entre" (Elizalde, 2012) ${ }^{50}$.

... acá es un contexto que está muy marcado el tema de qué tareas designan a las mujeres, qué tareas designan a los varones. Y que atraviesa a toda la escuela, desde el alumno hasta el equipo de gestión, jajajaja. Es un tema que históricamente está muy marcado, es una escuela de varones en la que hemos "usurpado" las mujeres. Y esa tensión también se nota, para bien y para mal, ¿eh? Porque hace que se repiense (Vice-Directora EEST N²).

Entre el profesorado, los modos percibidos de subjetivación no pasan tanto por el género, como por las familias y las experiencias de consumo. Las iniciativas didácticas se nutren del compromiso en la promoción de los valores, actitudes y saberes críticos: "Totalmente, es así, la escuela es el lugar justo para formar ciudadanos. No la tecnología, tampoco la casa. Porque en la casa ya tienen una ideología. En la escuela escuchás distintos puntos de vista..." (EEST $\mathrm{N}^{\circ} 1$, Matemáticas). ¿Qué significa que la escuela es el lugar “justo”? Que se reconoce el ámbito privilegiado, casi excluyente, para ejercer esa función. Repensada como esfera pública, articula un conjunto de enclaves identitarios, entendidos a partir de universos simbólicos desde los cuales son generados y desarrollados como habitus: "Por eso hay que darle espacio para cuidar, vos construís ciudadanía con tus prácticas, por tus decisiones” (EEST N² 2, Política y Ciudadanía).

En síntesis, las racionalidades que animan las actuaciones de los actores son potencialmente políticas, aun cuando no son enunciadas en estos términos. La política no está desfasada de la cultura, la matriz sobre la cual se soportan formas de politización juvenil. Así, se registran diversas formas de concebir la ciudadanía, alternativas a las definiciones formales y a los mandatos establecidos, como un campo en constante construcción. Al decir de Kriger y Daiban (2015), imaginar grados o matices nos anima a pensar en términos dinámicos, postulando la ciudadanización como proceso sociocultural y no como estado naturalmente alcanzable por los sujetos que viven en sociedad.

\subsubsection{Representaciones acerca del problema educación/ciudadanía}

Aunque la dimensión representacional es transversal de todo el análisis, cobra interés particular a los fines de indagar las fuerzas de conservación y de transformación de los sentidos y prácticas vinculadas a la ciudadanía en la complejidad de estos entornos. Se trata de un término poco referido, en contraste a la problemática del rol docente, una de las mayores preocupaciones desde

50 Siguiendo a la autora, el binarismo de género "tiene la fuerza arrolladora de su reproducción constante y transversal, que lo convierte no sólo en el principio modélico organizador de la totalidad social, sino en la condición misma de la inteligibilidad del mundo "tal cual es"' (2015: 134). En nuestro caso, el tema requiere desarrollos ulteriores. Pero el recorte del "joven escolarizado" intenta superar ese binarismo, convocando otras múltiples identidades. 
los comienzos del PCI. Caracterizado ese rol como directo responsable de la crisis, la calidad de enseñanza se mide de acuerdo a la capacidad de adaptación. Extendida en la EEST $\mathrm{N}^{\circ}$ 2, la antinomia entre buenos y malos profesores se instala en la construcción ideológica de un "agente estatal”, en el sentido del funcionario que debe direccionar y prescribir esos mandatos.

Después el diseño curricular te dice que el docente es un agente estatal que tiene la responsabilidad de transmitir la cultura mundial y contemporánea a las nuevas generaciones. Nosotros somos agentes porque somos la cara del Estado. A mí me paga el Estado, yo soy empleado del Estado. Si de la policía decimos que es un desastre, ¿a quién le estamos echando la culpa? Al Estado, porque no preparó bien a sus agentes (Vice-Director).

Desde este orden moral el directivo abunda en referencias a la "culpa" de docentes mal predispuestos, escasamente preparados, pero estas críticas no suponen su propia disposición al cambio sino cierto conformismo. Su consecuencia es una despolitización efectiva. En palabras de Schmucler (1997), el optimismo tecnológico se despreocupa de la verdad que la técnica establece sobre el mundo; la verdad, en cambio prescinde del elogio de lo óptimo y se aproxima a una ética que no necesita justificar lo existente como lo único posible. En este punto, las tecnologías ofrecen el lugar necesario para garantizar las condiciones de progreso que supuestamente se avecinan:

Yo tengo una visión optimista. Yo creo que los problemas se van a ir solucionando en función del desarrollo tecnológico del país para las nuevas generaciones, y yo no entro en política, no los ataco ni los defiendo, y no los voté. Lo que sí te digo es que esta escuela está equipada como nunca en la historia de los 70 y pico años que tiene esta escuela...

Desestimar posicionamientos más activos apela a la exclusiva responsabilidad del Estado como entidad abstracta y garante de derechos sociales. El ciudadano aparece como sujeto pasivo de esos derechos, pero no así sujeto actuante de lo público que haga posible su real cumplimiento. Se argumenta que las resistencias hacia el PCI se sostienen en niveles extendidos de discriminación. Las formas de retorización son particularmente irónicas en el Vice-Director:

¿Por qué hay tensiones? Porque todavía hay docentes que creen que no tiene que ser obligatoria, porque hay docentes que no creen que un chico merezca estar en el mismo lugar igualitario que otro, porque dice: qué hace ese negrito, qué hace ese boliviano de mierda...

En la segunda escuela, se entremezclan las falencias personales con un esencialismo irreflexivo que encierra otra forma de conformismo: "Y a veces pienso, porque soy limitada, cuál será la causa, si será esta, si será la otra... Son los docentes, es la escuela, o si esta escuela nació mal, o no, si ya se tiene esta mirada como... negativa" (Directora). Condensa una misma imagen descalificadora, sobre todo de los docentes taxis: además de mostrarse poco comprometidos y resistentes a los cambios, los recorridos intermitentes explicarían su inacción en las aulas; los demás parecen naturalmente capaces de innovar o bien de establecer redes de contención afectiva, aunque no en colaboración con la reconstrucción identitaria. A esta dualidad 
se suma una fuerte estigmatización hacia jóvenes "con mucha violencia", a lo que les deparaba "un futuro muy feo, o por lo menos incierto", contradiciendo la inclusión socio-educativa:

...hay un número importante de personal que son muy contenedores, no digo los que van y vienen pero los preceptores, yo misma, somos muy contenedores, muy cariñosos (...) O sea que la escuela, con todas las dificultades que tiene, ha logrado un hombre productivo para la sociedad, un hombre de bien. Eso también lo quiero destacar, porque es una satisfacción.

En la misma institución, creencias prejuiciosas construyen un alumno sin "cultura del esfuerzo", interés en el aprendizaje ni respeto a las normas de convivencia, rasgos que parecen agravarse significativamente con la presencia de las netbooks. Las concepciones docentes sobre su función se desplazan hacia el sentido restringido de educar, esto es, trasmitir contenidos. Es interesante examinar cómo posiciones pretendidamente críticas recrean una misma noción del “agente estatal”. Estas afirmaciones son recurrentes entre docentes de la EEST N 1.

...vino la Inspectora, bueno, jes tan fácil hablar detrás de un escritorio! Entonces, cuando hablan de la escuela, nos mostraron que se puede. Pero es distinto tener un chico así (problemático) en un grupo de 20, que cinco. ¿Cómo hacés? Yo cuando renuncié le dije a la Directora: Mirá, la próxima vez que yo entre al aula y no pueda trabajar, me retiro. Porque para estar estafando al Estado, porque a mí el Estado me paga para dar clase, no para estar: no mirés por la ventana, sentate, ponete a trabajar... En general, es un caos (Física).

El otro no es aquel con quien se establece el necesario vínculo pedagógico, sino quien permite delimitar la propia identidad, pero al precio de neutralizar toda reflexividad sobre la propia práctica. En este sentido, la inclusión digital queda reducida a la computadora, comprensible solo como regalo inmerecido: "Yo pago cantidad de impuestos, el gobierno les da las netbooks con los impuestos que yo pago...” En este sentimiento de injusticia aparece el reclamo de un orden moral o de un sistema de sanciones que permita reconstruirlo. Vale enfatizar el encadenamiento léxico en este fragmento, una posición estigmatizante donde la calificación del alumno "pobrecito" no resulta de una actitud compasiva sino de la justificación naturalizada de la subordinación:

Un tema es la falta de premios y castigos, otro tema es la obligatoriedad. Porque si yo tengo un chico al que no le gusta nada o una chica a la que le gusta repostería, lo importante es que sea feliz, ¿no? Porque hay cada drama, una chica en el salón que ha sido violada por el padre, que el que padre está preso en el penal, pobrecita. No en este grupo, ¿eh? Pero nosotros que venimos de familias normales... -ay, si me escuchan me matan- pero bueno... O en el Penal que hay alumnos que van vestidos de mujer, y hay que ajustarse. Yo desde que empecé a dar clase en el 87, de diez a quince años a esta parte es como haber caído en otro planeta (...) Un chico que tuve que, pobrecito, nadie creía en él y salió adelante. Un drama. Me partía el alma.

Discursos contrarios hacen de la inclusión social el fundamento de toda política educativa.

De ahí la primera ventaja del acceso digital: la netbook representa una forma de igualación al interior de los grupos. Las oportunidades de integración equitativa a un mercado de consumo 
aparecen como principio necesario, aunque no suficiente, de igualdad social. También entrañan las intersecciones entre la apropiación digital y las subjetividades adolescentes, en la comprensión de la diversidad que las atraviesan: "Estas chicas, por ejemplo, desde 1er. Año estaban divididas, entre las que no tenían computadora e Internet en la casa y las que sí tenían, que eran las caretas. Ahora todas tienen computadora..." (EEST N 1, Proyecto y Diseño Electrónico).

Los docentes de la EEST $N^{\circ} 2$ generalizan en sus alumnos situaciones de disponibilidad a computadoras personales e Internet en sus hogares. Acerca de las problemáticas globales, priorizan la calidad de la enseñanza, las relaciones empáticas y el reconocimiento de las necesidades del otro, una pedagogía tendiente a formar un sujeto reflexivo y dueño de su vida. Calificarlo de "pobrecito" adquiere otras connotaciones y no exime al docente de trabajar en pos de ese mejoramiento.

Porque el chico llega a la casa y encuentra a la mamá en la suya, al papá borracho. ¡Pobrecito! Si hay que premiarlo sólo porque se levanta a todos los días a las 6 de la mañana para venir a la escuela, y no tiene control familiar. Es que es así. Porque cómo tratás con ese chico que viene a la escuela, agotado, cansado, malcomido. La calidad educativa, jese es el desafío! (EMATP).

Aunque no se trata de un tema recurrente, los jóvenes revelan sobre la ciudadanía concepciones desafiantes de los modos tradicionales a partir de los cuales ha sido pensada la representación en el espacio público, la organización social y la participación que acompañan esas definiciones. Cabe precisar, retomando cuestiones precedentes, que desde los inicios del PCI identifican una acepción de ciudadanía de derechos y obligaciones, pero también validan la participación. Connota no solo su componente formal sino como dimensión pública, racional y afectiva de una comunidad democráticamente constituida. Dentro la escuela, se asume que los actitudes, hábitos y conocimientos implicados en esa formación está estrechamente asociados a la capacidad de sostener o desarrollar el centro de estudiantes como espacio principal, pero no único.

Las vinculaciones con el PCI son más controversiales. Avanzar hacia una educación conscientizadora implicaría que el alumno pueda repensar concepciones negativas, recuperando, desde una perspectiva gramsciana, el núcleo sano del sentido común, lo que podría llamarse buen sentido y que merece ser desarrollado, hecho unitario y coherente. Pero el desconocimiento inicial sobre el modelo, simbólicamente restringido a las netbooks, sirve de marco a la idea extendida de que cualquier propósito político es completamente ajeno a la educación. La analogía es significativa: "Pero hay mucho de asistencialismo, me hace acordar a ese candidato que repartía zapatillas. Bueno, ahora son computadoras" (EEST N 2, 6to. Año, Maestro Mayor de Obra).

Desde otras perspectivas, el acento está puesto en las prácticas, sobre las cuales los jóvenes establecen juicios críticos y pueden dar lugar al buen sentido. La autoridad docente, el compromiso 
personal, un clima favorable de convivencia, contrastan con situaciones de dependencia digital, según los propios usuarios. Se cuestiona la falta de regulaciones que habiliten experiencias de uso crecientemente autónomas: "Depende qué alumno quiere y quién no (aprender), porque si te portás mal, hacés lío y después igual te dan la netbook...” (estudiante EEST N 1, 4to. Año, Electrónica). $\mathrm{Su}$ compañero coincide en entramar el par derechos/obligaciones con las actuaciones conscientes: "Sí, la compu es tu derecho, pero tu obligación es cuidarla. Y usarla con responsabilidad, o sea, usarla para trabajar. ¡Pero hasta el año pasado jugábamos todo el día!”

Hacia la segunda etapa, algunos cuestionamientos adquieren continuidades. Giran en torno a un profesorado que no asume la oportunidad de estos cambios, en el marco de transiciones favorables a nivel institucional donde se persiguen los esfuerzos de inclusión digital. El trabajo docente es el punto crítico cuando los modelos establecidos se vuelven un obstáculo para emprender una enseñanza dialógica, innovar en la práctica, generar situaciones de aprendizaje socialmente significativo. Según esta postura, intervenciones docentes repetitivas, éticamente objetables, operan para eludir el conflicto: lo que se enseña no se discute, porque la forma en que se transmite el conocimiento inhibe la posibilidad de la pregunta (Etchegoyen, 2006). Así lo expresan las preguntas retóricas y las repeticiones léxicas:

¿Qué es más fácil? ¿El docente que viene hace quince años y hace lo mismo de siempre, o que tenga que hacer algo distinto? (...) Es muy fácil eso, es como no trabajar. Nadie lo cuestiona, no hay intercambio de ideas, no hay nada. Lo único que hacen es pasar a dar la lección, la repiten como lorito y si está muy bien le pongo un 8, si está muy mal le pongo un

2. Es facilísimo, es como no trabajar (Director EEST $\mathrm{N}^{\circ} 1$ ).

Una referencia casi ausente en el conjunto de los relatos y a lo largo de todo el período analizado, es la formación docente. Si ponemos el acento en las temporalidades múltiples que atraviesan imaginariamente a los procesos de inclusión digital, observamos que los discursos intentan conciliar la tensión presente/futuro. Esto es, entre las preocupaciones inmediatas que la presencia de la tecnología genera, definiendo las decisiones didácticas que la incluyan en las aulas; y las transformaciones que tales incorporaciones podrían provocar a largo plazo, a nivel de la calidad educativa. En esta doble lógica, el pasado implicado en la formación inicial queda relegado frente a la capacitación docente, que seguirá siendo un problema determinante en la implementación real del PCI. La excepción es el Director citado antes, que abunda en calificativos negativos: está "todo ausente", “demasiado lamentable", "sin ofender, pero son un desastre."

Otras posiciones desplazan la atención a los paradigmas de enseñanza que demandan contextos socioculturales de mutaciones aceleradas. Los significados de esta crisis reposan en una nueva "jerarquización de valores", donde el profesor se ve interpelado a actualizar los 
conocimientos que detenta, sus modelos pedagógicos de base: "Entonces un chico con otra cabeza, con una cabeza mucho más abierta que nosotros. Porque somos docentes del siglo XX, que formamos chicos del siglo XXI con una pedagogía del siglo XX”" (Vice-Directora EEST $\mathrm{N}^{\circ} 1$ ).

Mientras en la primera etapa las relaciones entre TIC y ciudadanía están prácticamente ausentes, ahora aparecen vinculadas al acceso a la información y el consumo de medios masivos. Todo este entramado abre un campo de redefiniciones del rol docente para intervenir en contextos complejos, donde el problema ya no es tanto la "apatía" del estudiante sino las familias que no suelen fomentar hábitos de lectura crítica. Ante esta ausencia, la escuela es portadora de esa función. Como advertimos, un rasgo extendido de esta segunda etapa es la mirada puesta en la comunicación como clave estratégica para concebir, fomentar y ejercer capacidades de agenciamiento ciudadano.

Conforme avanza el proceso de adecuación del PCI, se reivindica la diversidad cultural en tanto ámbito posible para concretar redes efectivas de comunicación, formas interactivas de enseñanza-aprendizaje y de promoción de valores básicos. Sintetizamos en el siguiente relato tres aspectos vinculados: 1- la composición heterogénea de los grupos, atravesada por las particularidades institucionales, socio-económicas y educativas; 2- el conjunto de intereses, afectos y experiencias que configuran lugares específicos de subjetivación juvenil; y 3 - la atención a esa diversidad como campo de disputas de sentido, que estructuran el espacio áulico al mismo tiempo que lo desbordan.

Ellos son de escuchar bandas nacionales, sea rock, o cumbia, o desde ese lado. Hay chicos que los padres son de otras partes de Latinoamérica, Uruguay, Paraguay, Bolivia, también está en debate ese tema, la discriminación. Hay casos, más que nada de palabra, no es que los segregan, pero hay palabras a veces peyorativas, pero no son muy de lo internacional, los chicos de 12 o 13 escuchan a los mejor más bandas de EE.UU., acá no. Entonces también trabajamos sobre eso, sobre el respeto (profesora EEST N 1 , Prácticas de Lenguaje).

Persiste también una mirada estigmatizante, bajo la tendencia a generalizar capacidades, actitudes y estilos de vida. Son discursos que no asumen las contradicciones que encierran, por cuanto confirman el rechazo a las oportunidades que la obligatoriedad de la educación secundaria y de una política inclusiva provee a estudiantes en condiciones de indefensión social: “...vienen $a$ perder el tiempo, a que le paguen la merienda, a fumarse un porro, yo a ellos los incluyo y el resto que es bueno, se te va. Y yo incluyo a un alumno que es... mala persona, ni siquiera mal alumno, es mala persona" (EEST N 1, Matemáticas). En torno a la construcción simbólica de la inclusión como "arma de doble filo", es significativo observar cómo se reiteran, con sentidos relativamente diferentes, expresiones adoptadas en la primera etapa: “¡A mí me pagan para dar clases (...) Hay un chico que, pobrecito, me dice: mi papá me dijo que se fue a trabajar y terminó preso." 
La diferencia de posiciones es más notable en esta institución y en este segundo período. Otros docentes refuerzan la confianza en que las transiciones favorables dinamizan posibilidades novedosas, cuyo principio organizador es la formación en valores. Se vehiculiza en las prácticas, en las que los jóvenes se sienten parte de un proyecto común, algo valioso que reconocen como propio y que es necesario defender: "Fijate que pintaron ellos mismos las aulas, eso habla bien de ellos, o sea, le dan un valor al espacio que utilizan para estudiar a diario... (Sistemas Productivos).

También en situaciones favorables, el proyecto de la autonomía organiza simbólicamente una modalidad de enseñanza donde "el chico es co-responsable del aprendizaje, que es lo que queremos de un técnico, que es además un ciudadano de una sociedad en construcción" (EEST $\mathrm{N}^{\circ}$ 2, Política y Ciudadanía). El CE se refuerza como lugar complementario -incluso, más determinante- que las asignaturas, donde se establecen las tempranas aproximaciones a la participación. Así rememoraba la misma entrevistada cuando en 2001, el grupo se movilizó en pos de condiciones adecuadas para la enseñanza-aprendizaje, convocó a las autoridades y a los medios de comunicación para reclamar por las deficiencias de calefacción del establecimiento: "Mucha gente piensa que los llevamos nosotros, y no, el chico toma o no esas ideas, pero después toma decisiones". Estas definiciones registran la enorme ambigüedad que reviste la politicidad que conllevan las prácticas culturales juveniles, como hipótesis o potencialidad política. ${ }^{51}$

Sintetizando los discursos adolescentes, en esta segunda etapa subrayan las posibilidades del acceso equitativo en tanto se evite un uso "político", partidario o electoral. El marco que formaliza esa convicción es un centro de estudiantes que trabaja "para la escuela". De acuerdo a su presidente, "tiene una posición sobre eso: que no se politice. Pero cada uno tiene un pensamiento y lo respetamos. Por eso discutimos cosas que tengan que ver con la escuela..." Su compañero redunda en que "el CE de la escuela siempre fue muy fuerte, sujeto a tradiciones selectivas en el reconocimiento común de ser "grasas": "La escuela siempre rechazó la política. Mi viejo estaba en la asociación estudiantil en ese entonces y me dice que la escuela siempre la rechazó."

Y en la EEST $N^{\circ}$ 1, una identidad en reconstrucción reviste la forma de compromisos más activos. Se edifica sobre un mundo de afectos donde se predica la importancia de ser responsable, mostrar autonomía, ser consciente de las propias decisiones, adoptar reflexivamente valores que resultan de consensos y no de la mera imposición. Los estudiantes se reconocen parte indispensable de este proceso de mejoramiento de la escuela, y le reclaman que deposite en ellos la confianza

51 Reflexiona Vommaro (2016) que para atribuir carácter político a un sistema de prácticas sociales, es preciso reconocer, al menos, cuatro aspectos: 1) que se produzca a partir de la organización colectiva; 2) que tenga un grado de visibilidad pública (un sujeto, acción o demanda); 3) que reconozca un antagonista a partir del cual la organización adquiere ese potencial político; y 4) que se formule una demanda que adquiera un carácter público y contencioso. 
necesaria. En el proceso emergente de institucionalización encuentran, paradójicamente, modos de desafiar la situación de marginación en la que viven. La figura del Director, como nueva forma de autoridad, es mediadora de esa trama representacional en la cual operan los desplazamientos exclusión/inclusión, antes/ahora, mejor/peor, adentro/afuera, ellos/nosotros:

Con Guyi está mejorando mucho la escuela. ¡Ahora no están los chicos que molestaban! Si vas abajo (en Básica) siguen saliendo, pero antes se escapaban mucho, el Director que estaba antes... Había chicos drogándose. Yo doy gracias, lo mejor que hicieron fue poner a Guyi, él es piola pero te dice las cosas. Sacate la gorra, ehhh... jodiendo. Y sacate ya... así, jodiendo, no quiero más peleas, te dice, te echo de la escuela. Ahora está más tranquilo...

Estos desplazamientos operan formas tácitas pero efectivas de ciudadanía bajo improntas culturales antes que estrictamente políticas. En esa construcción, profesores y directivos pueden proporcionar las condiciones para que, de acuerdo a Giroux (2013), los estudiantes se vean a sí mismos como agentes críticos con capacidad de actuación, para que se sientan responsables de sus acciones. Son ellos quienes realizan en sus trayectorias escolares procesos de des-ordenamiento cultural, donde pueden apropiarse de unos modelos y volverse subversivos de otros. En consecuencia, el reconocimiento que otorga la tradición es una forma parcial de identificación. Es, al mismo tiempo, un proceso de invención. Al jerarquizar valores emergentes como la confianza y la autonomía, introduce otras temporalidades, evitando cualquier acceso inmediato a una identidad originaria.

\subsubsection{Principales observaciones}

En apretado resumen, retomamos esquemáticamente las principales contribuciones al análisis de

\section{la Dimensión Ciudadanía/Educación:}

1- En su aspecto gnoseológico, la ciudadanía presenta un alto grado de indefinición. Se distinguen a lo largo del análisis dos acepciones: a- en relación a las asignaturas específicas y, bproyecto o problema transversal, siendo la primera la posición dominante. Lo que está mediando es la validación de la especialización del conocimiento y una concepción restringida de la ciudadanía en tanto a derechos y obligaciones. Se reclama a los contenidos de Construcción de Ciudadanía mayor especificidad, al mismo tiempo que la subestima, algo notable entre los jóvenes.

2- La segunda acepción emerge moderadamente y tiene creciente presencia en la segunda etapa. Y mientras se agudizan las críticas a las asignaturas o a sus modos de implementación, los jóvenes reclaman otros lugares de debates, el derecho a ser escuchados y reconocidos; el lugar paradigmático es el CE. El proceso que hemos caracterizado como "domesticación cruzada", anima al estudiante a apropiarse de la institución - de manera similar que con las TIC-, y en esas 
trayectorias encuentra formas conscientes de formación ciudadana ligada a la participación. Educación y ciudadanía son equivalentes, un concepto que se mantiene prácticamente inalterable.

3- En la primera etapa predominan los componentes normativos. La definición de la política, con continuidad en el tiempo, reside en su carácter electoralista o propagandístico; el PCI puede ser caracterizado como asistencialista. Pero paulatinamente el énfasis se desplaza hacia las actuaciones docentes que interceden en esa relación, que reconfiguran los sentidos de esa política transformando las redes de comunicación, generando modalidades alternativas de enseñanza. Así, surgen componentes crítico-participativos, los modos de consciencia y los espacios deliberativos.

4- El tema representacional manifiesta múltiples aristas. El PCI parece confirmar acepciones tecnocráticas de acuerdo a las cuales los docentes son agentes destinados a poner en funcionamiento el modelo. El Estado aparece como ente abstracto y garante de los derechos humanos. Pero evita pensar las diferencias institucionales. En la EEST $\mathrm{N}^{\circ}$ 1, el PCI recibe las resistencias de docentes que actualizan lecturas discriminatorias sobre sus alumnos, justificando sus situaciones de subordinación. Por el contrario, otros destacan sus alcances igualitarios al interior de los grupos. Los estudiantes desafían miradas negativas como los modos tradicionales de representarse la participación en sus diversas expresiones, como derecho inclusivo y ciudadano.

5- Tras cinco años, las dificultades de integración tecnológica actualizan las preguntas sobre la capacitación docente, renovando la dimensión temporal: las urgencias de la tecnología motivan la preocupación por la capacitación como proyecto, relegando la importancia de la formación inicial. Y entre esos saberes profesionales, hay una vinculación tácita con una formación ciudadana que desborda los contenidos y apela al valor estratégico de la comunicación, en torno a las interacciones en las aulas, pero también a consumos que reclaman ciudadanos de nuevo tipo.

6- Otros aspectos representacionales residen en la diversidad cultural, sea como obstáculo como, progresivamente, condición favorable para enriquecer las situaciones de enseñanzaaprendizaje. Si la ciudadanía no es enunciada directamente en esos términos, adquiere densidad en torno a un proyecto de autonomía que implica el necesario reconocimiento de esa diversidad. En base a las experiencias que las escuelas promueven -y que los jóvenes generan a sus márgenesemerge una ciudadanía bajo definiciones culturales, con plena potencialidad política.

\subsection{Ciudadanía/Tecnología: tensiones emergentes y anudamientos múltiples}

El problema de la ciudadanía ha sido objeto de muy diversas aproximaciones, pero escasamente comprendida desde sus intrincadas vinculaciones con las TIC. Uno de los emergentes es el concepto de ciudadanía digital, conforme a las expectativas sobre el rol privilegiado de Internet 
como red de acceso público y frente a las lógicas de segregación que producen los mercados. Un ciudadano digital es aquel que se nutre de las posibilidades de la sociedad-red, donde la información se comparte desde múltiples fuentes, los saberes se construyen colectivamente y se desenvuelven en un escenario dinámico de aprendizaje. No obstante, esta concepción deviene en simplista y tecnocrática si se reduce a una mera cuestión de consumo. Requiere una mirada más atenta a los modos en que los sujetos se apropian de las TIC y de otros medios, para evaluar sus condiciones de vida, visibilizar sus demandas, desarrollar espacios de deliberación y acción.

En el marco del Programa Conectar Igualdad, habrá que identificar sus potencialidades de acuerdo a los niveles de conocimiento, expectativas y valoraciones que detentan sus destinatarios. En especial, porque hay una trama simbólica que tiende a facilitar u obstaculizar las disposiciones hacia el uso eficiente de las tecnologías, en base a relaciones más o menos atribuidas con la formación de ciudadanía o con los procesos de inclusión social impulsados desde el Estado nacional. Las escuelas serán ámbitos privilegiados para la apertura y promoción de la ciudadanía en términos de "esferas públicas", en tanto contribuyan a problematizar sus propias determinaciones históricas, constituyendo espacios plurales de reconocimiento de capacidades individuales y colectivas, comprometidas en producir nuevas formas de comunidad democrática.

Por otra parte, las discusiones sobre los sentidos y alcances del PCI abren nuevos interrogantes acerca de la tan mentada “crisis de la autoridad docente". Martín Barbero (2002d) sostiene que la escuela tiende a negar los nuevos saberes mediados por las TIC, que redunda en un fortalecimiento del autoritarismo y la descalificación de los jóvenes como frívolos o irrespetuosos. Estas concepciones, no obstante, no agotan las tramas simbólicas en torno a qué es o cómo se desempeña la autoridad docente en estos entornos tecnológicos. Para Diker (2008), lo que está en juego es la valoración y reconocimiento de aquello que está en la base de su ejercicio (el conocimiento), como de su potencial para producir procesos de aprendizaje. La autoridad docente es una construcción constante, que resulta de renovar los vínculos personales y profesionales con los estudiantes para producir las condiciones necesarias para una formación integral y ciudadana.

La última concepción de ciudadanía que vamos a examinar es la ciudadanía juvenil. El denominador común es un escenario de profunda incertidumbre, donde los lugares de significación de la ciudadanía se han ido transformando a partir de la emotividad y el deseo, la crítica a los lugares establecidos, las experiencias que expresan la identidad de ser jóvenes, sus vínculos entre sí y con el mundo adulto encarnado por los padres, la escuela y el Estado. Empero, este concepto conlleva varios riesgos que ya hemos mencionado: desde cierto esencialismo que concibe a las identidades como entidades cerradas o a los jóvenes en ruptura con otras generaciones, hasta aquellas que exaltan su capacidad de resistencia, de movilización social o de orientación al cambio 
(o a la inversa, de absoluta apatía o indiferencia). Nuestra decisión ha sido conceptualizar la ciudadanía cultural, que integra, al tiempo que pretende superar, las divisiones clásicas como a las más novedosas ligadas a la "ciudadanía juvenil” y la "ciudadanía digital”.

Un aspecto revelador lo constituyen los centros de estudiantes. En conjunto, dinamizan acciones reivindicativas de los años de los '70 y principios de los '80, cuando actuaban de caja de resonancia de la conflictividad social. Frente a los imperativos políticos y curriculares de formar en ciudadanía, hoy la institución escolar parece producir cierta "sublimación" de la política, en virtud de la necesidad de negociar las identidades políticas, consensuar actividades o "camuflar" símbolos políticos (Núñez, 2010). Además, las organizaciones juveniles pueden exceder el ámbito institucional, para involucrar otros espacios más o menos espontáneos, adscribiendo a consignas globales o comunitarias. En muchos casos, encuentran modalidades de convocatoria, comunicación y reconocimiento que se efectivizan a través de las TIC. Son conocidas las experiencias en las que los estudiantes se abocaron a manifestaciones, cortes de calle, tomas de escuelas o pintadas, incorporando el uso de blogs, Facebook, Twitter o mensajes de textos. ${ }^{52}$

Ciertamente, la lucha por la hegemonía tiene aristas inusitadas. Porque una acción colectiva mediada por las TIC, más allá de la consigna que la convoque, configura modos de articulación entre lo local y lo global, entre la consciencia planetaria y la confirmación del espacio cotidiano. Además, valores tradicionales legitimados desde el proyecto educativo de ningún modo se reducen a sus funciones reproductivistas, sino que se actualizan constantemente, son resignificadas en las prácticas cotidianas. En este sentido, podemos asumir hipotéticamente que los jóvenes escolarizados materializan formas múltiples de re-semantización de la ciudadanía que parece confirmar una memoria común, pero a la vez ofrecer alternativas a la racionalidad dominante, en el marco de construcciones contingentes y relacionales que producen sus identidades específicas y que encuentran en las tecnologías interactivas un potente dinamizador.

En los apartados que siguen, nos centramos en el análisis de la trama Ciudadanía/TIC, de acuerdo a la propuesta de categorías desarrollada en el Capítulo 2. En síntesis, comprende como Subdimensiones: Programa Conectar Igualdad (conocimientos, significaciones, expectativas), Inclusión Digital (condiciones estructural-simbólicas para su realización), Información y Conocimiento (implicados en la creación de oportunidades para participar en el espacio público/mediático) y Configuración de Identidades Juveniles (definiciones sobre la juventud, espacios de construcción identitaria, relaciones con la formación ciudadana, etc.).

${ }^{52}$ La utilización de las redes sociales como herramientas de organización y movilización de estos colectivos expresan condiciones socio-históricas particulares, como demuestran experiencias en todo el mundo, como los "estudiantazos" argentinos, los “indignados" españoles o la "primavera árabe" (Natanson, 2012). 


\subsubsection{Conocimientos e interpretaciones acerca de Conectar Igualdad}

Aun si la ciudadanía es un significante ambiguo, una política educativa de envergadura despierta nuevos interrogantes sobre cómo la tecnología viene a impactar en este campo. Es posible identificar con mayor precisión las posiciones asumidas de los agentes educativos, sus expectativas reales y sus posibilidades para asimilar la complejidad de estos cambios. Los directivos parecen los únicos en contar con información privilegiada, si bien general, de los propósitos del Plan, los marcos legales a los que adscribe (la Ley Nacional de Educación, la Ley Provincial de Educación y la Ley de Educación Técnico-Profesional), junto con las políticas previas en escuelas técnicas y otras similares en Latinoamérica. Pero el PCI divide sus opiniones, entre una propuesta con la que se acuerda "en teoría" pero de dudosas posibilidades de adecuación, hasta la defensa entusiasta de la computadora como "bien de deseo" de los alumnos para evitar la deserción escolar.

La cuestión de la novedad entraña una serie de contradicciones. Por un lado, entre el acceso físico y el mejoramiento educativo: “Ahora están tooooodos parejitos, todos tienen su netbook, pero que no quede en la igualdad de oportunidades. Nosotros siempre decimos: igualdad de oportunidades pero con calidad de enseñanza" (Directora EEST №2). Por otro lado, con respecto a los mandatos conservadores: "Todo eso inmerso de la cosa nueva, de la nueva tecnología, pero todavía hay viejas estructuras que siguen estando presentes en la escuela. ¿Y cómo hacemos con eso?" Un punto de coincidencia entre instituciones con características tan disímiles reside en las tensiones nuevo/viejo, sobre las dificultades percibidas de la modernización tecno-educativa previas al PCI: "Yo no sé si una política educativa, por más que lo diga divino en el texto, lo puede trabajar, porque es muy difícil cambiar cabezas..." (Vice-Directora EEST N 1).

Este estado de desconcierto juega en contra de la incorporación efectiva de las netbooks, bajo modalidades alternativas a las tradicionales. Sobre ese fondo de comprensión se recortan razonamientos relativamente diferenciados acerca de las consecuencias del modelo. Identificamos un conjunto de posicionamientos que escapan a los binarismos absolutos a favor/en contra:

1- Posiciones favorables de tendencia difusionista: los mismos supuestos que comulgan con las oportunidades de la disponibilidad, pueden servir de argumentos que, paradójicamente, terminar por justificar las diferencias socioculturales de base: "A mí lo que venga de la parte de desarrollo y de la igualdad tecnológica, social y económica me parece bárbaro. El tema es el entorno" (profesora EEST N² 2, Geografía). El ejemplo es muy ilustrativo de este sesgo ideológico: “vos llevás este Programa a una escuela rural de una comunidad wichi, ellos, pobrecitos, la equidad la buscan desde otro punto de vista, está bien, tienen derecho al acceso ellos..." 
2- Posiciones favorables pero cautelosas: focalizan en sectores en condiciones socioeconómicas adversas, donde la del PCI constituye la única computadora. La igualdad digital que se predica se identifica en las relaciones entusiastas que estos jóvenes establecen con las netbooks en su tiempo libre o sus efectos multiplicadores en las familias, un lugar interpretativo común que permite suplir la desinformación. Pero evita dimensionar cuáles son sus repercusiones en el ámbito educativo o en la formación de la ciudadanía:

Sí... es el plan de las computadoras, ¿no? Pero en profundidad no lo conozco, no. ¿En qué sentido lo de ciudadanía? Sí hay una cuestión de igualdad, sobre todo en una escuela como esta, porque la mayoría de los chicos no tenían computadora y ahora pueden acceder (EEST $\mathrm{N}^{\circ}$ 1, Proyecto y Diseño Electrónico).

3- Posiciones críticas que cuestionan las posibilidades de implementación: sobre la "improvisación" del modelo se apoyan las dificultades particulares de cada institución, como la falta de competencias docentes y la gestión de proyectos colectivos de adecuación. Ya hemos referido a las expresiones que metaforizan a la netbook como herramienta potencialmente valiosa pero que exige habilidades de uso de las que adolece el conjunto de estos actores:

Pero la entrega de las netbooks fue como haber entregado el auto sin tener carnet o sin saber manejar. Otro diría: entregás el auto y después vas aprendiendo. No sé, es un tema político, claro, en otros países se están entregando. Como en Uruguay. Se habla de una escuela inclusiva para todos, pero es un cóctel... No sé si estamos preparados (EEST $\mathrm{N}^{\circ} 1$, Montaje de Proyectos Electrónicos).

4- Posiciones críticas que priorizan otras necesidades sociales: el modelo 1 a 1 puede estar restringido a la asignación de recursos económicos: “¿No es lo que está instalado en el imaginario colectivo de que es por una razón económica? Y llevalo más adelante, cuando van a la Facultad o al mundo del trabajo y no se encuentran con las condiciones con las que se deberían encontrar" (EEST N² 2, Matemáticas, O. Automotores). Estas interpretaciones se sustentan en un sistema de jerarquías, modelos teóricos (como la teoría de Maslow) o creencias del sentido común, en las cuales los accesos a las TIC no constituyen un derecho elemental frente a urgencias sociales o educativas. La expresión más negativa argumenta que las netbooks constituyen un "gasto", por definición, innecesario:

Pero vos ves un gasto enorme, jes un gasto tremendo! Está todo perfecto, todos tiene acceso, pero vas escuchando quejas, qué se yo: no tienen para comer. Está bien, podés hacer muchas lecturas. Mi poder de razonamiento es: ya está acá, ahora usémosla. Si te dignifica más, si está en otro escalón, eso me parece bárbaro. Por ahí a mí me hacen ruidos otras cosas, en la medida en que se resuelve esto y esto, porque en la escuela aquella... (la Técnica 1). Ahí te va a dar la pauta de otras necesidades (profesor EEST $N^{\circ} 2$, Electrotecnia).

Avanzada la segunda etapa, las más importantes preocupaciones de los directivos residen en las actuaciones de los docentes: todos ellos deben afrontar "un cambio de época", "nuevos 
parámetros", "nuevos paradigmas". Las resistencias pueden ser atribuidas a la creencia nostálgica hacia un pasado mejor y a los temores a un futuro inevitable. Con frecuencia se actualizan concepciones ecologistas, el imperativo de la adaptación, la integración funcional, la conducta como producto de una selección natural. La única dirección posible para una escuela "desajustada" parece ser la dictaminada por la modernización técnica. Estos discursos generan contradicciones, en el esfuerzo de neutralizar la conflictividad que estas innovaciones producen:

Me decía un profesor: Hay que aguantar. Como que hay que esperar que vengan -yo entendía- los alumnos como él fue. Y yo le dije: mirá, no va venir nada nuevo. Esta es nuestra escuela, y no van a venir alumnos como los de los '60. En realidad, el que está desubicado sos vos, el que se va a tener ir a la escuela sos vos, los chicos van a seguir y se van a modificar, pero para adelante, no para atrás. Y bueno, por ahí la netbook muestra eso, un elemento nuevo en una escuela que ha quedado... vieja (...) estás descontextualizado, si sos un factor resistente al cambio (Vice-Directora EEST $\mathrm{N}^{\circ} 2$ ).

Significativamente, en la EEST $\mathrm{N}^{\circ} 1$ encontramos interpretaciones similares que giran en torno a la idea de que la escuela siempre parece rezagada: "Pero el cambio social ahora es muy grande, o venimos corriendo muy lento" (Director). Ratifica esto una doble creencia: a - el modelo conjuga cierto asistencialismo, en el sentido de las que las netbooks "se entregaron como algo... para conceder a la población"; y b- el valor del acceso, el cual "tiene sus pros y sus contras, el chico tiene acceso a algo que no pudo haber tenido". En esta narrativa esa tecnología representa la carencia, ya no el "bien de deseo" ni la sensación de plenitud como finalidad última.

Un consenso generalizado guía las representaciones docentes acerca del PCI, que tienden a superar los sentidos restringidos ligados a la disponibilidad técnica. Registramos:

1- Posiciones favorables pero que problematizan el acceso equitativo: siendo la netbook la única disponible entre sus alumnos, esta profesora califica al PCI de igualador: "ahora los ves y la manejan con una rapidez, una velocidad bárbara, pero falta unirlo a lo pedagógico" (EEST N 1, Prácticas de Lenguaje). Esto afirma la premisa de que no es suficiente el acceso digital si no están dadas las condiciones de integración didáctica, como de los entornos socio-económicos y familiares que acompañen estos procesos acelerados de cambio: "Que no quede nada más en un bien material, nuevo, que ellos tiene, sino que les sirva como instrumento de conocimiento".

2- Posiciones favorables pero que cuestionan la implementación: el valor estructurante del PCI sigue siendo la igualación de oportunidades, como describe esta imagen: "y ver a un chico de la comunidad mapuche (usando la netbook) debajo de una planta es una satisfacción. Desde ese punto de vista, el programa es inclusivo, porque de otra manera no podrían haberla tenido nunca" (EEST N ${ }^{\circ}$ 2, Construcción de Ciudadanía). Las contradicciones que observa radica en el contexto inmediato de incorporación tecnológica: "El tema es qué se hace con eso, cómo y para qué se usa... El problema es que largaron las netbooks y nadie nos capacitó...” 
3- Posiciones críticas basadas en imágenes negativas sobre el alumno: el deterioro técnico configura el principal argumento en contra del acceso en los hogares, no tanto a consecuencia del uso familiar (puesto que la apropiación es esencialmente personal), sino a los traslados de los equipos. Estas percepciones, distintivas de la EEST $N^{\circ} 1$, están regidas por descalificaciones según las cuales los estudiantes perciben la netbook como "regalo", algo "gratis" que no valoran ni merecen. Persiste el significante del "facilismo", entendido como los logros obtenidos sin esfuerzo ni sacrificio. Esta visión meritocrática evita al docente reconocerse en la tarea de inculcar esos usos responsables; por el contrario, siente menoscabada su autoridad:

Yo estaba muy en contra, me parece que los padres debían sacarles, no sé, 50 pesos por mes, que sienten que cuesta algo. Así, sin esfuerzo, no. Se rompen las pantallas, se les cae, se le sientan encima. Cuando yo venía a la escuela y me hubieran encantado que me dieran la computadora, pero así, no, no me gusta este facilismo, para nada (...) No se las sacás ni a palo. Yo creo que tendría que ser para los que tienen aprobado el trimestre, para que el que tiene buen promedio... (Montaje de Proyectos Electrónicos).

4- Posiciones críticas centradas en nuevas intervenciones docentes: las dificultades observadas no impiden pensar una política de Estado orientada al cumplimiento de derechos, garantizar la terminalidad o mejorar los aprendizajes. Nuevamente, lo que media la institucionalización del PCI son las definiciones del ejercicio docente, en pos de formar en saberes críticos y valores según los cuales "cada derecho implica también obligaciones, compromiso con el otro, con la sociedad, con uno mismo. Un respeto, esto medianamente se logra. Acá hay mucho sentido de trabajo, de pertenencia, de identidad" (EEST N² 2, Informática).

Esta posición es la que anima mejores condiciones para la construcción de ciudadanía. Las TIC intervienen positivamente en una diversidad de situaciones de producción de conocimientos, donde se comunican, deliberan y problematizan los alcances del Programa. Si constituyen el emergente de estos cambios epocales, un "iceberg digital" imposible de obviar ni esquivar (Casablancas, 2017), es porque otorgan la oportunidad de revisar roles, funciones y modos de entender la enseñanza, que no se traducen en mero adaptacionismo. Los docentes logran así elucidar las determinaciones de su profesión, ayudar a sus alumnos a desnaturalizar los supuestos recibidos y a emprender con ellos procesos productivos y criteriosos de migración digital.

\subsubsection{Intersticios: desafíos pedagógicos de la Inclusión Digital}

A pesar de las dudas que el PCI genera en buena parte del profesorado, se advierte que el acceso tecnológico genera posibilidades de mayor igualdad social. Una de sus expresiones es la retención escolar. Pero ese voluntarismo deviene razón instrumental cuando elude toda explicación 
acerca de cómo la posesión personal colabora a que los jóvenes de sectores populares puedan escapar de las fuerzas que los determinan en un futuro inexorable. "Y las nuevas tecnologías son una herramienta fundamental para torcer esos destinos, esos chicos que vienen de familia pobre, el padre está preso en Sierra Chica, uy, qué hacemos con ese chico, es un futuro chorro" (ViceDirector EEST N²). Un campo semántico organiza relaciones entre pares (tecnología/educación) opuestos a otros (pobreza/delito), lo que conlleva juicios estigmatizantes de criminalización:

¿Cómo hacemos? A través de la educación, porque si no logramos que ese chico esté en la escuela, a través de las nuevas tecnologías, a través de las oportunidades académicas, a través de becas, porque si no ese chico el día de mañana te va a poner una pistola en la cabeza, ¡que es lo que está pasando!

Esta opinión conecta con las aristas afectivas de la propiedad personal y sus efectos multiplicadores en "familias de condición humilde" donde la llegada de la netbook constituye un "acontecimiento". Así describía este entrevistado a la expresión de un estudiante: "qué cara de feliz cumpleaños que tenés, ¿eh? Re contentos." Su colega advierte, en cambio, que la igualdad está garantizada en lo formal, pero la crisis de valores, la ausencia de las familias, la disparidad de conocimientos previos, dificulta su realización concreta en las aulas. La heterogeneidad de los grupos siempre adquiere connotaciones negativas: "Yo doy clases y te digo que cuesta horrores nivelar una clase, porque vos no podés nivelar para arriba, tenés que nivelar para abajo..."

Las emociones que la netbook despierta pueden ser atribuidas a la propiedad personal. Los calificativos son similares: "Los padres son los más contentos, porque hay pibes con muchas carencias..." (Vice-Directora EEST N 1). Signo de esas apropiaciones es el cuidado que le proveen al aparato, en la preservación de algo apreciado. Pero en este contexto desfavorable, esas experiencias ponen en evidencia, por contraste, una falta neurálgica para la cultura escolar: el deterioro edilicio, el desapego afectivo, su identidad institucional como proyecto ausente: "Porque si a vos te rayan las paredes es porque no has podido construir el sentido de pertenencia, si sentís que es tuyo no lo rayás. ¿Por qué con la computadora lo pueden hacer y con la escuela no?"

Entre los docentes, conviven las promesas redentoras de la modernización, con las preocupaciones acerca de los cambios de la autoridad pedagógica. La primera cuestión descansa en la idea de que la sociedad no ha logrado imprimir el mismo ritmo a los cambios que ocurren en la escuela, si bien "vamos hacia eso, es más, me parece que vamos más rápido que lo que yo pensaba” (EEST No 2, Geografía). Este razonamiento no explica cuál es esa meta que se persigue, o cómo ha de transitarse ese camino de transformación radical que garantizaría la aceleración tecnológica. En el segundo caso, esas expectativas producen frustraciones cuando la netbook representa el agravante de situaciones de desorden áulico; una respuesta "novedosa" adquiere la forma de resignación, sin alterar modelos sostenidos del docente normalizador/disciplinador 
(Diker y Serra, 2008). "Hay que adaptarse un poco a esto (al ruido), porque si no estás como un carcelero: apaguen esa música, apaguen esa netbook (...) Es feo estar como un guardián a cada minuto" (EEST N 1, Inglés). Lo que aúna ambos niveles interpretativos es, paradójicamente, la adaptación a un estado de cosas.

El PCI visibiliza sesgos ideológicos según las cuales los estudiantes están determinados a sus condiciones de pertenencia. El abandono de los padres, la crisis de valores de respeto y cultura del esfuerzo, los pobres desempeños de aprendizaje, vuelven insalvables las diferencias con los “buenos" alumnos. La introducción de las netbooks actualiza entonces una tercera matriz significante, asociada a sólidos ordenamientos morales, una mirada prejuiciosa que termina por obturar las oportunidades que abre una política inclusiva para atenuar niveles persistentes de fragmentación socio-educativa. Las comparaciones entre escuelas resultan muy significativas:

Yo entiendo lo de la inclusión, pero si a ese chico que el padre le pega, va a la escuela y le dan la netbook, le dan la bicicleta... Si es que el chico, pobrecito, no puede cambiar en la escuela, demuestra más rebeldía, más violencia que en la casa. Es difícil. ¿Qué pasa? Los otros chicos, los buenos, no pueden estar porque no aprenden nada, entonces se van a otras escuelas. La inclusión está excluyendo a los chicos que son buenos. Es una decadencia. Yo no quiero ser tan negativa, tan tétrica, pero con decirte que mi nena en Normal, que tenía todo 9 y 10, era la de medio pelo... Pero claro, tienen contención familiar, para los padres lo principal es la educación (EEST N 1 , Química).

Esta profesora de Literatura ostenta un firme posicionamiento sobre la inclusión digital, ratificando una cuarta posición que aquí sintetizamos: el acceso a la netbook no constituye una prioridad. En el marco de un grupo focal de EEST $N^{\circ} 2$, abunda en modalizadores, subjetivemas y expresiones irónicas que retorizan los sentidos del PCI frente a otras necesidades insatisfechas.

C. A mí me parece que la netbook llega haciendo caso omiso a la situación social, a las condiciones económicas, a la capacidad o a los usos que le puedan dar. Es como decir: ahora todos tenemos netbook, todos, todos, desde el más pobre al menos pobre. ¡Y es una mentira! Agranda las diferencias. Lo del acceso igualitario es una estupidez. Uno iguala cuando todos tienen real acceso a lo indispensable, no a la netbook, a salud, a trabajo, a educación. La netbook no iguala un carajo (...) A mí no me gusta hablar de igualdad porque yo sigo teniendo chicos que tienen su netbook pero que no se pueden comprar el libro que les pido, o que vienen con las zapatillas con unos bigotes así o vienen cagados de hambre...

Estas imágenes movilizan las discusiones con otros participantes del grupo focal. El juego dialéctico merece una mirada detenida: sobre la concesión acerca de la realidad de esas otras necesidades se apoya la antítesis con la segunda posición, un profesor de Electrotécnica (A):

C. Pero fijate en los programas: el uso de la tecnología "garantiza”, “igarantiza!”, el éxito en tal o cual cuestión. ¿De esto se sigue que "iguala"?

A. Bueno, tampoco estoy de acuerdo con eso. Con la netbook algo se iguala, porque el chico que no tenía acceso a la netbook, hoy tiene acceso, y tiene posibilidades.

C. ¿Posibilidades de qué tiene?

A. Por lo menos de acceso, me parece... 
C. Bueno, pero por lo menos estaríamos en un punto medio, en un gris. La netbook no es la salvación, cuanto mucho es una herramienta.

A. Claro, porque que el chico tiene hambre, que el chico tiene un agujero en la zapatilla también es cierto. Pero la netbook da posibilidades de acceso... Si no hubiera venido muchos chicos no tendrían posibilidades de tener una computadora en su casa...

Pero la presencia de las TIC anima otros tipos de trabajo, comprometidos en "una escuela que pueda enseñar pautas de estudios, una cultura organizacional que tenga que ver con una forma de construcción de ciudadanía” (EEST N 1, Análisis Matemático, O. Química). Estos ordenamientos implican formas novedosas de ejercer la autoridad docente, modalidades de enseñar más allá de los imperativos del currículum, los modelos pedagógicos establecidos o las exigencias de la modernización. El mismo profesor construye simbólicamente a la tecnología como un espacio de decisiones propias y que puede desarrollar en otros esos niveles de autonomía: “¿Qué significa? Que hay contenidos que el docente está obligado a dar. Pero hay huecos, intersticios, donde el docente pone en juego su formación. Creo que ahi entra la computadora."

En el segundo período, la problemática de la inclusión digital sigue configurando un referente fundamental, definitorio de las expectativas hacia el modelo 1 a 1 . Superados ciertos razonamientos iniciales (sobre todo, el entusiasmo adolescente con la netbook y su contracara, el desapego a la escuela), otros nudos significantes se sostienen en el tiempo, pero en marcos comprensivos más complejos. En sus dimensiones institucionales, las problemáticas experiencias que ha transitado la EEST $\mathrm{N}^{\circ} 1$ en los últimos años, nutren las referencias a un pasado adverso: "Lo que pasa que acá se había destruido todo, hay un miedo de que se destruya todo eso que está tan lindo" (Historia, 3er. Año). La digitalización define el proyecto de mejoramiento cultural y educativo, pero supeditado a las decisiones que son capaces de emprender los actores.

Desde otras perspectivas, sobreestimar el impacto de las TIC puede incluso reflotar las reservas que parecían presagiar la desaparición de la tarea docente, como cuestiona la ViceDirectora EEST No 2, antes profesora entrevistada: “Ahora vas a estar con una computadora con una voz cibernética, no... decítelo: ¡es un delirio!” Y ante la pregunta acerca de qué significa que la tecnología no constituye una prioridad social, ratifica la misma tesis que entonces:

No digo que no esté bien el acceso, igualar, y que lo pueda tener fulano y mengano, pero hay que ver el contexto, que eso solo no alcanza y por eso no se empieza. Suponete al principio era: las vamos a dejar acá porque el chico las rompe, las vende, si las tiene que vender porque necesita la plata, entonces hay un agujero que no estás tapando...

La adopción criteriosa de la tecnología configura un importante desafío. De ahí que la atención tiende a desplazarse desde un problema técnico a otro pedagógico. Los reordenamientos institucionales no resultan ajenos porque, en esta etapa, la escuela se vuelve 
razonablemente visible: "vamos a mirarnos nosotros" en tanto "conjunto de humanidades tratando de llevar adelante algo.” Al frente de estas transiciones, la Vice-Directora de la EEST No 1 juzga necesaria la modificación de las acciones, una consciencia reflexiva que conduce a revisar las opiniones personales: "Yo lo enfocaba a la máquina. Pero si la preparación pedagógica es el problema, entonces el docente va a tener ese problema con máquina o sin máquina (...) La máquina agrava un problema que ya está."

En respuesta a las demandas de capacitación, el Plan Nacional de Inclusión Digital Educativa (PNIDE) en que se encuadra el PCI desde 2015, afronta dos dificultades principales, en el entendido de la coordinadora regional. Primero, las resistencias de los profesores, junto con las realidades de sobrecarga laboral, en contraste con los maestros de Primaria con los cuales se vienen realizando experiencias formativas comparativamente exitosas. Segundo, las características distintivas de los adolescentes: "ellos nacieron con esto, con los celulares, con las tecnologías, nosotros no, y ellos por instinto van a saber cosas que nosotros no sabemos. Pero hay docentes que tienen miedo de pasar vergüenza”. El relato es contradictorio: si parece confirmar la brecha generacional, pone el acento en las prácticas, antes que en características atribuibles a priori, como nativos digitales: "Pero hoy no es tan así. Hay docentes que se están jubilando, ya hace 30 años que están implementando la misma estrategia didáctica y es difícil para ellos..."

Sin ser directamente descalificatorios del PCI, algunos docentes insisten en inscribirlo en políticas asistencialistas. No solo caen en la omisión de sus potencialidades para sostener la escolaridad como pleno derecho, sino que las reconocen contrarias a la obligatoriedad del nivel secundario. La educación se mide en términos de la utilidad concreta de sus resultados:

Este bagaje cultural que la escuela tiene que transmitir, tiene que estar porque si no estamos en el horno, pero qué de ese bagaje tenemos que enseñar, cómo lo tenemos que enseñar. ¿Y si al chico no le sirve? ¿Si es un genio y lo estamos atrasando? El hecho de que la hayan hecho obligatoria, la convierte en un lugar asistencialista (...) y eso no es inclusión. ¡Porque a lo mejor al chico no le sirve estar en la escuela! (EEST N 2 , Construcción de Ciudadanía).

Junto con las lecturas situadas en lo cotidiano, en la EEST $\mathrm{N}^{\circ} 2$ surgen interpretaciones acerca de cómo los profesores deben volverse disruptivos de lo que Hargreaves (1998) ha caracterizado como paradojas de la globalización. Es tan importante discutir sobre las culturas locales como enseñar a los jóvenes a tomar consciencia y responsabilizarse de las dimensiones globales de su mundo. Construir competencias ciudadanas se integra en un currículum que apunta al juicio crítico y el discurso teóricamente fundado. En el siguiente relato, "por lo menos" la asignatura Política y Ciudadanía habilita estos espacios de discusión, donde la referencia al nazismo connota las comparaciones con el asedio del consumismo y la ideología totalitaria de la globalización. 
Si desde la educación se te instala la idea de que tenés que estar en este paradigma, si no, no existís, que no es la de Hitler sino la del consumo. ¡Que frustra! Que ves un montón de cosas que parecen super accesibles, pero después te das vuelta y tenés la garrafa del gas.

La figura "por lo menos" es de referencia recurrente y merece mención aparte. Puede vincularse a lo que Eliseo Verón (1998) llama "porlomenismo", una forma de resignación que consiste en reconfortarse viendo lo que aún se ha podido salvar, un conformismo persistente que disfraza una renuncia epistemológica a la búsqueda de creatividad en un contexto de crisis. Indistintamente de las escuelas y durante ambos períodos, el término actualiza dos referentes principales, el primero centrado en el acceso físico: "por lo menos ellos tienen el beneficio de tener la computadora", "por lo menos el chico la tiene", "por lo menos están, por lo menos llegaron".

El segundo referente se centra en el estudiante. Recupera la función de retención escolar, a veces bajo la versión de la inclusión empobrecida y reproductora de las diferencias: "por lo menos que estén en la escuela", "si no aprende, por lo menos no haga otras cosas", "para que aprendan, por lo menos jugando". Esta posición pesimista se ve relativizada cuando el docente no se exime de la tarea de enseñar, si bien no siempre hay una objetivación plena de lo que estas determinaciones significan. La "trampa" metaforiza los intersticios en la práctica, la ruptura con los ordenamientos morales, los imperativos curriculares o los límites rígidos de la materia: “Ahora me estaba mostrando una piba un ejercicio, ni siquiera de Matemáticas, de Lengua, medio trampini, pero por lo menos que estén aprendiendo algo" (EEST No 1, Matemáticas).

La importancia del porlomenismo se hace evidente en el pensamiento pedagógico, pero adquiere diversos matices. En su versión todavía dominante, es signo de la continuidad de modelos conservadores que responden antes a una racionalidad tecnocrática, que a innovaciones genuinas que constituyen la razón de ser de una política de incorporación de TIC. Conforme a una dicotomía insalvable inclusión/exclusión, un discurso fatalista obtura toda problematización de sus propias contradicciones, materializadas en la renuncia al proyecto educativo de modificar esas condiciones que se perciben injustas. El porlomenismo también puede ofrecer argumentos a la concepción tecnoutópica en tanto la "revolución tecnológica" garantizaría la igualación de oportunidades, pero inviste la forma de neutralización (justificación) de las diferencias de base.

Un conjunto de experiencias propicia otras alternativas, donde el "por lo menos" revierte sus sentidos privilegiados. Por ejemplo, hay mayor disposición hacia la capacitación docente, donde el profesor se afirma como actor protagonista de estos cambios. A pesar de las dificultades, capacitarse se entiende como obligación y como derecho, para fortalecer la capacidad de decisión y actuación aportando de ese modo a su desarrollo profesional. La actualización de los saberes como las intervenciones novedosas, comienzan a abrir esos intersticios que dotan de significancia 
educativa, moral y política a la inclusión digital, especialmente cuando el consumismo parece instalarse como única forma de ciudadanía. Así, los profesores revelan progresivamente formas de pedagogía crítica capaces de desafiar al neoliberalismo y a otras tradiciones antidemocráticas.

\section{Discursos estudiantiles sobre el PCI y la integración tecnológica}

En base a lo ya analizado, sinteticemos las representaciones juveniles en torno a ambas Subdimensiones. Tempranamente, los estudiantes se auto-perciben interesados y en plena actuación con las netbooks. Logran dimensionar el papel de la tecnología en un presente inmediato y en la proyección de un futuro imaginado, escapando así de toda mirada prejuiciosa o paternalista de sus docentes que los acusan de apáticos, entusiasmados o "atrapados" por el consumo.

Primeramente, la falta de información acerca del modelo 1 a 1 agudiza un escepticismo marcado. Abonan la imagen de la "irrupción" "la rapidez" de las entregas, "no hubo reuniones formales", "la mala administración" de una Dirección "complicada" ante la necesidad de "que nos expliquen”, “¡la escuela necesita saber!” La recurrencia a términos negativos expresa la dimensión conflictiva de estos cambios: "De la Dirección, te digo la verdad, están todos desconectados, no ha llegado nada que indique al profesor cómo debe usar la netbook dentro del aula, no ha llegado nada. No, no sé nada, nunca había escuchado ese nombre" (estudiante EEST N² 2, 5to. Año, O. Electromecánica). El desconocimiento parece, implícitamente, ratificar el vaciamiento de sentido educativo, el base a que el PCI "es un título", es decir, "solo palabras", "una campaña que está buena, en tiempos de campaña, claro” (EEST N², 6to. Año, Informática).

A pesar de las dudas con respecto a los alcances educativos del PCI, registramos un caso excepcional, pero significativo, donde una política con orientaciones claramente inclusivas despierta un mundo de afectos asociados a la figura presidencial. La política está plenamente inscripta en un plano emocional y expresivo, desde el cual se vuelve inteligibles estos cambios:

Mmmm... no sé. El que ya la tuvo, bueno, el que no tenía, va a decir: iguau! Pero a nivel educativo, habrá que ver... Si esto tuvo que ver con las elecciones, no sé, pero a la mina (la presidenta) se le murió el marido y mirá... Yo todavía no he votado, pero cuando vote, la voy a votar a ella (EEST N 1, 5to. Año, O. Electrónica).

En cuanto a las condiciones de inclusión digital, en los estudiantes aparecen entramadas con los supuestos, a menudo contradictorios, acerca del PCI: sus premisas político-electorales, sus pretensiones de generalización, la improvisación, la desinformación, en conflicto con los beneficios percibidos de la igualdad digital, normalmente ligados al acceso material. Con frecuencia se recrean las representaciones sobre los contrastes entre la netbook y necesidades consideradas más urgentes o importantes, unos conceptos más extendidos en la EEST $N^{\circ} 2$. 
Este Programa ¿cómo se llama? Sí, creo que lo vi en la tele. Habla de igualdad. Bueno, igualar para los que no tenían computadora. No tenías computadora, ahora tooodos tenemos computadora. Y está bien. El contrato que firmamos decía que la computadora es para familia. Mmmm... para mí había otras prioridades (6to. Año, Maestro Mayor de Obra).

Las determinaciones materiales pueden orientar apreciaciones ácidas, sostenidas en la negación de la inclusión digital en tanto derecho prioritario. Conllevan miradas prejuiciosas hacia otros grupos juveniles, cuya contraparte es la identificación con la pertenencia a familias “de cierto nivel" o "parecidas", con "capacidad de pensar". En este aspecto, los estudiantes de la EEST $\mathrm{N}^{\circ} 2$ no encuentran oportunidades reales para problematizar estas creencias. Y al interior de los salones, aquellos "otros" son también quienes se distraen con la netbook, imagen que reposa en una segunda dicotomía: tiempo lúdico/tiempo educativo. El significante de la dispersión es más frecuente en esta primera etapa y en el contexto social de la EEST $\mathrm{N}^{\circ} 1$, donde el perjuicio sobre el desempeño escolar configura la preocupación más extendida. "Sí, algo he escuchado... Capaz que sí, pero no sé, porque acá a los chicos los perjudica en el aula, porque es un problema más para ellos. Si vas y mirás en las aulas, están todos en las computadoras” (6to. Año, Química).

Otros problemas remiten a los retrasos de las entregas, la falta de responsabilidad personal, los usos estrictamente instrumentales, la desorganización escolar, la disponibilidad deficiente de Internet (o la necesidad imperiosa de regularla). Los tipos de utilización pueden quedar en mero voluntarismo y, en ocasiones, erosionan las bases de la autoridad pedagógica. En este sentido, los estudiantes son conscientes de una cuestión clave: ningún docente está en condiciones de enseñar si al mismo tiempo debe luchar para hacerse del poder o para mantenerlo (Jaim Etcheverry, 2007). Ese poder no se confunde con autoritarismo ni con complacencia: "El profesor de Historia se sienta, pone el reloj y no tiene que volar una mosca. Hay profesores y profesores. Hay profesores que se ponen a jugar con nosotros a los jueguitos" (EEST N 1, 5to. Año, Electrónica).

Las incorporaciones eficientes dependen entonces de la iniciativa del docente. Estas actividades pueden ser extremadamente limitadas: "Él va explicando y dice: para la prueba, de la dispositiva número 1 a la 40. ¡Igual lo que él dice está en el PowerPoint! ¿Te das cuenta? Jajaja” (EEST $N^{\circ} 2$, 6to. Año, Automotores). Una de las razones atribuidas son las debilidades de la capacitación docente, que excede al lugar de la netbook para implicar también a la formación inicial, otro aspecto de la problemática autoridad docente. En la base de ese razonamiento está el conocimiento. El "facilismo" en la resolución de consignas se convierte en obstáculo epistemológico cuando se trata de proyectar la propia vida hacia los estudios universitarios:

...tuvimos una profesora que era ingeniera y no tenía la parte de didáctica para enseñarnos. Nos decía un problema, lo hacíamos en la computadora, te daba el resultado y te ahorrabas de hacer todo el procedimiento. ¡No aprendíamos nada! (...) Es importante aprender los ejercicios matemáticos que son la base de cualquier tecnicatura o ingeniería, que lo dan tan 
por arriba. Y por último, te lo explican y ¡lo hace la computadora! (EEST $\mathrm{N}^{\circ} 2,5$ to. Año, Electromecánica).

Hacia la segunda etapa, los relatos intersectan muy diversos significantes acerca del PCI, los primeros en continuidad, como los niveles de desconocimiento, el escaso tratamiento que recibe como tema de discusión, la autocrítica asociada a relaciones de dependencia digital, junto con la defensa de la igualdad que provee el acceso físico. Los estudiantes mayores, quienes han vivenciado todo el proceso de integración tecnológica desde el 2011, se muestran particularmente reflexivos. En la medida en que avanza la distribución de las netbooks en el Ciclo Básico, se generan inquietudes entre los más jóvenes: "No se habla en la escuela, vas a 1ero. y les preguntás ¿qué es PCI? Y te dicen: ¡la marca de la compu! Jajaja” (EEST $N^{\circ} 1$, 3er. Año). Adquieren centralidad las debilidades de la capacitación docente, antes como un problema del modelo que a consecuencia de la voluntad de los docentes: "La capacitación docente tendría que haberse hecho antes de entregar las computadoras, eso es lógico, ¿no? Sí querés que los profesores usen con los chicos las computadoras, antes tenés que capacitarlos a ellos...” (EEST $\mathrm{N}^{\circ}$ 2, 6to. Año, O. Electromecánica).

Otro tópico remite a las asociaciones negativas entre el PCI y la política. Este problema emerge cautelosamente en la primera etapa y cobra fuerza avanzada la implementación. Se sitúa en modelos en construcción: aquellos que dictaminan que lo que convoca a la participación estudiantil no es política sino el sentido de pertenencia que los abraza en un proyecto común, el trabajo colectivo, la representatividad de todos los estudiantes y el compromiso con la comunidad educativa. El presidente del CE de la EEST N 2 marca ese contraste cuando dice que "el Programa está muy bueno, pero no me gusta que hagan campaña con eso..."

Es notables que las consideraciones sobre el PCI no contradicen el valor de la inclusión digital. Las razones que esgrimen esas críticas apelan a la diversidad cultural, contextos sociales, marcos biográficos y códigos de referencia que reclaman distintos modos de implementación, y que son ajenos a una política partidaria. Sin embargo, esta creencia puede ratificar las imágenes negativas hacia otros juveniles. La tecnología se encuadra en un orden moral, como síntesis evidente de esas diferencias. "Para mí es mentira que la mayoría de los chicos no podían tener una computadora, porque muchos ahora se compran una computadora y están comiendo arroz en la casa. O no arreglan la ventana de la casa y tienen terribles celulares" (7mo. Año, Electromecánica). Conjugan apreciaciones acerca de las dificultades de uso escolar, como de sesgos ideológicos, de carácter excluyente, que la escuela parece confirmar como proyecto identitario. Consistentes con la "jerarquía de necesidades", van a contramano de realidades en las que la tecnología se integra en la experiencia vital de los jóvenes de todos los sectores sociales: 
Es bueno que todos tengan computadora. A la vez, si no estuviera no importa, no es algo que cambie el rumbo de la vida, jajaja. Yo sé que hay personas que les hizo bien tener la computadora, porque es una forma de conectarse con todo el mundo, pero en mi escuela, no hay tanta gente de clase baja, no es que les cambió la vida (EEST $\mathrm{N}^{\circ} 2,2 \mathrm{do}$. Año).

Creo que puede apuntar a la inclusión, porque algunos chicos de otras escuelas no tienen acceso a la computadora propia, ¡esta fue como un Dios! Jaja, guauuu... ¡la computadora! El tema es que estaría bueno que las usáramos para lo que se supone que se tiene que usar (EEST N 2, 4to. Año, Informática).

Los cuestionamientos se desplazan hacia la precaria utilización de las netbooks en las clases, una deficiencia que reside tanto en los usos juveniles ligados al entretenimiento como la falta de disposición docente hacia unos usos menos superficiales o tecnicistas. Sin embargo, progresivamente los estudiantes experimentan otro tipo de actividades, no siempre sofisticadas pero sí orientadas a la producción de contenidos o a su apropiación activa. Por ejemplo, en Prácticas del Lenguaje, la lectura literaria de acceso libre en Internet, la escritura y almacenamiento, el trabajo colaborativo, la evaluación en red, etc. De este modo, la utilización de las TIC se subordina a los requerimientos de las asignaturas y de los sujetos que participan en ellas. Así describe este estudiante la tarea que están realizando: "Estamos haciendo una presentación de PowerPoint, Sistemas Productivos es el tema, como la materia, pusimos un título, vamos a agregar imágenes, estamos describiendo lo que es producto...” (6to. Año, O. Química, EEST N 1).

Pero además de una dimensión cognitiva, las condiciones de la inclusión digital están implicadas en aspectos emocionales que se despliegan en las comunicaciones áulicas. Los estudiantes comprenden que con sus acciones pueden resentir, justificadamente, construcciones autoritarias del rol docente. La presencia de la computadora visibiliza los problemas vinculares, cuando es directamente prohibida: el profesor considera su utilización como expresión de rebeldía que debe ser disciplinada. Vale detenernos en este relato de este joven de la EEST $\mathrm{N}^{\circ}$ 1 (5to. Año, Electrónica), quien apela a gran cantidad de calificaciones de estas situaciones conflictivas donde ve afectada su sensibilidad personal; también ejemplifica el vínculo persistente con la familia mediado por la interactividad, y a los márgenes de la institución:

Con algunos profesores hemos tenido algunos roces fuertes. A uno no le gusta que tengamos la computadora, pero yo la dejo abajo del banco. No, no quiere que escuchemos música, por ahí estás hablando y él te habla mal, o vos sin querer, si les seguís discutiendo, peor. El otro día tuvimos un agarrón (...) vienen enojados y enseguida te sacan las computadoras, que copiemos en la carpeta. Pero en mi casa no tengo Internet, así que aprovecho acá. Y yo estaba hablando con mi vieja, porque vivo lejos, y me cagó a pedo...

Verificamos que los jóvenes manifiestan reflexiones tempranas no suficientemente comprendidas por los adultos. $\mathrm{Si}$ bien reproducen ciertas antinomias, formas de diferenciación/identificación que deben ser problematizadas, no recurren a aceptaciones 
difusionistas, mayormente las cuestionan: una netbook cuyo uso es placentero, motivador o estimulante, no conlleva necesariamente una apropiación significativa. Un proyecto de ciudadanía no puede desentenderse de esos modos de consciencia, en la que medida en que lo importante para ellos no es la presencia de un artefacto ni las situaciones de alta disposición tecnológica que provee, sino el conocimiento que es posible construir a partir de las prácticas y relaciones que en estos ambientes tienen lugar, en respuesta a propósitos concretos de aprendizaje.

\subsubsection{Información y Conocimiento: la problemática mediación comunicacional}

Avanzar en las definiciones de una ciudadanía cultural convoca la siguiente pregunta: ¿es posible evaluar la relación información/conocimiento como variable más tangible para los sujetos educativos, menos abstracta que los principios de la democracia? Es que dicha relación es en sí problemática. Adquiere diversos componentes, entre ellos, el esfuerzo solapado por homologar información con conocimiento, la confianza en las posibilidades de los usuarios atribuidas a priori, la crisis de la autoría frente a los des-ordenamientos de una cultura colaborativa. Y desde una perspectiva habermasiana, los desafíos de la educación cuando la transmisión de conocimientos deja de ser la tarea principal para encarar actividades de interacción e interpretación, la participación racional en el espacio público y los cambios que las TIC catalizan en ellas.

Ante la llegada del PCI, muchas definiciones docentes giran en torno a Internet, la "revolución fabulosa" a la que "hay que adaptarse". No despierta tanto una actitud resignada sino de la disposición a aprovechar la "biblioteca infinita", cuyo peso comparativo reside en su actualidad frente a la rápida obsolescencia de los libros. Con argumentos similares se tiende a reemplazar los viejos medios por los soportes móviles. No obstante, como ya se ha analizado, los usos demuestran continuidad con modalidades previas, igualmente conservadoras. Recurrir a la netbook para ilustrar un tema, motivar el interés o disciplinar a los grupos, se replica en la ausencia

\section{de la comunicación como base elemental del vínculo pedagógico.}

Porque tenés un televisor 29 pulgadas, y cuando los pibes se ponen ásperos los mandás a mirar una película a biblioteca. Y no es la idea. Te dicen: vamos a ver una película. Con qué grupo, con 3 ero. Y yo no puedo estar controlando tu práctica a ver qué producís. Porque ver la película es perder el tiempo, porque para eso la ves en tu casa. Tiene que haber una previa, la película es una herramienta, y luego una producción... (Vice-Directora, EEST $\mathrm{N}^{\circ} 1$ ).

El problema abre las discusiones acerca de la novedad de los medios interactivos, que implicarían unos usos mucho más poderosos; empero, como advierte Scolari (2008) este sentimiento de control se opone a los límites de libertad que le impone el productor de ese entorno. El acceso a la información, la navegación, el consumo, no revelan necesariamente producción de 
conocimientos si no hay una concepción crítica acerca de lo que esos datos implican o cómo se generan. Escapar de esa dialéctica control/libertad requiere de la mediación pedagógica, orientada a movilizar en los alumnos capacidades para discernir, seleccionar y leer críticamente la información disponible, como asimismo la curiosidad, la participación, la posibilidad de referenciar contenidos conceptuales de cierta complejidad, más allá de los soportes que se utilicen.

Yo ya venía trabajando con la computadora y otros recursos audiovisuales. Por ejemplo, el otro día vimos un fragmento de una película para que pudieran identificar características de la sociedad industrial clásica... se muestran muy interesados. Hay que incorporar la computadora, más en la era de la información... (profesor EEST Nº 1, Análisis Matemático).

La cuestión del control sobre la tarea, los grupos o el conocimiento producido, es una constante a lo largo de toda esta primera etapa. La netbook entra en tensa convivencia con la carpeta, particularmente considerada en la cultura escolar como conservación de lo registrado, en la evaluación y auto-evaluación de las prácticas. En el mismo discurso, “ellos me dicen: ¿para qué trabajamos en la carpeta, si escribimos en la computadora? Pero siguen trabajando en la carpeta, porque es una forma de control de los padres y también de nosotros los docentes." En otros casos, la inacción pedagógica se asienta en las dificultades para fomentar competencias comunicativas, contradictoriamente, percibidas como indispensables en el perfil del profesional técnico. Las comparaciones adquieren otras expresiones binarias, ratificando al libro como fuente excluyente de conocimiento. Este supuesto sirve de argumento a las actitudes "facilistas" de los adolescentes: "cuando buscan en Internet, copian los cuatro primeros renglones ¡y hasta que entienden...! Están viendo si encuentran un resumen. La cultura del menor esfuerzo" (EEST N 1, Física).

La disponibilidad de Internet fue ser valorada positivamente, pero el docente evita comprometerse en formar en los usos competentes de esa información. Las orientaciones están limitadas a indicar el sitio adecuado, sin explicitar criterios de búsqueda o de validación, lo que resulta en la repetición de los datos que es precisamente aquello que se cuestiona: “...les di como tema "caída libre vertical" y les dije: busquen en Google, que yo les voy a decir qué información sirve y qué no" (EEST N 1, Físico-Química). Estas disposiciones -o la falta de ellas- reafirman las continuidades de uso entre nuevos y viejos medios, entre medios digitales y analógicos. La tecnología aparece como algo extraño a la cultura escolar, o bien, naturalmente integrado a ella, revelando modalidades de adopción reproductora o adaptativa.

Durante la segunda etapa del PCI, la relación información/conocimiento es objeto de otras intervenciones. La diversificación de los soportes, la velocidad en el acceso, la practicidad de la disposición personal, reciben calificaciones positivas, pero menos difusionistas. En principio, porque las habilidades fluidas de navegación no pueden darse por asumidas, y la adopción 
criteriosa de Internet requiere ampliar y complejizar estrategias de enseñanza-aprendizaje. El espacio preponderante de evaluación de lo producido sigue siendo la carpeta. Pero la figura del control no se limita ahora al rechazo a la pérdida de la "cultura del esfuerzo", sino que alienta actitudes de responsabilidad y autonomía con la tarea más allá de los recursos utilizados, en el marco de decisiones planificadas o de situaciones espontáneas. Por ejemplo, para optimizar los tiempos, es frecuente que los estudiantes tomen fotografías con sus celulares de la pizarra, y la docente luego "controla" que esos apuntes estén copiados en las carpetas.

Las representaciones docentes median los tipos de uso que se demandan y efectivamente se producen. La EEST $N^{\circ} 1$ ha avanzado significativamente hacia una inclusión material-simbólica en condiciones sociales adversas, pero imágenes negativas de los consumos enmascaran niveles persistentes de discriminación. Demandan, en cambio, miradas proactivas, menos prejuiciosas:

Y primero, empezás estigmatizando al alumno. Segundo, empezás a desparramar esa estigmatización que vos estás construyendo de acuerdo a tu discurso moral. Tercero, yo no puedo decir porque ni tengo Facebook, pero capaz que abrís el Facebook de esa profesora y está en bolas con un chongo. ¡Entonces no entendés nada! (Director EEST N 1).

El desarrollo tecnológico no es entonces una cuestión técnica, "se da en el área más sensible que es en el área de la comunicación, semejante cantidad de información que es imposible de procesar. Noooo, para mí es tal la cantidad de información que no te permite aprender." Si la docencia presupone un posicionamiento ético, personalmente responsable y con mirada inclusiva, es también cierto que la enorme cantidad de información complejiza sobremanera las decisiones pedagógicas. Estos aspectos son condiciones de las decisiones docentes en la EEST N²: "Nadie te habla de conocimiento, iy cómo va a garantizar inclusión si no das conocimiento! Yo creo que no alcanza el acceso, jel conocimiento! (...) es un instrumento un poco perverso, si no hay comunicación no hay responsabilidad (Política y Ciudadanía).

El valor democrático de la comunicación cobra fuerza en procesos de mediatización, donde el acceso de la información pública constituye un derecho, pero también una competencia a ser progresivamente desarrollada. Significa formar un sujeto que reconstruye y da significado a la multitud de información que obtiene extra-escolarmente en los múltiples medios de comunicación, y desarrollar las competencias para utilizar de forma inteligente, crítica y ética la información disponible (Área Moreira, 2015). Estudiantes receptivos, actualizados y criteriosos, se muestran capaces de intervenir en temas de agenda pública que los afectan directamente: el voto juvenil, la identidad de género, la prevención de adicciones, el cuidado del medioambiente, todos ellos campos legítimos de construcción ciudadana. De ahí los aportes de estas discusiones:

Creo que no están muy informados, la mayoría no, solo si al chico le interesa, creo que eso (para la ciudadanía) es importante, porque el acceso a la información forma ideas sobre 
determinados temas, y después tienen que ver con la forma de manejarse, a mí me encanta que sea así. Me encantaría que sea así... (EEST Nº 1, Prácticas de Lenguaje, 3er. Año).

Ya no se trata de garantizar el libre flujo de la información sino el acceso a la producción de conocimiento y a la defensa de la identidad cultural. Como en el proyecto sobre la memoria de la EEST $N^{\circ}$ 1: los jóvenes utilizan creativamente las TIC para buscar testimonios, investigar fuentes documentales, registrar videos y fotografías, diseñar los medios para comunicar sus resultados a la comunidad. Y apuntar a la producción socialmente contextualizada, un insumo para la cultura escolar y con la participación de los vecinos, todos convocados a reconstituir ese legado histórico como a contribuir a sus transformaciones. Procesos de este tipo comportan "la necesidad de generar símbolos culturales comunes que susciten reconocimientos, acercamientos, diálogos y consensos en torno a un proyecto que, a la vez que colectivo, sea reconocido por todos los sujetos como propio" (Bruno, 2011: 116).

En suma, los modos tempranos de concebir a las TIC clausuran propuestas educativas más globales, aquellas que animen a proyectar integraciones superadoras de la utopía tecnológica o el presente inmediato anclado en las aulas. Martín Barbero (2001) ha advertido que la obsesión del presente implica a su vez una flagrante ausencia de futuro. Retomando a Lechner, sugiere que no logra cristalizarse una secuencia de acontecimientos, y sin la cual ninguna experiencia logra crearse, más allá de la retórica del momento, un horizonte de futuro. Pero avanzado el PCI, las tecnologías comportan otras temporalidades insertas en la práctica, nuevas significaciones que permiten dimensionar ese futuro en construcción. La comunicación puede mediar las relaciones información/conocimiento $\mathrm{y}$, con ello, ratificarse como premisa de la democracia o del conjunto de competencias ciudadanas que devienen fundamentales para su desarrollo.

\section{Libros e Internet: disputas de sentido en las percepciones juveniles}

En el marco de estas transiciones, adquiere centralidad Internet como registro de sentido y organizador de las prácticas. Actualiza unos imaginarios acerca de la Sociedad del Conocimiento, en la cual la informacionalización (Miége, 2010), la aceleración de la circulación de flujos de información, parece ser su rasgo más evidente. Este es el sentido que prima entre los más jóvenes, por lo que tienden a replicar la matriz hegemónica que homologa información con conocimiento. Significativamente, donde se vuelven visibles las distorsiones de la sociedad-red es en las escuelas.

Asumir las ventajas que reporta la introducción de las netbooks, descansa en modos previos de apropiación, sujetos a determinaciones concretas. Internet representa una falta o bien un facilitador, antes que un componente enteramente novedoso. Cabe recordar que una mayoría de 
quienes asisten a la EEST $N^{\circ} 1$ no cuentan con conectividad en sus hogares, pero sí en su escuela. En Industrial, esa correlación es precisamente la contraria. No obstante, los tipos de utilización parecen similares. Priorizan la velocidad en el acceso, la portabilidad de los equipos, ahorrar libros y fotocopias, desconocen usos alternativos a leer en la pantalla o descargar materiales. Wikipedia es el espacio emblemático de des-centramiento de la autoría del saber y de inteligencia colaborativa, ampliamente conocido y utilizado, no obstante, solo para buscar y copiar datos.

Pero los estudiantes están lejos de mostrarse pasivos. Nos preguntamos cómo interpretan los cambios de una institución tradicionalmente anclada en la cultura del libro, en los cuales gravitan las relaciones información/conocimiento. En la primera etapa se reconocen cuatro posiciones:

1-Internet tiende a desplazar a los libros como lugares privilegiados de información: esta opinión consigna creencias difusionistas, pero aducen la practicidad de la información disponible antes que un cuestionamiento al valor cultural de los libros. Más frecuentes entre alumnos de Informática, valoraciones de este tipo reposan en el sesgo tecnicista de la orientación:

Si las tecnologías van a reemplazar a los libros, creo que ya lo han hecho. O todavía no, pero no le falta mucho, porque buscás en Internet lo que sea y te aparece. Libros, resúmenes, incluso los trabajos prácticos que nos traen las profesoras están en Internet. Ya como que sacar fotocopias es medio de gusto... (EEST N² 2, 6to. Año, Informática).

\section{2- Comparados con Internet, los libros son fuentes irreemplazables de información}

fiable: la abundancia de datos disponibles como la dificultad para constatar su validez, veracidad o pertinencia para los propósitos de la tarea, pueden generar confusiones en los alumnos, entorpecer el trabajo y la optimización de los tiempos previstos.

Hay cosas que en Internet no lo encontramos, hay cosas que están mejor en el libro. Está mejor explicado. A veces Internet tiene complicaciones. No sé, ponés la palabra y aparece cualquier cosa (EEST N 1, 6to. Año, Química).

\section{3- Internet es una fuente ilimitada de datos, pero generalmente ajenos a los fines}

escolares: la utilización didáctica está sujeta a los requerimientos de las materias. En Prácticas del Lenguaje frecuentemente se prefiere la lectura en libros o fotocopias, en tanto la información recabada para resolver consignas debe adecuarse a los propósitos de las actividades.

Internet te da todo, el libro te da especificamente lo que pide la escuela. Ponele: buscás en el libro como dice ahí (el pizarrón): "átomo", está en el libro, en cambio en Internet está "átomo", "molécula" y todo eso, es un quilombo (EEST N 1, 4to. Año, Electrónica).

\section{4- La facilidad de acceso equipara a Internet con los libros, pero dependiendo de}

condiciones: las oportunidades de la navegación serán aprovechadas según competencias cognitivas y socio-comunicacionales, o la voluntad de desarrollarlas en ambientes intersubjetivos:

Buscar en Internet es más fácil, más rápido que buscar en los libros. Es lo mismo. En parte, sí; en parte, no. Porque a veces no encontrás cosas que buscás... Depende del grupo, hay 
grupos que saben buscar información y hay otros que los tiene que ayudar el profesor. Nosotros nos ayudamos mucho, obvio (EEST N 1, 4to. Año, Electrónica).

Avanzado el proceso de digitalización, modalidades incipientes de acceder, seleccionar y utilizar la información de Internet, responden a los principales reclamos de los chicos. Las actitudes que adoptan en esta segunda etapa no son necesariamente excluyentes, tampoco están estrictamente centradas en las experiencias escolares. Si bien persisten las diferencias tiempos lúdicos/escolares, suponen mayor comprensión de sus cruces y desplazamientos:

1- La utilidad de Internet frente a los libros depende de las asignaturas: el soporte papel sigue siendo la preferencia de un grupo de estudiantes para la lectura literaria y áreas afines. En los talleres se trabaja con manuales de acceso libre, pero en esta etapa se perciben las intervenciones docentes para promover capacidades para leer compresivamente, validar la información y producir conocimientos que no impliquen acumulación de datos ni redunden en la mera reproducción:

...el enfoque es más práctico y vamos a trabajar con esto, Autómatas, que se puede programar... se conecta a través de un cable a la netbook. Nos enseña cómo buscar, qué buscar, meter mano, jugar como quien dice, que leer diez libros (EEST $\mathrm{N}^{\circ}$ 1, 7mo. Año, Electrotécnica).

2- Las valoraciones sobre Internet derivan de los tipos de uso: mientras unos utilizan la netbook del PCI en todo momento, otros la valoran estrictamente como herramienta educativa, sobre todo cuando disponen de otra computadora personal. Estas significaciones median también la apropiación de Internet: "Esta computadora solo la uso acá, la otra para chatear, para estar... boludeando (risas). Twitter, Facebook, sí. Acá más Facebook. Porque algunos no lo saben usar al Twitter, para buscar información..." (EEST N 1, 6to. Año, Química).

3- Internet no solo como espacio de consumo, sino de producción: actitudes creativas se registran en grupos de distintas edades, trayectorias y contextos de pertenencia. Operan allí múltiples mediaciones, como las iniciativas personales, las orientaciones familiares, la legitimidad de la formación regida por el binomio formación técnica/doble jornada, todas involucradas en la combinación de aprendizajes formales e informales acerca de una pluralidad de temas:

A mí me gusta hacer juegos, estoy empezando hacer en 3D, siempre me interesó, por eso sigo Informática (...) Yo no la elegí, pero ahora que vengo me gusta mucho. Mis papás querían que viniera porque como es a la mañana y a la tarde, iyo a la tarde no hacía nada! Pero me terminó gustando, porque tenemos los talleres, podemos hacer un tablero de electricidad, además salimos con un título de técnico (2do. Año, EEST N ${ }^{\circ} 2$ ).

4- Los contenidos producidos en Internet no son considerados con valor educativo: las experiencias de autodidactismo adquieren rasgos diferenciados cuando remiten al entretenimiento, 
si bien convocan apropiaciones hábiles y entusiastas, ligadas a otros consumos culturales y mediadas por relaciones familiares. “¡Con mi hermano tenemos páginas de Internet! ¡Tenemos una de Gran Hermano! (...) mi hermano está estudiando en La Plata y no puede ver todo el día, entonces yo lo veo y publico..." (EEST N 1, 6to. Año, Química).

5- Internet es un componente más en entornos tecno-educativos: nuevas interfaces, desafiantes de los modelos conservadores de introducción de TIC, animan a los estudiantes a superar las oposiciones entre Internet y libros, netbooks y carpetas. Valoran espacios híbridos estructurados en torno a diversos lenguajes, soportes y medios, en los cuales interactúan con pares y docentes bajo propósitos genuinos de aprendizaje. "Y con este profesor, por ejemplo, buscamos noticias sobre los extranjeros en Olavarría, y lo buscamos en mi celular que tiene 3G. Ah, y de ahí la pasamos a la computadora y ahora estamos haciendo un PowerPoint" (EEST N 2, 2do. Año).

Estas situaciones aprovechan los soportes disponibles en las aulas, orientados a suplir las deficiencias de conectividad, los bloqueos o deterioros técnicos de las netbooks. Si en la EEST N ${ }^{\circ}$ 1 la cantidad de smartphones es comparativamente baja y reducida al Ciclo Superior, sus incorporaciones pedagógicas adquieren cualidades similares, lo que conlleva una importante forma de igualación en condiciones socioculturales todavía desfavorables. Conforme avanza la institucionalización del PCI, se renueva la pregunta acerca cómo capitalizar esas experiencias en clave ciudadana. Esto es, en pos de problematizar las retóricas hegemónicas definitorias de las tecnologías y las capacidades de los agentes para revertir sus sentidos, utilizándolas como canales de difusión de sus ideas o de reivindicación de sus reclamos, de maneras creativas y con intencionalidad transformadora.

\subsubsection{Identidades Juveniles: jóvenes negativizados, sujetos en potencia}

La última Subdimensión del entramado Ciudadanía/TIC reside la Configuración de las Identidades Juveniles, en orden de explorar las características que asume la socialización en la escuela, atendiendo tanto a los aprendizajes como a los repertorios de acción política a los que apelan los estudiantes. Un proyecto de formación ciudadana los compromete a reconocerse y a ser reconocidos en sus intereses comunes, y a su vez en su diversidad. Las definiciones de las “juventudes" (en plural) son evocadoras de procesos de identificación/diferenciación y de sus componentes afectivos y crítico-reflexivos, denotando un sinnúmero de referentes, entre ellos: alas relaciones con las TIC; b- los códigos lingüísticos; c- los lugares de pertenencia y participación institucional o local. Los tres ejes confluyen en otro campo problemático: la despolitización de la educación o su correlato necesario, el desfasaje entre política y ciudadanía. 
Es claro que los lenguajes, las narrativas y sensibilidades que los adolescentes ya producían en condiciones de interactividad, sirven de marcos interpretativos ante la irrupción del PCI. Entrañan tanto racionalidades integrativas como portadoras de formas específicas de diferenciación. Sin embargo, los adultos tienden a homogeneizar esos consumos juveniles. La brecha generacional da sustento a las calificaciones positivas sobre el acceso a las netbooks, entre quienes estarían mejor dotados para asumir la irreversibilidad de estos cambios: "más adelantados", dominan "otros idiomas" que tienen "incorporados", "totalmente naturalizados". En la base de este razonamiento está el imperativo del cambio, junto con la auto-percepción de la condición del docente/inmigrante en una distancia insalvable.

- Es realmente rarísima la agilidad que tienen ellos para buscar, para aprender con la netbook. Hay que aprovechar esto. Porque si vos les hacés leer el Quijote o el Martín Fierro del libro, iqué lo van a leer! A mí me cuesta leer en la computadora, yo tengo que imprimir para leer.

- Y cómo hacemos para atrapar a los chicos, si ellos están con todo esto de las imágenes, de lo audiovisual, como que estábamos atrasados... (psicopedagogas EEST No 2).

Ese distanciamiento puede redundar en una posición radicalmente opuesta. En la misma escuela: "Cuando entramos al aula están jugando. Ayer justo una alumna me decía: ¿Vio, profe, que no salen más al patio? No van afuera. ¿Por qué? ¡Porque están todos sentaditos adentro con su computadora!” (Matemáticas). Dominar fluidamente las TIC conlleva siempre la experiencia del entretenimiento, irreconciliable con los aprendizajes, carentes de motivaciones importantes o de "expectativas de vida". La imagen de un "material divino" si se usa "como se tiene que usar" convive con cierto fatalismo tecnológico: "Tengo un hijo adolescente y te puedo decir que es espantosa la obsesión que tiene con el juego ese, el Counter. ¡Y es ob-se-si-vo!” (EMATP). Comparten ambos relatos: a- la naturaleza lineal de la temporalidad escolar, donde irrumpen los tiempos fragmentarios del consumo; b- la cosificación de la tecnología y, con ello, de los mismos alumnos/consumidores; c- la juventud negada o negativizada (Cháves, 2010), sea en sus actuaciones (apáticas, banales, peligrosas) o como sujeto total (incompleto, en transición).

En las experiencias relatadas en la EEST $\mathrm{N}^{\circ} 1$, las situaciones conflictivas agudizan esas opiniones. Una postura defensiva o resignada revela una operación hegemónica en el intento de negativizar (criminalizar) las acciones del otro/juvenil. En la práctica, dificulta pensar alternativas, discutir estos problemas, diseñar estrategias colectivas. La netbook ocupa un lugar empobrecido, para disciplinar al alumno, evitar que deambule o interrumpa el ritmo normal de las clases.

Depende de la autoridad del docente. Yo le digo que cierre la computadora o que apague el celular. Bien, por las buenas ¿eh? Porque en esta escuela lo peor que podés hacer es ir por las malas. Un día la Directora entró, retó a un alumno y este agarró una silla y la tiró por la ventana esa... A la Vice-Directora le han rayado todo el auto... (profesor Proyecto y Diseño Electrónico). 
El uso del lenguaje verbal constituye otro punto dilemático. Se aduce que los chicos utilizan códigos propios, que trascienden el círculo íntimo para trasladarse al ámbito escolar. Más directos y resumidos, estos dialectos están tecnológicamente mediados y, además de ser un elemento diferenciador de edades, se utilizan para distinguirse de otros. Desde la perspectiva de los docentes de la EEST $N^{\circ}$, sus alumnos tienen dificultades para expresarse, encarnando lo que Bernstein (1970) denominó códigos restringidos, en base a la relación entre posición social y uso lingüístico: "Hay continuamente palabras nuevas, es un lenguaje que entienden ellos mismos y uno les tiene que estar preguntando todo el tiempo qué significa esa palabrita, porque no sabés si es un insulto o qué es" (Inglés). Con frecuencia, conllevan otra expresión de la cosificación de las TIC: "Pero eso ha sido siempre igual, van apareciendo modismos, lo que sea, según las épocas y los cambios. Eso nunca va a parar, aunque tengas un recurso tecnológico.”

En lo que respecta al conjunto de sentidos de pertenencia y formas de participación, cobra fuerza renovada la problemática de las configuraciones identitarias a partir de los recorridos en la web. Otra perspectiva que problematizamos recientemente (Fernández Massara, 2018) intenta superar la dicotomía nativos /inmigrantes, dado que el desarrollo de las plataformas y las redes es posterior a los términos nativos e inmigrantes digitales acuñados por Prensky (Facebook en 2004, YouTube en 2005, Twitter en 2006, etc.). De acuerdo a White y Le Cornu (2011), la metáfora del "lugar" evoca la sensación de estar presente con los demás, poniendo en relieve un tipo de personificación a medida que se proyectan aspectos de la identidad a una audiencia imaginada. De tales experiencias derivan dos posiciones. Independientemente de su edad, los visitantes no dejan "huella"; son usuarios, no miembros, de la web y le dan poco valor a estar en línea. Los residentes tienen un perfil en la red y se sienten parte de una comunidad, donde expresan sus identidades en sus interacciones con otros.

Para White y Le Cornu, no se trata de posiciones fijas, sino parte de un continuum. Ahora bien, no dejan claro qué implican esas habilidades, o bien cómo en esos lugares móviles, constantemente desplazados, pueden identificarse dos tipos de usuarios razonablemente distinguibles. Una persona se asume visitante según unas motivaciones, y residente según otras. En ocasiones, logra adecuar sus estrategias en tanto visitante, demostrando competencias intelectuales significativamente más sofisticadas. Esto no invalida el hecho de que las TIC, especialmente las redes sociales, intersectan procesos importantes de subjetivación, que merecen miradas más atentas, con intención educativa.

Estas posibilidades están ausentes en esta etapa. Las categorizaciones binarias sirven de argumento a las actitudes de rechazo, como a incorporaciones estrictamente técnicas. Y evitan 
comprender en su complejidad los dispositivos de construcción identitaria que esas experiencias entrañan, las formas comunicativas que definen ámbitos significativos de aprendizaje escolar. En la propuesta de Maggio (2016), recuperar el placer de comentar y ser comentado en la red, generando una cultura de intercambio en el marco de una conversación ampliada y productiva.

En contraste, las identificaciones válidas que los docentes reconocen en sus estudiantes, se soportan casi de modo excluyente en la institución. En la EEST $N^{\circ} 2$, reconocerse "grasas" aboga por la reconstrucción simbólica de ese mandato. Sirva de ejemplo la formación en los talleres, campo de convergencia del perfil técnico-profesional -anclado imaginariamente en la modernización tecnológica- y de las prácticas ritualizadas que dan sustento a un pasado glorioso.

Y se va a seguir enseñando a hacer el banquito, primero porque es un clásico de la escuela y todos los que los que pasaron por acá tienen el banquito en su casa, y por todo lo que aprenden para hacer el banquito. Igual que la clásica parrillita. Por eso es tan compleja la escuela técnica (Directora).

En las entrevistas realizadas, el centro de estudiantes aparece como representación simbólica de estas actuaciones y elemento residual de esa memoria compartida. Cierto es que en la EEST $\mathrm{N}^{\circ} 1$, el proyecto del CE, que funcionaba precariamente años atrás, debe capitular frente a las urgencias de los problemas pedagógicos, edilicios y de gestión que la aquejan. El CE de Industrial seguirá siendo el modelo emblemático, constitutivo de la cultura institucional y modelizador de las subjetividades. Pero allí las tecnologías no ocupan lugar alguno. En gran medida, esta vacancia deriva de la problemática institucionalización del PCI, dominado inicialmente por la perpetuidad de modelos fuertemente enquistados de uso tecnológico. Recibe opiniones reticentes o adopciones entusiastas, pero no trasciende los límites de los salones ni se replica en actividades juveniles que alteren los modos dominantes de esa participación.

Tras cinco años de implementado el PCI, se continúan los desfasajes ciudadanía/política, bajo otras premisas. Algunas posiciones tienden a descalificar las culturas juveniles en base a sus consumos tecnológicos. Y se privan de someter a discusión la creencia de que tales tecnologías, formalmente encuadradas en una política educativa, todavía representan aquello que irrumpe en la escuela y le es completamente extraño. Sinteticemos dos aspectos en el testimonio de la ViceDirectora de la EEST $\mathrm{N}^{\circ}$ 1: por un lado, las dificultades para discriminar la abundancia de datos: "Reciben tanta, tanta, información. El adulto puede seleccionar, ellos toman todo, todo les sirve, lo que está bien, lo que está mal, ellos toman todo, ellos consumen todo." Por otro, los conflictos que "vienen de afuera" y "potencian" las redes sociales. Si bien excepcionales en esta etapa, en estas imágenes arraigadas donde la tecnología constituye un mundo ajeno, potencialmente riesgoso. Estos conceptos profundizan el intento de neutralización ideológica de la escuela. 
Otros grupos docentes muestran esfuerzos novedosos de integración material y simbólica de las TIC. Registran formas de conciliar intereses, validar una autoridad pedagógica en constante recomposición, adoptar marcos normativos y, al mismo tiempo, resignificarlos en contextos de globalización. Utilizar a las netbooks y otros soportes se sostiene en concepciones más flexibles de las apropiaciones juveniles en estos entornos digitales. En el caso de la distracción en el aula: "Es una época de influencia mediática, de mucha conectividad en general, pero el chico que se dispersa, ya se dispersaba antes si se ponía a jugar al tutti-frutti...” (EEST N², Informática).

Pero educar para la ciudadanía supone avanzar hacia otros niveles de intervención, superando las creencias cosificantes y problematizando relaciones de poder que exceden la experiencia inmediata. Si bien incipientes o relegadas a materias específicas, estas propuestas trabajan no solamente con TIC sino acerca de ellas: "Mmmm... Este lenguaje deshumaniza. Y haber tomado consciencia de que es una estrategia que va en contra de lo que es la construcción del sujeto pensante, libre, responsable, te pone los pelos de punta" (EEST $\mathrm{N}^{\circ} 2$, Política y Ciudadanía). La mayor preocupación es la parálisis de la crítica. La alegoría de Matrix equivalente al mito de la caverna de Platón- expresa las paradojas acerca de cómo la sociedad postindustrial reproduce un pensamiento unidimensional (Marcuse, 1993), pero crea también condiciones de posibilidad para rebatir tópicos naturalizados en las prácticas de consumo, reconstruyendo la valía de la palabra como instrumento de contrapoder.

Uno de los chicos de Informática me dice: Yo prefiero vivir en la sociedad virtual, y no en la sociedad real. Matrix, la caverna de Platón. Y decime tus razones: menos riesgo, menos compromiso... ¡Todo lo que te humaniza! (...) Si el hombre pierde la capacidad de poner en palabras lo que piensa, está muerto.

Estos razonamientos van en línea a nuestras críticas a los sentidos de una ciudadanía consumidora. Advirtió hace años R. Ortiz que en el mundo del consumo se realizan las premisas ideológicas de toda discusión sobre la cultura de masas: "afirmar la existencia de una memoria internacional-popular es reconocer que en el interior de las sociedades de consumo se forjan referencias culturales mundializadas" (1994: 173). Las subjetividades desde las cuales los alumnos adoptan los requerimientos de la cultura moderna, especialmente cuando encarnan los dilemas de las identidades nacionales, incomodan posiciones docentes, sus ideales y saberes disciplinares. Pero también son los lugares de interpelación que les permiten cuestionar el orden establecido.

Una chica tiene toda la bandera inglesa en la carpeta, no, es One Direction, me dice. No, la simbología y la conquista ideológica que hace Inglaterra es fantástica, mal que nos pese. El consumismo y la mirada que ellos tienen, y cuando uno trabaja la identidad nacional, sí el país Argentina, sí el fútbol, pero cuando tienen estas propuestas salen estas cosas. Creo que es otra generación que tiene otra concepción del país... (EEST N 1 , Historia). 
Otro motivo de malestar docente son los lenguajes adolescentes. En la EEST No 2, puede remitir a diferencias con hábitos que habrán de desarrollarse a lo largo de la escolarización. Nuevamente, la referencia a los más jóvenes que aún no han adoptado normas de funcionamiento, los ubica en un lugar comprensible, legado de la primera etapa: el de sujetos en potencia, inmaduros o incompletos. Esta docente describe una situación en la que un chico es increpado por no saludar al ingresar a clase. La respuesta que recibe la sorprende significativamente y le despierta reflexiones acerca de los códigos interiorizados durante una etapa de transición.

Y él me dijo: porque me parecía que molestaba más si decía perdón, llegué tarde... O sea que lo que yo había entendido desde mis estructuras, como una falta de respeto, para él era más falta de respeto si decía: permiso, buen día, disculpe que me atrasé... (CDC).

El lenguaje es representativo de los problemas vinculares, en reclamo de disposiciones más empáticas ante las "faltas de respeto", en un marco de negociaciones entre un ordenamiento razonable y niveles de flexibilidad adecuados a estas transiciones. Algunas formas de adjetivación sobre los jóvenes recaen en cierta mirada paternalista y estereotipante, lo que tiende, contradictoriamente, a profundizar la distancia generacional: "los chicos son honestos: si te tienen que rajar puteadas, te rajan a puteadas (...) Los adultos, no. Te dan una palmadita por la espalda: Hola, ¿cómo estás? Y te das vuelta y te dan 800 puñaladas por la espalda” (Director EEST $N^{\circ} 1$ ). Desde este estilo de gestión se predica la necesidad de fortalecer una autoridad pedagógica que edifique su poder sobre la base del entendimiento, evitando intervenciones de los directivos.

Eran frecuentes estas situaciones, pero como esta es mi posición y yo la manifiesto abiertamente, entonces o me están dando la razón o me están tratando de loco. O entendieron que cada vez que yo entro lo único es desacreditarlo o que este tipo está loco y no me va a solucionar nada. Yo estoy convencido, como docente jamás he llamado al Director para que me resuelva una situación, porque el pibe no es tonto. No entiendo por qué se subestima a los pibes, son mucho más inteligentes y más vivos de lo que nosotros pensamos.

De modo similar, la Vice-Directora califica ese "vocabulario vulgar" que "el chico trae de la calle", tensando las redes de comunicación y el clima de convivencia que la institución se esfuerza por sostener en el tiempo. El profesor debe intentar tolerar- estas diferencias. Empero, no se advierte cómo estos desempeños pueden contribuir a mejorar tales competencias, para intervenir reflexivamente en situaciones comunicativas más formales o justificar las propias acciones evitando confusiones. Los binarismos con que se construyen estas imágenes son reveladoras:

Un alumno que jamás tuvo una situación de indisciplina, muy tranquilo, y viene desaforada la preceptora que a la profesora le dijo turra (...) Quiso salir del aula y la profesora no lo dejó salir como tienen pautado y (él) le dijo al que lo estaba esperando afuera: esa turra no me deja salir. Y la profesora lo escuchó. Y para ellos ese término es normal. La connotación que tiene para ellos no es la misma que para vos o para mí, para los adultos. Entonces yo había interpretado que en una discusión cara a cara la había llamado así. Pero el chico me 
dice: sí, yo reconozco que le dije turra. O sea, para él lo malo era que hubiera querido salir, y para la profesora, no que hubiera querido salir, sino que le hubiera dicho turra...

Con estos matices, la categoría de lo juvenil adquiere un carácter problemático, una noción inestable que debe ser comprendida en el marco de sus coyunturas históricas: "Ser joven siempre fue difícil. Siempre hubo cosas nuevas, los jóvenes las toman, los adultos nos horrorizamos, o no estamos tan de acuerdo..." (EEST N 1, Prácticas de Lenguaje). En ocasiones, estos conceptos animan una pedagogía dialógica, aprender de ellos y con ellos en situaciones donde el docente sostenga su saber especializado al tiempo que logre validar los saberes tecnológicos que manifiestan una mayoría de adolescentes. Algo que ambas partes perciben, dotando de significado el trabajo colaborativo y profundizando el vínculo pedagógico que los compromete.

El tercer eje en el que nos centramos, los lugares de participación o con sentido de pertenencia, implican algunos aspectos novedosos. En la EEST $N^{\circ} 1$, surge la necesidad imperiosa de discutir con los jóvenes los sentidos naturalizados que los determinan en su condición de dominados. En la descripción de esta realidad se presentan los contrarios: entre el ser y el debe ser, entre un presente desventajoso y la proyección de un futuro mejor, entre el consumo superficial y los marcos vivenciales con valor formativo. La selección léxica, los modalizadores, las referencias irónicas, expresan las tensiones entre imaginarios negativos y el potencial de intervención didáctica para movilizar esos cambios, en el discurso de este profesor:

Igual me resisto ¿eh? Pero ¿sabés lo que quieren ellos? Tener el mejor celular, el mejor, unas buenas llantas, unas buenas zapatillas, y una moto, esas de $110 \mathrm{cc}$. Esa es su aspiración, su visión es esa. Y yo le digo, pero no, eso no, es un escaloncito, no termina ahí, no, te dicen, a los 20 ya sos viejo. Y yo les hablo: no, ahí empezás a vivir, para tu vida, para tu alma, para tu corazón, para lo que quieras. ¡Y lucho contra eso! (Matemáticas).

Se trata de "un proceso y lleva tiempo" en una escuela "mal vista, mal barajada", pero en esas transiciones positivas los jóvenes son directos protagonistas, colaborando en la reconstrucción del proyecto identitario. La formación en valores es una propuesta tangible, ya no de mero disciplinamiento, en tanto interpela a sujetos que se perciben activos, emprendedores y desafiantes. Los términos se aglutinan en una misma cadena léxica: “...tratar el tema de los CE, volver a las Olimpíadas, cuidar la escuela. Ahora estamos con la idea de rasquetear todo, a pintar, a inculcar esa responsabilidad, esa identidad o ese sentido de pertenencia. Chicos: la escuela es de ustedes."

Desde la gestión, recuperar el CE es relegado a un segundo plano. El Director admite su importancia, a condición de que logre establecer un ámbito de participación democrática y no “chupamedias", un llamado a la verdadera autonomía. La contradicción con los docentes resulta notable: el mejoramiento visible de estas realidades no clausura para ellos el proyecto del CE, un derecho ganado aun si "no forma parte de la cultura de la escuela" (EEST $N^{\circ}$ 1, Sistemas 
Productivos). En contraste, registra formas de organización estudiantil alternativas al paradigma de Industrial: "Salvo la EEST N², que tiene esta cuestión tan tradicional, de pasar de generación en generación. Creo que en el caso nuestro estamos en una etapa de transición."

Ser "grasa" para los docentes de Industrial resulta de un peso mayúsculo, con continuidad en el tiempo. Describen orgullosamente experiencias en las que sus estudiantes abrazan simbólicamente a la institución, se dedican a mantener el edificio y perpetuar su legado, convocan encuentros con otros centros de estudiantes, aportando a la imagen activa, solidaria y colaborativa en apoyo a otras escuelas. La capacidad de agencia es un componente vital de la ciudadanía cultural, disruptivo de la educación normalizadora, donde las identidades en marcos de socialización componen un mundo de tensiones, intersecciones y amalgamas con otros:

No es un chico que se lo ha llevado de la mano, se le ha dado alternativas, para que tome decisiones, no es que se lo ha dejado solo, pero cuando llega a 5to. es un chico que ha desarrollado una autonomía, una independencia... Además, el chico se apropia de lo institucional, esa es la única forma de formar ciudadanos. Y se apropia de la institución no porque es de él sino porque es de todos... (profesora Política y Ciudadanía).

El lugar todavía marginal que ocupan las TIC responde al hecho de que, en opinión del profesorado, las relaciones son primordialmente interpersonales en una jornada extendida, si bien, como veremos, los estudiantes encuentran otros modos de interactuar con sus pares, ajenos a los mandatos institucionales y a las intervenciones de los adultos. Los vínculos entre participación y tecnologías son destacados por otros actores, externos a la escuela. Facilitar la comunicación, abrirse a la comunidad, solidarse con sus intereses, son alicientes para intentar incorporar esas experiencias. La pertenencia se articula a una escuela "intramuros", en coordenadas espacio-temporales que la digitalización en curso desplaza permanentemente.

Pero no hay una apertura a la comunidad, no sale del ámbito de la institución. Por otra parte, al alumno le haría muy bien, ayudar a otro es una satisfacción personal, hacer algo por el prójimo, por qué no abrir la institución a las redes sociales para la organización de otras cuestiones. No olvidemos que la tecnología tiene esta cuestión atemporal, que te podés conectar en cualquier momento y lugar... (coordinadora Postítulo TIC y Educación).

De reciente implementación, el Concejo Deliberante Estudiantil y el Parlamento Federal Estudiantil son dispositivos valiosos de interpelación al Estado. ${ }^{53}$ Estudiantes secundarios de 15 a 18 años son convocados a intervenir en la vida pública mediante presentación de proyectos donde visibilizan y debaten los problemas de la comunidad. Cierto es que ambos espacios reciben escasas

${ }^{53}$ El Concejo Estudiantil está integrado por concejales jóvenes quienes representan a su escuela en el Concejo Deliberante, donde debaten sus proyectos en las reuniones de comisión y en las sesiones. El Parlamento Federal, impulsado por el Ministerio de Educación desde 2014, los invita a llevar adelante una serie de encuentros en las escuelas; luego los proyectos seleccionados son tratados con jóvenes de todo el país en el Congreso de la Nación. 
menciones. En parte, a causa de la centralidad simbólica de la escuela, movilizadora de identidades que no son enunciadas como políticas. Pero estas prácticas no están escindidas de la vida social, se expresan de diversas maneras y no necesariamente a través de las organizaciones formales o espacios institucionalizados (Núñez y Litichever, 2015; Más Rocha, 2016).

La insistencia en el peso de las tradiciones obliga a la pregunta si un proyecto colectivo, sustentado en la práctica deliberativa y el acuerdo racional entre las partes, contribuye a la negación de los contradicciones políticas que dificultan la promoción de esos consensos, como ha advertido Martín Barbero (2015). ${ }^{54}$ En esta línea están los riesgos de perpetuar construcciones de la subjetividad juvenil vaciadas de potencial político. Ciudadanos "en transición” y separados de otros ámbitos (la familia, la calle, el mercado, etc.) aparecen determinados en la función de realizar el proyecto institucional, como sujetos uniformes en el polo subordinado de esa relación. "De este modo, el comportamiento identitario que se asocia a una "cultura juvenil" responde más bien al arraigo institucional de las prácticas, a su decantación y repetición" (Coicaud y Falón: 2015: 47).

Sin embargo, desde una perspectiva culturalista esas tradiciones forman parte del proceso general que crea convenciones e instituciones, a través de las cuales aquellos significados valorados por la comunidad educativa son vueltos activos en procesos de negociación. Formar en capacidades ciudadanas implica comprender en sus potencialidades sujetos actuantes en la configuración del mundo de la vida en el que intervienen, mediante decisiones razonadas y con niveles cada vez mayores de criticidad y autonomía. De ahí nuestro interés en recuperar las voces de los jóvenes, examinando cómo ellos incorporan, reconstruyéndolos, los sentidos objetivados de la escolarización, en una particular dialéctica instituido/instituyente que a la vez la trasciende.

\section{Actuaciones juveniles: contribuciones a una ciudadanía cultural}

Retomando dimensiones anteriores, las experiencias que interpelan y resignifican las identidades juveniles se asientan en diferentes prácticas, desde las tecnológicas hasta las implicadas en el deporte, la música, las series de televisión, la pertenencia escolar y los grupos de amigos. Los jóvenes hacen de los videojuegos y las redes sociales una utilización cada vez más acelerada y fluida, en esa virtualidad organizan procesos de reconversión de la popularidad, de la

\footnotetext{
${ }^{54}$ En sus revisiones de las concepciones de Habermas (y, en este punto, en coincidencia con las críticas de la democracia radical), Martín Barbero cuestiona una racionalidad comunicativa ajena a los conflictos de la hegemonía, cuando la relación información/comunicación es el motor más importante de dominio cultural. Empero, es precisamente en y desde la comunicación donde intervienen los ciudadanos en formación, desde sus adscripciones identitarias, en sus potencialidades críticas y transformadoras de los poderes dominantes.
} 
escenificación del yo y del sentido de comunidad. Las mismas prácticas pueden ser calificadas negativamente, como causales de modos renovados de indisciplinamiento o distracción escolar.

Estas transiciones no responden a binarismos de base, sean en términos de la experiencia inmediata de nativos e inmigrantes digitales o su versión renovada, residentes y visitantes, cuyo riesgo, además, es cierto estrechamiento de la dimensión histórica. Sin subestimar sus vínculos lúdicos, estéticos y expresivos con las TIC, los jóvenes están atentos a un panorama de mutaciones en registros simbólicos más complejos que la sola apropiación de la netbook: "Creo que de a poco se va a ir incorporando la tecnología. No tanto en eso (en educación), sino en otras cosas, los televisores, el transporte, los medios de comunicación. No creo que sea positivo en todos los sentidos" (EEST N 2, 5to. Año, Electromecánica). Aun en procesos de crisis, es la escuela la que puede encarar las discusiones acerca de los imperativos del capital, en vistas a articular escenarios estratégicos en la reconversión del sentido alternativo, no instrumental, de la comunicación.

Bajo esta premisa es concebida la educación: como derecho básico o como garante en el cumplimiento de otros derechos. El contraste con la tecnología es notable: el hecho de que esta mejore la calidad de vida no está en absoluto comprobado, una idea disruptiva del difusionismo hegemónico y extendida en el tiempo. Así, los estudiantes se animan a imaginar formas de adecuación del modelo 1 a 1 que respondan a las realidades singulares de sus escuelas. La respuesta del CE de la EEST N 2 es la acción directa, como lo describe su presidente: "Hicimos un proyecto de darle un cuaderno a un chico por curso, un delegado que represente a todos, para los chicos que este año les dan la computadora, para ver de qué sirve, cómo usarla, que tenga cuidado..." La cuestión del cuidado excede el acceso material: un equipo puede ser maltratado por el alumno si desconoce para qué sirve además de satisfacer sus ganas de entretenerse, lo que requiere tanto orientaciones claras de utilización como un marco mínimo de responsabilidad personal.

La relevancia del tema en la agenda del CE connota un campo de tensiones: el esfuerzo de despolitizar las acciones junto con el compromiso en encarar estos cambios. ¿Cómo se realizan es en esta etapa las relaciones identidad/ciudadanía? La participación estudiantil en la EEST $\mathrm{N}^{\circ} 2$ no es privativa del CE, en la creación de espacios de debate de ideas, emparentados antes con estrategias de adhesión simbólico-afectivo que con argumentaciones estrictamente racionales. Si retomamos a esta estudiante: "Para mí la ciudadanía tiene más que ver con participar de la escuela, sí, con la identidad. Porque los que estamos acá estamos porque amamos la escuela" (6to. Año, Informática). Por el contrario, "no, no, esto no es político, esto tiene que ver con la escuela”. La identidad se articula consistentemente entre las vivencias de un presente, la añoranza por un pasado virtuoso y aquello que permite proyectarse, "alzar a la escuela y que vuelva a hacer como antes..." 
Estas definiciones están sujetas a profundos atravesamientos que hacen a la problemática constitución de lo juvenil. Un caso remite a los embarazos adolescentes, en especial en situaciones de vulnerabilidad social como las que presenta la EEST $\mathrm{N}^{\circ} 1$. Una sala de Informática que ha sido reacondicionada como guardería, donde la profesora está dictando clases a un grupo de cinco chicas de 16 y 17 años. Una de ellas está embarazada, otra amamanta a su bebé y un niño de corta edad camina en su andador, en el suelo han dispuesto una manta y juguetes. En un ambiente cálido y afectuoso, una entrevistada comenta que, para continuar sus estudios, cuenta también con el apoyo de su familia. Además de percibirse como marco de contención, la escuela ratifica así el objetivo de concretar la terminalidad del nivel secundario en tanto derecho social.

En consideración de los avances del PCI, una creciente diversificación de las interacciones con TIC es el contexto desde el cual las culturas juveniles pueden complejizar sus aprendizajes, valorar sus alcances, discriminar su utilidad dentro y fuera de las aulas: "(La netbook) ahora me cansó un poco. Colegio y miro tele... cuando puedo y tengo tiempo, series en la compu..." (EEST $\mathrm{N}^{\circ} 1$, 3er. Año). Puede objetivar los riesgos del acoso o cyberbullying, algo que evita al adolescente ser encuadrado como residente digital: si despliega estéticas y sensibilidades en Internet, también reclama intervenciones más activas de la escuela en el tratamiento de sus impactos negativos. Tampoco la mirada es de visitante cuando tal objetivación surge de las participaciones en las comunidades de la red: "Pero en Facebook hay muchos riesgos. Y en la escuela no se habla nada sobre las redes... Esa chica que se suicidió porque estaba tan enamorada y el chico la había dejado, una boludez pero, bueno, pasa" (EEST N 1, 5to. Año, Electrónica).

En el contexto de la EEST $\mathrm{N}^{\circ} 2$, un alto grado de integración otorga continuidad a estos ordenamientos. No solo un legado, sino una construcción de la que los estudiantes se definen como artífices. Así lo expresa un mural que dibujaron en el fondo de un salón: el personaje del Increíble Hulk vistiendo la camiseta distintiva y rompiendo un paredón de ladrillos, "la fuerza de Industrial”, según el secretario del CE (6to. Año, Electromecánica). Para confirmarlo, narra orgullosamente cómo su compañero, proveniente de otra escuela, rindió materias por equivalencia para lograr el ingreso. EI significante de la "fortaleza" es un supuesto incuestionable: "siempre fue muy fuerte en Industrial el CE. Yo insistía con las Olimpíadas, porque se perdieron, siempre fue la demanda. Siempre está pendiente. ¡Mis viejos vinieron a la escuela y me cuentan lo que eran!” (7mo. Año, Electromecánica).

En su posicionamiento privilegiado, Industrial afirma su historicidad, actualiza sus componentes residuales, expresa sus continuidades intergeneracionales. Los discursos abundan en estas caracterizaciones: "Tiene mucho que ver con la ciudad, refleja la identidad de la ciudad, fue 
una de las primeras escuelas de Olavarría, por eso se llama Luciano Fortabat. Y te ponés a pensar: tus papás fueron a esta escuela..." (4to. Año, Informática). Estas imágenes se traducen en las formas de "trabajar para la escuela", desde pintar o limpiar los frentes, hasta representar los derechos estudiantiles e interceder en los conflictos. Con frecuencia, confirman un orden moral en vistas a las identificaciones con los pares y las diferenciaciones con los "otros", expresión emblemática de la antinomia nosotros/ellos. Esta crónica es por demás ilustrativa:

En el tiempo que estábamos nosotros, era el problema de la violencia, de las drogas y armas, ahora se calmó. Era un loquito que traía un arma a la escuela y se sacaba fotos con los compañeros (...) Si mirabas el historial del chico tenía problemas de violencia. Llamaban a los padres y eran peores que el chico, llamaban al padre y estaba más preocupado por dónde estaba el arma. Nosotros hablábamos con los chicos y les decíamos que hablaran, porque tenían miedo. ¡Este año hubo uno que hacía graffitis en toda la escuela! No querían decir. Y hablábamos con los compañeros porque no querían hablar ninguno, por miedo o por querer cubrirlo. Y les dijimos que lo escribieran en papel y lo pasaran por debajo de la puerta, sin nombre, nada. Y así fue (...) después o se fueron por voluntad o por insistencia. Se fueron muchos pibes que estaban molestando mucho... (expresidente del CE).

\section{Las tecnologías interactivas son integradas activamente mientras respondan a estas}

dinámicas escolares. Importantes mediadoras simbólicas de los aprendizajes áulicos, ahora también configuran ámbitos de intervención institucional. En ocasiones, esos usos desplazan los mandatos de los directivos y docentes. Configuran intersticios todavía moderados pero significativos para construir ciudadanía, alternativos a los modelos dominantes de comunicación estudiantil, moviendo las fronteras de la escuela "intramuros" y el conjunto de sus principios orientadores. Y esas prácticas pueden ejercerse en y desde las organizaciones formales.

Destaquemos dos tipos de actividades. En primer lugar, la utilización de las redes sociales como canales de difusión, para convocar reuniones y facilitar los intercambios. Operan como campo de luchas en tanto escapan al control de las autoridades, tornando visibles las críticas de las que estas resultan merecedoras. La conformación en 2012 de la Federación de Estudiantes Secundarios de Olavarría (FESO) es considerado resultado de una larga lucha. ${ }^{55}$ De acuerdo al presidente del CE, también presidente de la FESO, la iniciativa apunta a "ayudar a las escuelas que no tenían $\mathrm{CE}$ a tenerlos, porque es una ley, es un derecho, y que los directores no tengan ganas, molesta..." En el mismo sentido pueden ser activos protagonistas de movilizaciones sociales bajo consignas más globales (por ejemplo, en las marchas "Ni Una Menos") o adquirir presencia

${ }^{55}$ Constituye este un caso valioso de institucionalización de la participación juvenil. Tras varios años de discontinuidades, los CE quedan nucleados en la FESO para discutir problemáticas del colectivo estudiantil. El objetivo principal es el resurgimiento de las tradicionales Olimpíadas Estudiantiles, interrumpidas en 2008 como consecuencia de graves disturbios y todavía ancladas en el "palimpsesto" de la educación secundaria de la ciudad. 
mediática durante los festejos del Día del Estudiante (cada 21 de setiembre los estudiantes del último año de las escuelas secundarias presentan sus distintivos, una larga tradición en la ciudad).

El segundo lugar de mediación tecnológica es una publicación en formato digital. Además de la página de Facebook de representación institucional que gestiona un grupo de alumnos, se destaca la revista, Zona Grasa. Impresa en papel, aparece publicada en cartelera, al lado de la Dirección en el lugar donde antiguamente se ubicaba el cuadro de honor, simbolizando los profundos dis-locamientos de estas tradiciones. Al mismo tiempo, supone reafirmar los vínculos y, con ello, conciliar una diversidad de intereses y a aunarlos en un mismo fondo de comprensión:

Como todos tenemos celular, nos convocamos así por WhatsApp, después de las reuniones se dice cuándo va a ser la próxima y después seguimos en contacto por WhatsApp. También Facebook, tenemos una página de la Federación. La tecnología ayuda, también con otras escuelas nos comunicamos por Facebook. La página es para comunicar las cosas... (Secretario del CE).

Siendo estas prácticas consideradas apolíticas, al único caso nombrado como político lo registramos en la segunda escuela, bajo la influencia de los pares y fuera del ámbito escolar. Hay una identificación afectiva con organizaciones formales, consistente con el interés en ejercer el voto, una posición igualmente excepcional: “Sí, milito. Mi primo, que es re fanático, va a la Cámpora y me invitó. Bah, voy casi siempre, hablamos del próximo discurso de Cristina. Porque me entretiene. Me dio curiosidad y fui, y nos quedamos jodiendo..." (EEST No 1, 3er. Año).

Son distintivas de la EEST $\mathrm{N}^{\circ} 1$ formas de politicidad cotidiana que pueden entenderse como microrrupturas desde las cuales los jóvenes, sin implicar grandes movimientos, involucran y ponen en cuestión las injusticias y las desigualdades que atraviesan sus vidas (Langer, 2017). Primero, reivindican la búsqueda de soluciones a problemas de la comunidad. Indicador de ello es la creciente disposición a integrar el Concejo Estudiantil, un interés que este grupo de estudiantes no no comparten con los demás (más centrados en la organización de la FESO). Estas prácticas confrontan un imaginario dominante de doble signo: las formas instituidas de participación, de las cuales el CE de Industrial es el paradigma; y los "mapas urbanos" que históricamente han determinado a la EEST $N^{\circ} 1$ en situación de exclusión en la ciudad. Por comparación, lo que esta escuela pondera en esta etapa no es la "fortaleza" sino el "orgullo" de pertenecer.

Si para las autoridades no forma parte de las preocupaciones, para estos jóvenes, como para sus docentes, el CE sintetiza las deudas pendientes, un escenario posible y necesario. De ahí también las nuevas inquietudes que son pilares decisivos en la construcción de ciudadanías culturales basadas en la diversidad: en la densidad simbólica de la comunicación, la deliberación de las ideas, el reconocimiento de los otros y la búsqueda con ellos de una identidad como creación colectiva: "Justamente estamos charlando con los más chicos, les decíamos que ellos tienen que 
estar contentos y orgullosos de lo que tienen, porque cuando nosotros arrancamos no teníamos herramientas, ropa (de grafa), botines...” (expresidente del CE, 7mo. Año, Electrotécnica).

Una segunda cuestión remite a las relaciones interpersonales, pero no se agota en ellas. Desarrollar capacidades de agenciamiento ciudadano se sostiene en relaciones de empatía, responsabilidad y dominio de sí, desde trayectos favorables a la pertenencia institucional. En estas matrices la escuela encuentra sus posibilidades de continuidad dialéctica. Este alumno de 5to. Año hace una defensa enfática del Director: dejarlos a cargo "de todo el equipo de música" es una valiosa muestra de confianza; "esa Feria de Ciencias que hacía como diez años que no se hacía, y nos dijo: necesito ayuda. Nos tiene confianza... si hay que arreglar algo de electrónica, ayudamos para mejorar la escuela". Sumarse a los encuentros de ciencias o comprometerse con el cuidado edilicio conectan simbólicamente con transiciones positivas que convocan otras miradas, menos condenatorias, desde el barrio y la ciudad, el sistema educativo y los medios de comunicación.

Siguiendo a Reguillo Cruz (2012), para estudiantes en contextos de pobreza urbana, la vida se presenta como una incertidumbre, y sus luchas, sus elecciones y sus conflictos se convierten en sus principales fuentes diarias. En el terreno cotidiano se resuelve la diferencia entre adentro y afuera, cuando la imagen pública se vuelve una cuestión estructurante, habilitando a los sujetos a romper conscientemente con situaciones de discriminación. Estos reordenamientos inciden positivamente en un proyecto de construcción de ciudadanía, donde los sujetos juveniles pueden expresar una activa oposición a las desigualdades a las que la sociedad parece destinarlos:

Está bien que la escuela se muestre. Pero que haya más proyectos, más cosas, porque nos dicen, ehhh... vas a esa escuela, y les digo: no, vení a la escuela y fíjate, no son todos así. Y yo digo: si estás discriminando a la escuela, me estas discriminando a mí, mirá cómo estoy (se mira la ropa), qué, ¿yo soy un negro?

Desde el punto de vista de las configuraciones juveniles, el campo de la ciudadanía/tecnología adquiere una pluralidad de significaciones. Aunque el principal referente continúa siendo el centro de estudiantes, las diversas expresiones de la participación estudiantil tienen como resultante no tanto una política "no instituida" sino una nueva institucionalidad, portadora de una densidad material y simbólica en procesos de reconstitución del espacio público. En estos territorios los jóvenes amalgaman distintos repertorios estéticos, lenguajes y gustos. A través de las tecnologías interactivas, crean redes sociales, lugares de encuentro y de discusión sobre temáticas que los involucran y que los conectan con la sociedad, negociando y, en ocasiones, subvirtiendo los modelos escolares. En suma, se valen de esas potencialidades para hacer visibles sus demandas, ampliar sus competencias y fortalecer su capacidad de actuación, con vistas a contribuir a realidades más justas y democráticas. 


\subsubsection{Principales observaciones}

En atención a los cruces implicados en la construcción de ciudadanía, sintetizamos algunos resultados del análisis de la relación Ciudadanía/TIC en sus cuatro Subdimensiones:

1- El desconcierto que produce el PCI va acompañado de valoraciones positivas hacia políticas similares en la Argentina y en la región. Pero los directivos parecen ser los únicos en manejar información básica sobre los propósitos del modelo. Coinciden en las contradicciones que involucra, entre la disposición a la innovación y los mandatos conservadores. Entre sus posicionamientos: favorables, difusionistas; favorables pero cautelosos; críticos acerca de la implementación; críticos que priorizan otras necesidades sociales. En la segunda etapa: favorables pero que problematizan el acceso equitativo; favorables pero cuestionadores de la implementación; críticos basados en imágenes negativas sobre el alumno; críticos centrados en nuevas intervenciones. Estas últimas habilitan condiciones adecuadas para la construcción de ciudadanía.

2- Los docentes generan actitudes predominantemente consistentes con el pensamiento tecnocrático, en continuidad con formas previas de utilización de TIC. La relación inclusión digital/social es más evasiva. En contextos de vulnerabilidad, la netbook simboliza la oportunidad de igualación social o, por el contrario, relega el cumplimiento de necesidades más urgentes. Ambas concepciones se perpetúan pero, hacia la segunda etapa, los cambios institucionales conducen a pensar la implementación bajo otras lógicas. Un "porlomenismo" persistente puede condensar una actitud moralizante, justificadora de las diferencias, pero también abrir márgenes para establecer otros vínculos con los alumnos, intervenciones didácticas de nuevo tipo.

3- Contradiciendo sus definiciones como indiferentes o adictos a la tecnología, los estudiantes logran discriminar los usos de las netbooks. Cierto es que pueden atribuirle al PCI una intención asistencialista que, en ocasiones, subestima sus alcances educativos y redunda en exclusiones de otros juveniles. Pero avanzado el tiempo, las experiencias con las que entran en contacto los vuelven conscientes de sus posibilidades, demandando actitudes críticas y responsables como otro ejercicio docente, no autoritario ni complaciente. Y en torno a la ciudadanía, una base de acuerdo la conecta tácitamente con el PCI a lo largo de todo el proceso de adecuación: la asociación ciudadanía/educación, la defensa de la ciudadanía (y de su construcción) y la negación de la política con condicionante de la escolarización.

4- Las relaciones información/conocimiento pueden encarnar lugares más tangibles que las premisas de la democracia formal, ligadas a la comunicación. Entre una mayoría de los docentes, ambos conceptos se confunden: la convergencia digital se visibiliza estrictamente en las aulas. Las netbooks se utilizan superficialmente o acusan la incapacidad de los alumnos. Pero estos discursos 
adolecen de la voluntad de enseñar esas competencias tecnológicas que se reclaman. De manera similar se representan las dificultades de lecto-escritura, sobre todo entre profesores técnicos.

5- Hacia la segunda etapa, se registran desplazamientos desde la adopción reproductiva de Internet hacia actuaciones docentes más sensibles y criteriosas en el desarrollo de tales competencias, cuando lo importante no es la información en sí sino su valor para producir conocimiento. La comunicación empieza a emerger en valor estratégico para formar ciudadanos.

6- Los estudiantes generan sus propias interpretaciones, entre ellas: Internet tiende a desplazar a los libros como lugares información; los libros son fuentes irreemplazables de información fiable; Internet es una fuente ilimitada de datos, ajenos a los fines escolares; Internet es equiparable a los libros, pero según las condiciones. Y en la segunda etapa: la utilidad de Internet frente a los libros depende de las asignaturas; esos usos derivan de los tipos de uso; Internet no solo como espacio de consumo, sino de producción; los contenidos producidos en Internet no son considerados con valor educativo; por último, como componente de los entornos tecno-educativos.

7- Las identidades juveniles involucran aspectos afectivos y crítico-reflexivos. Priman en la primera etapa miradas adultocéntricas: los chicos dominan fluidamente las netbooks, pero manifiestan conductas adictivas, negadas e irreconciliables con las escolares. Recrear la brecha generacional termina por minar el aprovechamiento de las TIC; otra expresión de la misma son las críticas a los lenguajes juveniles. En opinión de los docentes de la EEST $N^{\circ} 2$, ser "grasas" es un componente insoslayable de identificación juvenil, pero divorciado de los usos tecnológicos.

8- Si bien subsisten estas nociones, progresivamente, comprenden las interacciones de las adolescentes con TIC, los códigos que adoptan y otras formas de subjetivación. El CE configura aún el modelo de participación estudiantil de Industrial, mientras en la EEST N ${ }^{\circ} 1$ no abandonan ese proyecto, junto con una formación integral que desarrolle la responsabilidad, la autonomía, el compromiso con la comunidad, capacidades consistentes con una educación para la ciudadanía.

9- El PCI moviliza importantes dispositivos de construcción identitaria, aunque los jóvenes no pueden elucidar claramente esa relación. Las netbooks no les despierta creencias binarias (por ejemplo, en las que se auto-perciban como nativos digitales), sino interpretaciones complejas, en registros simbólicos que exceden la apropiación personal. El temprano interés del CE pone de manifiesto que los estudiantes tienen consciencia acabada de las tensiones de la implementación y quieren involucrarse activamente en esas decisiones, en la defensa de su cultura institucional.

10- Durante la segunda etapa, la complejización de las mediaciones tecnológicas atraviesan las participaciones escolares, dinamizando modos distintivos de identificación. Los jóvenes resemantizan la "fortaleza" o el "orgullo", poniendo en acción esas identidades en usos normalizados y también alternativos de las TIC: páginas web y publicaciones digitales, redes sociales que los 
conectan entre sí y con otros, en convocatorias propias y desde el Estado, organizadas por las asignaturas y en proyectos orientados al espacio público/comunitario. Allí vuelven inteligibles cruces y desplazamientos entre la afirmación de la diversidad y la igualdad como derecho, entre una escuela "a-política” y sus improntas específicas ligadas a ciudadanías en construcción.

\subsection{A modo de cierre}

La problemática de la construcción de ciudadanía adquiere plena relevancia teórica en los estudios de comunicación. Permite avanzar en las discusiones acerca de las configuraciones juveniles y sus modos de participación en el campo de la cultura, donde se disputan los significados, alcances y estatuto político de esas actuaciones en el marco de estas coyunturas históricas. Acompañamos a S. Hall cuando argumenta que "las formas culturales mismas son importantes. Crean la posibilidad de nuevas subjetividades, pero no garantizan por sí mismas su contenido progresista o reaccionario. Para articularlas aún hace falta apelar a prácticas sociales y políticas” (2017: 252).

Enmarcados en las adecuaciones del Programa Conectar Igualdad, los sujetos avanzan de manera moderada pero sostenida hacia trayectos de migración digital, como concluimos en los primeros Capítulos. Podemos ahora confirmar que establecen muy diversas aproximaciones a la formación ciudadana, visibilizando la heterogeneidad de sus prácticas, los sentidos que construyen alrededor de la tarea de enseñar y de aprender, y las relaciones o tensiones percibidas con el modelo 1 a 1. El problema de la ciudadanía no surge inicialmente en los discursos, cuando las preocupaciones están centradas de manera casi exclusiva en los esfuerzos de incorporación de las netbooks. Es preciso enfatizar que en la educación secundaria técnica prima como matriz ideológica instituida la formación laboral, por encima de otros propósitos educativos.

En torno a la problemática ciudadanía/política/democracia, la ciudadanía es escasamente referida, algo que no se condice con la importancia asignada en la práctica. Mientras que en los discursos adquiere sentidos ambiguos, las condiciones que hacen a su construcción y puesta en acción estructuran las experiencias hacia los aprendizajes genuinos, socialmente significativos y de valor estratégico en los complejos escenarios de digitalización. En estos registros simbólicos se distinguen dos campos semánticos, íntimamente vinculados. Lo que los diferencia es el grado de definición más o menos explícita que presentan y el énfasis que reciben en cada etapa analizada.

En primer lugar, los sujetos remiten a la noción clásica asociada al conjunto de derechos y obligaciones. En vinculación estricta con la escolarización, aparece en combinatoria con la formación de valores. Más allá de los beneficios del acceso, la inclusión digital no se presenta como parte de esos derechos o como condición para proveer mejores competencias para su 
desarrollo, una cuestión consistente con el carácter fundamentalmente instrumental de los usos de las TIC. Estas relaciones seguirán siendo evasivas en la segunda etapa. En cambio, registran una presencia cada vez mayor los supuestos ligados a la participación. Constituye este un espacio multifacético, orientado a las negociaciones de sentidos, la argumentación de ideas y la discusión acerca de intereses que comprometen a un colectivo de personas. Bajo esta premisa de autonomización, el estudiante es alentado a convertir progresivamente la simple obediencia en capacidad de autogestión, esto es, de sujeto de derecho a sujeto movilizador de estos cambios.

En segundo lugar, otros referentes adquieren relaciones tácitas con la ciudadanía, y en orden a los contrastes entre modalidades esperadas y percibidas de apropiación digital: definidos como valores, expresan capacidades de agencia. La responsabilidad ya configuraba un importante organizador, en torno al cuidado del equipo como también a la reflexividad personal, confrontando con los efectos de la "distracción" o la "dependencia digital". Se entiende que tales usos requieren un mínimo de racionalización, junto con regulaciones mediadas por el docente y la institución. La responsabilidad y la racionalidad reciben un consenso sostenido y con continuidad en el tiempo. Más adelante, se intensifican las referencias a una autonomía materializada en una pluralidad de experiencias, sostenidas en la confianza auto-instituyente, el dominio de sí y la consciencia sobre las determinaciones que operan en la práctica.

Las tres capacidades de agenciamiento se instituyen en ámbitos de participación estudiantil, articulando una ciudadanía concebida como proceso en construcción antes que un estado preestablecido. La escuela representa el mundo de la vida donde esos propósitos se realizan, aportando visibilidad a los principios abstractos de la democracia. Este término recibe menciones tempranas desde las autoridades directivas: los esfuerzos de democratización al interior de las instituciones orientados a concretar los consensos necesarios en la adopción de normas. Las adecuaciones del modelo 1 a 1 constituyen un importante desafío en este aspecto. Por su parte, los estudiantes abogan por resolver las falsas antinomias entre el autoritarismo y la laxitud de los límites bajo un nivel esperable de ordenamiento, en marcos de constante negociación. Estas expectativas nutren valoraciones subyacentes de una forma deliberativa de la democracia.

El par semántico deliberación/participación recibe honda consideración en los discursos juveniles a lo largo de todo el análisis, por una parte, en el marco de las actuaciones del centro de estudiantes como realidad efectiva o posibilidad imaginada; por otra, en torno a las configuraciones de sus identidades afirmadas en la pertenencia institucional. Estos entrecruzamientos permiten ratificar que la formación hacia una democracia deliberativa en absoluto excluye la dimensión conflictiva de los contextos socioculturales: en la búsqueda de 
consensos se sostiene y complejiza la dialéctica entre el reconocimiento de intereses compartidos y la creciente heterogeneidad al interior de cada escuela y con respecto a otras.

La cuestión de la diversidad como plataforma de una ciudadanía cultural estructura las vinculaciones entre participación y globalización, en respuesta a la pregunta: ¿cuáles son las posibilidades de este proyecto colectivo frente a los avances de un mundo globalizado, cada vez más individualista y supeditado a los mecanismos del mercado? Al principio, tales relaciones exponen ideas difusionistas entre docentes que recrean cierto tecno-utopismo dominante, donde las innovaciones del sistema productivo conducen a una formación pragmática, orientada a los saberes actualizados y flexibles para el mundo del trabajo. La participación del sujeto está regida por los imperativos de la adaptación. En concepciones alternativas, extendidas en la segunda etapa, la hegemonía cultural empieza a ser discutida con los estudiantes, en relación con sus consumos.

A pesar de que la globalización amenaza con retraer definitivamente las identidades tradicionales, la nación se reconoce con fuerza. La escuela puede abrir los canales para trabajar sus sentidos, educar en sus potencialidades, como modos de desafiar la tendencia a homogeneizar los ideales y las prácticas, y al mismo tiempo comprender sus limitaciones como unidad cultural integradora de las diferencias. Por una parte, las identidades nacionales se conectan con las identidades escolares; por otra, ambas entran en tensión con las identidades juveniles, donde las mediaciones tecnológicas juegan un papel cada vez más constitutivo. Estas empiezan a ser incorporadas como temas de debate con potencialidad ciudadana, lo que da lugar, en términos habermasianos, a ampliar una racionalidad cognitivo-instrumental hacia racionalidades críticas y comunicativas más elaboradas. Así, los jóvenes se inscriben conscientemente en disputas de sentido donde ponen en juego la estetización de sus prácticas, los diversos modos de expresión identitaria, en suma, las experiencias incipientes de re-localización de lo global.

La relación ciudadanía/política es por demás compleja, toda vez que los actores nombran al PCI como una política pública escindida de sus orientaciones sociales y educativas. Vale recordar que los interrogantes que los nuclean es una implementación que se avizora como compleja, y frente al panorama generalizado de desconocimiento, reclaman ámbitos formales para debatir sus alcances en un marco de libertad. El Programa es el emergente de la presencia del Estado en la escuela; lo que se cuestiona no es una política pública en sí, sino las dificultades de adecuación, generando posicionamientos más o menos reflexivos acerca de cuestiones que debieron preverse. Estos discursos encuentran sustento en sistemas de creencias y sólidos marcos teóricos según los cuales el acceso digital no constituye una prioridad frente a necesidades sociales más urgentes.

Es notable que tanto las posiciones apologistas como otras dudosas o directamente reticentes, responden a un mismo marco ideológico, fuertemente arraigado: "la política...afuera". Esta 
imagen se funda en tres nociones articuladas: a- la política restringida a su carácter electoral o propagandístico; b- la escuela definida en sus límites adentro/afuera; c- la enseñanza escéptica, ajena a sus determinaciones ideológicas. En todo caso, la política aparece caracterizada negativamente y siempre en contraste con la educación. La ciudadanía adquiere valores positivos, que la vuelven imaginariamente equivalente a la educación, en tanto aparece por completo desfasada de la política. Otro referente de la problemática inscripción de la política es la Ley de Voto Joven: las posiciones favorables son excepcionales mientras que, contradictoriamente, lo que los jóvenes cuestionan es la falta de una sólida formación política que les permita comprometerse en las elecciones de gobierno mediante decisiones responsables y criteriosas.

Ese esfuerzo de despolitización, en buena medida alimentado por el imaginario instrumental, se ve desplazado con el tiempo: emergen actuaciones que adquieren densidad potencialmente política. Las tecnologías empiezan a incorporarse a modos de recomposición de los canales instituidos -con especial énfasis en el centro de estudiantes-, pero también en sus márgenes. Lo notable es que son los jóvenes desde sus propias experiencias interactivas, quienes llevan adelante formas alternativas de usar a las TIC, en ámbitos de construcción de ciudadanía que desbordan las fronteras espacio-temporales de sus escuelas. Revelan procesos de configuración y reconfiguración de sus subjetividades, que los colocan en lugares formativos de muy diverso tipo.

En las vinculaciones ciudadanía/educación, identificamos componentes cognitivos, en los que suelen centrarse las primeras referencias, acerca de: a- los contenidos de las asignaturas específicas; y b- como proyecto o problemática transversal. La ciudadanía configura un campo de tensiones, ya que se considera un área curricular de enorme relevancia, pero al mismo tiempo subestimada, como consecuencia de la ambigüedad de los contenidos o la falta de especialización de los docentes a cargo; ambos puntos son ampliamente destacados entre los estudiantes. Se acentúa la atención en los lugares de participación institucional, pero también las aulas registran formas de educar(se) en la ciudadanía transgrediendo los límites entre asignaturas, supeditadas antes a las iniciativas del profesor que a regulaciones formales y normativizadas.

Hacia la segunda etapa, los componentes primordiales son de tipo ético-normativo y críticoparticipativo, donde se inscriben las identidades institucionales, en continuidad en la EEST $\mathrm{N}^{\circ}$ 2 y en reconstrucción en el caso de la EEST $\mathrm{N}^{\circ} 1$. Las representaciones encarnan numerosos aspectos, entre ellos, el nuevo rol docente, confrontando el papel ético-político de la profesión y el esfuerzo por despolitizar su ejercicio. Sesgos ideológicos, solo aparentemente opuestos, se replican en el optimismo tecnocrático hasta en el rechazo a la inclusión entendida como derecho, enmascarado de una tecnofobia persistente. El efecto paradojal es reprimir un proyecto genuino de innovación. Los jóvenes pueden rebatir estos entramados dominantes. Generan oportunidades 
para aprender capacidades de agenciamiento bajo la atenta orientación de otros docentes o de maneras relativamente espontáneas, pero mediadas por esa socialización constitutiva.

Conforme a la relación ciudadanía/TIC, las condiciones de progresiva normalización del PCI propician otras formas de educar para la ciudadanía, excediendo largamente los alcances de una ciudadanía digital. De la centralidad de Internet -y como efecto, la equivalencia entre información y conocimiento- se avanza hacia la comprensión de que la enorme disponibilidad de datos no es condición suficiente para garantizar el conocimiento, tensionando las oportunidades falsamente democráticas de la globalización. Valoraciones de este tipo presuponen a la comunicación en su valor estratégico: en tanto competencias en desarrollo, ámbito de utilización de fuentes múltiples que puedan ser dominadas bajo objetivos propios, y también redes de intercambio que promuevan participaciones más activas. Las distintas posiciones juveniles permiten relativizar los intereses "naturales" que supuestamente los adolescentes detentan, pero además contrarían oposiciones taxativas entre nuevos/viejos soportes, para integrarlos en lugares híbridos de comunicación.

Los relatos ratifican los desfasajes extendidos entre ciudadanía y política. Sin embargo, no eximen a los jóvenes de reclamar ser escuchados y reconocidos en sus derechos. Resisten así a su situación de subalternidad, escapando de las generalizaciones románticas, que ven en todo acto juvenil una práctica política, como de aquellas moralizantes según una condición de apatía atribuida a priori. Sus lugares de intervención están en la cultura, en base a anclajes identitarios desde los cuales se definen matrices de identificación y diferenciación. Quienes pertenecen a la EEST $\mathrm{N}^{\circ} 2$ convocan las tradiciones resultantes de un proceso selectivo con fuerza hegemónica, que los conecta con el sentimiento "grasa" y con el centro de estudiantes en su lugar simbólico preponderante. Las nuevas determinaciones de la EEST $\mathrm{N}^{\circ} 1$ animan a sus estudiantes a hacer la defensa de su escuela, desafiar el modelo emblemático de Industrial y sus lógicas de participación $\mathrm{y}$, sobre todo, luchar contra las imágenes negativizantes que los han estigmatizado durante años.

En conjunto, los sujetos juveniles afirman esa identidad colectiva o colaboran en su búsqueda, en base a relaciones interpersonales, fluidas y tecnológicamente mediadas. Y en la medida en que estas tramas interaccionales se expanden socialmente, conforman espacios deliberativos en organizaciones formales e informales promovidas por sus pares, la escuela y el Estado. Se reconocen sujetos sociales y "hacen" política desde la vida cotidiana, lo que Vommaro (2013) ha llamado una "territorialización de la política". En base a sus capacidades ciudadanas en formación, pueden comprometerse con otros, convocar a los medios de comunicación y utilizar las redes sociales bajo distintas consignas, intervenir en movimientos de lucha por el reconocimiento social y el cumplimiento de derechos, las demandas del barrio o la comunidad. 
Concluyendo, estos recorridos reabren una pregunta medular para la educación: hasta qué punto está habilitando experiencias novedosas de politización, sin cerrar prematuramente la ciudadanía en un sentido formal, para involucrar otras propuestas colectivas y de reconstitución del espacio público. El PCI irrumpe en experiencias culturales que empiezan a acompañar, tensionar o profundizar estas condiciones, conformes a los desplazamientos desde las acepciones de una ciudadanía centrada en derechos y obligaciones, hacia la participación como componente vital de esa formación. Así, cobra creciente centralidad un sujeto actuante de lo público cuyas competencias deben ser desarrolladas, y es la escuela el ámbito privilegiado, si bien no el único, para emprender ese proyecto. Si los jóvenes reconocen prácticas que resignifican, o bien subvierten a las organizaciones estudiantiles, las TIC devienen mediadoras de estas nuevas actuaciones, implicando otras formas de institucionalidad y con plena potencialidad política. 


\section{CAPÍTULO 7: CONCLUSIONES}

La técnica -que fue durante siglos considerada como mero instrumento o utensilio, es decir, algo desprovisto de la menor densidad cognitiva-, ve ahora transformado su estatus radicalmente, pasando a constituirse en dimensión estructural de las sociedades contemporáneas a la vez que se llena de densidad simbólica y cultural. Y mientras eso sucede, la política está viviendo un proceso inverso: el que fue uno de los ámbitos más llenos de densidad simbólica, pues configuraba el modo de construir ciudadanía y de tejer el lazo social, se ha transformado en los últimos treinta años en un saber-hacer predominantemente técnico, es decir, en un saber instrumental del que desaparece la densidad ideológica y simbólica, es decir su capacidad de convocar, y de hacer sentirse junta a la gente. Jesús Martín Barbero (2009).

Esta tesis responde al título Formar ciudadanos en la era de Internet. Comprende las formas de construcción de ciudadanía en escenarios de digitalización, donde, al decir de Bauman, la desintegración de la trama social y de las agencias de acción colectiva es el efecto colateral de un poder global cada vez más fluido y escurridizo. Pero para que ese poder fluya, debe estar libre de fronteras, perfectamente desarraigado. El problema adquiere rasgos paradojales cuando es el Estado nacional quien direcciona procesos de incorporación de tecnologías y los sujetos se vuelven capaces de intervenir activamente en ellos, en sus experiencias situadas en la escuela, la institución moderna por excelencia. Las TIC irrumpen de manera discontinua, operando complejos desplazamientos y recreando los sentidos de la modernización tardía que Martín Barbero describía en su libro seminal de 1987. Las mediaciones culturales constituyen entonces el vasto campo problemático que dota de sustento a la investigación empírica, junto con su necesaria revisión y discusión a la luz de las actuales coyunturas latinoamericanas.

En torno a la relación tecnología/educación los estudios en comunicación tienen mucho que decir. Especial interés ha suscitado la implementación del Plan Conectar Igualdad, la política de inclusión digital de mayor trascendencia en nuestro país. Pero siendo una de las potencialidades fundamentales del modelo, en estos abordajes la construcción de ciudadanía ha sido prácticamente marginada. Sin pretender haber agotado el tema, en este largo recorrido apuntamos a dar avances significativos en este sentido, permitiendo generar nuevos interrogantes y formulaciones teóricas. Recuperando el objetivo general, profundizamos en las prácticas y representaciones mediadas por TIC en el período 2011-2015, en el caso de la educación secundaria técnica de Olavarría. Desde sus particularidades, cada establecimiento escolar desafía los alcances pretendidamente homogéneos del PCI, revelando estrategias propias, a la vez que razonablemente compartidas en el marco de la formación técnica y en una ciudad media del centro bonaerense. 
Desde las relaciones dialécticas entre las revisiones conceptuales y la elaboración o redefinición de categorías, se apuntó a trascender las meras generalizaciones para ahondar en el caso, bajo los propósitos de la teoría fundamentada. Una perspectiva interpretativa y hermenéutica deviene central en atención a las percepciones, expectativas y actuaciones donde se materializa el potencial de las TIC en sus vinculaciones con la educación para la ciudadanía, involucrando gran variedad de dimensiones. La propuesta metodológica apuntó a contribuir a investigaciones ulteriores. El estudio longitudinal logró además profundizar en el conjunto de continuidades y discontinuidades entre dos etapas, en contraste con los estudios habituales, de corte sincrónico. Apuntamos entonces a explicitar los diversos modos en que las condiciones para la apropiación de tecnologías y las distintas mediaciones que operan en ellas, constituyen el marco en el que se configura esa relación central entre TIC, educación y ciudadanía.

En dichas relaciones se realizan posibilidades efectivas de ciudadanización. Aunque no exenta de tensiones, una política de inclusión digital motoriza desplazamientos progresivos hacia apropiaciones crecientemente provechosas. En la medida en que los actores avanzan hacia la plena institucionalización del modelo, dimensionan alcances y limitaciones de las tecnologías con valor educativo, dando cuenta de los usos que se requieren para trascender el dominio instrumental. Allí estas condiciones revelan sus contradicciones: si por una parte parecen confirmar la hegemonía tecno-utópica, por otra, conjugan los espacios que animan experiencias críticas, con niveles crecientes de autonomía. En esta clave la construcción de la ciudadanía está atravesada por la mediación tecnológica. Se trata de una ciudadanía cultural en el reconocimiento de la diversidad, alternativa a la uniformidad que impone la globalización y donde la cultura deviene en el lugar estratégico para formar ciudadanos que ya no son solo portadores de derechos, sino sujetos actuantes de lo público. Las competencias tecnológicas adquieren de este modo potencialidad política porque dinamizan aprendizajes donde se disputan los sentidos tradicionales de la participación juvenil, dentro y fuera de las escuelas.

En un somero recorrido por las principales conclusiones, confirmamos que las prácticas, concepciones y condiciones configuran un complejo entramado sin que puedan desprenderse entre ellas relaciones lineales. Junto con un estado inicial de incertidumbre, aquello que recibe atención inmediata en las escuelas es el acceso, en sus aspectos materiales antes que simbólicos. Incluso entre opiniones opuestas, la netbook es calificada como herramienta, una persistente cosificación sobre el PCI que obtura posibilidades de integración alternativas a las instrumentales. Los modelos previos de uso digital están regidos por posiciones dominantes, docentes de formación técnica generalmente adoptantes tempranos, y consistentes con el imaginario hegemónico, de matriz 
tecnocrática. Una consecuencia es que el modelo 1 a 1 nunca reemplazará el modelo de laboratorio, tanto debido al deterioro técnico de los equipos como a formas arraigadas de organización escolar.

Las dificultades percibidas no remiten exclusivamente a las netbooks sino a los problemas de conectividad, del piso tecnológico y de posesión personal, que definen diferencias objetivas entre los centros educativos y al interior de cada uno. Pero, además, la viabilidad de otro tipo de acceso es incierta en tanto no se preste el mismo nivel de atención a las posiciones subjetivas, formativas e institucionales de los actores, que se traducen en muy diversas demandas sobre cómo innovar en los procesos de enseñanza-aprendizaje. Esto anticipa un desplazamiento significativo que excede, involucrándola directamente, a una política de Estado: del terreno del acceso personal hacia los usos socialmente compartidos de las tecnologías, con capacidad para nutrir los vínculos escolares conforme a objetivos individuales y colectivos de producción de conocimientos.

Nos preguntábamos cómo se define el tiempo escolar, cuáles son las prácticas y las formas de conocimiento que se le atribuyen, cómo los usos y no-usos de las tecnologías interactivas están mediando esas relaciones. EI tiempo escolar se representa en contraste al tiempo de ocio, una distinción que se experimenta como insalvable. En este punto, operan las distintas formas de reproducción ideológica al interior de la institución, las intervenciones de los docentes en el desarrollo de normas y valores tradicionales pero también convicciones muy firmes entre los/las alumnos/as. Con la irrupción del PCI, se reafirman tipos de usos escolares y extra-escolares, y las valoraciones asociadas a esa diferencia: predominantemente, usos instrumentales y no-usos, junto con los usos sociales ligados al entretenimiento. Estos se expanden, enriquecen y complejizan, vía experiencias como los videojuegos y las redes sociales. Los jóvenes son conscientes de lo que estas experiencias conllevan en su vida cotidiana, en la confirmación de sus gustos, sus identidades y las relaciones con sus pares, pero también de las tensiones que las TIC producen en las clases. En este marco reclaman usos más intensivos, pero cualitativamente diferentes.

En tanto política pública de inclusión digital, el Programa Conectar Igualdad abre novedosas oportunidades ligadas al acceso personal y áulico: docentes y estudiantes, en la diversidad de situaciones socio-económicas de las escuelas a las que pertenecen, tienen ahora iguales oportunidades de participar en la cultura digital. No obstante, en la práctica, se instalan o profundizan significaciones imaginarias donde el mito renovado del progreso se articula de manera consistente con la incorporación de las tecnologías a la enseñanza, encontrando en la formación técnica modos específicos de validación. Por caso, las actuaciones docentes se afirman en las diferencias especialistas/de área, dando sustento al ideario tecnicista, pero también permitiendo cuestionar posiciones privilegiadas y a movilizarse hacia sus cambios. 
La continuidad del PCI ofrece la posibilidad de normalizar la presencia de los dispositivos, aunque las contradicciones entre la amplia distribución, el deterioro técnico y los problemas de conectividad, son dificultades muy concretas. Pero motivan la creatividad de un grupo de profesores, habitualmente de formación general, en pos de evaluar otros usos de las tecnologías disponibles. Recuperan los saberes que los jóvenes usuarios han desarrollado en sus interacciones con TIC, animándolos a elucidar sus beneficios y limitaciones para el consumo crítico como para la producción de contenidos. Estas posiciones convocan un fuerte compromiso personal, narrativas profesionales y biográficas que trascienden el problema del acceso, apelando a otros usos y aprovechando las oportunidades múltiples de la interactividad.

Para el conjunto de los actores los usos aparecen organizados en torno a dicotomías (tiempo escolar/extra-escolar, estudio/entretenimiento, adentro/afuera), pero la presencia de las TIC -no únicamente las netbooks- atraviesa constantemente esas fronteras, revelando otras lógicas de enseñanza-aprendizaje en entornos tecnológicos. Ahora bien, los grados cada vez mayores de aceptación, los acuerdos tácitos que definen sus sentidos y que adquieren valor instituyente, prácticamente no encuentran sustento en normas claras a nivel institucional. De manera que estas experiencias resultan alentadoras, pero adolecen de marcos organizativos que logren capitalizarlas a mediano y largo plazo, con vistas a concretar proyectos de migración digital.

En las relaciones y divergencias que las comprometen, las dimensiones de los accesos y los usos se entrecruzan a su vez con la apropiación tecnológica. Como se dijo, si las TIC están imaginariamente escindidas de otras tecnologías, registran entre sí continuidades en la práctica. En ocasiones, la mirada evolucionista convoca la idea de que "esto reemplazará a aquello" o bien el necesario "equilibrio" que habrá de producirse una vez normalizada la inclusión. Sin embargo, en la convergencia digital las viejas tecnologías, sean la escritura, la televisión y muchas otras, siempre conservan un grado de distintividad irremplazable y, además, cada nueva tecnología produce cambios que requieren reajustes y reacomodamientos variados por parte de los usuarios. Cabe subrayar que los procesos de digitalización comprenden hibridaciones donde se conectan muy diversos soportes y lenguajes, a la vez que los resultados tardan en manifestarse justamente porque no solo lo instrumental está involucrado en ellos, sino sobre todo lo sociocultural.

Además, el conocimiento verdadero, socialmente significativo, parece residir en la legitimidad del libro, una concepción persistente incluso entre los jóvenes: jugar con la netbook es divertido, interesante y creativo, pero no implica per se un aprendizaje valioso o que pueda ser valorado como tal en la escuela. No obstante, avanzado el tiempo la apropiación del PCI posibilita nuevas redes de comunicación en el espacio áulico, actividades donde intervienen una diversidad de recursos, desde computadoras y celulares, hasta libros y carpetas. Estas situaciones permiten 
relativizar las diferencias, cuando lo importante no son unos aparatos, sino los saberes que se pueden generar con ellos, bajo la atenta orientación docente y con niveles crecientes de autonomía.

Estas interacciones están profundamente mediadas por las significaciones en el orden de lo cotidiano, donde opera una trama de asociaciones y alejamientos afectivos. Las valoraciones que sobre la netbook generan los jóvenes y que son promotoras de formas diversificadas de apropiación, conducen a atender a las diferencias socio-económicas de base. No puede afirmarse una relación determinante, pero resulta evidente que los grupos socialmente menos favorecidos (en el caso de la EEST $\mathrm{N}^{\circ}$ 1, donde la netbook del PCI suele ser la única computadora personal y, con frecuencia, de los hogares), entablan relaciones más íntimas, afectivas y entusiastas, que no se comparten con las familias. Esta apropiación puede retraer a la computadora a un mundo privado, ajeno a las orientaciones de los adultos $\mathrm{y}$, con ello, reticente a los efectos pretendidamente multiplicadores del acceso físico.

Acusados de tener actitudes "adictivas", a través de las netbooks los estudiantes suelen manifestar modos desafiantes hacia actividades instrumentales y transmisivas, ante docentes autoritarios o poco comprometidos. En la base de ese razonamiento seguirá estando la alta valoración que recibe el conocimiento escolar y la educación de calidad como un derecho irrenunciable. Pero ese derecho convoca también obligaciones, entre ellas, usos más responsables y criteriosos de la tecnología disponible. En la segunda etapa y en el conjunto de los estudiantes, esas percepciones se materializan en la autorregulación de los usos y la autonomización de los modos de aprender. Y encuentran correlato en algunos de sus docentes, cuando los usos abusivos en las aulas no implica meramente tolerarlos -en ocasiones, bajo la forma solapada de disciplinamiento- sino integrar provechosamente la netbook y los saberes que su uso conlleva, en espacios didácticos más estimulantes, menos apegados a los mandatos curriculares o a los criterios mercantilistas de consumo digital.

En otros casos, el mentado adaptacionismo que ha de impulsar la modernización educativa, constituye un obstáculo poderoso. Discutimos las miradas evolucionistas que encuentran sustento teórico en la Ecología de los Medios, no solo por la simplificación del ecosistema mediático, sino porque tiende a aceptar los beneficios de la era digital como universales y necesarios, invisibilizando sus dimensiones de poder. En todo caso, ¿qué significa que la escuela deba "adaptarse"? Los acercamientos de Martín Barbero a la metáfora ecológica corren el riesgo de caer en las perspectivas organicistas de matriz norteamericana. Otras expresiones problemáticas residen en la brecha entre nativos e inmigrantes digitales y la caracterización de los primeros como cultura prefigurativa. Los jóvenes establecen muy diversas relaciones con los adultos, las identidades heredadas y sus instituciones de pertenencia: antes que fracturas absolutas, 
registran continuidades $\mathbf{y}$ discontinuidades. $\mathrm{Y}$ son generalmente conscientes de estas configuraciones, basadas en modos de identificación y diferenciación con otros.

En suma, el PCI define el marco para promover que los actores puedan avanzar desde el acceso hacia trayectos provechosos de uso y apropiación de tecnologías. Es posible observar un proceso lento pero sostenido de estabilización de los marcos interpretativos sobre el modelo 1 a 1 , aun cuando no se materializan inmediatamente en modalidades innovadoras. Avanzado el tiempo, adquieren otra trascendencia experiencias incipientes, aunque efectivas, de apropiación de TIC. Al margen de las orientaciones formales del modelo y los marcos legales que las encuadran, son las escuelas las que revelan dinámicas particulares entre lo instituido y lo instituyente, son interiorizadas por los sujetos y generan, a su vez, espacios de relativa autonomía. A la vez, habilitan las condiciones necesarias para la progresiva institucionalización del PCI.

La innovación no depende entonces de la tecnología en sí o de la utilidad de sus aplicaciones, sino de las valoraciones acerca de cómo las TIC pueden ayudar a enseñar la asignatura, conforme a las características de sus destinatarios, sus sensibilidades, expectativas y creencias acerca de los sentidos de esa incorporación. El Programa expande las prácticas de producción, circulación y socialización de información; ofrece la posibilidad de incrementar experiencias comunicativas de otros modos y, en consecuencia, avanzar hacia el objetivo de igualdad de oportunidades en clave de calidad educativa para los jóvenes que asisten a escuelas públicas.

Estas nuevas posibilidades adquieren mayor precisión en la comprensión de las mediaciones donde los actores pueden participar activamente en esos procesos de adecuación. Las mediaciones escolares adquieren complejas negociaciones con las mediaciones tecnológicas. Definimos estas últimas como las matrices culturales en las que se materializan los modos de apropiación y uso de tecnologías interactivas, revelando estrategias de aprendizaje, participación social y adscripción identitaria desde las cuales se negocian y reconstruyen los sentidos hegemónicos de la Sociedad del Conocimiento. El análisis comprendió sus subdimensiones cognitivas, situacionales, lingüístico-comunicativas y, con especial detenimiento dada su importancia y escaso desarrollo en investigaciones previas, en las mediaciones institucionales.

Las escuelas técnicas fueron las primeras en recibir las netbooks, bajo la presunción de que la integración resultaría favorecida por un marco de especialización técnico-profesional. Pero en el binomio técnica/tecnología -aquel que dota de legitimidad al determinismo tecnológico como criterio de modernización-, el dominio instrumental de saberes "expertos" y acotados a asignaturas específicas (técnicas, talleres), el énfasis en el mundo del trabajo por sobre otros propósitos de la formación, convergen una serie de contradicciones, que vuelve a la plena integración del PCI una 
tarea compleja. Además, median las particularidades de cada escuela organizadas en torno la construcción identitaria, de fuerte configuración en un caso, de precaria definición en otro.

Como modo hegemónico, la técnica misma se convierte en instrumento del orden que sostiene las promesas del cambio educativo, razón de ser de un horizonte de expectativas naturalmente inserto en la experiencia cotidiana. Ahora bien, si los imaginarios tecnológicos rigen en buena medida esos procesos identitarios, ¿cuáles son las posibilidades de concebir otra relación con las TIC, con carácter instituyente? Es que, en tanto instituciones sociales imaginarias, las tecnologías no solo constituyen un espacio alienante, sino de creación. Encierran el proyecto de reproducción del statu quo, pero también una dimensión utópica: al decir de Castoriadis, escapan a la determinación absoluta porque no puede estar fundadas sobre una razón universal ni ser reducidas a la correspondencia con un pretendido ser-así del mundo.

Inicialmente, el PCI parece cristalizar la posición de la EEST $\mathrm{N}^{\circ} 2$ (en su doble superioridad sobre la educación media y la EEST $\mathrm{N}^{\circ} 1$ ), pero volviendo visibles sus tensiones internas. Por una parte, la escuela se revela ausente, ya que las actuaciones de las autoridades están centradas en la distribución del equipamiento. Por otra, una cultura estructurada pero sostenida en consensos, cede lugares para elucidar estos cambios y emprender diversas formas de implementación. Autopercibidos "grasas", los estudiantes se sienten parte de un presente vital y constitutivo, desde el cual disputan los sentidos de esa incorporación, en sintonía con sus afiliaciones institucionales a la vez atravesadas por sus experiencias con TIC. A contramano de los mandatos de la modernización, la importancia cardinal de la identidad se impone sobre cualquier cambio.

Las relaciones dialécticas entre tecnología e identidad institucional se vuelven inteligibles en la EEST $\mathrm{N}^{\circ}$ 1. El PCI enfrenta un escenario de cuestionada autoridad directiva, que parece incapaz de comprender, orientar y consensuar las decisiones implicadas en la implementación. Allí se revelan sus niveles de conflictividad interna, la identidad como proyecto fallido y su correlato en la ciudad, la imagen pública negativa. Estas dificultades parecen alimentar la cosificación sobre el modelo. Una política pública resulta crucial para movilizar la reconversión institucional, solo en cuanto los actores empiezan a impulsar las múltiples transformaciones que esas condiciones requieren. Las transiciones favorables que la escuela atraviesa en la segunda etapa, configuran experiencias de innovación educativa, pero también lugares de negociación y resistencia de las miradas tradicionalmente estigmatizantes, nuevos contextos proclives a la igualación de oportunidades. Los estudiantes se sienten interpelados a participar de la reconstrucción estructural e imaginaria de su escuela, que ahora vivencian como propia.

En sus transiciones en las aulas, las tecnologías impactan de manera decisiva en la autoridad docente. Revelan el predominio de modelos pedagógicos que replican una 
incorporación estrictamente instrumental o superflua. Reconocen los mismos estudiantes que el acceso áulico pone en evidencia los alcances precarios de esa utilización; un ejemplo es el "facilismo" que implica la resolución rápida y sin esfuerzo de una consigna. Los softwares disponibles suelen representar un aprendizaje repetitivo y ordenado, bajo la ficción del aula "aséptica". Pero el cierre del sentido solo puede ser relativo: en la atención de saberes múltiples y fragmentados, desafiantes de las tradiciones, se habilitan otras significaciones cuando ponen el acento en el sujeto que aprende y las relaciones pertinentes que establece con el conocimiento.

Parte importante de la enseñanza reside en la evaluación. Una lectura racional-cientificista encuentra sus anclajes en las racionalidades de la formación técnica, produciendo, bajo la apariencia de la novedad, un aislamiento cada vez mayor de los contenidos: la lógica del "orden" que contrarresta el "desorden" de los saberes convergentes. En cambio, la tecnología adquiere un rol provechoso en tanto no se reduzca a la calificación, la memorización de enunciados o la aplicación mecánica de reglas, sino que brinde elementos para que docente y alumno puedan conocer el estado de situación de la tarea que realizan juntos y favorecer una oportunidad de diálogo entre ambos, como parte constitutiva de esos procesos áulicos.

Como surge de la investigación, estas mediaciones constituyen el marco efectivo para generar competencias tecnológicas con finalidad educativa y de construcción ciudadana. Optamos por comprender las competencias tecnológicas en tanto comunicativas, por cuanto integran habilidades cognitivas, simbólicas y discursivas implicadas en la producción, interpretación y análisis de significados mediados por las tecnologías, el conjunto de condiciones que resultan favorables a su creación y desarrollo, como asimismo las disposiciones necesarias para ejercitar esas habilidades en contextos socioculturales múltiples. Entre tales competencias, registramos, nuevamente, el rol de la autonomía: usos crecientemente responsables y criteriosos de las tecnologías, que al mismo tiempo las exceden, para integrar habitus, lenguajes y sensibilidades esperables en estos marcos de socialización. Esto es, necesarias no solo para adoptar las normas propias de la institución sino, fundamentalmente, para la construcción de conocimiento crítico.

La concepción instrumental sigue siendo un problema cuando las competencias tecnológicas se perciben equivalentes a las técnicas, algo consistente con las tempranas valoraciones sobre el acceso físico y los beneficios operativos. En este sentido se suscitan preocupaciones sobre una temática transversal de la enseñanza: la capacitación docente. Significativamente, los profesores técnicos suelen ser los menos proclives a la capacitación, sea porque confían en su formación inicial o porque no ven utilidad en los saberes pedagógicos, recreando así otros binarismos persistentes: técnico/pedagógico, técnico/disciplinar y también específico/básico. En otros casos, la actualización del conocimiento como valor profesional, la orientación hacia el mundo laboral, 
la rápida obsolescencia de los saberes en la sociedad-red, son alicientes importantes. Las complicadas condiciones de trabajo (cuyo mayor exponente es el profesor taxi), imponen no tanto resistencia a la capacitación, como dificultades objetivas para llevarla adelante.

Desde su aprobación en 2015, el PNIDE apunta a responder esas demandas, profundizando y articulando las propuestas que ya se venían desarrollando. Por una parte, los conocimientos producidos en procesos de capacitación, no llegan a impactar de manera global o más allá de iniciativas personales. Por otra, hay mayor disposición hacia la capacitación, donde el profesor se afirma como actor protagonista. Capacitarse se entiende como obligación como así un derecho, toda vez que se orienta a fortalecer la capacidad de decisión y actuación contribuyendo a su desarrollo profesional. La actualización de los saberes como las intervenciones novedosas, comienzan a abrir esos intersticios que dotan de significancia educativa, moral y política a la inclusión digital, especialmente cuando el consumismo parece instalarse como única forma de ciudadanía. Así, los profesores revelan progresivamente formas de pedagogía crítica capaces de desafiar al neoliberalismo y a otras tradiciones antidemocráticas.

Al margen de las expectativas hacia las propuestas de capacitación, para el conjunto de los docentes el Programa debería haber producido transformaciones más profundas. Consideran necesario superar prejuicios y temores, asumir miradas críticas pero proactivas, en propuestas formales y de exploración de recursos que sirvan para actualizar la formación y establecer con sus alumnos formas dialógicas de enseñanza y trabajo colaborativo. Advierten que es un proceso lento y que son variadas las condiciones que deben darse para que pueda implementarse en todo su potencial. Una dificultad en las definiciones del modelo 1 a 1 es que los docentes no se sienten suficientemente interpelados. Además de la capacitación, requieren el acompañamiento en las tareas, la readecuación de las tecnologías, los consensos acerca de los objetivos que persigue la digitalización y el armado de dispositivos institucionales de apoyo al cambio.

Otro concepto muy discutido es la multitarea. Permite aprovechar los tiempos muertos y realizar simultáneamente varias acciones, pero asume connotaciones negativas: apenas toleradas o directamente excluidas, dados sus efectos distractivos en las clases, un agravante en casos de indisciplinamiento o bajo rendimiento escolar. Por tanto, representan la consecuencia contradictoria de la disponibilidad de las netbooks, la otra cara de la moneda de la igualdad en el acceso personal. Un aspecto que subyace a estas representaciones es el carácter privilegiado de la escritura. Sea en las posiciones apologistas hasta en las más cuestionadoras de las TIC, las dificultades comunicativas entre el alumnado recrean los binarismos con respecto a la cultura digital, adquiriendo rasgos paradojales: la escritura cobra centralidad en la educación técnica, pero 
es responsabilidad solo de "especialistas", profesores de Lengua. Aun así, las competencias tecnológicas presentan articulaciones, además de tensiones, con las competencias analógicas.

Vale insistir en el hecho de que si los jóvenes se autoperciben usuarios fluidos y entusiastas, no se reconocen como nativos digitales. En todo caso, el trabajo escolar exige para ellos una atención concentrada que no es explicable -ni realizada- desde la multitarea. Pero lo importante es la construcción simbólica que sobre ese aprendizaje producen y las condiciones que le son necesarias. El proceso de reconversión que atraviesa la EEST $\mathrm{N}^{\circ} 1$ pasa fundamentalmente por la redefinición de sus normas y rutinas, en marcos de socialización ordenados, al tiempo que más amables y flexibles. Sus estudiantes expresan tempranamente modos de consciencia, que en la segunda etapa se verifica en la mirada expectante hacia las nuevas autoridades, donde resuelven la falsa antinomia entre "libertad" y "libertinaje", anomia y autoritaritarismo.

La cuestión del control atraviesa los diversos niveles de actuación: desde la institución, por parte del docente y de los compañeros, y la autorregulación. En la dialéctica sujeción/subjetivación se dirime las posibilidades de autonomía, contraria a la dependencia digital. Destaquemos someramente tres casos, con implicaciones teóricas. Primero, domesticar las tecnologías conlleva experiencias diversificadas donde el dispositivo se vuelve propio y se lo integra a las propias identidades. Estas prácticas confirman la vigencia de los estudios de domesticación de tradición culturalista en la comprensión de los usos competentes de las TIC. Segundo, las utilizan para mantener el contacto con los padres. Allí se juegan las contradicciones aparentes entre la independencia y el control, la personalización del consumo y el fortalecimiento de los lazos afectivos, otro rasgo de las continuidades generacionales (y con valor substantivo durante la larga jornada escolar). Por último, la persistencia de la televisión, como aquello que conecta afectivamente, organizador de la temporalidad familiar. La muerte de los "viejos medios" que parecen presagiar las concepciones evolucionistas se vuelve un espejismo tecnocrático.

Se constata que las TIC asumen verdadero potencial cognitivo cuando la mediación pedagógica adquiere importancia en entornos interactivos. Convocan al docente al esfuerzo de comprender los lenguajes implicados en los intereses adolescentes, explorando combinaciones posibles entre soportes, narrativas y códigos y movilizando en base a ellos formas creativas de enseñar y aprender. Pero también cuando los estudiantes son partícipes de un proyecto educativo, recuperan sus saberes previos, pueden producir contenidos específicos de las asignaturas y trabajar de manera colaborativa en temáticas que los involucran. Estas representaciones presuponen el rechazo a las miradas estigmatizantes, como sujetos negados o en potencia, imágenes que alimentan la concepción la brecha generacional impidiendo relaciones más empáticas y comprensivas de experiencias previas en las aulas como un capital cultural valioso. 
En el marco de estas transiciones, problematizar la ciudadanía nos obligó a desmontar las categorías establecidas, desde distintos aportes disciplinares, para evaluar cómo el PCI establece el marco para animar condiciones más o menos novedosas orientadas a su formación. En este ámbito se desplazan los sentidos abstractos, mayormente evasivos, hacia tramas interaccionales donde se vuelven inteligibles y socialmente situados. Pretendemos haber contribuido a desambiguar la noción de ciudadanía como construcción socio-histórica, desde sus definiciones clásicas ligadas a los derechos políticos, civiles y sociales, hacia otras novedosas como ciudadanía consumidora, comunicativa, digital y juvenil.

Cada una de estas dimensiones se restringen al cumplimiento de derechos formales o a las características de los sujetos portadores, pero no comprenden la complejidad de una ciudadanía que encuentra en la cultura el espacio para su construcción y ejercicio efectivo. Así, la ciudadanía cultural constituye una categoría superadora porque focaliza en las capacidades de agenciamiento desde las cuales los ciudadanos son capaces de intervenir en su entorno, a la vez que presenta a la diversidad como condición estructurante, desafiante de la tendencia homogeneizadora de la globalización como de la segregación que producen los mercados.

Entendida como cultural, la ciudadanía juvenil define múltiples referentes, narrativas y sensibilidades en los que reposan los significados de ser joven, conectando distintas identidades sin que una implique la negación de las otras. En el reconocimiento de esa diversidad se realizan las posibilidades para generar una educación para y hacia la autonomía. El debate sobre la diversidad cultural se plantea hoy bajo el signo de una aparente contradicción, entre inclusión y exclusión, igualdad y diferencia, globalización y localización. Pero no es la tecnología en sí sino la comunicación el espacio estratégico que exige a la escuela densificar su proyecto de formar ciudadanías críticas, capaces de redefinir el espacio público donde el interés colectivo pueda coexistir con las demandas fragmentadas de los distintos actores.

Vinculada a la trama política/democracia, la ciudadanía adquiere mayores precisiones. Hemos optado por la democracia deliberativa en el pensamiento de J. Habermas porque permite comprender las lógicas de democratización al interior de las escuelas, al tiempo que su proyecto de formación de ciudadanías críticas, orientadas a desarrollar sociedades más justas y pluralistas. Una ciudadanía en construcción convoca espacios de reconocimiento recíproco, al derecho a informar y ser informado, a hablar y ser escuchado, a participar en las decisiones que conciernen al bien común. Basada en interacciones situadas, la racionalización de las acciones y la búsqueda de consensos, desborda la institucionalidad de la política para involucrar movimientos de muy diverso alcance que se realizan en el mundo de la vida, haciendo visibles y por tanto modificables las relaciones de poder. 
Los cimientos ontológicos del modelo habermasiano continúan generando controversias. Un punto crítico surge de una esfera pública ampliada, frente a la emergencia de Internet, dispositivos móviles y plataformas virtuales. Ahora bien, los entornos digitales no generan per se mayor democratización, transformaciones radicales en la participación pública o promoción del conocimiento: por caso, en las discusiones en las redes sociales se despliegan competencias tecno-comunicativas más o menos elaboradas, cuyo espacio privilegiado, no excluyente, de formación sigue siendo la educación formal. Se trata de competencias desarrolladas en experiencias situadas y también estructuralmente mediadas por las tecnologías. Reflexiones generales, en ocasiones sin suficiente sustento empírico, incurren en cierto tecnologismo que retrae esas complejas interfaces a sus componentes instrumentales, omitiendo el hecho de que usuarios competentes, lectores críticos y capaces de argumentar sólidamente sus posiciones, pueden ejercitar esas competencias en una multiplicidad de espacios socioculturales.

En rigor, la teoría de Habermas no está atada a lo espacial-dialógico. Su vigencia radica en que permite repensar una esfera pública atravesada no solo por interacciones cara a cara sino por una red de instituciones -vale recordar que las tecnologías, como las escuelas, constituyen instituciones sociales-, a la vez que incluso en la virtualidad, las prácticas están personal y socialmente situadas en lo cotidiano. $\mathrm{Si}$, como ha advertido Martín Barbero, un desanclaje acelerado de los referentes espacio-temporales decanta debilitándose el tejido social, su capacidad de aglutinación y convocatoria, ese "modo de estar juntos" hoy mediado por el flujo tecnológico, ofrece lógicas de re-localización donde se afirman las identidades y se reconvierten las tradiciones, materializando formas de negociación de los poderes dominantes. De ningún modo intenta neutralizar las particularidades históricas, políticas o ideológicas: el lugar decisivo de la ciudadanía cultural reside precisamente en el reconocimiento de esas diferencias. Consideramos que el motor de la transformación no es tanto el conflicto como la búsqueda de consensos: no niega las contradicciones, sino que las vuelven conscientes y orientadoras de las prácticas, con vistas a una superación que no puede ser sino dialéctica y, por ende, transformadora.

Otra razón para sostener el valor teórico y político de la democracia deliberativa, deriva de los discursos analizados. Si en los inicios del PCI la ciudadanía está ausente como problema, aparece vinculada a las tres capacidades fundamentales: la responsabilidad, la racionalidad y la autonomía, con especial énfasis de esta última en la segunda etapa. Formalmente, la ciudadanía designa el conjunto de derechos y obligaciones, como los contenidos de las asignaturas específicas. Por un lado, esta tendencia replica los criterios de la educación secundaria de tradición positivista, en el reconocimiento tácito de las asignaturas como estamentos separados, incluso cuando temáticas centrales -la ciudadanía, la tecnología, el lenguaje- son concebidas en sus 
atravesamientos de la formación como un todo. Por otro, aunque la asignatura seguirá siendo el principal marco experiencial para el docente, surgen otras orientaciones hacia la participación estudiantil y en el espacio público que la trascienden. La ciudadanía deja de ser un status formal frente al Estado para construirse como espacio de actuación, de agenciamiento ciudadano.

La política constituye un vasto campo de problemas. Se destacan dos aspectos, con continuidad en el tiempo: la concepción negativa, que se realiza bajo los esfuerzos de despolitización; y su correlato necesario, la concepción positiva de la ciudadanía en cualquiera de sus definiciones, consistente orgánicamente con la educación y directamente divorciada de la política. Mayormente, estas representaciones responden a la tendencia a calificar a la política como clientelar, asistencialista o propagandística, en otros términos, a confundirla con la política partidaria. La insistencia entre jóvenes y adultos acerca de "la política...afuera" resulta notable, juntamente con las apreciaciones generalmente positivas hacia el PCI como política educativa. Es que lo que prima en este significante es su valor educativo, asociado al acceso equitativo a las tecnologías y a las potencialidades sociales que estas entrañan.

Conforme avanza el proceso de normalización, aumentan los niveles de aceptación hacia el PCI. Se insiste en el hecho de que la inclusión digital puede ser muy valiosa, pero no una prioridad frente a las necesidades de cumplimiento de otros derechos sociales. Agudas discusiones suscita la Ley del Voto Joven, expresión de las opiniones que mayoritariamente atribuyen a la ciudadanía política el ejercicio formal de derechos, pero también ajena a la escolarización. La clave de la sensación de extrañamiento que experimentan los jóvenes radica en que no se sienten partícipes: el voto se vive como una imposición, una intromisión a la cotidianeidad escolar. Otro eje de interés es la nación: si ya no puede ser pensada como espacio privilegiado de identificación, tampoco se retrae de manera absoluta. Encarna valores residuales que actualizan el sentido de comunidad, formalizado en los actos patrios pero también en actividades de las que participan los alumnos. También constituye el referente para discutir los sentidos de una sociedad globalizada.

En cuanto a la trama ciudadanía/educación, es posible recuperar las definiciones de los actores, ambiguas en la primera etapa y predominantemente asociadas a una ciudadanía formal: en tanto derechos y obligaciones y de estricta incumbencia de las materias específicas. Resulta notable entre los jóvenes la subestimación de estas materias, frente a la alta valoración que le atribuyen como área temática, la importancia implícita de la participación social y de las actuaciones orientadas a ella. Estos aspectos adquieren mayor presencia en la segunda etapa, en torno a otra acepción: como proyecto transversal, la ciudadanía es una problemática compleja que requiere modalidades más innovadoras de abordaje, involucrando al alumno, sus intereses y afinidades, en espacios que escapan de los contenidos de las materias. 
En tanto contribuye a mejorar las redes de comunicación, el modelo 1 a 1 acompaña un desplazamiento clave en la formación ciudadana: de los componentes normativos a los críticoparticipativos. Y esta participación está ligada tanto a organizaciones formales como a marcos efectivos de socialización. Los modos de transitar la cultura escolar invitan a complejizar la noción de apropiación. Al igual que con las $\mathrm{TIC}$, los estudiantes se apropian de las escuelas generando un proceso de "domesticación cruzada". En la escuela "viva" se experimenta la consciencia de reconocerse "grasas" o de construir esa identidad rezagada. Un sujeto escolarizado no es un receptor pasivo de normas, hábitos y saberes, sino un actor inmerso en trayectorias móviles desde las cuales hacen propios estos escenarios, identifican sus contradicciones, los adaptan a sus objetivos y los integran al mundo de sus afectos, de maneras cada vez más autónomas.

En los inicios del PCI, percibido como aquello que irrumpe una institución razonablemente ordenada (o bien agrava su desordenamiento), la escuela tiende a retraerse a sus pautas básicas de socialización; resulta notable que los mismos estudiantes de la EEST $\mathrm{N}^{\circ} 1$ esgrimen como problema central la falta de "límites" que permitan encauzar el funcionamiento institucional, normas básicas que ellos transgreden constantemente pero que al mismo tiempo reclaman como condición básica de aprendizaje. Ese ordenamiento se logra medianamente hacia la segunda etapa analizada. Iniciativas de exploración didáctica con TIC, con frecuencia a partir de la articulación entre áreas y de trabajo con la comunidad, resultan muy valiosas pero, como se planteó, aún hace falta que la institución se convierta en un entorno estimulante, mediante la formulación de un plan institucional que organice recursos, saberes y disposiciones hacia la verdadera innovación.

En el contexto del aula se examinan las condiciones favorables para la construcción de conocimiento, se conectan saberes y lenguajes, se planifican y gestionan estrategias para desarrollar en los alumnos no solo aprendizajes curriculares sino subjetividades críticas, con valor ciudadano. Estas disposiciones están presentes en las competencias éticas y actitudinales que se pretenden formar, apelando al rol de la comunicación, alentando al reconocimiento del otro y el respeto a las diferencias, la participación en la vida escolar y el compromiso activo en sus cambios. Así emerge una ciudadanía resultante de la socialización, donde el docente asume un papel eminentemente transformador. En este punto, la pedagogía freiriana sigue ofreciendo enormes aportes para concebir una ciudadanía que trascienda la titularidad de los derechos, una educación implicada en los procesos de reflexión y acción, en el sentido de praxis social.

En esta línea avanzamos en la comprensión del entramado ciudadanía/TIC. Esta dimensión comprende concepciones sobre el PCI, propósitos y alcances de la inclusión digital, una complicada relación entre información y conocimiento, y la configuración de las identidades juveniles. Retomando observaciones previas, la primera sensación que produce el PCI es de 
desconcierto: el discurso extendido, incluso avanzada la segunda etapa, sobre su carácter “improvisado". Las condiciones de conectividad y la capacitación de los docentes son cuestiones que debieron preverse. Esta incertidumbre impacta negativamente en escuelas que encuentran en un orden funcional -como proyecto o realidad efectiva- sus lógicas validadas de conservación, sobre todo en contraste con la escuela media. Pero en torno a la relación inclusión digital/social, el PCI es el ámbito propicio para una diversidad de apreciaciones: la netbook simboliza la igualación social o bien relega el cumplimiento de demandas más urgentes.

Expresión de un tecnicismo extendido es la tendencia entre los docentes a confundir información con conocimiento. Progresivamente la comunicación emerge como mediadora de esas relaciones, en su valor estratégico para desarrollar competencias críticas de búsqueda, evaluación y uso de las fuentes de Internet, premisa básica para la construcción de ciudadanía en la convergencia digital. Los estudiantes resignifican los desfasajes entre lo escolar y lo extraescolar, pero también los cuestionamientos al carácter reproductivo de las actividades didácticas. Resulta claro además que esas habilidades digitales no son naturales, deben ser enseñadas. Con el tiempo, empiezan a dimensionar los sentidos de Internet en entornos donde nuevas y viejas tecnologías coexisten y se retroalimentan entre sí con verdadera intencionalidad educativa.

Volviendo a la ciudadanía juvenil, entendida en clave de las prácticas de los colectivos juveniles, ¿es posible dotarla de cierta especificidad, en base al reconocimiento de identidades que les son relativamente distintivas? Ciertamente, los jóvenes se posicionan en una diversidad de posiciones, desde la escuela logran hacer valer sus demandas, negociar las relaciones de poder que los determinan y llegar a acuerdos en marcos más dialógicos de sociabilidad. También se vuelven visibles en sus relaciones y tensiones con docentes y padres, en espacios dinamizados por tecnologías, en sus experiencias frente a los medios de comunicación, el barrio y la comunidad.

Cabe resaltar que la participación estudiantil se inscribe en particulares condiciones socioeducativas. Mientras que la EEST $\mathrm{N}^{\circ} 2$ ratifica una identidad entramada en la doble temporalidad del pasado nostálgico y la utopía de "volver a ser", quienes asisten a la EEST $\mathrm{N}^{\circ} 1$ resisten a la situación de desventaja a la que parecen condenados, una lucha que se experimenta en presente, en las posibilidades múltiples de apropiarse de la institución y comprometerse con su reconversión identitaria. No resignan el proyecto del centro de estudiantes, pero discuten el modelo emblemático de Industrial y logran conciliarlo con otras modalidades y niveles de participación. Así, en la "fortaleza" de la escuela o en el "orgullo" de pertenecer se depositan las expectativas sobre el centro estudiantil como espacio legítimo, no único, de actuación. Llamativamente, lo que integra a ambos grupos en una misma red de comprensión -que solo puede ser parcial, dada la diversidad cultural- son los intereses asociados a las TIC y su presencia mediadora de la participación. 
Aun cuando no es enunciada como política, las características que asume la socialización juvenil requiere una mirada más atenta a los repertorios de acción a los que los estudiantes apelan. Esta cuestión lleva a asumir que las tecnologías juegan un papel importante en las condiciones de inclusión digital encuadradas en el PCI y, evidentemente, las desplazan. Los jóvenes han avanzado hacia formas más competentes, creativas y provechosas de utilización, y las materializan en propuestas con sentido estrictamente pedagógico, convocadas por las asignaturas o proyectos institucionales, desde el centro de estudiantes o bien a sus márgenes. Páginas web, publicaciones digitales y redes sociales configuran los espacios donde pueden organizar actividades, reivindicar sus derechos, expresar puntos de vista, racionalizar sus acciones, establecer identificaciones con los otros/vecinos y con sus pares, involucrándose en consignas escolares, globales o comunitarias.

La educación se vuelve ámbito político porque es capaz de traspasar sus fronteras en la conformación de ciudadanías ligadas a la participación. Y en su vinculación con la mediación tecnológica, dinamizar los pasajes de una des-territorialización hacia una re-territorialización, donde la potencialidad política de esas acciones cobra la forma de una nueva institucionalidad. De esta manera se juegan atravesamientos de las formas instituidas de uso digital, desbordando tanto los mandatos escolares como los signados por el mercado. Lo que obliga a recuperar una dimensión simbólica que se revela eminentemente política: cuando encierra la posibilidad de comprender las múltiples mediaciones en y desde las cuales pueden formar a los sujetos como ciudadanos críticos y agentes de cambio social.

$\mathrm{Si}$ el PCI presenta contradicciones, su progresiva normalización se materializa en trayectorias en las que los sujetos se reconocen cada vez más hábiles en sus interacciones con TIC, más conscientes de sus aportes y limitaciones a las siempre complejas tareas de enseñar y aprender. Implica entonces atender a los atravesamientos, aquello que sucede en los discursos, más allá de las tecnologías. Así, la construcción de ciudadanía implica las diversas formas de apropiación y participación en el espacio público, a la vez que constituye a la escuela como esfera pública, en la cual se promueven capacidades ligadas a la autonomía, el respeto a la diversidad y la igualdad como derecho efectivamente realizado. Lo que se configura no es la disolución de la política sino nuevas formas de politicidad, como accionar concreto o como proyecto educativo, convocando la reconfiguración de las mediaciones que avanzan en los modos de expresión de las diversas voces y de representación de los vínculos que cohesionan a ciudadanos en formación.

En suma, concluimos que la educación formal es el ámbito que intersecta la importancia estratégica de la construcción de la ciudadanía con la potencialidad de las tecnologías interactivas en este campo. $\mathrm{Y}$ esta potencialidad no es solo educativa, sino eminentemente política. En las mediaciones tecnológicas se materializan las prácticas y representaciones asociadas 
a la promoción de conocimiento socialmente significativo, aquel que vuelve a los sujetos usuarios competentes y atentos a las tensiones que la omnipresencia de la tecnología genera en las sociedades actuales. Como dijimos, si las TIC son el lugar de desarrollo de los mandatos hegemónicos, al mismo tiempo habilitan las experiencias críticas donde ciudadanos en formación se muestran capaces de adecuar esa inclusión a sus propias demandas y con creciente autonomía, y con ello, reconstruir activamente los múltiples espacios de participación que los interpelan.

Junto a otras iniciativas como la Asignación Universal por Hijo, el Plan Conectar Igualdad revela un Estado que, aunque parezca un oxímorom, emergió como actor contrahegémonico. Es cierto que, como surge de los documentos oficiales, sostuvo una retórica de la tecnología como vector neutro susceptible de adaptación, desconociendo la singularidad de los ámbitos sociales e institucionales, la diversidad de sus demandas y niveles de apropiación. Empero, a la vez generó condiciones de posibilidad en las cuales los sujetos pudieron negociar, resignificar o subvertir los sentidos dominantes de una digitalización acelerada. Con todas sus limitaciones, el modelo 1 a 1 hubiera requerido mayor profundización y desarrollo. Examinamos en trabajos previos (Fernández Massara, 2015), las formas de concentración monopólica o cuasi-monopólica de los medios masivos y las tensiones suscitadas a raíz de la intervención estatal durante el gobierno anterior. Estas luchas hegemónicas condujeron a la sanción de la Ley de Servicios de Comunicación Audiovisual (26.522) en 2009, constituyendo el contexto de emergencia del PCI como de las discusiones renovadas sobre las relaciones ciudadanía/TIC.

En los últimos años, los avances de los modelos neoliberales en América Latina materializan una coyuntura histórica marcada por la rearticulación de los bloques de poder, donde la globalización configura el proceso generador de la expansión de la economía capitalista. En nuestro país, las orientaciones del gobierno de nuevo signo se traducen en el feroz ajuste en el sistema educativo, la vulneración de derechos adquiridos y la creciente fragmentación social. Al igual que con la LSCA, la derogación de Conectar Igualdad es muestra acabada de ello. Estos escenarios adversos presentan otras condiciones de productividad teórica para las ciencias sociales, redoblando el desafío de fortalecer la defensa de la democracia. Y echan nueva luz a la relevancia del PCI, en tanto marco definitorio para tensar los imperativos de la racionalidad técnica y legitimar a la educación como espacio articulador de la dimensión cultural del desarrollo con TIC.

Atender al rol de la educación adquiere otras aristas. Se la inviste de una suerte de sacralización de resabios iluministas, naturalizando sus alcances para concretar el proyecto largamente esperado de modernización. Asimismo, pone a los docentes bajo sospecha, ante la crisis educativa resultante de la globalización, los imperativos del mercado, las sucesivas reformas, la relación conflictiva entre saberes. Actualmente, los discursos hegemónicos avanzan en 
definiciones de corte tecnocrático, más cercanas a criterios mercantilistas del tipo costo-beneficio que a la calidad educativa entendida como derecho humano. Sin embargo, las instituciones dinamizan las disputas acerca de qué significan y cómo enfrentar estos cambios, cuáles son mediaciones donde entraman las formas culturales emergentes, aquellas que inciden en la configuración de los sujetos juveniles al momento de volver reconocibles sus demandas, comunicar estéticas y valores, y participar de la sociedad activamente en la que viven.

Concluyendo, si el potencial educativo de las TIC no es intrínseco a ellas, la incorporación de estas experiencias es esencial si lo que se pretende es que los estudiantes encuentren significado en el aprendizaje, sobre todo en situaciones de vulnerabilidad y con riesgo de abandono. Basado en el fortalecimiento de cada institución, construir sentido de pertenencia, tal como se ha analizado en esta tesis, redunda en que sientan que merece la pena aprender, que el aprendizaje está relacionado con su vida y les abre múltiples oportunidades a su futuro. Pero es claro que la inclusión educativa no alcanza. La interrupción del modelo 1 a 1 pone aún más en evidencia la primacía sociocultural de la tecnología, renovando el interés en formar ciudadanías reales y socialmente responsables que logren afrontar estas transformaciones. La densidad histórica del concepto, por un lado, y su creciente vaciamiento retórico, por el otro, exigen continuar explorando sus definiciones y modos de realización, lo que permita volver a plantear la dimensión ético-política que hace de la ciudadanía cultural un proyecto ineludible. 


\section{BIBLIOGRAFÍA}

AAVV (2005). Democracia y ciudadanía en la "Sociedad de la Información": desafios y articulaciones regionales. Córdoba: Escuela de Ciencias de la Información, UNC.

ADORNO, T. y HORKHEIMER, M. (1987). Dialéctica del Iluminismo. Buenos Aires: Sudamericana.

AGUIAR, H. (2007). El futuro no espera. Políticas para desarrollar la sociedad del conocimiento. Buenos Aires: La Crujía.

ANSART, P. (1986). Ideologías, conflicto y poder. México: Premia.

AON, N. y ZAPATA, N. (2011). “Jóvenes y consumos culturales. Una mirada sobre la recepción tecnológica y audiovisual en estudiantes de comunicación social”. Question, 1 (30). FPyCS, UNLP. Disponible en: https://perio.unlp.edu.ar/ojs/index.php/question/article/view/1051/1048

APPADURAI, A. (2001). La modernidad desbordada. Dimensiones culturales de la globalización. Buenos Aires: Fondo de Cultura Económica.

APREA, G. (2006). "Las representaciones de las TIC en relación con los procesos educativos". En CABELLO, R. (Coord.), Yo con la computadora no tengo nada que ver. Un estudio de las relaciones entre los maestros y las tecnologías informáticas en la enseñanza (145-141). Buenos Aires: Prometeo.

APREA, G., CALLELO, T. y QUINTAR, A. (Comps.) (2007). Los usos de las TICs. Una mirada multidimensional. Buenos Aires: UNGS, Prometeo.

AUSUBEL, D. P. (1963). The psicology of meaningful verbal learning. New York: Grune and Stratton.

ARABITO, J. y FERNÁNDEZ MASSARA, B. (2007). “La incorporación de las tecnologías de la información y la comunicación en la formación docente". Ponencia al 5to. Encuentro Argentino de Carreras de Comunicación Social. UNICEN, Olavarría.

ARABITO, J. y FERNÁNDEZ MASSARA, B. (2008). “TIC y educación: acerca de las representaciones de los estudiantes de formación docente”. Razón y Palabra (63). Monterrey, México. Disponible en: http://www.razonypalabra.org.mx/n63/bfernandez.html

ÁREA MOREIRA, M. (2002). Los medios y materiales de enseñanza. Fundamentos conceptuales. Documento para Tecnología Educativa, Universidad de La Laguna. Disponible en: http://tecnologiaedu.us.es/

ÁREA MOREIRA, M. (2009). Introducción a la tecnología educativa. España: Universidad de La Laguna. 
ÁREA MOREIRA, M. (2011). "Educar para la cultura líquida de la Web 2.0: apuntes para un modelo de alfabetización digital". Comunicación al I Congreso Internacional sobre Educación Mediática y Competencia Digital. Segovia.

ÁREA MOREIRA, M. (2015). "Reinventar la escuela en la sociedad digital. Del aprender repitiendo al aprender creando". En POGGI, M. (coord.), Mejorar los aprendizajes en la educación obligatoria: políticas y actores (pp 167-194). Buenos Aires: Instituto Internacional de Planeamiento de la Educación IIPE-Unesco.

ARENDT, H. (1997). ¿Qué es la política? Barcelona: Paidós.

ARMONY, A. (2011). “Derechos sociotecnológicos y ciudadanía”. En CHERESKY, I. (comp.), Ciudadanía y legitimidad democrática en América Latina (339-361). Buenos Aires: Prometeo.

BAQuero, R., CAMilloni, A., CARretero, M., CASTORINA, J. A., LENZI, A. y LITWIN, E. (1998). Debates constructivistas. Buenos Aires: Aique.

BAUMAN, Z. (2013). Modernidad líquida. Madrid: Fondo Cultura Económica.

BECERRA, M. (2010). "Mutaciones en la superficie y cambios estructurales. América Latina en el Parnaso informacional". En DE MORAES, D. (comp.), Mutaciones de lo visible. Comunicación y procesos culturales en la era digital (81-112). Buenos Aires: Paidós.

BENÍTEZ LARGHI, S. (2013). "Lo popular a partir de la apropiación de las TIC. Tensiones entre representaciones hegemónicas y prácticas”. Question, 1 (38) (otoño 2013). Disponible en: http://perio.unlp.edu.ar/ojs/index.php/question/article/view/1813/1575

BENÍTEZ LARGHI, S. (2016). "Elogio de un "fracaso". La dimensión simbólica del Programa Conectar Igualdad". Revista Argentina de Estudios de Juventud (10), noviembre 2016. FPyCS, UNLP, La Plata. Disponible en: https://perio.unlp.edu.ar/ojs/index.php/revistadejuventud/article/view/3732/3749

BENJAMIN, W. (1982). “La obra de arte en la época de su reproductibilidad técnica". En Discursos Interrumpidos 1. Madrid: Taurus.

BERNSTEIN, B. (1970). "Social class difference in commmunication and control". En BRANDIS, W. and HENDERSON, D., Social class, lenguage anda commnunication. London: Rotledge Kegan Paul.

BETTETINI, G. y COLOMBO, F. (1995). Las nuevas tecnologías de la comunicación. Barcelona: Paidós.

BILBAO, R. y RIVAS, A. (2011). Las provincias y las TIC: avances y dilemas de política educativa. Programa de Educación. Desarrollo Social. Buenos Aires: CIPPEC. Disponible en: https://www.cippec.org/wp-content/uploads/2017/03/2538.pdf 
BOLADERAS CUCURELlA, M. (2001). "La opinión pública en Habermas”. Anàlisi 26, Barcelona.

BOURDIEU, P. (2012). Los usos sociales de la ciencia, Buenos Aires: Buena Visión.

BRUNER, J. (2016). La importancia de la educación. Buenos Aires: Paidós.

BRUNNER, J. (2008). “¿Una sociedad movilizada hacia las TIC?”. En Las TIC: del aula a la agenda política. Ponencias del Seminario internacional "Cómo las TIC transforman las escuelas” (42-54). Buenos Aires: UNICEF Argentina e IIPE,

BRUNO, D. (2011). "La problematización del espacio público en la comunicación para el desarrollo". En ALEM, B. (comp.), Comunicación y espacio público (101-121). Buenos Aires: Imago-Mundi, UNGS.

BUCKINGHAM, D. (2008). Más allá de la tecnología. Buenos Aires: Manantial.

BUSANICHE, B. (2004). "Bestiario de la sociedad de la información". Ponencia al Coloquio Internacional Democracia y Ciudadanía en la Sociedad de la Información. UNC. Disponible en http://www.bea.org.ar/2004/11/bestiario-de-la-sociedad-de-la-informacin/

BURBULES, N. (2012). "El aprendizaje ubicuo y el futuro de la enseñanza". Encounters/Encuentros/Rencontres on Education, 13, pp. 3-14.

BURBULES, N. C. y CALLISTER, T. A. (2001). Riesgos y promesas de las nuevas tecnologías de la información. Madrid: Granica.

CABELLO, R. (2006). "Yo con la computadora no tengo nada que ver. Sobre usos posibles, usos mentados y no usos". En CABELLO, R. (Coord.), Yo con la computadora no tengo nada que ver. Un estudio de las relaciones entre los maestros y las tecnologías informáticas en la enseñanza (143-162). Buenos Aires: Prometeo.

CABELLO, R. (2007). “Sobre juegos en red, competencias tecnológicas y aprendizaje”. En CABELLO, R. y LEVIS, D. (Eds.), Medios informáticos en la educación a principios del siglo XXI (149-173). Buenos Aires: Prometeo.

CABELLO, R. (2008a). Argentina digital. Los Polvorines: UNGS.

CABELlO, R. (2008b). Las redes del juego. Buenos Aires: Prometeo.

CABELlO, R. (2009). "Mundos alternativos. Sobre jóvenes futuros docentes y su relación con los medios informáticos”. En MORALES, S. y LOYOLA, M. I. (Comps.), Los jóvenes y las TIC. Apropiación y uso en educación (81-98). Córdoba: UNC.

CABELLO, R. (2011). "TECNOVECTOR. Migraciones digitales como propuesta de alfabetización mediática digital en la formación docente”. En MORALES, S. y CABELLO, R. (Eds.), Enseñar con tecnologías. Nuevas miradas en la formación docente (17-45). Buenos Aires: Prometeo. 
CABELLO, R. (2013). "Migraciones digitales. Hacia un plan institucional de alfabetización digital”. En CABELLO, R. (Coord.), Migraciones digitales: comunicación, educación y tecnologías digitales interactivas (13-48). Los Polvorines: UNGS.

CABELLO, R. (2014). "Reflexiones sobre inclusión digital como modalidad de inclusión social”. Ponencia a las VIII Jornadas de Sociología. La Plata, UNLP.

CABRERA, D. (2006). Lo tecnológico y lo imaginario: las nuevas tecnologías como creencias y esperanzas colectivas. Buenos Aires: Biblos.

(2009). “Comunicación y educación. Dinámica de la identidad desde el imaginario social”.Ide@s, 4 (45), CONCYTEG, pp. 328-336.

CALDERÓN, F. (2007). “Ciudadanía y desarrollo humano”. En CALDERÓN, F. (Coord.), Ciudadanía y desarrollo humano. Cuadernos de gobernabilidad democrática I (31-63). Buenos Aires: Siglo XXI.

CARIDE, J. A. (Coord.) (2009). Los derechos humanos en la educación y la cultura. Rosario: Homo Sapiens.

CARLINO, P. (2005). Escribir, leer y aprender en la universidad. Una introducción a la alfabetización académica. Buenos Aires: Fondo de Cultura Económica.

CARLINO, P. (2013). “Alfabetización académica diez años después”. Revista Mexicana de Investigación Educativa, 18 (57). Consejo Mexicano de Investigación Educativa, A.C. Distrito Federal, México, pp. 355-381. Disponible en: http://www.redalyc.org/articulo.oa?id=14025774003

CASABLANCAS, S. (2017). "No es malo perder el rumbo: reconfiguraciones del rol docente en el contexto digital”. En SEVILLA, H., TARASOW, F. y LUNA, M. (Coords.), Educar en la era digital. Docencia, tecnología y aprendizaje (17-33). México: Pandora.

CASSANY, D. (2002). "La escritura y la enseñanza en el entorno digital". Ponencia al XIII Congreso Internacional de la Asociación Lingüística y Filología de América Latina (ALFAL), San José de Costa Rica, Ciudad Universitaria Rodrigo Facio, 18 al 23 de febrero.

CASSANY, D. y AYALA, G. (2008). "Nativos e inmigrantes digitales en la escuela", CEE Participación Educativa (9), pp. 53-71. Disponible en: http://www.educacion.gob.es/revista-cee/pdf/n9-cassany-daniel.pdf.

CASTELLS, M. (2001). La era de la información. México: Siglo XXI.

CASTORIADIS, C. (2003). La institución imaginaria de la sociedad I y II. Buenos Aires: Tusquets.

CASTORIADIS, C. (2005). “¿Qué democracia?”. En Figuras de lo pensable (145-185). Buenos Aires: Fondo de Cultura Económica. 
CASTRELO, V. (2018). "La esfera pública habermasiana. Su obsolescencia en tiempos de nuevas plataformas digitales”. Inmediaciones de la Comunicación, 13 (1), enero-junio 2018. Universidad ORT Uruguay (71-87).

CHARTIER, R. (2008). “Aprender a leer, leer para aprender”. En MILLÁN, J. A. (Coord.), La lectura en España. Informe 2008: Leer para aprender. Madrid: Fundación Germán Sánchez Ruipérez y Federación de Gremios Editores de España.

CHÁVES, M. (2005). "Juventud negada y negativizada: representaciones y formaciones discursivas vigentes en la Argentina contemporánea". Última Década, 13 (23). Valparaíso. Centro de Estudios Sociales, pp. 9-29. Disponible en: http://www.cidpa.chttp://www.redalyc.org/articulo.oa? id=19502302

CHÁVES, M. (2010). Jóvenes, territorios y complicidades. Una antropología de la juventud urbana. Buenos Aires: Espacio Editorial.

CHÁVES, N. (1994). La imagen corporativa. Madrid: Gustavo Gili.

COICAUD, S. y FALÓN, L. (2015). “Jóvenes, identidades y posicionamientos políticos actuales”. En COICAUD, S. (Ed.). La educación como construcción de subjetividad política. Jóvenes escuela y proyectos (39-57). Buenos Aires: Miño y Dávila.

COGO, D. (2011). “Los Estudios de Recepción en América Latina: perspectivas teóricometodológicas". PortalComunicación.com. InCom- UAB, pp. 1-14. Disponible en: http://portalcomunicacion.com/lecciones det.asp?lng=esp\&id=48

CROVI DRUETTA, D. (2004). "Educar en red. Nuevas tecnologías y procesos educativos". Institut de la comunicación. InCom, Universidad de Barcelona. Disponible en: http://www.portalcomunicacion.com/esp/home.html

CROVI DRUETTA, D. (2007). "Retos de las universidades en la sociedad de la información y el conocimiento". En CABELLO, R. y LEVIS, D. (Eds.), Medios informáticos en la educación a principios del siglo XXI (177-196). Buenos Aires: Prometeo.

CROVI DRUETTA, D. (2013). "Repensar la educación desde la cultura digital”. En MORALES, S. y LOYOLA, M. I. (Comps.), Nuevas perspectivas en los estudios de comunicación. La apropiación tecno-mediática (11-23). Buenos Aires: Imago Mundi.

CROVI DRUETTA, D. y GARAY CRUZ, L. M. (2015). "Educomunicación en América Latina. Tendencias y expectativas”. En BOLAÑO, C., DRUETTA, D. y CIMADEVILLA, G., La contribución de América Latina al campo de la comunicación (223-255). Buenos Aires: Prometeo.

CULLEN, C. (2012). "El rizoma ciudadano". En CULLEN, C. y BONILLA, A. (Comps.), La ciudadanía en jaque I (11-21). Buenos Aires: Stella, La Crujía. 
DA PORTA, E. (2011a). “Algunos límites de los estudios de recepción para estudiar los procesos de mediatización de las subjetividades juveniles. Una propuesta para trabajar desde la apropiación”. Ponencia al II Encuentro sobre juventud, medios de comunicación e industrias culturales (JUMIC), FFyL, UNT, Tucumán. Disponible en: http://es.scribd.com/doc/156148008/SUJETOSMIRADAS-PRACTICAS-Y-DISCURSOSG-Palazzo-y-P-Gomez-coords-pdf\#scribd

DA PORTA, E. (2011b). “Comunicación y Educación: algunas reflexiones para la búsqueda de nociones estratégicas”. En DA PORTA, E. (Comp.), Comunicación y educación: debates actuales desde un campo estratégico (41-60). Córdoba: Gráfica del Sur.

DA PORTA, E. (2012). "La apropiación tecnomediática como un proceso de sujeción/subjetivación. Notas teóricas y metodológicas”. Ponencia al XI Congreso Latinoamericano de Investigadores en Comunicación. ALAIC, Montevideo, Uruguay.

DA PORTA, E. (2017). "Escuelas, mediaciones y experiencias significativas". Revista Latinoamericana de Ciencias de la Comunicación, 4 (26). ALAIC, 193-202. Disponible en: file://C:/Users/user/Downloads/912-2336-1-PB\%20(1).pdf

DIKER, G. (2008). “Autoridad y Transmisión: Algunas notas teóricas para re-pensar la educación”. Educación y Humanismo (15), Noviembre 2008. Universidad Simón Bolívar, Barranquilla, $\quad$ 58.69. Disponible en: www.unisimonbolivar.edu.co/publicaciones/index.php/educacionyhumanismo

DIKER, G. y SERRA, J. C. (2008). La cuestión docente: Argentina, las políticas de capacitación docente. Buenos Aires: Fundación Laboratorio de Políticas Públicas.

DUSSEL, I. (2016). "La inclusión digital y la nueva frontera de los derechos en el siglo XXI. Notas sobre el Programa Conectar Igualdad”. En BRENER, G. y GALLI, G. (Comps.), Inclusión y calidad como políticas educativas de Estado o el mérito cómo opción única del mercado (145-160). Buenos Aires: Crujía.

DUSSEL, I. y QUEVEDO, L. A. (2010). VI Foro Latinoamericano de Educación; Educación y nuevas tecnologías: los desafios pedagógicos ante el mundo digital. Buenos Aires: Santillana.

ECO, U. (2004). Apocalípticos e integrados. Barcelona: Lumen.

ECO, U. y CARRIÉRE, J. C. (2010). Nadie acabará con los libros. Barcelona: Lumen.

ELIZALDE, S. (2012). "La juventud en la mira de las ciencias sociales, los medios y las leyes. Preguntas y desafíos sobre las diferencias de género y sexualidad”. En KRIGER, M. (Comp.) Juventudes en América Latina. Abordajes multidisciplinares sobre identidades, culturas y políticas, del siglo XX al siglo XXI. Buenos Aires: CAICYT-CONICET. 
ELIZALDE, S. (2015). "Estudios de juventud en el Cono Sur: epistemologías que persisten, desaprendizajes y compromiso intelectual. Una reflexión en clave de género". Última Década (42), Proyecto Juventudes, junio 2015, pp. 129-145.

ETCHEGOYEN, M. A. (2006). Educación y ciudadanía. La búsqueda del buen sentido en el sentido común. Buenos Aires: La Crujía.

FAINHOLC, B. (2003). Las mediaciones tecnológicas educativas. La Plata: UNLP.

FAINHOLC, B. (2004). "El concepto de mediación en la tecnología educativa adecuada y crítica". Disponible en: http://portal.educ.ar/debates/educacionytic/nuevos-alfabetismos/elconcepto-de-mediacion-en-la-tecnologia-educativa-apropiada-y-critica.php

FEIXA, C. (2006). “Generación XX: Teorías sobre la juventud en la era contemporánea”. Revista Latinoamericana de Ciencias Sociales, Niñez y Juventud, 4 (2). Manizales, Colombia. Hahn.

FERNÁNDEZ MASSARA, B. (2012a). El campo de la comunicación: condiciones de objetivación en la tesis de grado. Question, 1 (33). Verano (enero-marzo) 2012. FPyCSUNLP. Disponible en: https://perio.unlp.edu.ar/ojs/index.php/question/article/view/1356/1215

FERNÁNDEZ MASSARA, B. (2012b). Nuevas tecnologías en la educación argentina: problemas y desafíos ante la brecha digital. Saarbrücken, Editorial Académica Española.

FERNÁNDEZ MASSARA, B. (2014). “Sobre libros y pantallas: encuentros y desencuentros en la cultura digital". Estudios sobre las Culturas Contemporánea, 20 (40). México: Universidad de Colima, pp. 117-140.

FERNÁNDEZ MASSARA, B. (2015). Jóvenes y política: posibilidades emergentes de reconstrucción del espacio público/mediático. Trabajo Final para la Diplomatura en Estudios sobre Jóvenes, Medios y Política en América Latina. FPyCS. UNLP. Centro Redes, Unidad asociada a CONICET.

FERNÁNDEZ MASSARA, B. (2016a). "Mediaciones tecnoeducativas. Consideraciones teóricas a partir de la obra de Jesús Martín Barbero”. Comunicación y Sociedad (27). Departamento de Estudios de la Comunicación Social. Universidad de Guadalajara, México. Setiembre a diciembre, pp. 197-220. Disponible en: http://comunicacionysociedad.cucsh.udg.mx/index.php/comsoc/article/view/1771/5489

FERNÁNDEZ MASSARA, B. (2016b). "Imaginarios tecnológicos y subjetividades juveniles en condiciones de mediatización”. En GRAVANO, A., SILVA, A. y BOGGI, S. (Eds.). En Ciudades vividas. Sistemas e imaginarios de ciudades medias bonaerenses (345-362). Buenos Aires: Café de las Ciudades. 
FERNÁNDEZ MASSARA, B. (2017). “Apropiación digital y conocimiento: condiciones de implementación de Conectar Igualdad". En CABELLO, R. y LÓPEZ, A. (Eds.), Contribuciones al estudio de procesos de apropiación de tecnologías (145-155). Buenos Aires: Gato Gris, Red de Investigadores sobre Apropiación de Tecnologías.

FERNÁNDEZ MASSARA, B. (2018). "Domesticar a las TIC. Aspectos emocionales de las competencias tecnológicas". Ponencia al XVI ENACOM. FADECCOS, Facultad de Ciencias Sociales, UNICEN. Olavarría.

FERNÁNDEZ MASSARA, B., MARMISOLLE, G. y PALLERO, S. (2017). “Comunicar teorías desde las teorías de la comunicación. Desafíos y problematizaciones sobre el lugar de la teoría en la formación universitaria". Ponencia a las VI Jornadas de Antropología Social del Centro. Facultad de Ciencias Sociales, UNICEN. Olavarría.

FINQUELIEVICH, S. y PRINCE, A. (2007). El (involuntario) rol social de los cibercafés. Buenos Aires: Dunken.

FOLLARI, R. (2003). Teorías débiles (para una crítica de la reconstrucción y de los estudios culturales). Rosario: Homo Sapiens.

FREIRE, P. (1973). La educación como práctica de la libertad. Buenos Aires: Siglo XXI.

FREIRE, P. (1985). Pedagogía del oprimido. Buenos Aires: Siglo XXI.

FREIRE, P. (1998). Pedagogía de la esperanza. Buenos Aires: Siglo XXI.

FULLAN, M. (2002). Los nuevos significados del cambio. Barcelona: Octaedro.

GADAMER, H. G. (2004). Truth and Method. London: Continuum.

GAITÁN MOYA, J. A. y PIÑUEL RAIGADA, J. L. (1998). Técnicas de investigación en Comunicación Social. Madrid: Síntesis.

GARCÍA CANCLINI, N. (1995). Consumidores y ciudadanos. Conflictos multiculturales de la globalización. México: Grijalbo.

GARCÍA CANCLINI, N. (1999). Imaginarios urbanos. Buenos Aires: Paidós.

GARCÍA CANCLINI, N. (2006). “El consumo cultural: una propuesta teórica”. En SUNKEL, G. (Coord.), El consumo cultural en América Latina (72-95). Bogotá: Convenio Andrés Bello.

GARCÍA CANCLINI, N. (2007). Lectores, espectadores e internautas. Barcelona: Gedisa.

GÉLIGA VARGAS, J. (2006). “Acceder, cruzar, nivelar: disyuntivas escolares ante la brecha digital”. En CABELLO, R. (Coord.), Yo con la computadora no tengo nada que ver. Un estudio de las relaciones entre los maestros y las tecnologías informáticas en la enseñanza (41-87). Buenos Aires: Prometeo.

GIOVINE, R. y MARTIGNONI, L. (2010). Politicas educativas e instituciones escolares en Argentina. Tandil: UNICEN. 
GIMENO SACRISTÁN, J. (1991). El currículum. Una reflexión sobre la práctica. Madrid: Morata.

GIRARDI, L. \& SÁ MARTINO, S. M. (2007). “Diante da Televisão”. Entrevista com OROZCO GÓMEZ, G. Communicare, 7 (1), pp. 13-18.

GIROUX, H. (1997). Cruzando límites. Trabajadores culturales y políticas educativas. Madrid: Paidós.

GIROUX, H. (2013). "La pedagogía educativa en tiempos oscuros". Praxis Educativa, XVII (17). Santa Rosa: Facultad de Ciencias Humanas, UNLPam, pp. 13-26. Disponible en: https://cerac.unlpam.edu.ar/index.php/praxis/article/view/776/712

GLASER, B. y STRAUSS, A. (1967). The discovery of grounded theory: strategies for qualitative research. New York: Aldine Publishing Company.

GONZÁLEZ, J. (1999). “Tecnología y percepción social evaluar la competencia tecnológica”. En Estudios sobre las Culturas Contemporáneas, V(9), pp. 155-165. México: Universidad de Colima.

GRAMSCI, A. (1998). Introducción a la filosofía de la praxis. México: Fontamara.

GRANOSVKY, P. (2016). "Perspectivas sobre la díada educación-trabajo en las sociedades contemporáneas”. Cuadernos de Pensamiento Crítico Latinoamericano (31), febrero 2016. Segunda época. Disponible en: http://biblioteca.clacso.edu.ar/clacso/se/20160307102013/CuadernoN31SegEpoca.pdf

GRAVANO, A. (2005). "Palimpsesto urbano: sobre-escritura de huellas diacrónicas de la ciudad imaginada" e "Imaginarios urbanos, gestión social y la cuestión de lo popular en la ciudad media”. En GRAVANO, A. (Comp.). Imaginarios sociales de la ciudad media. Emblemas, fragmentaciones y otredades urbanas. Estudios de Antropología urbana (31-49 y 159-177). Tandil: UNICEN.

GRAVANO, A. (2013). Antropología de lo urbano. Tandil: UNICEN.

GRAVANO, A. (2016). “Tres hipótesis sobre la relación entre sistema urbano e imaginarios de ciudades media”. En GRAVANO, A., SILVA, A. y BOGGI, S. (Eds.). En Ciudades vividas. Sistemas e imaginarios de ciudades medias bonaerenses (69-90). Buenos Aires: Café de las Ciudades.

HABERMAS, J. (1986). Historia y crítica de la opinión pública. México: Gustavo Gili.

HABERMAS, J. (1997). Teoría de la acción comunicativa. Madrid: Taurus.

HABERMAS, J. (1998). Facticidad y validez. Sobre el Derecho y el Estado democrático de derecho en términos de teoría del discurso. Madrid: Trotta. 
HALL, S. (2010). Sin garantías. Problemáticas y trayectorias en los estudios culturales. Quito, Ecuador: Universidad Andina Simón Bolívar- Envión.

HALL, S. (2017). Estudios culturales 1983. Una historia teorética. Buenos Aires: Paidós.

HARGREAVES, A. (1998). Profesorado, cultura y posmodernidad. Madrid: Morata.

HOFFMANN, B. (2003). "Retos al desarrollo en la era digital”. Diálogos de la Comunicación (67). Lima: FELAFACS.

HOGGART, R. (2013). La cultura obrera en la sociedad de masas. Buenos Aires: Siglo XXI.

HUERGO, J. (1998). Comunicación/Educación. Ámbitos, prácticas y perspectivas. La Plata: Ediciones de Periodismo y Comunicación.

HUERGO, J. (2010). "Lo que articula lo educativo en las prácticas socioculturales". En Intersecciones en Comunicación, 4 (4). Olavarría, Facultad de Ciencias Sociales- UNICEN, pp. 199-208.

HUERGO, J. y MORAWICKI, K. (2005). La incorporación de medios y tecnologías en prácticas educativas. La Plata: Centro de Comunicación y Educación, UNLP.

IGARZA, R. (2009). Burbujas de ocio. Nuevas formas de consumo cultural. Buenos Aires: La Crujía.

ISLAS, O. (2007). "Las TIC en la formación en Comunicación. Apuntes para construir una comunicología efectivamente productiva, desde la ecología de los medios”. En CABELLO, R. y LEVIS, D. (Eds.), Medios informáticos en la educación a principios del siglo XXI (287305). Buenos Aires: Prometeo.

JAIM ETCHEVERRY, G. (2007). La tragedia educativa. Buenos Aires: Fondo de Cultura Económica.

JENKINS, H. (2008). Convergence Culture. La cultura de la convergencia de los medios de comunicación. Buenos Aires: Paidós.

JENKINS, H. (2011). Entrevista en GVIRTZ, S. y NECUZZI, C. (Comps.) Educación y tecnologías. Las voces de los expertos. Buenos Aires: Conectar Igualdad, ANSES.

JODELET, D. (2011). “Aportes del enfoque de las representaciones sociales al campo de la educación”. Espacios en blanco. Revista de educación, 21, junio 2011. UNICEN, pp. 133154. Disponible en: http://www.redalyc.org/articulo.oa?id=384539803006

KAUFMAN, E. (2007). "Sobre políticas y modelos de gestión para el Gobierno Electrónico y la Sociedad de la Información y el Conocimiento”. En KAUFMAN, E. (Coord.), Políticas públicas y tecnologías. Líneas de acción para América Latina (37-89). Buenos Aires: La Crujía. 
KOEHLER, M. y MISHRA, P. (2006). “Technological Pedagogical Content Knowledge: A Framework for Teacher Knowledge". Teachers College Record, 108 (6). Disponible en: http://punya.educ.msu.edu/publications/journal_articles/mishra-koehler-tcr2006.pdf

KRIGER, M. (2010). Jóvenes de escarapelas tomar. Escolaridad, comprensión histórica y formación política en la Argentina contemporánea. La Plata: FPyCS, UNLP.

KRIGER, M. (2013). "La invención de la juventud, entre la muerte de las naciones y su resurrección". En Juventudes en la Argentina y América Latina. Cultura, política e identidades del siglo XX al XXI. Centro Redes (www.centroredes.org.ar/), Argentina.

KRIGER, M. y BRUNO, D. (2013). “Juventud y política en el contexto argentino: Creencias, valoraciones, disposiciones y prácticas políticas de jóvenes estudiantes (Buenos Aires, 201012)”. En C@hiers de psychologie politique, (22). Université de Caen, France.

KRIGER, M., y DAIBAN, C. (2015). "Del ideal del ciudadano al ciudadano en situación: un estudio sobre los modelos de ciudadanía y los posicionamientos subjetivos de jóvenes ciudadanos en la Argentina actual (Buenos Aires y Conurbano, 2011-13)”. FOLIOS. Segunda época (41), primer semestre de 2015, pp. 87-102.

LACLAU, E. y MOUFFE, C. (1987). Hegemonía y estrategia socialista. Madrid: Siglo XXI.

LAGO MARTÍNEZ, S. (Coord.) (2015). De tecnologías digitales, educación formal y políticas públicas: aportes al debate. Buenos Aires: Teseo.

LAGO MARTÍNEZ, S., MAROTIAS, A., MAROTIAS, L. y MOVIA, G. (2006). Internet y lucha política. Los movimientos sociales en la red. Buenos Aires: Capital Intelectual.

LANDAU, M. (2004). "Los múltiples significados de ser ciudadano. Ciudadanía y construcción de subjetividades en la Buenos Aires actual”. En MURILLO, S. (Coord.), Sujetos a la incertidumbre. Transformaciones sociales y construcción de subjetividad en la Buenos Aires actual. Buenos Aires: CCC.

LANDAU, M. (2006). “Ciudadanía y ciudadanía juvenil”. Conferencia en el marco del Programa de Transformaciones Curriculares. Materia Construcción de Ciudadanía. La Plata: DGCyE.

LANDAU, M. (2008). "Cuestión de ciudadanía, autoridad estatal y participación ciudadana". Revista Mexicana de Sociología, 70 (1), enero-marzo 2008, pp. 7-45.

LANDOW, G. P. (1995). Hipertexto. La convergencia de la teoría crítica contemporánea y la tecnología. Barcelona: Paidós.

LANGER, E. (2017). "Las desigualdades sociales y las luchas por mejorar para jóvenes escolarizados". Revista Argentina de Estudios de Juventud (11), noviembre 2017. La Plata: 
FPyCS,

UNLP.

Disponible

en:

https://perio.unlp.edu.ar/ojs/index.php/revistadejuventud/article/view/4497/3657

LECHNER, N. (1996). "La política ya no es lo que fue”. Nueva Sociedad (114), julio-agosto.

LECHNER, N. (2000). "Nuevas ciudadanías". Revista de Estudios Sociales (5), Santafé de Bogotá.

LEFORT, C. (1991). La invención democrática. Buenos Aires: Nueva Visión.

LEVIS, D. (2007). “Enseñar y aprender con informática/Enseñar y aprender informática”. En: CABELLO, R. y LEVIS, D. (Eds.), Medios informáticos en la educación a principios del siglo XXI (21-50). Buenos Aires: Prometeo.

LEY DE EDUCACIÓN NACIONAL No 26.206/06. Disponible en: http://www.me.gov.ar/doc_pdf/ley_de_educ nac.pdf

LEY DE EDUCACIÓN TÉCNICO-PROFESIONAL N $\mathrm{N}^{\circ}$ 26.058/05. Disponible en: http://www.me.gov.ar/doc pdf/ley26058.pdf

LEY NACIONAL DE CREACIÓN DE CENTROS DE ESTUDIANTES No 26.877/13. Disponible en: http://www.unterseccionalroca.org.ar/imagenes/documentos/leg/Ley $\% 2026877 \% 20 \% 28$ ce ntros\%20de\%20estudiantes\%29.pdf

LEY DE LOS CENTROS DE ESTUDIANTES DE LA PROVINCIA DE BUENOS AIRES N 14.581/13. Disponible en: http:/www.gob.gba.gov.ar/legislacion/legislacion/l-14581.html

LION, C. (2006). Imaginar con tecnologías. Relaciones entre tecnologías y conocimiento. Buenos Aires: La Crujía.

LIPSMAN, M. (2014). "El enriquecimiento de los procesos de evaluación mediados por las TIC en el contexto universitario". Revista Iberoamericana de Evaluación Educativa, 7 (2), pp. 215-222.

LOYOLA, M. I. (2011). "Y en el aula, ¿qué hacemos? Estrategias (posibles y realizables)". En CABELLO, R. y MORALES, S. (Eds.), Enseñar con tecnologías. Nuevas miradas en la formación docente (109-130). Buenos Aires: Prometeo.

LOZANO, E. (1991). "Del sujeto cautivo a los consumidores nomádicos”. Diálogos de la Comunicación (30). Lima: FELAFACS.

MAGGIO, M. (2016). Enriquecer la enseñanza. Los ambientes con alta disposición tecnológica como oportunidad. Buenos Aires: Paidós.

MAGGIO, M., LION, C. y SARLÉ, P. (Coord.) (2012). Creaciones, experiencias y horizontes inspiradores: la trama de Conectar Igualdad. Buenos Aires: Educ.ar. Ministerio de Educación de la Nación. 
MANNHEIM, K. (1993). “El problema de las generaciones”. Revista española de investigación sociológica (62), pp. 193-242.

MARGULIS, M. y URRESTI, M. (2008). “La juventud es más que una palabra”. En La juventud es más que una palabra. Ensayos sobre cultura y juventud. Buenos Aires: Biblos.

MARCUSE, H. (1993). El hombre unidimensional. Ensayo sobre la ideología de la sociedad industrial avanzada. Buenos Aires: Planeta.

MARSHALL, T. H. (1965). Class, citizenship and social development. New York: Anchor Books. MARTÍN BARBERO, J. (1987). De los medios a las mediaciones. México: Gustavo Gili.

MARTÍN BARBERO, J. (2001). “Transformaciones comunicativas y tecnológicas de lo público”. Metapolítica. Revista trimestral de teoría y ciencia de la política, 5 (17). México, eneromarzo.

MARTÍN BARBERO, J. (2002a). “Tecnicidades, identidades, alteridades: des-ubicaciones y opacidades de la comunicación en el nuevo siglo”. Diálogos de la Comunicación (64). Lima: FELAFACS.

MARTÍN BARBERO, J. (2002b). “Jóvenes, comunicación e identidad”. Pensar Iberoamérica. Revista de Cultura de la OEI $\mathrm{N}^{\mathrm{O}} 0$. Disponible en: http://www.oei.es/pensariberoamerica/ric00a03.htm

MARTÍN BARBERO, J. (2002c). "Ensanchando Territorios. Comunicación/Cultura/Educación”. Nodos de Comunicación/Educación (1). La Plata, septiembre 2002.

MARTÍN BARBERO, J. (2002d). La educación desde la comunicación. México: Gustavo Gilli.

MARTÍN BARBERO, J. (2002e). Oficio de Cartógrafo. Travesías Latinoamericanas de las Comunicación en la Cultura. Santiago de Chile: Fondo de Cultura Económica.

MARTÍN BARBERO, J. (2003). "Saberes hoy: diseminaciones, competencias y transversalidades". Revista Iberoamericana de Educación (32). Mayo-agosto 2003. Disponible en: http://www.rieoei.org/rie32a01.htm

MARTÍN BARBERO, J. (2007). "Heredando el futuro. Pensar la educación desde la comunicación”. Nómadas (5). Santafé de Bogotá, Colombia.

MARTÍN BARBERO, J. (2008). “Lo público: experiencia urbana y metáfora ciudadana”. CIC Cuadernos de Información y Comunicación (13) (sin mes). Madrid: Universidad Complutense de Madrid, pp. 213-226. Disponible en: https://revistas.ucm.es/index.php/CIYC/article/viewFile/CIYC0808110213A/7247

MARTÍN BARBERO, J. (2009). “Cuando la tecnología deja de ser una ayuda didáctica para convertirse en mediación cultural". Teoría de la Educación. Educación y cultura en la 
sociedad de la información, 10 (1). Marzo 2009. Disponible en: http://www.redalyc.org/pdf/2010/201018023002.pdf

MARTÍN BARBERO, J. (2010). “Convergencia digital y diversidad cultural”. En DE MORÁES, D. (Comp.), Mutaciones de lo visible. Comunicación y procesos culturales en la era digital (137-165). Buenos Aires: Paidós.

MARTÍN BARBERO, J. (2015). “¿Desde dónde pensamos la comunicación hoy?”. Chasqui. Revista Latinoamericana de Comunicación (128), abril-julio 2015. Sección Tribuna. Ecuador: CIESPAL, pp. 13-29. Disponible en: http://www.revistachasqui.org/index.php/chasqui/article/view/2545/2445

MARTÍN BARBERO, J. y LLUCH, G. (2011). Proyecto Lectura, Escritura y Desarrollo en la sociedad de la información. Bogotá: CERLALC-UNESCO.

MÁS ROCHA, S. M. (2016). “El Estado y la regulación de la participación estudiantil: la normativa sobre Centros de Estudiantes Secundarios". Polifonías Revista de Educación, V (8), pp. 44-70. Disponible en: http://www.polifoniasrevista.unlu.edu.ar/sites/www.polifoniasrevista.unlu.edu.ar/files/site/ 8\%20M\%C3\%A1s\%20Rocha.pdf

MATA, M. C. (2004). “Comunicación, ciudadanía y poder: pistas para pensar su articulación”. Diálogos de la Comunicación (64). Lima: FELAFACS.

MATA, M. C. (2006). “Comunicación y ciudadanía. Problemas teórico-políticos de su articulación”. Revista Fronteiras - estudos midiáticos, VIII (1). Río de Janeiro, abril 2006, pp. 5-15. Disponible en: file:///C:/Users/user/Downloads/6113-18691-1-SM.pdf

MATTELART, A. (2002). Historia de la sociedad de la información. Barcelona: Paidós.

MATTELART, A. (2003). "La sociedad de la información. El enfrentamiento entre proyectos de sociedad". Diálogos de la Comunicación (67). Lima: FELAFACS.

MATTELART, A. y NEVEU, E. (2004). Introducción a los estudios culturales. Barcelona: Paidós.

MIÈGE, B. (2010). “La cuestión de las TIC. Hacia nuevos planteamientos”. En DE MORAES, D. (Comp.), Mutaciones de lo visible. Comunicación y procesos culturales en la era digital (1544). Buenos Aires: Paidós.

MORALES, S. (2007). "Brecha digital y educación en la Sociedad global de la educación. En CABELLO, R. y LEVIS, D. (Eds.), Medios informáticos en la educación a principios del siglo XXI (61-83). Buenos Aires: Prometeo.

MORALES, S. (2009). "La apropiación de TIC. Una perspectiva”. En MORALES, S. y LOYOLA, M. I. (Comps.), Los jóvenes y las TIC. Apropiación y uso en educación (99-120). Córdoba: UNC. 
MORALES, S. (2011). “Acceso y apropiación de Tecnologías de la Información y la Comunicación. Una propuesta de política pública en educación”. En CABELLO, R. y MORALES, S. (Eds.), Enseñar con tecnologías. Nuevas miradas en la formación docente (47-75). Buenos Aires: Prometeo.

MORALES, S. (2013a). “Apropiación tecno-mediática. El capitalismo en su encrucijada”. En MORALES, S. y LOYOLA, M. I. (Comps.), Nuevas perspectivas en los estudios de comunicación. La apropiación tecno-mediática (37-51). Buenos Aires: Imago Mundi.

MORALES, S. (2013b). "Desafíos metodológicos para el estudio de la apropiación tecnomediática”. Ponencia al VI Encuentro Panamericano de Comunicación. Córdoba: Escuela de Ciencias de la Información, UNC.

MORDUCHOUWICZ, R. (2010). Los adolescentes y las redes sociales. Escuela y medios. Buenos Aires: Ministerio de Educación.

MORDUCHOUWICZ, R. (2014). Los chicos y las pantallas. Las respuestas que todos buscamos. Buenos Aires: Fondo de Cultura Económica.

MORLEY, D. (2008). Medios, modernidad y tecnología. Hacia una teoría interdisciplinaria de la cultura. Barcelona: Gedisa.

MOUFFE, C. (1999). El retorno de lo político. Barcelona: Paidós.

MOULTHROP, S. (1989). “El hipertexto y la política de la interpretación”. En VEGA, J. M. (ed.) (2003), Literatura hipertextual y teoría literaria (23-31). Madrid: Marenostrum.

MOULTHROP, S. (1991). "Beyond the Electronic Book: A Critique of Hypertext Rhetoric", Hypertext '91. New York: Association of Computing Machinery, pp. 291-298.

MOYANO, R. (2006). “Competencias tecnológicas percibidas por los docentes del Partido de Malvinas Argentinas.” En CABELLO, R. (Coord.), Yo con la computadora no tengo nada que ver. Un estudio de las relaciones entre los maestros y las tecnologías informáticas en la enseñanza (209-254). Buenos Aires: Prometeo.

MUÑOZ GONZÁLEZ, G. (2010). "De las culturas juveniles a las ciberculturas del siglo XXI”, ponencia al Congress of the Latin American Studies Association. Toronto, Canadá.

MUÑOZ GONZÁLEZ, G. y MUÑOZ GAVIRIA, A. (2008): "La ciudadanía juvenil como ciudadanía cultural: una aproximación teórica desde los estudios culturales”. Revista Argentina de Sociología, 6 (11). Buenos Aires.

MUROLO, N. L. (2014). Hegemonía de los sentidos y usos de las tecnologías de la comunicación por parte de jóvenes del conurbano bonaerense Sur. Estudio realizado en Quilmes 20112014. Tesis Doctoral. FPyCS. UNLP. 
NATANSON, J. (2012): ¿Por qué los jóvenes están volviendo a la política? De los indignados a La Cámpora. Buenos Aires: Random House.

NEGROPONTE, N. (1995). El mundo digital. Barcelona: Ed. B.

Nuevas voces, nuevos escenarios: estudios evaluativos sobre el Programa Conectar Igualdad (2011). Informe de Evaluación de Conectar Igualdad, Argentina. Disponible en: http://repositorio.educacion.gov.ar/dspace/handle/123456789/96946

NÚÑEZ, P. (2010). Política y poder en la escuela media. La socialización política juvenil en el espacio escolar. Tesis Doctoral. UNGS, IDES.

NÚÑEZ, P. (2013): “La política en la escuela: sensibilidades juveniles, justicia y derechos”. En Juventudes en la Argentina y América Latina. Cultura, política e identidades del siglo XX al XXI. Centro (www.centroredes.org.ar/), Argentina.

NÚÑEZ, P. y LITICHEVER, L. (2015). Radiografías de la experiencia escolar: ser joven(es) en la escuela. Buenos Aires: Grupo Editor Universitario.

O'DONNELL, G. (2007). Disonancias. Críticas democráticas a la democracia. Buenos Aires: Prometeo.

O'DONNELL, G. y SCHMITTER, P. (1986). Transiciones desde un gobierno democrático/4. Conclusiones tentativas sobre democracias inciertas. Barcelona: Paidós.

ONG, W. (2000). Oralidad y escritura. Tecnologías de la palabra. Buenos Aires: Fondo de Cultura Económica.

OROZCO GÓMEZ, G. (1993). "Dialéctica de la mediación televisiva. Estructuración de estrategias de recepción por los televidentes". Anàlisi, 15, pp. 31-44.

OROZCO GÓMEZ, G. (1996). Televisión y audiencias: un enfoque cualitativo. Madrid: Ediciones de la Torre.

OROZCO GÓMEZ, G. (2006). "Los estudios de recepción: de un modo de investigar a una moda, y de ahí a muchos modos”. En SAINTOUT, F. y FERRANTE, N. (Comps.) ¿Y la recepción? Balance crítico de los estudios sobre el público (15-31). Buenos Aires: La Crujía.

OROZCO GÓMEZ, G. (2012). "Televisión y producción de interacciones comunicativas". Comunicación y Sociedad (18), julio-diciembre. Disponible en: http://148.202.18.157/sitios/publicacionesite/pperiod/comsoc/revista18/2.pdf

ORTIZ, R. (1994). Mundialización y cultura. Buenos Aires: Alianza.

ORTIZ, R. (2014). Universalismo/diversidad. Contradicciones de la modernidad-mundo. Buenos Aires: Prometeo. 
ORTIZ CASALLAS, E. M. (2013). "Las representaciones sociales: un marco teórico apropiado para abordar la investigación social educativa". Revista de Ciencias Sociales, XIX(1), eneromarzo 2013. Universidad del Zulia. Maracaibo, Venezuela.

PÉREZ GÓMEZ, A. I. (2007). La naturaleza de las competencias básicas y sus implicaciones pedagógicas. Cantabria, Consejería de Educación. Ecuador: Universidad Andina Simón Bolívar, Envión.

GIMENO SACRISTÁN, J. y PÉREZ GÓMEZ, A. I. (1996). Comprender y transformación la enseñanza. Madrid: Morata.

PERISSÉ, A. (2010). "La ciudadanía como construcción histórico-social y sus transformaciones en la Argentina contemporánea”. Nómada, Revista Crítica de Ciencias Sociales y Jurídicas 26. Universidad Complutense de Madrid.

PERKINS, D. (2006). “QQué es la comprensión?” En La enseñanza para la comprensión. Vinculación entre la investigación y la práctica (65-93). Buenos Aires: Paidós.

PIEVI, N. y BRAVÍN, C. (2009). Documento metodológico orientador para la investigación educativa. Buenos Aires: Ministerio de Educación de la Nación.

PIÑUEL RAIGADA, J. L. y GAITÁN MOYA, J. A. (1995). Metodología general. Conocimiento científico e investigación en comunicación social. Madrid: Síntesis.

PIÑUEL RAIGADA, J. L. (2002). "Epistemología, metodología y técnicas del análisis de contenido". Estudios de Sociolingüística 3 (1), pp. 1-42.

PISCITELLI, A. (1995). Ciberculturas en la era de las máquinas inteligentes. Buenos Aires: Paidós.

PISCITELLI, A. (2005). "Inmigrantes digitales vs. nativos digitales". Disponible en: http://portal.educ.ar/debates/educacionytic/nuevos-alfabetismos/inmigrantesdigitalesvs.nativos-digitales.php.

PISCITELLI, A. (2009). Nativos digitales. Dieta cognitiva, inteligencia colectiva y arquitecturas de participación. Buenos Aires: Santillana.

PLAN DIGITAL DE INCLUSIÓN DIGITAL Y EDUCATIVA (PNIDE) Res. 244/15. Disponible en: http://www.me.gov.ar/consejo/resoluciones/res15/244-15.pdf

PROGRAMA CONECTAR IGUALDAD. Decreto 459/10 Disponible en: http://www.bnm.me.gov.ar/giga1/normas/14691.pdf

PROGRAMA CONECTAR IGUALDAD. ANEXO "Las políticas de inclusión digital educativa”. Disponible en: $\quad$ https://www.alfabetizaciondigital.redem.org/wpcontent/uploads/2015/07/123-10_01.pdf 
PROGRAMA NACIONAL “UNA COMPUTADORA PARA CADA ALUMNO” No 82/09.

Disponible en: http://www.inet.edu.ar/wp-content/uploads/2012/10/82-09.pdf.

QUIROZ, T. (2009). “Internet y los jóvenes. Identidades y nuevos espacios de comunicación”. En MORALES, S. y LOYOLA, M. I. (Comps.), Los jóvenes y las TIC. Apropiación y uso en educación (35-44). Córdoba: UNC.

REGUILlO CRUZ, R. (2003). “Ciudadanías juveniles en América Latina”. Última Década, Revista del Centro de Investigación y Difusión Poblacional (19). Viña del Mar, Chile.

REGUILlO CRUZ, R. (2012). Culturas juveniles. Formas politicas del desencanto. Buenos Aires: Siglo XXI.

RIVERA, J. (1987). La investigación en Comunicación Social en la Argentina. Buenos Aires: Puntosur.

RIVERA, J. (1997). Comunicación, medios y cultura. Líneas de investigación en la Argentina 1986- 1996. Ediciones de Periodismo y Comunicación. UNLP, La Plata.

ROCANGLIOLO, R. (2003). "Visión de la sociedad de la información y del conocimiento desde la sociedad civil”. Diálogos de la Comunicación (67). Lima: FELAFACS.

ROMERO, L. A. (2012). Breve historia contemporánea de la Argentina 1916-1920. Buenos Aires: Fondo de Cultura Económica.

SANDOVAL, L. R. (2012). Tecnología, comunicación y ciudadanía. Usos políticos de Internet y las TIC en la Argentina reciente (1997-2009). Buenos Aires: Biblos.

SANDOVAL, L. R. (2013). Medios, masas y audiencias. Lecturas sobre teoría social de la comunicación. Comodoro Rivadavia: EDUPA, UNPSJB.

SAUTU, R, BONIOlO, P., DAlle, P. y ElBERT, R. (2010). Manual de metodología. Construcción del marco teórico, formulación de los objetivos y elección de la metodología. Buenos Aires: Prometeo.

SAINTOUT, F. (Ed.). (2003). Abrir la comunicación: tradición y movimiento en el campo académico. La Plata: Ediciones de Periodismo y Comunicación.

SAINTOUT, F. (2011). "Política y juventud: transformaciones en el cruce de los siglos". En CHARDON, M. C. (Coord.), Transformaciones del espacio público. Los actores, las prácticas, las representaciones (53-64). Buenos Aires: La Crujía.

SAINTOUT, F. y FERRANTE, N. (2006). “Los estudios de recepción en Argentina hoy: rupturas, continuidades y nuevos objetos”. En ¿Y la recepción? Balance crítico de los estudios sobre el público (151-165). Buenos Aires: La Crujía. 
SAVIANI, D. (1983). "Las teorías de la educación y el problema de la marginalidad en América Latina”. Revista Argentina de Educación, II (3). Asociación de Graduados en Ciencias de la Educación.

SCHMITTER, P. y KARL, T. L. (1993). “Qué es y qué no es la democracia”. Sistema (116).

SCHMUCLER, H. (1997). Memoria de la comunicación. Buenos Aires: Biblos.

SCHMUCLER, H. y MATA, M. C. (Coord.) (1992). Política y comunicación. ¿Hay un lugar para la política en la cultura mediática? Córdoba: Universidad Nacional de Córdoba.

SCOLARI, C. (2008). Hipermediaciones. Elementos para una teoría de la comunicación digital interactiva. Barcelona: Gedisa.

SCOLARI, C. (2009). “Alrededor de la(s) convergencia(s). Conversaciones teóricas, divergencias conceptuales y transformaciones en el ecosistema de medios”. Signo y Pensamiento, XXVIII (54), enero - junio 2009.

SCOLARI, C. (2010). "Ecología de los medios. Mapa de un nicho ecológico". Quaderns del CAC, XIII (1), pp. 17-25.

SCOLARI, C. (2015). Ecología de los medios. Entornos, evoluciones e interpretaciones. Buenos Aires: Gedisa.

SCRIBANO, A. (2008). El proceso de investigación social cualitativo. Buenos Aires: Prometeo. Segundo Informe Nacional de monitoreo y evaluación del plan Ceibal (2011). Departamento de Monitoreo y Evaluación del Plan Ceibal, Uruguay. Disponible en: http://www.ceibal.org.uy/docs/Segundo-informe-nacional-de-monitoreo-y-evaluacion-delPlan-Ceibal-2010.pdf

SGRÓ, M. (2008). “Introducción”. En SGRÓ, M. (Org.), Teoría crítica de la sociedad, educación, democracia y ciudadanía (11-30). Tandil: UNICEN.

SIBILIA, P. (2008). La intimidad como espectáculo. Buenos Aires: Fondo de Cultura Económica.

SILBER, J. (2011). "Recorridos recientes y trazos actuales de las tendencias pedagógicas en la Argentina”. En GRINBERG, S., ROLDÁN, S., CESATARE, M. (Comps.), Pedagogías desde América Latina, tensiones y debates contemporáneos. VI Encuentro Nacional de Cátedras de Pedagogía. Buenos Aires: LEA, pp. 185-194. Disponible en: http://psicologiaporlavida.blogspot.com.ar/2011/08/recorridos-recientes-y-trazosactuales.html

SILVA, A. (1992). Imaginarios urbanos. Bogotá y San Paulo: cultura y comunicación urbana en América Latina. Bogotá: Tercer Mundo.

SILVERSTONE, R. (1996). Televisión y vida cotidiana. Buenos Aires: Amorrortu.

SILVERSTONE, R. (2004). ¿Por qué estudiar los medios? Buenos Aires: Amorrortu. 
SUÁREZ GUERRERO, C. (2006). "Los entornos virtuales de aprendizaje como instrumento de evaluación". Investigación Educativa, 10 (18). Julio-Diciembre 2006, pp. 41-56.

SUNKEL, G. (2002). "Una mirada otra. La cultura desde el consumo". En D. MATO (Ed.), Estudios y otras prácticas intelectuales latinoamericanas en cultura y poder. Caracas: CLACSO. Disponible en: http://bibliotecavirtual.clacso.org.ar/ar/libros/cultura/sunkel.doc

SUNKEL, G. (2006). “El consumo cultural: una propuesta teórica”. En SUNKEL, G. (Coord.), El consumo cultural en América Latina. Bogotá: Convenio Andrés Bello.

TABACHNIK, S. (2007). "Retratos secretos. Figuraciones de la identidad en el espacio virtual”, en Revista Latina de Comunicación Social (62), II época, enero-diciembre, La Laguna, Tenerife. Disponible en: http://www.ull.es/publicaciones/latina/200701TabachnikS.pdf

TAYLOR, S. y BOGDAN, R. (1987). Introducción a los métodos cualitativos de investigación. Buenos Aires: Paidós.

TENTI FANFANI, E. (2010). Sociología de la educación. Buenos Aires: Ministerio de Educación de la Nación. Disponible en: http://repositorio.educacion.gov.ar/dspace/bitstream/handle/123456789/96375/EL002802.p df? sequence $=1$

TERIGI, F. (2012). Los saberes de los docentes: formación, elaboración en la experiencia e investigación. Buenos Aires: Santillana.

TORRES, C. A. (2008). "Democracia, educación y multuculturalismo: dilemas de la ciudadanía en el mundo global”. En MORA-NINCI, C. y RUIZ, G., Sociología política de la educación en perspectiva internacional y comparada. Contribuciones de Carlos Alberto Torres (181225). Buenos Aires: Miño y Dávila.

SILEONI, A. (2016). “Calidad educativa y políticas públicas”. En BRENER, G. y GALLI, G. (Comps.). Inclusión y calidad como políticas educativas de Estado o el mérito cómo opción única del mercado (53-68). Buenos Aires: Crujía.

STONE WISKE, M. (2006). “¿Qué es la enseñanza para la comprensión?” En La enseñanza para la comprensión. Vinculación entre la investigación y la práctica (95-126). Buenos Aires: Paidós.

UNICEF (Fondo de las Naciones Unidas para la Infancia) (2015). Resultados de la Encuesta Nacional sobre Integración de TIC en la Educación Básica Argentina. Informe general. Programa TIC y Educación Básica. Buenos Aires. Disponible en: https://www.unicef.org/argentina/sites/unicef.org.argentina/files/201803/EDUCACION_01_TICS-Educacion-InformeGeneral.pdf 
VASILACHIS DE GIALDINO, I. (1993). Métodos Cualitativos I. Los problemas teóricoepistemológicos. Buenos Aires: CEAL.

VERÓN, E. (2001). Esto no es un libro. Barcelona: Gedisa.

VERÓN, E. (1998). La Mediatización. Buenos Aires: Eudeba. FFyL, UBA.

VERÓN, E. (2013). La semiosis social 2. Buenos Aires: Paidós.

VIDOZ, S. y COICAUD, A. (2015). “Aportes para pensar la ciudadanía”. En COICAUD. S. (ed.). La educación como construcción de subjetividad política. Jóvenes escuela y proyectos (1938). Buenos Aires: Miño y Dávila.

VIEYTES, R.; (2004). Metodología de la investigación en organizaciones, mercado y sociedad. Epistemología y técnicas. Buenos Aires: Ed. de las Ciencias Sociales.

VOMMARO, P. (2013a): "Relaciones entre juventudes, políticas y culturas en la Argentina y en América Latina actuales: miradas desde las formas de participación política de los jóvenes en movimientos sociales y desde las políticas públicas". En Juventudes en la Argentina y América Latina. Cultura, política e identidades del siglo XX al XXI. Centro Redes (www.centroredes.org.ar/), Argentina.

VOMMARO, P. (2013b). "Las relaciones entre juventudes y políticas en la América Latina contemporánea: una aproximación desde los movimientos estudiantiles”. Revista Sociedad (32), pp. $127-144$

Disponible en: http://ri.conicet.gov.ar/bitstream/handle/11336/9468/CONICET_Digital_Nro.13424.pdf?se quence $=1 \&$ isAllowed $=\mathrm{y}$

VOMMARO, P. (2015). Juventudes y políticas en la Argentina y en América Latina: tendencias, conflictos y desafios. Buenos Aires: Grupo Editor Universitario.

YARTO WONG, C. (2010). "Limitaciones y alcances del enfoque de domesticación de la tecnología en el estudio del teléfono celular”. En Comunicación y Sociedad. Nueva época (13), enero-junio. Disponible en: http://www.scielo.org.mx/pdf/comso/n13/n13a8.pdf

WHITE, D. S. y LE CORNU, A. (2011). "Visitors and Residents: A new typology for online engagement". First Monday, 16 (9). Disponible en: http://firstmonday.org/ojs/index.php/fm/article/view/3171/3049

WILLIAMS, R. (1992). Tecnologías de la comunicación e instituciones sociales. En WILLIAMS, R. (Comp.), Historia de la comunicación. Vol. 2. De la imprenta a nuestros días (183-209). Barcelona: Bosch.

WILLIAMS, R. (2009). Marxismo y Literatura. Buenos Aires: Las Cuarenta.

WILLIAMS, R. (2017). La política del modernismo. Buenos Aires: Godot. WINOCUR, R. (2009). Robinson Crusoe ya tiene celular. México: Siglo XXI. 
WINOCUR, R. (2013a). “Una revisión crítica de la apropiación en la evaluación de los programas de inclusión digital”. En MORALES, S. y LOYOLA, M. I. (comp.), Nuevas perspectivas en los estudios de comunicación. La apropiación tecno-mediática (pp. 53-64). Buenos Aires: Imago Mundi.

WINOCUR, R. (2013b). "Los diversos digitales y mediáticos que nos habitan cotidianamente”. En WINOCUR, R., Hegemonía cultural y políticas de la diferencia (245-261). Buenos Aires: CLACSO.

WOLTON, D. (2000). Internet ¿y después? Barcelona: Gedisa.

WORTMAN, A. (2006). "Viejas y nuevas significaciones del cine en la Argentina”. En: SUNKEL, G. (coord.), El consumo cultural en América Latina. Bogotá, Convenio Andrés Bello.

WORTMAN, A. (2007). Industrias culturales argentinas: entre lo local y lo global. El impacto de las nuevas tecnologías de la comunicación y la información. Disponible en: http://estatico.buenosaires.gov.ar/areas/produccion/industrias/observatorio/documentos/An uario_OIC_2006_2007.pdf 